DEPARTMENT OF THE INTERIOR

UNITED STATES GEOLOGICAL SURVEY

CHARles D, WALCOTT, Director

T $\mathrm{H} \mathrm{E}$

\title{
TERTIARY AND QUATERNARY PECTENS OF CALIFORNIA
}

BY

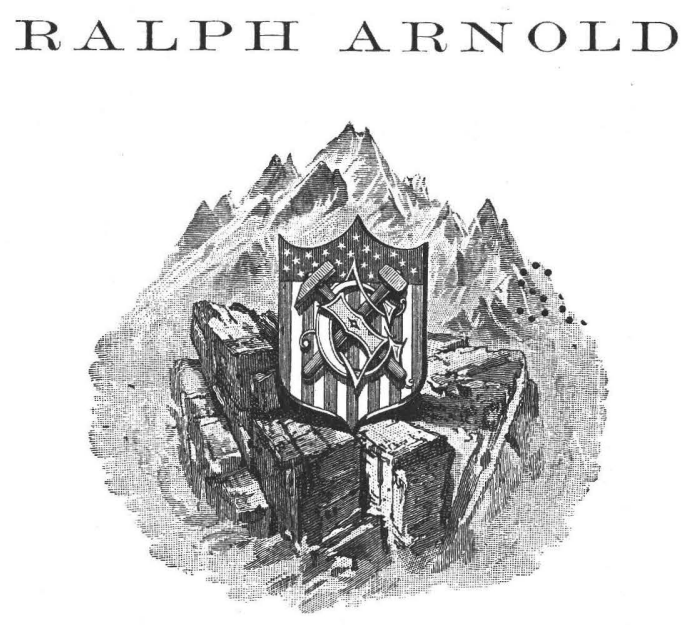

W A SHIN G TON

GOVERNMENT PRINTING OFFICE

1906 


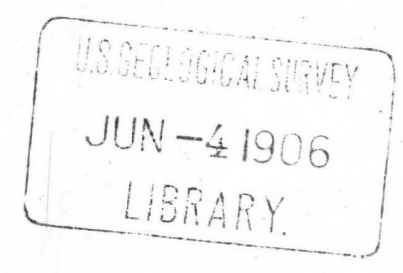

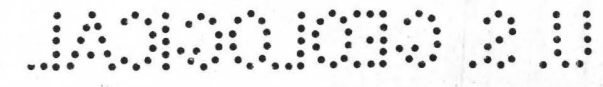

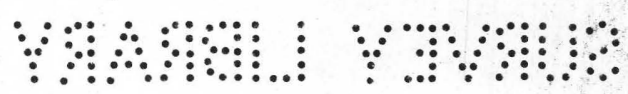




\section{* CONTENTS AND ILLUSTRATIONS.}

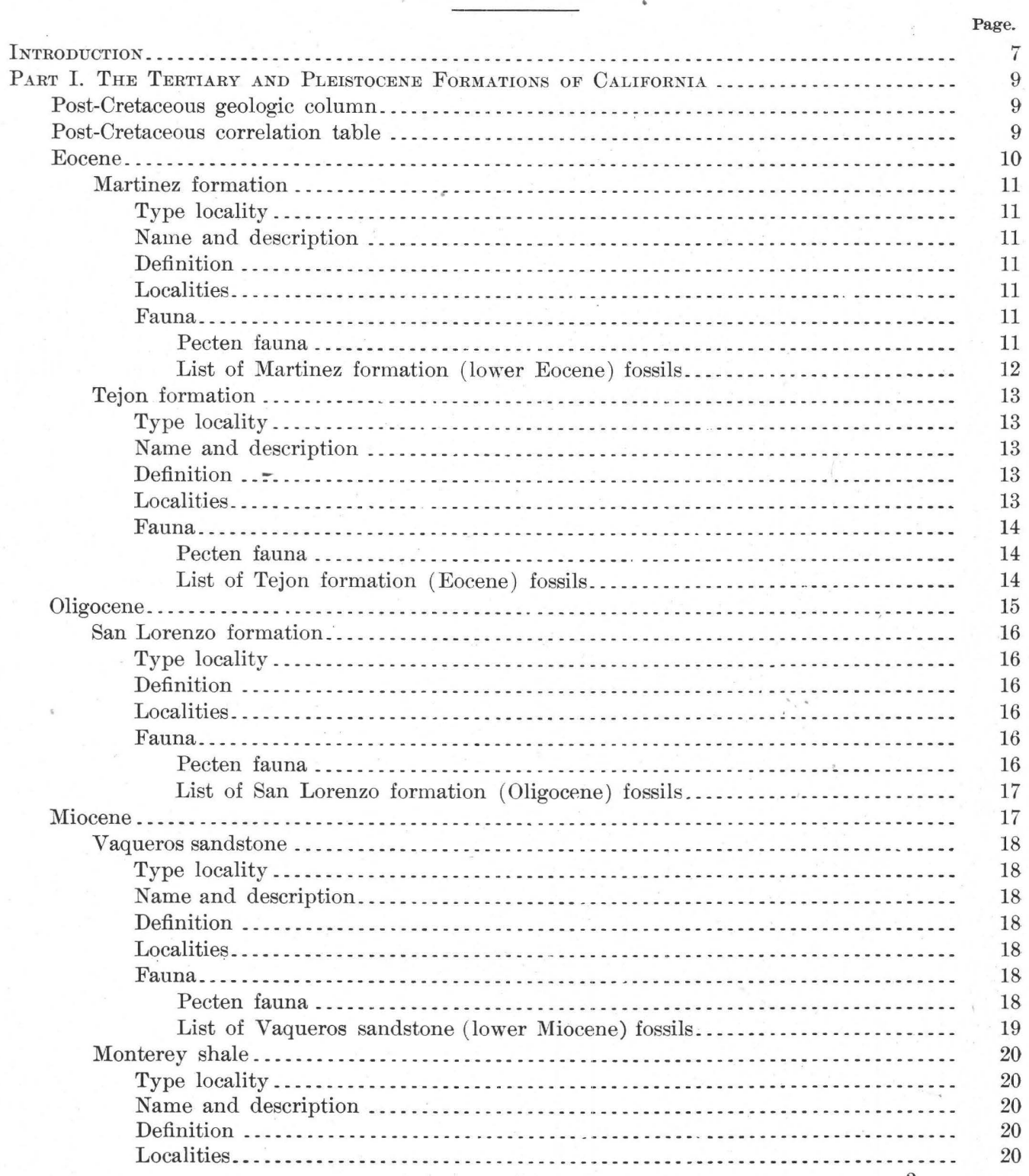


Part I. The Tertiary and Pleistocene Formations of California--Continued. Miocene-Continued.

Monterey shale-Continued. $\quad$ Page.

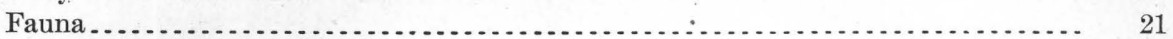

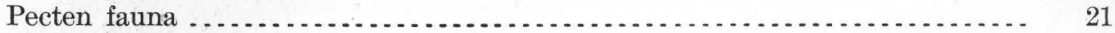

List of Monterey shale (middle Miocene) fossils ........................ 21

List of fossils from the Carrizo Creek beds (Miocene) .................. 22

San Pablo formation......................................................... 22

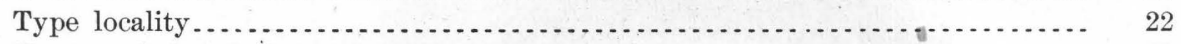

Name and description ................................................... 22

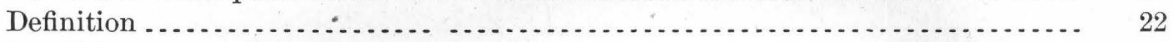

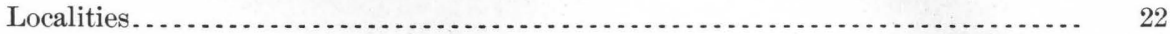

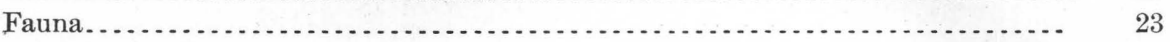

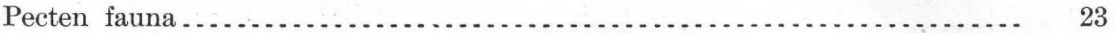

List of San Pablo formation (upper Miocene) fossils.................... 23

List of Santa Margarita formation (= San Pablo) fossils from Salinas Valley and southward ........................................... 24

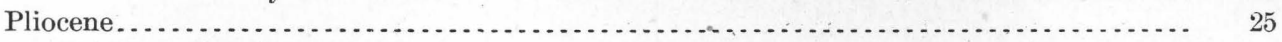

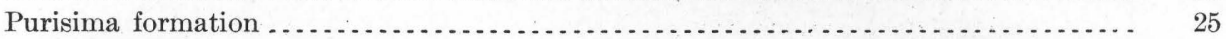

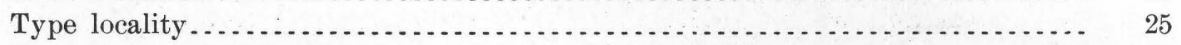

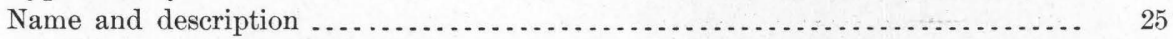

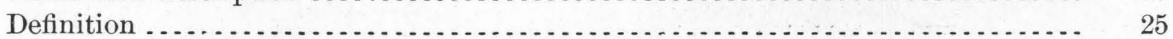

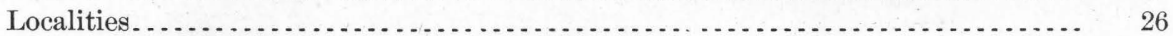

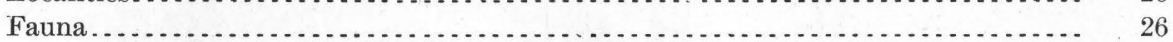

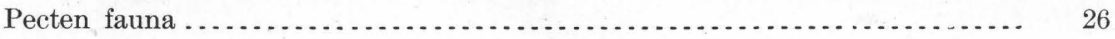

List of Purisima formation (lower Pliocene) fossils ................... 27

List of San Diego formation fossils.............................. 28

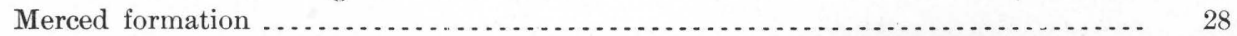

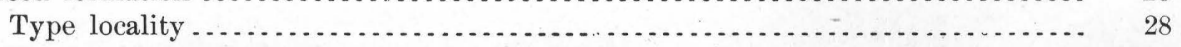

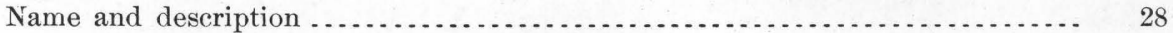

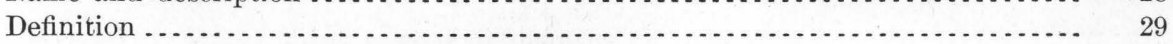

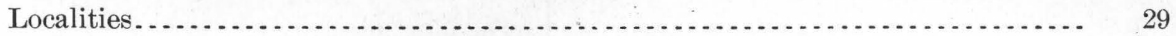

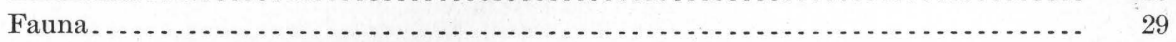

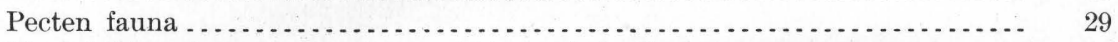

List of Merced formation (upper Pliocene) fossils...................... 30

List of Pliocene fossils from Deadman Island....................... 30

Pleistocene .............................................................. 31

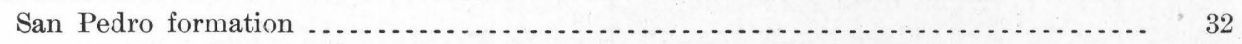

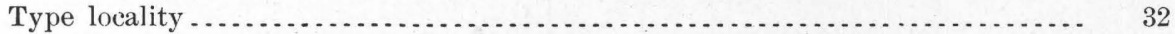

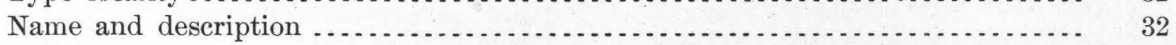

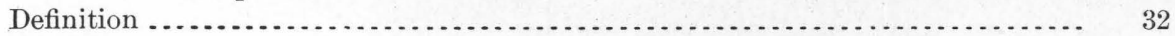

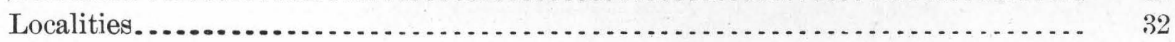

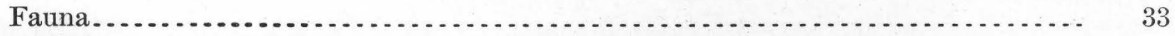

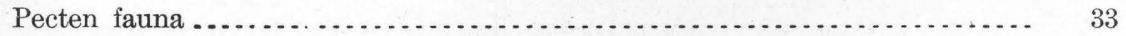

List of San Pedro formation (Pleistocene) fossils.................... 33

Geologic range of the California Pectens ........................................ 37

Summary of the range of species and varieties............................ 40

Part II. Synopsis and Descriptions of Subgenera and Species . . . . . . . . . . . . . . . . . 41

Synopsis of subgenera and species............................................. 41

Summary of the subgenera and species.................................. 44

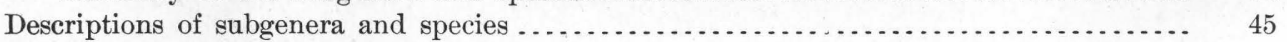

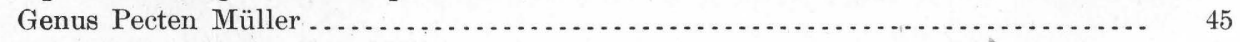

Subgenus Pecten s. s. Müller ................................................ 48

Subgenus Patinopecten Dall........................................ 48

Subgenus Nodipecten Dall ......................................... 49 
Part II. Synopsis and Descriptions of Subgenera and Species-Continued.

Descriptions of subgenera and species-Continued.

Genus Pecten Müller-Continued. Page.

Subgenus Chlamys Bolten ......................................... 49

Subgenus Lyropecten Conrad ........................................ 49

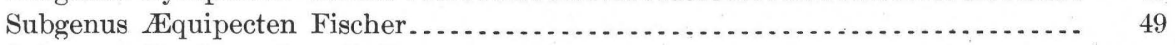

Subgenus Plagioctenium Dall ......................................... 50

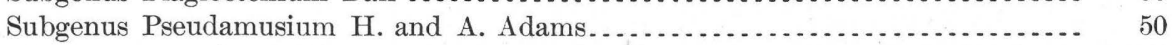

Subgenus Amusium Bolten.......................................... 50

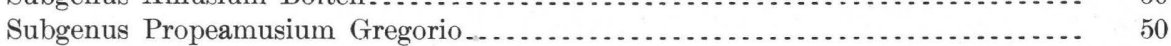

Subgenus Hinnites Defrance ....................................... 50

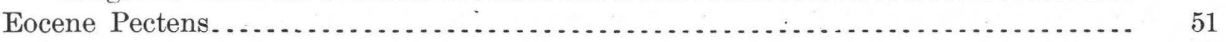

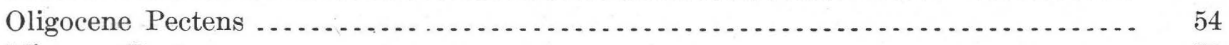

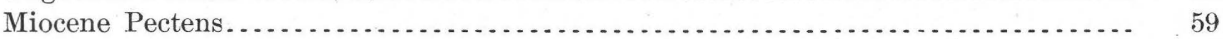

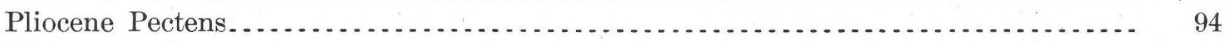

Pleistocene Pectens . . . . . . . . . . . . . . . . . 127

Recent Pectens . . . . . . . . . .

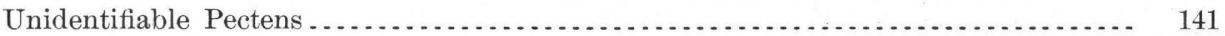

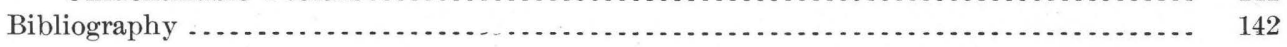

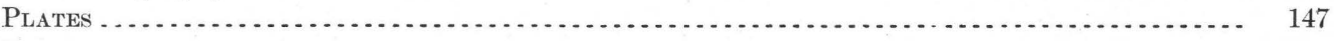

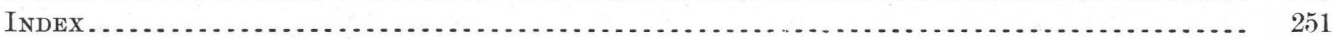

Plate I. Sketch map of California, showing the principal fossiliferous Tertiary localities....

II. Pecten calkinsi n. sp., P. landesi n. sp., P. proavus n. sp., and P. interradiatus Gabb

III. Pecten clallamensis n. sp., P. waylandi n. sp., P. peckhami Gabb, P. branneri

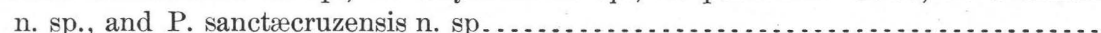

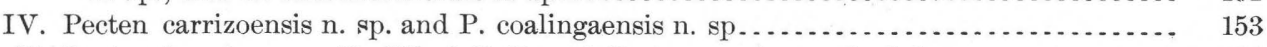

V. Pecten keepi n. sp., P. dilleri Dall, and P. sespeensis var. hydei n. var.......... 155

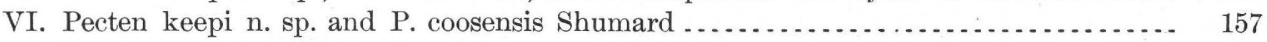

VII. Pecten propatulus Conrad and P. coosensis Shumard . . . . . . . . . . . . . . . . . . 159

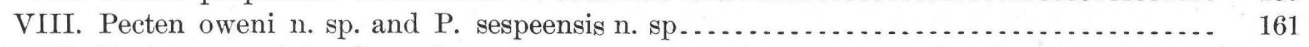

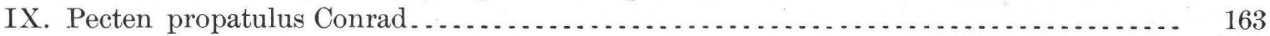

X. Pecten fucanus Dall and P. wattsi var. morani n. var........................ 165

XI. Pecten wattsi n. sp., P. hamlini n. sp., P. nutteri n. sp., and P. crassicardo Conrad var. hamiltoni $n$. var ............................................. 167

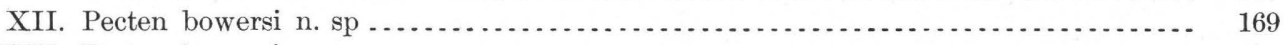

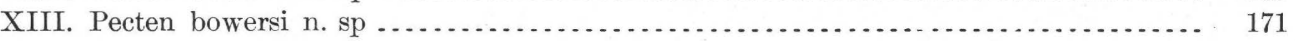

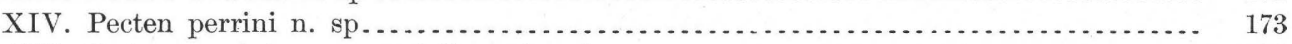

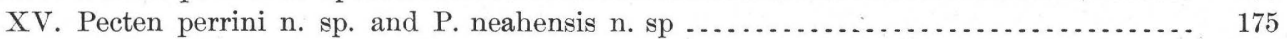

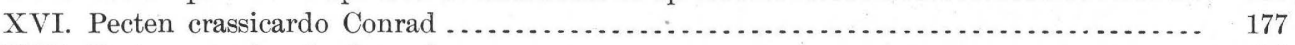

XVII. Pecten crassicardo Conrad . . . . . . . . . . . . . . . . . . . . . . . . . . . . . . . . . . . . 179

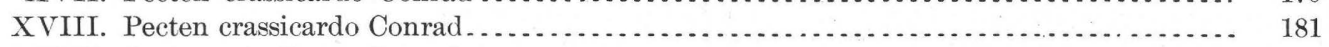

XIX. Pecten estrellanus Conrad ............................................. 183

XX. Pecten estrellanus Conrad and P. estrellanus Conrad var. catalinæ n. var .......... 185

XXI. Pecten estrellanus Conrad . . . . . . . . . . . . . . . . . . . . . . . . . . . . . . . . . 187

XXII. Pecten miguelensis n. sp . . . . . . . . . . . . . . . . . . . . . . . . . . . . . . . . 189

XXIII. Pecten miguelensis n. sp., P. estrellanus Conrad var. terminus n. var., P. vaughani n. sp., P. stanfordensis n. sp., and P. lompicoensis n. sp ..................... 191

XXIV. Pecten magnolia Conrad . . . . . . . . . . . . . . . . . . . . . . . . . . . . . . . . . 193

XXV. Pecten magnolia Conrad, P. cerrosensis Gabb var. mendenhalli n. var., and P.

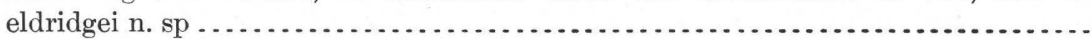


Plate XXVI. Pecten deserti Conrad, P. andersoni n. sp., and P. andersoni var. barkerianus n. var.....................

XXVII. Pecten discus Conrad, P. pabloensis Conrad, and P. lompicoensis n. sp .........

XXVIII. Pecten lompocensis n. sp. and P. pedroanus Trask ..........................

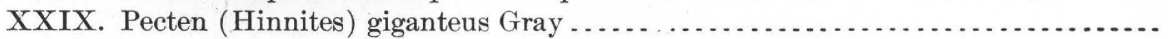

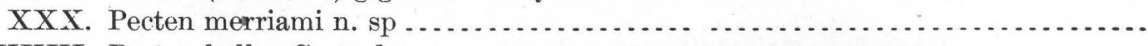

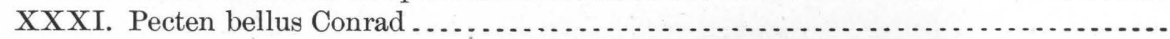

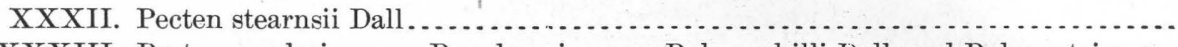

XXXIII. Pecten vogdesi n. sp., P. auburyi n. sp., P. hemphilli Dall, and P. lecontei n. sp.

XXXIV. Pecten vogdesi n. sp., P. auburyi n. sp., P. purisimaensis n. sp., and P. turneri

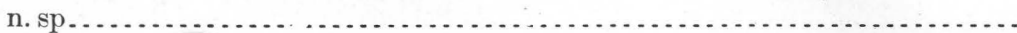

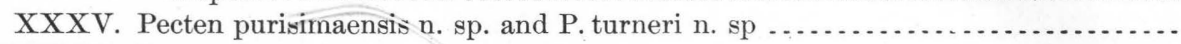

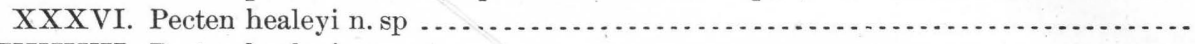

XXXVII. Pecten healeyi n. sp . . . . . .

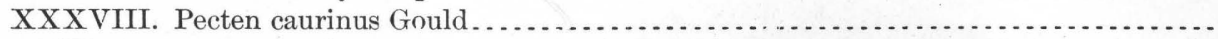

XXXIX. Pecten caurinus Gould and P. paucicostatus Carpenter .....................

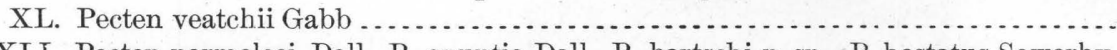

XLI. Pecten parmeleei Dall, P. opuntia Dall, P. bartschi n. sp., P. hastatus Sowerby,

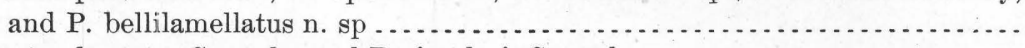

XLII. Pecten hastatus Sowerby and P. circularis Sowerby

XLIII. Pecten hastatus Sowerby var. navarchus Dall, P. hastatus Sowerby var. hindsii Carpenter, and P. hastatus Sowerby var, hericius Gould ....................

XLIV. Pecten jordani Arnold, P. hastatus Sowerby var. strategus Dall, P. cerrosensis

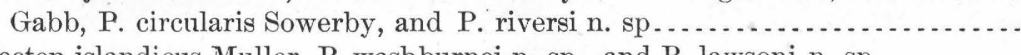

XLV. Pecten islandicus Muller, P. washburnei n. sp., and P. lawsoni n. sp...........

XLVI. Pecten excavatus Anton, P. latiauritus Conrad, P. latiauritus Conrad var. monotimeris Conrad, P. latiauritus Conrad var. cerritensis n. var., P. latiauritus Conrad var. fucicolus Dall, and P. latiauritus Conrad var. delosi n. var.............

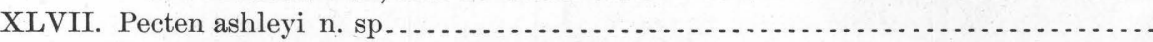

XLVIII Pecten ashleyi n. sp., P. randolphi Dall, and P. randolphi Dall var. tillamookensis

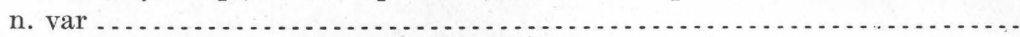

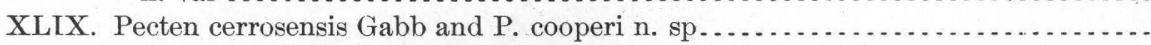

L. Pecten circularis Sowerby var. æquisulcatus Carpenter, P. palmeri Dall, and P. davidsoni Dall

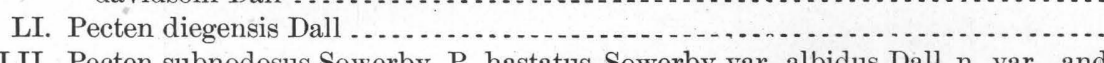

LII. Pecten subnodosus Sowerby, P. hastatus Sowerby var. albidus Dall n. var., and

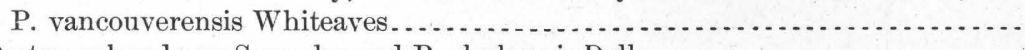

LIII. Pecten subnodosus Sowerby and P. alaskensis Dall ......................

FIG. 1. Pecten circularis Sowerby var. æquisulcatus Carpenter; right valve, exterior... 2. The same; right valve, interior.

Page. 197 199 201 203 205 207 209 211 



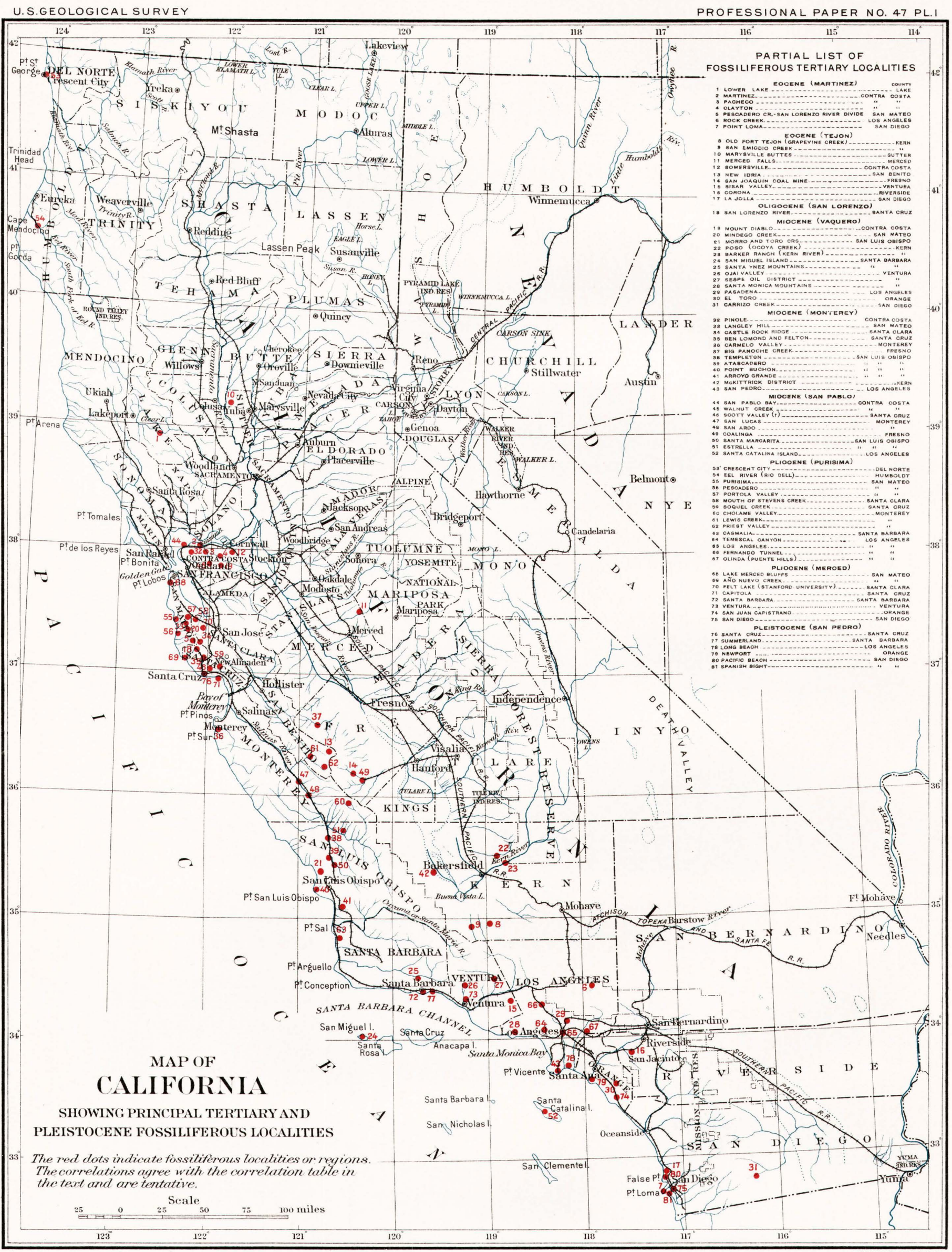




\title{
THE TERTIARY AND QUATERNARY PECTENS OF CALIFORNIA.
}

\author{
By Ralph Arnold.
}

\section{INTRODUCTION.}

This paper consists of two parts. The first is a brief outline of the different Tertiary and Pleistocene formations of California, giving the type localities, where, when, and by whom first described, their salient characters, where they and their supposed equiyalents are known to occur, the species of Pecten found in them, and their typical fauna as far as known. The second is devoted to the description and illustration of all of the known Tertiary, Pleistocene, and Recent Pectens of the western coast of North America from Alaska to and including the Gulf of California. With the description of each species is also given an account of its geologic and geographic range and, where practicable, its associated fauna.

This particular genus was chosen for study because of its great value for the stratigraphic determination of the Tertiary formations of the west coast and because of the large amount of material available at the time the work was undertaken. The genus is admirably adapted to purposes of correlation because of $(a)$ its occurrence in every important Tertiary horizon in California, (b) the limited vertical and wide geographic range of most of its species, and $(c)$ the comparatively simple yet salient characters which mark the different species.

The present paper is a larger and more comprehensive one than was contemplated when the work was first begun. The original plan was simply to monograph only the fossil Pectens of California, but as the work progressed it soon became apparent that the original subject could be thoroughly treated only by a more or less detailed consideration of the fossil Pectens of the adjacent territory and the living members of the genus found along the whole western coast of North America. To give the paper its greatest possible value, it became necessary to define as accurately as possible the stratigraphic and geographic range of each species; and in order to do this consistently an examination of all of the available marine Tertiary paleontologic material from the west coast was undertaken. Then, that the data thus obtained might be made more available and that the relations of the different faunas and horizons of the California Tertiary might be the more clearly set forth, it was deemed advisable to include a brief outline of the characteristics, geographic range, and faunas of the different Tertiary formations.

It was obvious that any scheme of classification of the Pectinidæ based wholly upon specimens from the Pacific coast would necessarily be disconnected and unsatisfactory. It seemed advisable, therefore, to adopt some system which was founded 
upon material from a much wider geographic range. Doctor Dall's classification of the family, given in his "Tertiary Fauna of Florida," not only fulfilled this requirement, but had the added desirability of being based partly upon a considerable amount of west coast Tertiary and living material. Dall's classification, with but slight alteration, has, therefore, been adopted for this paper.

Collections belonging to the following institutions and individuals were exam. ined by the writer during the preparation of this report:

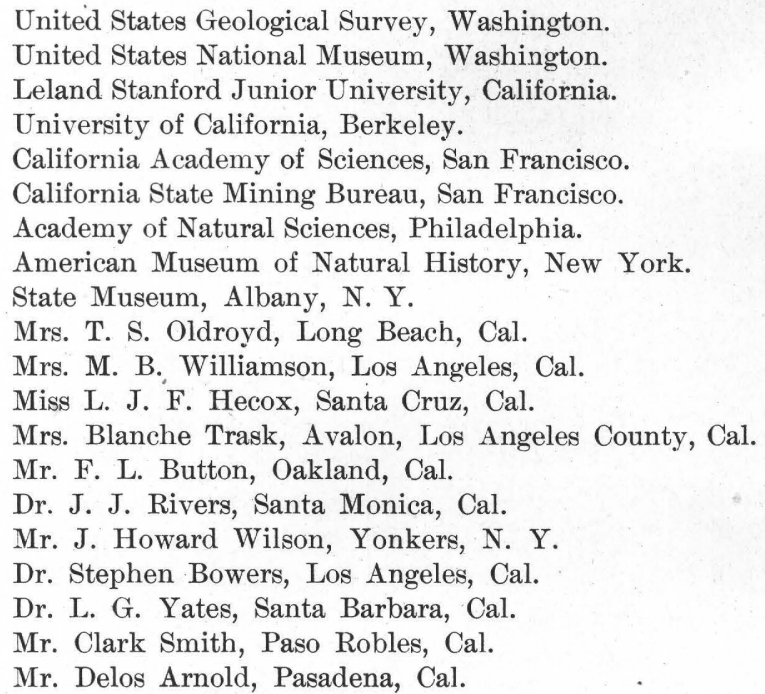

The writer is indebted to Dr. Wm. H. Dall, of the United States Geological Survey, for kindly assistance and helpful suggestions given during the preparation of this paper. In addition to those already mentioned, the writer wishes to extend his thanks to the following for assistance and courtesies extended: Dr. J. C. Branner, Dr. J. P. Smith, Dr. J. C. Merriam, Dr. T. W. Stanton, Mr. Edward Hoitt Nutter, Prof. J. M. Hyde, Mr. G. H. Eldridge, Mr. Homer Hamlin, Dr. T. Wayland Vaughan, Dr. Paul Bartsch, Mr. L. M. Loomis, Mr. F. M. Anderson, Mr. Lewis E. Aubury, Dr. H. W. Fairbanks, Dr. H. A. Pilsbry, Mr. C. W. Johnson, and many others.

The illustrations are, with the exceptions noted in the explanations, half-tone reproductions of retouched photographs. To give an even color effect, the Williams process of coating the specimen was used on most of the specimens before photographing. My acknowledgments and thanks are due to Miss M. K. Sumner, Miss Maude Baggett, Miss Marian Page, and Mr. H. C. Hunter, artists; to Mr. E. M. Bane, photographer; and to Messrs. J. L. Ridgway and N. W. Carkhuff, chiefs, respectively, of the sections of illustrations and photography, for the very satisfactory execution of the drawings. 
P A R T I.

\section{TERTIARY AND PLEISTOCENE FORMATIONS OF CALIFORNIA. POST-CRETACEOUS GEOLOGIC COLUMN.}

The process of marine sedimentation has been going on at one place or another within the California province almost without interruption since the beginning of the Cretaceous, and as a result the greater portion of this long period is represented by formations which outcrop over much of the territory between the Sierra Nevada mountain range and the Pacific Ocean. The only great break in the record, as shown by the faunas of the different formations, is that between the Tejon (Eocene) and its overlying beds. Each of the other formations is more or less closely related faunally to those immediately above or below, where the formations are of a more or less similar lithologic character.

The stratigraphic relations between adjacent formations vary in different localities. At one place two formations may be separated by à marked unconformity, while at another locality, only a comparatively short distance away from the first, the same formations may rest in an apparently conformable position with relation to each other. In general, however, the relations existing between the different formations is that indicated by the accompanying diagram of the California postCretaceous column.

POST-CRETACEOUS CORRELATION TABLE.

The following correlation table of the principal marine Tertiary and Pleistocene formations of California, together with a brief outline of the typical ones, is tentative and based on the information at hand at the beginning of 1905. Further study will doubtless add many new formations to the list, some of which may represent horizons different from those of the known divisions, but the relative position of those already known is probably about as indicated in the table.

The faunal lists given under each formation comprise the species found at the type locality of the formation, and, in addition, such other species as are found in beds which have been quite definitely correlated with the latter. These correlations are necessarily very broad and are intended only to indicate in a general way the contemporaneity of the strata in question. The names used in the lists of fossils are those commonly applied to the respective species by the west coast paleontologists. Owing to the imperfect state of our knowledge

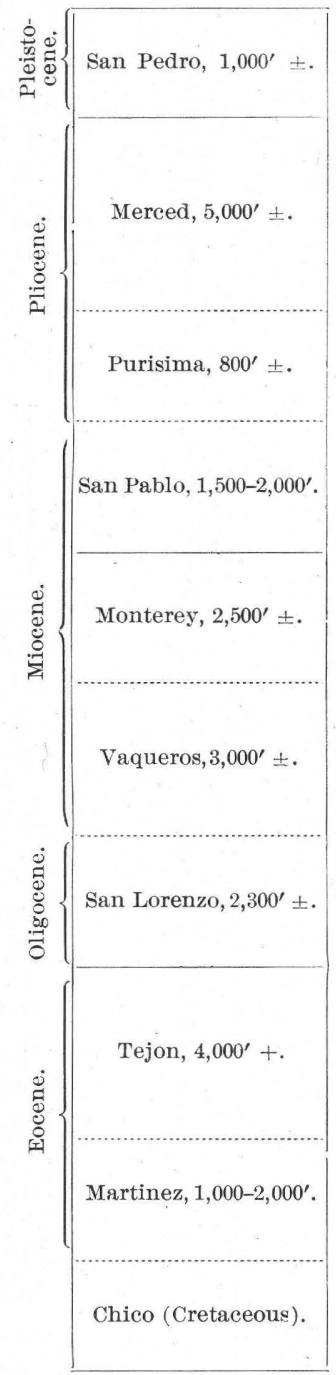

The Tertiary and Pleistocene column of California. Total thickness, 21,000 feet + . Note. - Full lines represent unconformity; broken lines, conformity. regarding the nomenclature of the California Tertiary fauna, there is a probability 
that some of the names used are erroneous. The writer, therefore, reserves the privilege of revising any of the names should future study warrant it.

A tentative correlation table of the principal marine Tertiary and Pleistocene formations of California to 1905.

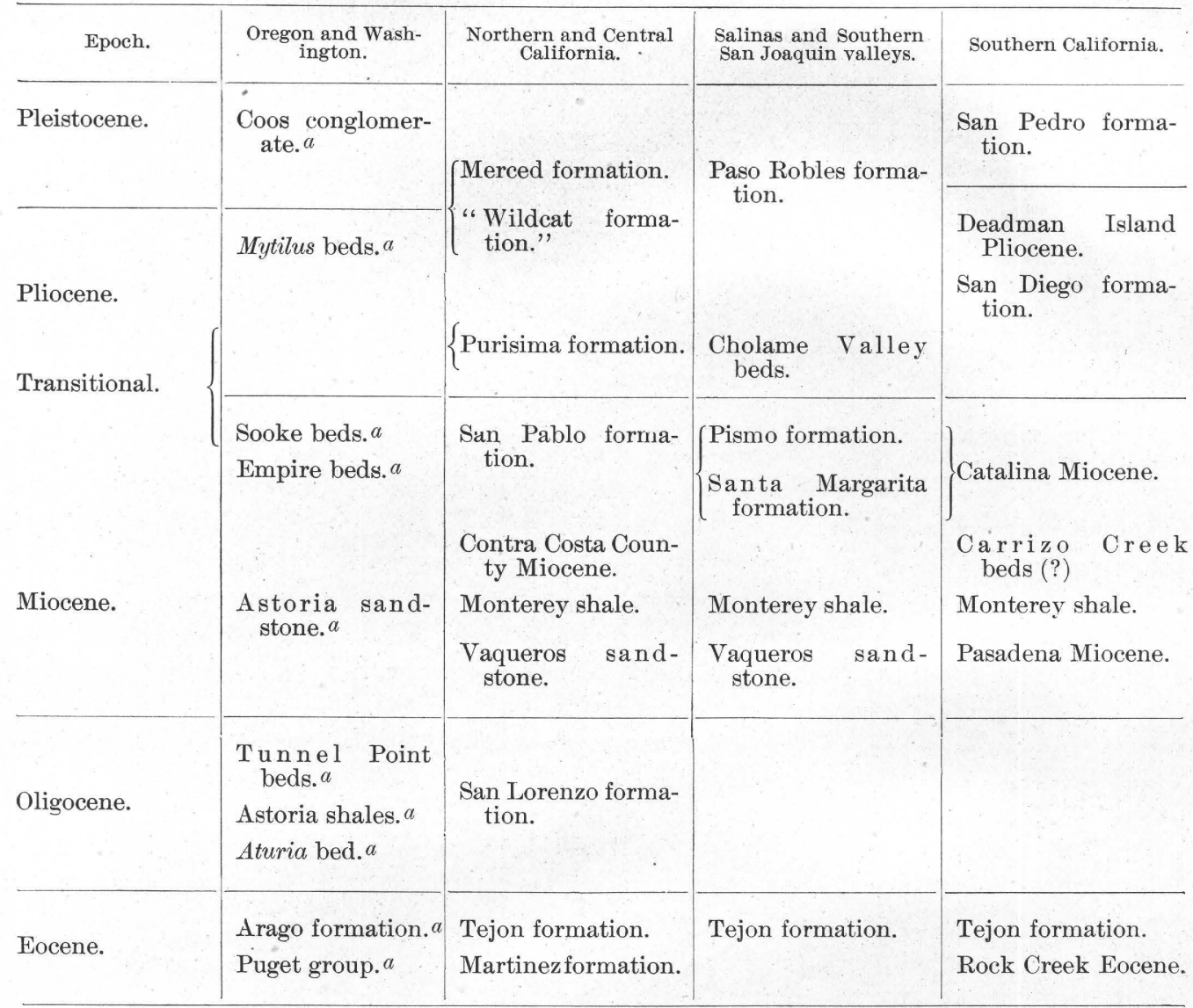

a Dall, W. H., North Am. Tertiary horizons: Eighteenth Ann. Rept. U. S. Geol. Survey, 1898, pt. 2, pp. 323-343.

NoTE.-The author disclaims responsibility for those names in the above table which he does not discuss in this paper.

\section{EOCENE.}

At least two horizons are recognizable in the Eocene of the west coast, viz, the Martinez and the Tejon; and there may also possibly be a third, which is represented by the richly fossiliferous beds exposed in the vicinity of Little Falls, Lewis County, Wash. The last-mentioned horizon is probably above that of the Tejon, although its relative position has not as yet been carefully worked out. On account of the lack of definite information concerning the affiliations of its fauna, the Little Falls beds will be included in the Tejon. The separation of the Martinez and Tejon formations is based principally upon paleontologic evidence, there being no apparent unconformity between them, although their lithologic characters are usually somewhat different. 
MARTINEZ FORMATION.

TYPE LOCALITY.

The type locality is south of the town of Martinez, Contra Costa County, Cal.

NAME AND DESCRIPTION.

This formation was named and described by J. D. Whitney in California Geological Survey, Paleontology, vol. 2, 1869, preface, p. xiii.

DEFINITION.

Dr. J. C. Merriam, in his paper on "The geologic relations of the Martinez group of California at the typical locality," a gives the following definition of the Martinez formation, which is generally accepted by paleontologists and geologists:

"The Martinez group, comprising in the typical locality between 1,000 and 2,000 feet of sandstones, shales, and glauconitic sands, forms the lower part of a presumably conformable series, the upper portion of which is formed by the Tejon. It contains a known fauna of over sixty species, of which the greater portion is peculiar to itself. A number of its species range up into the Tejon, and a very few long-lived forms are known to occur also in the Chico (Cretaceous). Since the Martinez and Chico are faunally only distantly related, it is probable that an unconformity exists between them. Though satisfactory correlation of California formations with the subdivisions of the standard geological scale can be accomplished only when the local scale is fully worked out, we may, for the present at least, accept Mr. Stanton's correlation of the Martinez with a portion of the Eocene."

LOCALITIES.

Martinez, Clayton, Pacheco, and Army Point (near Benicia), Contra Costa County. Lower Lake, Lake County.

Between headwaters of Pescadero Creek and San Lorenzo River, San Mateo County (?).

Rock Creek, Los Angeles County.

Point Loma, San Diego County (Eocene here may include the Martinez).

FAUNA.

Pecten fauna.-The Pecten fauna of this horizon consists, so far as known, of only one species, Pecten (Chlamys) proavus n. sp., and this from a locality of doubtful Martinez age.

a jour. Geol., vol. 5, p. 775. 
The fauna of the Martinez consists essentially of the following species:

List of Martinez formation (lower Eocene) fossils. a

[Those species followed by $(\mathrm{L})$ are found in the lower beds at Martinez; those by (U), upper beds at Martinez; those by $(B)$, beds at Benicia; those by $(\mathrm{C})$, beds at Lower Lake; and those by $(\mathrm{P})$ outcrop on ridge between headwaters of San Lorenzo River and Pescadero Creek, San Mateo County.]

FORAMINIFERA.

Foraminifera nummuloid (U). Foraminifera, $3 \mathrm{sp}$. indet. (L).

ANTHOZOA.

Flabellum remondianum Gabb (LBC). Trochocyathus zitteli Vaughan (L).

ECHINOIDEA.

Cidaris (?) spines (P).

Schizaster lecontei Merriam (LU).

BRACHIOPODA.

Terebratulina tejonensis Stanton (BCP). Terebratula (?) n. sp. (P).

\section{PELECYPODA.}

Arca biloba Weaver (LU).

Cardium cooperi Gabb (LU).

Crassatellites unioides Stanton (C).

Cucullæa mathewsonii Gabb (LUBC).

Glycymeris veatchii Gabb var. major Stanton (C).

Leda alæformis Gabb (BC).

Leda gabbi Conrad (LUC).

Lima multiradiata Gabb (C).

Meretrix sp. (LB).

Modiolus merriami Weaver (LU).

Modiolus ornatus Gabb (UC).

Nucula truncata Gabb (LUB).

Ostrea (cf.) idriaensis Gabb (P).

Pecten proavus n. sp. (P).

Phacoides turneri Stanton (C).

Pholadomya nasuta Gabb (LUB).

Plicatula ostreiformis Stanton (C).

Semele (?) n. sp. (P).

Solen parallelus Gabb (C).

Solen stantoni Weaver (U).

Tapes (aff.) quadrata Gabb (LB).

Tellina æqualis Gabb (C).

Tellina hoffmanniana Gabb (C).

Tellina martinezensis Weaver (LU).

Tellina hornii Gabb (UC).

Tellina undulifera Gabb (UB).

Teredo sp. (L).

Thracia karquinesensis Weaver (U).

Venericardia planicosta Lamarck var. hornii

Gabb (U).
GASTEROPODA.

Actæon lawsoni Weaver (LB).

Ampullina (cf.) striata Gabb (UBC).

Architectonica tuberculata Weaver (U).

Brachysphingus liratus Gabb (UBC).

Bullinula subglobosa Weaver (U).

Cerithiopsis alternata Gabb $(\mathrm{C})$.

Cylichna costata Gabb (LC).

Dentalium cooperi Gabb (LUC).

Dentalium stramineum Gabb (U)

Discohelix californicus Weaver (L).

Ficopsis angulatus Weaver (U).

Fusus æquilateralis Weaver (L).

Galerus excentricus Gabb (C).

Helcion (cf.) dichotoma Gabb (P).

Heteroterma gabbi Stanton (UC).

Heteroterma striata Stanton (C).

Heteroterma trochoidea Gabb (U).

Heteroterma, indet. (U).

Lunatia hornii Gabb (C).

Megatabennus (?) n. sp. (P).

Megistostoma striata Gabb (U.)

Morio tuberculatus Gabb (U).

Natica sp.

Neptunea mucronata Gabb (L).

Perissolax blakei Conrad (B).

Perissolax tricarnatus Weaver (LUBC).

Serpula (?) sp. (LP).

Siphonalia lineata Stanton (LUC).

Strepsidura pachecoensis Stanton (U).

Tritonium (cf.) californicum Gabb (P).

Tritonium eocenicum Weaver (U).

Tritonium impressum Weaver (U).

Tritonium pulchrum Weaver (U).

Turbinella crassitesta Gabb (L).

Turritella conica Weaver (U).

Turritella infragranulata Gabb (UBC).

Turritella martinezensis Gabb (L).

Turritella pachecoensis Stanton (U).

Turris sp. indet. (U).

Urosyca caudata Gabb (LUBC).

Urosyca robusta Weaver $(\mathrm{L})$.

Xenophora zitteli Weaver (L).

CRUSTACEA.

Cancer (U).

Crustacean remains, macruran (U).

a Compiled from lists by Merriam, J. C., Jour. Geol., vol. 5, 1897, p. 773; Stanton, T. W., Seventeenth Ann. Rept. U. S. Geol. Survey, pt. 1, 1896, p. 1025; and Weaver, C. E., Bull. Dept. Geol., Univ. of Cal., vol. 4, 1905, No. 5, pp. 110-111. 
TEJON FORMATION.

TYPE LOCALITY.

The type locality is in the region about Fort Tejon, Kern County, Cal.

\section{NAME AND DESCRIPTION.}

This formation was named and described by J. D. Whitney in California Geological Survey, Paleontology, vol. 2, 1869, preface, p. xiii.

\section{DEFINITION.}

The original definition and description of this formation is as follows:

"The Tejon group *** the division B of Paleontology, volume 1, is peculiar to California. It is found most extensively developed in the vicinity of Fort Tejon and about Martinez. From the latter locality it forms an almost continuous belt in the Coast Ranges to Marshs, 15 miles east of Mount Diablo, where it sinks under the San Joaquin plain. It was also discovered by the different members of the Survey at various points on the eastern face of the same range as far south as New Idria, and in the summer of 1866 by Mr. Gabb in Mendocino County, near Round Valley, the latter locality being the most northern point at which it is as yet known. $\therefore * *$

"This group contains a large and highly characteristic series of fossils, the larger part peculiar to itself, while a considerable percentage is found extending below into the next group (Martinez) * * *."

\section{LOCALITIES.}

Fort Tejon, Uvas Pass, and San Emidio, Kern County.

Marysville Buttes, Sutter County.

Merced Falls, Merced County.

Martinez, Somersville, Clayton, and Marshs, Contra Costa County.

New Idria and Griswold, San Benito County.

Coalinga and San Joaquin coal mines, Fresno County.

North side of Sisar Valley, Ventura County.

North side Santa Ana Mountains, 4 miles south and 5 miles northwest of Corona, Riverside County.

San Luis Rey to San Diego, Rose Canyon and Point Loma Peninsula, San Diego County.

Peninsula of Lower California, latitude $29^{\circ} 30^{\prime}$.

Port Crescent, Clallam County; Little Falls, Lewis County, and Oakville, Chehalis County, Wash. (Landes and Arnold).

In Oregon at the following localities, according to Diller (1896):

Nehalem River, 5 miles east of Nehalem, and also midway between Jewell and Mishawaka. Wilson River toll road, 22 miles from Tillamook.

Vineyard Hill, 4 miles north of Corvallis.

Benson's and Howe's, 5 miles north of Corvallis.

Scott's, Cooper's, and Newton's, southwest of Corvallis.

Roger's, in section 27, T. 13 S., R. $6 \mathrm{~W}$.

Monroe, Comstock, Cleveland, Callahan's, and Camas, Douglas County.

Near mouth of Little River, 20 miles northeast of Roseburg.

Marshfield, Jordan Point, and Cape Arago, southward to near mouth of Coquille River. 


\section{FAUNA.}

Pecten fauna.-The Pecten fauna of the Tejon group consists, so far as known, only of three species, $P$. calkinsi n. sp., $P$. landesi n. sp., and $P$. interradiatus Gabb. The first two probably belong to the subgenus Chlamys, but are not closely allied to any of the subsequent members of this group, so far as known. $P$. interradiatus belongs to the Propeamusium group and appears to be the precursor of such forms as $P$. stanfordensis, $P$. waylandi, and $P$. clallamensis.

The following species have been found in the Tejon formation in different parts of California:

$$
\text { List of Tejon formation (Eocene) fossils. a }
$$

[Those marked with an asterisk $(*)$ have been found at the type locality.]

$$
\text { ANTHOZOA. }
$$

Flabellum californicum Vaughan. Flabellum remondianum Gabb.

Trochocyathus californicus Vaughan. Trochocyathus stantoni Vaughan.

Trochocyathus striatus Gabb.

$$
\text { PELECYPODA. }
$$

*Arca horni Gabb.

Astarte semidentata Cooper.

*Axinea cor Gabb (=Glycymeris id.).

* Axinea sagittata Gabb (=Glycymeris id.).

Barbatia morsei Gabb.

*Cardium breweri Gabb.

*Cardium cooperi Gabb.

*Cardium (Lævicardium) linteum Conrad.

Corbula alæformis Gabb.

*Corbula horni Gabb.

Corbula parilis Gabb.

Corbula primorsa Gabb.

${ }^{*}$ Crassatellites grandis Gabb.

*Crassatellites uvasana Conrad.

Donax latus Gabb.

*Dosinia elevata Gabb.

*Dosinia gyrata Gabb.

*Leda gabbi Conrad.

Lima multiradiata Gabb.

Lucina? cretacea Gabb.

* Meretrix californica Conrad.

*Meretrix horni Gabb.

*Meretrix ovalis Gabb.

*Meretrix uvasana Conrad.

*Modiolus ornatus Gabb.

*Mysia? polita Gabb.

*Mytilus ascia Gabb.
PELECYPODA-continued.

*Mytilus humerus Conrad.

* Nucula truncata Gabb.

Ostrea appressa Gabb.

Ostrea idriaënsis Gabb.

*Septifer dichotomus Gabb.

Solen (Hypogella) diegoensis Gabb.

Stalagmium concentricum Gabb.

*Tapes conradiana Gabb.

Tapes? cretacea Gabb.

*Tapes? quadrata Gabb.

*Tellina californica Gabb.

*Tellina horni Gabb.

*Tellina longa Gabb.

*Tellina rémondi Gabb.

Unio penultimus Gabb.

Venus æquilateralis Gabb.

*Venericardia planicosta Lamarck.

*Venericardia planicosta var. hornii Gabb.

GASTEROPODA.

*Acmra tejonensis Gabb.

Amauropsis alocata Gabb.

Ancilla (Oliverato) californica Cooper.

Ancilla elongata Gabb.

*Architectonica cognata Gabb.

*Architectonica horni Gabb.

Bela clathrata Gabb.

Bittium longissimum Cooper.

Brachysphingus liratus Gabb.

Brachysphingus sinuatus Gabb.

* Bulla horni Gabb.

* Bullia (Molopophorus) striata Gabb.

Cancellaria irelaniana Cooper.

Cerithiopsis alternata Gabb.

a Compiled from lists by Cooper, J. G., Seventh Ann. Rept. California State Mineralogist, p. 271 et seq.; Cooper, J. G., Bull. California State Mining Bureau No. 4, p. 39 et seq.; Stanton, T. W., Seventeenth Ann. Rept. U. S. Geol. Survey., p. 1021 et seq.; Merriam, J. C., Jour. Geol., vol. 5, p. 771. 
List of Tejon formation (Eocene) fossils-Continued.

GASTEROPODA-continued.

* Conus horni Gabb.

* Conus rémondi Gabb.

Cordiera gracillima Cooper.

* Cordiera microptygma Gabb.

* Cypræa (Luponia) bayerquei Gabb.

Cypræa (Epona) mathewsoni Gabb.

* Dentalium cooperi Gabb.

* Dentalium stramineum Gabb.

Diodus tenuis Gabb.

Drillia ullreyana Cooper.

* Enspira alveata Conrad.

* Fasciolaria io Gabb.

Fasciolaria læviuscula Gabb.

* Fasciolaria sinuata Gabb.

Ficopsis cooperi Gabb.

* Ficopsis horni Gabb.

Ficopsis rémondi Gabb.

* Fusus californicus Conrad.

* Fusus diaboli Gabb.

* Fusus martinez Gabb.

Fusus supraplanus Cooper.

Galerus excentricus Gabb.

Gyrodes dowelli White.

Loxotrema turrita Gabb.

* Lunatia horni Gabb.

* Lunatia nuciformis Gabb.

Lunatia shumardiana Gabb. Mangilia saturalis Cooper.

Margaritella crenulata Gabb.

Megistostoma striatum Gabb.

Mitra cretacea Gabb.

Mitra simplicissima Couper.

* Morio (Sconsia) tuberculatus Gabb.

Nassa antiquata Gabb.

* Nassa cretacea Gabb.
GASTEROPODA - continued.

* Natica uvasana Gabb.

* Naticina obliqua Gabb.

Neptunea (Tritonofusus) cretacea Gabb.

Neptunea? gracilis Gabb.

Neptunea? supraplicata Gabb.

Nerita (Theliostyla) triangulata Gabb.

Neverita globosa Gabb.

* Neverita secta Gabb.

* Olivella mathewsoni Gabb.

* Perissolax blakei Conrad.

Pleurotoma perkinsiana Cooper.

Potamides carbonicola Cooper.

Potamides? davisiana Cooper.

*Rimella canalifera Gabb.

Rimella simplex Gabb.

Scalaria (Opalia) mathewsoni Gabb.

*Siphonodentalium pusillum Gabb.

*Spirocrypta pileum Gabb.

*Surcula claytonensis Gabb.

Surcula crenatospira Cooper.

Surcula inconstans Cooper.

Surcula monilifera Cooper.

Surcula præattenuata Gabb.

Surcula raricostata Gabb.

* Surcula sinuata Gabb.

Terebra californica Gabb.

Terebra wattsiana Cooper.

*Tritonium californicum Gabb.

Tritonium (Trachytriton) diegoensis Gabb.

*Tritonium (Trachytriton) fusiforme Gabb.

*Tritonium horni Gàbb.

*Tritonium paucivaricatum Gabb.

*Tritonium (Trachytriton). tejonensis Gabb.

*Tritonium whitneyi Gabb.

Turritilla martinezensis Gabb.

\section{OLIGOCENE.}

The recognition of Oligocene strata on the western coast of North America has been more or less uncertain. Doctor Dall ${ }^{a}$ has recognized what he considers to be an Oligocene fauna from several localities in the northwestern part of Oregon, but as very little detailed paleontologic work has been done in that section no adequate lists of the fossils are available. Certain gray shales in the vicinity of Porter, Chehalis County, Wash., and shales near Bean Point, King County, and along the Strait of San Juan de Fuca, on the north side of Clallam County, in the same State, contain a fauna which may also be Oligocene. 
Within the last five years strata have been discovered in the Santa Cruz quadrangle which contain a fauna representing a horizon probably lower than any of the known lower Miocene horizons of California. The faunal relations and stratigraphic position of this new formation have led the writer to believe that it belongs in the Oligocene.

With the exceptions above noted, no marine Oligocene has heretofore been recognized on the west coast north of that found in the Central American States.

\section{SAN LORENZO FORMATION.}

TYPE LOCALITY.

The type locality is on San Lorenzo River, $2 \frac{1}{2}$ miles above the town of Boulder Creek, Santa Cruz County, Cal.

\section{DEFINITION.}

The San Lorenzo formation consists essentially of a series of grayish "muddy" shales and fine sandstones, which are typically exposed along the bed of the San Lorenzo River, about 2 miles above Boulder Creek, Santa Cruz County. The formation extends westward from the type locality into the Big Basin, on the north side of which it rests conformably against the older yellowish sandstones (possibly Oligocene in age) of the Butano Ridge. To the southeast of the exposures on San Lorenzo River the formation, in the shape of a broad anticlinal nose, gradually dips conformably under the sandstones and conglomerates of the lower Miocene. The approximate thickness of the formation in the vicinity of the type locality is about 2,300 feet.

\section{LOCALITIES.}

San Lorenzo River, Boulder Creek, Kings Creek, Twobar Creek, Bear Creek, and Love Creek, all near the town of Boulder Creek, Santa Cruz County.

FAUNA.

The fauna of the San Lorenzo formation consists, for the most part, of forms best suited by the conditions prevalent during the deposition of sandy shales. In other words, it is a moderately deep-water fauna. It shows several species found in the Monterey shale, but it also contains many species which appear to be closely related to Tejon (Eocene) forms. Bearing in mind these faunal relations and the stratigraphic position of the formation, it appears probable that it belongs in the Oligocene.

Pecten fauna.-In this horizon we meet with the common Miocene Pserdamusium, P. peckhami, and characteristic representatives of Pecten s. s. and Chlamys, the groups which are so well represented in the later formations. $P$. (Pecten) sanctrecruzensis is quite closely allied to P. bellus and P. hemphilli, which are found in the Pliocene, while in the top of the formation, associated with a transitional Oligocene-Miocene fauna, is $P$. (Chlamys) branneri, the analogue and probable precursor of $P$. islandicus, and the latter's related forms. $P$. clallamensis and $P$. waylandi from the Oligocene-Miocene series of Washington should also probably be included in the Oligocene fauna. 
The following species have been found in the San Lorenzo formation at the type locality, or within a radius of four or five miles from it:

List of San Lorenzo formation (Oligocene) fossils.

[Those marked with an asterisk (*) have been found at the type locality.]

BRACHIOPODA.

Terebratula cf. nitens Conrad.

PELECYPODA.

Arca sp. A.

*Callista angustifrons Conrad.

Callista sp. A.

Cardium (cf.) breweri Gabb.

Cardium (Lævicardium?) n. sp.

Corbula sp. A.

Cytherea (cf.) vespertina Conrad.

Cytherea sp. A.

Leda, 3 sp., A, B, and C.

Macoma nasuta Conrad.

* Macoma, 2 sp., A and B.

Modiolus (aff.) rectus Conrad.

* Modiolus n. sp.?

Neæra (aff.) pectinata Cpr.

* Nucula n. sp. A.

Nucula n. sp. A var.

Ostrea (cf.) idriaensis Gabb.

Panopea (cf.) generosa Gould.

Pecten peckhami Gabb.

Pecten sanctæcruzensis n. sp.

Phacoides acutilineatus Conrad.

Phacoides (Myrtea?) n. sp.

Solemya ventricosa Conrad yo.?.

Solen n. sp. (aff.) curtus Conrad.

*Tellina (cf.) arctata Conrad.

*Tellina (cf.) oregonensis Conrad.

Thracia (aff.) trapezoides Conrad.

Thyasira n. sp. *
PELECYPODA-continued.

Venus (cf.) lenticularis Gabb.

Yoldia impressa Conrad.

Actæon sp. A.

Astyris n. sp. A.

Bela clathrata Gabb.

Crepidula prærupta Conrad?

* Cylichna (aff.) petrosa Conr. or horni Gabb.

* Dentalium near substriatum Conr. or cooperi Gabb.

* Dentalium n. sp. A.

Dolium? n. sp.?.

Fusus (cf.) mathewsonii Gabb.

* Fusus (ef.) oregonensis Conrad.

Fusus (aff.) thracius Conrad.

* Fusus, 3 n. sp., A, B, and C.

Fusus or Perissolax sp. A.

Galerus excentricus Gabb.?

Galerus (aff.) mammillaris Brod.

*Lunatia (cf.) shumardiana Gabb.

Natica sp. A.

Neverita saxea Conrad.

* Pleurotoma (aff.) raricostata Gabb.

Pleurotoma, 2 sp., A and B.

Scala (Opalia) sp. A.

Sigaretus scopulosus Conrad.

Solarium (aff.) amoenum Conrad.

*Solarium n. sp. A.

CEPHALOPODA.

Aturia ziczac Sowerby (?).

\section{MIOCENE.}

Three divisions are commonly recognized in the Miocene of California, the lower (Vaqueros), middle (Monterey), and upper (San Pablo). At certain localities the relations existing between these three divisions are very clear, while at others they are obscure, and at still others it appears as if the lower two are interbedded with each other to a greater or less extent. In the vicinity of Mount Diablo, Doctor Merriam is able to differentiate a fourth division lying between the Monterey shale and the San Pablo, which he calls the Contra Costa County Miocene, and which is characterized, according to him, ${ }^{a}$ by Clypeaster (?) brewerianus, Trochita costellata, several new species of Modiolus, ete. This last horizon has not as yet been recognized outside of the Mount Diablo Range.

$a$ Merriam, J. C., Bull. Dept. Geol. Univ. Cal., vol. 3, No. 16, 1904, p. 378. 


\title{
VAQUEROS SANDSTONE.
}

TYPE LOCALITY.

The type locality is Los Vaqueros Valley, Monterey County, Cal.

\author{
NAME AND DESCRIPTION.
}

This formation name was suggested by Mr. Homer Hamlin and first used by Dr. H. W. Fairbanks in the descriptive text of the San Luis folio (California), 1904, p. 3.

\section{DEFINITION.}

The Vaqueros sandstone lies conformably beneath the Monterey shale and rests conformably upon the San Lorenzo formation and unconformably upon the Tejon (Eocene) or older formations. It varies in thickness in different localities, its maximum being between 2,000 and 3,000 feet.

Martinez, Contra Costa County.

\section{LOCALITIES.}

Mount Diablo Kange in Contra Costa and Alameda counties.

Santa Cruz Mountains, in San Mateo, Santa Clara, and Santa Cruz counties (Mindego Creek, Stevens Creek, Boulder Creek, etc.).

Los Vaqueros Valley and Santa Lucia Range, Monterey County.

Lynchs Mountain, Corral de Piedra Creek, Hazzard Canyon, Morro Creek, La Panza, and Toro Creek San Luis Obispo County.

Barker's ranch (Kern River), Poso Creek, San Emidio Canyon, 6 miles southeast of Annette, and Avenal Canyon, Kern County.

San Miguel Island and Santa Inez Mountains, Santa Barbara County.

Ojai Valley, Sespe oil district, and Santa Monica Mountains, Ventura County.

Santa Monica Mountains, Eagle Rock Valley, and Pasadena, Los Angeles County. (This formation may also be younger than the Vaqueros.)

Santa Ana Mountains and El Toro, Orange County.

Carrizo Creek, San Diego County (?). (Probably younger than the Vaqueros.)

According to Merriam, the lower Miocene or Agasoma zone occurs in Oregon, and the same horizon is probably represented still farther north by a part of the Oligocene-Miocene series of Washington.

\section{FAUNA.}

The Vaqueros has a very characteristic fauna, consisting of numerous forms peculiar to itself besides many species found in the overlying formations. A few Vaqueros species are found in the transitional beds between it and the San Lorenzo (Oligocene), but none of the members of its fauna, so far as known, reach into the Tejon (Eocene). On account of the occurrence of species of the peculiar genus Agasoma in the lower Miocene, Doctor Merriam has given it the appropriate name "Agasoma zone." $a$ He has tentatively divided this into two stages; the probably lower of the two characterized by Turritella hoffmanni and the upper by Turritella ocoyana. No differentiation of the two stages is attempted in this paper.

Pecten fauna.-The Pecten fauna of the Vaqueros sandstone or Agasoma zone is a large one and consists of the following species: $P$. andersoni, $P$. andersoni

\footnotetext{
$a$ Bull. Dept. Geol. Univ. Cal., vol. 3, 1904, p. 378.
} 
var. barkerianus, $P$. bowersi, $P$. branneri, $P$. crassicardo and its variety hamiltoni, P. (Hinnites) giganteus, P. estrellanus, P. magnolia, P. miguelensis, P. peckhami, $P$. perrini, $P$. sespeensis and its variety hydei, $P$. sanctroruzensis, and $P$. vaughani.

The following species are of uncertain stratigraphic standing; some or all of them may extend into the lower Miocene: $P$. carrizoensis, $P$. cerrosensis var. mendenhalli, $P$. deserti, $P$. fucanus, $P$. hamlini, $P$. keepi, $P$. neahensis, $P$. nutteri, $P$. propatulus, and $P$. stanfordensis.

The following is the fauna (with the exception of Pecten) found in the Vaqueros sandstone of central California:

List of Vaqueros sandstone (lower Miocene) fossils.

[Those marked with an asterisk (*) are supposed to be characteristic of this horizon.]

ECHINOIDEA

Scutella fairbanksi Merriam.

BRACHIOPODA.

*Terebratella (?) n. sp., A.

PELECYPODA.

Angulus (cf.) buttoni Dall.

Arca (cf.) canalis Conrad.

Arca microdonta Conrad.

(*?)Cardium (Trachycardium) n. sp., A.

Chione succincta Valenciennes (?).

*Chione mathewsonii Gabb.

Chione n. sp., A (very large).

*Corbula (cf.) evansiana Shumard.

*Dosinia conradi Gabb.

*Dosinia mathewsonii Gabb.

Dosinia (cf.) montana Conrad.

Dosinia (aff.) ponderosa Gray.

*Glycymeris n. sp. A (very large).

Leda taphria Dall.

*Leda sp.?.

Macoma (cf.) calcarea Gmelin.

Macoma nasuta Conrad.

Mactra californica Conrad (?).

Mytilus mathewsonii Gabb.

*Ostrea (aff. ) titan Conrad.

Panopea generosa Gould?.

Pecten (see previous list).

*Periploma n. sp. A.

Phacoides acutilineatus Conrad.

Phacoides richthofeni Gabb.

*Pinna alamedensis Yates.

Psammobia edentula Gabb.

Saxidomus gibbosus Gabb.

Solen sicarius Gould.

Tapes truncata Gabb.

*Tellina n. sp. A (aff.) bodegensis Hinds.

Tellina sp.

*Tirela ineziana Conrad.

Venus pertenuis Gabb.

*Yoldia n. sp. A (aff.) cooperi Gabb.
GASTEROPODA.

*Acmra n. sp. A.

*Actæon n. sp. A.

* Agasoma barkerianum Cooper.

*Agasoma (cf. ) gravida Gabb.

*Agasoma kernianum Cooper.

Astyris n. sp. (aff.) tuberosa Cpr.

*Calliostoma n. sp. B.

*Chlorostoma n. sp. A.

*Conus n. sp. A.

Crepidula princeps Conrad.

*Cuma biplicata Gabb.

*Dentalium n. sp., B.

*Fissuridea n. sp., A.

*Fusus sp. A.

Galerus (aff.) excentricus Gabb.

Galerus mammillaris Brod. (?)

Megatebennus bimaculatus Dall.

Nassa (cf.) mendica Gould.

* Natica ocoyana Conrad.

Neverita callosa Gabb.

*Ocinebra (aff.) lurida Midd.

Olivella pedroana Conrad.

*Pyrula (?). sp.

Sigaretus scopulosus Conrad.

*Solarium sp.

*Tritonium sp.

Trochita costellata Conrad (?)

Trophon ponderosum Gabb.

*Turritella hoffmanni Gabb.

*Turritella ocoyana Conrad.

*Turritella variata Conrad.

CRUSTACEA.

Balanus estrellanus Conrad.

PISCES.

*Galeocerdo productus Agassiz.

* Lamna clavata Agassiz.

*Oxyrhina tumula Agassiz. 
MONTEREY SHALE.

TYPE LOCALITY.

The type locality is vicinity of Monterey, Monterey County, Cal.

NAME AND DESCRIPTION.

This formation was named and described by William P. Blake in Proceedings of the Academy of Natural Sciences of Philadelphia, vol. 7, 1855, pp. 328-331.

DEFINITION.

In describing the shale beds in the vicinity of Monterey Blake has the following to say regarding the stratigraphic relations: "This interesting formation, teeming with the skeletons of microscopic organisms, appears to overlie and to be conformable with the Tertiary strata that underlie a part of the town of Monterey and extend to and beyond the mission of San Carlos. These strata rest upon a porphyritic granite, which forms the projection of the coast called Point Pinos, and is the bulwark of the bay." The only fossils mentioned by Blake as occurring in the formation are: Tellina congesta Conrad, Lutraria traskii Conrad, and diatoms belonging to the genus Coccinodisous.

The term "Monterey shale," as now accepted, applies to the very characteristic shale formation typically developed in the Santa Lucia and Santa Cruz ranges. It sometimes attains a thickness of over 2,000 feet, and at some localities is interbedded with layers of sandstone or thin strata of a rather impure limestone. The formation is underlain conformably by the Vaqueros sandstone at most localities, but at a few it rests directly upon older rocks. In some places the line of demarcation between the Vaqueros and Monterey is very distinct, while at others the beds seem to merge into each other through a series of alternating sand and shale layers. As suggested by Doctor Lawson, the shale probably has an inshore equivalent of sandstone, whose fauna is doubtless entirely different from that of the shale and probably shows a marked resemblance to that of the underlying Vaqueros and overlying Contra Costa County Miocene. Following the deposition of the Monterey came the great upheaval along the coast which resulted in the elevation of the shales and their subsequent erosion. As a result of this a line of marked unconformity generally separates the Monterey from the overlying formations.

LOCALITIES.

Southeast of Pinole, Contra Costa County.

Langley Hill and Alpine district, San Mateo County.

Castle Rock Ridge, Santa Clara County.

Castle Rock Ridge, vicinity of Ben Lomond, Felton, Gibbs, and Santa Cruz, Santa Cruz County.

Monterey, Carmelo Valley, and Santa Lucia Range, Monterey County.

Big Panoche Creek to Kreyenhagens, Fresno County.

Templeton, Atascadero, Lopez Canyon, Point Buchon to near mouth of Davis Canyon, northeast of Arroyo Grande, and other localities in San Luis Obispo County.

Northwest of Tulare Lake, Tulare County. 
McKittrick district, Kern County.

Ojai ranch and vicinity, Ventura County.

Santa Inez Mountains, Santa Barbara County.

San Pedro, Santa Monica Mountains, and east of Los Angeles, Los Angeles County.

\section{FAUNA.}

The fauna of the Monterey shale is quite limited, and the fossils are generally preserved only in the form of casts or molds. Pecten peckhami is one of the most abundant fossils, but as it is not confined to the Monterey its value as an agent of correlation is only nominal. The most characteristic species appear to be Arca montereyana and a large, coarse-sculptured Leda.

Pecten fauna.-The Pecten fauna of the Monterey (including such species as are found both below and above it, or in its included sandstones, but which, on account of habitat, are not found in the typical shale) is as follows: P. andersoni, $P$. crassicardo, $P$. estrellanus, $P$. (Hinnites) giganteus, $P$. pedroanus, and $P$. peckhami.

The following species have a more or less uncertain stratigraphic status, and some or all of them may extend into or through the Monterey or its equivalents: $P$. bowersi, $P$. carrizoensis, $P$. cerposensis var. mendenhalli, $P$. discus, $P$. fucanus, P. keepi, P. lompicoensis, P. neahensis, P. nutteri, P. perrini, P. propatulus, and $P$. stanfordensis.

The following species have been found in the Monterey shale near the type locality or in the Santa Cruz Mountains, just to the north and across Monterey Bay from it.

List of Monterey shale (middle Miocene) fossils.

[Those marked with an asterisk (*) are supposed to be characteristic.]

PELECY PODA.

* Arca montereyana Osmont. Callista angustifrons Conrad.

Chione mathewsonii Gabb.

* Corbula sp., probably new.

Cytherea sp. A.

* Diplodonta n. sp. (aff.) serricata Reeve.

* Glycymeris (?) n. sp.

* Leda n. sp. A.

* Leda n. sp. B.

* Lutraria traskii Conrad.

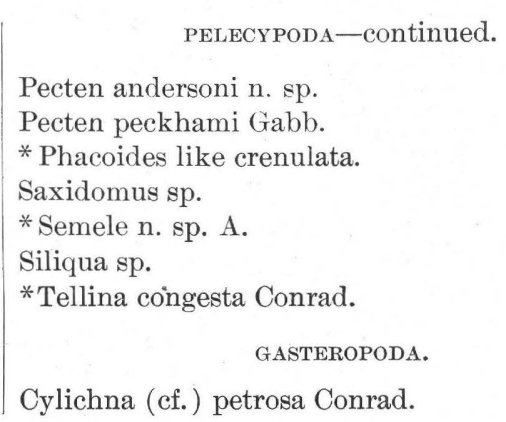

The fauna of the Carrizo (reek beds, which are undoubtedly Miocene but of uncertain horizon, belongs to an entirely separate biologic province from that of the principal California Miocene, and for that reason has few species in common with any of the other known California deposits. The following is a list of the fossils so far recognized from the Carrizo Creek beds. (See also list of fossils from Santa Rosalia, Lower California, under Pecten cerrosensis var. mendenhalli, p. 85.) 
List of fossils from the Carrizo Creek beds (Miocene).

ANTHOZOA.

Diploria bowersi Vaughan (Mss.).

Favia merriami Vaughan.

Plesiastrea californica Vaughan (Mss.).

Siderastrea californica Vaughan (Mss.).

Stephanocoenia fairbanksi Vaughan.

Stephanocoenia fairbanksi var. columnaris Vaughan.

ECHINOIDEA.

Clypeaster bowersi Merriam.

\section{PELECY PODA.}

Anomia subcostata Conrad.

Arca n. sp. (?) A.

Cardium (Trachycardium) n. sp. (aff.) quadrigenarium Conrad.

Dosinia sp., perhaps new.

Gastrochæna sp.

Lithophaga sp.
PELECYPODA-continued.

Ostrea vespertina Conrad.

Pecten carrizoensis n. sp.

Pecten cerrosensis var. mendenhalli n. var.

Pecten deserti Conrad.

Pecten (Hinnites) giganteus Gray.

Pecten keepi n. sp.

Phacoides (cf.) acutilineatus Conrad.

Pholas (aff.) crucigera Sowerby.

GASTEROPODA.

Cypræa sp. indet., large and probably new. Malea (+Dolium) near ringens Sowerby. Oliva (?) sp. indet.

Polynices (Neverita) recluziana Deshayes. Strombus n. sp. (aff.) granulatus Sowerby. Strombus (?) n. sp. B.

Tivela (cf.) ineziana Conrad.

Turritella (cf.) hoffmanni Gabb.

\section{SAN PABLO FORMATION.}

TYPE LOCALITY.

The type locality is south side of San Pablo Bay, near Union oil refinery, Contra Costa County, Cal.

\section{NAME AND DESCRIPTION.}

The formation was named and described by Dr. J. C. Merriam, in Bulletin of the Department of Geology, University of California, vol. 2, No. 4, 1898, p. 113 et seq.

DEFINITION.

The formation at the type locality consists of a series of sandstones, tuffs, and ashes with an approximate total thickness of between 1,500 and 2,000 feet. At this locality it rests apparently conformably upon the Contra Costa County Miocene. In the Salinas Valley, and at many other places, formations which are probably the equivalents of the San Pablo rest unconformably upon the Monterey shale. In the Santa Cruz quadrangle, beds containing the supposedly characteristic San Pablo echinoderm, Astrodapsis tumidus Rémond, rest unconformably upon the Monterey, and are overlain conformably by at least a part of the Purisima (lower Pliocene).

\section{LOCALITIES.}

San Pablo Bay, Walnut Creek, and Kirkers Pass, Contra Costa County.

Scott Valley, Santa Cruz County.

San Ardo and other localities in the Salinas and adjacent valleys, Monterey County.

Coalinga and vicinity, Fresno County.

Estrella Valley; Santa Margarita and vicinity, 3 miles east of La Panza, Cammatta ranch, Music P. O., and Pismo and vicinity, San Luis Obispo County.

Santa Catalina Island, Los Angeles County. 
FAUNA.

Doctor Merriam, in his original definition of the San Pablo formation, says: ${ }^{a}$ "The series of strata characterized by the presence of Astrodapsis and Scutella (Clypeaster) gabbi may, with reference to its more important features, be treated as a distinct formation, and will be referred to in this paper as the San Pablo formation." By definition, therefore, the formation is limited in a general way to the zones of the above-mentioned echinoderms. In most of the localities where the formation has been recognized, at least one of these forms has generally been detected. Ostrea titan, Tamiosoma gregaria, Pseudocardium gabbi, Chorus belcheri, a small Ocinebra, and several species of. Pecten are also commonly found in its fauna.

According to Merriam the fauna of the San Pablo is known so far by about fifty species, of which nearly one-third are peculiar to this formation, about onefourth are known also from the Contra Costa County Miocene, and one-sixth from the Merced; while of the total number a little less than one-half are extinct. The writer has noted several San Pablo species extending down into the Vaqueros (lower Miocene); while his estimate of the extinct species is about 65 per cent, rather than a little less than 50 per cent as given by Merriam.

Pecten fauna.-The Pecten fauna of the San Pablo, and its supposed equivalents in age, consists of the following species: Pecten andersoni, P. coosensis, P. crassicardo and its variety hamiltoni, $P$. discus, $P$. eldridgei, $P$. estrellanus and vars. catalinx and terminus, P. (Hinnites) gigantens, P. hastatus var. hericius, P. nutteri, P. oweni, P. pabloensis, P. pedroanus.

The following species of more or less uncertain status may occur in the San Pablo or its equivalents: P. carrizoensis, $P$. cerrosensis var. mendenhalli, $P$. dilleri, $P$. fucanus, $P$. keepi, $P$. neahensis, $P$. propatulus.

The following fossils have been found in the San Pablo formation at San Pablo Bay, Kirker Pass, and other localities in the Mount Diablo region.

List of San Pablo formation (upper Miocene) fossils. ${ }^{b}$

[Those marked with an asterisk (*) have been found by the writer at the type locality; those followed by (C) are supposed to be characteristic, and those followed by $(\mathrm{L})$ also oceur in the recent fauna of the coast.]

ECHINOIDEA.

*Asterias rémondi Gabb $(\mathrm{C})$.

*Astrodapsis tumidus Rémond (C).

*Astrodapsis whitneyi Rémond (C).

Astrodapsis n. sp. Merriam (C).

Scutella (Clypeaster) gabbi Rémond (C).

\section{PELECYPODA.}

*Cardium (cf.) quadrigenarium Conrad (L). Cyrena californica Gabb.

Dosinia ponderosa Gray (L).

Gari alata Gabb (C).

*Glycymeris (+Axinea) sp.
PELECY PODA-continued.

Macoma nasuta Conrad (L).

* Mactra californica Conrad (?) (L).

Mactra falcata Gould (L).

Modiolus sp. (C ?).

*Mulinia densata Gabb (C).

Mytilus sp. (C ?).

Ostrea bourgeosii Gabb (C).

Ostrea titan Conrad (C).

* Pecten andersoni n. sp.

* Pecten pabloensis Conrad (C).

* Pecten crassicardo Conrad.

Pinna alamedensis Yates.

a Merriam, J. C., 1898, p. 113.

b Turner, H. W., Jour. Geol., vol. 6, pp. 483 et seq., from which a part of this list is copied. 
List of San Pablo formation (upper Miocene) fossils-Continued.

PELECYPODA-continued.

Pseudocardium gabbi Rémond. * Saxidomus gracilis Gould (L). Solen sp.

Tapes staminea Conrad (L). Tapes staleyi Gabb (?).

* Tresus nuttalli Conrad (L).

* Zirphæa sp. (C?)

* Acmæa sp. (C).

GASTEROPODA.

Bittium asperum Gabb (L).

Calliostoma n. sp. (?) Merriam (C ?).

* Chlorostoma (?) sp. (C ?).

Crepidula adunca Sowerby (L).

Crepidula princeps Conrad ? (L).
GASTEROPODA-continued.

Fusus (?) sp. (C ?).

Litorina rémondi Gabb (C).

Litorina planaxis Phil. (L).

Lunatia lewisii Gould (L).

* Ocinebra (aff.) cancellina Philippi (C).

Ocinebra lurida Middendorf (?) (L).

* Olivella pedroana Conrad (L).

* Opalia sp. (C?).

Purpura canaliculata Duclos (L).

Purpura saxicola Valenciennes (L).

Ranella ealifornica Hinds (L).

*Tritonium (Priene ?) sp. (C ?).

*Trochita filosa Gabb.

Trochita n. sp. Merriam (C).

Trophon ponderosum Gabb.

In addition to the above the following species have been found in the Santa Margarita formation (probable equivalent of the San Pablo) in the Salinas Valley, Monterey County, and southward:

List of Santa Margarita formation (= San Pablo) fossils from Salinas Valley and southward.

$$
\text { ECHINOIDEA. }
$$

Astrodapsis tumidus Rémond.

Cidaris spines and fragments of tests.

$$
\text { PELECY PODA. }
$$

Arca canalis Conrad.

Arca (cf.) microdonta Conrad. Cardium (cf.) meekianum Giabb.

Cardium (cf.) quadrigenarium Conrad.

Chione n. sp. (large; coarse sculpture).

Chione sp. (medium sized).

Glycymeris (cf.) patulus Conrad.

Lima sp.

Mactra (cf.) californica Conrad.

Mactra (cf.) falcata Gould.

Mytilus sp. (very large).

Ostrea attwoodi Gabb.

Ostrea bourgeoisii Rémond.

Ostrea titan Conrad.

Pecten crassicardo Conrad.

Pectén discus Conrad.

Pecten eldridgei n. sp.

Pecten estrellanus Conrad.

Pecten estrellanus var. terminus n. var.
PELECYPODA-continued.

Pecten hastatus Sby. var. hericius Gould.

Pecten oweni n. sp.

Phacoides acutilineatus Conrad.

Pseudocardium (cf.) gabbi Rémond.

Saxidomus (cf.) gibbosus Gabb.

Solen sicarius Gould.

Tresus sp.

Venus pertenuis Gabb.

Astyris sp.

GASTEROPODA.

Chorus belcheri Hinds.

Fusus (aff.) robustus Trask.

Nassa sp.

Natica or Neverita sp.

Ocinebra (aff.) cancellina Philippi.

Olivella (cf.) pedroana Conrad.

Pisania n. sp. (aff.) fortis Carpenter.

Trochita filosa Gabb.

Turritella sp.

CRUSTACEA.

Balanus estrellanus Conrad.

Tamiosoma gregaria Conrad. 
PLIOCENE.

Two more or less distinct faunal zones are recognizable in the Pliocene; the lower characterized by many forms identical to or closely related to those of the Miocene; while the upper appears to lack these older species and contains but comparatively few forms which are not found living at the present time. The fauna of the Purisima formation is characteristic of the lower horizon, while that of the Merced represents the upper.

PURISIMA FORMATION.

TYPE LOCALITY.

The type locality is in the vicinity of the mouth of Purisima Creek, San Mateo County, Cal.

NAME AND DESCRIPTION.

This formation was named and described by H. L. Haehl and Ralph Arnold in Proceedings of the American Philosophical Society, vol. 43, No. 175, 1904, pp. $22-24$.

\section{DEFINITION.}

The Purisima formation consists of a series of conglomerates, fine sandstones, and sandy shales, with a total thickness of about 800 feet, and is typically developed in the vicinity of the lower portion of Purisima Creek, San Mateo County. The formation also covers a considerable territory in other parts of the Santa Cruz quadrangle, especially that portion of the area adjacent to the coast and north of Pescesdero Creek. Beds of age probably equivalent to at least a part of the Purisima are known from the Cholame Valley, Monterey County, and elsewhere south of the type locality. At least a portion of the beds on Eel River, Humboldt County, are doubtless the equivalent of the Purisima. As pointed out by Ashley, ${ }^{a}$ the Purisima formation (his "Transition beds") and its probable equivalents appear in their lower portions to be more or less transitional toward the Miocene.

Much uncertainty exists in the mind of the writer as to the exact relation existing between the Purisima and San Pablo formations. After a careful examination of a large amount of material from the type localities of the two formations and also from supposedly equivalent formations in the Salinas Valley and adjacent regions, supplemented by field studies at most of the localities from which the material was obtained, it appears evident that the two formations are quite intimately related. Just exactly what the nature of this relation is, however, has not yet been determined. It is a complex problem, and is one which will require much careful field and laboratory study for its solution. The Purisima fauna, taken as a whole, appears to be younger than the aggregate San Pablo fauna, and for the sake of convenience will be tentatively considered as the later of the two. 
The greater part of the San Pablo should, without question, be placed in the Miocene, while the major portion of the Purisima is undoubtedly Pliocene. In accordance with these facts each formation has been arbitrarily placed in that epoch with which it appears to be the more closely allied.

Crescent City, Del Norte County.

\section{LOCALITIES.}

Eel River, Humboldt County.

Tomales Bay, Marin County.

Halfmoon Bay to Pescadero Creek, vicinity of La Honda, Alpine district, and ridge west of Portola Valley, San Mateo County.

Near mouth of Stevens Creek, Santa Clara County.

West branch of Soquel Creek and Scott Valley, Santa Cruz County.

Cholame Valley, Lewis Creek, and Priest Valley, Monterey County.

Vicinity of Coalinga, Kreyenhagens, and the Kettleman Hills, Fresno County.

Cosmalia, Santa Barbara County.

Temescal Canyon in Santa Monica Mountains, Third street and Broadway tunnels in Los Angeles, and San Fernando tunnel, Los Angeles County.

Olinda, Orange County.

Cerros Island, off the coast of Lower California, Mexico.

The formations exposed at the following localities probably represent the upper part of the Purisima and the lower part of the Merced, and correspond to Dall's San Diego formation:

Santa Barbara and Rincon asphalt mine, Santa Barbara County; Piru Creek and Eureka Canyon, Ventura County; Santa Monica Canyon and San Pedro, Los Angeles County; San Juan Capistrano, Orange County; San Diego and Pacific Beach, San Diego County.

\section{FAUNA.}

The fauna of the Purisima in central California contains a few species which extend into the Vaqueros (lower Miocene), many more which are common to it and to the San Pablo (upper Miocene), and a large number which are found in the Merced above it or are living at the present time. A number of the species common to the San Pablo and the Purisima are not found in the Merced or later, while a large number of the species found in both the Merced and the Purisima do not extend into the San Pablo, so far as known. Quite a number of the forms found in the Purisima are peculiar to this formation. Of the total Purisima fauna, about 30 per cent are believed to be extinct.

The fauna of the "Wildcat" series of Humboldt County, as determined by Merriam and given by Lawson, ${ }^{a}$ indicates the probable contemporaneity of at least a part of this series with the Purisima. The lower part of the San Diego formation probably represents the middle and upper portions of the Purisima.

Pecten fauna.-The Pecten fauna of the Purisima and supposed equivalent formations is as follows: P. ashleyi, P. auburyi, P. bartschi, P. bellus, P. bellilamellatus, $P$. caurinus, $P$. cerrosensis, $P$. coalingaensis, $P$. cooperi, $P$. dilleri, $P$. estrellanus var. catalinæ, P. (Hinnites) giganteus, P. hastatus and its varieties hericius, hindsii, navarchus, strategus, $P$. healeyi, $P$. hemphilli, $P$. islandicus, $P$. jordani, $P$. latiau- 


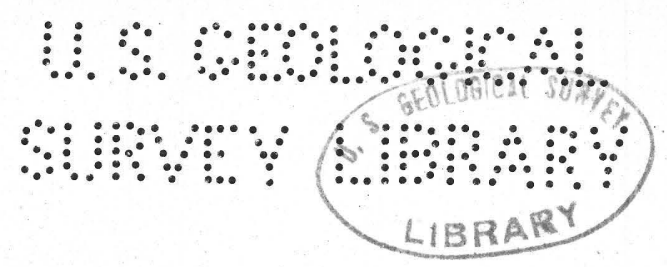

PLIOCENE FORMATIONS.

ritus, P. lawsoni, P. lecontei, $P$. merriami, $P$. nutteri, P. opuntia, $P$. oweni, $P$. parmeleei, $P$. pedroanus, $P$. purisimaensis, $P$. riversi, $P$. stearnsii, $P$. turneri, $P$. veatchii, $P$. washburnei, $P$. wattsi, and $P$. wattsi var. morani.

The following species have been found in the Purisima formation at different localities in the Santa Cruz quadrangle:

List of Purisima formation (lower Pliocene) fossils.

[Those species marked with an asterisk (*) are supposed to be characteristic; those followed by (M) are also found in the Miocene; those by $(\mathrm{N})$ in the Merced, and those by $(l)$ are still living.]

ECHINOIDEA.

Astrodapsis n. sp. Merriam.

Scutella interlineata Stimpson.

BRACHIOPODA.

Glottidia albida Hinds.

PELECYPODA.

Arca canalis Conrad (M).

Arca trilineata Conrad (M).

Callista angustifrons Conrad (M) (l? ?).

Cardium meekianum Gabb (M ?).

* Cardium meekianum Gabb n. var. A.

Chione gnidia Broderip and Sowerby $(l)$.

Chione sp.

Clidiophora punctata Conrad $(l)$.

Corbula sp.

Cryptomya californica Conrad $(l)$.

* Cryptomya n. sp. A. (aff. californica Conrad).

Dosinia ponderosa Gray $(l)$.

Dosinia sp.

* Lævicardium n. sp. (aff. substriatum Conrad).

Leda (cf.) fossa Baird ( $l$ ?).

Leda taphria Dall $(l)$.

Macoma calcarea Gmelin $(l)$.

Macoma inquinata Deshayes $(l)$.

Macoma nasuta Conrad (l.).

Mactra californica Conrad $(l)$.

Mactra hemphilli Dall $(l)$.

Modiolus rectus Conrad $(l)$.

Moerella salmonea Carpenter $(l)$.

Mytilus mathewsonii Gabb (M).

Nucula castrensis Hinds $(l)$.

Panomya ampla Dall $(l)$.

Panopea generosa Gould $(l)$.

* Pecten hastatus Sowerby (smooth var.).

* Pecten healeyi n. sp.

Pecten nutteri n. sp.

Pecten oweni n. sp.

* Pecten purisimaensis n. sp.

Phacoides acutilineatus Conrad (M).

Phacoides nuttalli Conrad $(l)$.

Saxidomus gibbosus Gabb (M).
PELECYPODA-continued.

Siliqua lucida Conrad (l).

siliqua patula Dixon $(l)$.

Spisula catilliformis Conrad $(l)$.

Spisula falcata Gould $(l)$.

Solen sicarius Gould.

Tapes staleyi Gabb (N) (M?).

Tapes tenerrima Carpenter $(l)$.

Tellina (cf.) congesta Conrad (M).

* Tellina n. sp., A.

Tresus nuttalii Conrad (M).

Venus pertenuis Gabb (M).

Yoldia cooperi Gabb $(l)$.

Yoldia scissurata Dall $(l)$.

Zirphæa gabbi Tryon (l).

GASTEROPODA.

Admete gracilior Carpenter (N).

Astyris californiana Gaskoin $(l)$.

Astyris gausapata Gould ( $(l)$.

Astyris richthofeni Gabb $(\mathrm{N})$.

Bittium asperum Gabb $(l)$.

Boreotrophon pacificus Dall $(l)$.

*Buccinum n. sp. A.

*Calliostoma n. sp. A.

Chrysodomus liratus Martyn (l).

Chrysodomus tabulatus Baird $(l)$.

*Chrysodomus n. sp. A.

Crepidula princeps Conrad (M) (N).

Crepidula navicelloides Nuttall $(l)$.

Crepidula (cf.) onyx Sowerby $(l)$.

Crepidula rugosa Nuttall.

*Dolichotoma n. sp. (aff. carpenteriana Gabb).

Drillia incisa Carpenter $(l)$.

*Fusus n. ap. (aff. rugosus Trask).

*Galerus inornatus Gabb.

Leptothyra paucicostata Dall (l).

Lunatia lewisii Gould $(l)$.

Nassa californiana Conrad (N).

Nassa mendica Gould (l).

Nassa perpinguis Hinds $(l)$.

Natica clausa Broderip and Sowerby $(l)$.

*Neptunea humerosa Gabb. 


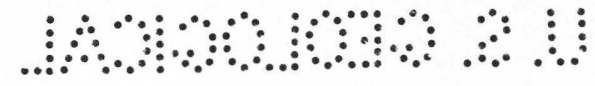

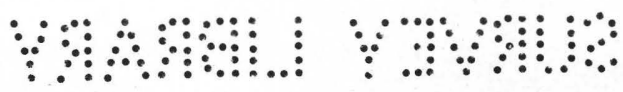

List of Purisima formation (lower Pliocene) fossils-Continued.

GASTEROPODA-continued.

Neverita recluziana Petit $(l)$.

Olivella intorta Carpenter $(l)$.

Pleurotoma perversa Gabb $(l)$.

Pleurotoma sp.

Priene oregonensis Redfield $(l)$.

Purpura crispata Chemnitz $(l)$.

Rostellaria indurata Conrad (M).

Serpulorbis squamigerus Carpenter $(l)$.
GASTEROPODA-continued.

Sigaretus debilis Gould $(l)$.

Solariella peramabilis Carpenter $(l)$.

Tornatina culcitella Gould $(l)$.

Tritonium sp.

*Voluta n. sp. (?) A.

CRUSTACEA.

Balanus estrellanus Conrad (M).

The San Diego formation in a general way is the representative of the Purisima in southern California, although the former, at least the fossiliferous horizon, may not extend as far back in the time scale as the base of the latter. The fauna of the San Diego formation as developed in the type section at Pacific Beach, north of San Diego, San Diego County, is as follows:

List of San Diego formation fossils.

[Those marked with an asterisk (*) are supposed to be extinct.]

ECHINOIDEA.

Echinarachnius excentricus Eschscholtz. Strongylocentrotus purpuratus Stimpson.

BRACHIOPODA.

Laqueus jeffreysi Dall.

PELECY PODA.

Leda taphria Dall.

Macoma nasuta Conrad.

Mactra (Spisula) catilliformis Conrad.

Metis alta Conrad.

Modiolus rectus Conrad.

Ostrea veatchii Gabb.

Pecten ashleyi n. sp.

Pecten bellilamellatus $\mathrm{n}$. sp.

Pecten cerrosensis Gabb.

Pecten cooperi n. sp.

Pecten hastatus Sowerby.

Pecten hastatus var. hericius Gould.
PELECYPODA-continued.

Pecten hastatus var. navarchus Dall.

Pecten healeyi n. sp.

Pecten hemphilli Dall.

- Pecten opuntia Dall.

Pecten stearnsii Dall.

Phacoides acutilineatus Conrad.

Phacoides nuttalli Conrad (=Lucina id.).

Pododesmus macroschisma Deshayes.

Tapes staminea Conrad.

GASTEROPODA.

Crepidula princeps Conrad.

Dentalium neohexagonum Sharp and Pilsbry.

Neverita recluziana Petit.

Opalia anomala Stearns.

Opalia varicostata Stearns.

Purpura crispata Chemnitz.

Scala stearnsii Dall.

Scala tincta Carpenter.

Turritella cooperi Carpenter.

MERCED FORMATION.

TYPE LOCALITY.

The type locality is the sea cliff south of Lake Merced, San Mateo County, Cal.

NAME AND DESCRIPTION.

This formation was named and described by A. C. Lawson, in Bulletin of the Department of Geology, University of California, vol. 1, No. 4, 1893, pp. 142 et seq. 


\section{DEFINITION.}

The type section of the Merced formation consists of a series of rather soft, gray sandstones and sandy shales, interbedded with hard pebbly conglomerates, hard well-cemented shell layers, and occasional lignitic seams. The total thickness of the formation is approximately 5,000 feet. In age the Merced probably represents the upper Pliocene and lower Pleistocene, although there is no apparent unconformity in the type section, which is certainly Pliocene at the base and Pleistocene at the top.

\section{LOCALITIES.}

Mytilus beds, Shoalwater Bay, Oreg. (Dall, 1898, p. 336).

Upper portion of the "Wildcat formation," Eel River, Humboldt County (?).

Sea cliffs south of Lake Merced and foothills between them and Twelvemile Creek; north of Pillar Point; uppermost beds in sea cliff at mouth of Año Nuevo Creek, San Mateo County.

Felt Lake, near Stanford University, Santa Clara County.

Uppermost beds at Capitola, Santa Cruz County.

Beds at Bath House Beach and at least a portion of Packards Hill beds, Santa Barbara, Santa Barbara County.

Old irrigating ditch north of Ventura, Ventura County.

Pliocene and lower portion of San Pedro formation, Deadman Island and San Pedro; Santa Monica Canyon, Los Angeles County.

San Juan Capistrano, Orange County.

Upper portion of San Diego formation, Pacific Beach, and San Diego, San Diego County.

FAUNA.

The fauna of the lower beds in the Merced formation indicates clearly their Pliocene age, while at the top the fossils show the Pleistocene origin of this part of the formation. In using "Merced" in its broader sense as a horizon name in the California column it is deemed advisable to confine it, in a general way, to that period of the standard geologic scale (viz, the Pliocene) to which the great bulk of the sediments of the formation belong. In correlating, however, the equivalence of the lower portion of the next higher formation (the San Pedro) to the upper portion of the Merced should be borne in mind.

Pecten fauna.-No Pectens have so far been recorded from the type section of the Merced, although beds of probable equivalent age to the Pliocene portion of it have yielded the following species: P. ashleyi, P. bellus, P. bellilamellatus, $P$. caurinus, P. cerrosensis, P. cooperi, P. (Hinnites) giganteus, P. hastatus and its varieties hericius, hindsii, navarchus, and strategus, $P$. healeyi, $P$. hemphilli, $P$. islandicus, $P$. jordani, $P$. latiauritus, $P$. opuntia, $P$. parmeleei, $P$. riversi, and P. stearnsiz.

The following fauna has been found at or in the immediate vicinity of the type locality of the Merced formation, and may be taken as characteristic of the horizon represented by the whole formation: 
[Those unmarked have been reported from the type locality; those followed by ( $T$ ) have been found only at Twelvemile Creek or Twelvemile House; those with (F) between Mussel Roek and Twelvemile House, and those with (S) at Felt Lake, near Stanford University. Those species marked with an asterisk (*) are supposed to be extinct.]

ECHINOIDEA.

Echinarachnius excentricus Eschscholtz. * Scutella interlineata Stimpson.

PELECYPODA.

*Arca trilineata Conrad.

Cardium corbis Martyn.

* Cardium meekianum Gabb. Cardium quadrigenarium Conrad (F).

Chione succincta Valenciennes.

Cryptomya californica Conrad.

Macoma calcarea Gmelin.

Macoma inquinata Deshayes ( $\mathrm{T}$ ).

Macoma nasuta Conrad.

Macoma (like sabulosa Spngl.).

Mactra californica Conrad.

Modiolus rectus Conrad (T).

Mytilus californianus Conrad.

Mytilus edulis Linné.

Ostrea sp. ?

Pecten latiauritus Conrad (S).

Pododesmus macroschisma Deshayes.

Psephis lordi Baird.

* Saxidomus gibbosus Gabb.

Saxidomus yracilis Gould.

Siliqua patula Dixon.

Solen sicarius Gould.

Spisula falcata Gould.

* Tapes staleyi Gabb.

Tapes staminea Conrad.
PELECYPODA-continued.

Tresus nuttalli Conrad.

Venericardia ventricosa Gould.

GASTEROPODA.

Astyris gausapata Gould.

*Astyris richthofeni Gabb.

Bittium asperum Gabb.

Bittium filosum Gould.

Chrysodomus liratus Martyn.

Chrysodomus tabulatus Baird. .

Crepidula princeps Conrad.

Crepidula navicelloides Nuttall.

Drillia incisa Carpenter.

Drillia inermis Hinds.

Litorina planaxis Philippi (S).

Lunatia lewisii Gould.

Monoceros engonatum Conrad.

Margarita pupilla Gould (S).

Nassa fossata Gould.

Nassa mendica Gould.

Natica clausa Broderip and Sowerby.

Olivella biplicata Sowerby.

Olivella intorta Carpenter.

Pleurotoma sp. indet. (F).

Purpura canaliculata Ducl.

Purpura saxicola Valenciennes.

* Trochita filosa Gabb.

Turritella sp.

In southern California the Merced is represented by a somewhat different fauna from that found at the type locality. The Pliocene of Deadman Island, Los Angeles County, though representing a horizon probably a little lower than the bulk of the Merced, has a fauna which may be taken as approximately representing the Merced horizon in the southern part of the State. This Deadman Island fauna is as follows:

List of Pliocene fossils from Deadman Island.

[Those marked with an asterisk $(*)$ are believed to be extinct.]

$$
\text { ANTHOZOA. }
$$

Caryophyllia californica Vaughan.

$$
\text { BRACHIOPODA. }
$$

Laqueus jeffreysi Dall.

* Terebratalia smithi Arnold.

\section{PELECY PODA.}

Chama pellucida Sowerby. Corbula luteola Carpenter. Cumingia californica Conrad. Kellia laperousii Deshayes. Leda taphria Dall. 
List of Pliocene fossils from Deadman Island-Continued.

PELECYPODA-continued.

Lyonsia californica Conrad. Macoma calcarea Gmelin.

Macoma inquinata Deshayes.

Marcia subdiaphana Carpenter (Clementia id.)

Mytilimeria nuttalli Conrad.

Nucula castrensis Hinds.

Panomya ampla Dall.

Panopea generosa Gould.

Pecten caurinus Gould.

Pecten hastatus Sowerby.

Pecten hastatus var. hericius Gould.

Pecten hastatus var. hindsii Carpenter.

* Pecten jordani Arnold.

*Pecten stearnsii Dall.

Phacoides acutilineatus Conrad.

Phacoides californicus Conrad.

Pholadidea penita Conrad.

Protocardia centifilosa Carpenter.

Solen sicarius Gould.

* Thracia trapezoides Conrad.

Thyasira gouldii Philippi.

Thyasira bisecta Conrad.

Venericardia barbarensis Stearns.

Venericardia ventricosa Gould.

Venus (Chione) simillima Sowerby.

$$
\text { GASTEROPODA. }
$$

Acmæa insessa Hinds.

Amphissa corrugata Reeve.

Bela fidicula Gould.

Bittium asperum Gabb.

Calliostoma canaliculatum Martyn.

Calliostoma tricolor Gabb.

Cerithidea californica Haldemann.

Chlorostoma brunneum Philippi.

Chlorostoma montereyi Kiener.

Chrysodomus sp. indet.

Chrysodomus rectirostris Carpenter.

Chrysodomus tabulatus Baird.

Clathurella conradiana Gabb.

Columbella gausapata Gould.

Columbella gausapata var. carinata Hinds.
GASTEROPODA-continued.

Conus californicus Hinds.

Cryptochiton stelleri Middendorf.

* Drillia merriami Arnold.

Drillia torosa Carpenter.

Fusus barbarensis Trask.

Hipponyx antiquatus Linné.

Litorina planaxis (Nuttall) Philippi.

Mangilia sculpturata Dall.

Nassa californiana Conrad.

Nassa fossata Gould.

Nassa mendica Gould.

Nassa mendica var. cooperi Forbes.

Nassa perpinguis Hinds.

Natica clausa Broderip and Sowerby.

Neverita recluziana Petit.

Ocinebra interfossa Carpenter.

Olivella biplicata Sowerby.

Olivella intorta Carpenter.

Olivella pedroana Conrad.

* Pleurotoma bartschi Arnold.

* Pleurotoma dalli Árnold.

Pleurotoma perversa Gabb.

* Pleurotoma renaudi Arnold.

* Pleurotoma smithi Arnold.

Priene oregonensis Redfield.

Puncturella cucullata Gould.

Puncturella galeata Gould.

Scala indianorum Carpenter.

Solariella cidaris A. Adams.

Solariella peramabilis Carpenter.

* Taranis strongi Arnold.

Terebra simplex Carpenter.

Thalotia caffea Gabb.

Tornatina eximia Baird.

Trophon gracilis Perry.

Trophon pacificus Dall.

Trophon stuarti Smith.

* Trophon orpheus var. præcursor Arnold.

Trophon tenuisculpta Carpenter.

Turritella cooperi Carpenter.

* Turritella jewetti Carpenter.

\section{PLEISTOCENE.}

The marine Pliocene and Pleistocene deposits of California are intimately associated, and at many places grade into each other with no perceptible physical break between them. At others, however, an unconformity exists between the two, and in some localities the Pleistocene itself may be separated into two divisions, with a more or less distinct line of demarcation between them. Such a condition as that last mentioned is found in the vicinity of San Pedro, Los Angeles County, where 
probably the best development of the fossiliferous marine Pleistocene on the coast is exposed. This locality is taken, therefore, as the type for the Pleistocene of California.

SAN PEDRO FORMATION.

TYPE LOCALITY.

The type locality is vicinity of San Pedro, Los Angeles County, Cal.

NAME AND DESCRIPTION.

This formation was named and described by W. H. Dall, Table of North American Tertiary horizons: Eighteenth Ann. Rept. U. S. Geol. Survey, pt. 2, 1898, p. 335.

DEFINITION.

As redefined by the writer, ${ }^{a}$ this formation includes "all of the strata of Deadman Island and San Pedro lying stratigraphically above the brown Pliocene sandstone and below the raised beach formation of Deadman Island." In the type locality the San Pedro consists of a series of conglomerates and sands, both more or less incoherent and extremely, fossiliferous, with a total thickness of approximately 100 feet. Near Ventura, beds of probable similar age attain a thickness of about 1,000 feet.

The formation may be divided into two distincthorizons-a lower and an upperseparated at all points in the vicinity of the type locality by an unconformity. The lower part of the formation represents at least the base of the Pleistocene, and may possibly extend into the Pliocene. It is probably contemporaneous with the upper portion of the Merced, and contains a fauna which appears to be transitional between that of the Pliocene on which it rests and that of the characteristic Pleistocene above.

The upper beds of the San Pedro formation are certainly Pleistocene, and as their fauna is more or less characteristic it will be cited as typical of the major portion of the Pleistocene.

LOCALITIES.

Deposits contemporaneous in a general way with the San Pedro formation, particularly the upper division, occur at numerous places along the coast from Alaska to Lower California. Only those localities known to be fossiliferous will be cited, however. They are as follows:

Point Holmes, Comox, Vancouver Island, British Columbia (Newcombe).

Port Blakeley, near Seattle, Wash., and other localities in the Puget Sound country.

Fossil Point, Coos Bay, Oreg. (Dall, 1898, p. 336).

Ilwaco, near the mouth of the Columbia River, and Newport, Oreg. (Diller, 1896, p. 479 et seq.)

Fort Ross, Humboldt County.

Purisima and Punta Año Nuevo, San Mateo County.

South shore of San Pablo Bay (unconformably above the San Pablo formation), Contra Costa County. Santa Cruz, Santa Cruz County.

Vicinity of Ventura and Summerland, Ventura County.

San Pedro, Long Beach, Bells Station, and Los Cerritos Hill, Los Angeles County.

Newport, Orange County.

Two miles south of Delmar, Pacific Beach, Spanish Bight, and San Diego, San Diego County.

a Arnold, Delos and Ralph, The marine Pliocene and Pleistocene stratigraphy of the coast of southern California: Jour. Geol., vol. 10, 1902, p. 124 . 
FAUNA.

The fauna of the upper portion of the San Pedro.formation consists of species which are nearly all found living at the present time. One noticeable thing regarding this fauna is we fact that wherever found it generally contains species which, though living, are found now only south of the locality yielding the fauna; thus indicating somewhat more tropical conditions during the Pleistocene than are prevalent at the present time on the California coast.

Pecten fauna. - The Pecten fauna of the upper, or characteristically Pleistocene, portion of the San Pedro and equivalent formations is as follows: Pecten alaskensis, $P$. caurinus, $P$. circularis, and variety rquisulcatus, $P$. diegensis, $P$. (Hinnites) giganteus, $P$. hastatus and varieties hericius, hindsii, navarchus, and strategus, $P$. islandicus, $P$. latiauritus and varieties cerritensis, delosi, fucicolus and monotimeris, P. subnodosus, and P. vogdesi.

The following fauna has been found in the upper beds of the San Pedro formation in the vicinity of the type locality, and may be taken as characteristic of the Pleistocene for the coast of California:

\section{List of San Pedro formation (Pleistocene) fossils.}

[Those marked with an asterisk (*) are known so far at San Pedro only from the lower portion of the San Pedro formation.]

$$
\text { ANTHOZOA. }
$$

Caryophyllia arnoldi Vaughan.

Caryophyllia pedroensis Vaughan.

Paracyathus pedroensis Vaughan.

ECHINOIDEA.

Echinarachnius excentricus Eschscholtz. Strongylocentrotus franciscanus Agassiz. Strongylocentrotus purpuratus Stimpson.

\section{PELECYPODA.}

Aligena cerritensis Arnold. Amiantis callosa Conrad.

Angulus buttoni Dall.

Anomia lampe Gray.

Arca labiata Sowerby.

Astarte (Crassinella) branneri Arnold.

* Bornia retifera Dall.

Callista newcombiana Gabb.

* Callistata subdiaphana Carpenter.

Cardita (Carditamera) subquadrata Carpenter. (Lazaria id.)

Cardium corbis Martyn.

Cardium elatum Sowerby.

Cardium procerum Sowerby.

Cardium quadrigenarium Conrad.

Chama exogyra Conrad.

Chama pellucida Sowerby.

Clidiophora punctata Conrad.

* Cooperella subdiaphana Carpenter.
PELECYPODA-continued.

Corbula luteola Carpenter.

Cryptomya californica Conrad.

Cumingia californica Conrad.

Diplodonta orbella Gould.

Diplodonta serricata Reeve.

Donax californica Conrad.

Donax lævigata Deshayes.

Glycymeris barbarensis Conrad.

Glycymeris septentrionalis Middendorf.

* Kellia suborbicularis Montague.

* Kellia laperousii Deshayes.

* Kennerlia bicarinata Carpenter.

*Kennerlia filosa Carpenter.

Lævicardium substriatum Conrad.

*Leda fossa Baird.

*Leda hamata Carpenter.

*Leda minuta var. præcursor Arnold.

Leda taphria Dall.

*Lima dehiscens Conrad.

Lithophaga plumula Hanley.

Lyonsia californica Conrad.

*Macoma calcarea Gmelin.

Macoma indentata Carpenter.

Macoma inquinata Deshayes.

Macoma nasuta Conrad.

Macoma nasuta var. kelseyi Dall.

Macoma secta Conrad.

Macoma yoldiformis Carpenter.

Mactra californica Conrad. 
List of San Pedro formation (Pleistocene) fossils-Continued.

IELECYPODA-continued.

Mactra exoleta Gray.

Mactra hemphilli Dall.

Metis alta Conrad.

Modiolus fornicatus Carpenter.

Modiolus rectus Conrad.

*Mórella salmonea Carpenter.

*Mytilimeria nuttalli Conrad.

Mytilus edulis Linné.

* Neæra pectinata Carpenter.

*Nucula (Acila) castrensis Hinds.

Nucula suprastriata Carpenter.

Ostrea lurida Carpenter.

*Panomya ampla Dall.

Panopea generosa Gould.

Pecten caurinus Gould.

Pecten circularis Sowerby.

Pecten circularis var. æquisulcatus Carpenter.

Pecten hastatus Sowerby.

*Pecten hastatus var. hericius Gould.

*Pecten hastatus var. strategus Dall.

*Pecten jordani Arnold.

Pecten latiauritus Conrad.

Pecten latiauritus var. cerritensis n. var.

*Pecten latiauritus var. delosi n. sp.

Pecten latiauritus var. monotimeris Conrad.

Pecten subnodosus Sowerby.

Pecten vogdesi $n$. sp.

Periploma argentaria Conrad.

Petricola carditoides Conrad.

Petricola (Petricolaria) cognata C. B. Adams.

Petricola denticulata Sowerby.

Phacoides (+Lucina) acutilineatus Conrad.

Phacoides (+Lucina) californicus Conrad.

Phacoides (+Lucina) tenuisculptus Carpenter.

Pholadidea penita Conrad.

Platyodon cancellatus Conrad.

Pododesmus (Monia) macroschisma Deshayes.

* Protocardia centifilosa Carpenter.

Psammobia edentula Gabb.

* Psephis salmonea Carpenter.

Rupellaria lamellifera Conrad.

Sanguinolaria nuttalli Conrad.

Saxidomus gracilis Gould.

Semele decisa Conrad.

Semele pulchra Sowerby.

* Semele pulchra var. montereyi Arnold.

* Septifer bifurcatus Conrad.

Siliqua lucida Conrad.

Siliqua patula Dixon var. nuttalli Conrad.

Solen sicarius Gould.

Spisula catilliformis Conrad.

Spisula falcata Gould.
PELECYPODA-continued.

Tagelus californianus Conrad.

Tapes lacineata Carpenter.

Tapes tenerrima Carpenter.

Tellina bodegensis Hinds.

Tellina idæ Dall.

Tellina rubescens Hanley.

* Thracia trapezoides Conrad.

*Thyasira gouldii Philippi.

Tivela crassatelloides Conrad.

Tresus nuttalli Conrad.

Venericardia barbarensis Stearns.

* Venericardia ventricosa Gould.

Venus tantilla Gould (Psephis id.).

Venus (Chione) fluctifraga Sowerby.

Venus (Chione) gnidia Broderip and Sowerby.

Venus (Chione) neglecta Sowerby.

Venus (Chione) simillima Sowerby.

Venus (Chione) succincta Valenciennes.

* Verticordia novemcostata Adams and Reeve.

Yoldia cooperi Gabb.

* Yoldia scissurata Dall.

Zirphæa gabbi Tryon.

GASTEROPODA.

Acmæa depicta Gould.

Acmæa insessa Hinds.

Acmæa instabilis Gould.

Acmæa mitra Eschscholtz.

Acmæa paleacea Gould.

Acmæa pelta Eschscholtz.

Acmæa spectrum (Nuttall) Reeve.

Actæon (Rictaxis) punctocoelata Carpenter.

Actæon traskii Stearns.

* Admete gracilior Carpenter.

* Amalthea antiquata Linné. (Hipponyx id.)

Amalthea cranioides Carpenter.

Amalthea tumens Carpenter.

Amphissa corrugata Reeve.

* Amphissa ventricosa Arnold.

Amphissa versicolor Dall.

Bela fidicula Gould.

* Bela sanctæ-monicæ Arnold.

Bittium asperum Gabb.

* Bittium californicum Dall and Bartsch.

Bittium filosum Gould.

Bittium quadrifilatum Carpenter.

Bittium rugatum Carpenter.

Bittium williamsoni Arnold.

Bulla punctulata A. Adams.

Bulla quoyi Gray.

* Cadulus fusiformis Sharp and Pilsbry.

Cæcum californicum Dall. 
List of San Pedro formation (Pleistocene) fossils-Continued.

GASTEROPODA-continued.

Cæcum crebricinctum Carpenter.

* Cæcum magnum Stearns.

Calliostoma annulatum Martyn.

Calliostoma canaliculaturn Martyn.

Calliostoma costatum Martyn.

Calliostoma gemmulatum Carpenter.

Calliostoma tricolor Gabb.

Cancellaria cooperi Gabb.

Cancellaria crawfordiana Dall.

Cancellaria tritonidea Gabb.

Cerithidea californica Haldemann.

Chlorostoma aureotinctum Forbes.

Chlorostoma brunneum Philippi.

Chlorostoma funebrale A. Adams.

Chlorostoma funebrale var. subapertum Carpenter.

Chlorostoma gallina Forbes.

Chlorostoma montereyi Kiener.

Chlorostoma pulligo Martyn (Phorcus id.).

Chlorostoma (Omphalius) viridulum var. ligulatum Menke.

Chorus belcheri Hinds.

Chrysodomus rectirostris Carpenter.

* Chrysodomus tabulatus Baird.

Clathurella conradiana Gabb.

* Columbella (Astyris) californiana Gaskoin.

Columbella ( Æsopus) chrysalloidea Carpenter.

Columbella (Astyris) gausapata Gould.

Columbella (Astyris) gausapata var. carinata Hinds.

Columbella (Anachis) minima Arnold.

* Columbella (Asopus) oldroydi Arnold.

Columbella solidula var. præcursor Arnold.

Columbella (Astyris) tuberosa Carpenter.

Conus californicus Hinds.

Coralliophila nux Reeve.

* Crepidula aculeata Gmelin.

Crepidula adunca Sowerby.

Crepidula dorsata Broderip.

Crepidula princeps Conrad.

Crepidula onyx Sowerby.

Crepidula rugosa Nuttall.

Crucibulum spinosum Sowerby.

* Cryptochiton stelleri Middendorf.

Cylichna alba Brown.

Cypræa spadicea Gray.

* Cythara branneri Arnold.

Dentalium indianorum Carpenter.

Dentalium neohexagonum Sharp and Pilsbry.

Dentalium pseudohexagonum Dall.

Dentalium semipolitum Broderip and Sowerby.

* Diastoma, sp. indet.

Drillia cancellata Carpenter.
GASTEROPODA - continued.

Drillia hemphilli Stearns.

Drillia inermis Hinds.

Drillia inermis var. penicillata Carpenter.

Drillia johnsoni Arnold.

* Drillia merriami Arnold.

* Drillia montereyensis Stearns.

Drillia pudica Hinds.

Drillia torosa Carpenter.

Erato columbella Menke.

* Eulima falcata Carpenter.

Eulima hastata Sowerby.

Eulima micans Carpenter.

Eupleura muriciformis Broderip.

Eupleura muriciformis var. curta Arnold.

Fissuridea aspera Eschscholtz.

Fissuridea inæqualis Sowerby.

Fissuridea murina (Carpenter) Dall.

Fissurella volcano Reeve.

Fusus barbarensis Trask.

Fusus luteopicius Dall.

Fusus robustus Trask.

* Fusus rugosus Trask (=F. arnoldi Cossmann).

Gadinia reticulata Sowerby.

Galerus mammillaris Broderip.

Hàliotis fulgens Philippi.

Haminea virescens Sowerby.

Helix (Epiphragmophora) sp. indet.

Isapis fenestrata Carpenter.

Ischnochiton regularis Carpenter.

* Ivara turricula (Carpenter) Dall and Bartsch.

Lacuna compacta Carpenter.

Lacuna porrecta Carpenter.

Lacuna solidula (Loven) Carpenter.

* Lamellaria stearnsii Dall.

Leptothyra bacula Carpenter.

Leptothyra carpenteri Pilsbry.

* Leptothyra paucicostata Dall.

Litorina planaxis (Nuttall) Philippi.

Litorina scutulata Gould.

Lucapina crenulata Sowerby.

Lucapinella callomarginata Carpenter.

Macron kellettii A. Adams.

Macron lividus A. Adams.

Mangilia angulata Carpenter.

Mangilia hooveri Arnold.

Mangilia interfossa var. pedroana Arnold.

Mangilia interlirata Stearns.

* Mangilia oldroydi Arnold.

* Mangilia painei Arnold.

* Mangilia sculpturata Dall.

Mangilia striosa C. B. Adams.

Margarita optabilis var. knechti Arnold. 
List of San Pedro formation (Pleistocene) fossils-Continued.

GASTEROPODA-continued.

* Margarita optabilis var. nodosus Arnold. Margarita parcipicta var. pedroana Arnold. Marginella jewettii Carpenter.

Megatebennus bimaculatus Dall.

Mitra maura Swainson.

* Mitramorpha filosa Carpenter.

* Mitramorpha intermedia A rnold.

Monoceros engonatum Conrad.

Monoceros lapilloides Conrad.

Mopalia ciliata Sowerby.

Murex (Pteronotus) festivus Hinds.

Murex (Pterohytis) foliatus Martyn.

Murex (Pterohytis) nuttalli Conrad.

Murex (Chicoreus) leeanus Dall.

Murex (Cerostoma) monoceros Sowerby.

Murex trialatus Sowerby.

Nassa californiana Conrad.

Nassa cerritensis Arnold.

Nassa fossata Gould.

Nassa insculpta Carpenter.

Nassa mendica Gould.

Nassa mendica var. cooperi Forbes.

Nassa perpinguis Hinds.

Nassa tegula Reeve.

Nassa versicolor var. hooveri Arnold.

* Natica clausa Broderip \& Sowerby.

Natica (Lunatia) lewisii Gould.

Neverita recluziana Petit.

Norrisia norrisii Sowerby.

* Ocinebra barbarensis Gabb.

Ocinebra foveolata Hinds.

Ocinebra interfossa Carpenter.

Ocinebra keepi Arnold.

Ocinebra lurida Middendorf.

Ocinebra lurida var. aspera Baird.

Ocinebra lurida var. cancellina Philippi.

Ocinebra lurida var. cerritensis Arnold.

* Ocinebra lurida var. munda Carpenter.

Ocinebra micheli Ford.

Ocinebra perita Hinds.

Ocinebra poulsoni Nuttall.

*Odostomia gouldii Carpenter.

*Odostomia nuciformis var. avellana Carpenter.

Odostomia tenuis Carpenter.

Olivella biplicata Sowerby.

Olivella intorta Carpenter.

Olivella pedroana Conrad.

Opalia borealis Gould.

Opalia crenitoides var. insculpta Carpenter.

Pachypoma inæquale Martyn.

Paludestrina curta Arnold.

Paludestrina stokesi Arnold.
GASTEROPODA-continued.

Phasianella compta Gould. *Physa heterostropha Say.

Pisania fortis Carpenter.

Planorbis tumidus Pfeiffer.

Planorbis vermicularis Gould.

Pleurotoma (Borsonia) bartschi Arnold.

Pleurotoma (Dolichotoma) carpenteriana Gabb.

Pleurotoma (Dolichotoma) cooperi Arnold.

*Pleurotoma (Borsonia) dalli Arnold.

*Pleurotoma (Borsonia) hooveri Arnold.

*Pleurotoma (Leucosyrinx) pedroana Arnold.

Pleurotoma perversa Gabb.

*Pleurotoma (Drillia) renaudi Arnold.

*Pleurotoma (Spirotropsis) smithi Arnold.

Pleurotoma (Dolichotoma) tryoniana Gabb.

Pomaulax undosus Wood.

Priene oregonensis Redfield.

Puncturella cucullata Gould.

*Puncturella galeata Gould.

Purpura crispata Chemnitz.

Purpura saxicola Valenciennes.

Pyramidella conica var. variegata Carpenter.

Ranella californica Hinds.

Rissoa acutelirata Carpenter.

Scala bellastriata Carpenter.

Scala crebricostata Carpenter.

Scala hemphilli Dall.

Scala hindsii Carpenter.

Scala indianorum Carpenter.

Scala tincta Carpenter.

* Seila assimilata C. B. Adams.

Serpulorbis squamigerus Carpenter.

Sigaretus debilis Gould.

Siphonalia kellettii Forbes.

Spiroglyphus lituella Mörch.

* Styliferina tenuisculpta Carpenter.

Taranis strongi Arnold.

Terebra (Acus) simplex Carpenter.

* Thalotia caffea Gabb.

Tornatina cerealis Gould.

Tornatina culcitella Gould.

Tornatina harpa Dall.

Triforis adversa Montague.

Trivia californica Gray.

Trivia solandri Gray.

Tritonium gibbosus Broderip.

Trophon (Boreotrophon) cerritensis Arnold.

* Trophon (Boreotrophon) gracilis Perry.

Trophon (Boreotrophon) multicostatus Eschscholtz.

* Trophon orpheus var. præcursor Arnold.

Trophon (Boreotrophon) pedroanus Arnold. 
List of San Pedro formation (Pleistocene) fossils-Continued.

GASTEROPODA-continued.

Trophon (Boreotrophon) pacificus Dall.

* Trophon stuarti Smith.

* Trophon (Boreotrophon) triangulatus Carpenter.

* Turbonilla adleri Dall \& Bartsch.

* Turbonilla arnoldi Dall \& Bartsch.

Turbonilla aurantia Carpenter.

Turbonilla crebrifilata Carpenter.

* Turbonilla gibbosa Carpenter.

Turbonilla laminata Carpenter.

Turbonilla latifundia Dall \& Bartsch.

Turbonilla lowei Dall \& Bartsch.

Turbonilla muricata Gould.

* Turbonilla pentalopha Dall \& Bartsch.

Turbonilla similimis C. B. Adams.

Turbonilla stearnsii Dall \& Bartsch.
GASTEROPODA-continued.

Turbonilla subcuspidata Carpenter.

Turbonilla tenuicula Gould.

* Turbonilla torquata Gould.

* Turbonilla torquata var. stylina Carpenter.

Turbonilla tridentata Carpenter.

Turritella cooperi Carpenter.

Turritella jewetti Carpenter.

* Vermicularia, sp. indet.

Vitrinella williamsoni Dall.

Volvarina varia Sowerby.

* Volvula cylindrica Carpenter.

PIȘCES.

Urolophus halleri Cooper(?)

GEOLOGIC RANGE OF CALIFORNIA PECTENS.

Range of species and varieties.

[? shows limits somewhere between which the species belongs.]

\begin{tabular}{|c|c|c|c|c|c|c|c|c|c|c|}
\hline \multirow{2}{*}{ 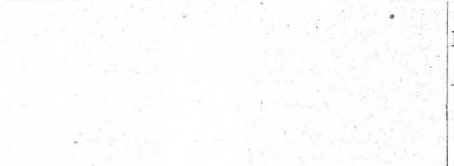 } & \multirow{2}{*}{$\mid \begin{array}{l}\text { Recent. } \\
\text { Living. }\end{array}$} & \multirow{2}{*}{ 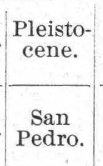 } & \multicolumn{2}{|c|}{ Pliocene. } & \multicolumn{3}{|c|}{ Miocene. } & \multirow{2}{*}{$\begin{array}{c}\begin{array}{c}\text { Oligo- } \\
\text { cene. }\end{array} \\
\begin{array}{c}\text { San Lo- } \\
\text { renzo. }\end{array}\end{array}$} & \multicolumn{2}{|c|}{ Eocene. } \\
\hline & & & $\begin{array}{l}\text { Mer- } \\
\text { ced. }\end{array}$ & $\begin{array}{c}\text { Purisi- } \\
\text { ma. }\end{array}$ & $\begin{array}{c}\text { San } \\
\text { Pablo. }\end{array}$ & $\begin{array}{c}\text { Monte- } \\
\text { rey. }\end{array}$ & $\begin{array}{c}\text { Vaque- } \\
\text { ros. }\end{array}$ & & Tejon. & $\begin{array}{c}\text { Marti- } \\
\text { nez. }\end{array}$ \\
\hline \multicolumn{11}{|l|}{ Pecten: } \\
\hline alaskensis Dall ............. & ttt' & t†t† & & $\ldots$ & $\ldots \ldots$ & $\ldots \ldots$ & $\ldots$. & & & ...... \\
\hline andersoni n. sp.................. & & $\ldots$ & & ...... & $\dagger \dagger$ & $+\dagger+\dagger$ & $+1+\dagger$ & $\cdots$ & & \\
\hline var. barkerianus n. var... & & & & ...... & (...... & $\ldots \ldots$ & $+\dagger \dagger+$ & $\ldots \ldots$ & & (...... \\
\hline ashleyi n. sp ..................... & & & $\dagger+$ & $\dagger+\dagger$ & $\cdots$ & (.... & ..... & & & \\
\hline auburyi n. sp ................. & & & (..... & $+\dagger+\dagger$ & & (....... & & - . . . & & ..... \\
\hline bartschi n. sp ................... & & & ..... & $+\dagger+\dagger$ & & & & & & \\
\hline bellus Conrad ............ & & $\ldots$. & t† & $+\dagger+t$ & & ....... & $\therefore$. & & & \\
\hline bellilamellatus n. sp......... & & & $\dagger+$ & $+\dagger+t$ & & $\mid \cdots \ldots$ & $\ldots \ldots$ & $\ldots$ & & \\
\hline bowersi n. sp.................... & & & & ..... & ...... & $? ? ? ?$ & ††† & $\ldots \ldots$ & & \\
\hline branneri n. sp................ & & & & $\ldots \ldots$ & -..... & (...... & $+\dagger+\dagger$ & $+\dagger$ & & \\
\hline calkinsi n. sp $\ldots . . . . . . .$. & $\mid \ldots .$. & & & $\ldots .$. & $\ldots \ldots$ & $\ldots \ldots$ & $\ldots$. & $\ldots$. & $+\dagger+\dagger$ & \\
\hline 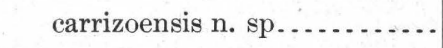 & ...... & ...... & & $\therefore \ldots$ & $? ? ? ?$ & $? ? ? ?$ & ???? & & & \\
\hline caurinus Gould............. & ††† & ††† & $\dagger+\dagger+$ & ††† & & & & & & \\
\hline cerrosensis Gabb ............. & ...... & ....... & $+\dagger$ & $\dagger+\dagger+$ & & $\ldots \ldots$ & & $\ldots \ldots$ & & \\
\hline var. mendenhalli $\mathrm{n}$. var. . & (...... & ....... & ...... & (...... & $? ? ? ?$ & $? ? ? ?$ & $? ? ? ?$ & ....... & & \\
\hline circularis Sowerby ........... & $+\dagger+\dagger$ & $+t+t$ & $? ? ? ?$ & $? ?$ & & & & & & \\
\hline var. æquisulcatus Cpr.... & $+\dagger+\dagger$ & $\dagger+\dagger$ & & & & & & - . . . & & \\
\hline clallamensis n. sp......... & & $\ldots \ldots$ & & & & & $\dagger \dagger$ & t† & & \\
\hline coalingaensis n. sp.......... & & & & $\dagger+\dagger \dagger$ & & & & $\ldots .$. & & \\
\hline 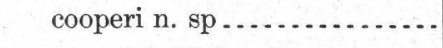 & & & $\dagger+$ & $+\dagger+\dagger$ & -..... & & & $\cdots \cdots$ & $\ldots$. & $\cdots$ \\
\hline coosensis Shumard.. & & & & & t+tt & & & & & \\
\hline
\end{tabular}


Range of species and varieties-Continued.

[? shows limits somewhere between which the species belongs.]

\begin{tabular}{|c|c|c|c|c|c|c|c|c|c|c|}
\hline & \multirow{2}{*}{$\begin{array}{l}\text { Recent. } \\
\text { Living. }\end{array}$} & \multirow{2}{*}{ 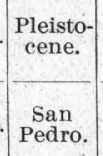 } & \multicolumn{2}{|c|}{ Pliocene. } & \multicolumn{3}{|c|}{ Miocene. } & \multirow{2}{*}{ 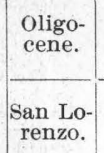 } & \multicolumn{2}{|c|}{ Eocene. } \\
\hline & & & $\begin{array}{l}\text { Mer- } \\
\text { ced. }\end{array}$ & $\begin{array}{c}\text { Purisi- } \\
\text { ma. }\end{array}$ & $\begin{array}{c}\text { San } \\
\text { Pablo. }\end{array}$ & $\begin{array}{c}\text { Monte- } \\
\text { rey. }\end{array}$ & $\begin{array}{c}\text { Vaque- } \\
\text { ros. }\end{array}$ & & Tejon. & $\begin{array}{l}\text { Marti- } \\
\text { nez. }\end{array}$ \\
\hline var. hamiltoni $\mathrm{n}$. var & ..... & & & & $\begin{array}{l}t+t+ \\
+t+t\end{array}$ & $\begin{array}{l}+\dagger+\dagger \\
? ? ? ?\end{array}$ & $\begin{array}{l}\dagger \dagger \dagger \dagger \\
? ? ? ?\end{array}$ & & & \\
\hline davidsoni Dall. ............ & $t+t+$ & & & & & & & & & \\
\hline deserti Conrad ....... & ...... & ...... & & & ???? & ???? & $? ? ? ?$ & & & \\
\hline diegensis Dall......... & $t+t+$ & $t+t+$ & & & & & & & & \\
\hline dilleri Dall ........... & & & & $? ? ? ?$ & $? ? ? ?$ & & & & & \\
\hline diseus Conrad........ & & & & $\ldots . .$. & $t+t+$ & $? ? ? ?$ & & & & \\
\hline eldridgei n. sp ........ & & & & 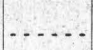 & $+t+t$ & & & & & \\
\hline estrellanus Conrad ....... & & & & & $t+t+$ & $t+t+$ & $t+t+$ & & & \\
\hline var. catalinæ $\mathrm{n}$. var . & & & & $t+$ & $+t$ & & & & & \\
\hline var. terminus $\mathrm{n}$. var... & 20 & & & & $t+t+$ & & & & & \\
\hline excavatus Anton .......... & $++t+$ & ...... & & & & & & & & \\
\hline fucanus Dall ......... & ....... & & & & ???? & $? ? ? ?$ & ???? & & & \\
\hline giganteus Gray ........... & $t+t+$ & $+1+t$ & $t+t+$ & t+t+ & $t+t+$ & $t+t+$ & $+t+t$ & & & \\
\hline hamlini n. sp ............ & …. & ..... & & ...... & $? ? ? ?$ & ???? & ???? & & & \\
\hline hastatus Sowerby .......... & t+t+ & $\dagger+\dagger \dagger$ & $+\dagger+\dagger$ & $+\dagger+t$ & & & & . & & \\
\hline var. albidus Dall n. var.. & $t+t+$ & ...... & .... & … & & & & & & \\
\hline var. hericius Gould...... & titt & $+t+t$ & $t+t+$ & tt+t & $+t$ & & & & & \\
\hline var. hindsii Carpenter... & t+tt & $t+t+$ & t+tt & t+ & & & & & & \\
\hline var. navarchus Dall ..... & $++t+$ & $+t+t$ & $++1+$ & $+t$ & & & & & & \\
\hline var. strategus Dall........ & $++t+$ & $+t+t$ & $+t+t$ & t† & & & & & & \\
\hline healeyi n. sp................ & ...... & & -.... & $t+t+$ & & & & & & \\
\hline hemphilli Dall .......... & & & $+t$ & t+tt & & & & & & \\
\hline interradiatus Gabb....... & - . . . & ..... & ...... & ...... & & & & & $t+t+$ & \\
\hline islandicus Müller......... & tttt & $+t+t$ & $t+t+$ & 胡 & & & & & & \\
\hline jordani Arnold........... & . & ..... & $+t+t$ & $+\dagger$ & & & & & & \\
\hline keepi n. sp.............. & & & 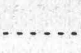 & .... & ???? & $? ? ?$ & $? ? ? ?$ & & & \\
\hline landesi n. sp ............. & & & & & & & & & $t+t+$ & \\
\hline latiauritus Conrad ........... & $t+t+$ & tht+ & $\dagger+\dagger+$ & t十 & & & & & & \\
\hline var. cerritensis n. var.... & ...... & $+t+t$ & & & & & & & & \\
\hline var. delosi n. var........ & $t+t+$ & $t+t+$ & & -..... & -... & & & & & \\
\hline var. fucicolus Dall....... & $t+t+$ & $+1+t$ & & 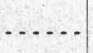 & & & & & & \\
\hline var. monotimeris Con .... & t+t+ & $t+t+$ & & & & & & & & \\
\hline lawsoni n. sp ................... & & & & $t+t+$ & & & & & & \\
\hline lecontei n. sp ............... & 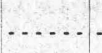 & & & $+++\dagger$ & & . & ...... & & & \\
\hline lompicoensis n. sp............ & & & & & & ???? & $? ? ? ?$ & & & \\
\hline lompocensis $\mathrm{n} . \mathrm{sp} \ldots \ldots \ldots$. . . & & & & & . & & $t+t+$ & & & \\
\hline
\end{tabular}


Range of species and rarieties-Continued.

[? shows limits somewhere between which the species belongs.]

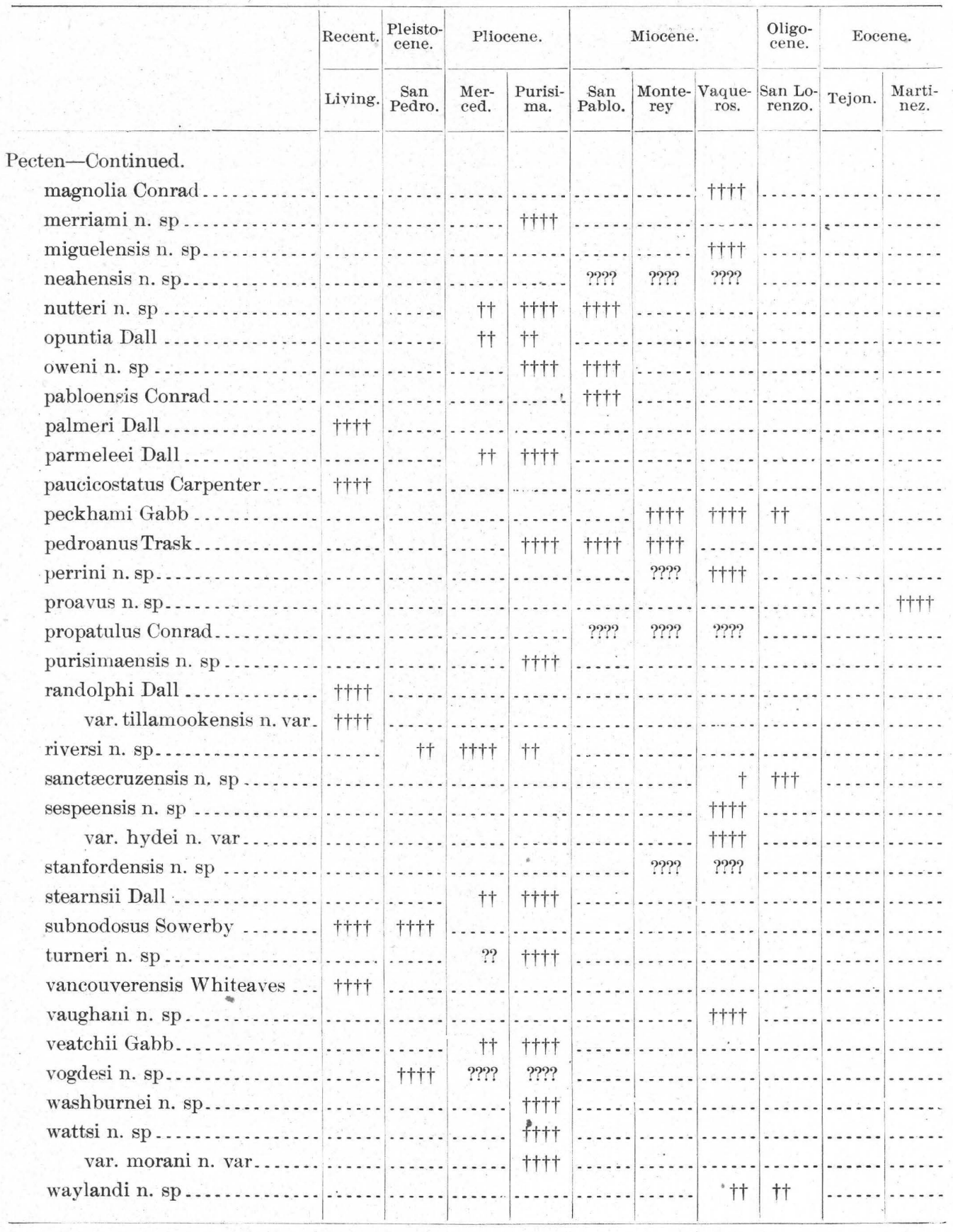




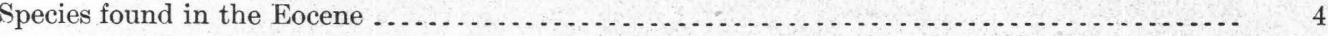

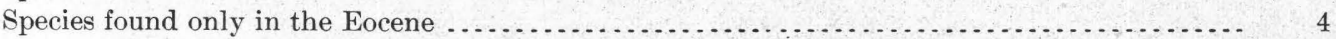

Species transitional between the Eocene and Oligocene $. . \ldots \ldots \ldots \ldots \ldots \ldots \ldots \ldots \ldots \ldots \ldots \ldots . . . \ldots$ None.

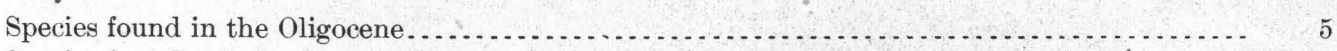

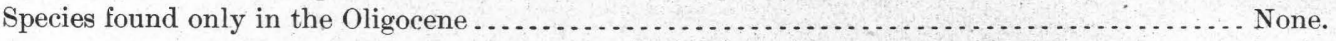

Species transitional between the Oligocene and Miocene $\ldots \ldots \ldots \ldots \ldots \ldots \ldots \ldots \ldots \ldots \ldots . . .5$

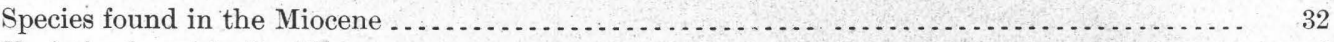

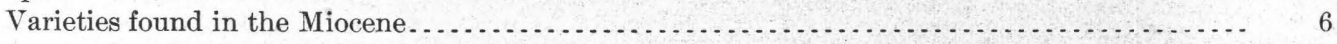

Species found only in the Miocene ............................................ 23

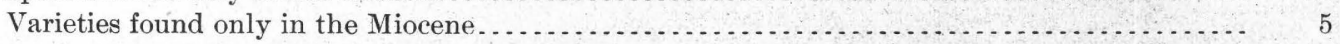

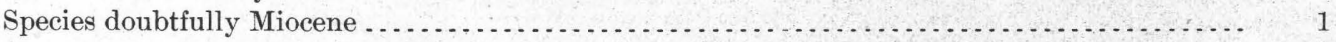

Species transitional between the Miocene and Pliocene $\ldots \ldots \ldots \ldots \ldots \ldots \ldots \ldots \ldots \ldots \ldots \ldots \ldots . . .4$

Varieties transitional between the Miocene and Pliocene $\ldots \ldots \ldots \ldots \ldots \ldots \ldots \ldots \ldots \ldots \ldots \ldots . .2$

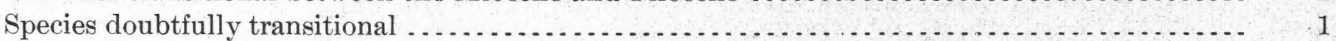

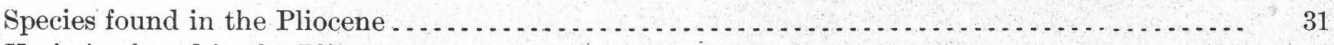

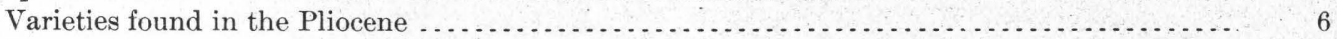

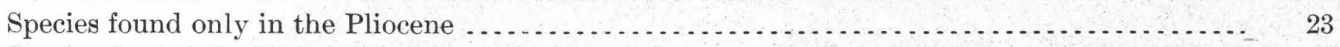

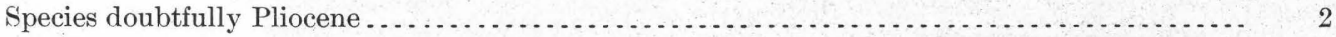

Species transitional between the Pliocene and Pleistocene......................... 7

Varieties transitional between the Pliocene and Pleistocene......................... 3

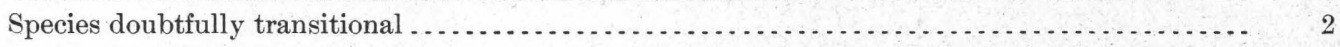

Species found in the Pleistocene............................................. 11

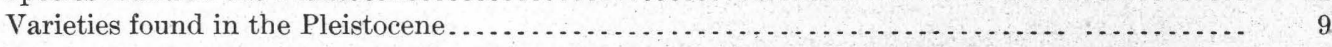

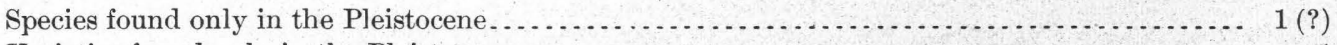

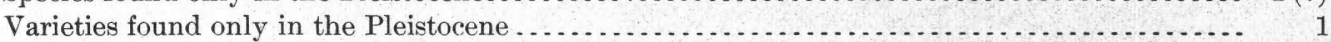

Species transitional between Pleistocene and Recent............................. 9

Varieties transitional between Pleistocene and Recent . . $\ldots \ldots \ldots \ldots \ldots \ldots \ldots \ldots \ldots \ldots \ldots \ldots \ldots . . .6$

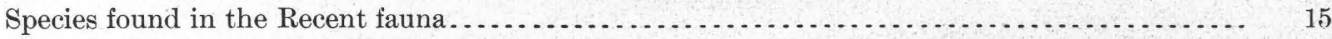

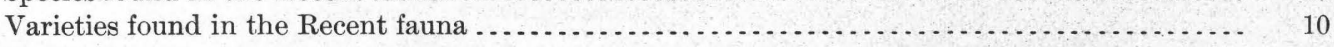

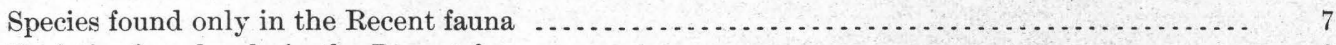

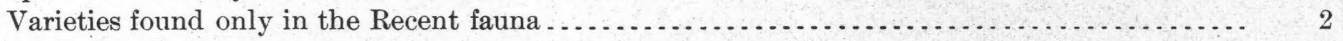

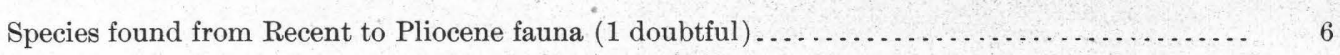

Varieties found from Recent to Pliocene fauna ................................. 4

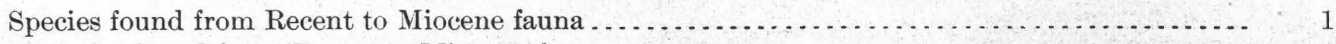

Varieties found from Recent to Miocene fauna ................................... 1 


\section{P A R T I.}

\section{SYNOPSIS AND DESCRIPTIONS OF SUBGENERA AND SPECIES. ${ }^{a}$}

SYNOPSIS OF SUBGENERA AND SPECIES.

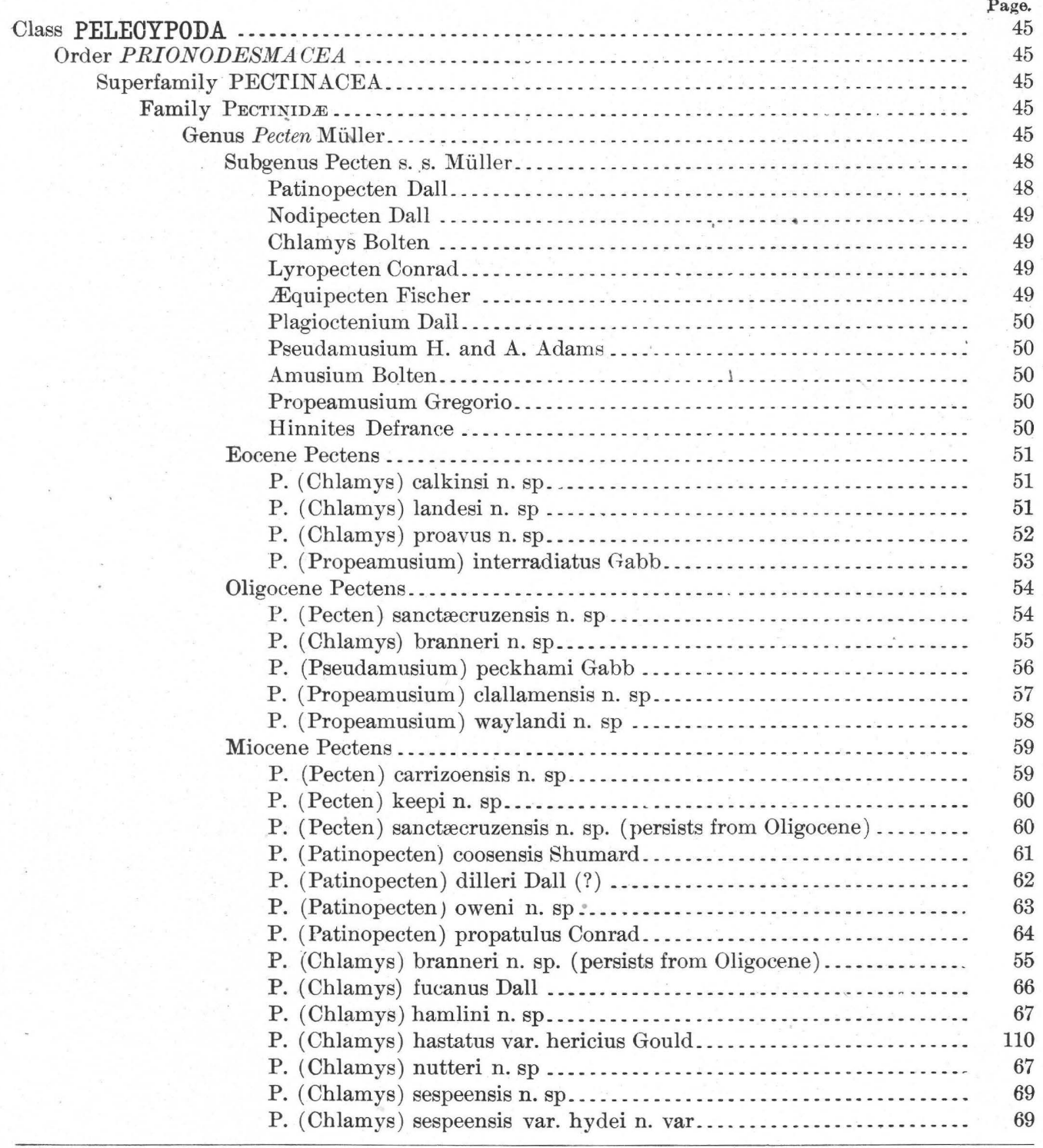

aThe description of each species will be found under the heading of the epoch in which the species is first known to occur. Any species persisting into a following epoch will be listed in the synopsis also under the heading of the latter with an explanatory note. 
Class PELECYPODA - Continued.

Order PRIONODESMACEA-Continued.

Superfamily PECTINACEA-Continued.

Family Pectinid e-Continued.

Genus Pecten Müller-Continued.

Miocene Pectens-Continued.

P. (Lyropecten) bowersi $n$. sp ..................................

P. (Lyropecten) crassicardo Conrad ............................ 71

P. (Lyropecten) crassicardo var. hamiltoni n. var .................... 73

P. (Lyropecten) estrellanus Conrad ................................ 74

P. (Lyropecten) estrellanus var. catalinæ $\mathrm{n}$. var................. 76

P. (Lyropecten) estrellanus var. terminus n. var ................. 77

P. (Lyropecten) magnolia Conrad .......................... 77

P. (Lyropecten) miguelensis $n$. sp ............................... 79

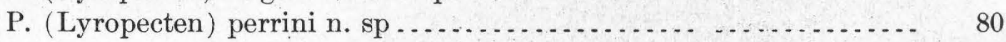

P. (Lyropecten) vaughani $n$. sp............................ 81

P. (Plagioctenium) andersoni n. sp.......................... 82

P. (Plagioctenium) andersoni var. barkerianus n. sp ............. 83

P. (Plagioctenium) cerrosensis var. mendenhalli $n$. var............ 84

P. (Plagioctenium) deserti Conrad .......................... 85

P. (Plagioctenium) discus Conrad .......................... 86

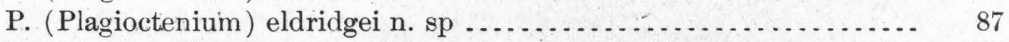

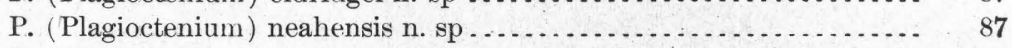

P. (Plagioctenium) pabloensis Conrad ....................... 88

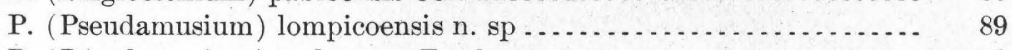

P. (Pseudamusium) pedroanus Trask ....................... $\quad 90$

P. (Pseudamusium) peckhami Gabb (persists from Oligocene) ...... 56

P. (Propeamusium) clallamensis n. sp. (persists from Oligocene)..... 57

P. (Propeamusium) stanfordensis n. sp ........................ 91

P. (Propeamusium) waylandi n. sp. (persists from Oligocene) ...... 58

P. (Amusium) lompocensis n. sp............................ 92

P. (Hinnites) giganteus Gray ............................... 93

Pliocene Pectens ........................................ 94

P. (Pecten) auburyi $n$. sp ................................. 94

P. (Pecten) belius Conrad ................................ 95

P. (Pecten) coalingaensis n. sp............................ 97

P. (Pecten) hemphilli Dall ............................... 97

P. (Pecten) lecontei $n$. sp ..................................... 98

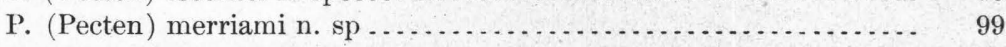

P. (Pecten) stearnsii Dall ................................... 100

P. (Pecten) vogdesi $n$. sp ................................. 100

P. (Patinopecten) caurinus Gould ......................... 101

P. (Patinopecten) dilleri Dall (persists from the Miocene ?) .......... 62

P. (Patinopecten) healeyi n. sp ............................ 103

P. (Patinopecten) oweni n. sp. (persists from Miocene) ........... 63

P. (Patinopecten) purisimaensis n. sp ...................... 105

P. (Patinopecten) turneri $\mathrm{n}$. sp ........................... 106

P. (Nodipecten) veatchii Gabb ........................... 106

P. (Chlamys) bartschi n. sp ................................. 107

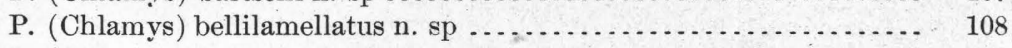

P. (Chlamys) hastatus Sowerby ......................... 108

P. (Chlamys) hastatus var. hericius Gould (persists from Miocene) ... $\quad 110$

P. (Chlamys) hastatus var. hindsii Carpenter ................... 111

P. (Chlamys) hastatus var. navarchus Dall ..................... 112

P. (Chlamys) hastatus var. strategus Dall ..................... 113

P. (Chlamys) islandicus Müller ............................ 113 
Class PELECYPODA-Continued.

Order PRIONODESMACEA-Continued.

Superfamily PECTINACEA-Continued.

Family Pectinid 开-Continued.

Genus Pecten Müller-Continued.

Pliocene Pectens-Continued.

Page.

P. (Chlamys) jordani Arnold . . . . . . . . . . . . . . . . . . . . . . . . . . 114

P. (Chlamys) latiauritus Conrad ................................ 115

P. (Chlamys) lawsoni n. sp . . . . . . . . . . . . . . . . . . . . . . . . 117

P. (Chlamys) nutteri n. sp. (persists from Miocene) ............... 69

P. (Chlamys) opuntia Dall ................................ 118

P. (Chlamys) parmeleei Dall ................................ 119

P. (Chlamys) washburnei n. sp .................................. 119

P. (Chlamys) wattsi n. sp ....................................... 120

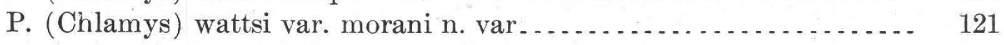

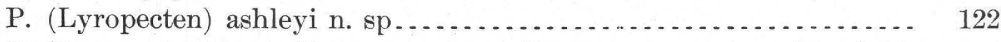

P. (Lyropecten) estrellanus var. catalinæ n. var. (persists from

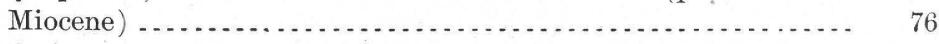

P. (Plagioctenium) cerrosensis Gabb .......................... 123

P. (Plagioctenium) circularis Sowerby (?) .................... 125

P. (Plagioctenium) cooperi n. sp ............................... 124

P. (Pseudamusium) pedroanus Trask (persists from Miocene) ........ 90

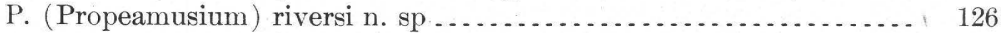

P. (Hinnites) giganteus Gray (persists from Miocene) $\ldots . . . . . . . .93$

Pleistocene Pectens ......................................... 127

P. (Pecten) diegensis Dall . . . . . . . . . . . . . . . . . . . . . . . . . . . 127

P. (Pecten) vogdesi n. sp. (persists from Pliocene) ............... 100

P. (Patinopecten) caurinus Gould (persists from Pliocene) .......... 101

P. (Nodipecten) subnodosus Sowerby ................................ 128

P. (Chlamys) hastatus Sowerby (persists from Pliocene) ........... 108

P. (Chlamys) hastatus var. hericius Gould (persists from Miocene) .. 110

P. (Chlamys) hastatus var. hindsii Carpenter (persists from Pliocene) - 111

P. (Chlamys) hastatus var. navarchus Dall (persists from Pliocene) .. 112

P. (Chlamys) hastatus var. strategus Dall (persists from Pliocene) .... 113

P. (Chlamys) islandicus Müller (persists from Pliocene) . . . . . . . . . . 113

P. (Chlamys) latiauritus Conrad (persists from Pliocene) ........... 115

P. (Chlanys) latiauritus var. cerritensis n. var................... 129

P. (Chlamys) latiauritus var. delosi n. var..................... 130

P. (Chlamys) latiauritus var. fucicolus Dall ....................... 131

P. (Chlamys) latiauritus var. monotimeris Conrad .................. 131

P. (Plagioctenium) circularis Sowerby (persists from Pliocene) ....... 125

P. (Plagioctenium) circularis var. æequisulcatus Carpenter . . ......... 132

P. (Propeamusium) alaskensis Dall ........................... 133

P. (Propeamusium) riversi n. sp. (persists from Pliocene) ........... 126

P. (Hinnites) giganteus Gray (persists from Miocene) ............. 93

Recent Pectens ................................................ 134

P. (Pecten) diegensis Dall (persists from Pleistocene) ..............

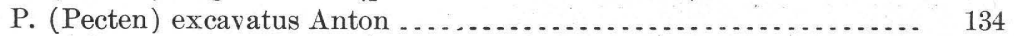

P. (Patinopecten) caurinus Gould (persists from Pliocene) .......... 101

P. (Nodipecten) subnodosus Sowerby (persists from Pleistocene) .... 128

P. (Chlamys) hastatus Sowerby (persists from Pliocene) ........... 108

P. (Chlamys) hastatus var. albidus Dall n. var.................. 136

P. (Chlamys) hastatus var. hericius Gould (persists from Miocene) .. 110

P. (Chlamys) hastatus var. hindsii Carpenter (persists from Pliocene) _ 111

P. (Chlamys) hastatus var. navarchus Dall (persists from Pliocene).. 112

P. (Chlamys) hastatus var. strategus Dall (persists from Pliocene).... 113 
Class PELECYPODA-Continued.

Order PRIONODESMACEA-Continued.

Superfamily PECTINACEA-Continued.

Family Pectinide-Continued.

Genus Pecten Müller-Continued.

Recent Pectens-Continued.

P. (Chlamys) islandieus Müller (1)

P. (Chlamys) latiauritus Conrad (persists from Pliocene)

P. (Chlamys) latiauritus var. delosi n. var. (persists from Pleistocene). 130

P. (Chlamys) latiauritus var. fucicolus Dall (persists from Pleistocene) _ 131

P. (Chlamys) latiauritus var. monotimeris Conrad (persists from

Pleistocene $)$...................................... 131

P. (Equipecten) palmeri Dall ............................... 136

P. (Plagioctenium) paucicostatus Carpenter .................... 137

P. (Plagioctenium) circularis Sowerby (persists from Pliocene) ...... 125

P. (Plagioctenium) circularis var. æquisuleatus Carpenter (persists

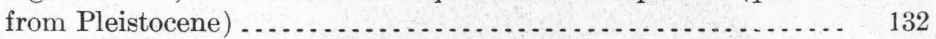

P. (Pseudamusium) davidsoni Dall .......................... 138

P. (Pseudamusium) randolphi Dall ........................ 138

P. (Pseudamusium) randolphi var. tillamookensis n. var .......... 139

P. (Pseudamusium) vancouverensis Whiteaves.................. 140

P. (Propeamusium) alaskensis Dall (persists from Pleistocene)....... 133

P. (Hinnites) giganteus Gray (persists from Miocene) ............. 93

Unidentifiable Pectens ........................................ 141

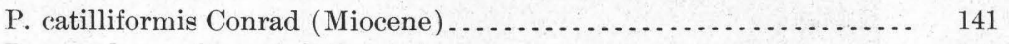

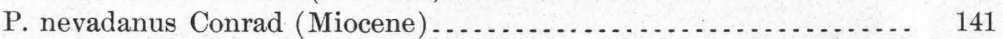

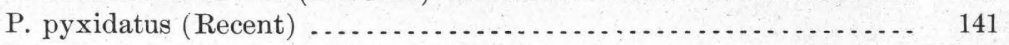

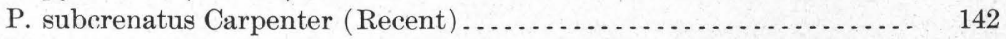

P. townsendi Gould (Recent) $\ldots \ldots \ldots \ldots \ldots \ldots \ldots \ldots \ldots \ldots \ldots \ldots, 142$

Summary of the subgenera and species.

Number of subgenera represented $\ldots \ldots \ldots \ldots \ldots \ldots \ldots \ldots \ldots \ldots \ldots \ldots \ldots \ldots \ldots \ldots \ldots \ldots \ldots \ldots .11$

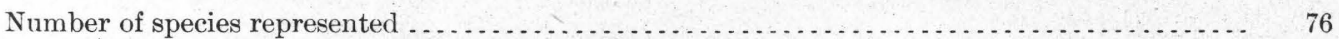

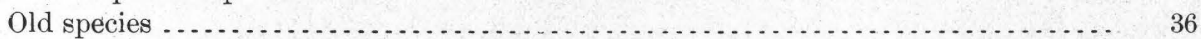

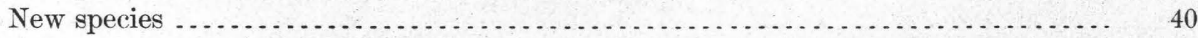

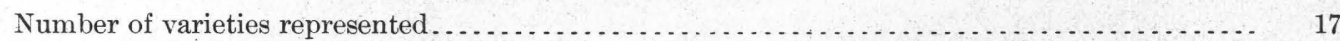

Old varieties. . . . . .

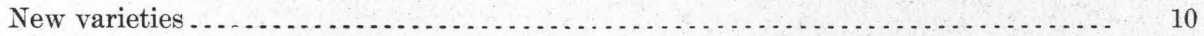

Number of species included in Pecten s. s....................................... 13

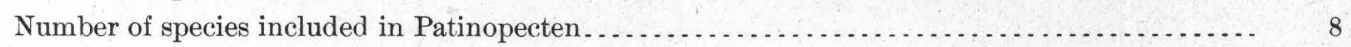

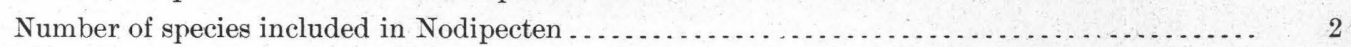

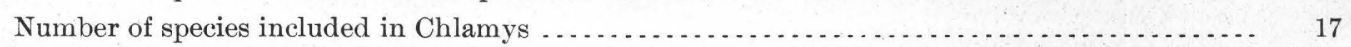

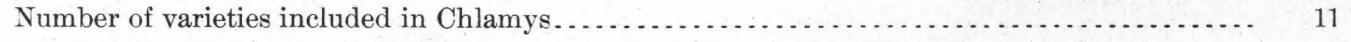

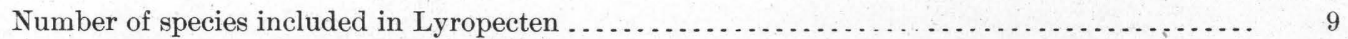

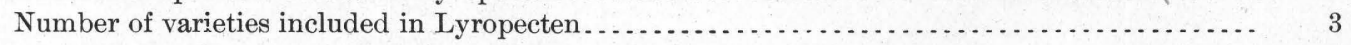

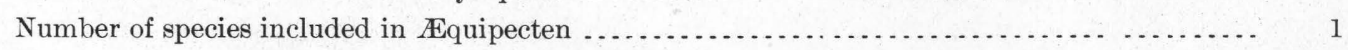

Number of species included in Plagioctenium . . . . . . . . . . . . . .

Number of varieties included in Plagioctenium . . . . . . . . . . . . .

Number of species included in Pseudamusium . . . . . . . .

Number of varieties included in Pseudamusium ................................. 1

Number of species included in Amusium ..................................... 1

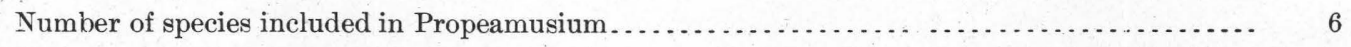

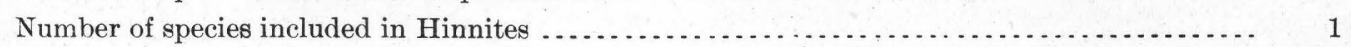


SYNOPSIS AND DESCRIPTIONS OF SUBGENERA AND SPECIES.

DESCRIPTIONS OF SUBGENERA AND SPECIES.

Class PELECYPODA.

Order PRIONODESMACEA.

Superfamily PECTINACEA.

Family Pectinide.

Genus Pecten $a$ Müller.

1776. Pecten (Klein, 1753) Müller, Prodr. Zool. Dan., p. 248.

1778. Pecten Da Costa, Brit. Conch., p. 140.

1798. Pecten Bolten, Mus. Bolt., p. 165.

1799. Pecten Lamarck, Prodr. d'un Nouv. Class. Coq., p. 88.

1898. Pecten Dall, Trans. Wagner Free Inst. Sci., vol. 3, pt. 4, p. 689.

Type, Ostrea maxima Linné.

GENUS PECTEN MÜLLER.

"The shell of Pecten comprises two generally more or less discrepant valves, united along a long, straight hinge line by an inconspicuous ligament and a central strong resilium. A single rounded adductor leaves its impression pretty

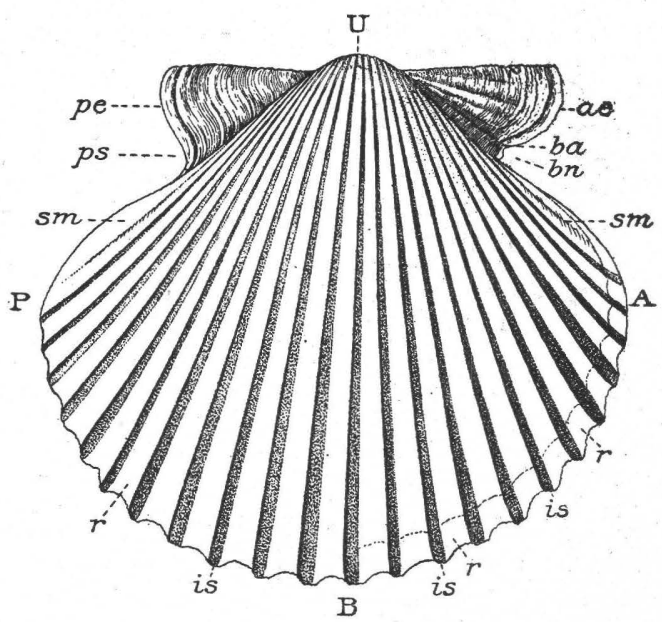

FIg. 1.-Pecten circularis Sowerby var. æxuisulcatus Carpenter. Right valve, i. e., the valve having the byssal notch; exterior. Dimensions: "Altitude" is distance between the base (B) and the apex of the shell or umbo (U); "longitude" is the distance between the anterior extremity (A) and the posterior extremity (P); "diameter" is the maximum perpendicular distance from the plane of the periphery (margin or border) to the top of the arched disk, when the shell is lying interior downward; A, anterior end; P, posterior end; B, base; U, umbo; U P B A, disk; $a e$, anterior ear or auricle; $p e$, posterior ear or auricle; $b n$, byssal notch or sinus; $b a$, byssal area; $p s$, posterior sinus; $s m$, submargins or lateral areas; $r$, ribs; $i s$, interspaces.

high up, a little before the mesial line of the valves, and the pedal retractors are usually attached to the left valve above it, being often obsolete on the right side. The ends of the resilium are received by subtriangular or oval pits in the

$a$ The generic and subgeneric classification and descriptions, and also the general discussion relating to Pecten, are taken from Doctor Dall's monograph of the genus in "The Tertiary Fauna of Florida," Trans. Wagner Free Inst. Sci., vol. 3, pt. 4, 1898, pp. 689-758. In many cases parts of the discussion and descriptions have been copied verbatim. Unless otherwise stated, all passages occurring in quotations have been copied from the above monograph. 
umbonal region. These pits may be shallow or deep; their basal margin sometimes projects slightly into the cavity of the valves; their apex is always nearly coincident with the umbonal point of the valve. In a few species in the right valve the lateral margins of the pit are raised into tooth-like processes, which fit into corresponding depressions in the opposite valve (e. g., P. swiftii Bernh.), but these are not homologous with the so-called teeth of Plicatula and Spondylus. Outside of these, radiating fanlike from the apex of the valve, are frequently found one to three pairs of more or less prominent laminæ, which I call the cardinal crura, and farther away and below on the ridges which mark the lower boundary of the ears will sometimes be found another pair, only distally conspicuous, which I have named the auricular crura. The cardinal crura are most conspicuous in heavy shells, especially such as Pecten proper and Lyropecten, and serve to adjust the closing of the valves, as does the hinge armature of the Teleodonts. In a few species the crura are

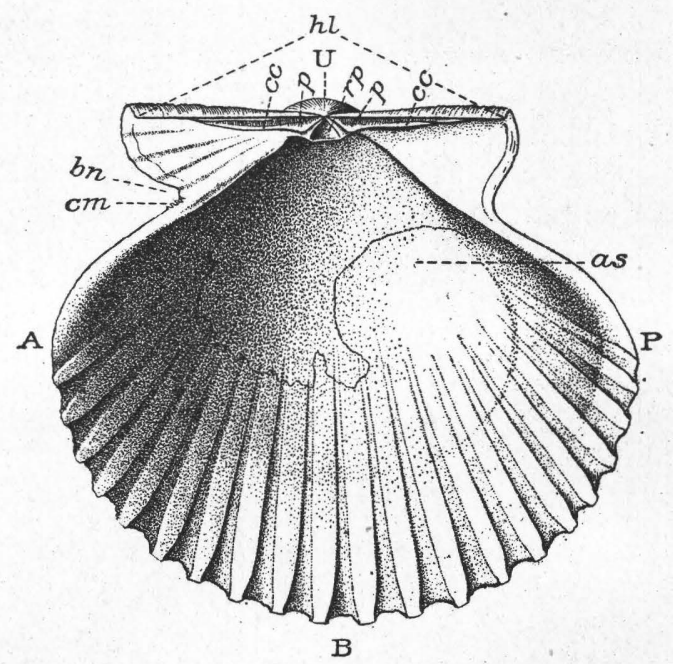

FIG. 2.-Same species as fig. 1. Right valve; interior. A; P, B and U as in fig. $1 ; h$, hinge line; $r p$, resilial pit; $p p$, provinculum; $c c, c c$, cardinal crura; $b n$, byssal notch; $c m$, etenolium; $a s$, adductor scar.

sufficiently prominent to actually interlock with the valves half open; in many others hardly any trace of them is visible. Almost all species possess in the nepionic stage a well-marked provinculum, formed by an elongated area on each side of the pit, covered by long, narrow, close-set taxodont teeth, separated by narrow grooved interspaces. In most species the provinculum is evanescent or represented in the adult only by faint vertical striæ, which cross the cardinal crura. In a few small, thin-shelled, mostly deep-water species the provinculum is persistent and functional (e. g., P. thalassinum Dall), forming an interlocking hinge.' In Pecten proper, Chlamys, and some other groups the upper cardinal margin of the right valve is bent over that of the left valve. There are occasional species in which the adult valves have each a flat area along the whole cardinal margin, covered by the ligament and forming, a $\vee$-shaped groove between the upper margins of the valves, as in $P$. swiftii. The disk of the valve is usually rounded or oblique below and at the sides, 
but above continued on each side in a straight line to the umbo. The shell adjacent to these straight lines is frequently slightly different in sculpture from the rest of the disk, forming narrow areas, which were called by Conrad the 'submargins.' Above the submargins the auricles or ears project, usually differentiated by a linear depression ending in a sinus below. This sinus is sometimes absent in the posterior ears, as it is in the very young stages of the shell, but it is not an important systematic character, since the same species (e. g., P. latiauritus Conr.) may exhibit varieties some of which have a well-developed posterior sinus while others are without it. The right anterior sinus is usually emphasized by a flexuosity in the lower edge of the ear above it for the accommodation of the byssus, and on the upper part of submargin are usually found a number of small, regularly spaced spines, which in life separate the threads of the byssus and thus keep it from twisting with the motion of the water. The growth of the margin of the valve and ear does not always march with the development of these spines, so that a species which normally has them may exhibit stages when the valve margin has grown over the old set and the new set has not been formed, nuch like the inequalities of growth shown by the margin of the aperture and the internal liræ of some Gasteropods. This set of spines, resembling a short comb with curved teeth, has been called ctenolium, pectineum, and pectinidium. In old very heavy shells, which are held in place more by their own weight than by the formation of a byssus, they are often absent, but may usually be traced in the groove corresponding to the younger stages or fasciole of the sinus."

The shell of Pecten, being thin in proportion to its surface, is in the adult usually ribbed or fluted. This condition is brought about, doubtless, by natural selection, and serves to strengthen the valves which, in swimming and falling to the bottom, are often subjected to rude shocks. Shelly matter is sometimes deposited internally in the shape of radiating liræ to still further strengthen the disk. In addition to the ribs and riblets, the surface of Pecten may be ornamented by fine, almost microscopic groovings, which radiate from the umbo (shown in $P$. peckhami), or by a minute concentric sculpture due to imbricated incremental lines. A combination of minute concentric and radial sculpture often gives the surface, especially in Chlamys, a checkered squamation or microscopic reticulation.

"The original prototype of Pecten, judging from the stages of recent shells and the succession of the fossils, was a thin, nearly smooth shell, with a taxodont provinculum and the posterior ears ill-defined." These characteristics have been altered in the subsequent forms to meet conditions of environment, in some instances certain features appearing and then becoming obsolete as their usefulness decreased.

"The discrepancy in size of the valves appears to be more or less related to the activity of the animal; the species in which the difference is greatest being probably the more sedentary."

$P$. excavatus is an example of a species in which the discrepancy is very great, the right valve being extremely convex, while the left is somewhat concave. Where a discrepancy is shown the right is usually the more convex valve, although in some instances, notably in P. bowersi and $P$. andersoni, the reverse is true.

The swimming habit is often exercised by Pecten, it being more common to the thin-shelled, light, and young individual than to the thick-shelled, adult, and 
sedentary forms. The movement, although quite rapid, is jerky, and is produced by the expulsion of water through the cavity of the auricles; the ventral margins of the valves being in advance as the animal moves.

"In various geological horizons, as well as in the existing fauna, certain species of Pecten assume a sessile habit, involving an irregular subsequent growth of the valves after attachment to other objects, as in Hinnites. These species have no necessary genetic connection with one another except what they gain from their relations to the Pectinidx as a group, and must be regarded as purely sporadic adjustments of individual forms to a particular environment."

"The influence of the environment is very marked among the Pectens. As in mammals and birds, the same species in the northern part of its range is larger than in the south, unless it is a distinctively tropical species. But in color the rule is reversed, the southern species being lighter and more brightly tinted than the northern ones in the same species. The specimens which live in deep water and swim actively are usually thinner shelled and smoother, while those which inhabit the lagoons are heavier, have more conspicuous concentric sculpture and more solid shells."

The Pectens seem to form a natural genus which may be separated for convenience into groups; but as might be expected when the fossil forms are taken into consideration, these groups merge into one another by insensible gradations. Whatever might be advisable were our knowledge of the Pectinidx confined to the recent species, any paleontological division of them can not ignore the intergradation which is so obvious between the different types of which the extremes appear so unlike.

The subdivisions adopted here, although more or less widely separated in the California fauna, are known elsewhere to be connected by intimate gradations. For that reason they are assigned to a rank compatible with such relations. As would be expected, the relative importance attached to the characteristics upon which groups are founded is regulated more or less by the personal equation; therefore, in order to avoid the complications often arising from a too close discrimination, it has been deemed advisable in this paper to make all of the subdivisions which are worthy of a group name bear the grade of subgenus.

The following groups of Pecten are represented in the Tertiary and living fauna of California:

$$
\text { Subgenus Pecten s. s. Müller. }
$$

Type $P$. maximus Linné.

Right valve moderately inflated, left valve flattish; sculpture of strong ribs with radial striation, more or less roughened by simple concentric lamellation or incremental sculpture; ears subequal.

This group includes the following. Pectens: auburyi, bellus, carrizoensis, coalingaensis, diegensis, excavatus, hemphilli, keepi, lecontei, merriami, sanctæcruzensis, stearnsii, and vogdesi.

\section{Subgenus Patinopecten Dall, 1898.}

Type $P$. caurinus Gould.

Valves with small ribs, flat on the right valve, and sometimes dichotomous; 
smaller and more rounded on the left valve; concentric sculpture inconspicuous; radial striæ absent or obsolete, ears subequal; valves nearly equilateral.

To this group belong the following Pectens: coosensis, caurinus, dilleri, healeyi, oweni, purisimaensis, propatulus, and turneri.

\section{Subgenus Nodipecten Dall, 1898.}

Type $P$. nodosus Linné.

Shell like Lyropecten, but the ribs intermittently nodose, with more or less prominent hollow nodes or bullæ; radial striation pronounced; ears unequal, the posterior smaller, the valves often more or less oblique; imbricate surface layer sometimes very marked. ( $P$. wattsi is a connecting link between this subgenus and the typical Chlamys.)

The only representatives of this group are $P$. subnodosus and $P$. veatchii.

\section{Subgenus Chlamys Bolten, 1798.}

Type P. islandicus Müller.

Valves moderately inflated, subequal, similar, oblique, or with unequal ears, the posterior smaller; Camptonectes striation and imbricate surface layer usually present; shell usually solid and opaque; byssal notch and ctenolium present.

Under this subgenus are grouped the following Pectens: bartschi, bellitamellatus, branneri, calkinsi, fucanus, hamlini, hastatus and vars. hericius, albidus, hindsi, navarchus and strategus, islandicus, jordani, landesi, latiauritus and vars. cerritensis, delosi, fucicolus and monotimeris, lawsoni, nutteri, opuntia, parmeleei, proavus, sespeensis, and its variety hydei, washburnei, wattsi, and its variety morani.

Subgenus Lyropecten Conrad, 1862.

Type P. estrellanus Conrad.

Shell resembling Pecten s. s., but with both valves convex; usually of large size, heavy, and with radial striation and minute concentric imbrication; ribs entire, and not dichotomous; valves equilateral and sometimes more or less undulated in the vicinity of the umbones.

This group includes the following Pectens: Ashleyi, bowersi, crassicardo and its variety hamiltoni, estrellanus and its varieties catalinæ and terminus, magnolia, miguelensis, perrini, and vaughani.

\section{Subgenus Aquipecten Fischer, 1887.}

Type P. opercularis Linné.

Shell thin, orbicular, with subequal inflated valves, usually equilateral, with uniform, well-marked radial, not dichotomous, ribs and finely imbricate radial striation; ears subequal; valves internally lirate on the edges of the grooves corresponding to the external ribs; Camptonectes striation present, but usually obscured by the radial sculpture; ctenolium and byssal notch obvious.

The single representative of this group is $P$. palmeri.

17260-No. $47-06-4$ 
Subgenus Plagioctenium Dall, 1898.

Type P. circularis Sowerby.

Resembling Equipecten but without radial striation; the concentric sculpture in looped lamellæ; the ribs strong, frequently smooth above; the submargins impressed below the subequal auricles; the valves well inflated with a tendency to oblique growth in the adult.

This group includes the following species of Pecten: Andersoni, andersoni var. barkerianus, cerrosensis and its variety mendenhalli, circularis and its variety xquisulcatus, cooperi, discus, deserti, eldridgei, neahensis, pabloensis, pancicostatus.

Subgenus Pseudamusium H. and A. Adams, 1858.

Type $P$. exoticus Chemnitz $=P$. pseudamusium (Klein) Sowerby.

Shells small, thin, more or less translucent; inner face of the disk without liræ; sculpture discrepant on the two valves, the right valve having the concentric and the left valve the radial elements most pronounced; valves usually flattish or compressed.

The following Pectens are placed in this group: Davidsoni, lompicoensis, peckhami, pedroanus, randolphi and its variety tillamookensis, and vancowverensis.

Subgenus Amusium Bolten, 1798.

Type P. pleuronectes Linné.

Valves flattish, internally lirate, externally usually smooth or faintly striated, both valves being similarly sculptured; the ctenolium absent and the byssal notch obsolete.

This group is represented by the single species $P$. lompocensis.

Subgenus Propeamusium Gregorio, 1883.

Type $P$. inequisculptus Tiberi (=P. fenestratus Forbes).

Right valve impressed about the distal margin, which is not fully calcified, partially concave, the sides partially closed away from the ears; the internal liræ present but shorter; the external sculpture chiefly concentric, while on the left valve, if present, it is radial; the recent forms usually glassy or pale colored in both valves.

In this group are included the following Pectens: Alaskensis, clallamensis, interradiatus, riversi, stanfordensis, and waylandi.

Subgenus Hinnites Defrance, 1821.

Type $H$. cortezi Defrance.

Shell (up to advanced youth) a typical Chlamys, later becoming sessile and irregular, in which stage the resilial pit is elongated and cardinal margin develops an obscure area.

This group is represented by the single species Pecten giganteus. 


\section{EOCENE PECTENS.}

[Those known first to appear in the Eocene formations.]

Pecten (Chlamys) calkinsi n. sp.

Pl. II, figs. 1 and 2.

Description.-Shell averaging about 35 millimeters in altitude, subcircular, equivalve or nearly so, equilateral, rather thin, somewhat ventricose, and with only slightly serrate margins. Right valve with the exterior surface ornamented by about 55 small, squarish, slightly imbricated ribs, which show a tendency to become dichotomous near the end in some specimens; interspaces channeled and about one-half as wide as the ribs; hinge line about three-fifths the length of the disk; ears equal in length, flat and with the swell of the disk commencing at right angles to them; anterior ear sculptured by 4 or 5 imbricated radiating ridges; byssal notch distinct; posterior ear sculptured in a similar manner to the anterior. Left valve similar to the right except that in the former the ribs are slightly more rounded and the anterior ear has no notch.

Dimensions.--Alt. $30 \mathrm{~mm}$.; long. $31 \mathrm{~mm}$; hinge line $18 \mathrm{~mm}$.; diameter $6 \mathrm{~mm}$.

So far as known this species has no closely allied forms in any of the other California Tertiary formations, and for that reason is admirable as a diagnostic form for the Tejon. The type and several other specimens of this species were among some material collected by Dr. H. W. Fairbanks on the north side of the Sisar Valley, north of the Astarte oil wells, Ventura County. At this locality it was associated with the following characteristic Tejon fauna: Arca sp., Cardium breweri, Meretrix horni, Modiolus ornatus, Tapes sp., Turritella wvasana, Venericardia planicosta Lam. var. homii.

The types of $P$. calkinsi are now in the collection of the University of California. Named in honor of Mr. Frank C. Calkins, of the United States Geological Survey.

$$
\text { RANGE. }
$$

Eocene (Tejon). Sisar Valley, Ventura County (Fairbanks).

$$
\text { Pecten (Chlamys) landesi n. sp. }
$$

Pl. II, figs. 3, 4, and 5 .

Description.- Shell averaging about 34 millimeters in altitude, about as long as high, subcircular, inequivalve, equilateral, thin, slightly ventricose, and with serrate margins. Right valve more ventricose than left, and flattening toward the periphery in the adult; surface ornamented by from 25 to 40 subequal, rounded, more or less imbricate ribs, separated from each other by subequal, eoncave-bottomed interspaces, which average about as wide as the ribs; hinge line slightly longer than one-half length of disk; ears somewhat unequal, the anterior being slightly the longer; anterior ear sculptured by 4 prominent radials, while the posterior has from 6 to 8 less prominent ones; byssal notch deep; whole surface of disk and ears crossed by numerous fine imbricating lamelli. Left 
valve more compressed than right, similarly sculptured, but with both ears slightly obliquely truncated, the anterior one showing a broad shallow notch. Hinge and muscle scars similar to $P$. islandicus.

Dimensions.-Alt. $34 \mathrm{~mm}$.; long. $33.5 \mathrm{~mm}$; hinge line $19 \mathrm{~mm}$; diameter 12 mm. (right valve $7 \mathrm{~mm}$., left valve $5 \mathrm{~mm}$.).

The general outline and convexity of all the shells of this species appear to be about the same, but the ribs are quite variable, as regards both number and shape. In most cases the ribs are evenly rounded and about equal in width to the interspaces, but in some cases they are ridgelike and narrower than the interspaces. In some specimens a few of the ribs become dichotomous distant 10 or 15 millimeters from the umbo, and small riblets are intercalated in a few of the interspaces at about the same distance. One specimen is contracted at a distance of about 30 millimeters, and shows several intercalaries beyond the line of contraction. Some of the specimens of $P$. landesi remind one somewhat of P. membranosus Morton, from the Eocene of North Carolina, although the latter has more and narrower ribs, and is ornamented by finer imbricating sculpture than the former. $P$. landesi is distinguishable from $P$. proavus by its relatively longer disk and fewer but more prominent, regular, and less imbricated ribs. It is distinguishable from $P$. calkinsi by its smaller size when adult, fewer but more elevated ribs, and relatively much shorter hinge line.

$P$. landesi is found quite abundantly in a dark-greenish sandstone bed that outcrops about 100 yards west of the junction of Stillwater and Olequa creeks (U. S. Nat. Mus. locality 4019) one-fourth mile southwest of Little Falls, Lewis County, Wash. It is also found in a similar matrix in the bed of Olequa Creek (U. S. Nat. Mus. 4024), 1 mile north of the first locality. It is associated in this formation with a characteristic Eocene fauna, among which are the following species: Venericardia planicosta Lamarck, Thracia dilleri Dall, Crassatellites sp., Meretrix sp., Ostrea sp., Pteria (cf.) limula Conrad, Cardium 2 sp., Barbatia sp., Glycymeris sp., Corbula sp., Callista sp., Turritella (cf.) uvasana Conrad, Fusus 4 sp., Ocinebra sp., Ranella sp., Calyptrophorus sp., Lunatia sp., Turbinella (?) sp., Murex 2 sp., Conus sp., Cassis sp., Tritonium sp., Dentaliurn (cf.) cooperi Gabb, and Nautilus sp. This horizon is probably upper Eocene, possibly above the Tejon. Named in honor of Prof. Henry Landes, Seattle, Wash.

RANGE.

Eocene (probably upper). Vicinity of Little Falls, Lewis County, Wash. U. S. Nat. Mus. locality 4019; 4024. (Arnold.)

\section{Pecten (Chlamys) proavus n. sp.}

PI. II, figs. 6, 7, and 8 .

Description.-Shell averaging about 50 millimeters in altitude, much higher than long, compressed, subequivalve, and equilateral, except for the ears; base regularly rounded; margins smooth; sides straight and forming an acute angle at the umbo. Left valve with numerous more or less unequal, narrow, thread-like, imbricated ribs, between which are occasionally much finer intercalaries; interspaces about as wide as ribs, channeled and flat bottomed; whole surface of disk and 
ears ornamented by numerous, sharp, imbricating lamellæ of growth, which appear more prominently on the anterior portion of the disk; posterior ear short, slightly obliquely truncated, and sculptured by numerous radials and imbricating lamellæ; anterior ear unknown, but probably much longer than posterior.

Dimensions.-Alt. $38 \mathrm{~mm}$.; long. $30 \mathrm{~mm}$.; hinge line (restored and approximate) $18 \mathrm{~mm}$.; diameter $7 \mathrm{~mm}$.

This species is closely allied to P. traski Gabb, from the Cretaceous of the Pacific coast. It differs from the latter, however, in not having the diagonal microscropic sculpture so characteristic of that species.

A fragment of a much larger specimen than the type of $P$. proavus, from the same beds and probably the same species, shows, near the periphery, narrow ridge-like ribs separated by rather wide interspaces in each of which are two or three fine thread-like riblets. (Pl. II, fig. 8.)

The type of $P$. proavus, which is now in the collection of the department of geology, Stanford University, is a poorly preserved cast of a left valve on which part of the original shell matter is still preserved. It came from beds of probable lower Eocene (Martinez) age in the ridge between the headwaters of Pescadero Creek and San Lorenzo River, San Mateo County. At this locality it was associated with the following fauna: Terebratulina tejonensis, Tritonium (cf.) californicum, Patella (cf.) traski, Helcion dichotoma, Ostrea (aff.) idriaensis, Turbo sp., Acmæa or Patella sp., Terebratula n. sp., Cidaris (?) spines Semele sp. After an examination of the above fauna Doctor Stanton was of the opinion that it was younger than the Chico (Cretaceous). It is certainly not typical Tejon (middle or upper Eocene), but appears to be closer to the Martinez fauna than to any other, and is, therefore, tentatively placed in the horizon of the latter.

RANGE.

Lower Eocene (Martinez?). Between the headwaters of Pescadero Creek and the San Lorenzo River, San Mateo County (H. S. Gay; Arnold).

\section{Pecten (propeamusium) interradiatus Gabb.}

Pl. II, figs. 9, 10, and 11 .

1869. Pecten interradiatus Gabb, Pal. Cal., vol. 2, 1869, pp. 199-200, pl. 33, figs. 98, 98a.

1888. Pecten interradiatus Gabb, Cooper, Seventh Ann. Rent. Cal. St. Min., 1887, p. 289. (From "Cretaceous B," which is Eocene).

Description.- "Shell small, subcircular, equivalve, equilateral, compressed, thin; upper [left] valve, ears equal, moderately large; lower [right] valve, right ear long, deeply and narrowly emarginate. Surface marked by very numerous fine radiating lines, and obscure lines of growth. Internal surface of both valves bearing 8 straight, equidistant, large ribs of variable length among themselves, extending from the beaks to near the middle of the shell and ending abruptly."

Dimensions.-Alt. $25 \mathrm{~mm}$; long. $24 \mathrm{~mm}$; hinge line $15 \mathrm{~mm}$; d diameter $2.5 \mathrm{~mm}$.

This species may be distinguished from P. stanfordensis by its larger size, narrower anterior ear of right valve, and fewer number of interior ribs. It is.also . distinguishable from $P$. clallamensis and $P$. waylandi by its larger size and inconspicuous external surface sculpture. 
Gabb states that the type of $P$. interradiatus is from the "buff-colored shale east of New Idria, at or near the summit of the Tejon Group" [Eocene], where he found it very abundant. Two specimens from the collection of the University of California, which were collected by Mr. H. W. Turner at New Idria, are in a hard, dark-colored shale.

A Pecten allied to $P$. interradiatus, accompanied by the following note, was sent to the writer by Dr. J. C. Merriam, of Berkeley: "Road cutting below Professor Richer's house at mouth of Strawberry Canyon, Berkeley. Cutting now walled up. A. C. L. Cretaceous shale.". This species, which is represented by an internal cast, is 12 millimeters in altitude, 10 millimeters in longitude, and has a hinge line 3.5 millimeters in length. It has 10 prominent rounded internal ribs extending from the umbo nearly to the periphery, and in several of the broad interspaces a rounded interealary, which begins at a distance of about 7.5 millimeters from the umbo and extends nearly to the periphery. The anterior ear of the shell (which is a right valve) is slightly longer than the posterior, arcuate in front, and has but a faint suggestion of a byssal notch.

The figures of $P$. interradiatus, which are natural size, are copied from the originals of the type in Pal. Cal., vol. 2, pl. 33, figs. 98, 98a.

RANGE.

Eocene (upper Tejon). New Idria, San Benito County (Gabb; Turner).

OLIGOCENE PECTENS.

[Those known first to appear in the Oligocene formations.]

Pecten (Pecten) sanct acruzensis n. $\mathrm{np}$.

Pl. III, figs. 12 and 13.

1903. Pecten (Pecten) twobarensis Arnold, MS.

Description.- Shell averaging about 50 millimeters in altitude, slightly longer than high, plano-convex, equilateral, rather thin; base regularly rounded; sides only slightly concave above; margins smooth. Right valve quite convex and ornamented with about 12 prominent, perpendicular-sided, slightly convex-topped ribs, separated by flat-bottomed, channeled interspaces about equal in width to the ribs; surface sculptured by small, almost imperceptible, obsolete, radiating striations and numerous fine sharp concentric lines; hinge line considerably longer than one half length of disk; ears subequal; anterior with shallow byssal notch and fine, sharp concentric lines; posterior similarly sculptured, but rectangularly truncated. Left valve flat, with slight concavity near umbo; lateral areas rather prominent; ribs squarish, with slightly convex tops narrower than those of the right valke and with proportionally wider interpaces; ears subequal, rectangularly truncated, and with surface sculptured by numerous fine, sharp incremental lines.

Dimensions.-Alt. $52 \mathrm{~mm}$.; long. $55 \mathrm{~mm}$; ; hinge line $32 \mathrm{~mm}$.; diameter about $13 \mathrm{~mm}$; ; unbonal angle $110^{\circ}$.

This species is allied to $P$. bellus and may be its precursor, as it is very similar to the latter in most respects. $P$. sanctæcruzensis may be distinguished 
from $P$. bellus by its fewer ribs (11 instead of 14) and relatively smaller size when adult.

P. sanctrecruzensis is so far known only from beds which appear to be transitional from the Oligocene to the lower Miocene. At locality No. 111 (L. S. J. U. Geol. Survey) on Twobar Creek, one-fourth mile above its junction with San Lorenzo River, Santa Cruz County, the type was found associated in a soft sandstone with the following species: Pecten branneri n. sp., Cythera $(c f$.$) vespertina,$ Tritonium sp. No. 1, Corbula (?) sp., Yoldia (cf.) impressa, Nucula n. sp. (large, with coarse sculpture), Leda sp. B. and C., Cidaris (?) spines, Callista sp., Tellina (Angulus) sp., Cardium n. sp., near cooperi, Teredo sp., Chione ( $f$.) matherssoni. One mile southeast of Cowell's asphaltum quarry (locality 30), near Santa Cruz, P. sanctromzensis is associated with P. peckhami, Nucula sp., Phacoides sp., and Chione-sp.

The type, a beautifully preserved mold of a left valve, is now in the collection of the department of geology, Stanford University. A small cobblestone containing two right and two left valves of $P$. sanctrocuzensis was found by Miss L. J. F. Hecox, of Santa Cruz, as float in Bear Creek, about 2 miles from the type locality. One of these right valves is figured and serves as a cotype.

RANGE.

Oligocene-Miocene. Twobar Creek and Bear Creek, Santa Cruz County (Arnold; Hecox).

Pecten (Chlamys) branneri n. sp.

Pl. III, figs. 9, 10, and 11 .

Description.-Adult shell averaging about 80 millimeters in altitude, higher than long, equivalve, slightly convex, and equilateral, except for ears; sides only slightly concave above; base regularly rounded below. Right valve with from 20 to 22 prominent, narrow, more or less sealy or spiny ribs, which in the adults are sometimes medially sulcated or dichotomous; interspaces generally much broader than the ribs, channeled and usually containing a spiny or scaly intercalary rib; whole surface sculptured by imbricating incremental lines, often also by microscopic reticulations; hinge line about two-thirds length of disk; anterior ear much produced and sculptured by 6 to 10 imbricated ridges, which are separated by equally wide reticulated interspaces; byssal notch profound; posterior ear about three-fifths length of anterior, and sculptured similarly. Left valve similar to right.

Dimensions.-Alt. $65 \mathrm{~mm}$.; long. $58 \mathrm{~mm}$; hinge line $40 \mathrm{~mm}$; diameter 14 mm.; umbonal angle $83^{\circ}$.

This species varies considerably in the degree of importance of the minor sculpture, such as reticulation, imbrication, and size of the sulcations and intercalaries. Although unquestionably allied to the Chlamys group, it has larger posterior ears than other species of the group that have come under the writer's notice. P. branneri resembles $P$. islandicus in size, outline, and general sculpture, but is distinguishable by having only about one-half as many ribs and much larger posterior ears. 
So far as is known, P. branneri is confined to the lowest horizon of the Miocene and top of the Oligocene. It is very abundant at the type locality, Tuff Hill, near Stanford University. One large right valve was also obtained from the fine sandstone immediately overlying the San Lorenzo shale series (Oligocene) in Twobar Creek, near the town of Boulder Creek, Santa Cruz County.

The type, like all of the known specimens of the species, is a mold, and is now in the collection of the department of geology, Leland Stanford Junior University. Named in honor of Dr. J. C. Branner, professor of geology in that institution.

RANGE.

Miocene (lower). Tuff Hill, Stanford University, Santa Clara County (Branner; J. P. Smith; Arnold).

Oligocene (upper) or Miocene (lower). Twobar Creek, near Boulder Creek, Santa Cruz County (Newson; Arnold).

\section{Pecten (Pseudamusium) Peckhami Gabb.}

Pl. III, figs. 6,7 , and 8 .

1869. Pecten peckhami Gabb, Pal. Cal., vol. 2, 1869, pp. 59, 60, pl. 16, figs. 19 and 19a.

1888. Pecten peckhami Gabb, Cooper, Seventh Ann. Rept. Cal. St. Min., 1888, p. 258.

1898. Pecten peckhami Gabb, Dall, Trans. Wagner Free Inst. Sci., vol. 3, pt. 4, 1898, p. 705.

Description.-Shell averaging about 20 millimeters in altitude, subcircular, subequivalve, slightly inequilateral, thin, usually compressed, and with smooth margins. Right valve with the disk showing several small, more or less obsolete, irregular concentric undulations, numerous fine incremental lines and numerous fine obsolete radiating lines; hinge line about two-thirds of the longitude of the disk; anterior ear produced, separated from the body of the shell by a marked groove and a deep, narrow sinus, and prominently sculptured by 6 or 7 radiating ridges and numerous concentric elevated incremental lines; posterior ear not separated by any distinct line from the disk surface and ornamented only by concentric lines and obsolete undulations. Left valve similar to right except that the anterior ear is flat, the swell of the shell commencing with nearly a right angle with the ear surface; surface of anterior ear usually sculptured only by incremental lines, but occasionally with radiating striæ also.

Dimensions.-Alt. $21 \mathrm{~mm}$.; long. $21 \mathrm{~mm}$; hinge line $14 \mathrm{~mm}$.; diameter $2 \mathrm{~mm}$.

As a rule only the molds or casts of this species are found in the shales in which they occur, and for this reason some of the characteristics of sculpture of the species are generally lacking. For example, in a large series of specimens examined, only two or three of the shells showed the radiating sculpture. The disks are generally obliquely distorted and often compressed, but the sculpture on the anterior ear of the right valve is almost always present and is quite characteristic.

In California this species is found from the San Lorenzo formation (Oligocene) to the Monterey or middle Miocene. $P$. peckhami is found abundantly in the Monterey shale in Néwell Creek canyon, 2 miles above Ben Lomond, Santa Cruz County, where it is associated with Arca montereyana Osmont, Corbula sp., Cyth- 
erea sp., Diplodonta n. sp., Venericardia (?) n. sp., Leda 2 n. sp., Phacoides sp., Semele n. sp., and Tellina cf. congesta Conrad.

P. peckhami is also abundant in certain horizons of the Oligocene-Miocene of Washington, and Mr. Diller has found it in some shales in Oregon. It occurs $\mathrm{n}$-ar the base of the Oligocene-Miocene section between Bean and Restoration points, west of Seattle, King County, Wash., associated with Clypeaster (?) sp., Terebratula sp., and Teredo sp. At Freshwater Bay, Clallam County, Wash., it is found with Dolium petrosum Conrad, Fusus sp., Natica or Lunatia sp., Nucula ef. decisa Conr., Volutilithes n. sp., Dentalium substriatum Conrad, Phacoides acutilineatus Conrad, Solemya sp., Leda sp., and Marginella or Erato sp. Farther west along the Strait of Juan de Fuca, $1 \frac{1}{2}$ miles east of Gettysburg, Clallam County, Wash., P. peckhami is associated with Nucula sp., Leda n. sp., Dentalium substriatum Conrad, Natica sp., etc. One of the specimens of P. peckhami from near Bean Point, Washington, shows the anterior ear of the left valve to be ornamented by about 13 fine elevated radiating lines. Owing to the comparatively good state of preservation of the Washington specimens, nearly all of them show the minute concentric and radiating sculpture of the disk and ears in addition to the characteristic undulations of the former.

RANGE.

Miocene (middle). San Pablo, Contra Costa County (Gabb); southeast of Pinole, Contra Costa County (Lawson); Langley Hill, Alpine district, and south of Portola, San Mateo County; Felton and Ben Lomond, Santa Cruz County (Smith, Newsom, Arnold); Carmelo Valley, Monterey County (Lawson, Turner); Templeton, San Luis Obispo County (Fairbanks, F. M. Anderson); northwest of Tulare Lake, Tulare County (Watts); Ojai ranch, Ventura County (type locality) (S. F. Peckham); Big Panoche Creek, Fresno County (Turner); 4 miles south of McKittrick, Kern County (Eldridge).

Oligocene-Miocene. Ridge west of the headwaters of Boulder Creek and western slope of the south end of Ben Lomond Mountain, Santa Cruz County (Newsom, Arnold). In Washington at localities $4112 \mathrm{a}$ and 4113, between Bean and Restoration points, King County; locality 4121, Freshwater Bay; location 4120, 2 miles west of Port Crescent; locality 4114, $1 \frac{1}{2}$ miles east of Gettysburg, Clallam County (Arnold).

\section{Pecten (Propeamusium) clallamensis n. $\mathrm{sp}$.}

Pl. III, figs. 1, 2, 3, and $3 a$.

Description.-Adult shell averaging about 10 millimeters in altitude, subcircular, equivalve, equilateral, thin, compressed, and with smooth margins. Right valve ornamented externally by numerous equally elevated, sharp, slightly imbricate, concentric lamellæ, separated by equal interspaces, each of which is about five times as wide as the thickness of a lamella; hinge line somewhat longer than one-half length of disk; ears decidedly unequal, the anterior being about twice as long as the posterior; anterior ear arcuate in front and sculptured by numerous regular, sharp, elevated, concentric lamellæ and 5 or 6 slightly elevated, unequally spaced radials; 
byssal notch not profound; posterior ear rectangularly truncated and ornamented with concentric sculpture similar to that of the anterior; interior of disk strengthened by nine strong, rounded, elevated, radiating ribs, which terminate abruptly at a length of 6 or 7 millimeters; the middle ribs are straight, but occasionally the lateral ones are faintly arcuate toward the middle rib. Left valve beautifully ornamented externally by numerous regular, thin, concentric, imbricating, prominently elevated lamellæ which, sloping at an angle of about $45^{\circ}$ toward the umbo, rise into 10 or 11 prominent, rounded, radiating pseudo-ribs, separated by somewhat wider interspaces, in nearly every one of which is an intercalated, imbricated pseudo-riblet; this riblet begins only after the shell has attained a height of about 1.5 to 2 millimeters; ears similarly sculptured to those of the right valve.

Dimensions. -Alt. (type, left valve) $10 \mathrm{~mm}$.; long. $9.5 \mathrm{~mm}$.; hinge line $5.5 \mathrm{~mm}$.; diameter about $0.75 \mathrm{~mm}$.

This beautiful little Pecten appears to be allied to P. stanfordensis, but is easily distinguished from the latter by its beautifully lamellated surface, and in possessing 9 instead of 10 or more internal riblets.

The type of $P$. clallamensis is a left valve (U. S. N. M. No. 164922) and was found at locality 4100, $1 \frac{1}{2}$ miles east of Pillar Point, near the mouth of the Pysht River, Clallam County, Wash., where it was associated with Aturia cf. ziczac Sowerby, Dolium petrosum Conrad, Fusus sp., Natica or Lunatia, Marginella or Erato sp., Nucula sp., Leda sp. (large, smooth), Tellina (Angulus) sp., Solemya sp., Dentalium substriatum Conrad. The cotype is a right valve (U. S. N. M. No. 164923), is from locality 4070, Bean Point, King County, Wash., and is associated there with Terebratula sp., Turritella sp., Marginella or Erato sp., Natica or Lunatia sp., Glycymeris sp., and Astyris sp.

Both of the localities at which $P$. clallamensis have so far been found are in the lower portion of the Oligocene-Miocene series.

RANGE.

Oligocene-Miocene. Mouth of Pysht River, Clallam County, and Bean Point, west of Seattle, King County, Wash. (Arnold).

\section{Pecten (Propeamusium) waylandi n. sp.}

\section{Pl. III, figs. 4 and 5 .}

Description.-Adult shell averaging about 9.5 millimeters in altitude, somewhat longer than high, subcircular, equivalve, equilateral, thin, somewhat convex in youth, but becoming more compressed with age; margins smooth. Disk of right valve sculptured by numerous fine lines of growth and numerous, more or less obsolete, fine radiating lines; hinge line equal to about one-half the length of the disk; ears subequal; anterior arcuate in front and faintly sculptured concentrically by sharp lines and radially by faint ridges; byssal notch narrow and shallow; posterior ear slightly obliquely truncated and sculptured by faint radial ridges and fine, sharp, concentric lines; interior of disk strengthened by 8 subequal, strong, narrow, smooth, convex-topped riblets, which are widely separated and which terminate abruptly at about 6 to 8 millimeters from the umbo; these 
internal riblets are usually straight, but the ones distant from the center are often slightly arcuate toward the center. Left valve, up to an altitude of 6 or 8 millimeters, ornamented by 8 more or less prominently elevated, narrow, convex-topped radiating ridges, corresponding with the same number of equally long, smooth, convex-topped internal riblets; whole surface of disk sculptured by numerous subequal, inequidistant, sharp, radiating lines (usually varying from 5 to 7 between each major ridge) and faint incremental lines, the latter becoming prominent as the radiating ridges become obsolete; ears similar to those of right valve, with the exception that there is no byssal notch in the anterior one.

Dimensions.-Alt. $9.5 \mathrm{~mm}$.; long. $12 \mathrm{~mm}$; hinge line $5.5 \mathrm{~mm}$.; diameter about $0.75 \mathrm{~mm}$.

This little Pecten is closely allied to P. stanfordensis, but may be distinguished from the latter by the more prominently elevated ridges on the left valve, the greater prominence of its microscopic radial sculpture, and the smaller number (8 instead of 10 to 12) of internal riblets. $P$. waylandi is distinguishable from $P$. clallamensis, with which it is associated, by its relatively longer disk, simple and less prominent external sculpture, and fewer ( 8 instead of 9 ) internal riblets. It is allied to $P$. interradiatus Gabb, but is much smaller, being only about one-half as large, has a much shorter hinge line, and its left valve is much more strongly sculptured; it also occurs in a horizon probably later than that in which $P$. interradiatus is found.

The type of $P$. waylandi (U.S.N.M., No. 164924) was found with the type of P. clallamensis at locality $4100,1 \frac{1}{2}$ miles east of Pillar Point, near the mouth of the Pysht River, Clallam County, Wash., and a list of its associated species is given in the discussion under $P$. clallamensis. The cotype of $P$. waylandi (U.S.N.M., No. 164925), a mold of the interior of a right valve, was found at locality $4115,2 \frac{1}{2}$ miles west of Gettysburg, Clallam County, Wash., where it was associated with Fusus sp., Leda sp., Macoma or Tellina sp., and Aturia ef. ziczac Sowerby. The faunas associated with $P$. waylandi, at both of the localities where it has so far been found, indicate the lower portion of the widely distributed Oligocene-Miocene series.

The species is named in honor of Mr. Russell G. Wayland, of Seattle, Wash., who assisted the writer during part of his paleontological reconnaissance trip along the northwestern coast of Washington in the summer of 1904.

RANGE.

Oligocene-Miocene, $2 \frac{1}{2}$ miles west of Gettysburg, and $1 \frac{1}{2}$ miles east of Pillar Point, near the mouth of the Pysht River, Clallam County, Wash. (Arnold).

MIOCENE PECTENS.

[Those known first to appear in the Miocene formations.]

Pecten (Pecten) carrizonnsis n. sp.

Pl. IV, figs. $1,1 \mathrm{a}, 1 \mathrm{~b}, 2,3$, and $3 a$.

1898. Pecten sp. indet., Dall, Trans. Wagner Free Inst. Sci., vol. 3, pt. 4, p. 706, line 13.

Description.-Shell averaging about 42 millimeters in altitude, longer than high, inequivalve, plano-convex, equilateral, and with smooth margins; base evenly rounded; sides concave above. Right valve convex, ornamented by about 18 or 
19 prominent, square, flat-topped, medially sulcated ribs; interspaces channeled and slightly narrower than ribs; whole surface sculptured by fine, regular, concentric incremental lines; hinge line less than one-half length of disk; ears subequal, convex, and ornamented by concentric lines. Left valve flat or slightly concave, ornamented by about 17 prominent, equal, equidistant, narrow, convex-topped ribs, which are separated by flat-bottomed interspaces much wider than the ribs; surface sculptured by numerous fine, regular, wavy, concentric lines; ears concave and sculptured by concentric lines.

Dimensions.-Alt. $36 \mathrm{~mm}$; long. $40 \mathrm{~mm}$; hinge line $15 \mathrm{~mm}$; diameter $8 \mathrm{~mm}$.; umbonal angle (left valve) $105^{\circ}$.

This species belongs to the group of which $P$. diegensis is the living member. $P$. carrizoensis, $P$. stearnsii, and $P$. diegensis taken in chronologic order as above may represent a genetic series. The three species are alike in most respects: They are all plano-convex, have squarish, more or less sulcated or longitudinally ridged ribs, convex ears on the right valve, and rather narrow, rounded ribs and concave ears on the left.

$P$. carrizoensis differs from the other two members of the group in the smaller number and less prominence of its ribs and in its relatively much shallower and narrower interspaces.

The Pecten mentioned by Dall on page 706 of the Transactions of the Wagner Free Institute as coming from the Miocene deposits near San Diego was compared with the type of $P$. carrizoensis and found to be of this species.

The type locality of $P$. carrizoensis is at the head of Garnet Canyon, about 12 miles north of the Mexican boundary, in the Carrizo Creek district, San Diego County. The beds in this district contain a fauna different from any of the other known California formations, but from other considerations it is deemed almost certain that the deposits are of Miocene age. Just what horizon the beds represent has not yet been determined. (See list of Carrizo Creek district fossils in Part I, p. 22, and list of Santa Rosalia, Lower California, fossils under P. cerrosensis var. mendenhalli, p. 85.)

The type of $P$. carrizoensis, which was collected by Dr. Stephen Bowers, is now in the collection of Delos Arnold.

RANGE.

Miocene. Head of Garnet Canyon, 12 miles north of Mexican boundary, San Diego County (Bowers); Santa Rosalia, Lower California, west of and across the Gulf from Guaymas, Mexico (G. P. Merrill; E. Palmer).

Pecten (Pecten) Keepi n. $\mathrm{sp}$.

Pl. V, fig. 1; Pl. VI, figs. 1 and $1 a$.

Description.-Shell averaging about 75 millimeters in altitude, longer than high, plano-convex, equilateral, and with smooth margins; sides concave above; lateral area very broad. Right valve ventricose and ornamented by about 20 low, broad, rounded ribs, separated by shallow interspaces in which are low, broad intercalaries; the sulcation on the interior of the valve corresponding to the 
intercalary is often quite prominent; whole surface sculptured by inconspicuous incremental lines; hinge line more than one-half length of disk; ears equal, somewhat convex, rather obliquely truncated and turned up slightly at the corners; sculpture of ears consists of fine incremental lines; byssal notch rather small. Left valve flat, with a slight tendency toward concavity near the umbo, with broad lateral areas and with 18 or 19 low, rather flat-topped ribs; interspaces somewhat wider than the ribs; surface sculptured by fine incremental lines; ears concave, obliquely truncated and sculptured by more or less irregular concentric lines.

Dimensions.-Alt. $75 \mathrm{~mm}$; ; hinge line to ventral margin $72 \mathrm{~mm}$.; long. $82 \mathrm{~mm}$.; hinge line $35 \mathrm{~mm}$.; diameter $20 \mathrm{~mm}$.; umbonal angle (left valve) $102^{\circ}$.

This species is distinguishable from $P$. vogdesi and $P$. excavatus, which it resembles in general characteristics by its greater relative length, somewhat less convexity, greater umbonal angle, broader lateral areas and lower ribs.

This species is found associated with $P$. carrizoensis and Ostrea vespertina in beds in the Carrizo Creek district which are probably of Miocene age. The type is from Alverson Canyon, San Diego County, and is now in the collection of Delos Arnold. Named in honor of Prof. Josiah Keep, of Mills College, whose works on California conchology have greatly stimulated the study of that subject on the Pacific coast.

RANGE.

Miocene. Eight miles north of Mexican boundary, in Alverson Canyon, Carrizo Creek district, San Diego County (Bowers); Santa Rosalia, Lower California, west of and directly across the Gulf from Guaymas, Mexico (E. Palmer).

Pecten (Patinopecten) coosensis Shumard.

Pl. VI, fig. 2; Pl. VII, figs. 2 and $2 a$.

1858. Pecten coosensis Shumard, Trans. St. Louis Acad. Sci., vol. 1, pt. 2, 1858, p. 122.

1864. Pecten coosaensis Shumard, Meek (typ. err.), Miocene check list, Smithsonian Miscell. Coll., 1864, p. 3 (fide Dall, 1898).

1869. Pecten coosensis Shumard, Gabb, Pal. Cal., vol. 2, 1869, p. 122.

1898. Pecten (Patinopecten) coosensis Shumard, Dall, Trans. Wagner Free Inst. Sci., vol. 3, pt. 4, 1898, p. 700 , pl. 26 , fig. 2.

Description. - Shell averaging about 110 millimeters in altitude, slightly longer than high, valves both well compressed, equilateral, and with margins smooth; sides only slightly concave, and sloping at only a moderately low angle. Right valve with 29 to 31 prominent T-rail shaped ribs, flattened and sometimes faintly dichotomous above, overhanging narrow, deep, almost flat-bottomed channels; whole surface sculptured with more or less prominent fine concentric lines; hïnge line nearly equal to one-half length of disk; anterior ear slightly produced and sculptured by radiating ridges and imbricating concentric lines; byssal notch wide and deep; posterior ear rectangularly truncated, and sculptured by sharp incremental lines and sometimes by obsolete radial ridges. Left valve with narrower, rounded, concavesided ribs and wider, round-bottomed interspaces; sculpture of numerous, sharp, 
raised, concentric lines; ears subequal, and having incremental and sometimes obsolete radial sculpture.

Dimensions. - Alt. $110 \mathrm{~mm}$; long. $115 \mathrm{~mm}$; hinge line $54 \mathrm{~mm}$; diameter $26 \mathrm{~mm}$.

This fine species is distinguishable by the great number and shape of its ribs. Specimens found at Howe's place, northeast of Corvallis, Benton County, Oreg., have only from 25 to 27 ribs on the right valve. Otherwise the specimens are similar to the typical form.

Found abundantly in the Empire beds at Coos Bay, Oregon, whence the type came.

RANGE.

Miocene. Coos Bay, Oregon (Shumard; Dall; A. W. Crawford and others);

Howe's place, northeast of Corvallis, Benton County, Oreg. (Diller).

Pecten (Patinopecten) Dilleri Dall.

Pl. V, fig. 2 .

1901. Pecten (Lyropecten) dilleri Dall, Nautilus, vol. 16, no. 10, Feb., 1901, p. 117.

The original description is as follows:

Description. - "Shell large, averaging about 190 millimeters in altitude, rather compressed, nearly orbicular with a relatively short, straight, hinge line, dorsally rectangular, nearly smooth, subequal ears, the posterior with 3 small riblets; a wellmarked though shallow byssal fold; and moderately thick valves. The right valve is somewhat more convex and strongly sculptured, bearing 29 to 30 high, narrow, T-rail shaped ribs, flattened above, overhanging narrower, deep, nearly smooth channels; and with marked concentric imbrication, feeble on top of the ribs but articularly scaly at their sides. The sculpture of the left valve is less pronounced, hidden in the matrix, but apparently similar."

Dimensions. - "Alt. $192 \mathrm{~mm}$.; long. $175 \mathrm{~mm}$.; diameter about $35 \mathrm{~mm} . "$

In the type the lateral edges are slightly defective, the submargins very narrow.

This species is close to $P$. purisimaensis, and is no doubt genetically related to that form. Although the left valve of $P$. dilleri has not been seen, it is safe to assume from the close relationship of this species and $P$. purisimaensis that the left valve of the former is ornamented with narrow, ridge-like ribs which are separated by concave-bottomed interspaces relatively wider than those of the right valve.

P. dilleri is so far known only from beds of probable upper Miocene (although possibly lower Pliocene) age at Rio Dell, on the Eel River, Humboldt County, where the type, was collected by Mr. J. S. Diller, of the United States Geological. Survey.

RANGE.

Upper Miocene or lower Pliocene. Rio Dell, Eel River, Humboldt County (Dall; Diller). 
Pecten (Patinopecten) oweni n. sp.

Pl. VIII, figs. $1,1 a$, and $1 b$.

1888. Pecten pabloensis Cooper (not Conrad), Seventh Ann. Rept. Cal. St. Min., 1888, p. 258 ("Foxins, Santa Barbara County"' record, only).

1898. Pecten sp., Dall, Trans. Wagner Free Inst. Sci., vol. 3, pt. 4, 1898, p. 705, line 27.

Description.-Shell averaging about 85 millimeters in altitude, slightly longer than high, inequivalve, equilateral, and with more or less serrate margins; base regularly rounded; sides somewhat concave above. Right valve much more convex than the left, with 15 or 16 subequal, strong, elevated, squarish ribs, which become more or less deeply medially sulcated after about 40 or 50 millimeters in length; interspaces about as wide as ribs, channeled and ornamented with more or less prominent rounded intercalary riblets; whole surface of disk sculptured by fine lines of growth; hinge line considerably longer than length of disk; anterior ear slightly longer than posterior, obsoletely radially ribbed, and with sharp incremental sculpture; byssal notch quite prominent and equal in width to about onethird width of ear; posterior ear rectangularly truncated and with prominent incremental, but nearly obsolete, radial sculpture. Left valve less ventricose than right; ribs quite high, narrow, and rounded; interspaces much wider than ribs, with round bottoms, and each ornamented by a prominent rounded intercalary rib; surface sculptured by numerous sharp, regular, concentric lines; ears slightly obliquely truncated and sculptured as those of right valve. Hinge as in $P$. caurinus.

Dimensions.-Alt. $85 \mathrm{~mm}$; long. $90 \mathrm{~mm}$.; hinge line $54 \mathrm{~mm}$; diameter $24 \mathrm{~mm}$.

This species is quite closely allied to $P$. healeyi, of which it is probably the precursor. It may be distinguished from the latter by its smaller size, greater convexity, fewer and stronger ribs, more prominent intercalary riblets on the right valve, and relatively much longer hinge line.

$P$. oweni is found in a horizon which is probably low down in the Pliocene, and also in deposits, such as those at Foxin's ranch, Santa Barbara County, from which the type comes, that may be upper Miocene. Specimens of this species have been found in the lower part of the Purisima (Pliocene) formation north of the mouth of Purisima creek. There appears to be more or less of a gradation from $P$. oweni to $P$. healeyi as we go up in the Purisima formation. The rather convex, 17 and 18 ribbed forms of $P$. healeyi, mentioned as occurring at Lobitas and Purisima, seem to furnish a more or less intimately connecting link between the latter species and $P$. oweni.

The type of $P$. oweni, which is figured, is now in the collection of the University of California. This specimen was labeled "P. pabloensis" by Doctor Cooper and furnished the erroneous record of $P$. pabloensis from "Foxins, Santa Barbara County" (see Cooper, 1888, p. 258).

In the Pliocene beds of Temesical Canyon, near Santa Monica, Los Angeles County, $P$. oweni is associated with $P$. stearnsii, $P$. estrellanus var. catalinæ, $P$. cerrosensis and other Pliocene species. 
$P$. oweni is associated with the following possibly upper San Pablo (upper Miocene) fauna at the Double Eagle wells, in the Coalinga district, Fresno County: Tamiosoma gregaria, Pisania (aff.) fortis, Tresus (?) sp., Glycymeris patulus (?), and Saxidomus gibbosus. This fauna, although containing Tamiosoma gregaria, lacks the two most characteristic species of the San Pablo formation of this locality, viz, ' Pecten estrellanus and Ostrea titan. The beds at the Double Eagle wells represent the upper part of the San Pablo as developed in the Coalinga district, so that P. oweni may, therefore, be considered as only occurring in the upper part of the San Pablo, or, in other words, in beds transitional from the San Pablo (upper Miocene) to the Purisima (lower Pliocene). Just above the first railroad bridge across Wartham Creek, Fresno County, $P$. oweni is associated with the following fauna in beds probably representing about the same horizon as those exposed at the double Eagle wells above referred to: Saxidomus gibbosus, Chione n. sp. (large, coarse sculpture), and Tamiosoma gregaria.

A 17-ribbed right valve of $P$. oweni was found 2 miles south of San Lucas, Monterey County, associated with Pecten estrellanus and varieties, Astrodopsis tumidus, Balanus estrellanus, etc.

Named at the request of Mr. F. M. Anderson after Josiah Owen, of Los Gatos, Cal.

RANGE.

Pliocene (lower). North of Purisima, San Mateo County (F. L. Hess); Olinda, Puente Hills, Orange County (Eldridge); Lonoak, Salinas Valley, Monterey County (U. S. Nat. Mus. locality 3830), (Hamlin); Lewis Creek, 9 miles below Priest Valley, Monterey County (loeality 3833), (Hamlin). Temescal Canyon, Santa Monica Mountains, Los Angeles County (Rivers).

Miocene (upper?) Foxins, Santa Barbara County (University of California collection); Double Eagle wells, Coalinga district, Fresno County (Eldridge); railroad bridge across Wartham Creek, Fresno County (Eldridge); San Lucas, Monterey County (Hamlin; Arnold).

\section{Pecten (Patinopecten) propatulus Conrad.}

Pl. VII, fig. 1; Pl. IX, figs. $1,1 a, 2$, and $2 a$.

1849. Pecten propatulus Conrad, Geol. Wilkes Expl. Exped., app. 1, 1849, p. 726, pl. 18, figs. 13, $13 a$. 1864. Pecten propatulus Conrad, Meek, Miocene Checklist, S. I. Misc. Coll., 1864, p. 26 (fide Dall). 1869. Pecten propatulus Conrad, Gabb, Pal. Cal., vol. 2, 1869, p. 103. (California localities excepted.) 1888. Pecten propatulus Conrad, Cooper, Seventh Ann. Rept. Cal. St. Min., 1888, p. 258 (in part).

1898. Pecten (Patinopecten) propatulus Conrad, Dall, Trans. Wagner Free Inst. Sci., vol. 3, pt. 4, 1898, p. 699.

Description.-Shell averaging about 95 millimeters in altitude, as high as long, equivalve, equilateral, rather thin, somewhat ventricose and with smooth margins; base regularly rounded; sides straight and sloping at a rather low angle. Right valve with 15 or 16 subequal, squarish ribs, some of which are generally obsoletely medially sulcated; interspaces subequal, flat-bottomed, about as wide as ribs and sometimes containing faint intercalaries; whole surface ornamented with fine, sharp, 
incremental lines; hinge line less than one-half length of the disk; anterior ear slightly longer than posterior, arcuate-ended, and ornamented above the byssal area by 4 or 5 prominent radiating riblets, which, with the byssal area, are crossed by numerous fine concentric lines; posterior ear rectangularly truncated, and ornamented by several radiating riblets and numerous incremental lines. Left valve somewhat similar to right, but with narrower, ridge-like ribs and the broader interspaces sometimes showing a more or less prominent intercalary riblet in the later stages of growth; surface, when perfect, microscopically tessellated; ears radiately and concentrically sculptured.

Dimensions.-Alt. $93 \mathrm{~mm}$.; long. $93 \mathrm{~mm}$; hinge line $38 \mathrm{~mm}$.; diameter $12 \mathrm{~mm}$.

One of Conrad's cotypes from the Miocene of Astoria, Oreg. (U. S. Nat. Mus., $154155)$, shows the ribs and surface of the disk in a perfect state of preservation. The ribs on the right valve are broad, squarish, and all morè or less medially sulcated, and with the surface sculptured by fine lines of growth and microscopic tessellations. The left valve shows more or less prominent intercalaries in each interspace, and has the whole surface beautifully tessellated.

This species has been confused by some authors with $P$. caurinus Gould, from which it differs by being smaller, more convex, and having fewer (15 instead of 20) ribs, and a tessellated surface on the left valve.

P. propatulus is common in the Astoria Miocene of the Columbia River. A specimen probably of this species, having 15 primary ribs on each valve, intercalary riblets in most of the interspaces, and the typical tessellated surface, was found at Newport, Yaquina Bay, Oreg.

A variety of $P$. propatulus, with possibly an average of one or two more ribs and the intercalaries and medial sulcations slightly more prominently developed, is found at Griswoldsville, San Benito County, Cal., and at several other localities in the southern Mount Diablo Range. At Griswoldsville P. propatulus is associated with the following species: Phacoides acutilineatus, Arca canalis, Panopea generosa, Cryptomya californica, Nucula castrensis, Sigaretus sp., Trochita filosa, Dosinia sp. (thin, flat).

A more or less close relationship appears to exist between $P$. propatulus, $P$. oweni, and $P$. healeyi. The last is distinguishable by its more numerous ribs (having generally 20 or more), and $P$. oweni by its much stronger intercalaries and deeper medial sulcations. P. propatulus is found in a horizon which is probably somewhat lower than any in which either $P$. oweni or $P$. healeyi occur.

RANGE.

Miocene (middle? and upper?). Clallam Bay, Strait of Fuca, Washington (Diller; Arnold); Astoria, Oreg. (Dana; Dr. H. C. Kinney, and others); Newport, Yaquina Bay, Oreg. (H. Hill); Point Simpson, B. C. (No. 3518, Cal. Acad. Sci. Coll.); Griswoldsville, San Benito County, Cal. (Turner, Cooper). 17260-No. $47-06-5$ 
Pegten (Chlamys) fucanus Dall.

Pl. X, figs. 1,2 , and $2 a$.

1898. Pecten (Chlamys) fucanus Dall, Trans. Wagner Free Inst. Sci., vol. 3, pt. 4, 1898, p. 704, pl. 26, fig. 7.

1904. Pecten (Chlamys) fucanus Dall, Harriman Exped. Repts., Alaska geology, Neozoic invert. fossils, p. 113.

Description.-Adult shell averaging nearly 100 millimeters in altitude, about as long as high, inequivalve (the left being the more convex), equilateral, moderately thin, and with nearly smooth margins. Right valve with from 14 to 17 more or less unequal, prominent, rather squarish, radiately striate ribs, between which (especially the anterior and posterior ones) are occasionally intercalated small riblets; interspaces unequal and averaging somewhat narrower than the ribs; whole surface of disk sculptured by rather prominent lines of growth and a fine subsidiary tessellation; hinge line longer than one-half length of disk; ears equal in length; the anterior rather narrow and sculptured by 4 prominent radials and fine, imbricating, incremental lamellæ; the posterior rectangularly truncated and sculptured by more, but less prominent radials and fine concentric lamellæ; byssal notch profound. Left valve usually having 15 or 16 unequal, prominent, convex-topped ribs, the median one generally being stronger than the rest, with the second or third one from it on each side only a little less prominent; the prominent ribs, especially the median one, is generally surmounted by elevated imbricating scales; the other ribs are simply radially striated, as are the interspaces, which often carry one or more elevated riblets; the submargins are radially threaded, as are the subequal ears, which are rectangularly truncated, and also bear marked concentric lamellæ; the fine subsidiary tessellation is also present on well-preserved specimens of this valve. The resilial pit is of moderate size, and the cardinal edge is deeply grooved parallel to and just below the margin. The interior of both valves reflects the external ribbing.

Dimensions.-Alt. $85 \mathrm{~mm}$.; long. $80 \mathrm{~mm}$.; convexity of right valve $5 \mathrm{~mm}$.; of left valve $15 \mathrm{~mm}$; hinge line $50 \mathrm{~mm}$.

The difference between the convexity and ribbing of the two valves, together with the variation in size, shape, and ornamentation of the individual ribs of the same valve, are the prominent characteristics of this species. It is not closely allied to any other species of Chlamys, but, instead, shows in its sculpture some affinity to certain species of Patinopecter.

The type of "P. fucanus (U. S. N. M., No. 107790) is the mold of the exterior and interior (a cast of the former being Pl. X, fig. 2) of a left valve which was found by Mr. J. S. Diller in the Miocene sandstone on the coast just east of Clallam Bay, Clallam County, Wash. It was associated in the sandstone formation with the following species: Sigaretus sp., Crepidula sp., Dentalium sp., Mytilus sp., Mactra or Spisula sp., Venericardia sp., Nucula (cf.) decisa Conrad, Leda sp., Tellina (cf.) arctata Conrad, Tellina sp., Chione sp.

The writer found $P$. fucanus at several localities (U. S. Nat. Mus. localities $4074,4077,4081,4082$ ) on the coast between Clallam Bay and the mouth of the Pysht River, 7 miles farther east. At all of these places it was associated with 
characteristic Miocene fossils, among which was a large Pecten (probably propatulus Conrad) with medially sulcated ribs on the right valve.

RANGE.

Miocene. Between Clallam Bay and Pysht River, Clallam County, Wash. (Diller; Arnold); north end of Popoff Island, Alaska (Dall).

Pecten (Chlamys) hamlini n. $\mathrm{sp}$.

Pl. XI, fig. 2.

Description.-Type somewhat distorted but originally about 60 millimeters in altitude, and probably somewhat shorter than high; moderately convex; base evenly rounded; sides nearly straight. Right valve with 4 broad, squarish ribs, each ornamented above by about 5 prominent imbricated radiating ridges, and separated by relatively narrow interspaces; hinge line more than one-half length of disk; anterior ear much longer than posterior and ornamented by several imbricated radiating ridges; byssal notch quite prominent; posterior ear short and radially ridged.

Dimensions.-(Of the distorted type.) Alt. $60 \mathrm{~mm}$.; long. $68 \mathrm{~mm}$.; hinge line $40 \mathrm{~mm}$; d diameter $24 \mathrm{~mm}$.

This species is closely allied to $P$. wattsi, but is distinguishable from the latter species by its relatively broader (?) disk and longer hinge line. The characteristics of sculpture are approximately the same in the two species.

The geologic position of $P$. hamlini is somewhat uncertain, although the meager fauna with which it is associated at the type locality points toward its correlation with the Vaqueros or lower Miocene. The type of $P$. hamlini (U.S.N.M. No. 164844) was collected by Mr. Homer Hamlin near the head of Slack's Canyon, in the Mount Diablo Range, Monterey County, where it was associated with P. estrellanus Conrad, Chione n. sp. (large, and with coarse sculpture), Chione (cf.) mathewsonii Gabb, and Mactra (aff.) catilliformis Conrad.

A specimen, which is probably a left valve of $P$. hamlini, was found associated with Pecten branneri in the lower Miocene at Tuff Hill, near Stanford University, Santa Clara County. This specimen has three widely separated, narrow, ridge-like ribs, and the interspaces are ornamented by a number of rather coarse radiating riblets; altitude 31 millimeters.

RANGE.

Miocene (lower?). Locality 3851, U. S. Nat. Mus., head of Slacks Canyon, Mount Diablo Range, Monterey County (Hamlin); Stanford University (Tuff Hill), Santa Clara County (Arnold).

\section{Pecten (Chlamys) nutteri n. sp.}

Pl: XI, figs. 3,4 , and $4 a$.

Description.-Shell averaging about 65 millimeters in altitude, slightly higher than long, inequivalve, equilateral, more or less ventricose, and often showing 
several constrictions or undulations of interrupted growth; margins somewhat coarsely serrate; base regularly rounded; sides straight, and forming an acute angle at the umbo. Right valve with about 8 to 10 , unequal, rather prominent, flat-topped ribs, each of which is channeled by one or more deep, narrow, concave sulcations which divide the primary rib from umbo to margin into two or more generally unequal but evenly convex riblets; interspaces somewhat narrower than the ribs, and containing from 1 to 3 prominent rounded riblets; the riblets become more numerous and the major ribs less prominent anteriorly and posteriorly; the minor sculpture consists of squamose lines of growth, which are more prominent on the ribs, and beautiful microscopic checkered tessellation which is best developed in the major and minor interspaces; hinge line from two-fifths to nearly one-half length of disk; anterior ear prominent and sculptured by 5 or 6 elevated radiating ridges and imbricating concentric lamellæ; byssal notch moderately deep; posterior ear rectangularly truncated, a little less than one-half length of anterior, and similarly but less prominently sculptured. Left valve with unequal, rather narrow, convex ribs, the alternate ones being more prominent than those intermediate; extremities of the ribs sometimes ornamented by longitudinal riblets; interspaces of about equal width to the ribs, and ornamented by one or three alternately prominent intercalaries; surface sculptured by imbricating incremental lines; the constrictions, when present, are more pronounced in this valve; ears sculptured similarly to those of the right valve. Hinge with a pair of prominent cardinal crura adjacent to the umbonal pit in the right valve.

Dimensions.-Alt. $64 \mathrm{~mm}$; long. $57 \mathrm{~mm}$; hinge line $27 \mathrm{~mm}$; diameter $21 \mathrm{~mm}$.

This species is allied to $P$. parmeleei and $P$. wattsi but is distinguishable by having a larger number of ribs, which are also narrower and more coarsely radially sculptured. The Miocene forms of $P$. nutteri have more prominent and deeply sulcated ribs on the right valve, are generally more convex and more prominently constricted, and have relatively longer posterior ears than the later forms.

P. nutteri, so far as known, ranges from the Mount Hamilton Range Miocene to the lower Pliocene. It is found rather abundantly in a certain layer in the sea cliff, one-half mile south of the mouth of San Gregorio Creek, San Mateo County, associated with a characteristic lower Pliocene (Purisima) fauna. The species is named in honor of Mr. Edward Hoitt Nutter, who has rendered the writer much valuable assistance in the preparation of this paper. The type is from San Gregorio, San Mateo County, and is now in the collection of the department of geology, Stanford University.

RANGE.

Pliocene (lower). Purisima to Pescadero, San Mateo County (J. P. Smith, W. R. Hamilton, Arnold); Kreyenhagen's ranch, Fresno County (Watts).

Miocene (upper). Near Mount Hamilton, Santa Clara County (No. 5805, Cal. St. Min. Bur. Coll., collected by Mrs. A. E. Bush). 
Pecten (Chlamys) sespeensis n. sp.

Pl. VIII, figs. $2,2 a$, and 3 .

1888. Pecten hastatus Cooper (not Sowerby), Seventh Ann. Rept. Cal. St. Min., 1888, p. 257 (Miocene of Estrella, San Luis Obispo County?).

Description.--Shell averaging about 50 millimeters in altitude, higher than long, inequivalve but both valves equally slightly convex, rather thin, and equilateral, except for ears. Right valve, with about 9 pairs of narrow, rounded, nearly smooth ribs, each pair being separated from the adjacent ones by interspaces, which are generally slightly wider than the interspace between the members of the pair; surface sculptured by incremental lines; hinge line about two-thirds length of disk; anterior ear much produced, sculptured by several prominent radials and numerous incremental lines; posterior ear over one-half as long as anterior, and sculptured similarly; byssal notch prominent. Left valve with about nine prominent, narrow, squarish, somewhat convex-topped ribs separated by much broader interspaces, along the bottom of which run one or more thread-like intercalaries of greater or less prominence; ears similar to those of the right valve.

Dimensions.-Alt. $37 \mathrm{~mm}$; long. $30 \mathrm{~mm}$; hinge line $19 \mathrm{~mm}$.; diameter $12 \mathrm{~mm}$.; umbonal angle $75^{\circ}$.

This species is closely allied to, and is probably the precursor of $P$. hastatus Sowerby. It corresponds to P. hastatus in size, shape, and number of major ribs, but differs from the latter in having longer anterior ears and scarcely any secondary sculpture of minor riblets and scaly surface. P. sespeensis approaches more closely to the smooth form of $P$. hastatus found in the Pliocene, but may be easily distinguished from that form by its longer posterior ears and lack of much secondary sculpture.

The only specimens of this species known are rather poorly preserved easts, with now and then small fragments of the shell hanging to them, which come from beds of lower Miocene age, locally known as "oil rocks," in the Sespe oil district, Ventura County. Type and cotype, No. 12480, California State Mining Burreau. Other specimens of the same species, Nos. 12427 and 14759 C. S. M. B. On Tar Creek, Ventura County, Mr. Eldridge found P. sespeensis associated with Turritella (cf.) hoffmanni, Ostrea sp., and Modiolus sp.

RANGE.

Miocene (lower.) Sespe oil district, Ventura County (Watts); Tar Creek, Ventura County (Eldridge).

Pecten (Chlamys) sespeensis var. hydei n. vä.

Pl. V, figs. $3,3 a$, and $3 b$.

1903. Pecten (Chlamys) hydei Arnold. MS.

Description.-Shell averaging about 45 millimeters in altitude, much higher than long, subequivalve, slightly convex, and subequilateral, except for ears; anterior sides more concave than posterior; base regularly rounded; umbonal angle 
comparatively small. Right valve with about 20 subequal, promizent, rounded, somewhat imbricated ribs, which increase gradually in number by division and intercalation as the shell grows; interspaces somewhat narrower than ribs and often containing one or two thread-like intercalaries; ears as in $P$. hastatus var. hericius except less imbricated, and the posterior relatively larger. Left valve similar in every respect to right.

Dimensions.-Alt. $46 \mathrm{~mm}$; long. $39 \mathrm{~mm}$.; diameter $13 \mathrm{~mm}$.; umbonal angle $82^{\circ}$.

This variety is characterized by the nearly uniform size of its ribs and interspaces. The shell has a tendency to contract somewhat upon reaching an altitude of about 35 or 40 millimeters. $P$. var. hydei is closely allied to the typical $P$. sespeensis, but may usually be distinguished by its more nearly equal ribs, which are generally more strongly imbricated.

In a tributary of Little Sespe Creek, Ventura County, Mr. Eldridge found $P$. var. hydei associated with Scutella fairbanksi, Ostrea sp., Arca sp., and Balanus. Near the Torrey wells, Ventura County, the same gentleman found it with Mytilus mathewsonii, and Ostrea (aff.) titan. In the Ojai Valley it occurs with Pecten magnolia and Chione n. sp. (large; coarse sculpture).

The type specimen is from Lynch's Mountain, Monterey County, where it was found associated in the lower Miocene (Vaqueros sandstone) with Turritella hoffmanni, Pecten estrellanus, and other species characteristic of this horizon. It is now in the collection of Delos Arnold. Named in honor of Prof. James M. Hyde, of the University of Oregon.

RANGE.

Miocene (lower). Lynch's Mountain, Monterey County (Arnold); vicinity of Little-

Sespe Creek, Torrey oil wells, and Ojai Valley, Ventura County (Eldridge).

Pecten (Lyropecten) bowersi n. sp.

Pl. XII, figs. 1 and 2; Pl. XIII, figs. 1 and $1 a$.

1856. ? Pecten nevadanus Conrad, Pac. R. R. Rept., vol. 5, p. 329, pl. 8, fig. 77 .

Description.-Shell averaging about 150 millimeters in altitude and length, inequivalve, equilateral, rather thick, ventricose, and with smooth margins; hase regularly rounded; sides sloping, the anterior 'ones slightly concave upward. Right valve considerably less ventricose than left, the surface of the disk being almost flat until an altitude of 50 or 60 millimeters is reached, when it begins to be more or less convex; surface ornamented with about 18 subequal, prominent, rounded ribs, which; with the interspaces, are obsoletely radiately striate and crossed by fine wavy incremental lines; the ribs tend to become smaller toward the sides of the disk, there being a varying number of riblets near the sides in different specimens; interspaces subequal, round bottomed, about as wide as the ribs, and sometimes containing an auxiliary riblet; hinge line about three-fifths length of shell; ears about equal in length, anterior ear divided into two nearly equal parts by a line radiating from the apex, the part above the dividing line being ornamented by 3 or 4 radiating ribs and concentrie lines while the lower part (byssal area) is ornamented by imbricating incremental lines which are convex 
toward the apex; byssal notch wide and of medium depth; posterior ear rectangularly truncated, radiately ribbed, and crossed by concentric incremental lines. Left valve prominently and evenly ventricose; sculptured the same as the right valve except that most of the interspaces contain an auxiliary riblet; anterior ear arcuate ended, radiately ribbed, and with concentric incremental sculpture; posterior ear as in right valve.

Dimensions.-Alt. $150 \mathrm{~mm}$; long. $150 \mathrm{~mm}$; hinge line (restored) $90 \mathrm{~mm}$.; diameter $55 \mathrm{~mm}$.

This species is distinguishable by its large size, almost smooth rounded ribs, and the greater convexity of the left valve. The flat surface of the right valve near the apex is also a very noticeable characteristic. P. bowersi is placed in the section Lyropecten because of its hinge and general affinity to the group. It, however, lacks the radial secondary sculpture found developed to a greater or less degree on most of the species of this group, and is also different from the other members examined by the writer in having the left valve noticeably the more convex.

$P$. bowersi ranges from the lower to possibly the middle Miocene, being found associated in some localities with $P$. magnolia, and in others with $P$. discus.

The type which is figured is from Santa Inez Canyon, Santa Barbara County, and is now in the collection of the University of California. Named in honor of Dr. Stephen Bowers, of Los Angeles, one of the pioneer geologists of southern California, to whom the writer is indebted for much valuable material and information used in the preparation of this paper.

RANGE.

Miocene (middle?). Gillis's ranch, 10 miles southwest of Paso Robles, San Luis Obispo County (J. P. Smith).

Miocene (lower). Santa Inez Canyon, Santa Barbara County (Voy; J. H. Wilson); La Panza Creek, San Luis Obispo County (Fairbanks; R. Moran; Arnold); Barker ranch, and "top of hill" at Long Tom mine and Miller Bros. ranch east of Annette P. O., Kern County (Watts; Arnold); 30 miles north of Santa Monica and 1 mile from ocean, Ventura County (R. E. Maynard); Santa Monica Mountains, Los Angeles and Ventura counties (Bowers). Station No. 550, Santa Ana Mountains (Watts).

\section{Pecten (Lyropecten) crassicardo Conrad.}

Pl. XVI, figs. 1 and $1 a$; Pl. XVII, figs. 1, $1 a$, and $1 b$; Pl. XVIII, figs. 1, 2, and $2 a$.

1856. Pallium crassicardo Conrad, Proc. Acad. Nat. Sci. Phila., 1856, p. 313.

1857. ? Spondylus [=Pecten] Estrallensis Conrad, Proc. Acad. Nat. Sci. Phila., first series, vol. 8, for 1856,1857, p. 315 .

1857.? Spondylus [=Pecten] Estrellanus Conrad, Pac. R. R. Rept., vol. 7, 1857, p. 191, pl. 1, fig. 3; not Pallium [=Pecten] estrellanum Conrad, Pac. R. R. Repi., vol. 6, pt. 2,1856, p. 71, pl. 3, fig. 15. 1863. Pecten crassicardo Conrad, Proc. Acad. Nat. Sci. Phila., 1862, p. 291.

1867. Lyropecten crassicardo Conrad, Am. Jour. Conch., vol. 3, 1867, p. 6.

1869. Liropecten crassicardo Conrad, Gabb, Pal. Cal., vol. 2, 1869, p. 105 (in part, at least).

1888. Liropecten crassicardo Conrad, Cooper, Seventh Ann. Rept. Cal. St. Min., 1888, p. 246 (in part, at least). 
1894. Pecten estrellanus Conrad, Cooper, Bull. Cal. St. Min. Bureau, No. 4, pt. 5, 1894,p. 57 (in part). 1898. Pecten magnolia Dall, Trans. Wagner Free Inst. Sci., vol. 3, pt. 4, p. 702 (in part); not Pecten magnolia Conrad, Pac. R. R. Rept., vol. 7, 1857, p. 191, pl. 1, fig. 2.

1901. Pecten magnolia Dall, Nautilus, vol. 14, 1901, p. 117 (in part); not P. magnolia Conrad, 1857.

1904. Pecten (Lyropecten) diabloensis Arnold, MS. (a distorted specimen of $P$. crassicardo being the type).

Description.-Adult, shell averaging about 130 millimeters in altitude, about as long as high, inequivalve, convex, equilateral (except for ears), thick, and generally prominently and abruptly constricted or undulated one or more times near the umbo and sometimes at later stages of growth; sides nearly straight; base regularly rounded; margins smooth. Right valve with 14 to 17 prominent, perpendicularsided, convex-topped ribs, which are separated by more or less deeply channeled, flat-topped, convex-bottomed interspaces somewhat narrower than the ribs; whole surface of ribs and interspaces sculptured by numerous radial striæ and fine, minutely wavy, imbricating, concentric lines; hinge line about four-sevenths length of disk; anterior ear somewhat produced, subarcuate laterally and sculptured by about 5 prominent radial ridges and numerous fine imbricating incremental lines; posterior ear about three-fourths length of anterior, sculptured similarly, but slightly less prominently, and rectangularly truncated. Left valve similar to right, except that the ribs are narrower, and the interspaces correspondingly-broader; ears similar to posterior one of right valve. Hinge with a deep resilial pit, on each side of which are several prominent lateral crura or teeth.

Dimensions.-Alt. $140 \mathrm{~mm}$.; long. $138 \mathrm{~mm}$; hinge line $85 \mathrm{~mm}$.; diameter 50 mm.; umbonal angle $105^{\circ}$.

The tops of the ribs sometimes overhang the interspaces and also sometimes appear smooth. Great variation is shown in regard to the number, abruptness, and prominence of the constrictions on the disk. One or two are generally present near the umbo in most specimens, and some show as many as six or seven at different periods of growth. The specimens of this species from Orange County are generally freer from constrictions and the disks are usually more compressed than in the forms from central California; otherwise the former are normal types.

$P$. crassicardo is characterized by its comparatively few ribs, which, with the interspaces, are more or less prominently striated. It is distinguishable from $P$. ashleyi, by its relatively much greater length, fewer ribs, and tendency to be constricted at different stages of growth; distinguishable from $P$. magnotia, with which it is often confused, by its more numerous and much narrower ribs, relatively shorter hinge line, more prominently striate ears, and its tendency to become constricted; distinguishable from $P$. estrellanus, with which it is often associated, by its fewer and rather finely striate ribs and lack of a major intercalary riblet (the bottoms of the interspaces of $P$. crassicardo being striate rather than containing a riblet). Some of the lateral ribs and interspaces, and the surface near the periphery of the disk in adults of $P$. estrellanus generally show sculpture similar to that characteristic of P. crassicardo.

$P$. crassicardo is found abundantly in the San Pablo, or upper Miocene formation of central California, and also in beds of possibly lower Miocene age in southern California. 
Mr. Homer Hamlin and the writer found P. crassicardo associated with the following fauna in beds of somewhat uncertain age, in a small ravine one-half mile south of J. C. Griffin's ranch house, Priest Valley, Monterey County; P. discus Conrad, Agasoma (aff.) barkerianum Cooper, Mytilus (aff.) mathewsonii Gabb, Venus pertenuis Gabb, and Ostrea titan Conrad.

In the Valcito Valley, Fresno County, Mr. H. W. Turner found P. crassicardo with Venus pertenuis, Dosinia ( $f$.) ponderosa, and Tellina sp.

Mr. Eldridge found P. crassicardo associated with the following species in beds of probable lower Miocene age on the ridge between the Upper and Lower Ojai valleys, Ventura County: Pecten lompocensis, Turritella $(c f$.$) hoffmanni, Phacoides$ sp. (flat), Ostrea sp., Nassa sp., Dentalium sp., Chione sp., Leda sp., Balanus sp., and Tritonium or Fusus sp.

Dr. Stephen Bowers has found P. crassicardo with the following species in the Miocene of Laguna Canyon, San Joaquin Hills, Orange County: Pecten estrellanus, Glycymeris ? sp., Turritella hoffmanni, Chione n. sp. (large, coarse sculpture), Agasomakernianum, and Gyrodes? sp.

A beautiful specimen of P. crassicardo in the National Museum (No. 154154) labeled from "California" is associated in the matrix with Saxidomus gracilis, Tresus nuttalli, and Litorina rémondi. As the last mentioned species is found only at Kirker Pass it is safe to assume that this magnificent specimen (which is figured) is from that locality.

The type of $P$. crassicardo (Pl. XVIII, fig. 1), which is now in the collection of the Philadelphia Academy of Natural Sciences, is simply labeled "California. Pres. by Dr. Wilson."

RANGE.

Miocene (upper). San Pablo Bay, Contra Costa County (Merriam, Arnold, and others); Kirker Pass, Contra Costa County (U. S. N. M.); Mount Diablo, Contra Costa County (Pioche collection, Univ. Cal.); Scott Valley, Santa Cruz County (Miss L. J. F. Hecox); Cammatta ranch and San Juan Valley, east of San Luis Obispo, San Luis Obispo County (Fairbanks, Moran, Arnold); Priest Valley, Monterey County (Hamlin, Arnold); San Ardo, Monterey County (Fairbanks, Hamlin, Anderson, W. C. Dudley for Cal. St. Min. Bureau, Arnold); Quailwater Creek, San Luis Obispo County (Anderson); Ventura County (No. 12772, C. S. M. B.); Sunset district, Kern County (Eldridge); Valcito Valley, Fresno County (Turner).

Miocene (middle or lower). Devils Den, Kern County; Ojai Valley, Ventura County (Eldridge); ? El Toro and Laguna Canyon, Orange County (Bowers, Arnold).

Pecten (Lyropecten) Crassicardo Conrad var. hamiltoni n. var.

Pl. XI, figs. 5 and 6.

Description.-Adult shell averaging about 60 millimeters in altitude, subequivalve, equilateral, convex; sides concave above; margins smooth. Right valve with 15 to 17 prominent convex-topped ribs, separated by interspaces narrower 
than the ribs; surface of ribs and interspaces sculptured by rather coarse radiating lines and imbricating incremental lamellæ; anterior ear longer than the posterior, and with 4 prominent, finely imbricated radials; byssal notch rather deep; posterior ear rectangularly truncated, and with radial and concentric sculpture. Left valve similar to right, except with slightly wider interspaces. The disk of this variety is generally contracted after reaching an altitude of 40 millimeters or more.

Dimensions.-Alt. $40 \mathrm{~mm}$; long. $47 \mathrm{~mm}$; hinge line about $30 \mathrm{~mm}$; diameter about $14 \mathrm{~mm}$.

This variety is closely allied to the typical $P$. crassicardo, and probably is the ancestral form. It is distinguishable from the latter by its smaller size when adult, narrower, lower, and more strongly and evenly convex-topped ribs, narrower anterior ear on the right valve, and tendency to become more contracted, and consequently more convex when adult or at an altitude of about 60 millimeters. $P$. var. hamiltoni resembles $P$. estrellanus in size and shape, and in the earlier stages of growth is almost indistinguishable on account of having but a single line down the middle of the interspace, which resembles the intercalary riblet of $P$. estrellanus. After attaining an altitude of about 30 millimeters the two species are easily separated, as at that stage of growth the radial striation becomes apparent on the ribs of $P$. var. hamiltoni, and the radial line in the interspace is supplemented by others, thus ornamenting the interspace with several radial lines rather than with an intercalary riblet, as in $P$. estrellanus. The tendency to undulations caused by temporary contractions in the growth of the disk near the umbo is often exhibited to a slight degree in some specimens of $P$. var. hamiltoni.

This variety is known only from the Mount Hamilton Range, where it is quite common from a few miles south of Mount Hamilton to Mount Diablo, in Contra Costa County. P. var. hamiltoni occurs in the horizon of the Miocene which is so well developed in the vicinity of Alum Rock Canyon, Santa Clara County. The type is from this locality, and is now in the U. S. National Museum (No. 164845). Named in honor of Mr. W. R. Hamilton, of Bodie, Cal.

$$
\text { RANGE. }
$$

Miocene (upper). Alum Rock Canyon, Santa Clara County (Turner; J. P. Smith; Arnold); Mount Hamilton, Santa Clara County (Crawford); Mount Hamilton Range in Alameda County (Yates).

\section{Pecten (Lyropecten) estrellanus Conrad.}

Pl. XIX, figs. 1 and $1 a$; Pl. XX, figs. 1, 2, and $2 a$; Pl. XXI, figs. $1,1 a, 1 b, 2,2 a$, and $2 b$.

1856. Pallium estrellanum Conrad, Pac. R. R. Rept., vol. 6 , pt. 2,1856 , p. 71 , pl. 3 , fig. 15 .

1856. Pallium estrellanum Conrad, Pac. R. R. Rept., vol. 7, pt. 2, 1856, p. 191, pl. 3, figs. 3 and 4.

1857. Pallium estrellanum Conrad, Proc. Acad. Nat. Sci. Phila., vol. 8 for 1856, p. 313.

1863. Lyropecten estrellanus Conrad, Proc. Acad. Nat. Sci. Phila., vol. 6 for 1862, p. 291.

1863. Lyropecten voloformis Conrad, Proc. Acad. Nat. Sci. Phila., vol. 6 for 1862, p. 291.

1869. Liropecten estrallanus Conrad, Gabb, Pal. Cal., vol. 2, 1869, p. 105. 
1888. Liropecten estrellanus Conrad, Cooper, Seventh Ánn. Rept. Cal. St. Min., 1888, p. 246.

1894. Liropecten estrellanus Conrad, Cooper, Bull. Cal. St. Min. Bureau, No. 4, pt. 5, 1894, p. 57, pl. 5. figs. 65-67 (text only in part).

1898. Pecten (Lyropecten) Heermanni Dall, Trans. Wagner Free Inst. Sci., vol. 3, pt. 4, 1898, p. 701 (not P. Heermanni Conrad, Proc. Acad. Nat. Sci. Phila., vol. 7, 1855, p. 267, which is $P$, caurinus Gould).

Description.-Shell averaging about 90 millimeters in altitude, somewhat longer than high, equivalve, equilateral, of medium thickness, generally quite ventricose, and with margins more or less serrate; base evenly rounded; sides sloping, slightly concave above. Right valve with 16 to 20 prominent, squarish ribs separated by channeled interspaces which are narrower than the ribs; interspaces each with one sharply outlined, squarish riblet in the middle; surface sculptured by fine raised incremental lirulæ which loop back over the ribs and riblets, and, on the anterior and posterior portions of the disk, by radiating striæ, which increase in number as the periphery of the disk is approached; hinge line straight and nearly equal to one-half length of disk; ears equal; anterior ear arcuate in front and ornamented above byssal area by three or four radiating ridges and numerous incremental lines; byssal notch sharply defined; byssal area with incremental sculpture only; posterior ear with slightly concave end and ornamented by 5 or 6 radiating ridges and more or less prominent incremental lines. Left valve with the ribs narrower and having more sloping sides and rounded tops than those of the right; interspaces wider; auxiliary riblets inclined to be dichotomous near the ends in the more mature specimens; the looping incremental lirulæ and the secondary radiating lines apparently more highly developed in this valve than in the right; ears similar to the posterior ear of the right valve.

Dimensions. -Alt. $93 \mathrm{~mm}$; ; long. $105 \mathrm{~mm}$; hinge line $50 \mathrm{~mm}$.; diameter $47 \mathrm{~mm}$.

This is a most variable species in size, shape, and sculpture, the above description applying to the most common form. One peculiar characteristic sometimes shown by this species is a contraction or interruption in the growth at different stages. See Pl. XXI, figs. 1, 1a, 1b. Up to the first interruption the sculpture is generally simple and quite constant, but afterwards it (especially the radial) becomes more complex, the riblets in the interspaces becoming dichotomous and the radiating lines becoming more numerous and prominent.

The variety of this species described as Lyropecten voloformis by Conrad is the extremely convex type. Conrad thought that the valves were unequal in the very convex shell, but in all the specimens of this sort examined by the writer, both valves show an equal amount of convexity. This very ventricose form is common near Coalinga, Fresno County, in beds of probable San Pablo (upper Miocene) age.

Specimens of this species from Catalina Island show more ribs (right valves, 19 to 21) than the average, and also appear to be slightly inequivalve, the left valve being the more ventricose. The characteristic interruption and constriction took place on most of the Catalina specimens at an altitude of about 55 millimeters.

A specimen of this species from San Benito County, collected by Mr. H. W. Turner, is very convex, and shows beautiful equal, equidistant, looped lamellæ over the surface of the valve. The intercalary riblets on this specimen are sharply defined. 
Between San Lucas and San Ardo, Monterey County, Mr. Homer Hamlin found a specimen of $P$. estrellanus measuring 125 millimeters in altitude, which shows the striations well developed on the anterior and posterior ribs and near the ends of the middle ribs and interspaces. The flat forms grading into var. catalinx were found associated at this locality with the typical convex shells.

In central California, especially in the region about the Salinas Valley, the $P$. estrellanus associated with the large Ostrea titan Conrad usually have nineteen ribs, while those found in the horizon of Ostrea palmula Carpenter and Chorus belcheri Hinds average two or three less. The latter horizon appears to be above that of 0 . titan.

In the region around Coalinga, Fresno County, $P$. estrellanus is very common, and is usually associated with Tamiosoma gregaria, Ostrea titan, Venus pertenuis, Chione n. sp. (large; coarse sculpture), Arca canalis, etc., in beds which may be the equivalent of the San Pablo formation. The significance of the total absence of $P$. estrellanus from the type locality of the San Pablo is not at present known.

So far as is definitely known, this species is confined to the Miocene, where it is found in nearly every county of California from Napa to Orange. In some places it is found associated with a characteristic lower Miocene fauna, while at others the same form will be found in the San Pablo or upper Miocene.

RANGE.

Miocene: Napa County (Lockwood); Solano County (Cooper); Alamedả County (Yates); Mount Hamilton Range (J. P. Smith; Arnold); Santa Cruz Mountains (Ashley; Arnold); San Lucas and San Ardo, Monterey County (Anderson; Hamlin); Lynch's Mountain, Monterey County (C. S. Smith); 15 miles northeast of San Miguel, Monterey County (Hamlin; Arnold); San Luis Obispo and Santa Barbara counties (Conrad; Fairbanks; R. Moran; J. H. Wilson; Arnold, and others); Coalinga, Fresno County (Watts; Eldridge; L. D. O'Neal); San Benito County (Turner); Santa Ana Range, Orange County (Watts); El Toro, Orange County (Bowers).

Pecten (Lyropecten) estrellanus Conrad var. catalinde n. var.

Pl. XX, figs. $3,3 a$, and 4 .

Description.-Shell averaging about 65 millimeters in altitude, considerably longer than high, equivalve, equilateral, of medium thickness, only slightly ventricose, and with margins more or less serrate; base evenly rounded; sides only slightly concave above. Right valve with 19 or 20 square, flat-topped ribs, all of which are sculptured by incremental lines and the 3 or 4 outer ribs on each side by more or less prominent radial lines; interspaces narrower than ribs and ornamented by a prominent squarish riblet; hinge line over one-half length of disk; anterior ear arcuate in front, with rather small byssal notch, and ornamented by concentric lines and 5 or 6 rather prominent radiating ridges; posterior ear with concave end and ornamented by numerous fine radiating ridges and incremental lines. Left valve similar to right except that the ears are both like the posterior one of the right valve, and the interspaces are relatively a little wider. 
Dimensions.-Alt. $62 \mathrm{~mm}$.; long. $72 \mathrm{~mm}$; hinge line $40 \mathrm{~mm}$; diameter $12 \mathrm{~mm}$.

This species is similar in general characteristics to the typical $P$. estrellanus, but differs from it in being much flatter, having a relatively much longer hinge, and, on the average, more ribs. The characteristic constriction of $P$. estrellanus is also lacking in this variety, so far as known.

$P$. var. catalinx ranges from the upper Miocene to the Pliocene. On Santa Catalina Island it is associated with the typical $P$. estrellanus, in beds which are probably upper Miocene, while at Temescal Canyon, near Santa Monica, it is associated with the well-known Pliocene species $P$. stearnsii, $P$. cerrosensis, and Laqueus californicus (or jeffreysi).

The type, which is figured and is now in the collection of Delos Arnold, was found in a limy matrix near the isthmus, Santa Catalina Island, Los Angeles County, by Mr. F. H. Thurston.

RANGE.

Pliocene (lower). Temescal Canyon, Santa Monica Mountains, Los Angeles County (Watts).

Miocene (upper). Isthmus, Santa Catalina Island, Los Angeles County (Thurston, Mrs. Trask);? San Ardo and vicinity, Monterey County (Hamlin, Anderson).

Pecten (Lyropecten) estrellanus conrad var. terminus n. var.

Pl. XXIII, figs. 2 and $2 a$.

Description. - Shell averaging about 70 millimeters in altitude, somewhat longer than high, ventricose, subequivalve, equilateral; margins coarsely serrate. Right valve with about 15 prominent, squarish ribs, separated by narrower channeled interspaces, in each of which runs a prominent intercalary; surface of ribs and interspaces obsoletely radially striate; hinge line more than one-half length of disk; ears subequal, the anterior strongly radially ribbed, the posterior with finer sculpture; byssal notch deep and rather narrow. Left valve similar to right, except that the ribs are relatively narrower.

Dimensions.-Alt. $70 \mathrm{~mm}$.; long. $75 \mathrm{~mm}$; hinge line $43 \mathrm{~mm}$.; diameter $32 \mathrm{~mm}$.

This variety is distinguishable from the typical form by its fewer and broader ribs, relatively longer hinge line, and finer obsolete radial striation; and from var. catalinæ by its fewer ribs and greater convexity.

The type of $P$. var. terminus is from the upper Miocene or San Pablo horizon of Monterey County, and is now in the collection of the University of California.

RANGE.

Miocene (upper). Monterey County (University of California).

Pecten (Lyropecten) magnolia Conrad.

Pl. XXIV, figs. 1 and 2; Pl, XXV, fig. 1.

1857. Pecten magnolia Conrad, Pac. R. R. Rept., vol. 7, 1857, p. 191, pl. 1, fig. 2.

1888. Liropecten veatchii Cooper (not of Gabb), Seventh Ann. Rept. Cal. St. Min., 1888, p. 246 ("Pliocene, Ojai Valley").

1898. Pecten magnolia Conrad, Dall, Trans. Wagner Free Inst. Sci., vol. 3, pt. 4, 1898, p. 702 (in part). 1901. Pecten magnolia Dall, Nautilus, vol. 14, 1901, p. 117 (in part.) 
Description.- Shell averaging about 150 millimeters in altitude, slightly longer than high, subequivalve, equilateral, rather thick, somewhat ventricose, and with smooth margins; base regularly rounded; sides sloping above, and slightly concave. Right valve slightly more convex than left, with about 9 to 11 broad, flat-topped, equal, equidistant ribs; interspaces slightly narrower than ribs and flat-bottomed; whole surface of ribs and interspaces covered by imbricated radiating riblets (about 10 on each rib) and fine, concentric incremental lines; hinge line about two-thirds the length of the disk; anterior ear slightly longer than the posterior, with arcuate end and fine concentric incremental sculpture, but obsolete radiating ridges; posterior ear with no radial sculpture whatever; byssal notch relatively small. Left valve quite similar to right but with narrower, more rounded ribs; sculpture of radiating riblets and fine wavy incremental lines; interspaces broader than in right valve; ears almost identical to those of right.

Dimensions.-Alt. $146 \mathrm{~mm}$; long. $150 \mathrm{~mm}$; hinge line $105 \mathrm{~mm}$; diameter $65 \mathrm{~mm}$.

The original description and figure of this species are poor, but there is no question in the writer's mind as to which species Conrad applied this name. There is no other large Pecten in the Miocene of the West Coast having the small number and characteristically large, striate ribs, and ears with so little radiate sculpture. The figure of the type, poor as it is, shows that there was little or no radiate sculpture on the ears of the specimen or specimens serving as the type for the drawings. Furthermore, there is no other Pecten, except the species above described, which would bring out the following comment, which Conrad, in his original description, applied to P. magnolia:

"This species will compare in size with $P$. Jeffersonius Say, and is so remarkably similar to it that it may prove to be the same species when more perfect specimens are collected."

The specimens which served as the types for Conrad's $P$. magnolia are in the U. S. National Museum (Nos. 13311 and 13325), and came from the Santa Inez Mountains, Santa Barbara County. Although much broken, these specimens show the ribbing and sculpture of the original shell almost perfectly.

In many of the worn specimens of this species the radiating striæ have been lost, and the ribs appear smooth. Internal casts show smooth rounded ribs for both valves. The distinguishing characteristics of this magnificent species, some of which attain an altitude of over 210 millimeters, are its size, small number and equality of ribs, equality of ears, and almost total lack of any radiating sculpture on the ears.

P. magnolia is somewhat closely allied to $P$. crassicardo, and is no doubt its precursor. It is distinguishable from the latter by its fewer (9 to 11, instead of 14 to 17), broader, more square-cut and more coarsely radially sculptured ribs, and the obsolete radial sculpture on its ears.

$P$. magnolia is one of the most characteristic of the lower Miocene, or Vaqueros formation, fossils. In the region around Mindego Hill, San Mateo County, it is found in the Vaqueros sandstone associated with the following fauna: Agasoma barkerianum, Agasoma (cf.) gravida, Agasoma kernianum, Arca (cf.) microdonta, 
Balanus (cf.) estrellanus, Cardium (Trachycardium) n. sp., Chione mathewsonï, Chione n. sp. (large; coarse sculpture), Crepidula princeps, Cuma bipticata, Dosinia conradi, Dosinia mathewsonii, Dosinia ( $c f$.) montana, Dosinia (aff.) ponderosa, Galerus (aff.) eccentricus, Glycymeris n. sp. (large), Phacoides ucutilineatus, Phacoides richthofeni, Mytilus mathewsonii, Neverita rechuziana, Ostrea (aff.) titan, Panopea generosa, Pecten estrellanus, Pecten (Plagioctenium) andersoni, Solen sicarius, Tivela ineziana, Trochita costellata, Turritella hoffmanni. On the south fork of the lower Ojai Valley, Ventura County, Mr. Eldridge found $P$. magnolia associated with Chione n. sp. (large; coarse sculpture), Mytilus mathewsonii, Turritella hoffmanni, Pecten sespeensis var. hydei, and other lower Miocene forms.

RANGE.

Miocene (lower). Mindego Creek, 10 miles south of Stanford University (Arnold); Corral de Piedra Creek, San Luis Obispo County (J. H. Wilson; Robert Moran; Fairbanks); Hazard Canyon, 12 miles southwest of San Luis Obispo (N. H. Drake); Morro and Toro creeks, San Luis Obispo County (Fairbanks; R. Moran); Santa Inez Mountains, Santa Barbara County (Conrad); near Oceanic quicksilver mine, San Simeon, San Luis Obispo County (L. Wagner); Ojai Valley, Ventura County (Eldridge).

Pecten (Lyropecten) Miguelensis n. sp.

Pl. XXII, figs. $1,1 a$, and $1 b$; Pl. XXIII, fig. 1.

1898. Pecten (Lyropecten) Heermanni Dall, (not Conrad), Trans. Wagner Free Inst. Sci., vol. 3, pl. 4, p. 701. (Specimens in U. S. Nat. Mus., No. 6397, labeled P. Heermanni by Conrad; Pl. XXIII, fig. 1.)

Description.-Shell averaging about 110 millimeters in altitude, about as long as high, inequivalve, subequilateral, rather thin, and with margins more or less serrate; base rounded; sides slightly concave above, the posterior being slightly longer than the anterior. Right valve more convex than the left, with 17 or 18 prominent rounded ribs, each sculptured by several (10 or 11 at extremity of ribs in type) distinct radiating raised riblets and numerous sharp, minutely wavy, incremental lines; interspaces narrower than ribs, and containing by a prominent radial auxiliary rib, which is ornamented by the incremental sculpture, and toward the periphery of the disk, by two or more radiating riblets as in the large ribs; hinge line somewhat longer than one-half the length of the disk; anterior ear arcuate in front, with small byssal notch, and sculptured by 5 or 6 prominent, rounded, radiating ridges and numerous sharp, concentric lines; posterior ear with 10 or 11 radiating riblets and fine incremental sculpture. Left valve less ventricose than the right, but otherwise similar to it, except that the ribs are slightly narrower and the interspaces relatively broader; ears similar to those of the right valve except that the anterior one lacks the byssal notch.

Dimensions._Alt. $107 \mathrm{~mm}$; long. $110 \mathrm{~mm}$; hinge line $60 \mathrm{~mm}$.; diameter $50 \mathrm{~mm}$.

This species is distinguishable from $P$. estrellanus and others of the same group by its larger size, inequality of valves (which are more or less inequilateral), and radially striate surface from umbo to periphery. It sometimes shows the constric- 
tions common to $P$. estrellanus. $P$. miguelensis may be the $P$. catilliformis of Conrad (Pac. R. R. Rept., Vol. V, Pt. II, p. 83, Pl. IX, fig. 83, 1857), but his description is so brief and his figure so poor that it is impossible to make anything definite out of it.

P. miguelensis is confined to the Miocene (probably lower horizon).

The type is a slightly crushed specimen from San Miguel Island. It is the specimen figured, and is now in the collection of the University of California.

RANGE.

Miocene. San Miguel Island (Univ. of Cal.); Santa Rosa Island (No. 12333, Cal. St.

Min. Bureau); Santa Inez Valley, near Santa Barbara (J. H. Wilson); Santa Inez

Mountains, near Santa Barbara, Santa Barbara County (Pác. R. R. Expedition).

\section{Pecten (Lyropecten) perrini n. sp.}

Pl. XIV, figs. 1 and $1 a$; Pl. XV, fig. 1 .

Description.-Shell averaging about 150 millimeters in altitude, somewhat longer than high, inequivalve, equilateral, of medium thickness, ventricose, and with smooth margins; base regularly rounded; sides sloping and decidedly concave above: Right valve nearly flat, with about 23 unequal, narrow, more or less rounded, and often prominently imbricated, radiating ribs, which are sometimes dichotomous; interspaces unequal, narrow, and occasionally ornamented by a small auxiliary riblet; surface sculptured by fine incremental lamellæ which are much more prominent in some specimens than in others; hinge line about one-half length of disk; ears about equal in length; anterior ear wide, ornamented by concentric incremental sculpture; byssal notch wide and deep; posterior ear ornamented by several prominent, more or less imbricated radiating ridges, and concentric sculpture. Left valve quite prominently ventricose, otherwise similar to the right, except that the ribs seem to vary even more in relative size and,spacing; anterior ear lacking notch, otherwise ears similar to those of the right valve.

Dimensions.-Alt. $150 \mathrm{~mm}$; long. (restored) $160 \mathrm{~mm}$; hinge line (restored) $80 \mathrm{~mm}$; diameter $55 \mathrm{~mm}$.

This is a most variable species, there being no two specimens sculptured in exactly the same manner in a series of over fifty specimens examined. The convexity of the valves is almost constant, the variable factors being the number and relative importance of the intercalary ribs, and the prominence of the incremental sculpture.

The geologic range of $P$. perrini is from the lower to the middle (?) Miocene. It is found associated with Pecten magnolia, and other characteristie lower Miocene fossils between Morro and Toro creeks, San Luis Obispo County, while at Roblar, in the same county, it is found with $P$. discus, a species found usually in the Santa Margarita formation.

The type, an imperfect specimen, of which both valves are figured, is from the lower Miocene between Morro and Toro creeks, San Luis Obispo County, 
and is now in the collection of the department of geology, Stanford University. Named in honor of Dr. James Perrin Smith, professor of paleontology at the Leland Stanford Junior University.

$$
\text { RANGE. }
$$

Miocene (middle?). Roblar, 12 miles from Paso Robles, and on ranch of W. F. Gillis, 10 miles southwest of Paso Robles, San Luis Obispo County (J. P. Smith).

Miocene (lower). Between Morro and Toro creeks, and on the Lenton ranch, between Morro and Old creeks, San Luis Obispo County (Fairbanks, R. Moran); 30 miles north of Santa Monica and 1 mile from the ocean, Ventura(?) County (R. E. Maynard); Pyramid Mountain, Greenhorn Mountains, Kern County (No. 12925, C. S. M. B.) (Watts).

\section{Pecten (Lyropecten) vaughani $n . s p$.}

Pl. XXIII, figs. $3,3 a$, and $3 b$.

Description.-Shell averaging about 40 millimeters in altitude, slightly longer than high, inequivalve, equilateral, convex, and showing constrictions with consequent undulations on the right valve and nodose ribs on the left; base regularly rounded; sides nearly straight above; margins smooth. Right valve with 12 prominent convex ribs separated by concave-bottomed interspaces somewhat narrower than the ribs; surface of ribs and interspaces sculptured by numerous fine, imbricated, thread-like, radial lines, between which are fine imbricating concentric liræ, the lines multiplying by intercalation toward the periphery of the disk; hinge line about five-eighths length of disk; ears unequal, the anterior much elongated, rather narrow, and ornamented by 4 very prominent, rounded, sharply imbricated radials and numerous fine imbricating incremental liræ; byssal notch deep; posterior ear about one-half length of anterior, somewhat concave behind, and ornamented by about 6 radial and numerous fine incremental liræ. Left valve similar to right, but with narrower, sharper ribs and correspondingly broader interspaces; the second, fourth, seventh, tenth, and twelfth ribs from the posterior end are more prominent than the others, and are subnodose at the lines of undulation of the disk; anterior ear similar to that of the right valve but with 2 or 3 more radials, which are less prominent; posterior ear like that of right.

Dimensions.-Alt. $37 \mathrm{~mm}$.; long. $40 \mathrm{~mm}$; hinge line about $25 \mathrm{~mm}$; diameter $15 \mathrm{~mm}$.

This beautiful little Pecten, though allied to P. magnolia, P. crassicardo, etc., is distinguishable by its small size, obviously unequal ears, long and strongly radially sculptured right anterior ear, deep byssal notch, undulating disk, and finely striated, concave-bottomed interspaces. This form seems to combine the number of ribs of $P$. magnolia ( $P$. magnolia generally has one to three less), with the sculpture of $P$. crassicardo var. hamiltoni, the undulations of $P$. crassicardo, and the long, strongly sculptured, right anterior ear of the typical Chlamys. It appears to be a connecting link between the typical Chlamys and Lyropecten. 
The range of this species is not definitely known. It is found in the Miocene, probably lower, of the Ojai Valley, Ventura County. The type, which was collected at the above locality by Dr. Stephen Bowers, is now in the collection of Delos Arnold. The species is named in honor of Dr. T. Wayland Vaughan, of the United States Geological Survey.

\section{RANGE. \\ Miocene (lower). Ojai Valley, Ventura County (Bowers). \\ Pecten (Plagioctenium) andersoni n. sp.}

Pl. XXVI, figs. $5,5 a, 6,7,8$, and $8 a$.

1894. Pecten discus Cooper (not Conrad), Bull. Cal. St. Min. Bureau, No. 4, pt. 5, 1894, p. 57, pl. 5, figs. 55 and 56 (in part).

Description.-Shell averaging about 35 millimeters in altitude, generally somewhat longer than high, both valves convex, more or less inequivalve and inequilateral; margins smooth; base regularly rounded; sides concave above. Right valve with 14 to 18 prominent rounded ribs, separated by flat-bottomed interspaces, which are generally of about equal width to, but sometimes narrower than, the ribs; surface sculptured by numerous, sharp, imbricating, incremental lines, and sometimes, at irregular intervals, by more or less prominent lines of interrupted growth; hinge line more than one-half length of disk; ears subequal; anterior ear with 3 or 4 sharp radials and numerous fine concentric lines; byssal notch quite pronounced; posterior ear sculptured similarly to anterior, and truncated nearly rectangularly. Left valve more convex than the right, sculptured similarly and with similar ears, except that the notch in the anterior is not so pronounced.

Dimensions.-Alt. $37 \mathrm{~mm}$; long. $44 \mathrm{~mm}$; hinge line $23 \mathrm{~mm}$.; diameter about $8 \mathrm{~mm}$; umbonal angle $105^{\circ}$.

A prominent characteristic of this species is that the left is decidedly the more convex of the two valves. In this respect it is similar to $P$. latiauritus and varieties. In fact, the young of $P$. andersoni is almost indistinguishable, in some instances, from small specimens of $P$. latiauritus var. monotimeris. The young of $P$. andersoni are equilateral, are relatively more convex, and have more prominent ribs than the adult forms.

Those specimens of $P$. andersoni found in the earlier formations appear to be somewhat smaller, and have on an average fewer ribs (14 to 17) than those in the later Miocene horizons, which have from 15 to 18 . Exceptions to this rule, however, are not rare, one specimen, for example, from the same locality as the type (which has 16 ribs on the left valve) having 18 ribs.

It would not be surprising to the writer to find, after an examination of a large series of $P$. andersoni and allied forms from the upper Miocene, that it is more or less closely related to $P$. discus. Large specimens of $P$. andersoni very closely resemble some specimens of $P$. discus but differ from the latter in the fewer number (14 to 18 ) of their ribs, $P$. discus having 18 to 21 . 
$P$. andersoni ranges from the lower to the middle (and probably upper)

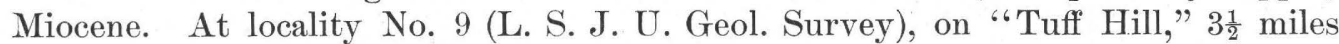
southeast of Stanford University, $P$. andersoni is associated with the following species: Pecten branneri, Chione n. sp., Phacoides acutilineatus, Venus (cf.) pertenuis, Terebratella (?) n. sp., Glycymeris sp., and Balanus sp. (cf.) estrellanus. At locality No. 4, not far from but stratigraphically considerably above No. 9, we find $P$. andersoni with the the following: Agasoma barkerianum, Arca microdonta, Chione sp., Callista n. sp. A., Dosinia mathewsonii, Leda (cf.) taphria, Phacoides acutilineatus, Mactra californica, Natica ocoyana(?), Saxidomus gibbosus, Tapes. truncata (?), Trochita costellata, Tellina (Angulus) sp., Tritonium sp., Tivela

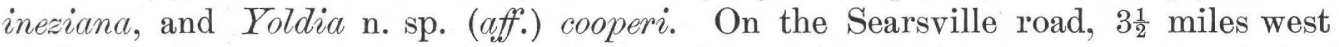
of Stanford University (locality 2), P. andersoni is associated with the following among other species: Agasoma gravida, Agasoma kernianum, Dosinia (aff.) ponderosa, and Pinna alamedensis. At Barker's ranch, Kern County, Mr. Watts found $P$. andersoni associated with Agasoma barkerianum and kernianum and other supposedly characteristic lower Miocene forms. $P$. andersoni occurs with P. crassicardo in the upper Miocene 3 miles south of Mount Diablo. In Avenal Canyon, Kern County, $P$. andersoni is associated with $P$. andersoni var. barkerianus, Turritella ocoyana, Venus sp., Ostrea sp., and a large flat Dosinia. In the Devils Den country, Kern County, P. andersoni is found with P. crassicardo in beds of probable lower Miocene (Vaqueros) age.

The type of $P$. andersoni, which is now in the collection of the department of geology, Stanford University, is from locality 1.27, three-fourths mile below Zayante station on Zayante Creek, Santa Cruz County, where it was found associated with P. sespeensis var. hydei and Balanus ( $c f$.) estrellanus. The beds from which the type was taken lie only a few feet below, and conformable with, the base of the characteristic Monterey shales, which are very well developed in the vicinity.

RANGE.

Miocene (upper). Three miles south of Mount Diablo, Contra Costa County (University of California); Pacheco, Contra Costa County (J. P. Smith); San Pablo Bay, near Pinole, Contra Costa County (Merriam, Arnold).

Miocene (middle and lower). Locality 127, Zayante Creek, three-fourths mile below Zayante station; near Glenwood (Miss Hecox); near Magnetic Springs; near Felton (locality 32), Santa Cruz County; near Stanford University, at localities 1, 2, 3, 4, 9, 34, and 35, Santa Clara and San Mateo counties (Branner, J. P. Smith, Arnold, and others); Barker ranch, Kern County (Watts); New Almaden (Turner); Contra Costa County (Lawson); near head of Slacks Canyon, NE. $\frac{1}{4}$ sec. 9, T. 22 S., R. 13 E., Mount Diablo meridian, Monterey County (Hamlin); Avenal Canyon, Kern County (Eldridge); Devils Den, Kern County (Eldridge).

Pecten (Plagioctenium) andersoni var. barkerianus n. var.

Pl. XXVI, fig. 9.

Description.-Shell averaging about 40 millimeters in altitude, somewhat longer than high, equilateral, somewhat ventricose, and with serrate margins; base regu- 
larly rounded; sides nearly straight, sloping at a moderately low angle. Left valve with 17 rather narrow, prominent rounded ribs, each with a rounded, thread-like riblet running longitudinally along its top; at more or less regular intervals small obsolete spines protrude from the riblet; interspaces wider than the ribs, with sloping sides, and flat bottoms; whole surface of disk crossed by very fine incremental lines; hinge line longer than one-half length of disk; ears subequal, rectangularly truncated, and sculptured by radiating ridges and incremental lines.

Dimensions.-Alt. $40 \mathrm{~mm}$; long. $44 \mathrm{~mm}$; hinge line $28 \mathrm{~mm}$.; diameter $7 \mathrm{~mm}$.

This variety, which is characterized by the thread-like riblet along the top of each primary rib on the left valve, has been found only in beds of lower Miocene age (Turritella ocoyana zone) in the southern San Joaquin country. It is found associated with the following characteristic fauna in the bluffis of the Kern River, 1 mile below the power-development station, Kern County: Conus n. sp., Mactra near planulata, Phacoides sp., Tellina near idæ, Trochita filosa, Agasoma kernianum, Agasoma barkerianum, Leda taphria, Leda (aff.) fossa, Cancellaria n. sp., Pleurotoma (Dotichotoma) n. sp., Pleurotoma (Leucosyrinx) near pedroana, Chione n. sp. near gnidia, Dentalium 2 n. sp., Nassa ( $f f$.$) perpinguis, Pleurotoma sp.,$ Neptunea n. sp., Crucibulum n. sp., Turritella ocoyana, Cancellaria $(c f$.) vetusta, Phacoides (cf.) nuttalli, Natica or Lunatia sp., Terebra sp. (probably new), Trophon (cf.) ponderosum, Drillia (aff.) torosa, Solen (aff.) sicarius. At Avenal Canyon, Kern County, Mr. Eldridge found $P$. var. barkerianus with $P$. andersoni, Turritella ocoyana, Dosinia (large and flat), Venus sp., and Ostrea sp.

The type of $P$. var. barkerianus was found east of the Barker ranch house, near Kern River, Kern County, and is now in the collection of the California Academy of Sciences.

RANGE.

Miocene (lower). Barker ranch, Kern County (Watts): Avenal Canyon and bluffs of Kern River near power-development station, Kern County (Eldridge).

Pecten (Plagioctenium) cerrosensis gabb var.? mendenhalli $n$. var.

Pl. XXV, figs. $2,2 a$, and $2 b$.

Description.-Shell, when adult, averaging about 75 millimeters in altitude. Similar to $P$. cerrosensis in shape, convexity, and ribbing, but differing from the latter in being much smaller when adult, having fewer ribs (about 19 in the former, while the latter has usually 21 or more), much less prominent incremental lines, and a relatively longer hinge line.

Dimensions (of a medium-sized specimen).-Alt. $43 \mathrm{~mm}$.; long. $44 \mathrm{~mm}$; hinge line $28 \mathrm{~mm}$.; diameter $17 \mathrm{~mm}$.

Although this form is closely allied to $P$. cerrosensis, it, nevertheless, should possibly have specific rank, as the differences between it and the typical $P$. cerrosensis are constant, and it belongs to a different geologic horizon. Not enough is known about its range and relations, however, to warrant a wider separation, at present, than that of a variety.

The type is from beds of probable Miocene age (the equivalent of the Carrizo Creek beds) at Santa Rosalia, Lower (alifornia, directly west of and across the Gulf 
of California from Guaymas, Mexico. At the type locality it is associated with the following fauna: Pecten carrizoensis, Pecten keepi, Cardium sp., Chione n. sp., Glycymeris sp., Ostrea sp. (large), Codakia sp. (very large), Semele (aff.) pulchra, Cardita (Carditamera) sp., Strombus sp., Malea (aff.) ringens, echinoid spines, etc.

The type of $P$. var. mendenhalli is U. S. N. M. No. 164849, and is from Santa Rosalia, Lower California, where it was collected by Doctor Merrill. Named in honor of Mr. Walter C. Mendenhall, of the United States Geological Survey.

RANGE.

Miocene. Santa Rosalia, Lower California (G. P. Merrill; E. Palmer); head of Garnet Canyon, about 12 miles north of the Mexican boundary, and Alverson Canyon, about 8 miles north of the Mexican boundary, San Diego County (W. C. Mendenhall; S. Bowers).

\section{Pecten (Plagioctenium) deserti Conrad.}

Pl. XXVI, figs. 1, 2, 2a, 3, 4, and $4 a$.

1855. Pecten deserti Conrad, Desc. Fos. and Shells., House Doc., 129, July, 1855, p. 15 (fide Dall).

1856. Pecten deserti Conrad, Pac. R. R. Rept., vol. 5, 1856, p. 325, pl. 5, fig. 41.

1888. Pecten deserti Conrad, Cooper, Seventh Ann. Rept. Cal. St. Min., for 1887, p. 257.

1894. Pecten (Plagioctenium) deserti Conrad, Dall, Trans. Wagner Free Inst. Sci., vol. 3, pt. 4, 1898, p. 703.

Description.-Shell averaging about 32 millimeters in altitude, about as long as high, biconvex, equivalve, subequilateral, and with serrate margins; sides straight and sloping at a steep angle. Right valve with 22 or 23 high, narrow, close-set, smooth, rounded ribs, which sometimes show looped incremental lines on their tops near extremities; interspaces deep, narrow, slightly concave bottomed, and ornamented on the bottom by numerous fine, sharp, straight, incremental lines; hinge line about three-fourths length of disk; ears subequal; the anterior slightly convex and ornamented by 4 radiating ridges and numerous incremental lines, while the posterior is ornamented by 6 or 7 radials and numerous concentric lines; byssal notch rather small. Left valve similar to the right, except possibly that the ribs are relatively slightly taller. Hinge strong, with a deep resilial pit and a submarginal channel parallel with the upper margin; numerous parallel microscopic lines perpendicular to the hinge line visible in the crural grooves.

Dimensions.-Alt. $32 \mathrm{~mm}$; long. $33 \mathrm{~mm}$; hinge line $25 \mathrm{~mm}$.; diameter $17 \mathrm{~mm}$.

This species is distinguishable from allied forms by its strong hinge, tall, narrow, close-set ridges and straight incremental sculpture in the bottoms of the interspaces.

$P$. deserti has so far been found only in beds supposed to be of Miocene age, in the Carrizo Creek district, Colorado Desert, San Diego County. From the evidence at hand it seems likely that $P$. deserti occupies a somewhat different horizon (possibly lower) than that containing $P$. carrizoensis, $P$. keepi, and $P$. cerrosensis var. mendenhalli.

RANGE.

Miocene. East end of Carrizo Mountain, and Ulsa oil well, north of the Mexican boundary, San Diego County (Conrad; Fairbanks; Bowers; Mendenhall). 
Pecten (Plagioctenium) discus Conrad.

Pl. XXVII, figs. $1,1 a, 2,3$, and 4 .

1857. Pecten discus Conrad, Pac. R. R. Rept., vol. 7, pt. 2, 1857, p. 190, pl. 3, fig. 1.

1869. Pecten discus Conrad, Gabb, Pal. Cal., vol. 2, 1869, p. 122.

1888. Pecten discus Conrad, Cooper, Seventh Ann. Rept. Cal. St. Min., 1888, p. 257.

1888. Pecten pabloensis Conrad, Cooper, Seventh Ann. Rept. Cal. St. Min., 1888, p. 258 (in part).

1894. Not Pecten discus Cooper, Bull. Cal. St. Min. Bureau, No. 4, pt. 5, 1894, p. 57, pl. 5, figs. 55, 56. (=P. andersoni $\mathrm{n} . \mathrm{sp}$.

1898. Pecten (Chlamys?) discus Conrad, Dall, Trans. Wagner Free Inst. Sci., vol. 3, pt. 4, 1898, p. 704.

Description.--Shell averaging about 50 millimeters in altitude, about as long as high, equivalve, equilateral, thin, rather compressed, and with smooth margins; umbonal angle large, averaging about $108^{\circ}$; sides somewhat concave above. Right valve with 17 to 20 moderately strong, rounded ribs, separated by rather flat interspaces about equal in width to the ribs; surface sculptured by regular, elevated, wavy, incremental lines and, at irregular intervals, generally by more or less prominent lines of interrupted growth; hinge line about one-half length of disk; ears unequal, the anterior showing several strong radials, while on the posterior the radials are obsolete; both ears sculptured by fine concentric lines. Left valve similar to right; ears more or less distinctly radially ridged and obliquely truncated.

Dimensions.-Alt. $48 \mathrm{~mm}$;; long. $50 \mathrm{~mm}$; hinge line $24 \mathrm{~mm}$; diameter $8 \mathrm{~mm}$.; umbonal angle $108^{\circ}$.

This species, of which the type is a poor specimen, being preserved as a cast in indurated clay, is characterized by its moderately strong, convex ribs, compressed disk, and strikingly unequal ears on the right valve. Specimens of $P$. discus having the shell material preserved always show moderately high, convex ribs; the internal casts (in which form the species is generally found) have the ribs more or less squarish, and low. The specimens having the fewest number of ribs have the widest lateral areas or submargins. The type does not show the radial sculpture found in most cases on the ears of the left valve.

$P$. discus is closely allied to $P$. pabloensis but has the constant difference of larger size when adult and stronger rounded ribs instead of weak squarish ones. It occurs in approximately the same horizon as P. pabloensis and seems to represent the latter in what is probably the equivalent of the San Pablo (upper Miocene) formation in the region south of the typical San Pablo Bay locality, although at some localities it has been found in beds of probable middle Miocene age.

About the head of Crescent Creek, near Oil City, Fresno County, P. discus is associated with the following: Ocinebra near cancellina, Trochita filosa, Mytilus mathewsonii (?), Arca sp. indet., and Voluta (?) sp. This appears to be an uncertain horizon in the Miocene.

RANGE.

Miocene (upper). Walnut Creek, Contra Costa County (Univ. of Cal. collection); Santa Margarita, San Luis Obispo County (J. H. Henry); Assuncion ranch, San Luis Obispo County (Fairbanks; Arnold; R. Moran); Huasua ranch, 20 miles north of Santa Maria, Santa Barbara County (C. E. Knecht). 
Miocene (middle or lower?) Roblar, 12 miles from Paso Robles, and on ranch of W. F. Gillis, 10 miles southwest of Paso Robles, San Luis Obispo County (J. P. Smith); Oil City, Fresno County (Eldridge).

\section{Pecten (Plagioctenium) eldridgei n. $\mathrm{sp}$.}

Pl. XXV, figs. $3,3 a, 3 b, 4,4 a, 5,5 a$, and 6 .

Description.-Shell averaging about 20 millimeters in altitude, nearly as high as long, equivalve, somewhat oblique (the posterior portion being the longer), very thick and heavy, very ventricose, and with serrate margins; base unequally rounded; sides somewhat concave above and sloping at a moderately steep angle. Right valve with 19 or 20 small, rather low but sharply defined, squarish ribs; interspaces about one-half as wide as ribs, channeled, and with flat bottoms; surface of disk ornamented by numerous sharp concentric lines which loop back over the ribs; more or less prominent constrictions, indicating interrupted growth, are common on most specimens; hinge line equal to about three-fourths length of disk; anterior ear slightly longer than posterior, deeply notched, and ornamented by 3 or 4 prominent radiating ridges and numerous imbricating incremental lines; posterior ear rectangularly truncated and ornamented by 8 or 10 radiating ridges and incremental sculpture. Left valve similar to right, except that the ribs are slightly narrower and more rounded; ears similar to those of right valve except that the anterior one is not as deeply notched. Hinge similar to that of $P$. circularis except stronger and with the auricular crura much more highly developed. Adductor impressions very deep.

Dimensions.-Alt. $20 \mathrm{~mm}$.; long. $21 \mathrm{~mm}$.; hinge line $15 \mathrm{~mm}$; diameter $15 \mathrm{~mm}$.

This species is similar in many respects to $P$. circularis, but is characterized by its smaller size, greater ventricosity, thicker and heavier shell, deep adductor impressions, and more or less prominent constrictions. It sometimes attains an altitude of 45 millimeters, as shown by fragments collected at the type locality.

$P$. eldridgei appears to be confined to the oil-bearing strata of the San Joaquin Valley, which are probably San Pablo or upper Miocene in age.

The type, which is figured and is now in the United States National Museum, was collected in the hills south of the Dabney water wells, McKittrick district, Kern County. Named in honor of the late Mr. G. H. Eldridge, of the United States Geological Survey.

RANGE.

Miocene (upper). McKittrick district, Kern County (Eldridge); Buena Vista and McKittrick, Kern County (Watts).

\section{Pecten (Plagioctenium) neahensis n. sp. \\ Pl. XV, figs. $2,2 a$ and $2 b$.}

Description.-Adult shell averaging about 45 millimeters in altitude, somewhat longer than high, subequivalve, subequilateral, prominently ventricose, especially for about the first 25 millimeters of altitude, after which it is sometimes more compressed; sides concave above; base evenly rounded; margins smooth. Right valve with 19 prominent rounded ribs, separated by somewhat narrower 
interspaces; surface sculptured by fine incremental lirulæ which loop back over the tops of the ribs; hinge line over one-half length of disk; ears subequal; anterior with 4 or 5 prominent radials, posterior with one or two less prominent ones; both ears sculptured by fine incremental lines; byssal notch rather prominent. Left valve a little less ventricose than right and with ribs narrower and more sharply convex above and the interspaces relatively broader; ears as in right valve.

Dimensions.-Alt. $43 \mathrm{~mm}$; long. $50 \mathrm{~mm}$; hinge line $28 \mathrm{~mm}$; diameter $28 \mathrm{~mm}$.

This species is probably allied to $P$. circularis and $P$. circularis var. æquisulcatus, but may be distinguished by its fewer and narrower ribs and longer hinge line.

The type (U. S. N. M. No. 5912) is labeled "Neah Bay, Washington," and was collected by Lieut. J. G. Swan. The beds in the immediate vicinity of Neah Bay were found by the writer to be almost entirely unfossiliferous, so that it is probable that $P$. neahensis, instead of coming from Neah Bay, comes from some of the fossiliferous strata farther east, possibly from those in the vicinity of Clallam Bay.

RANGE.

Miocene. Clallam County, near (?) Neah Bay, Washington (J. G. Swan).

Pecten (Plagioctenium) pabloensis Conrad.

Pl. XXVII, figs. 5, 5a, 6, $6 a$, and 7 .

1857. Pecten pabloensis Conrad, Pac. R. R. Rept., vol. 6, pt. 2, 1857, p. 71, pl. 3, fig. 14 .

1888. Pecten pabloensis Conrad, Cooper, Seventh Ann. Rept. Cal. St. Min., 1888, p. 258 (in part).

1898. Pecten (? Plagioctenium) pabloensis Conrad, Dall, Trans. Wagner Free Inst. Sci., vol. 3, pt. 4, 1898, p. 703.

Description. - Shell averaging about 35 millimeters in altitude, about as high as long, equivalve, equilateral, thin, only slightly ventricose, and with smooth margins; sides sloping at a low angle and quite prominently concave above: Right valve with 18 to 20 square, flat-topped, radiating ribs, which are narrower and less distinct laterally and become more feeble as the periphery of the disk is approached; interspaces about as wide as the ribs, flat bottomed and often separated from the principal ribs by impressed lines which give the interspaces the appearance of bearing intercalary riblets; whole surface of disk sculptured by fine concentric lines and, in some instances, more or less prominent lines showing interrupted growth; hinge line somewhat longer than one-half length of disk; anterior ear slightly longer than posterior, deeply notched, and ornamented by 4 or 5 coarse radiating ridges and sharp, raised incremental lines; posterior ear slightly concave behind, and covered by numerous incremental lines and several obsolete radiating ribs. Left valve similar to the right except that in some cases the ribs are slightly more rounded above, and the looped or wavy concentric lines are more conspicuous; ears similar to those of the right.valve except that the anterior one lacks the deep byssal notch. Hinge as in $P$. circularis except that the cardinal crura are very faint, while the auricular crura are quite prominent. 
Dimensions.-Alt. $35 \mathrm{~mm}$.; long. $35 \mathrm{~mm}$; hinge line $20 \mathrm{~mm}$; diameter $6 \mathrm{~mm}$.

The measurements given above are from an average-sized specimen. One left valve examined was 50 millimeters in altitude, but this size is exceptional for specimens from the type locality (shore of San Pablo Bay).

The prominence of the ribs seems to be the most variable factor in this species. As a rule the ribs are sharp and well defined until the shell attains an altitude of 10 or 15 millimeters, when they broaden out and become low, those near the sides almost losing their identity in some specimens. One specimen examined retained the elevated and sharply defined ribs up to an altitude of over 25 millimeters, and very much resembled a young $P$. circularis var. xquisulcatus.

$P$. pabloensis is so far known only in the San Pablo, or upper Miocene formation. At the type locality, on the shore of San Pablo Bay, Contra Costa County, a bed several feet thick is made up almost entirely of valves of this species. At this locality $P$. pabloensis is associated with $P$. crassicardo and P. andersoni (?).

Miocene (upper). Shores of San Pablo Bay, Contra Costa County (Newberry; Merriam; Arnold).

\section{Pecten (Pseudamusium) Lompicoensis n. $\mathrm{s}$ p.}

Pl. XXIII, fig. 5; Pl. XXVII, fig. 8.

Description.-Adult shell averaging about 11 millimeters in altitude, subcircular, inequivalve, thin, compressed; margins smooth. Right valve ornamented externally by numerous sharp, elevated, equal, equidistant, imbricating, concentric lamellæ; hinge line equal to one-half length of disk; ears unequal; anterior nearly twice as long as the posterior, arcuately truncated and sculptured by regular, sharp, imbricating, concentric lamellæ and 6 or 7 faint radials; posterior ear short, somewhat obliquely truncated and sculptured by concentric lamellæ; byssal notch only faintly indicated. Left valve sculptured by concentric lamellæ similar to those of the right, and, in addition, having numerous fine radiating striæ, which usually become obsolete near the periphery in the adult shell; ears similar to those of the right valve, except that in the specimens examined no radials were noted on the anterior one. Hinge similar to that of $P$. randolphi.

Dimensions (of slightly distorted specimen).-Alt. $11.5 \mathrm{~mm}$; long. $11 \mathrm{~mm}$.; hinge line $5.5 \mathrm{~mm}$.

This beautiful little Pecten is allied to $P$. peckhami, but is distinguishable from the latter by its much more prominent and regular concentric lamellæ, and by its well-defined ears, the anterior one of which on the right valve is relatively much shorter and broader than the analogous one in P. peckhami. The byssal notch in $P$. lompicoensis is also only faintly indicated, while in $P$. peckhami the noteh is profoundly developed.

$P$. lompicoensis is known only from the Miocene (exact horizon doubtful) shales at the head of Lompico Creek, Santa Cruz County, where it is associated with a Phacoides resembling acutilineatus Conrad.

RANGE.

Miocene. Head of Lompico Creek, Santa Cruz County (Newsom, Arnold). 


\section{Pecten (Pseudamusium) pedroanus Trask.}

Pl. XXVIII, figs. 4 and 5.

1856. Plagiostoma Pedroana Trask, Proc. Cal. Acad. Nat. Sci., vol. 1, 1856, p. 93, pl. 3, figs. 1, 1a. 1856. Plagiostoma truncata Trask, Proc. Cal. Acad. Nat. Sci., vol. 1, 1856, p. 94, pl. 3, fig. 3.

1856. Plagiostoma annulatus Trask, Proc. Cal. Acad. Nat. Sci., vol. 1, 1856, p. 94, pl. 3, fig. 2.

1869. Pecten Pedroanus Trask, Gabb, Pal. Cal., vol. 2, 1869, p. 60.

1888. Pecten pedroanus Trask, Cooper, Seventh Ann. Rept. Cal. St. Min., for 1887, p. 258.

1898. Pecten pedroanus Trask, Dall, Trans. Wagner Free Inst. Sci., vol. 3, pt. 4, 1898, p. 705.

The original description is as follows:

Description. - "Shell compressed, subtriangular, with 8 or 9 flatly rounded concentric annulations, which are nearly as distinctly marked on the interior of the valve for about half the height from the ventral margin; beaks acute at the apex, and as high as the line of the auricles; anterior auricle rounded in front, and has a small, thin fold extending from the umbone to the center of its anterior margin, and is covered with about 13 small, rounded, radiating striæ, which converge at the beak; beaks at the anterior third; subacute; anterior margin rounded, and somewhat produced; ventral margin smoothly arched; posterior margin rounded, becoming slightly arcuate toward the dorsum of the shell; posterior auricle angulate and obtusely truncate posteriorly."

Dimensions.-Alt. $30 \mathrm{~mm}$.; long. $37 \mathrm{~mm}$; hinge line $13.5 \mathrm{~mm}$.

The above is Doctor Trask's original description with measurements of the type. Gabb has the following to say of this species: ${ }^{a}$

"In 1856 Doctor Trask named three species of Plagiostoma, giving full descriptions and well-executed figures as above. His specimens are casts of a number of distorted Pectens, perhaps normally a little oblique, but in most cases with the obliquity exaggerated by pressure. They belong without question to but one species, and the first name given will have to be retained. I have carefully studied the specimens, and have visited the locality from which they were obtained. The deposit belongs to the bituminous shale of the upper Miocene, which underlies the whole or the greater part of the Los Angeles plain, crops out on the beach at San Pedro, under the post-Pliocene, and has been reached by artesian borings under the city itself.

"The species is about an inch in diameter, ears subequal, shell thin, perhaps normally a little oblique, and the shell substance contains a few concentric undulations or ribs, which are retained in the cast. No specimens show any shell preserved; so that if there was any surface sculpture, it is as yet unknown."

The writer has examined several specimens of this species collected by Mr. W. L. Watts in the oil fields of southern California. Some of these specimens show the original shell material, which, upon a careful examination, revealed no trace whatever of any but the concentric undulating sculpture.

The best preserved specimens of this species examined by the writer were taken from the Third street tunnel in Los Angeles by Mr. Homer Hamlin and are now in the U. S. National Museum (No. 164840). In several of these specimens the original shell material is quite well preserved, and in one case Camptonectes 
sculpture of numerous faint radiating ribs, microscopic striæ, and numerous more or less prominent lines of interrupted growth were plainly seen. The sculpture was very similar, if not identical, to that of $P$. randolphi. $P$. pedroanus and $P$. randolphi are also alike in shape and general characteristics, and the only difference noted in a comparison of the two was the slightly larger size and more prominently undulated disks of the former. A careful examination of better material of the fossil form, if any is ever obtained, may lead to a union of the two species.

The Third street tunnel beds are of soft bluish shale, which yielded besides P. pedroanus the following fauna: Pecten ashleyi, P. stearnsii, P. opuntia, Glyphis densiclathrata, Pecten latiauritus, Nassa n. sp.?, Macoma sp. indet., Arca multicostata, Lima hamlini, Buccinum sp. indet., Neverita recluziana, Astarte? sp., Priene oregonensis, Ostrea veatchii, Pleurotoma sp. indet., carditoid, coral, bird bone, and crab claw.

This fauna indicates a horizon about the same as that of the San Diego formation, and is Pliocene (probably lower) in age. It therefore seems likely that $P$. pedroanus, which has heretofore been considered a typical Monterey or middle Miocene species, also occurs in the Pliocene, and may possibly be Dall's recent deep-water species, $P$. randolphi.

RANGE.

Pliocene (lower). Clark estate, Los Angeles and Puente Hills, Los Angeles County (Watts); Third street tunnel, Los Angeles (Hamlin); Joyce wells, Whittier district, Puente Hills, Los Angeles County (Eldridge).

Miocene. San Pedro (Trask, Gabb); 4 miles south of McKittrick, Kern County

(Eldridge).

Pecten (Propeamusium) stanfordensis n. $\mathrm{sp}$.

Pl. XXIII, fig. 4 .

Description.-Shell averaging about 9 millimeters in altitude, subcircular, equivalve, equilateral, thin, only slightly ventricose, and with smooth margins. Right valve with the exterior surface ornamented by numerous fine concentric undulations and, in some cases, microscopic radiating striæ; interior with 10 to 12 prominent, rounded, equidistant ribs extending from the umbo to or near to the periphery of the disk, those ribs nearest the center of the shell being straight, while those near the sides are somewhat arcuate toward the central rib; hinge line slightly longer than one-half the length of the disk; ears equal in length, and ornamented by the fine concentric undulations; anterior ear with a small byssal notch. Left valve similar to right, except that its anterior ear lacks the byssal notch.

Dimensions.-Alt. $7 \mathrm{~mm}$; long. $7.2 \mathrm{~mm}$; hinge line $4 \mathrm{~mm}$.; diameter $1.2 \mathrm{~mm}$.

In the specimens showing the original shell material the internal ribs sometimes break out and leave corresponding grooves in the disk, thus showing that they are of a rather secondary growth compared to that of the disk.

This species is somewhat similar to $P$. interradiatus of the Tejon (Eocene), but may be distinguished from it by having 10 to 12 instead of 8 ribs, being 
smaller, and having the ribs reach to or nearly to the periphery rather than abruptly terminating near the middle of the disk.

The type specimen, which is the one figured, is now in the collection of Delos Arnold. It is from the buff-colored Miocene shale in a small ravine on the Burke ranch, one-third mile south of Los Trancos Creek, near Stanford University, San Mateo County. This species is named in honor of Leland Stanford Junior University.

So far this species has been found only in the type locality, where it is associated with Pecten pedroanus (?) and several small undetermined pelecypods. Its range, as determined stratigraphically, is probably middle Miocene or Monterey. Its associated fauna also adds weight to this theory.

RANGE.

Miocene (middle). Burke ranch, 3 miles south of Stanford University (Branner, J. P. Smith, R. Arnold).

Pecten (Amusium) lompocensis n. sp.

Pl. XXVIII, figs. 1, 2, and 3 .

Description.-Adult shell averaging about 100 millimeters in altitude, somewhat longer than high, compressed, subequivalve, equilateral, and thin; base regularly rounded; sides straight, or nearly so; margins smooth. Right valve with external surface smooth except for very fine and numerous concentric and nearly obsolete radiating stria; internal surface sculptured by about fourteen pairs of rather prominent rounded radiating liræ, the members of each pair being separated by flat spaces usually of about two-thirds the width of the major interspaces (in one case the spaces between the members of each pair were as wide as the interspaces); hinge line about two-fifths the length of the disk; ears subequal, obliquely truncated, and finely concentrically sculptured; anterior with a faint suggestion of a byssal notch; ctenolium absent. Left valve similar in all respects to the right except that the anterior ear has a straight, rather than an areuate end.

Dimensions. - Alt. $103 \mathrm{~mm}$; long. $113 \mathrm{~mm}$; hinge line $40 \mathrm{~mm}$; diameter $20 \mathrm{~mm}$.

This very unique species, of which there are no closely allied forms in the Tertiary or living faunas of the west coast, so far as known, is somewhat analogous to $P$. (Amusium) mortoni Ravenel of the Miocene and Pliocene of eastern America. It is distinguishable from the latter species, however, by the smaller number, greater prominence, and more regular arrangement of the internal ribs. $P$. lompocensis is included in Amusium because it appears to show stronger affinities for this than for any other group.

$P$. lompocensis was first discovered in the limy beds which outcrop about 4 miles south of Lompoc, Santa Barbara County, where the types, which are now in the collection of the California Academy of Sciences, were collected by Mr. Frank M. Anderson. At the type locality this unique form is found associated with the following species in beds of probable lower Miocene age: Pecten crassicardo, Ostrea (aff.) titan, Lima n. sp., Cidaris (?) sp., Terebratella 2 sp., and Scutella 
sp. On the ridge between the Upper and Lower Ojai Valleys, Ventura County, Mr. Eldridge has found $P$. lompocensis with the following species, in beds which he thinks are of lower Miocene (Vaqueros) age: Pecten crassicardo, Turriteilla (cf.) hoffmanni, Phacoides sp. (flat), Ostrea sp., Nassa sp., Dentalium sp., Chione sp., Leda sp. Bälanus sp., Tritonium or Fusus sp.

RANGE.

Miocene (lower ?). Four miles south of Lompoc, Santa Barbara County (F. M. Anderson); ridge between upper and lower Ojai valleys, Ventura County (Eldridge).

\title{
Pecten (Hinnites) giganteus Gray.
}

\author{
Pl. XXIX, figs. 1, 2, and 2. a
}

1826. Hinnites giganteus Gray, Ann. Phil., 2d ser., vol. 12, 1826, p. 103.

1834. Hinnita poulsoni Conrad, Jour. Acad. Nat. Sci., Phila., vol. 7, p. 182, pl. 14.

1843. Hinnites giganteus Gray, Sowerby, Thes. Conch., vol. 1, Hinnites, p. 80, pl. 20, figs. 3-5.

1853. Hinnites giganteus Gray, Reeve, Conch. Icon., vol. 8, Hirnites, Oct., 1853, sp. 2, pl. 1, fig. 3.

1857. Hinnites crassa Conrad, Pac. R. R. Rept., vol. 7, pt. 2, p. 190, pl. 2, figs. 1 and 2.

1863. Hinnites giganteus Gray, Carpenter, Brit. Assn. Rept., 1863, p. 645.

1863. Hinnites crassa Conrad, Carpenter, Brit. Assn. Rept., 1863, p. 595.

1869. Hinnites giganteus Gray, Gabb, Pal. Cal., vol. 2, 1869, p. 105.

1887. Hinnites giganteus Gray, Whiteaves, Trans. Roy. Soc. Canada, vol. 4, sec. 4, 1887, p. 119.

1888. Pecten (Hinnites) giganteus Gray, Küster, and Kobelt, Conch.-Cab., vol. 17, pt. 2, Spondylus und Pecten, sp. 228, taf. 65, figs. 9 and 10.

1888. Hinnites giganteus Gray, Cooper, Seventh Ann. Rept. Cal. St. Min., 1888, p. 243 (Santa Rosa Island record excepted).

1892. Hinnites giganteus Gray, Keep, West Coast Shells, p. 165, fig. 138.

1892. Hinnites giganteus Gray, Williamson, Proc. U. S. Nat. Mus., vol. 15, 1892, p. 193.

1898. Hinnites giganteus Gray, Dall, Trans. Wagner Free Inst. Sci., vol. 3, pt. 4, 1898, p. 711.

1898. Hinnites crassa Conrad, Dall, Trans. Wagner Free Inst. Sci., vol. 3, pt. 4, p. 711.

1903. Pecten (Hinnites) giganteus Gray, Arnold, Mem. Cal. Acad. Sci., vol. 3, pt. 2, 1903, p. 115.

1904. Pecten (Hinnites) giganteus Gray, Keep, West American Shells, p. 42, fig. 22.

Description.-Shell averaging about 75 millimeters in altitude, usually not quite so long as high, irregular, inequivalve, generally inequilateral on account of attachment to irregular surface; shell quite thick; margins smooth. Right valve more ventricose than left, ornamented by 9 to 18 narrow, irregular, prominently squamose ribs, between which in the flat interspaces are less prominent raised lines similarly sculptured; hinge line more than one-half length of disk; ears subequal, and more or less prominently sculptured by fine, squamose, radiating lines; byssal sinus sometimes visible. Left valve less ventricose than right, otherwise similar. Hinge rather narrow and heavy; fosset deeply excavated, oblique, narrow, and angular; hinge is dark purple in living shells.

Dimensions.-Alt. $70 \mathrm{~mm}$.; long. $65 \mathrm{~mm}$.; hinge line $40 \mathrm{~mm}$. in length, $10 \mathrm{~mm}$. in width; diameter $35 \mathrm{~mm}$.

The young of this species is free swimming until an altitude of about 20 or 30 millimeters is reached, when they become attached to some fixed object. If this object happens to have an irregular surface, as is generally the case, the shell grows irregular in consequence. The young, up to the time of attachment, are indis- 
tinguishable from the young of $P$. hastatus and varieties, except possibly that the ribs on the right valve of Hinnites are rather more irregular in size than those of Chlamys.

After comparing Conrad's types of Hinnites crassa with a large series of living Hinnites giganteus, the writer has no hesitation in pronouncing the two species identical. The types of $H$. crassa were collected from the upper Miocene near Santa Margarita. (See PI. XXIX, fig. 1.)

$P$. (Hinnites) giganteus ranges from the lower Miocene to the living fauna. $\mathrm{Mr}$. Eldridge found it associated with Turritella hoffmanni in a small gulch east of Wiley Canyon, Ventura County.

RANGE.

Living. Strait of Fuca to San Diego (Cooper); Quatsino Sound, B. C. (Dawson). Pleistocene. Santa Barbara to San Diego (Cooper); upper and lower San Pedro formation, San Pedro (Arnold).

Pliocene. Pacific Beach, San Diego (Arnold); Ventura County, Los Angeles County (Cooper).

Miocene (upper). Santa Margarita, San Luis Obispo County (Conrad).

Miocene (lower). Gulch east of Wiley Canyon, Ventura County (Eldridge).

Miocene (horizon?) Carrizo Creek district, San Diego County (Bowers).

PLIOCENE PECTENS.

[Those known first to appear in the Pliocene formations.]

Pecten (Pecten) auburyi n. sp.

Pl. XXXIII, figs. 2 and $2 a$; Pl. XXXIV, figs. 2 and $2 a$.

1900. Pecten indet., Merriam, Bull. Cal. St. Min. Bureau, No. 19, 1900, p. 222.

Description.-Adult shell averaging about 60 millimeters in altitude, somewhat longer than high, inequivalve, plano-convex, equilateral, and with smooth margins. Right valve convex and ornamented by about 16 or 17 prominent, rather narrow, convex-topped ribs; interspaces slightly narrower than the ribs, and with concave bottoms; whole surface sculptured by prominent, fine, sharp, subequal incremental lines; hinge line less than one-half length of disk; ears subequal and convex; anterior ear with two or three obsolete radiating ridges, prominent concentric sculpture, and small hyssal notch; posterior ear with concentric sculpture only. Left valve flat or slightly concave, ornamented by 16 or 17 prominent, narrow, convex-topped ribs, which are separated by deep, almost flat-bottomed interspaces slightly wider than the ribs; whole surface sculptured by prominent, fine, sharp, equal, concentric lines; ears slightly concave, rectangularly truncated, and sculptured by fine, sharp, concentric lines.

Dimensions.-Alt. $47 \mathrm{~mm}$; long. $50 \mathrm{~mm}$; hinge line $21 \mathrm{~mm}$; diameter 12 mm.; umbonal angle (left valve) $93^{\circ}$.

This species is quite closely related to $P$. lecontei, but is distinguishable from the latter by the smaller angle at the apex $\left(102^{\circ}\right.$ in the latter), much narrower sharper ribs, and stronger sculpture on the right valve.

$P$. auburyi has so far been found only in beds of probable lower Pliocene age. About 1 mile east of the Chandler wells. Puente Hills, Los Angeles County, it is 
associated, according to Doctor Merriam (see Merriam, 1900, p. 222), with Cancellaria 2 n. sp., Crepidula sp. indet., Drillia sp., Hinnites near giganteus, Natica (Neverita (aff.) rechuziana, Priene (aff.) oregonensis, Ranella californica, and Trochita sp. indet. At Olinda, Puente Hills, Orange County, Mr. Eldridge found P. auburyi with the following lower Pliocene fauna: Pecten ashleyi, P. wattsi, P. oweni, var., Priene (aff.) oregonensis, Cardium ( $f f$. ) quadrigenarium, Neverita recluziana, Phacoides californicus, Fusus (cf.) barbarensis, Arca multicostata (?), Nassa perpinguis (?), Chione sp., Leda taphria, Fissuridea murina, Nassa fossata, Phacoides richthofeni, Phacoides nuttalli, Phacoides (cf.) acutilineatus, Cardium ( $f f$.) corbis, Chione sp., Dentalium neohexagonum, Solen (cf.) sicarius, Turritella cooperi, Crepidula rugosa, Astyris sp., Cancellaria n. sp., Calliostoma costatum, Modiolus (cf.) rectus, Bulla punctulata, and Dentalium n. sp. (like Miocene form).

The type specimen is from the first-mentioned locality, and is now in the State Mining Bureau. Named in honor of Mr. Lewis E. Aubury, State Mineralogist of California, through whom the writer was enabled to procure the valuable Pecten material in the State museum.

RANGE.

Pliocene. Locality 38, 1 mile east of the Chandler wells, Puente Hills, Los Angeles County (Watts): Several localities in the vicinity of Olinda and Brea Canyon, Puente Hills, Orange County (Eldridge).

\section{Pecten (Pecten) Bellus Conrad.}

Pl. XXXI, figs. 1 and $1 a$.

1857. Janira bella Conrad, Proc. Acad. Nat. Sci. Phila., for 1856, p. 312.

1857. Janira bella Conrad, Pac. R. R. Rept., vol. 6, 1857, p. 71, pl. 3, fig. 16.

1869. Janira bella Conrad, Gabb, Pal. Cal., vol. 2, 1869, p. 105, pl. 16, fig. 20.

1888. Janira bella Conrad, Cooper, Seventh Ann. Rept. Cal. St. Min., 1888, p. 244.

1898. Peclen (Pecten) bellus Conrad, Dall, Trans. Wagner Free Inst. Sci., vol. 3, pt. 4, 1898, p. 704; not P. bellis McCoy (teste Dall, 1898).

1900. Vola sp. indet., Merriam, Bull. Cal. St. Min. Bureau, No. 19, 1900, p. 222, table III.

1903. Pecten (Pecten) bellus Conrad, Arnold, Mem. Cal. Acad. Sci., vol. 3, 1903, p. 103, pl. 21, figs. 1, 2.

Description.-Shell large, thin, inequivalve, elegantly, radiately ribbed. Left (upper) valve slightly convex, the point of greatest convexity being generally about one-fourth the distance from the apex toward the ventral margin; between this point of greatest convexity and the apex there is a deeply depressed area, the depression generally not affecting the two outer ribs on each side, which inclose the depression on the sides; surface of left valve ornamented by 13 or 14 prominent, flat-topped, sometimes faintly bicarinated, radiating ribs, which have flat, sloping sides; these ribs become broader, less elevated, and less sharply angulated near the periphery in the adult; interspaces slightly wider than the tops of the ribs, with slightly rounded bottoms; whole surface of left disk covered with fine, sharp, concentric, regular lamellæ; ears rather small, subequal, slightly concave, finely concentrically lamellated, separated from the disk by an impressed line. Right (lower) valve prominently convex, the point of greatest convexity being about one-third the distance from the apex to the ventral margin of the disk; the umbo in this valve curves sharply and meets the plane of the ears at an angle of about 90 degrees; surface 
of right valve ornamented by 14 or 15 prominent, nearly flat-topped, square, radiating ribs, some of them with one or two longitudinal obsolete lines; the ribs become somewhat less elevated and the sides more sloping as the periphery is approached in the adult; surface of right disk ornamented with close, fine, squamose, concentric wrinkles; ears subequal, arched, covered with crowded, elevated lamellæ; byssal notch small.

Dimensions.-Alt. $80 \mathrm{~mm}$; lat. $108 \mathrm{~mm}$; diam. $32 \mathrm{~mm}$; length of hinge line, $45 \mathrm{~mm}$.

The description, measurements, and figures are of Gabb's type specimen of Janira bella (No. 960, Collection Academy Natural Sciences, Philadelphia), which was kindly lent to the writer by Prof. H. A. Pilsbry, curator of Mollusca.

$P$. stearnsii and $P$. diegensis are distinguishable from $P$. bellus by the more numerous ( 25 or 28 in the first, 20 or 22 in the second), narrower, sharper defined, perpendicular-sided, radiating ribs on the right valve, and by the evenly rounded, prominently and evenly lamellated ribs of the left valve. $P$. hemphilli is distinguishable from $P$. bellus by its smaller size; by having on the right valve more numerous (15 or 16 in the former), round-topped, narrower, nearly perpendicularsided, radiating ribs, which retain their prominence for their entire length; by the less convexity of the disk; and by the more numerous, narrower, and more elevated radiating ribs of the left valve. $P$. hemphilli has the same depression below the apex in the left valve, but the lesser convexity of the rest of the disk lessens the prominence of the depression, which is so marked in most specimens of $P$. bellus. $P$. excavatus is distinguishable from $P$. bellus by its smaller size, greater convexity of right valve, greater concavity of left valve, greater number of ribs, and by the auxiliary ribs in the left valve.

After a careful comparison of a large series of $P$. bellus with Conrad's description and figure and Gabb's figure and type specimen, the writer has no hesitancy in adopting the synonymy given at the beginning of this article. Dall is of the opinion that Conrad's species and that of Gabb are different. This idea was probably caused by the exaggeration of the bicarination of the ribs in Conrad's figure. Several of the specimens of $P$. bellus examined by the writer show this bicarination to a greater or less degree, although as a rule the ribs are nearly smooth-topped. A large series of $P$. bellus and $P$. hemphilli show the differences enumerated in a previous paragraph to be constant for the adults. The young of both species up to an altitude of 20 millimeters are nearly identical in appearance.

P. bellus, so far as known, is confined to the Pliocene. It occurs abundantly in the Pliocene formation on Packards Hill, Santa Barbara, and in other localities in the vicinity. The type was obtained near Santa Barbara.

RANGE.

Fliocene. Santa Barbara (Conrad; Gabb; Yates; Cooper; Arnold); Top of hill, Long Tom mine, Kern County (Watts); Eureka Canyon, west side, near mouth, Ventura County (Eldridge); Rincon asphalt mine, Santa Barbara County (Watts); Loc. 33, east side of Piru Creek, near railroad bridge, Ventura County (Watts); ? Temescal Canyon, north of Santa Monica, Los Angeles County (Rivers). 
Pecten (Pecten) coalingaensis n. sp.

Pl. IV, figs. 4, 4à, and 5 .

Description.-Shell about 45 millimeters in altitude, longer than high, planoconvex, or nearly so, equilateral, and with smooth margins. Right valve ventricose and ornamented by about 20 ribs which have narrow, somewhat convex tops, and sides which slope at angles of about $45^{\circ}$; interspaces quite deeply impressed, channeled, and flat bottomed; surface sculptured by fine incremental lines; hinge line slightly longer than one-half length of disk; ears equal, convex, and ornamented by 2 or 3 obsolete radiating ridges and numerous fine incremental lines. Left valve flat, with 19 prominent convex ribs, a surface sculpture of fine regular incremental lines, and concave ears which are slightly obliquely truncated.

Dimensions.-Alt. $45 \mathrm{~mm}$; long. $52 \mathrm{~mm}$; hinge line $28 \mathrm{~mm}$; diameter $18 \mathrm{~mm}$.

This species is easily distinguishable by the peculiar shape of the ribs on the right valve. The type (right valve) was collected by Mr. L. D. O'Neal from beds of probable lower Pliocene age near Coalinga, Fresno County, and is now in the collection of the Leland Stanford Junior University. A left valve, which is undoubtedly of this species, was found by Mr. Watts near Kreyenhagen's ranch, Fresno County, and is now in the collection of the California Academy of Sciences. This left valve measures as follows: Alt. $35 \mathrm{~mm}$.; long. $37 \mathrm{~mm}$; hinge line $13 \mathrm{~mm}$.

RANGE.

Pliocene (lower). Coalinga, Fresno County (L. D. O'Neal); Kreyenhagen's ranch, Fresno County (Watts, Anderson, Arnold).

\section{Pecten (Pecten) hemphilli Dall.}

Pl. XXXIII, figs. $3,3 a$, and $3 b$.

1879. Pecten hemphilli Dall, Proc. U. S. Nat. Mus., vol. 1, 1879, p. 15.

1888. Pecten hemphilli Dall, Cooper, Seventh Ann. Rept. Cal. St. Min., 1888, p. 257.

1898. Pecten (Pecten) hemphilli Dall, Trans. Wagner Free Inst. Sci., vol. 3, pt. 4, 1898, p. 706.

1903. Pecten (Pecten) hemphilli Dall, Arnold, Mem. Cal. Acad. Sci., vol. 3, 1903, p. 105.

Description.-Shell of medium size, thin, inequivalve. Upper (left) valve flat or slightly concave, with a concave depression between middle of valve and umbo; surface of this valve sculptured by 16 or 17 very prominent, rather narrow radiating ribs, which are nearly flat-topped and have nearly perpendicular sides; interspaces wider than ribs, with rounding bottoms; fine incremental lamellæ cover the surface of this valve; ears square-cornered and concave, covered with incremental lamellæ. Lower (right) valve convex, the convexity being most apparent between middle of valve and umbo; sculptured by 16 prominent squarish ribs, which are similar to those on the upper valve, except that they are slightly broader and have a more rounded top; whole surface sculptured by very fine incremental lines; ears similar to those of upper valve except convex, the right one having 3 or 4 radiating ridges and a small byssal notch.

17260-No. $47-06-7$ 
Dimensions.-Alt. $56 \mathrm{~mm}$; long. $63 \mathrm{~mm}$.; diam. $15 \mathrm{~mm}$; hinge line $28 \mathrm{~mm}$.

This species is readily distinguishable from $P$. steamsii and $P$. diegensis by its smaller size, greater convexity of lower valve, and fewer ribs. Distinguishable from $P$. bellus by smaller size, flat or concave upper valve, and narrow, more elevated and prominent, radiating ribs. Common in the upper horizon of the Pliocene at Pacific Beach, and also in the strata exposed on Tenth street, near Russ School, San Diego.

$$
\text { RANGE. }
$$

Pliocene. Temescal Canyon, north of Santa Monica, Los Angeles County (Rivers); Pacific Beach, Russ School, and "San Diego well," San Diego (Hemphill, Dall, Arnold).

\section{Pecten (Pecten) Lecontei n. $\mathrm{sp}$.}

Pl. XXXIII, figs. $4,4 a$, and $4 b$.

Description.-Shell averaging about 60 millimeters in altitude, longer than high, plano-convex, equilateral, and with smooth margins; base evenly rounded; sides concave above. Right valve convex, and ornamented by about 18 prominent round-topped, perpendicular-sided, smoothish ribs, separated by interspaces, which are narrower than the ribs and have nearly flat bottoms; surface sculptured by fine wavy incremental lines, which are generally worn off from the tops of the ribs; hinge less than one-half the length of the disk; ears somewhat convex; the anterior with 2 or 3 broad, nearly obsolete, radiating ridges, imbricating incremental lines, and a rather small byssal notch; the posterior rectangularly truncated, and with fine incremental sculpture. Left valve flat or slightly concave, ornamented by about 17 prominent rounded ribs, which are separated by interspaces about equal in width to the ribs; surface sculptured by numerous fine, sharp, regular, raised, incremental lines; ears concave, rectangularly truncated, and covered by fine sharp incremental lines.

Dimensions.--Alt. $59 \mathrm{~mm}$.; long. $65 \mathrm{~mm}$; hinge line $29 \mathrm{~mm}$.; diameter 18 mm.; umbonal angle (left valve) $102^{\circ}$.

This species is distinguishable from $P$. diegensis, $P$. bellus, $P$. stearnsii and other members of this group by the number and convexity of the ribs on the right valve. The left valves of $P$. lecontei and $P$. diegensis are somewhat similar, although the former has fewer ribs and is generally slightly more concave.

$P$. lecontei has so far been found only in the Pliocene of Cerros Island, where it is associated with $P$. veatchii, $P$. cerrosensis, and Ostrea veatchii. The type is now in the collection of Delos Arnold. Named in honor of the late Prof. Joseph Le Conte, of the University of California.

RANGE.

Pliocene. Cerros Island, Lower California (University of California). 
Pecten (Pecten) merriami n. sp.

Pl. XXX, figs, $1,1 a$, and 2.

1900. Pecten meekii Merriam (not of Conrad, $1857=$ P. caurinus Gould), Bull. Cal. St. Min. Bureau, No. 19,1900, p. 222

Description.-Shell averaging about 115 millimeters in altitude, longer than high, inequivalve, equilateral, of medium thickness, and with smooth margins; base evenly rounded; sides straight or only slightly concave above, sloping at a rather low angle. Right valve decidedly ventricose, with 18 or 19 subequal, strong, square ribs, some of which show faint medial sulcations near their extremities; interspaces flat-bottomed and somewhat narrower than ribs; whole surface of disk sculptured by more or less prominent lines of growth; hinge line more than one-half length of shell; ears about equal in length; anterior ear with faint byssal notch, obsolete radiating ridges and fine incremental sculpture; posterior ear rectangularly truncated, and with faint radial and fine concentric sculpture. Left valve flat to concave, with a more or less prominent bulge just below the umbo, as in $P$. bellus; ribs prominent and rounded, relatively flatter and broader as the periphery of the disk is approached; interspaces about as wide as the ribs, round-bottomed, and some of them showing a faint intercalary riblet; surface sculptured by fine, sharp, looped, concentric lines; ears ornamented by 5 or 6 rather prominent radiating ridges and numerous fine concentric lines.

Dimensions.-Alt. $115 \mathrm{~mm}$.; long. $130 \mathrm{~mm}$; hinge line $70 \mathrm{~mm}$; diameter $30 \mathrm{~mm}$.

$P$. merriami is distinguishable from $P$. bellus, to which it is allied, by its much larger size when adult, more numerous ribs (18 to 19 in the former, 14 to 15 in the latter), relatively longer hinge line (the hinge line of the former being about 60 per cent of the length of the disk, while that of the latter is only about 45 per cent), and the radial ridging of the ears.

The types of this species, which are the only specimens of it so far known, were collected by Mr. Watts from light-colored shale underlying the conglomerate on San Felician Creek, near Piru, Ventura County. The following fauna, as given by Doctor Merriam, ${ }^{a}$ was associated with $P$. merriami at the type locality: Echinarachnius near excentricus, Macoma near secta, Nassa sp. indet., Pachypoma n. sp., Solen sicarius, and, as determined by the writer, Pecten cerrosensis. This fauna indicates beds of probable lower Pliocene age. The type of $P$. merriami is now in the collection of the California State Mining Bureau, San Francisco.

Named in honor of Dr. John C. Merriam, professor of paleontology, University of California, to whom paleontologists are indebted for so much of their knowledge regarding the faunas of the California Tertiary.

RANGE.

Pliocene (lower). San Felician Creek, near Piru, Ventura County (Watts). 


\section{Pecten (Pecten) stearnsir Dall.}

Pl. XXXII, figs. 1 and $1 \alpha$.

1869. Janira dentata Gabb (not Sowerby), Pal. Cal., vol. 2, 1869, p. 104 (in part).

1879. Pecten stearnsii Dall, Proc. U. S. Nat. Mus., vol. 1, 1879, p. 14.

1888. Janira dentata Cooper (not Sowerby), Seventh Ann. Rept. Cal. St. Min., 1888, p. 244 (in part).

1898. Pecten (Pecten) stearnsii Dall, Trans. Wagner Free Inst. Sci,, vol. 3, pt. 4, 1898, p. 706, pl. 26, fig. 5.

1900. Vola sp. indet., Merriam, Bull. Cal. St. Min. Bureau, No. 19, 1900, p. 222, table 4.

1903. Pecten (Pecten) stearnsii Dall, Arnold, Mem. Cal. Acad. Sci., vol. 3, 1903, p. 106, pl. 12, fig. 3.

Description.- Shell of medium size, subcircular, inequivalve, concavo-convex, thin; right valve slightly convex, with about 26 regular, even, square ribs, separated by channeled interspaces somewhat narrower than the ribs; the top surface of each rib is flattened with a broad, shallow groove in the middle, with one or two faint riblets on each side of the groove; whole surface covered with concentric lamellæ which are much finer and about twice as crowded as those of the left valve; left valve flattened or concave, with about 24 regularly rounded, vaulted, even ribs, separated by slightly wider channeled interspaces; the whole surface covered with fine, sharp, concentric, regular lamellæ, a little looped backward over the tops of the ridge; ears of this valve concave, with obsolete radiating ridges, and fine, concentric lamellæ; ears of right valve subequal, arched, covered with crowded, elevated lamellæ; byssal notch very small.

Dimensions.-Alt. $62 \mathrm{~mm}$; long. $71 \mathrm{~mm}$; diameter $14 \mathrm{~mm}$.; hinge $25 \mathrm{~mm}$.

According to Doctor Dall this is the precursor of $P$. diegensis, from which it differs by having 5 or 6 more ribs, which in the adult have a conspicuous medial sulcus.

P. stearnsii, so far as known, is confined to the Pliocene. It is quite abundant at Pacific Beach, near San Diego, where it is associated with P. healeyi, P. hemphilli, Opalia varicostata, O. anomala, Scala stearnsii, Pecten parmeleei, and other unique forms. In a well at San Juan Capistrano it was found by Watts associated with Turritella cooperi, Venericardia ventricosa, Arca trilineata, Nassa mendica, etc. Two left valves have been found in the Pliocene at Deadman Island, near San Pedro.

RANGE.

Pliocene. Temescal Canyon, Santa Monica Mountains, Los Angeles County (Watts, Rivers); San Pedro (Arnold); San Juan Capistrano, Orange County (Watts); Pacific Beach, near San Diego (Hemphill, Stearns, Dall, Arnold); Third street tunnel, Los Angeles (Hamlin).

Pecten (Pecten) vogdesi n. $\mathrm{sp}$.

Pl. XXXIII, figs. 1 and $1 a$; Pl. XXXIV, fig. 1 .

1888. Janira dentata Cooper, Seventh Ann. Rept. Cal. St. Min., 1888, p. 244 (Quaternary records).

1903. Pecten (Pecten) dentatus Arnold, Mem. Cal. Acad. Sci., vol. 3, 1903, p. 105 (Pleistocene record).

Description.-Shell similar to P. excavatus, except averaging larger and with the following differences: Right valve, somewhat less convex, has 19 or 20 broader, flatter ribs, which are separated by relatively broader interspaces that occasionally show faint intercalary riblets or faint longitudinal striations. Left valve with fewer ribs 
than $P$. excavatus, and having no intercalary riblets, or else faint ones, which become obsolete near the periphery of the disk; ears slightly less concave than in $P$. excavatus.

Dimensions.-Alt. $69 \mathrm{~mm}$; hinge line to ventral margin (right valve) $67 \mathrm{~mm}$.; long. $73 \mathrm{~mm}$.; hinge line $35 \mathrm{~mm}$.; diameter $24 \mathrm{~mm}$.; umbonal angle (left valve) $98^{\circ}$.

All of the Pleistocene specimens of the group of which $P$. excavatus is the living representative have the constant differential characteristics above enumerated. These differences are so constant and so pronounced that they are deemed by the writer to be of specific importance.

A fragment of a right valve in the California Academy of Sciences from the Pleistocene of Ventura County is over 120 millimeters in length.

The type of this species (a right valve) is from the upper San Pedro formation at San Pedro, and is now in the collection of Delos Arnold. The cotype, a left valve from the Pleistocene of Ventura County, is now in the collection of the California Academy of Sciences. The horizon of some large specimens of this species in the Philadelphia Academy collected by Mr. Hemphill near San Diego is uncertain. Named in honor of Gen. A. W. Vogdes, U. S. Army.

RANGE.

Pleistocene. San Pedro (Arnold); Ventura County (Bowers); San Diego (Hemphill). Pliocene (?). San Diego (Hemphill); Cholas Valley, near San Diego (Stearns).

\section{Pecten (Patinopecten) caurinus Gould.}

Pl. XXXVIII, figs. 1, $1 a$, and 1b; Pl. XXXIX, figs. 1 and 2.

1850. Pecten caurinus Gould, Proc. Bost. Soc. Nat. Hist., vol. 3, 1850, p. 345.

1852. Pecten caurinus Gould, Wilkes Expl. Exped., vol. 12, p. 458, figs. 569, 569a, $569 b$.

1855. Pecten Heermanni Conrad, Proc. Acad. Nat. Sci. Phila., vol. 7, 1855, p. 267 (not P. (Lyropecten) Heermanni Dall, Trans. Wagner Free Inst. Sci., vol. 3, pt. 4, 1898, p. 701, nor Pecten Heermanni Dall, Nautilus, vol. 14, 1901, p. 117, = P. estrellanus Conrad).

1857. Pecten Meekii Conrad, Proc. Acad. Nat. Sci. Phila., for 1856, 1st ser., vol. 8, 1857, p. 313.

1857. Pecten Meekii Conrad, Pac. R. R. Rept., vol. 7, pt. 2, 1857, p. 190, pl. 1, fig. 1.

1863. Amusium caurinum Gould, Carpenter, Brit. Assn. Rept., 1863, p. 645.

1863. Pecten Yessoensis Carpenter, loc. cit., p. 645 (not P. Yessoensis Jay, Perry's Voyage, 1856); $+P$. propatulus Carpenter, loc. cit., p. 679 (not Conrad, 1849). Fide Dall, 1898.

1886. Not Pecten caurinus Dall, Bull. Mus. Comp. Zool., vol. 12, p. 216, pl. 5, fig. 4, 1886 (= P. vancouverensis Whiteaves).

1888. Pecten caurinus Gould, Küster and Kobelt, Conch.-Cab., vol. 17, pt. 2, Spondylus und Pecten, sp. 108 , p. 152 , taf. 43 , fig. 1 .

1888. Amusium caurinus Gould, Cooper, Seventh Ann. Rept. Cal. St. Min., 1888, p. 228 (excepting "Japan").

1888. Pecten propatulus Cooper, loc. cit., p. 258 ("Eel River, Humboldt County").

1889. Not Pecten caurinus Dall, Bull. U. S. Nat. Mus., no. 37, 1889, pl. 5, fig. 4 (=P. vancouverensis Whiteaves).

1892. Pecten caurinus Gould, Williamson, Proc. U. S. Nat. Mus., vol. 15, 1892, p. 193.

1892. Amusium caurinum Gould, Keep, West Coast Shells, 1892, p. 168.

1898. Pecten (Patinopecten) caurinus Gould, Dall, Trans. Wagner Free Inst. Sci., vol. 3, pt. 4, 1898, p. 710.

1903. Pecten (Patinopecten) caurinus Gould, Arnold, Mem. Cal. Acad. Sci., vol. 3, 1903, p. 107, pl. 13, fig. 6.

1903. Not Pecten caurinus Dall, Bull. U. S. Nat. Mus., no. 37 (reprint), pl. 5, fig. 4, 1903 (=P. vancouverensis Whiteaves).

1904. Pecten caurinus Gould, Keep, West. Am. Shells, pp. 38-39. 
Description.-Shell averaging about 150 millimeters in altitude, slightly longer than high, valves much compressed (the right generally slightly more convex than the left), equilateral, and with smooth margins; sides straight or only slightly concave above. Right valve with 20 to 25 strong, flat-topped, squarish ribs, which, in some well-preserved specimens, show faint obsolete radial striæ; interspaces flat-bottomed and about equal in width to the ribs; whole surface of disk sculptured by fine incremental lines; hinge line less than onehalf length of disk; anterior ear only very slightly longer than posterior, ornamented with fine, sharp, incremental lines, but generally having no radial sculpture whatever; byssal notch prominent; posterior ear rectangular behind, and with sculpture similar to anterior. Left valve slightly less ventricose than right, with narrow rounded ribs and wide concave-bottomed interspaces; surface ornamented by fine, regular, raised, wavy, concentric lines, and sometimes more or less tesselated; ears obliquely truncated and sculptured with sharp incremental lines and sometimes by obsolete radiating ridges.

Dimensions.-Alt. $105 \mathrm{~mm}$; long. $110 \mathrm{~mm}$; hinge line $48 \mathrm{~mm}$.; diameter $15 \mathrm{~mm}$.

The measurements are for a specimen considerably under the average in size.

This species has caused considerable confusion in the nomenclature of the West Coast. In 1855 Conrad described a couple of small right valves of $P$. caurinus and named the species "Pecten Heermanni." The following is his original description and notes (see synonymy above): "Suborbicular, thin, compressed; ribs about 21, square, smooth; ears moderate in size. Locality, California. Doctor Heermann. Allied to $P$. eboreus of the Virginia Miocene, but very distinct; only two inferior valves were obtained; slightly convex." The type of $P$. Heermanni (so labeled in Conrad's own writing), and the other specimen referred to in the description are now in the Philadelphia Academy of Sciences, where they were examined and photographed by the writer. They are both right valves of young $P$. caurinus and undoubtedly came from the unique bryozoan marl of Santa Barbara, both specimens showing the characteristic matrix and blue-gray color of specimens of $P$. caurinus from that locality. Some time after 1855 Conrad labeled a $P$. estrellanus and also some fragments of $P$. miguelensis in the National Museum with the name "P. Heermanni." One of these latter specimens is referred to by Doctor Dall (see Dall, 1898 and 1901) as the type of P. Heermanni. This error of Conrad's caused Dall to apply the name "Heermanni" to P. estrellanus.

The type of P. Meekii Conrad is in the National Museum (No. 13333) and has been examined by the writer. It, also, is a $P$. caurinus from the bryozoan marl of Santa Barbara. The "San Raphael Hills," from whence the type of P. Meekii came, according to Conrad, are near Santa Barbara.

P. Yessoensis Jay, from Amori, Rikonoken, Japan, differs from P. caurinus by having a more convex shell, wider, lower, more rounded ribs on the right valve, less prominent ribs on the left valve, and by having larger ears, which are truncated more nearly at right angles.

$P$. caurinus ranges from the Pliocene upward. It has been reported from the Miocene by several authors, but so far none of these records have been authenticated. 
A Pecten having 19 ribs, and allied to, if not identical with, $P$. caurinus, was found in the lower Pliocene (?) sandstone at the mouth of the Raft River, Jefferson County, Wash. The ribs on the right valve of this specimen were narrower and those on the left valve were somewhat higher than those of a typical caurinus.

Pecten caurinus is found abundantly in the lower Pliocene along Eel River, Humboldt County. Some of the specimens from this locality have as many as 25 ribs, and the ribs are, in some cases, higher and narrower than in the typical form. On Eel River above the mouth of Price Creek, Mr. J. S. Diller found $P$. caurinus associated with the following fauna: Astyris richthofeni, Callista subdiaphana, Chrysodomus n. sp., Kennerlia grandis, K. bicarinata, Macoma calcarea, Macoma (cf.) nasuta, Natica clausa, Panomya ampla, Pleurotoma perversa, Priene n. sp. (?) near oregonensis, Tapes staleyi, Thracia trapezoides, Trophon near multicostatus, and Yoldia scissurata. This is a Pliocene fauna.

From Switch Gulch to French Gulch, on the Eel River, $P$. caurinus is found with the following: Cardium meekianum, Natica clausa, Mactra $(c f$.) californica, Siliqua patula, Macoma calcarea, M. inquinata, Tapes staleyi, Tresus nuttalli, Solen (cf.) sicarius, Pleurotoma perversa, Thracia trapezoides, Chrysodomus n. sp., Yoldia scissurata, Psephis (cf.) tantilla, Trophon near multicostatus, Scutella or Echinarachnius sp. indet. This is also a Pliocene fauna.

A magnificent specimen of $P$. caurinus, measuring nearly 200 millimeters in altitude, was found by Dr. Stephen Bowers in the Pliocene near Santa Paula, Ventura County.

The type of P. caurinus is in the U. S. National Museum, No. 5954.

Living. Puget Sound (Carpenter).

Pleistocene. Santa Barbara; San Pedro (Cooper, Mrs. A. E. Bush, Arnold).

Pliocene. Mouth of Raft River, Jefferson County, Washington (Arnold); above mouth of Price Creek, from Switch Gulch to French Gulch, and south of the middle of Rio Dell Bluff, Eel River (J. S. Diller); Eel River, Humboldt County (W. S. Monroe, A. C. Lawson); T. 1 N., Humboldt meridian, Humboldt County (J. M. Graham); Eagle Prairie, Humboldt County; San Fernando, Los Angeles County (Cooper); Santa Paula, Ventura County (Bowers, Watts); Santa Barbara; San Pedro (Arnold).

\section{Pecten (Patinopecten) healeyi n. sp.}

Pl. XXXVI, figs. 1 and $1 a$; Pl. XXXVII, figs. $1,1 a$, and 2.

1879. Pecten expansus Dall, Proc. U. S. Nat, Mus., vol. 1, 1879, p. 14; not Pecten expansus Smith, Quart. Jour. Geol. Soc., vol. 3, 1847, pp. 413, 419, pl. 18, fig. 21.

1898. Pecten (Patinopecten) expansus Dall, Trans. Wagner Free Inst. Sci., vol. 3, pt. 4, 1898, p. 706, pl. 26, fig. 1.

1903. Pecten (Patinopecten) expansus Dall, Arnold, Mem. Cal. Acad. Sci., vol. 3, 1903, p. 108.

1904. Pecten expansus Dall, Rivers, Bull. So. Cal. Acad. Sci., vol. 3, no. 5, p. 69.

Description.--Shell averaging about 130 millimeters in altitude, length about equal to height, inequivalve (the right slightly more ventricose than the left), equilateral, and with smooth margins; base evenly rounded; sides only slightly 
concave above. Right valve somewhat ventricose, and ornamented by 18 to 21 strong, squarish, subequal primary ribs, which become more or less dichotomous, and sometimes trichotomous, after 30 or 40 millimeters in length; medial sulcus of rib more or less deep, in some cases being as deep as the interspaces near the ends, thus completely dividing the primary rib; interspaces subequal, much narrower than the ribs, quite deeply channeled, and often ornamented by a small, rounded intercalary riblet; whole surface crossed by numerous fine lines of growth; hinge line less than one-half length of disk; anterior ear only slightly longer than left, arcuate in front, and ornamented by several obsolete radial ridges and numerous sharp incremental lines; byssal notch quite prominent; posterior ear slightly obliquely truncated, and ornamented by sharp incremental lines and sometimes by obsolete radiating ridges. Left valve much compressed; ribs narrow and rounded, more or less sharply toward the top (there being in some cases a narrow, slightly raised line along the top); interspaces wide, and each ornamented by a more or less prominent, rounded, intercalary riblet; whole surface striated concentrically by fine, sharp, wavy lines; ears obliquely truncated and sculptured similarly to those of the right valve.

Dimensions.-Alt. $112 \mathrm{~mm}$.; long. $112 \mathrm{~mm}$.; hinge line $50 \mathrm{~mm}$.; diameter $18 \mathrm{~mm}$.

The measurements are of a specimen somewhat below the average in size. A fine specimen from San Gregorio, San Mateo County, measures $180 \mathrm{~mm}$. in altitude.

The most variable factors in this species seem to be the depth and width of the medial sulci on the ribs of the right valve, and the prominence of the intercalary riblet in the left.

The specimens from San Gregorio and Pescadero, San Mateo County, show, on the average, flatter ribs, more highly developed medial sulci, and intercalary ribs on the left valve that almost equal the primary ones in importance. Specimens from Purisima and Lobitas, which appear to represent a somewhat lower horizon than the San Gregorio and Pescadero beds, are smaller, slightly more convex, and have two or three less ribs.

As the forms from both San Diego and San Mateo counties appear to vary through an almost analogous series of mutations, the slight differences enumerated above have not been deemed of even varietal importance.

A variety of $P$. healeyi with 17 ribs is found at Brea Canyon, 4 miles southeast of Newhall, Los Angeles County, associated with the folıwing fauna: Phacoides acutilineatus, P. richthofeni, Dosinia ponderosa (?), Tritonium sp., Conus n. sp. (?), Pomaulax sp., Turritella cooperi, Tellina idæ, Neverita recluziana, Trochita filosa, Chione near succincta, Cardium near corbis, Nassa near fossata. This fauna is probably well down in the Pliocene.

$P$. healeyi appears to have a very limited vertical range at the few localities where it is known. In San Mateo County it is found in the Purisima formation, which lies conformably beneath the Merced series, while in San Diego it is very abundant in beds of lower Pliocene age. The great abundance of this species in both the Purisima and San Diego formations may possibly be taken as evidence of their partial contemporaneity.

It was with regret that a name so well established in the paleontological literature of the Pacific coast as $P$. expansus was found to be preoccupied. Since, however, 
it becomes necessary to rename the species, it is with pleasure that the writer is enabled to dedicate it to Dr. William Healey Dall.

RANGE.

Pliocene. Purisima to Pescadero, and Punta Año Nuevo, San Mateo County (J. P. Smith, Arnold); Temescal Canyon, Santa Monica Mountains, Los Angeles County (Rivers); Pacific Beach, San Diego County, (Hemphill, Dall, Arnold, and others); Tia Juana, Mexico (A. W. Greeley); Brea Canyon, 4 miles southeast of Newhall, Los Angeles County (U. S. Nat. Mus.)

\section{Pecten (Patinopecten) purisimaensis n. $\mathrm{np}$.}

Pl. XXXIV, fig. 3; Pl. XXXV, figs. 1 and $1 a$.

Description.-Shell averaging about 125 millimeters in altitude, length same as height, valves both equally well compressed, equilateral, and with the margins smooth; base regularly rounded; sides relatively short, straight, sloping at a moderate angle. Right valve with about 24 prominent, T-rail-shaped ribs, flattened and sometimes faintly dichotomous above, overhanging deep, channeled, flatbottomed interspaces, which are about equal in width to the ribs; whole surface of disk with incremental sculpture, which develops into prominent scales on the sides of the ribs; hinge line equal to about two-fifths length of disk; anterior ear only slightly longer than posterior, sculptured by about three prominent radiating ridges and numerous imbricating incremental lines; byssal notch prominent, but not deep, being equal in width to one-half width of ear; posterior ear obliquely truncated, and ornamented by about three prominent radiating ribs and imbricating incremental lines. Left valve with narrow, rather sharp, concavesided ribs and wide concave-bottomed interspaces; surface with fine incremental sculpture; ears obliquely truncated and sculptured similar to those of right, except that the radiating ridges are finer and more numerous.

Dimensions.-Alt. $125 \mathrm{~mm}$; long. $125 \mathrm{~mm}$; hinge line $50 \mathrm{~mm}$.; diameter $25 \mathrm{~mm}$.

This magnificent species is allied to $P$. coosensis and $P$. dilleri, one of which is probably its precursor. P. purisimaensis is easily distinguishable, however, by the fewer and broader ribs on the right valve, narrower, sharper ribs and broader interspaces on the left, and from $P$. coosensis by the prominent radial sculpture of the ears.

P. purisimaensis is characteristic of the Purisima (lower Pliocene) formation, where it is associated with $P$. healeyi, $P$. nutteri, Crepidula princeps, Phacoides acutilineatus, Rostellaria indurata, etc.

The type is from the beds on the coast north of Pescadero, and is now in the collection of Delos Arnold.

RANGE.

Pliocene (lower). Purisima to Pescadero, and Punta Año Nuevo, San Mateo County (J. P. Smith; W. R. Hamilton; Arnold). 


\section{Pecten (Patinopecten) turneri $\mathrm{n} . \mathrm{sp}$.}

Pl. XXXIV, fig. 4; Pl. XXXV, figs. 2 and 3.

1888.? Pecten propatulus Cooper, Seventh Ann. Rept. Cal. St. Min., 1888, p. 258 ("Tomales, Marin County").

Description.-Shell averaging about 70 to 80 millimeters in altitude, length same as height, both valves equally compressed, equilateral, and with smooth margins; base regularly rounded; sides nearly straight and sloping at a rather low angle. Right valve with eighteen to twenty-two high, narrow, flat-topped, concavesided ribs, which, in most cases, show a distinct medial sulcus after reaching a length of 30 or 35 millimeters; interspaces much wider than ribs, round bottomed and sometimes ornamented near the end by a faint intercalary riblet; whole surface of disk finely concentrically striated; hinge line slightly longer than one-half length of disk; ears equal, rectangularly truncated; anterior ear sculptured by four or five prominent radiating ridges and numerous fine incremental lines; byssal notch shallow but distinct; posterior ear with sculpture similar to anterior. Left valve with narrow rounded ribs, which are separated by round-bottomed and concave-sided interspaces much wider than the ribs; surface sculptured by fine, distinct, wavy, concentric lines; ears as in right valve, except lacking byssal notch. Hinge as in $P$. caurinus.

Dimensions.-Alt. $65 \mathrm{~mm}$; long. $65 \mathrm{~mm}$; hinge line $35 \mathrm{~mm}$.; diameter $6 \mathrm{~mm}$.

The type is a smaller specimen than the average of this species.

$P$. turneri is allied to the group of which $P$. caurinus is the commonest representative. Its diagnostic characteristics are its small size for one of this group, narrow, sulcated ribs on right valve and radially striate ears.

Found in the Pliocene at Arroyo San Antonio, near Tomales Bay, Marin County, by Dr. H. W. Turner, late of the United States Geological Survey, after whom it is named.

The type, which is figured, is now in the collection of the department of geology, Leland Stanford Junior University.

$$
\text { RANGE. }
$$

Pliocene. Tomales Bay, Marin County (Turner).

\section{Pecten (Nodipecten) veatchil Gabb.}

$$
\text { Pl. XL, figs. } 1 \text { and } 1 a \text {. }
$$

1869. Pecten Veatchii Gabb, Pal. Cal., vol. 2, 1869, p. 32, pl. 10, fig. 56 .

1888. Liropecten veatchii Gabb, Cooper, Seventh Ann. Rept. Cal. St. Min., 1888, p. 246.

1898. Pecten Veatchii Gabb, Dall, Trans. Wagner Free Inst. Sci., vol. 3, pt. 4, 1898, p. 705.

Description.-Shell averaging about 130 millimeters in altitude, slightly broader than high, subequivalve, equilateral, of medium thickness, somewhat ventricose, and with margins finely serrate; base regularly rounded; sides sloping above with slight concavity. Right valve slightly less ventricose than left, with about 8 broad, flat ribs arranged in pairs, and a few small linear ribs on the sides; the 
whole surface is covered by several more or less prominent concentric undulations and numerous fine, squarish, imbricated, raised riblets; hinge line a little more than one-half the length of the disk; anterior ear about one and two-thirds length of posterior, ornamented by about 12 radiating riblets and numerous fine, sharp, imbricating, incremental lines; byssal notch about one-fourth length of ear in depth; posterior ear much smaller than anterior, but sculptured in a similar manner. Left valve with about 7 broad, flat, round-cornered ridges of unequal size, which are separated by interspaces of unequal width, there being 3 or 5 prominent ribs, between each pair of which is a smaller one; the surface of this valve is sculptured similarly to that of the right, except that the concentric undulations on the ribs become more or less prominent nodes toward the apex of the shell; ears similar to those of the right valve, except that the anterior one has a simple arcuate end and no notch.

Dimensions.-Alt. $130 \mathrm{~mm}$; long. $145 \mathrm{~mm}$; hinge line $75 \mathrm{~mm}$; diameter $50 \mathrm{~mm}$.

This species is quite similar to and is no doubt the precursor of $P$. subnodosus, from which it differs by attaining a larger size and having fewer and broader ribs. Like the living form, it is quite variable as regards the number and rugosity of its ribs.

The only locality from which this magnificent species has so far been reported is Cerros Island, off the coast of Lower California, where it is associated with $P$. cerrosensis, $P$. lecontei, Ostrea veatchii, and $O$. cerrosensis in beds of probable Pliocene age. Doctor Cooper confused one of the large Miocene Pectens $(P$. magnolia) with this species when he reported it from the Pliocene of Ojai Valley, Ventura County. (See Seventh Ann. Rept. Cal. St. Min., 1888, p. 246.)

The specimen figured is the type, which is now in the collection of the University of California.

RANGE.

Pliocene. Cerros Island, off Lower California (Dr. J. A. Veatch).

Pecten (Chlamys) bartschi n. sp.

Pl. XLI, fig. 3 .

Description.-Adult shell averaging about 60 millimeters in altitude, somewhat shorter than high, convex, slightly inequilateral; base regularly rounded; margins smooth. Valves with about 40 prominent (more or less unequal) narrow threadlike ribs, ornamented on top by numerous short imbricating spines; interspaces deep, narrow, and channeled; lateral areas rather narrow, perpendicular to disk, and slightly concave. Ears similar to those of P. islandicus.

Dimensions.-Alt $62 \mathrm{~mm}$; lat. $50 \mathrm{~mm}$.; diameter $28 \mathrm{~mm}$.

This species, of which only two or three rather poorly preserved specimens are known, is quite closely related to $P$. opuntia, but is readily distinguishable by its much larger size when adult, lack of concentric constriction in the later stages of growth, and relatively shorter disk.

P. bartschi is found in beds of probable lower Pliocene age at Crescent City, Cal., where it is associated with Terebratalia near hemphilli Dall, Phacoides 
acutilineatus Conrad, and Pecten parmeleei Dall. The type is figured and is now in the U. S. National Museum, No. 164841.

RANGE.

Pliocene (lower). Crescent City, Del Norte County, Cal., south side of Light-House Point, north of wharf (Diller).

\section{Pecten (Chlamys) bellilamellatus $n$. sp.}

Pl. XLI, figs. $6,6 a, 7$, and $7 a$.

Description.-Shell averaging about 18 millimeters in altitude, about as long as high, equivalve, both valves moderately convex, inequilateral; sides nearly straight; margins not serrate. Right valve with 15 or 16 prominent narrow, sharply convex-topped ribs with sloping sides; interspaces much wider than ribs, with narrow, flat bottoms; surface sculptured by numerous, regular, equidistant, thin, concentric, imbricating lamellæ, which cut squarely across the bottoms of the interspaces, curve convexly toward the umbo on the sides of the ribs, and loop gracefully downward away from the umbo on the tops; hinge line equal to the length of the disk; ears equal in length; anterior ear convexly truncated, separated from the disk by a deep, sharply defined, byssal notch, and sculptured by fine, regular, incremental lamellæ and five or six subequal radials; posterior ear acutely pointed, radially striate, and with incremental sculpture similar to but not quite as prominent as that of the anterior. Left valve similar to right; anterior ear more prominently sculptured, both radially and concentrically, than the posterior.

Dimensions.-Alt. $18 \mathrm{~mm}$; long. $18 \mathrm{~mm}$; hinge line $18 \mathrm{~mm}$; diameter 8 mm.; umbonal angle $100^{\circ}$.

This species is characterized by its small size when adult, long hinge line, narrow, sharply topped ribs and beautifully curved incremental lamellæ. It is easily distinguishable from $P$. latiauritus and varieties, with which it is allied, by the above-enumerated characteristics.

$P$. bellitamellatus is so far known only from the Pliocene at Pacific Beach, San Diego, where it is associated with $P$. healeyi, $P$. stearnsii, etc. Type in the collection of Delos Arnold.

RANGE.

Pliocene. Pacific Beach, San Diego County (Arnold).

Pecten (Chlamys) hastatus Sowerby.

Pl. XLI, fig. 4; Pl. XLII, figs. $1,1 a, 2$, and $2 a$.

1843. Pecten hastatus Sowerby, Thes. Conch., vol. 1, 1843, p. 72, pl. 20, fig. 236 (not of Reeve, 1852= $P$. var. hericius Gld.; in part not of Carpenter, 1863; nor of Cooper, 1888).

1857. Pecten altiplectus [typ. err.] Conrad, Proc. Acad. Nat. Sci. Phila., for 1856, 1st ser., vol. 8, 1857 , p. 313.

1857. Pecten altiplicatus Conrad, Pac. R. R. Rept., vol. 7, 1857, p. 191, pl. 3, fig. 2.

1869. Pecten hastatus Sowerby, Gabb, Pal. Cal., vol. 2, 1869, p. 104. 
1887. ?Pecten hastatus Sowerby, Whiteaves, Trans. Roy. Soc. Canada, vol. 4, sec. 4, 1887, p. 119.

1898. Pecten hastatus Sowerby, Dall, Trans. Wagner Free Inst. Sci., vol. 3, pt. 4, 1898, p. 708.

1903. Pecten (Chlamys) hastatus Sowerby, Arnold, Mem. Cal. Acad. Sci., vol. 3, 1903, p. 109, pl. 11, figs. $4,4 a$.

1904. Pecten hastatus Sowerby, Keep, West. Am. Shells, p. 40.

Description. - Shell averaging about 64 millimeters in altitude, slightly shorter than high, inequivalve, equilateral (except for ears), compressed and with serrate margins; base evenly rounded below; sides slightly concave above. Right valve with 9 pairs of narrow, elevated, spiny ribs, along the sides of which are a pair of smaller spiny riblets; major interspaces much wider than ribs, concave-bottomed and ornamented by 1 or 3 thread-like, spiny, intercalary riblets; whole surface sculptured by microscopic imbricating lines, of which the spines on the ribs and riblets are only modifications; hinge line equal to one-half length of disk; ears unequal, the anterior being about two and one-half times the length of the posterior; anterior ear with 7 or 8 prominently spiny radials and minor riblets, and imbricating incremental lines; byssal notch deep and almost as wide as ear; posterior ear small, and sculptured by fine, spiny radials and imbricating incremental lines. Left valve with about 9 narrow, very prominently spiny ribs; interspaces wide, concave-bottomed, and ornamented by a single prominent, central, imbricated riblet, on each side of which are minor thread-like riblets; whole surface of disk with fine incremental sculpture as in right valve; ears similar to those of right valve except that the anterior one has more ribs and riblets and no byssal notch. Hinge with almost obsolete cardinal crura. Color, golden yellow to pink, the left valve being the darker.

Dimensions.--Alt. $64 \mathrm{~mm}$.; long. $62 \mathrm{~mm}$.; hinge line $31 \mathrm{~mm}$; diameter $22 \mathrm{~mm}$.

This beautiful species, which is the southern representative of the group of which var. hericius is the normal form, is characterized by the great prominence of the spines which adorn the major ribs of both valves. A fossil specimen of this species from the bryozoan Pliocene marl of Santa Barbara served as Conrad's type of $P$. altiplicatus. (See Pl. XLI, fig. 4.)

A variety of $P$. hastatus, found associated with the typical form in the Pliocene at San Pedro, Santa Barbara, and San Diego, has the strongly individualized ribs which characterize the type, but almost completely lacks the prominent spines. The young of this smooth form, and also of the typical spiny form, up to an altitude of about 15 millimeters are indistinguishable from the young of Hinnites giganteus.

Whiteaves reports P. hastatus from Quatsino Sound, British Columbia. In describing his specimens, which were collected by Doctor Dawson, he mentions the few prominent ribs with a single row of high spines which characterize this species.

RANGE.

Living. Quatsino Sound, British Columbia (Dawson, Whiteaves); Monterey (Button); San Pedro (Oldroyd, Raymond); Catalina Island (Arnold); San Diego (Raymond). (In all cases dredged.)

Pleistocene (lower San Pedro formation). Bath-house Beach, Santa Barbara; Deadman Island, San Pedro (Arnold). 
Pliocene. Packard's hill, Santa Barbara (Yates, Wilson, Bowers, and Arnold); Ventura County (Bowers); Deadman Island, San Pedro (Mrs. A. E. Bush, Voy, Wilson, Oldroyd, Williamson, Arnold, and others); Temescal Canyon, Santa Monica Mountains, Los Angeles County (Rivers); Pacific Beach, San Diego (Arnold).

Pecten (Chlamys) hastatus Sowerby var. hericius Gould.

Pl. XLIII, figs. 3 and $3 a$.

1850. Pecten hericius Gould, Proc. Bost. Soc. Nat. His., vol. 3, 1850, p. 345.

1852. Pecten hericius Gould, Wilkes Expl. Exped., vol. 12, 1852, p. 457, fig. 570.

.1852. Pecten hastatus Reeve (not of Sowerby), Conch. Icon., vol. 8, pl. 11, fig. and sp. 43.

1863. Pecten hastatus Carpenter (not of Sowerby), Brit. Assn. Rept., 1863, p. 645 (in part).

1888. Pecten hastatus. Küster and Kobelt (not of Sowerby, 1843), Conch.-Cab., vol. 17, pt. 2, sp. 210 , p. 233 , taf. 62 , figs. 1 and 2.

1888. Pecten hastatus Cooper (not of Sowerby), Seventh Ann. Rept. Cal. St. Min., 1888, p. 257 (in part).

1898. Pecten (Chlamys) hericeus Gould, Dall, Trans. Wagner Free Inst. Sci., vol. 3, pt. 4, 1898, p. 708.

1903. Pecten (Chlamys) hericeus Gould, Arnold, Mem. Cal. Acad. Sci., vol. 3, 1903, p. 110, pl. 11, fig. 2 .

1904. Pecten hericeus Gould, Keep, West. Am. Shells, pp. 39-40, fig. 19.

Description.-Adult shell averaging about 70 millimeters in altitude, not quite as long as high, both valves compressed, equilateral (except for ears), which are decidedly unequal; margins finely serrate; sides markedly concave above; umbo acute. Right valve with 9 or 10 pairs of spiny fasciculi, the middle rib of each fascicule being the most prominent; interspaces about as wide as the fasciculi, and ornamented by several more or less spiny riblets; spaces between the riblets of the fasciculi and large interspaces channeled and ornamented by fine imbricating incremental lines, but free from any reticulations whatever; hinge line a little over one-half the length of the disk; anterior ear about two and one-half times longer than the posterior, ornamented by imbricating concentric lines, and above the notch by several subequal spiny riblets; byssal notch wide and deep; posterior ear small, and ornamented by numerous fine spiny riblets. Left valve with about 9 or 10 elevated fasciculi, the middle rib of each fascicule being quite prominently spinose; the spaces between the major fasciculi each occupied by a minor fascicule of more or less scaly riblets; interspaces between the riblets channeled and with imbricating incremental sculpture; ears sculptured as in right valve except that the riblets are smaller and more numerous on the anterior ear. Hinge weakly developed. Color pink to greenish, left valve the darker.

Dimensions.-Alt. $73 \mathrm{~mm}$.; long. $65 \mathrm{~mm}$.; hinge line $34 \mathrm{~mm}$.; diameter $21 \mathrm{~mm}$.

This variety appears to be the normal form of the group of $P$. hastatus, the typical hastatus having the imbricating spines on the ribs extremely developed. The only difference between $P$. hastatus and this variety is in the relative prominence and abundance of the ribs and riblets forming the fasciculi. In the right valve of the adult var. hericius each fascicule consists of three nearly equal spiny 
riblets (the middle riblet of the three being slightly more prominent and spiny), between which and the middle riblet of the adjoining interspace are two small riblets (and sometimes another still smaller pair of intercalaries), while in the adult $P$. hastatus the fascicular arrangement on the right valve is obscure, there being a central spiny rib with 2 and sometimes 4 faint scaly riblets between the major rib and the middle riblet of the interspace. The fasciculi of the left valve of $P$. hericius are convex, and consist of a central more or less spiny rib, between which and the middle riblet of the fascicule of the interspace are about 9 to 12 thread-like scaly riblets; while in $P$. hastatus there is a high narrow rib with steeply sloping sides, having a top ornamented by numerous tall curved spines; between this rib and the rib running down the interspace are from three to five faint thread-like scaly riblets.

$P$. var. hericius ranges from the Miocene (Santa Margarita formation) to the Recent fauna.' The fossil forms average smaller, and appear to have slightly more scaly secondary riblets, but in all other respects they are identical with the living shells.

A single specimen of Pecten, closely allied to if not identical with $P$. var. hericius, was found associated with $P$. estrellanus Conrad, Ostrea palmula Cpr., Tamiosoma gregaria Conrad, Chorus belcheri Hinds, and Astrodapsis tumidus Rémond, near San Lucas, Monterey County.

The type of $P$. hericins is from the Strait of Juan de Fuca, off the north coast of Washington, and is now in the U. S. National Museum (No. 5955).

$$
\text { RANGE. }
$$

Living. Puget Sound (Dall, Carpenter, Button).

Pleistocene (lower San Pedro formation). Deadman Island, San Pedro (Arnold). Pliocene. Temescal Canyon, Santa Monica Mountains, Los Angeles County

(Rivers); Deadman Island, San Pedro (Voy, Arnold); Pacific Beach, San Diego (Hemphill, Arnold).

Miocene (upper). San Lucas, Monterey County (Hamlin, Arnold).

Pecten (Chlamys) hastatus Sowerby var. hindsi Carpenter.

Pl. XLIII, figs. 1, 2, and $2 a$.

1863. Pecten hastatus (? var.) hindsii Carpenter, Brit. Assn. Rept., 1863, p. 645.

1887. Pecten hericeus var. hindsii Carpenter, Whiteaves, Trans. Roy. Soc. Canada, vol. 4, sec. 4, 1887, p. 119.

1898. Pecten hericeus var. hindsii Carpenter, Dall, Trans. Wagner Free Inst. Sci., vol. 3, pt. 4, 1898, p. 709.

Description. - Shell smaller than $P$. var. hericius, averaging about 58 millimeters in altitude; shape and convexity as in var. hericius; margins smooth. Right valve with about 26 close-set, sometimes wide, flattish, usually dichotomous, smooth ribs, which show fine lines of growth on their surface; interspaces narrow, channeled, and sculptured by minute reticulations; hinge line one-half as long as disk; anterior ear produced, sculptured by about six radials and prominently imbricating concentric 
lines; byssal notch prominent; posterior ear small and with radials and imbricating concentric sculpture. Left valve with small, obscurely fasciculated, imbricated ribs, each fascicule having one major and several much smaller and more prominently imbricated riblets; interspaces very narrow and sculptured as in right valve; ears similar to those of right valve except lacking notch in anterior one. Color pink to white, the left valve being the darker.

Dimensions.-Alt. $58 \mathrm{~mm}$; long. $57 \mathrm{~mm}$.; hinge line $29 \mathrm{~mm}$.; diameter $18 \mathrm{~mm}$.

Doctor Dall, in mentioning this variety, says: "The typical specimens seem remarkably distinct from $P$. hericens var. navarchus, but in a large series intergradation is obvious." Carpenter in his original description mentions that var. hindsii "passes from hastatus toward islandicus."

\section{RANGE.}

Living. Bering Sea to Monterey (Dall); Victoria, B. C. (Button); Quatsino Sound and vicinity of Vancouver Island (Dawson; Whiteaves).

Pleistocene. Sucia Island, Puget Sound (Newcombe).

Pliocene. Deadman Island, near San Pedro (Arnold).

Pecten hastatus Sowerby var. Navarchus Dall.

Pl. XLIII, figs. $1,1 a$, and $1 b$.

1844. Pecten rubidus Hinds, Zool. Voy. Sulph., 1844, p. 61, pl. 17, fig. 5 (not P. rubidus Martyn, 1784).

1898. Pecten hericeus var. navarchus Dall, Trans. Wagner Free Inst. Sci., vol. 3, pt. 4, 1898, p. 708.

1904. Pecten rubidus Hinds, Keep, West Am. Shells, p. 40.

Description.-Shell averaging about 55 millimeters in altitude, higher than long, subequivalve, both valves only slightly ventricose, thin, sides only slightly concave above. Right valve light colored, less ventricose than left, with numerous small, subangular, flat-topped, dichotomous, and slightly imbricated ribs; surface obscurely tessellated; anterior ear quite prominent, with about 6 prominent radiating ridges and numerous imbricating incremental lines; byssal notch of medium size; posterior ear small, with distinct radial ridges and imbricating sculpture. Left valve reddish or pinkish, more ventricose than right, with numerous small fasciculated and quite prominently imbricated ribs, each fascicule having one prominent rib in the middle with lesser ones on the sides; the major interspaces occupied by a small riblet; ears as in right valve except lacking byssal notch. Margins not prominently serrate.

Dimensions.-Alt. $55.5 \mathrm{~mm}$. ; long. $54 \mathrm{~mm}$; hinge line $21 \mathrm{~mm}$.; diameter $17 \mathrm{~mm}$.

This variety is smaller and more delicate than $P$. islandicus, and has fasciculated rather than dichotomous ribs on the left valve.

RANGE.

Living. Aleutian Islands southward to Lower California (Dall); Kodiak Island, Alaska (Greeley and Snodgrass). 
Pleistocene. Bowlder clay of Comox, Vancouver Island (Newcombe).

Pliocene. Deadman Island, San Pedro (Dall, Stearns); Timms Point, San Pedro (Arnold); Pacific Beach, San Diego (Hamlin).

Pecten (Chlamys) hastatus Sowerby var. strategus Dall.

Pl. XLIV, 2, $2 a, 3$, and 4 .

1898. Pecten hericeus var. strategus Dall, Trans. Wagner Free Inst. Sci., vol. 3, pt. 4, 1898, p. 709 1903. Pecten (Chlamys) hericeus var. strategus Dall, Arnold, Mem. Cal. Acad. Sci., vol. 3, 1903, p.

110, pl. 11, fig. 5 (right valve of a young specimen figured).

Description.-Adult shell averaging about 35 millimeters in altitude, slightly higher than long, inequivalve, equilateral, except for ears; both valves nearly flat up to an altitude of about 22 millimeters, where they generally become more convex by contraction, and the sculpture becomes more complicated. Right valve with 9 to 12 prominent, subequal, broad, nearly flat-topped, usually dichotomous, turgid ribs, with sometimes smaller intercalary riblets, all of which break up more or less suddenly into fasciculi of two or more riblets upon reaching an altitude of about 22 millimeters; interspaces subequal, broad, and channeled; whole surface of disk and ribs microscopically tessellated; hinge line equal to about one-half length of disk; anterior ear much produced, and sculptured by fine imbricating incremental lines and about 6 radial ridges; byssal notch prominent; posterior ear nearly obsolete, sculptured similarly to right. Left valve resembling the right except that the ribs are narrower, more convex, and with the intercalary riblets usually more imbricated; interspaces broader than in right valve; anterior ear with about 8 imbricated ridges. Color of recent specimens bright scarlet.

Dimensions.-Alt. $35 \mathrm{~mm}$; long. $34 \mathrm{~mm}$; hinge line $17 \mathrm{~mm}$. ; diameter 16 mm.; umbonal angle $83 \mathrm{~mm}$.

This variety is easily distinguished by its few broad ribs, which increase in number very rapidly both by division and intercalation after reaching an altitude of about 20 millimeters. Some of the Pleistocene (lower San Pedro formation) specimens from San Pedro retain a pinkish color.

Living. Unalaska (Dall).

RANGE.

Pleistocene. Alaska (Dall); Deadman Island, San Pedro (Arnold); Bath-house

Beach, Santa Barbara (Arnold).

Pliocene. Packards Hill, Santa Barbara (J. H. Wilson).

Pecten (Chlamys) islandicus Müller.

Pl. XLV, figs. 1 and $1 a$.

1776. Ostræa Islandicus Müller, Prodr. Zool. Dan., No. 2990, p. 248.

1778. Pecten cinnabarina Born, Mus., p. 103. (Fide Dall, 1898.)

1780. Ostrea Islandica Müller, Fabricius, Fauna Grönl., p. 415.

1784. Pecten Islandicus Müller, Chemnitz, Conch., vol. 7, p. 304, pl. 65, figs. 615 and 616.

1784. Pecten rubidus Martyn, Univ. Conch., vol. 2, pl. 153, fig. 1.

1797. Ostrea demissa Solander, Museum Colonnianum, p. 52, No. 986.

$17260-$ No. $47-06-8$ 
1831. Pecten Pealei Conrad, Amer. Mar. Conch., p. 12, pl. 2, fig. 2.

1836. Pecten Islandica Müller, Lamarck, Anim. Sans. Vert., ed. 2, vol, 7, p. 145, No. 42.

1843. Pecten Islandicus Müller, Sowerby, Thes. Conch., vol. 1, Pecten, figs. 159-161.

1844. Pecten Fabricii Philippi, Abbild. und Beschreib. Conchyl., vol. 1, p. 101, pl. 1, fig. 5.

1853. Pecten Islandicus Müller, G. O. Sars, Moll. Reg. Arcticæ Norvegiæ, p. 16, pl. 2, fig. 2.

1888. Pecten islandicus Müller, Küster and Kobelt, Conch.-Cab., vol. 17, pt. 2, Spondylus und Pecten, No. 24, p. 59, taf. 16, figs. 1 and 2 .

1888. Pecten islandicus Chemnitz, Küster and Kobelt, op. cit., p. 105, taf. 30, figs. 1-6.

1888. Not Pecten islandicus Cooper, Seventh Ann. Rept. Cal. St. Min., 1888, p. 257 (= P. jordani Arnold, 1903).

1897. Chlamys islandica (Chemn.), Verrill, Trans. Conn. Acad. Sci., vol. 10, June and July, 1897, p. 72 , pl. 16 , figs. $2-5 b$; pl. 20 , fig. 9 ; pl. 21 , fig. 2 .

1898. Pecten (Chlamys) islandicus Müller, Dall, Trans. Wagner Free Inst. Sci., vol. 3, pt. 4, p. 708.

1901. Pecten isiandicus Müller, Brögger, Norges Geol. Undersögelse, No. 31, p. 228, fig. 23, tab. 5, figs. $1, a, b, c$, and $d$.

Description.-Shell averaging about 80 millimeters in altitude, subcircular, somewhat higher than long, subequivalve, both valves only slightly convex, equilateral, except for ears; of medium thickness; sides only slightly concave above; base evenly rounded; color of living shell pinkish to salmon, the left valve being the more highly colored. Right valve with numerous narrow, square, flat-topped, imbricated ridges, which multiply slowly, both by division and intercalation, as the shell grows; interspaces narrow, channeled, and minutely reticulated; hinge line equal to more than one-half length of disk; anterior ear much produced, sculptured by numerous sharp imbricating lines and 5 or 6 major radiating ridges and some intercalaries; byssal notch quite prominent; posterior ear a little over onehalf as long as the anterior, and sculptured in the same way. Left valve similar to right, except possibly that the imbrication is a little more pronounced.

Dimensions.-Alt. $83 \mathrm{~mm}$.; long. $77 \mathrm{~mm}$; hinge line $44 \mathrm{~mm}$.; diameter $27 \mathrm{~mm}$.; apical angle $84^{\circ}$.

This species is characterized by its large size when adult, large number of subequal scaly ribs, reticulated, channeled interspaces, and the relatively long posterior ear for a member of this group.

Only two authentic specimens of this species are known from California; both are from the Pliocene of Deadman Island, San Pedro, one being in the Voy collection at the University of California and the other in the collection of Delos Arnold.

Living. North Atlantic; Bering Sea (Dall).

Pleistocene. Bowlder clays of the northwest American coast, Alaska, and British Columbia (Dall).

Pliocene. Deadman Island, San Pedro (Voy, Arnold).

Pecten (Chlamys) Jordani Arnold.

Pl. XLIV, figs. $1,1 a$, and $1 b$.

1903. Pecten (Chlamys) jordani Arnold, Mem. Cal. Acad. Sci., vol. 3, 1903, p. 111, pl. 12, figs. 6 and 7.

Description. - Shell shape of $P$. islandicus, averaging about 45 millimeters in altitude, somewhat shorter than high, inequivalve, both valves convex, equilateral 
except for ears, rather thin, and with smooth margins. Right valve with about 25 to 30 angular smooth-topped, imbricated ribs, which become dichotomous after reaching a length of about 30 millimeters; interspaces deeply channeled and narrower than ribs; anterior ear imperfectly radially ribbed with 6 ridges, and showing elevated, concentric incremental lines; posterior ear nearly obsolete, showing about 4 ribs; byssal notch not deep. Left valve with 25 to 30 narrow, convex ribs, showing imbricating sculpture only slightly; interspaces as wide as or wider than ribs; after a diameter of 30 millimeters has been reached by the left valve small intercalary ribs appear in most of the widening interspaces; anterior ear with 5 narrow, imbricated ridges separated by wide interspaces. Both valves show a tendency to contract suddenly at the basal margin upon nearing completion of growth; surface of both valves covered with a minute lattice-like sculpture, which is generally worn off on exposed portions of the shell.

Dimensions.-Alt. $45 \mathrm{~mm}$.; long. $42 \mathrm{~mm}$.; hinge line $18 \mathrm{~mm}$.; diameter $15 \mathrm{~mm}$.

This species is allied to the group of which $P$. istandicus is the type. Although distinetly separated from the other members of the group, it is, nevertheless, quite closely related to $P$. hastatus var. navarchus and var. hindsii. The right valves of $P$. jordani and of the two varieties above mentioned are very similar, but the left valve of $P$. jordani is entirely different from that of the other two, having simple, lattice-like sculptured ribs instead of imbricated, fasciculated ones. P. jordani is distinguishable from $P$. hastatus, and the latter's variety hericius by its lack of fasciculated ribs. No gradation between $P$. jordani and other members of the group has been noticed by the writer, whereas in nearly all the other cases a large series shows obvious intergradation between the different forms.

P. jordani is found in both the Pliocene and lower Pleistocene, but is not known as living.

$$
\text { RANGE. }
$$

Pleistocene (lower San Pedro formation). Deadman Island, San Pedro; Santa Barbara (Arnold).

Pliocene. Deadman Island, San Pedro (Bush, Wilson, Oldroyd, Arnold); Santa

Barbara; Pacific Beach, San Diego (Arnold).

\section{Pecten (Chlamys) latiauritus Conrad.}

Pl. XLVI, figs. $2,2 a, 3$, and $3 a$.

1837. Pecten latiauritus Conrad, Jour. Acad. Nat. Sci. Phila., vol. 7, 1837, p. 238, pl. 18, fig. 9

1842. Pecten latiauratus Conrad, Sowerby, Thes. Conch., vol. 1, pt. 1, 184?, p. 57, pl. 12, figs. 20, 21.

1844-1847. Pecten tunica Philippi, 1844; + P. mesotimeris Sowerby, 1847 (fide Dall, 1898).

1852. Pecten latiauritus Conrad, Reeve, Conch. Icon., vol. 8,1852 , pl. 1 , fig. 5 .

1863. Pecten latiauritus Conrad, Carpenter, Brit. Assn. Rept., 1863, p. 645.

1888. Pecten latiauritus Conrad, Küster and Kobelt, Conch.-Cab., vol. 17, pt. 2, Spondylus und Pecten, No. 163, p. 203, taf. 54, figs. 7 and 8.

1888. Pecten latiauritus Conrad, Cooper, Seventh Ann. Rept. Cal. St. Min., 1888, p. 257.

1892. Pecten latiauritus Conrad, Keep, West Coast Shells, 1892, p. 167. 
1892. Pecten latiauritus Conrad, Williamson, Proc. U. S. Nat. Mus., vol. 15, 1892. p. 193.

1898. Pecten (Chlamys) latiauritus Conrad, Dall, Trans. Wagner Free Inst. Sci., vol. 3, pt. 4, 1898, p. 709 .

1903. Pecten (Chlamys) latiauritus Conrad, Arnold, Mem. Cal. Acad. Sci., vol. 3, pt. 2, 1903, p. 111, pl. 12, figs. 2 and $2 \alpha$.

1904. Pecten latiauritus Conrad, Keep, West Am. Shells, p. 40.

Description.- Shell averaging about 25 millimeters in altitude, about as long as high, inequivalve, compressed, inequilateral, disk obliquely produced posteriorily, thin; sides straight; margins smooth. Right valve more compressed than left, with 12 to 16 low, rather squarish ribs, separated by equal, more or less distinctly channeled interspaces; whole surface sculptured by numerous fine concentric lines; hinge line nearly as long as disk; ears subequal in length; anterior ear long and narrow, with 5 or 6 prominent radials and numerous fine concentric lines; byssal notch deep and distinctly separating ear from disk; posterior ear from rectangularly to acutely pointed, sculptured by obsolete radials and concentric lines. Left valve. somewhat more convex than right, otherwise similar to it; anterior ear generally shorter and more prominently sculptured than posterior.

Dimensions.-Alt. $25 \mathrm{~mm}$.; long. $23 \mathrm{~mm}$.; hinge line $20 \mathrm{~mm}$.; diameter $9 \mathrm{~mm}$.; umbonal angle $90^{\circ}$.

This species is characterized by its small size, oblique disk, thinness, long hinge line, and deep byssal notch. The sculpture of the shell is usually well marked. The ribs are sometimes faintly medially sulcated, and the interspaces sometimes contain a faint intercalary riblet in the later stages of growth. The Pleistocene shells, as a rule, are rather more strongly ribbed than the living.

A pair of valves in the U. S. National Museum (No. 96964), from U. S. Fish Commission Station No. 2840, Santa Barbara Islands, is labeled " $P$. tumbezensis Orb." This shell is probably an albino variety of $P$. latiauritus, having just a touch of color on the interior of the posterior ear of the left valve. The true $P$. tumbezensis is from the Peruvian part of the South American coasts.

In the Third street tunnel, Los Angeles, $P$. latiauritus has been found associated with the following fauna: Pecten pedroanus, $P$. ashleyi, P. opuntia, P. stearnsii, Glyphis densiclathrata, Nassa n. sp.?, Macoma sp. indet., Arca multicostata, Lima hamlini, Buccinum sp. indet., Neverita recluziana, Astarte sp., Priene oregonensis, Ostrea veatchii, Pleurotoma sp. indet., and a carditoid. As this fauna indicates a horizon well down in the Pliocene, it extends the geologic range of $P$. latiauritus much further back than heretofore known.

$P$. latiauritus is found living attached to kelp, those specimens inhabiting the deeper, quieter waters being less strongly sculptured than those which are subjected to a more strenuous existence nearer the shore.

RANGE.

Living. Monterey (Yates); Santa Barbara to San Diego (Carpenter and others). Pleistocene. Santa Barbara; San Pedro (Cooper); San Pedro; San Diego (Arnold, Wilson, Dall).

Pliocene. Third street tunnel, Los Angeles (Hamlin). 
Pecten (Chlamys) Lawsoni n. sp.

Pl. XLV, figs. 3 and 4 .

Description.-Adult shell averaging about 70 millimeters in altitude, not as long as high, inequivalve, only slightly convex, equilateral, ears unequal; base regularly rounded; sides only slightly concave above; margins somewhat serrate. Right valve with about 18 to 20 subequal, prominent, narrow, round-topped, rugose ridges, separated by somewhat wider interspaces, in each of which runs a single more or less rugose riblet; some of the ribs are occasionally medially sulcated or dichotomous; surface sculptured by numerous irregular incremental lines, which give the ribs a squamose appearance when they are unworn; ears unequal, the anterior with three or four rather prominent rugose radials and numerous incremental lines; the posterior with several less prominent radials, and incremental sculpture; byssal notch rather profound. Left valve with 9 or 10 prominent narrow, round-topped, rugose major ribs, between each two of which there is a single minor rib similar to and almost equaling in prominence the major ribs; a single thread-like intercalary is visible in most of the interspaces; surface sculptured as in the right valve; ears similar to those of right valve except that there is no prominent notch between the anterior one and the disk.

Dimensions.-Alt. 70 mm.; long. $81 \mathrm{~mm}$; diameter $24 \mathrm{~mm}$; umbonal angle $87^{\circ}$.

This species is closely allied to $P$. hastatus, but is distinguishable by the paucity of its secondary sculpture (such as spines and secondary intercalaries), the nearly equal prominence of the major and minor ribs in the left valve, and the equality of the interspaces in the right. (The ribs in the right valve of $P$. hastatus occur in pairs, each pair being separated from those adjacent by spaces perceptibly wider than the interspaces between the members of each pair.) The smooth variety of $P$. hastatus mentioned as occurring in the Pliocene at San Diego, San Gregorio, etc., appears to occupy a position about midway between the typical $P$. hastatus and P. lawsoni.

The type of $P$. lawsoni, which is now in the collection of the California Academy of Sciences, was collected by Mr. F. M. Anderson from the Pliocene at the Waldorf asphalt mine, 4 miles south of Guadaloupe, Santa Barbara County. Mr. Anderson has kindly furnished the following list of fossils from the beds at this mine: Crepidula princeps Conrad, Turritella cooperi Carpenter, Bittium asperum Gabb, Priene oregonensis Redfield, Trochita costellata Conrad, Lunatia lewisii Gould, Natica sp., Calliostoma gemmulatum Carpenter, Scala sp., Nassa perpinguis Hinds, Pleurotoma near carpenteriana Gabb, Pleurotoma near tryoniana Gabb, Pyrula (?) sp., Drillia torosa Carpenter, Purpura crispata Chemnitz, Columbella richthofeni Gabb, Dentalium sp., Acmæa sp., Panopea generosa Gould, Leda taphria Dall, Arca 2 sp., Venericardia ventricosa Gould, Pandora scapha Gabb, Tellina sp., Pecten 2 sp., Martesia ovoides Gould, Phacoides (+ Lucina) near acutilineatus Conrad, Phacoides sp., Macoma sp., Mytilus sp., Ostrea sp., Echinarachnius sp., and coral.

The writer is also indebted to $\mathrm{Mr}$. Anderson for the following list of fossils from a locality 1 mile north of Schumann switch, (3 miles east of the Waldorf asphalt mine), Santa Barbara County: Trochita near costellata Conrad, Trochita near 
inornata Gabb, Calliostoma sp., Lunatia lewisï Gould, Glycymeris (+ Pectunculus) near patulus Conrad, Glycymeris sp., Venericardia ventricosa Gould, Pecten lawsoni n. sp., Pecten ashleyi n. sp., etc.

Named in honor of Dr. A. C. Lawson, professor of geology at the University of California.

RANGE.

Pliocene (lower). Waldorf asphalt mine, 4 miles south of Guadaloupe, and 1 mile north of Schumann switch, Santa Barbara County (F. M. Anderson).

\title{
Pecten (Chlamys) opuntia Dall.
}

\author{
Pl. XLI, fig. 2.
}

1898. Pecten (Chlamys) opuntia Dall, Trans. Wagner Free Inst. Sci., vol. 3, pt. 4, 1898, p. 707, pl. 29, fig. 6.

1903. Pecten (Chlamys) opuntia Dall, Arnold, Mem. Cal. Acad. Sci., vol. 3, 1898, p. 113.

Description.-Shell averaging about 35 millimeters in altitude, slightly shorter than high, subequivalve, equilateral (except for ears), both valves nearly flat until altitude of about 20 to 25 millimeters is reached, when they grow more convex; contracted at basal margin when adult; sides only slightly concave above. Right valve with 40 to 60 subequal, narrow, imbricated, more or less dichotomous ribs, which are separated by channeled interspaces about equal in width to the ribs; hinge line about two-fifths as long as disk; anterior ear much produced, sculptured by about six prominent, sharply imbricated radials, and imbricating incremental lines; byssal notch quite prominent; posterior ear nearly obsolete, radially and concentrically sculptured; whole surface of disk and ears sometimes microscopically checkered or tessellated. Left valve similar to right.

Dimensions.-Alt. $43 \mathrm{~mm}$.; long. $40 \mathrm{~mm}$.; hinge line $16 \mathrm{~mm}$; diameter $12 \mathrm{~mm}$.; umbonal angle $78^{\circ}$.

This species is allied to $P$. hastatus var. navarchus, from which it differs by its smaller and not fasciculated radial ribs, more elongated anterior ear, more densely. radially costate posterior ear, small size when adult, and by a tendency to be suddenly contracted at the basal margin on the completion of growth. P. opuntia is distinguishable from other members of this group by its large number of nearly equal thread-like ribs and small umbonal angle.

$$
\text { RANGE. }
$$

Pliocene. Pacific Beach, San Diego (Hemphill; Hamlin; Arnold); Packard's Hill, Santa Barbara (J. H. Wilson, Arnold); Rincon Creek, Santa Barbara County (Watts); Third Street tunnel, Los Angeles (Hamlin); Temescal Canyon, Santa Monica Mountains, Los Angeles County (Rivers). 


\section{Pecten (Chlamys) Parmeleei Dall.}

Pl. XLI, figs. $1,1 a, 5$, and $5 a$.

1898. Pecten (Chlamys) Parmeleei Dall, Trans. Wagner Free Inst. Sci., vol. 3, pt. 4, p. 708, pl. 37, figs. 14 and $14 a, 1898$.

Description.-Shell averaging about 50 millimeters in altitude, somewhat shorter than high, rather compressed, inequivalve, equilateral; ears unequal. Left valve with 5 prominent, narrow, smooth, and convex-topped ribs, separated by much wider interspaces which are scúlptured by numerous, rather fine, radial riblets; whole surface of disk covered by profuse, coalescent, microscopically checkered squamation; anterior ear produced and ornamented by several small radials and microscopic sculpture; posterior ear short, but otherwise as anterior. Right valve similar to the left, except that the ribs, which in the right valve correspond to the interspaces of the left, are much broader than those of the left; interspaces relatively narrower. The disks of both valves are constricted at irregular intervals, which tends to give the ribs a nodose appearance.

Dimensions.-Alt. $45 \mathrm{~mm}$; long. $38 \mathrm{~mm}$.

This species is close to P. swiftii Bernhardi, of Japan, but smaller, and differs by the smooth top surface of the ribs, which in $P$. swiftii are more or less striated or coarsely threaded, and by the not alternated radial riblets on the left anterior ear; also, especially, by the peculiar microscopic squamation which makes a complete external coating to the valve. $P$. parmeleei differs from $P$. wattsi by its narrower ribs on the left valve, finer radials in the interspaces, less prominent constrictions of the disk, and peculiar microscopic sculpture.

Only two specimens of this species have so far been found: a left valve (the type, U. S. N. M. 154479) from the Pliocene at Pacific Beach, near San Diego, and an imperfect right valve (U. S. N. M. 164842) from the Pliocene at Crescent City, Cal.

RANGE.

Pliocene. Crescent City, Del Norte County, south side of Light-House Point, north of wharf (Diller); Pacific Beach, San Diego (Parmelee).

\section{Pecten (Chlamys) washburnei n. $\mathrm{sp}$.}

$$
\text { Pl. XLV, fig. } 2 \text {. }
$$

Description.-Shell averaging over 100 millimeters in altitude, somewhat shorter than high, subequivalve, equilateral (except for the ears), rather thin; base regularly rounded; sides somewhat concave above. Left valve with about 65 more or less unequal, faintly squamose, low, squarish ribs; interspaces about as wide as the ribs, and sometimes ornamented by an intercalary thread or riblet; whole surface of disk ornamented by imbricating lamellæ; anterior ear somewhat convex in front, and with a faint suggestion of a notch, sculptured by about 12 rather low imbricated radials; posterior ear about one-half as long as the anterior, obliquely truncated, and ornamented by faint radials and imbricating lamellæ. 
Right valve unknown, but, judging by the affinity which this species bears to $P$. islandicus, it should be similar to the left valve, with the exception that the anterior ear should have a deep byssal notch, and the ribs should be slightly broader and the interspaces correspondingly narrower.

Dimensions.-Alt. $110 \mathrm{~mm}$.; long. about $100 \mathrm{~mm}$; hinge line about $50 \mathrm{~mm}$.; diameter $30 \mathrm{~mm}$.

This species is closely allied to $P$. islandicus, and may be its direct precursor. It is distinguishable from the latter, however, by its larger size (being the largest species of this group yet known from the Pacific coast), more numerous, lower, and smoother ribs, and less obliquely truncated posterior ears.

P. washburnei occurs in beds on the Yachates River, Lincoln County, Oreg., where it is associated with the following fauna: Opalia condoni Dall, Terebratella transversa Sby, Acmæa sp., Strongylocentrotus $(c f$.) purpuratus Stimpson, Cidaris (?) sp., Natica or, Neverita sp., Buccinum (?) sp., Calliostoma sp. Doctor Dall is of the opinion that these beds are the equivalent of those at Eugene, Oreg., of whose position in the stratigraphic column there is much uncertainty. Tentatively, however, this species will be placed with those from the lower Pliocene.

This species is named in honor of Mr. Chester Washburne, of Eugene, Oreg., whose work in the Oregon Tertiary has added many new species to the lists. The type is now in the U. S. National Museum (No. 164843), locality 3593.

$$
\text { RANGE. }
$$

Pliocene (lower?). Yachates River, Lincoln County, Oreg. (Washburne)。

$$
\text { Pecten (Chlamys) wattsi n. } \mathrm{sp} \text {. }
$$

$$
\text { Pl. XI, figs. } 1 \text { and } 1 a \text {. }
$$

Description.--Shell averaging about 65 millimeters in altitude, slightly higher than long, equilateral, of medium thickness, decidedly ventricose, and with margins slightly finely serrate; base regularly rounded; sides sloping above, with slight concavity. Left valve with 5 high, rather narrow, rounded, almost smooth ribs, which are made prominently nodose by several very pronounced concentric undulations, or constrictions; interspaces much wider than ribs and each ornamented by about 5 small, subequal, rounded, imbricated riblets; whole surface of disk with a profuse, coalescent, microscopically checkered squamation; hinge line about twofifths length of disk; anterior ear with arcuate end, and with surface sculptured by about 5 prominent imbricated riblets and several concentric undulations; posterior ear obsolete. Right valve about equal to left in convexity, with broad, flat-topped ribs and narrower interspaces, both being longitudinally sculptured by subequal riblets; ears similar to left; byssal notch not prominent; surface sculpture microscopic; constrictions less pronounced than in left valves.

Dimensions.-Alt. $67 \mathrm{~mm}$; long. $59 \mathrm{~mm}$; hinge line $20 \mathrm{~mm}$.; diameter $36 \mathrm{~mm}$.

This species is even more closely allied to P. swiftii Bernhardi (Jour. de Conch., vol. 7,1858 , p. 90 , pls. i and ii), of Japan, than is $P$. parmeleei. It is distinguishable from $P$. swiftii, however, by its broader ribs, not alternated radial riblets on the right anterior ear, and by the smaller number of secondary 
riblets in the wide interspaces. The specimens of $P$. wattsi are too poorly preserved to show satisfactorily the microscopic sculpture of the surface, but what is left of this sculpture appears to be very much like that of P. swiftii.

$P$. wattsi differs from $P$. parmeleei in having broader and more strongly nodose ribs, more numerous (6 instead of 4) radials on the anterior ear, and most of all by the fewer and much larger-sized secondary radial riblets in the major interspaces. The poor state of preservation of the type of $P$. wattsi precludes any definite statements regarding its microscopic surface sculpture, but from as good a comparison as could be made under the circumstances the two species appear to have somewhat different kinds.

$P$. wattsi is found in beds near Kreyenhagen's ranch, Fresno County, which are supposed to be of lower Pliocene age. It has been collected from beds of lower Pliocene age (Purisima formation) on Pescadero Creek, San Mateo County, and at other localities in the southern part of the State. At Olinda, Puente Hills, Orange County, Mr. Eldridge found $P$. wattsi associated with $P$. ashleyi, $P$. auburyi, P. oweni var., Priene (aff.) oregonensis, Cardium ( $c f$. .) quadrigenarium, Neverita rechuiana, Phacoides californicus, and Fusus (cf.) barbarensis, in beds of probable lower Pliocene age.

The type is from Kreyenhagen's ranch, Fresno County, and is now in the collection of the California Academy of Sciences. It is named in honor of Mr. W. L. Watts, whose collecting has added very materially to the list of west coast fossil Pectens.

$$
\text { RANGE. }
$$

Pliocene (lower). Pescadero Creek, one-fourth mile above Jones Gulch, San Mateo County (Newsom; Arnold); Kreyenhagen's ranch, Fresno County (Watts); Olinda, Puente Hills, Orange County (Eldridge).

Pecten (Chlamys) wattsi var. morani n. var.

Pl. X, figs. $3,4,5$, and 6 .

Description.-Adult shell averaging about 65 millimeters in altitude, much shorter than high, inequivalve, equilateral, moderately convex, and with slightly serrate margins. Right valve less convex than the left, ornamented by 4 very broad, prominent, flat-topped ridges, each of which earries from 5 to 7 strong, squarish, elevated, subequidistant riblets; interspaces narrow and rather deep, each ornamented by 1 or 2 squarish riblets; hinge line about one-third length of disk; anterior ear much more prominent than the posterior, regularly arcuate-ended and sculptured by 5 or 6 radials; byssal notch only slightly developed; posterior ear very short, obliquely truncated and radially striate. Left valve more convex than right, and usually more or less undulated by constrictions; disk with 5 subequal, narrow, ridge-like ribs, separated by wide interspaces, in each of which are from 2 to 5 subequal, prominent, squarish riblets; whole surface ornamented by a superimposed tessellation, which is usually worn off in the adult shells; ears similar to those of the right valve, there being nearly as pronounced a byssal notch in the anterior ear of the left valve as in the anterior one of the right. 
Dimensions.-Alt. $64 \mathrm{~mm}$; long. $53 \mathrm{~mm}$; hinge line $19 \mathrm{~mm}$. ; diameter,

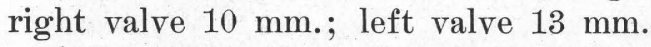

This variety is similar to the typical $P$. wattsi, except that it is somewhat less convex and less constricted, and, as a consequence, has no prominent nodes on the ribs of the left valve. Both the typical $P$. wattsi and its variety morani are allied to $P$. hamlini, but are much taller and have relatively much shorter ears and narrower ribs. The degree of convexity is approximately the same in $P$. hamlini and $P$. wattsi var. morani.

P. wattsi var. morani is known so far only from beds exposed on Mr. T. H. Moran's place, Priest Valley, Monterey County, where it is associated with Arca $(c f$.$) trilineata Conrad, Ostrea (c f$.$) lurida Carpenter, Echinarachnius (c f$.$) excen-$ tricus Eschscholtz, and Scutella fairbanksi Merriam?. This fauna probably indicates a lower Pliocene horizon.

The type is an almost perfect left valve (U. S..N. M. No. 164929) and, together with the other figured specimens, comes from Mr. Moran's place in Priest Valley, Monterey County.

RANGE.

Pliocene (lower). T. H. Moran's place, SW. $\frac{1}{4}$ sec. 14, T. 20 S.. R. 12 E., Mount

Diablo meridian, Priest Valley, Monterey County (Hamlin and Arnold).

Pecten (Lyropecten) ashleyi n. $\mathrm{sp}$.

Pl. XLVII, figs. 1 and $1 a$; Pl. XLVIII, fig. 1

1895. Pecten estrellanus Ashley (not of Conrad, 1857), Proc. Cal. Acad. Sci., ser. 2, vol. 5, 1895, p. 338.

Description.-Adult shell averaging about 150 millimeters in altitude, much longer than high, subequivalve, convex, inequilateral, the posterior portion of the disk being obliquely produced; sides concave above. Right valve with about 18 or 19 prominent, rather squarish, flat-topped (convex-topped near umbo) ribs which are more or less prominently sculptured by numerous thread-like, somewhat imbricated, radial ridges; interspaces narrower than ribs, channeled and ornamented by an intercalary riblet and, in the later stages of growth, by several imbricated radial lines; hinge line about one-half length of disk; anterior ear somewhat produced, prominently notched and sculptured by numerous imbricating incremental lines and several more or less prominent unequal radials; posterior ear slightly shorter than anterior, and similarly sculptured except with more, but less conspicuous, radials. Left valve slightly more convex than right and similar to it except that the ribs are slightly narrower and more convex, and the interspaces are correspondingly wider and generally have the bottom entirely sculptured with subequal radial lines, with the prominent intercalary lacking; ears subequal, rectangularly truncated and sculptured in a similar manner to the posterior ear of the right valve.

Dimensions.-Alt. $152 \mathrm{~mm}$; long. $175 \mathrm{~mm}$; hinge line $85 \mathrm{~mm}$.; diameter $65 \mathrm{~mm}$.; apical angle $110^{\circ}$.

This magnificent species is characterized and is distinguishable from allied forms by its great relative length and numerous ribs ( $P$. crassicardo, a nearly 
allied form, having only 16 or 17$)$. $P$. ashleyi is distinguishable from $P$. cerrosensis, with which it is generally associated, by the smaller number of ribs and the longitudinal sculpture of the same.

In the Third street tunnel, Los Angeles, $P$. ashleyi is associated with the following fauna: Pecten opuntia, P. latiauritus, $P$. pedroanus, P. stearnsii, Glyphis densiclathrata, Nassa n. sp.?, Macoma sp. indet., Arca multicostata, Lima hamlini, Buccinum sp. indet., Neverita recluziana, Astarte sp., Priene oregonensis, Ostrea veatchii, Pleurotoma sp. indet., carditoid, coral, bird bone, crab's claw. This association of species indicates a horizon of the lower Pliocene.

A fragment of a large specimen of $P$. ashleyi was found by Doctors Dall and Stearns in the low hills across the mesa three-fourths of a mile northeast of Pacific Beach, near San Diego.

P. ashleyi is also found in the Pliocene at Cerros Island and San Fernando. The type is from Cerros Island, and is now in the collection of the University of California. Named in honor of Dr. G. H. Ashley, of the United States Geological Survey, whose pioneer work in the Santa Cruz Mountains added greatly to the knowledge of the West Coast Tertiary.

$$
\text { RANGE. }
$$

Pliocene. Cerros Island, off Lower California (Univ. of Cal.): Temescal Canyon, Santa Monica Mountains, Los Angeles County (Rivers); Third street tunnel, Los Angeles (Hamlin); near Pacific Beach, San Diego (Dall, Stearns); San Fernando, Los Angeles County (Ashley); Cosmalia, Santa Barbara County (F. M. Anderson); Olinda, Puente Hills, Orange County (Eldridge).

\section{Pecten (Plagioctenium) Cerrosensis Gabb.}

Pl. XLIV, fig. 5; Pl. XLIX, figs. 1, 1a, and $1 b$.

1869. Pecten cerrosensis Gabb, Pal. Cal., vol. 2, 1869, p. 32, pl. 9, figs. 55, 55a.

1898. Pecten cerrosensis Gabb, Dall, Trans. Wagner Free Inst. Sci., vol. 3, pt. 4, 1898, p. 705.

1898. Pecten (Plagioctenium) subventricosus Dall, Wagner Free Inst. Sci., vol. 3, pt. 4, 1898, p. 707, pl. 29, fig. 8 .

1903. Pecten (Plagioctenium) subventricosus Dall, Arnold, Mem. Cal. Acad. Sci., vol. 3, 1903, p. 114. 1904. Pecten subventricosus Dall, Rivers, Bull. So. Calif. Acad. Sci., vol. 3, no. 5, p. 69.

1904. ?Pecten ventricosus Sowerby, Rivers, op. cit., p. 69.

Description.-Adult shell averaging about 100 millimeters in altitude, somewhat longer than high, subequivalve, biconvex, inequilateral, being somewhat obliquely produced posteriorly; margins more or less sharply serrate; sides nearly straight and sloping at a rather steep angle. Right valve slightly less convex than left, with 21 to 23 prominent rounded, smooth-topped ribs, which in the adult broaden and become ornamented above with looped incremental lines near the periphery of the disk; interspaces considerably narrower than the ribs, with sloping sides and flat, narrow bottoms, which are ornamented by a dense fringe of fine, sharp concentric lamellæ; hinge line a little more than one-half as long as disk; anterior ear slightly longer than posterior, and ornamented by ridges and numerous imbricating concentric lines; byssal notch of medium size; posterior ear nearly ${ }^{*}$ 
rectangularly truncated, and ornamented by more or less prominent radiating ridges and numerous fine incremental lines. Left valve similar to the right, except that the ribs are slightly narrower and the interspaces wider; anterior ear showing a shallow concave margin near disk, otherwise ears similar to those of the right valve. Hinge similar to that of $P$. circularis var. requisulcatus.

Dimensions.-Alt. $105 \mathrm{~mm}$; long. $112 \mathrm{~mm}$; hinge line $56 \mathrm{~mm}$.; diameter $35 \mathrm{~mm}$.

This species is close to $P$. var. requisulcatus, but may be distinguished from that species by its larger size when adult, less ventricose valves, more and rounder ribs, and shorter hinge line. The San Fernando forms have slightly squarer ribs and, so far as known, do not reach the enormous size (the type being over 200 millimeters in altitude) attained by the specimens from the type locality; otherwise they are identical. One Ventura County specimen has an altitude of over 100 millimeters.

A variety of this species (No. 14644 C. S. M. B.) from Brown's Canyon, near Santa Monica, Los Angeles County, has a somewhat wider umbonal angle $\left(105^{\circ}\right)$ and a slightly obliquely truncated posterior ear on the right valve; otherwise the specimen is typical.

P. cerrosensis is confined to the Pliocene, but no doubt ranges through nearly the whole of this epoch. The forms in the San Fernando beds show a closer affinity to $P$. var. æquisulcatus, of which they may be the precursors.

RANGE.

Pliocene. Station 3, 1 mile north of Camulos, Ventura County (Watts); San Fernando tunnel, Los Angeles County (Ashley, Watts, Arnold); Temescal Canyon, Santa Monica Mountains, Los Angeles County (Rivers); Browns Canyon, Santa Monica, Los Angeles County (Watts); Pacific Beach, well at Twenty-second and H streets, San Diego, and Cholas Valley, San Diego County (Stearns); Pacific Beach (Hemphill, Arnold); Cerros Island, off Lower California (Veatch and others); Turtle Bay, Lower California (Hemphill).

Pecten (Plagioctenium) cooperi n. sp.

Pl. XLIX, figs. 2, 3, and 4 .

Description.-Shell averaging about 30 millimeters in altitude, slightly longer than high, both valves moderately convex, disks slightly obliquely produced posteriorly, moderately thick; disk generally characterized by several more or less prominent concentric zones of interrupted growth, which show as color bands even on the fossil shells; sides nearly straight; margins serrate. Right valve with 18 to 20 flat-topped, squarish ribs, which tend to flatten out and become more convex topped in the later stages of growth; interspaces narrower than the ribs, and crossed on the bottom by numerous, fine, sharp, incremental lirulæ, which become obsolete on the ribs excepting in the later stages of growth; hinge line somewhat more than one-half length of disk; anterior ear slightly produced and ornamented by 4 or 5 prominent radials and numerous incremental lines; byssal notch deep and sharply defined; posterior ear slightly obliquely trun- 
cated, and sculptured by obsolete radials and fine incremental lines. Left valve similar to right, except that the ribs are narrower and the interspaces correspondingly broader.

Dimensions.-Alt. $30 \mathrm{~mm}$; long. $31 \mathrm{~mm}$; hinge line $17 \mathrm{~mm}$.; diameter 12 mm.; umbonal angle $95^{\circ}$.

This species is characterized by the number of its ribs and the concentric imbricating bands of interrupted growth. It is distinguishable from P. cerrosensis by its fewer ribs, less prominent lirulæ on the sides of the ribs, and its prominent concentric bands of interrupted growth; distinguishable from $P$. circularis and varieties by its less ventricosity, fewer ribs, and its characteristic concentric sculpture. Specimens of this species were noticed in a box in the National Museum with P. subventricosus $[=P$. cerrosensis $]$ from Pacific Beach, San Diego.

P. cooperi is so far known only from the Pliocene of Pacific Beach, near San Diego. Type and cotype now in the collection of Delos Arnold. Named in honor of the late Dr. J. G. Cooper, one of the pioneer paleontologists of the Pacific Coast.

RANGE.

Pliocene. Pacific Beach, San Diego (Hemphill, Arnold).

Pecten (Plagioctenium) circularis Sowerby.

Pl. XLII, figs. 3, 4, 5, and 6; Pl. XLIV, figs. $6,6 a, 6 b$, and 7 .

1835. Pecten tumidus Sowerby, Proc. Zool. Soc. Lond., 1835, p. 109; not Pecten tumidus Turton, 1822, nor Zeiten, 1830.

1835. Pecten circularis Sowerby, Proc. Zool. Soc. Lond., 1835, p. 110.

1843. Pecten ventricosus Sowerby, Thes. Conch., vol. 1, pt. 1, Pecten, p. 51, pl. 12, figs. 18, 19, and 26; $+P$. tumidus Sowerby, 1835 .

1843. Pecten circularis Sowerby, Thes. Conch., vol. 1, pt. 1, Pecten, p. 51, No. 18, pl. 12, fig. 23.

1852. Pecten ventricosus Sowerby, Reeve, Conch. Icon., vol. 8, Pecten, sp. 31, Nov., 1852, pl. 7, figs. $31 a$ and $b$.

1853. Pecten circularis Sowerby, Reeve, Conch. Icon., vol. 8, June, 1853, Pecten, sp. 137, pl. 31, fig. 137.

1869. Pecten ventricosus Sowerby, Gabb, Pal. Cal., vol. 2, p. 104 (=P. var. xquisulcatus Carpenter, in part).

1888. Pecten ventricosus Sowerby, Küster and Kobelt, Conch.-Cab., vol. 17, pt. 2, sp. 64, p. 100, taf. 28, figs. 1-3.

1888. Pecten (Dentipecten) circularis Sowerby, Küster and Kobelt, Conch.-Cab., vol. 17, pt. 2, sp. 151, p. 188 , taf. 51, figs. $5-8$.

1888. Pecten ventricosus Sowerby, Cooper, Seventh Ann. Rept. Cal. St. Min., 1888, p. 258.

1898. Pecten (Plagioctenium) ventricosus Sowerby, Dall, Trans. Wagner Free Inst. Sci., vol. 3, pt. 4, 1898, p. 710. . [ P. inca Orb., 1847; ?=P. pomatia Val., Voy. Venus, 1835, pl. 19, fig. 3 (fide Dall, 1898.)]

1898. Pecten (Pecten) compactus Dall, Trans. Wagner Free Inst. Sci., vol. 3, pt. 4, 1898, p. 707, pl. 34, fig. 5 (right valve of a young specimen).

1903. Pecten (Plagioctenium) ventricosus Sowerby, Arnold, Mem. Cal. Acad. Sci., vol. 3, 1903, p. 114, pl. 11, figs. $3,3 a, 6$, and $6 a$ (=P. var. æquisulcatus Carpenter, 1863, in part).

1904. Pecten ventricosus Sowerby, Keep, West Am. Shells, pp. 41-42.

Description.-Shell averaging about 46 millimeters in altitude, about as long as high, subequivalve, very convex, inequilateral, the posterior portion of the disk 
being somewhat obliquely produced; margins sharply serrate; sides quite concave above. Right valve with 19 to 21 squarish, close-set, smooth ribs, which, in the adult, flatten out and have sloping sides near the periphery of the disk; interspaces very narrow and channeled; whole surface of disk sculptured by obsolete, wavy lines of growth; hinge line about two-thirds length of disk; ears equal in length, separated from disk by a prominent groove posteriorly and small ridge anteriorly; anterior ear with 4 rather faint radials, and numerous fine, imbricating incremental lines; byssal notch deep, its upper side being about parallel with the hinge line; posterior ear with delicately curved extremity, and ornamented by fine incremental lines, and also on the lower half by faint rádials. Left valve darker colored than right, and with the ribs narrower, flat-topped, and having sloping sides; interspaces wider, and covered both on the bottom and sides by fine, sharp, concentric lamellæ; ears as in the right valve, except that the anterior one is not so conspicuously notched. Hinge strong, the pair of cardinal crura in the right valve being exceedingly well developed. Color patterns from light to dark brownish red.

Dimensions.-Alt. $46 \mathrm{~mm}$.; long. $47 \mathrm{~mm}$; hinge line $32 \mathrm{~mm}$.; diameter $33 \mathrm{~mm}$.

This typical form is characterized by its great and regular convexity, broad ribs, and strong hinge. Type from Gulf of California.

Found living from the Gulf of California southward to Panama; in the Pleistocene farther north. Erroneously reported from the Philippines by Sowerby.

RANGE.

Living. Gulf of California to Panama (Sowerby, Carpenter, Button); St. Elena, off western coast of Colombia, South America (Sowerby).

Pleistocene. San Pedro; San Diego; Lower California (Hemphill, Stearns, Orcutt); Ventura; San Pedro; San Diego (Arnold); Springville, Ventura County (Bowers).

Pliocene (?). Cholas Valley, near San Diego (Stearns).

Pecten (Propeamusium) riversi n. sp.

Pl. XLIV, figs. 8 and 9.

Description.-Shell averaging about 14 millimeters in altitude, about as long as high, circular in outline, equilateral, compressed, white, translucent; margins smooth. Right valve much compressed; surface smooth except for numerous very fine, regular, imbricating lamellæ; hinge line one-half length of disk; ears distinctly separated from disk by impressed line, subequal in length; the anterior arcuate in front and with about 12 subequal prominent radials and numerous fine, regular, imbricating, incremental lamellæ; the posterior slightly obliquely truncated and sculptured similarly to the anterior, except that the radials are nearly obsolete; byssal notch of medium prominence. Interior of disk smooth until an altitude of 15 millimeters is reached, when about 20 to 22 small, rounded, radiating ribs appear and continue to the periphery. Left valve somewhat more convex than the right, and ornamented externally by numerous unequal, prominently imbricated ribs, the alternate ones being intercalated between slightly larger ones; whole surface sculptured by fine imbricating lamellæ; 
anterior ear similar to that of the right valve, except that it is more strongly radially ribbed and is less sinuated; posterior ear similar to that of right valve, except that it is more strongly ribbed. Interior of left valve similar to that of the right, and having the radial ribs developed only after attaining an altitude of about 15 millimeters.

Dimensions.-Alt. $17 \mathrm{~mm}$.; long. $18 \mathrm{~mm}$; hinge line $9 \mathrm{~mm}$; diameter $3.5 \mathrm{~mm}$.

This species is very closely allied to P. alaskensis, of which it is undoubtedly the precursor. It differs from the latter in having the external ribs on the left valve more prominently imbricated above, and in having the internal ribs of both valves appearing only after an altitude of about 15 millimeters has been attained.

The relations existing between $P$. riversi and $P$. alaskensis are a good illustration of Hyatt's law of acceleration of development. ${ }^{a}$ In the former, the Pliocene precursor of the latter, the internal riblets are developed only in the adults or after an altitude of about 15 millimeters is reached. In P. alaskensis, the living species, this characteristic has been pushed backward in the process of development to or nearly to the embryonic stage, continuing, however, in the later stages of growth, and appearing as a well-developed internal riblet from near the umbo to the periphery.

$P$. riversi is known at present from only two localities, the Pliocene of Santa Monica Canyon and the Pleistocene (lower San Pedro formation) of Deadman Island, near San Pedro. The species is named in honor of Dr. J. J. Rivers, of Oceanpark, whose work in the fossiliferous deposits of Santa Monica and vicinity has thrown much light on the distribution of the later Tertiary and Pleistocene formations.

The type, which is now in the collection of Delos Arnold, is from the Pliocene of Santa Monica Canyon, Los Angeles County, and was collected by Doctor Rivers.

RANGE.

Pleistocene (lower San Pedro formation), Deadman Island, near San Pedro (Arnold). Pliocene. Santa Monica Canyon, Los Angeles County (Rivers).

PLELSTOCENE PECTENS.

[Those known first to appear in the Pleistocene formations.]

Pecten (Pecten) diegensis Dall.

Pl. LI, figs. 1, $1 a$, and $1 b$.

1844. Pecten floridus Hinds, Zool. Voy. Sulph., 1844, p. 60, pl. 17, fig. 6; not Ostrea $=($ Pecten $)$ florida Gmelin, 1792 ( fide Dall).

1852. Pecten floridus Hinds, Reeve, Conch. Icon., vol. 8, 1852, pl. 8, fig. and sp. 34 .

1888. Pecten (Vola) floridus Hinds, Küster and Kobelt, Conch.-Cab., vol. 17, pt. 2, Spondylus und Pecten, sp. 173, taf. 57, fig. 2.

a"All modifications and variations in progressive series tend to appear first in the adolescent or adult stages of growth, and then to be inherited at earlier and earlier stages, according to the laws of acceleration, until they either become embryonic or are crowded out of the organization and replaced in the development by characters of later origin".-A. Hyatt, in "Genesis of the Arietidæ," preface, p. ix. 
1888. Janira florida Hinds, Cooper, Seventh Ann. Rept. Cal. St. Min., 1888, p. 244 (P. hemphilli and $P$. stearnsii in part).

1898. Pecten (Pecten) diegensis Dall, Trans. Wagner Free Inst. Sci., vol. 3, pt. 4, 1898, p. 710.

1903. Pecten diegensis Dall, Arnold, Mem. Cal. Acad. Sci, vol. 3, 1903, p. 106, pl. 12, fig. 5.

1904. Pecten diegoensis Dall, Keep, West. Am. shells, p. 39.

Description.-Shell averaging about 60 millimeters in altitude, longer than high, inequivalve, plano-convex, or nearly so, equilateral and with smooth margins; base evenly rounded; sides slightly concave above. Right valve somewhat convex (more pronounced near the umbo), and ornamented by about 22 or 23 prominent T-railshaped ribs, flattened, and generally longitudinally ridged or sulcated on top, which overhang deep, narrow; flat-bottomed interspaces; whole surface sculptured by numerous fine, sharp, incremental lines; hinge line slightly less than one-half length of disk; ears equal, slightly convex, rectangularly truncated, sculptured by fine, sharp, incremental lines; anterior ear with small byssal notch. Left valve flat or nearly so, generally concave near apex, ornamented by 21 or 22 prominent, narrow, convex-topped ribs, which are separated by concave-bottomed interspaces about equal in width to the ribs; whole surface prominently sculptured by numerous regular, fine, sharp, concentric, raised lines; ears concave, convexly truncated, and ornamented by the same concentric sculpture as the disk. Color, red and reddish brown, the left valve always being much darker than the right.

Dimensions.-Alt. $58 \mathrm{~mm}$.; long. $64 \mathrm{~mm}$; hinge line $29 \mathrm{~mm}$.; diameter $13 \mathrm{~mm}$.; umbonal angle (left valve) $95^{\circ}$.

This species is distinguishable from its nearest relative, and probable precursor, $P$. stearnsii, by the smaller number and greater height of its $(P$. diegensis) ribs, and relatively somewhat longer hinge line. The ribs of $P$. diegensis have sometimes as many as three longitudinal sulci. Mrs. Oldroyd has two specimens taken from fishermen's nets at San Pedro, which measure over 150 millimeters ( 6 inches) in length, and are exceptionally high colored for this species.

RANGE.

Living. Monterey (Button; Mrs. Lambert and others); San Pedro (Oldroyd; Raymond); Catalina Island, 10 fathoms (Arncld); San Diego (Raymond). (In all cases dredged.)

Pleistocene. San Diego (Hemphill).

\section{Pecten (Nodipecten) subnodosus Sowerby.}

Pl. LII, fig. 1; Pl. LIII, figs. 1 and $1 a$.

1835. Pecten subnodosus Sowerby, Proc. Zool. Soc., 1835, p. 109.

1842. Pecten subnodosus Sowerby, Thes. Conch., vol. 1, pt. 1, 1842, p. 112, pl. 15, fig. 97.

1852. Pecten subnodosus Sowerby, Reeve, Conch. Icon., vol. 8, Monog. Genus Pecten, Nov., 1852, pl. 4, fig. and sp. 20.

1867. Pecten intermedius Conrad, Am. Jour. Conch., vol. 3, 1867, p. 7 (fide Dall, 1898).

1888. Pecten subnodosus Sowerby, Küster and Kobelt, Conch.-Cab., vol. 17, pt. 2, Spondylus und Pecten, no. 71 , p. 112 , taf. 32 , fig. 3 .

1897. Lyropecten subnodosus Sowerby, Verrill, Trans. Conn. Acad. Sci., vol. 10, p. 64.

1898. Pecten (Nodipecten) subnodosus Sowerby, Dall, Trans. Wagner Free Inst. Sci., vol. 3, pt. 4, 1898, p. 710 . 
Description. - Shell averaging about 110 millimeters in altitude, slightly broader than high, subequivalve, subequilateral, of medium thickness, somewhat ventricose, and with margins finely serrate; base regularly rounded; sides sloping and nearly straight. Right valve slightly less ventricose than left, with about 9 or 10 broad, flat, subequal ribs; interspaces subequal, with slightly rounded bottoms; whole surface sculptured by numerous (averaging about 7 on each large rib) radiating riblets, whose surfaces and interspaces are crossed by numerous fine, wavy lirulæ of growth; several faint undulations are also generally noticeable on the disk; hinge line slightly longer than one-half length of disk; anterior ear about one and three-eighths times the length of the posterior, arcuate in front, and ornamented by several prominent radiating riblets and fine, sharp, incremental lines; byssal notch not very prominent; posterior ear rectangularly truncated and sculptured similarly to anterior. Left valve resembling the right except that it is slightly more ventricose and the ribs are ornamented by more or less elevated, hollow nodes, those on the alternating ribs being the more prominent.

Dimensions.-Alt. $112 \mathrm{~mm}$; long. $120 \mathrm{~mm}$; hinge line $66 \mathrm{~mm}$.; diameter $45 \mathrm{~mm}$.

Doctor Dall is of the opinion that there is little reason for separating this form from the $P$. nodosus of the Antilles, although he says the latter is generally thinner, and has the nodosity more pronounced.

A fragment of a left valve of a variety of $P$. subnodosus from the upper San Pedro formation (Pleistocene) of Deadman Island, San Pedro, has 17 ribs whose sides are concavely excavated, thus giving them a somewhat T-shaped cross section. The middle rib and the fourth rib on each side of it are very prominent, while the other ribs are much smaller. Sculpture as in typical $P$. subnodosus.

The specimen figured is a living shell from the western coast of Mexico, and is now in the collection of the department of geology, Leland Stanford Junior University.

$$
\text { RANGE. }
$$

Living. Coast of Lower California to Ecuador and the tropical shores of South America (Carpenter).

Pleistocene. San Pedro (A. A. Wright; Arnold); Cerros Island and other points on the coast of Lower California (Dall).

Pliocene. Temescal Canyon, Santa Monica Mountains, Los Angeles County (Rivers).

Pecten (Chlamys) latiauritus Conrad var. cerritensis n. var.

$$
\text { Pl. XLVI, figs. } 6 \text { and } 7 .
$$

1903. Pecten (Chlamys) latiauritus Conrad var. fragilis Arnold, Mem. Cal. Acad. Sci., vol. 3, pt. 2, 1903, p. 112, pl. 12, fig. 8; not Pecten fragilis Jeffreys, Ann. and Mag. Nat. Hist., 4th ser., vol. 18, 1876, p. 424.

Description.-Shell of same general type as P. latiauritus. More compressed and much thinner; ribs seven to nine, very low and rounded, with shallow, rounded interspaces; surface smooth, the concentric sculpture being nearly obsolete; hinge long; ears rather sharply pointed.

$$
\text { 17260-No. } 47-06 \longrightarrow 9
$$


Dimensions.-Alt. $26 \mathrm{~mm}$.; long. $26 \mathrm{~mm}$; hinge line $25 \mathrm{~mm}$.; diameter $7.8 \mathrm{~mm}$.

This variety is distinguishable from Dall's variety fucicolus, which it resembles, by having a longer hinge line and generally more pointed ears.

Found associated with the typical species in the Pleistocene (upper San Pedro formation) at San Pedro and San Diego.

RANGE.

Pleistocene. San Pedro; San Diego (Arnold).

Pecten (Chlamys) latiauritus Conrad var. delosi n. var.

Pl. XLVI, figs. 9, 9a, 10, and $10 a$.

Description.-Shell averaging about 12 millimeters in altitude, slightly longer than high, subequivalve, both valves only slightly convex, inequilateral, the disk being decidedly oblique to the hinge line and somewhat produced posteriorly; sides nearly straight; margins rough. Right valve with about 16 prominent smoothtopped squarish ribs; interspaces wider than the ribs, flat-bottomed and ornamented on the bottom and sides by numerous prominent, regular, equidistant, imbricating, incremental lamellæ; hinge line as long as, or slightly longer than, the disk; ears about equal in length; anterior ear long and narrow, separated from the disk by a deep, sharply defined, byssal notch and sculptured by five or six prominent radials and numerous, regular, imbricating, incremental lamellæ. Left valve similar to right except that the ribs are slightly narrower and the incremental lamellæ extend over the tops of the ribs in some specimens; ears acutely pointed and sculptured by numerous regular, sharp lamellæ; anterior somewhat shorter than the posterior and with four major and as many intercalary radials; posterior with four or five radials.

Dimensions.-Alt. $12 \mathrm{~mm}$.; long. $12.5 \mathrm{~mm}$.; hinge line $13.5 \mathrm{~mm}$.; diameter 3.5 mm.; umbonal angle $98^{\circ}$.

This beautiful little Pecten, one of the smallest found in our fauna, is characterized by its extremely long hinge line and prominently lamellated surface. It is distinguishable from the typical $P$. latiauritus and varieties, with which it is allied, by its longer hinge line and prominently lamellated interspaces.

The living specimens have the ribs more prominently lamellated above than the fossil forms. $P$. var. delosi appears to occupy somewhat deeper (and consequently colder) water than the typical form. The specimens of P. latiauritus found in the Santa Barbara and Monterey regions appear to lean strongly toward this variety.

$P$. delosi has been found fossil so far only in the lower San Pedro formation (Pleistocene) at Deadman Island, near San Pedro. Types now in the collection of Delos Arnold, the writer's father, after whom the species is named. Living specimens dredged in 15 fathoms at Catalina Island.

RANGE.

Living. Santa Catalina Island, Los Angeles County, in 15 fathoms (Arnold); Santa Barbara (Dall); Monterey (Button).

Pleistocene (lower San Pedro formation). Deadman Island, San Pedro (Arnold). 
Pecten (Chlamys) latiauritus Conrad var. fucicolus Dall.

Pl. XLVI, figs. 8 and $8 a$.

1898. Pecten latiauritus var. fucicolus Dall, Trans. Wagner Free Inst. Sci., vol. 3, pt. 4, 1898, p. 710.

Description. - Shell of same general type as P. latiauritus. Moderately compressed, smooth, concentric sculpture obsolete; ribs low, rounded, wide, entire; hinge line shorter than in the type, and without any sinus between the posterior ear and the disk.

Dimensions.-Alt. $30 \mathrm{~mm}$; long. $31 \mathrm{~mm}$.

"This form lives attached by the byssus to the giant kelp of the Californian coast, and the absence of shock, due to the floating situs, is probably correlated with the obsolescence of the ribs and the posterior sinus. Intergradations with the type are not at all rare." (Dall, 1898.)

RANGE.

Living. Santa Barbara, south to Cape St. Lucas (Dall). Pleistocene. San Pedro; San Diego (Dall; Arnold).

Pecten (Chlamys) latiauritus Conrad var. monotimeris Conrad. Pl. XLVI, figs. 4,5 , and $5 a$.

1837. Pecten monotimeris Conrad, Jour. Acad. Nat. Sci. Phila., vol. 7, 1837, p. 233, pl. 18, fig. 10.

1863. Pecten monotimeris Conrad, Carpenter, Brit. Assn. Rept., 1863, p. 645.

1888. Pecten monotimeris Conrad, Küster and Kobelt, Conch.-Cab., vol. 17, pt. 2, Spondylus und Pecten, No. 257 , p. 276 , taf. 72 , figs. 7 and 8 .

1888. Pecten latiauritus Conrad, Cooper, Seventh Ann. Rept. Cal. St. Min., 1888, p. 257 (in part).

1892. Pecten monotimeris Conrad, Keep, West Coast Shells, 1892, p. 167, fig. 140.

1897. Pecten (Leptopecten) monotimeris Conrad, Verrill, Trans. Conn. Acad. Sci., vol. 10, p. 69.

1898. Pecten latiauritus var. monotimeris Conrad, Dall, Trans. Wagner Free Inst. Sci., vol. 3, pt. 4, 1898, p. 709.

1903. Pecten (Chlamys) latiauritus Con. var. monotimeris Conrad, Arnold, Mem. Cal. Acad. Sci., vol. 3, pt. 2, 1903, p. 112, pl. 12, figs. 4 and $4 a$.

1904. Pecten latiauritus var. monotimeris Conrad, Keep, West Am. Shells, p. 40, fig. 20.

Description.-Shell of the general type of $P$. latiauritus, but more oblique, inflated, and markedly shorter, with smaller ears; ribs generally prominent and squarish, and interspaces deeply channeled; incremental sculpture sometimes very pronounced.

Dimensions.-Alt. $20 \mathrm{~mm}$; long. $19 \mathrm{~mm}$.; hinge line $16 \mathrm{~mm}$.; diameter $9 \mathrm{~mm}$.

This variety is characterized by its ventricosity, well-defined ribs, and relatively short disk and hinge line. $P$. var. monotimeris is very common at Los Cerritos Hill, near San Pedro, but is much rarer in the other Pleistocene localities than the typical P. latiauritus.

Found in the fossil state in the upper San Pedro formation (Pleistocene); also occurs recent.

Living. Fort Point, San Francisco (Button); Santa Barbara to San Diego (Dall). Pleistocene. Santa Barbara; San Pedro (Dall); San Pedro; San Diego; Ventura (Arnold); New port, Orange County (No. 11895, C. S. M. B.) (Watts). 
Pecten (Plagioctenium) circularis Sowerby var. aquisulcatus Carpenter.

Pl. L, figs. 1, $1 a$, and $1 b$; also text fig. 1, p. 45 ; fig. 2, p. 46.

1863. Pecten [ventricosus var.?] æquisulcatus Carpenter, Brit. Assn. Rept., 1863, p. 645.

1865. Pecten (?var.) xquisulcatus Carpenter, Ann. and Mag. Nat. Hist., 3d ser., vol. 15, 1865, p. 179.

1869. Pecten ventricosus Gabb, Pal. Cal., vol. 2, 1869, p. 104.

1888. Pecten rquisulcatus Carpenter, Küster and Kobelt, Conch.-Cab., vol. 17, pt. 2, Spondylus und Pecten, no. 249, p. 269, taf. 71, figs. 1 and 2.

1888. Pecten ventricosus Cooper, Seventh Ann. Rept. Cal. St. Min., 1888, p. 258 (Quaternary record only).

1892. Pecten æquisulcatus Carpenter, Keep, West Coast Shells, 1892, p. 166, fig. 139.

1893. Pecten rquisulcatus Carpenter, Williamson, Proc. U. S. Nat. Mus., vol. 15, for 1892, p. 193.

1898. Pecten (ventricosus var.?) rquisulcatus Carpenter, Dall, Trans. Wagner Free Inst. Sci., vol. 3, pt.4, 1898, p. 711.

1898. Pecten (Plagioctenium) ventricosus Dall, Trans. Wagner Free Inst. Sci., vol. 3, pt. 4, 1898, p. 710 (in part).

1902. Pecten rquisulcatus Carpenter, Williamson, Bull. So. Cal. Acad. Sci., vol. 1, No. 5, May, 1902, pp. 51-64, pls. 4-6.

1903. Pecten (Plagioctenium) ventricosus Arnold, Mem. Cal. Acad. Sci., vol. 3, 1903, p. 114, pl. 11, figs. $3,3 a$.

1903. Pecten (Plagioctenium) newsomi Arnold, Mem. Cal. Acad. Sci., vol. 3, 1903, p. 113, pl. 11, figs. 1 and $1 a$ (a young shell).

1904. Pecten æquisulcatus Carpenter, Keep, West Am. Shells, p. 39, fig. 18.

Description.-Adult shell averaging about 75 millimeters in altitude, much longer than high, the anterior portion of the disk being obliquely produced; sides somewhat concave above; shell rather thin; margins serrate. Right valve with 20 to 22 moderately prominent, flat-topped ribs separated by much narrower, flatbottomed interspaces; lateral areas about as wide as two normal ribs; whole surface of disk sculptured by fine, sharp, looped, incremental lines; hinge line about fiveeighths length of disk; ears equal in length; anterior ear sculptured with fine concentric lines and 7 or 8 more or less prominent radials; byssal notch deep and sharply defined; posterior ear rectangularly truncated, and sculptured by concentric lines and obsolete radials. Left valve with narrower ribs, which have more sloping sides, and more prominent lamellæ of growth in the interspaces; interspaces correspondingly broader; ears similar to those of right valve, except that the posterior is not sharply notched. Color, white to light reddish yellow blotched with shades of reddish brown, the left valve being always perceptibly darker colored than the right.

Dimensions.-Alt. $72 \mathrm{~mm}$.; long. $83 \mathrm{~mm}$.; hinge line $51 \mathrm{~mm}$.; diameter $36 \mathrm{~mm}$; umbonal angle $100^{\circ}$.

This variety is more or less variable in regard to its convexity, obliquity, relative width and height of ribs, and coloration. In the young specimens the right valve is perceptibly more convex than the left; the ribs are relatively much squarer and more prominent, the interspaces correspondingly narrower and deeper, the hinge line comparatively longer, and the umbonal angle appears to be less, than in the adults. The tendency of the ribs to flatten out and the concentric sculpture to become more irregular and rough as the shell grows older is evident to a greater or less degree in nearly all of the specimens examined. 
The Pleistocene shells, as a rule, are more convex (the right valve noticeably more so than the left), somewhat less oblique, and the ribs are slightly broader and more compact, than the living specimens. The young of $P$. var. xquisulcatus have the characteristics of the Pleistocene form and are scarcely distinguishable from the young of $P$. cerrosensis.

$P$. var. requisulcatus varies from the typical $P$. circularis of the Gulf of California and west Mexican coast fauna by its larger size when adult, flatter and thinner disk, narrower ribs, and more subdued coloration. These two forms seem to have separated during the Pleistocene, the living shells not appearing to give a satisfactory conrection, while a large series of Pleistocene specimens shows an obvious gradation. Doctor Dall (1898, p. 694), in speaking of the influence of environment npon the Pectens, thus mentions the relation between $P$. circularis and $P$. var. rquisulcatus: "As in mammals and birds, the same species in the northern part of its [Pecten] range is larger than in the south, unless it is a distinctively tropical species. But in color the rule is reversed, the southern specimens being lighter and more brightly tinted than the northern ones in the same species. The specimens which live in deep water and swim actively are usually thinner shelled and smoother, while those which inhabit the lagoons are heavier, have more conspicuous concentric sculpture and more solid shells. These differences are very marked in our common east coast $P$. irradians, of which $P$. dislocatus Say is the southern lagoon form; and parallel differences appear in the similarly related $P$. ventricosus $[=P$. circularis $]$ and its variety rquisulcatus on the Pacific coast * * *."

$P$. var. xquisulcatus ranges from the Pleistocene to the Recent fauna.

RANGE.

Living. Santa Barbara to Pacific side of Lower California.

Pleistocene. San Pedro; San Diego; Lower California (Hemphill, Stearns, Orcutt);

Ventura; San Pedro; San Diego (Arnold); Springville, Ventura County (Bowers).

\section{Pecten (Propeamusium) alaskensis Dall.}

Pl. LIII, figs. 2, $2 a$, and 3 .

1872. Pecten (Pseudamusium?) Alaskensis Dall, Am. Jour. Conch., vol. 7, 1872, p. 155, pl. 16, fig. 4.

1886. Pecten (Propeamusium) alaskensis Dall, Bull. Mus. Comp. Zool., vol. 12, no. 6, 1886, p. 215, pl. 5 , figs. $7,7 a$.

1887. Not Pecten alaskensis Whiteaves, Trans. Roy. Soc. Canada, vol. 4 , sec. 4 , 1887, p. 119 (=P. vancouverensis Whiteaves, 1893).

1888. Pecten alaskensis Dall, Küster and Kobelt, Conch.-Cab., vol. 17, pt. 2, Spondylus und·Pecten, sp. 220 , p. 245 , taf. 64 , figs. 7,8 .

1889. Pecten (Propeamusium) alaskensis Dall, Bull. U. S. Nat. Mus., No. 37, 1889, pl. 5, figs. $7,7 a$.

1893. Pecten Alaskensis Dall, Newcombe, Rept. on Mar. Sh. Brit. Columbia, Bull. Nat. Hist. Soc. Brit. Columbia, 1893, art. 5, p. 53.

1895. Pecten (Pseudamusium) Alaskensis Dall, Taylor, Trans. Roy. Soc. Canada, 2d ser., vol. 1, 1895, sec. 4, p. 27.

1897. Amusium (Propeamusium) Alaskensis Dall, Verrill, Trans. Conn. Acad. Sci., vol. 10, p. 65.

1898. Pecten (Propeamusium) alaskensis Dall, Trans. Wagner Free Inst. Sci., vol. 3, pt. 4, 1898, p. 711.

The original description is as follows:

Description. - "Shell nearly equilateral, inequivalve, flesh color, with a blush of salmon color on the umbo of the superior valve. Internally white, the salmon color 
showing through the valve. Shell suborbicular, barring the auricles, which are wide and prominent. Lower [or right] valve flattened, 0.1 inch ( 2.5 millimeters) smaller than the upper one; sculpture of fine, close, equal, concentric ridges, sharply defined and separated by narrow non-canaliculated grooves. Valves covered with a fine velvety epidermis, ashy and very finely radiately striate. Surface of the valve, except for the ridges, smooth. Anterior auricle long, prominent, with a deep sinus. Posterior auricle small; both with strong elevated lines of growth, which rise into scales on the 8 or 9 fine ribs with which the anterior auricle is furnished. Hinge line straight, smooth. Inside of the valve polished, furnished with 21 rounded, radiating ribs, with traces of others intercalated near the margin; nodulous or swollen at the more prominent ridges of growth and at the margin.

"Upper [or left] valve similar, inside; anterior auricle shorter, not so deeply sinuated. Valve more convex than the under one, and a little larger. Dorsal areas finely granulate. Umbo smooth; half way toward the margin the striæ of increase become more conspicuous, and about 35 pseudoribs radiate toward the margin. These are formed by the elevation of the concentric lines of growth like ruffles, in such a way that the edge of one fluting of the ruffle overhangs the beginning of the next, and so on. These are very fragile, and when broken away show the nearly smooth surface of the valve underneath, without any true rib at all. Faint ribs are intercalated between the pseudoribs toward the margin."

Dimensions.-Alt. $19.5 \mathrm{~mm}$.; long. $19.5 \mathrm{~mm}$; hinge line $9 \mathrm{~mm}$; diam. $5 \mathrm{~mm}$.; umbonal angle $100^{\circ}$.

This beautiful little deep-sea form is distinguishable from the other small Pectinidæe of a like habitat by its internal liræ and the lack of radiating sculpture on the right valve. Its nearest allied species in the Pacific coast waters is $P$. davidsoni, which, so far as known, is confined to the deep waters west of certain parts of Alaska.

$P$. alaskensis is found living, and is also preserved in some of the Pleistocene deposits of Alaska and Vancouver Island. No record has as yet been made of it in the fossil state in any of the Pleistocene deposits of California. (See P. riversi, pp. 126-127.)

RANGE.

Living. Bering Sea to Panama Bay, usually in deep water (Dall).

Pleistocene. Various points in Alaska (Dall); Point Holmes, Comox, Vancouver Island (W. Harvey; C. F. Newcombe; Dall).

\title{
RECENT PECTENS.
}

[Those known only in the recent fauna of the west coast.]

\section{Pecten (Pecten) excavatus Anton.}

\author{
Pl. XLVI, figs. $1,1 a$, and $1 b$.
}

1835. Pecten dentatus C. B. Sowerby, Proc. Zool. Soc., 1835, p. 109; Thes. Conch., vol. 1, pt. 1, 1842, p. 49, pl. 15, figs. 105-106; not Pecten dentatus J. Sowerby, Min. Conch. Gt. Brit., vol. 6,1829 , p. 143 , tab. 574 , fig. 1 .

1839. Pecten excavatus Anton, Verzeichniss der Conchylien, 1839; p. 19, No. 710 (erroneously reported from China). 
1845. Pecten excavatus Anton, Philippi, Abbild. und Beschr. Conchyl., vol. 1, p. 201, Pecten, pl. 2, fig. 1, 1845 (also erroneously reports this species from China).

1846. Pecten excavatus Valenciennes, Voy. Venus, 1846, pl. 19, fig. 1.

1853. Vola dentata Sowerby, H. and A. Adams, Gen. Rec. Moll., vol. 2, 1853, p. 554.

1863. Janira dentata Sowerby, Carpenter, Brit. Assn. Rept., 1863, p. 645.

1869. Janira dentata Sowerby, Gabb, Pal. Cal., vol. 2, 1869, p. 104.

1888. Pecten (Vola) dentatus Sowerby, Küster and Kobelt, Conch.-Cab., vol. 17, pt. 2, Spondylus und Pecten, sp. 112, p. 155, taf. 44, figs. 1 and 2.

1888. Janira dentata Sowerby, Cooper Seventh Ann. Rept. Cal. St. Min., 1888, p. 244, (P. stearnsii in part).

1897. Pecten dentatus Sowerby, Verrill, Trans. Conn. Acad. Sci., vol. 10, p. 57.

1903. Pecten (Pecten) dentatus Sowerby, Arnold, Mem. Cal. Acad. Sci., vol. 3, p. 104, pl. 12, figs. 1 and $1 a$.

Description.-Shell averaging about 70 millimeters in altitude, slightly longer than high, inequivalve, płano-convex, equilateral, and with more or less coarsely serrate margins; sides concave above. Right valve very convex, the disk near the apex projecting above the hinge line; ribs 22 or 23 , evenly convex, much broader than high, and separated by interspaces which have only the importance of impressed lines; surface smooth except for incremental lines which loop down ward on the tops of the ribs; hinge line greater than one-half length of disk; ears equal, convex, rectangularly truncated; anterior with two or three obsolete radiating ridges, and concentric sculpture; posterior generally with concentric sculpture only. Left valve concave, ornamented by 22 or 23 prominent, rather narrow, squarish, flat-topped ribs, which are sometimes longitudinally faintly sulcated or ridged; interspaces slightly wider than ribs, flat-bottomed, and each containing a prominent, rounded intercalary riblet; surface sculptured by numerous fine, sharp, regular concentric lines, which appear most prominent in the spaces between the ribs and riblets; ears equal, concave, laterally rectangular and sculptured by fine, sharp, incremental lines and two or three more or less prominent radiating ridges. Color salmon to salmon-pink, the left valve being the darker.

Dimensions.-Alt. $65 \mathrm{~mm}$; hinge line to ventral margin $59 \mathrm{~mm}$; long. 67 $\mathrm{mm}$.; hinge line $35 \mathrm{~mm}$; diameter $25 \mathrm{~mm}$.; umbonal angle (left valve) $98^{\circ}$.

This is the living representative of a genetic group which comprises $P$. keepi, $P$. vogdesi, and $P$. excavatus. Beginning with the oldest in the series, $P$. keepi, and advancing chronologically, the right valve becomes more convex, the lateral areas, which in $P$. keepi are very broad, become narrower, the ribs become more numerous, narrower, and higher, the interspaces correspondingly narrower, the hinge line relatively longer, and the ears more curved.

$P$. excavatus is of the same shape as the Japanese species $P$. laqueatus Sowerby, which has fewer, but squarer, broader ribs on the right valve. This last species has been reported from the Tertiary of Japan by Doctor Brauns in his Geology of the Environs of Tokio. "P. laqueatus has been erroneously cited by Reeve from California" (Dall).

Cooper mistook the flat valve of $P$. stearnsii for $P$. excavatus and labeled a specimen in the State Museum collection at the University of California, 
Berkeley, "Janira dentata Sby, San Pedro, Quaternary." The specimen undoubtedly came from the Pliocene of Deadman Island, instead of from the Quaternary.

$P$. excavatus is known only as living, and so far has been noted only from the Gulf of California, where it is a very common species in some localities.

RANGE.

Living. Gulf of California (Sowerby; Valenciennes; Carpenter; Button, and others).

Pecten (Chlamys) hastatus Sowerby var. albidus Dall n. var.

Pl. LII, figs. 2 and $2 \alpha$.

1904. Pecten (Chlamys) hericius var. albidus Dall, MS.

Description.-Shell of the same shape and general appearance as $P$. var. hericius, but smaller when adult, being only about 45 millimeters in altitude. The sculpture on the right valve consists of numerous elevated, narrow, thread-like, imbricated riblets, which have the appearance of being grouped together in three or more unequal, equidistant, more or less convex fasciculi; the interspaces between the fasciculi are ornamented by riblets of equal prominence to those forming the fasciculi; anterior ear with about seven equal, prominently imbricated radials; posterior ear short and with radial and imbricating sculpture; byssal notch quite prominent. Left valve similar to right, but with the fasciculi corresponding to the interspaces of the right valve, and consequently much narrower than the fasciculi of that valve. Color, white to very light pink.

Dimensions.-Alt. $45 \mathrm{~mm}$; long. $40 \mathrm{~mm}$; hinge line $19 \mathrm{~mm}$.; diameter $14 \mathrm{~mm}$.

This variety is characterized by its broad, low fasciculi and light color. Type, No. 150207 , U. S. Nat. Mus., from U. S. F. C. Sta. 3313, Iliuliuk Harbor, Unalaska, 68 fathoms, $42.7^{\circ}$ bottom temperature.

RANGE.

Living. U. S. F. C. Stas. $3311,3313,3318,3321$, Bering Sea, in 54 to 85 fathoms

(U. S. Fish Commission).

\section{Pecten (Aequipecten) palmeri Dall.}

Pl. L, figs. $2,2 a, 3$, and $3 a$.

1897. Pecten palmeri Dall, Nautilus, vol. 11, No. 8, Dec., 1897, p. 85.

The original description is as follows:

Description.- "Shell thin, orbicular, compressed, equilateral, white to yellowish brown, with concentric or zig-zag narrow bands or flecks of dark rose color; 15 strong ribs rounded in the young, mesially keeled and longitudinally threaded in the 
adult, separated by narrower channeled interspaces, each mith a mesial thread; all crossed by lamellose, concentric, rather sparsely distributed elevated lines; submargins and ears closely radially threaded with imbricated threads. Both valves similarly sculptured."

Dimensions.-Alt. $47.5 \mathrm{~mm}$; ; long. $53 \mathrm{~mm}$; diameter about $20 \mathrm{~mm}$.

This species is easily distinguishable by its flat, orbicular disk and peculiar sculpture. It is known only in the recent faunas, and is found near the head of the Gulf of California, from whence the type and several other valves were obtained by Dr. E. Palmer some years ago.

RANGE.

Living. Near head of Gulf of California (E. Palmer).

Pecten (Plagioctenium) paucicostatus Carpenter.

Pl. XXXIX, figs. $3,3 a$, and 4 .

1863. Pecten paucicostatus Carpenter, Brit. Assn. Rept., 1863, p. 645.

1865. Pecten paucicostatus Carpenter, Ann. and Mag. Nat. Híst., 3d ser., vol. 15, 1865, p. 179.

1888. Pecten paucicostatus Carpenter, Küster and Kobelt, Conch.-Cab., vol. 17, pt. 2, Spondylus und Pecten, no. 9, p. 281

Description. - Shell averaging about 35 millimeters in altitude, longer than high, subequivalve, moderately ventricose; thick-shelled; margins smooth. Right valve subequilateral, slightly more ventricose than the left; ribs 12 to 14, prominent, convex-topped, subangular; interspaces slightly wider than the ribs, somewhat rounded; incremental sculpture fine and regular, not looped; hinge line about fivesevenths length of disk; ears moderately prominent; anterior ear with about five prominent radiating ridges and numerous incremental lines; byssal notch prominent; posterior ear similar to anterior in sculpture, except that it is not quite so pronounced as in the latter. Left valve with prominent subangular ribs, slightly narrower than those of the right valve; interspaces correspondingly wider and flat-bottomed; ears similarly sculptured to those of right valve.

Dimensions. - Alt. $34.5 \mathrm{~mm}$; long. $37 \mathrm{~mm}$; hinge line $25 \mathrm{~mm}$.; diameter $13 \mathrm{~mm}$.

The specimen described is No. 15643 , U. S. N. M. It is dark brown in color, with no patterns or blotches. This species is distinguishable from $P$. latiauritus and varieties by its much heavier shell, dark uniform color, shorter hinge line, and fine uniform concentric lines. The type is labeled "Santa Barbara" by Jewett, but is unquestionably from the Gulf of California, as no species with its characteristics are known outside of the tropical fauna. Besides, Jewett was known to be quite careless regarding the localities of his specimens.

$$
\text { RANGE. }
$$

Living. Gulf of California (Jewett, Stearns). 


\title{
Pecten (Psecdamusium) davidsoni Dall.
}

\author{
Pl. L, figs 4 and $4 a$.
}

1897. Pecten Davidsoni Dall, Nautilus, vol. 11, No. 8, Dec., 1897, p. 86.

1902. Pecten Davidsoni Dall, Proc. U. S. Nat. Mus., vol. 24, 1902, p. 559, pl. 40, figs. 5 , 6.

1904. Pecten davidsoni Dall, Keep, West Am. Shells, p. 41, figs. 21a, $21 b$.

The original description is as follows:

Description. - "Shell small, suborbicular, compressed, waxen white, the left valve with 21 rounded ribs, surmounted by (when not worn off) continuous rows of minute subglobular scales, the interspaces wider, flat, and perfectly smooth, ears very small, the anterior with five or six imbricated radii; sculpture obsolete near the umbones; right valve sculptured with faint concentric impressed lines over the whole surface, and distally with numerous minute, obsolete, fine, scaly riblets; posterior ear transversely striated, very small, anterior one with four or five scaly radii, a well-marked sinus leaving an imbricated fasciole and no ctenolium. Interior polished, the left valve fluted internally in harmony with the external ribs."

Dimensions.-Alt. $14 \mathrm{~mm}$.; long. $14 \mathrm{~mm}$.; diameter $3.5 \mathrm{~mm}$.

This little shell somewhat resembles $P$. alaskensis externally, but lacks the radiating liræ internally, is smaller, and has faint radiating sculpture on the right valve, which is wanting in $P$. alaskensis.

This deep sea form is known only in the living fauna. The type (U. S. N. M., 107747) is from the Davidson Bank, Alaska, in 280 fathoms, green-mud bottom.

RANGE.

Living. Davidson Bank, Alaska, 280 fathoms; north of Unalaska, in Bering Sea, 351 fathoms (U. S. Fish Commission).

\section{Pecten (Pseudamusium) randolphi Dall.}

Pl. XLVIII, figs. 2 and $2 a$.

1897. Pecten Randolphi Dall, Nautilus, vol. 11, No. 8, Dec., 1897, p. 86.

1902. Pecten Randolphi Dall, Proc. U. S. Nat. Mus., vol. 24, 1902, p. 559, pl. 40, fig. 2.

1904. Pecten randolphi Dall, Keep, West Am. Shells, p. 41.

The original description is as follows:

Description. - "Shell small, thin, glassy, unsculptured, except by minute ' Camptonectes' striation which covers both valves, and more or less obscure concentric undulations which are most distinct on the right valve near the umbo, and in some specimens altogether absent; hinge straight and short, anterior ears distinct, posterior ears not defined by any fold or sinus, outline suborbicular, valves compressed, especially the right one; right anterior ear with six small imbricated radii above, below a wide, transversely striated fasciole derived from a well-marked byssal sinus; ctenolium with four or five functional spines."

Dimensions.-Alt. $27.5 \mathrm{~mm}$; long. $26 \mathrm{~mm}$; diameter $5 \mathrm{~mm}$.

This species is the living representative of the group consisting of the three very closely allied, if not identical forms, $P$. peckhami, $P$. pedroanus, and $P$. randolphi. The poor state of preservation of the fossil specimens precludes any definite state- 
ment as to their equivalence, but from the large amount of material examined it is clearly evident that the three are very closely related. P. peckhami averages smaller than the other two and has usually only four radials on the right anterior ear, while $P$. pedroanus is the largest of the group and is generally much more prominently undulated than the others. The three species are so much alike, at any rate, that with the usually poor state of preservation of the Miocene fossil forms it would be impossible to make any definite distinctions in 99 per cent of the cases that have fallen under the observation of the writer. This being true, it is quite evident that the two forms, P. pedroanus and P. peckhami, which heretofore have always been considered diagnostic species of the Miocene, at once lose their value as agents of correlation. A further study of well-preserved fossil material, if any is ever obtained, will undoubtedly tend to make clear the relations existing between the members of this very interesting little group.

The type of $P$. randolphi (U. S. N. M., 107749) was dredged by the U. S. Fish Commission steamer Albatross off Destruction Island, Washington, in 516 fathoms, bottom temperature, $38^{\circ} \mathrm{F}$.

$$
\text { RANGE. }
$$

Living. Bering Sea to West Mexico, in 225 to 1,005 fathoms (U. S. Fish Commission.)

\section{Pecten (Pseudamusium) Randolphi Dall var. tillamookensis n. var.}

\section{Pl. XLVIII, figs. 3 and $3 a$.}

Description. - Shell resembling P. randolphi in outline and general characteristics. Disk ornamented by numerous more or less prominent, fine, radiating ridges, microscopic radiating striæ, and incremental lines of varying prominence. The radiating ridges are narrow and thread-like, and appear to be more prominent anteriorly and near the lines of interrupted growth; the ribs are affected similarly to the disk by the interruptions in growth. The microscopic striæ cover the whole surface of the disk and ribs and in a general way radiate from the umbo, but are seldom parallel to the ribs; on the portion of the disk and ear posterior to the umbo the striæ are perpendicular to the lines of growth and are thus nearly parallel and not radiating. The right anterior ear has from 6 to 12 prominently imbricated radials.

Dimensions. -Alt. $30 \mathrm{~mm}$.; long. $30 \mathrm{~mm}$; hinge line $17 \mathrm{~mm}$.; diameter $7 \mathrm{~mm}$.

This variety appears to combine some of the characters of $P$. vancouverensis with $P$. randolphi, having the prominent radial sculpture of the former and the relatively large, undulated disk of the latter; the ears in $P$. var. tillamookensis are sculptured more nearly like the former, having from 1 to 6 more radials than $P$. randolphi.

This variety generally occurs in deeper water, along the northwestern coast, than the typical form, being found at depths of from 400 to 800 fathoms.

The type, U. S. N. M. 150233, is from off Tillamook Bay, Oregon, at U. S. F. C. Sta. 3346, at a depth of 786 fathoms.

\section{RANGE.}

Living. From north of Unalaska, 351 fathoms, to off Tillamook Bay, 736 fathoms. (U. S. Fish Commission.) 
1886. Pecten caurinus Dall (not Gould), Bull. Mus. Comp. Zool., vol. 12, 1886, p. 216, pl. 5, fig. 4 (supposed young of $P$. caurinus).

1887. Pecten (Pseudamusium) Alaskensis Whiteaves (not Dall), Trans. Roy. Soc. Canada, vol. 4, sec. 4, for 1886, 1887, p. 119.

1889. Pecten caurinus Dall (not Gould), Bull. U. S. Nat. Mus., No. 37, 1889, pl. 5, fig. 4 (supposed young of $P$. caurinus).

1893. Pecten (Pseudamusium) Vancouverensis Whiteaves, Ottawa Naturalist, vol. 7 (being vol. 9, Trans. Ottawa Field-Nat. Club), 1893, p. 133, pl. 1, figs. 1, 1 a.

1893. Pecten (Pseudamusium) Vancouverensis Whiteaves, Newcombe, Bull. Nat. Hist. Soc. Brit. Columbia, 1893 , art. 5 , p. 53.

1895. Pecten (Pseudamusium) Vancouverensis Whiteaves, Taylor, Trans. Roy. Soc. Canada, 2d ser., vol. 1 , 1895 , sec. 4 , p. 26.

1904. Pecten vancouverensis Whiteaves, Keep, West Am. Shells, p. 41.

The original description is as follows:

Description. - "Shell small [averaging about 7.5 millimeters in altitude], equi valved, compressed lenticularly, both valves being equally convex, ovately subcircular in outline apart from the ears and rather oblique; valves extremely thin and fragile, translucent and almost transparent, pale horn color with a slightly yellowish hue. Beaks placed a little behind the midlength; hinge line straight and very long; ears unequal in size, the posterior pair, which are much smaller than the anterior, alike, indistinctly defined, and merging gradually and imperceptibly into the general convexity and marginal contour of that side of each valve; anterior ears large, subtriangular, prolonged laterally, and longer than high, distinctly defined, that of the left valve somewhat convex in outline above and concave below, that of the right valve with a deep and acutely angular byssal sinus at its base.

"Surface marked by densely crowded and exceedingly minute, irregular, and rarely continuous, but, on the whole, radiating, simple or bifurcating raised lines, also by comparatively large, regularly disposed, and distant squamose radii. In the center of each valve the minute and nonsquamose raised lines are essentially parallel to the larger squamose radii, but on the sides the former are disposed obliquely to the latter. The surface of the anterior ear of each valve is minutely cancellated with extremely minute raised lines, which are almost parallel to the hinge line, in addition to the coarser cross lines. The whole sculpture of the exterior of the test is far too minute to be clearly seen without the aid of a microscope or powerful simple lens, but under either of these a few faint concentric lines of growth are also visible."

Dimensions.-Alt. $7.5 \mathrm{~mm}$.; long. $7.75 \mathrm{~mm}$.; diameter $2.25 \mathrm{~mm}$.

This beautiful little Pecten is easily distinguishable from the other members of the same group by its smaller size when adult, fine radiating lines of sculpture externally, and by its relatively longer hinge line.

$$
\text { RANGE. }
$$

Living. Sitka Harbor, 12 fathoms (Dall); Forward Inlet, Quatsino Sound (Dawson); Departure Bay (Taylor, Macoun); off San Pedro, Los Angeles County, 200 fathoms (Oldroyd); Avalon Harbor, Catalina Island, 15 fathoms (Arnold). 
UNIDENTIFIABLE PECTENS.

Pecten catilliformis Conrad.

1856. Pecten catilliformis Conrad, Pac. R. R. Rept., vol. 5, p. 329, pl. 9, fig. 83.

1888. Pecten catilliformis Conrad, Cooper, Seventh Ann. Rept. Cal. St. Min., for 1887, p. 257 (in part).

1898. Pecten catilliformis Conrad, Dall, Trans. Wagner Free Inst. Sci., vol. 3, pt. 4, p. 700.

Original description and notes._-Orbicular, plano-convex, with radiating striæ and distinct rounded ribs; ears equal.

"This large Pecten has such a general resemblance to $P$. madisonius Say, of the Virginia Miocene, that I have no doubt it existed at the same period, or at least after the Eocene. There is none such now living on the coast of California, and none in the Eocene, of this group of large pectens, which occur almost everywhere in the Miocene deposits of the Atlantic slope.

"Locality.-Ocoya Creek [Kern County]."

The type of this species was the internal cast of some large Lyropecten (?) probably allied to crassicardo, estrellanus, or bowersi. According to Dall the type is unknown as the species was described by Conrad from drawings made by Prof. W. P. Blake. The figure in the Pacific Railroad Report is, so poor and the description so meager that it is probable the species will remain for a long time unrecognized.

\section{Pecten nevadanus Conrad.}

1856. Pecten nevadanus Conrad, Pac. R. R. Rept., vol. 5, p. 329, pl. 8, fig. 77.

1888. Pecten nevadanus Conrad, Cooper, Seventh Ann. Rept. Cal. St. Min., for 1887, p. 258 (in part). 1898. Pecten nevadanus Conrad, Dall, Trans. Wagner Free Inst. Sci., vol. 3, pt. 4, 1898, p. 700.

Original description and notes._-"Ovate, flat or slightly concave; ribs 17, large, flattened on the back; interstices strongly wrinkled transversely.

"This shell is so nearly allied to $N$. (should be $P$.) Humphreysï of Maryland that, taken in connection with $P$. catilliformis, * * * it may be regarded as a Miocene species. The strata in which they occur may safely be referred to that period.

"Locality.-Ocoya Creek [Kern County]."

This species, like the last, was, according to Dall, described by Conrad from one of Professor Blake's drawings of an external mold. The figure and description in the Pacific Railroad Report appears to fit $P$. bowersi quite closely. The size of the shell, number and shape of ribs, and the characteristically sculptured byssal area are similar in the two species, but the writer has hesitated to place the latter in the synonymy of $P$. nevadanus, owing to the uncertainty of using so few characteristics in a definite specific determination of such importance.

\section{Pecten pyxidatus Carpenter.}

1863. Pecten pyxidatus Carpenter, Brit. Assn. Rept., 1863, p. 667.

1898. Pecten pyxidatus Dall, Trans. Wagner Free Inst. Sci., vol. 3, pt. 4, 1898, p. 711.

This species is listed by Carpenter as having been collected by Captain Stone at Guaymas, Gulf of California. According to Doctor Dall this is probably a Chinese species. 
1863. Pecien subcrenatus Carpenter, Brit. Assn. Rept., 1863, p. 667.

1898. Pecten subcrenatus Carpenter, Dall, Trans. Wagner Free Inst. Sci., vol. 3, pt. 4, 1898 , p. 711.

This species is cited by Carpenter as being a possible synonym for the $P$. pyxidatus above referred to. It is characterized as a list name by Doctor Dall, and is now unidentifiable.

\section{Pecten townsendi Gould.}

1863. Pecten Townsendi Gould, Carpenter, Brit. Assn. Rept., 1863, p. 532.

1898. Pecten Tounsendi Gould, Dall, Traus. Wagner Free Inst. Sci., vol. 3, pt. 4, 1898, p. 711.

This species is said by Carpenter to come from Puget Sound. It is also a list name, was never characterized, and is, consequently, now unidentifiable.

Agassiz, Louis.

\section{BIBLIOGRAPHY.}

1856. Notice of the fossil fishes: Pac. R. R. Rept., vol. 5, appendix, pp. 313-

Anton, H. E. 316 , pl. 1. Washington.

1839. Verzeichniss der Conchylien. Pectinea, pp. 18-20. Halle.

Arnold, Delos and Ralph.

1902. The marine Pliocene and Pleistocene stratigraphy of the coast of southern California: Jour. Geol., vol. 10, No. 2, pp. 117-138, pls. 1-5, figs. 1-7. Chicago.

Arnold, Ralph.

1903. The paleontology and stratigraphy of the marine Pliocene and Pleistocene of San Pedro, Cal.: Mem. Cal. Acad. Sci., vol. 3, pp. 420, pls. 37. San Francisco, June, 1903.

Arnold, Ralph, Haehl, H. L., and.

1904. The diabase of the Santa Cruz Mountains in San Mateo County, Cal.:

Ashley, G. H. Proc. Am. Phil. Soc., vol. 43, pp. 15-53, figs. 1-25. Philadelphia.

1895. The Neocene stratigraphy of the Santa Cruz Mountains, California: Proc. Cal. Acad. Sci., 2d ser., vol. 5, pp. 273-367, pls. 22-25. San Francisco.

Blake, Wм. P.

1856. Notice of remarkable strata containing the remains of Infusoria and Polythalamia in the Tertiary formation of Monterey, Cal.: Proc. Acad. Nat. Sci. Phila., vol. 7, 1855, pp. 328-331.

Brauns, David.

1881. Geology of the environs of Tokio: Mem. Sci. Dept., Univ. of Tokio, No. 4.

BRÖGGER, W. C.

1901. Om de senglaciale og postglaciale nivaforandringer i Kristianiafeltet (Molluskfaunan): Norges Geologiske Undersogelse, No. 31, pp. 731, plates 19, text figures 69. Kristiania, 1901. 
Carpenter, P. P.

1857. Report of the present state of our knowledge with regard to the Mollusca of the west coast of North America: Rept. Brit. Asso. Adv. Sci. for 1856. pp. 159-368, 4 pls. London.

1864. Supplementary report on the present state of our knowledge with regard to the mollusks of the west coast of North America: Rept. Brit. Asso. Adv. Sci. for 1863, pp. 517-686. London, 1864.

Clatrk, W. B.

1891. Correlation papers, Eocene: Bull. U. S. Geol. Survey, No. 83. Washington.

Conrad, T. A.

1856. Descriptions of the fossil shells: Pac. R. R. Rept., vol. 5, appendix, pp. 317-330, pls. 2-9. Washington.

1857. Description of three new genera; twenty-three new species middle Tertiary fossils from California, and one from Texas: Proc. Acad. Nat. Sci. Phila., 1st ser., vol. 8, 1856, pp. 312-316. Philadelphia.

1857. Description of the Tertiary fossils collected on the survey: Pac. R. R. Rept., vol. 6, pt. 2, pp. 69-73, pls. 2-5. Washington.

1857. Report on the paleontology of the survey: Pac. R. R. Rept., vol. 7, pt. 2, pp. 189-196, pls. 1-10. Washington.

1863. Descriptions of new genera, subgenera and species of Tertiary and Recent shells: Proc. Acad. Nat. Sci. Phila., 2d ser., vol. 6, 1862, pp. 284-291.

1867. Paleontological miscellanies: Am. Jour. Conch., vol. 3, 1867, pp. 5-7. Philadelphia.

Cooper, J. G.

1888. Catalogue of Californian fossils: Seventh Ann. Rept. Cal. State Min., pp. 223-308. Sacramento.

1894. Catalogue of Californian fossils, parts 2, 3, 4, and 5: Bull. Cal. State Min. Bureau, No. 4. San Francisco.

DALL, W. H.

1871. Diagnoses of sixty new forms of mollusks from the west coast of America and the north Pacific Ocean: Am. Jour. Conch., vol. 7, pp. 93-160, pls. 13-16. Philadelphia.

1878. Fossil mollusks from later Tertiaries of California: Proc. U. S. Nat. Mus., vol. 1, pp. 10-16. Washington.

1886. Report on the results of dredging by the U. S. Coast Survey steamer "Blake." XXIX. Report on the Mollusca, pt. 1, Brachiopoda and Pelecypoda: Bull. Mus. Comp. Zoöl., vol. 12, No. 6, pp. 171-318, pls. 1-9, Cambridge, Mass., September, 1886.

1889, 1903. A preliminary catalogue of the shell-bearing ma:ine mollusks and brachiopods of the southeastern coast of the United States, with illustrations of many of the species: Bull. U. S. Nat. Mus., No. 37, pp. 215, pls. 47. Washington, 1889. Reprint, pp. 232, pls. 95. Washington, 1903. 
DALL, W. H.-Continued.

1897. New west American shells: Nautilus, vol. 11, No. 8, pp. 85-86. Philadelphia.

1898. The Tertiary fauna of Florida; Family Pectinidæ: Trans. Wagner Free Inst. Sci., vol. 3, pt. 4, pp. 689-758, and plates. Philadelphia, April, 1898.

1898. A table of North American Tertiary horizons, correlated with one another and with those of western Europe, with annotations: Eighteenth Ann. Rept. U. S. Geol. Survey, pt. 2, pp. 323-348. Washington.

1901. A new Lyropecten: Nautilus, vol. 14, No. 10, pp. 117-118. Philadelphia.

1902. Illustrations and descriptions of new, unfigured, or imperfectly known shells, chiefly American, in the U. S. National Museum: Proc. U. S. Nat. Mus., vol. 24, pp. 499-566, pls. 27-40. Washington.

1904. Neozoic invertebrate fossils; a report on collections made by the expedition: Harriman Exped. Repts., Alaska Geol., pp. 99-122, pls. 9-10.

DaLl, W. H., and Harris, G. D.

1892. Correlation papers, Neocene: Bull. U. S. Geol. Survey, No. 84. Washington.

Diller, J. S.

1896. A geological reconnaissance in northwestern Oregon: Seventeenth Ann. FaIrbanks, H. W. Rept. U. S. Geol. Survey, pt. 1, pp. 441-520. Washington.

1904. San Luis folio: Geologic Atlas U. S., folio 101, U. S. Geol. Survey. Washington, June 10, 1904.

Gabi, W. M.

1864, 1869. Geological Survey of California, Paleontology, vol. 1, pp. 243, pls. 32,1864 ; vol. 2 , pp. 299, pls. 36, 1869. Philadelphia.

Haehl, H. L., and Arnold, Ralph.

1904. (See Arnold, Ralph, 1904.)

Hamlin, Homer. .

1904. Water resources of the Salinas Valley, California: Water-Sup. and Irr. Paper No. 89, U. S. Geol. Survey. Washington.

Harris, G. D., Dall, W. H., and.

1892. (See Dall, 1892.)

JACKSON, R. T.

1890. Phylogeny of the Pelecypoda: Mem. Bost. Soc. Nat. Hist., vol. 4, No. 8. Boston.

Keep, Josiah.

1892. West Coast Shells, pp. 230, figs. 182. San Francisco.

1904. West American Shells: a description in familiar terms of the principal marine, fresh-water, and land mollusks of the United States found west of the Rocky Mountains, including those of British Columbia and Alaska, pp. 360, text figs. 303. The Whitaker \& Ray Co., San Francisco.

Kobelt, W., Küster, C. H., and.

1888. (See Küster, C. H., 1888.) 
Küster, C. H., and Kobelt, W.

1888. Systematisches Conchylien-Cabinet (Martini und Chemnitz) Die Gattungen Spondylus und Pecten, pp. 296, pls. 72. Bauer \& Raspe, Nurnberg, 1888.

Lawson, A. C.

1893. The Post-Pliocene diastrophism of the coast of southern California: Bull. Dept. Geol., Univ. Cal., vol. 1, No. 4, pp. 115-160, pls. 8-9. Berkeley.

1894. The geomorphogeny of the coast of northern California: Bull. Dept. Geol., Univ. Cal., vol. 1, No. 8, pp. 241-272. Berkeley.

1895. Sketch of the geology of the San Francisco peninsula: Fifteenth Ann. Rept. U. S. Geol. Survey, 1893-94, pp. 399-476, pls. 5-12. Washington.

Merriam, J. C.

1896. Note on two Tertiary faunas from the rocks of the southern coast of Vancouver Island: Bull. Dept. Geol., Univ. Cal., vol. 2, No. 3, pp. 101108. Berkeley.

1897. The geologic relations of the Martinez group of California at the typical locality: Jour. Geol., vol. 5, No. 8, November-December, 1897, pp. $767-775$.

1898. The distribution of the Neocene sea urchins of middle California and its bearing on the classification of the Neocene formations: Bull. Dept. Geol., Univ. Cal., vol. 2, No. 4, pp. 109-118. Berkeley.

1900. Lists of fossils in "Oil and Gas Yielding Formations of California," by W. L. Watts: Bull. Cal. State Min. Bureau, No. 19, pp. 218-224. Sacramento.

1904. A note on the fauna of the lower Miocene in California: Bull. Dept. Geol., Univ. Cal., vol. 3, No. 16, pp. 377-381. Berkeley.

Newcombe, C. F.

1893. Report on the marine shells of British Columbia: Bull. Nat. Hist. Soc.

Osmont, Vance C. British Columbia, art. 5, pp. 29-72. Richard Wolfenden, Victoria.

1905. A geological section of the coast ranges north of the bay of San Francisco: Bull. Dept. Geol., Univ. Cal., vol. 4, No. 3, pp. 39-87, pls. $6-7$.

1905. Arcas of the California Neocene: Bull. Dept. Geol., Univ. Cal., vol. 4, Philippi, R. A. No. 4 , pp. $89-100$, pls. 8-11.

1845. Abbildungen und Beschreibungen neuer oder wenig gekannter ConchyReeve, L. A. lien, Bd. 1, Pecten, pp. 201-204, taf. viii, 6. Cassel.

1855. Conchologia Iconica, vol. 8, Monograph of the genus Pecten, species RIVERS, J. J. 1-176, pls. 1-35. London.

1904. Descriptions of some undescribed fossil shells of Pleistocene and Pliocene formations of the Santa Monica range: Bull. So. Cal. Acad. Sci., vol. 3, No. 5, May, 1904, pp. 69-72, figs. 1-4. Los Angeles. $17260-$ No. $47-06-10$ 
Sowerby, G. B.

1835. Descriptions of new species of shells in the collection of Mr. Cuming: Proc. Zool. Soc. Lond., 1835, pp. 109-112. London.

1843. Thesaurus Conchyliorum, vol. 1, Monograph of the genus Pecten, pp. $45-82$, pls. 12-20. London.

SOWERBY, JAMES.

1829. The Mineral Conchology of Great Britain. (Continued by James D. C. Stanton, T. W. Sowerby.) Vol. 6, + index to vols. 1-6, pp. 250. London.

1896. The faunal relations of the Eocene and upper Cretaceous on the Pacific Coast: Seventeenth Ann. Rept. U. S. Geol. Survey, pt. 1, pp. 10051060, pls. 63-67. Washington.

Taylor, George W.

1895. Preliminary catalogue of the marine Mollusca of the Pacific Coast of Canada, with notes on their distribution: Trans. Roy. Soc. Canada, 2 d ser., vol. 1, sec. 4, pp. 17-100. Ottawa.

Trask, J. B.

1855. Descriptions of Californian fossil shells: Proc. Cal. Acad. Nat. Sci., vol. 1, pp. 40-42. San Francisco.

Turner, H. W.

1898. Notes on some igneous, metamorphic, and sedimentary rocks of the

Vadghan, T. W.

Coast Ranges of California: Jour. Geol., vol. 6, pp. 483-499. Chicago.

1900. The Eocene and Oligocene coral faunas of the United States: Mon. U. S. Geol. Survey, vol. 39, pp. 263, pls. 24. Washington.

Verrill, A. E.

1897. A study of the family Pectinidæ, with a revision of the genera and subgenera: Trans. Conn. Acad. Sci., vol. 10, pp. 41-96, pls. 16-21.

Weaver, Charles E.

1905. Contribution to the paleontology of the Martinez group: Bull. Dept. Geol., Univ. Cal., vol. 4, No. 5, pp. 101-123, pls. 12-13.

WEeKs, F. B.

1902. North American geologic formation names; bibliography, synonymy, and distribution: Bull. U. S. Geol. Survey, No. 191, pp. 448. Washington.

Whiteaves, J. F.

1887. On some marine invertebrata dredged, etc., in British Columbian waters: Trans. Roy. Soc. Canada, vol. 4, sec. 4, pp. 111-137. Montreal.

1893. Notes on some marine Invertebrata from the coast of British Columbia: Ottawa Nat., vol. 7 (being vol. 9 Trans. Ottawa Field Nat. Club),

WHITNEY, J. D. pp. 133-137, pl. 1. Ottawa.

1869. Geological Survey of California, Paleontology, vol. 2, preface, pp. vii-xiv. Philadelphia.

Willitamson, Mrs. M. B.

1902. A monograph on Pecten rquisulcatus Carpenter: Bull. So. Cal. Acad. Sci., vol. 1, No. 5, May 1, 1902, pp. 51-64, pls. 4-6. Los Angeles. 


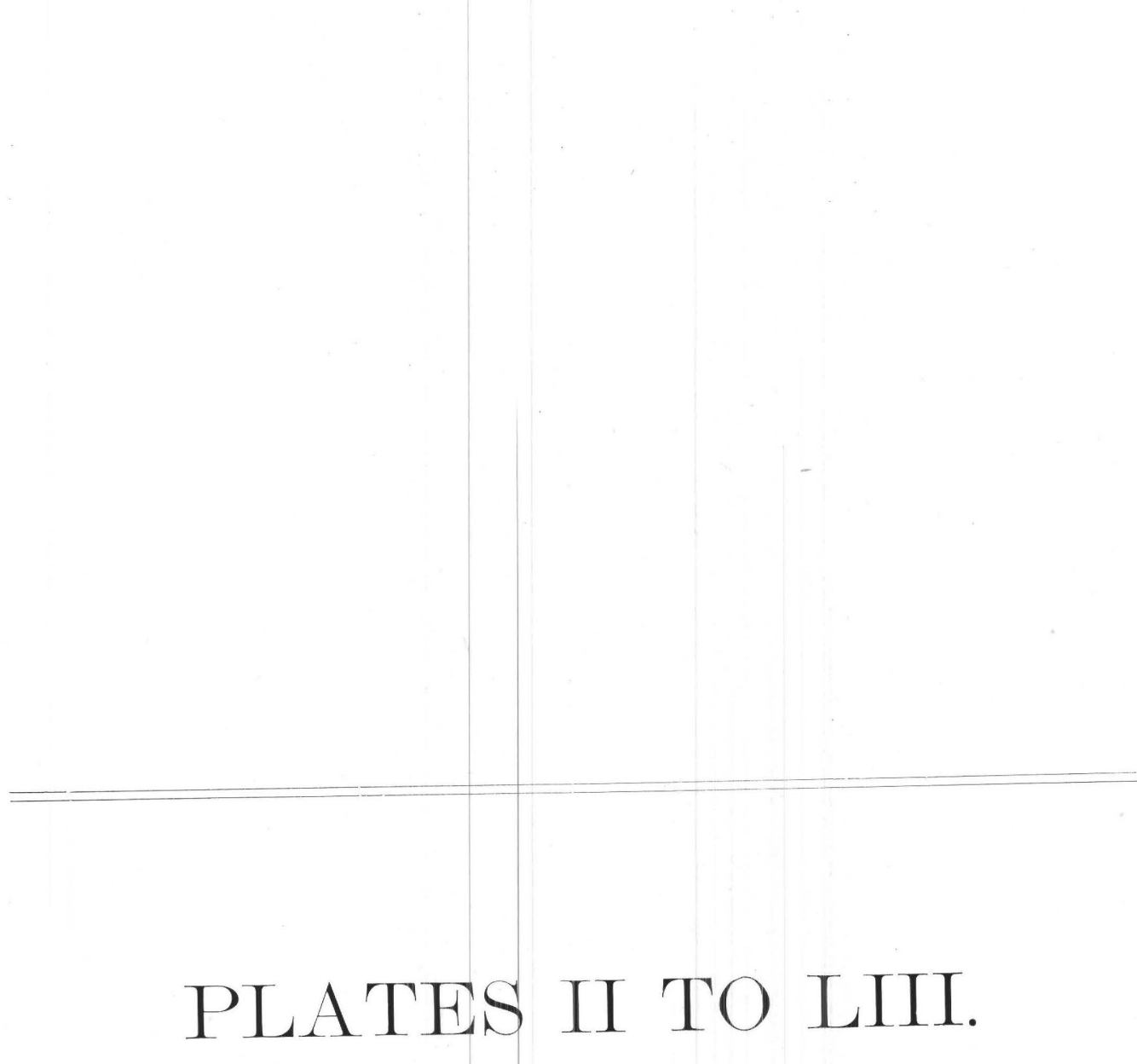

147 


\section{P L A T E I I.}

\section{EOCENE PECTENS.}

[Unless otherwise stated all figures are approximately natural size.]

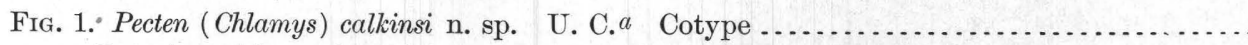

Exterior of imperfect right valve; altitude $29 \mathrm{~mm}$. Tejon formation (Eocene), Sisar Valley, Ventura County, Cal. (S.) ${ }^{a}$

FIG. 2. Pecten (Chlamys) calkinsi n. sp. U. C. Type

Exterior of imperfect left valve; altitude $45 \mathrm{~mm}$. Same locality as fig. 1. (S.)

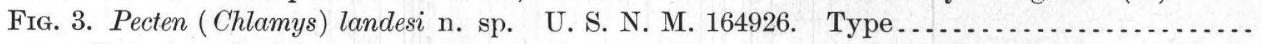

Exterior of right valve; altitude $31 \mathrm{~mm}$. Eocene, Little Falls, Lewis County, Wash. (M. P.)

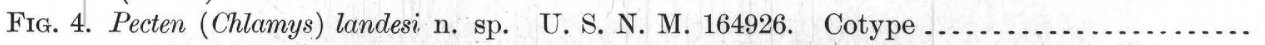

Exterior of left valve; altitude $22.5 \mathrm{~mm}$. Same locality as fig. 3. (M. P.)

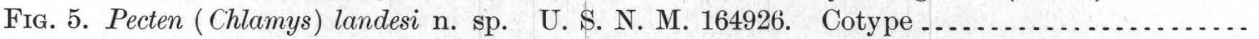

Fxterior of right valve (coarse-ribbed form); altitude $34 \mathrm{~mm}$. Same locality as last. (M. P.)

Fig. 6. Pecten (Chlamys) proavus n. sp. U. S. N. M. 164930. Type.

Mold of interior of left valve, showing portion of external surface sculpture; altitude $38 \mathrm{~mm}$. Eocene, between headwaters of San Lorenzo River and Pescadero Creek, San Mateo County, Cal. (M. B.)

FIG. 7. Same specimen as fig. 6

Portion of disk showing sculpture; enlarged twice.

Fig. 8. Pecten (Chlamys) proavus n. sp. U. S. N. M. 164930. Cotype

Fragment of a large specimen. Same locality as fig. 6 .

Fig. 9. Pecten (Propeamusium) interradiatus Gabb. Tỳpe

Exterior of left valve; altitude $25 \mathrm{~mm}$. Copied, with slight alteration, from Pal. Cal., vol. 2, pl. 33, fig. 98. Tejon formation (Eocene), New Idria, San Benito County, Cal.

FIG. 10. Same specimen as fig. 9

Mold of interior of left valve; altitude $25 \mathrm{~mm}$. Copied, with slight alteration, from Pal. Cal., vol. 2, pl. 33, fig. 98 .

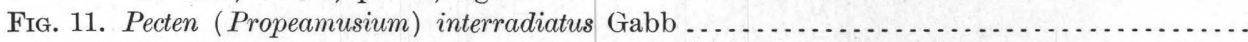
Outline of hinge line and ear of right valve. Copied, with slight alteration, from Pal. Cal., vol. 2, pl. 33, fig. 98a.

$a$ The initials immediately following the name of the specimen are those of the institution or individual to which the specimen belongs, and to which reference is made in the introduction; the initials or letter at the conclusion of the explanation indicates the artist who retouched the figure. 


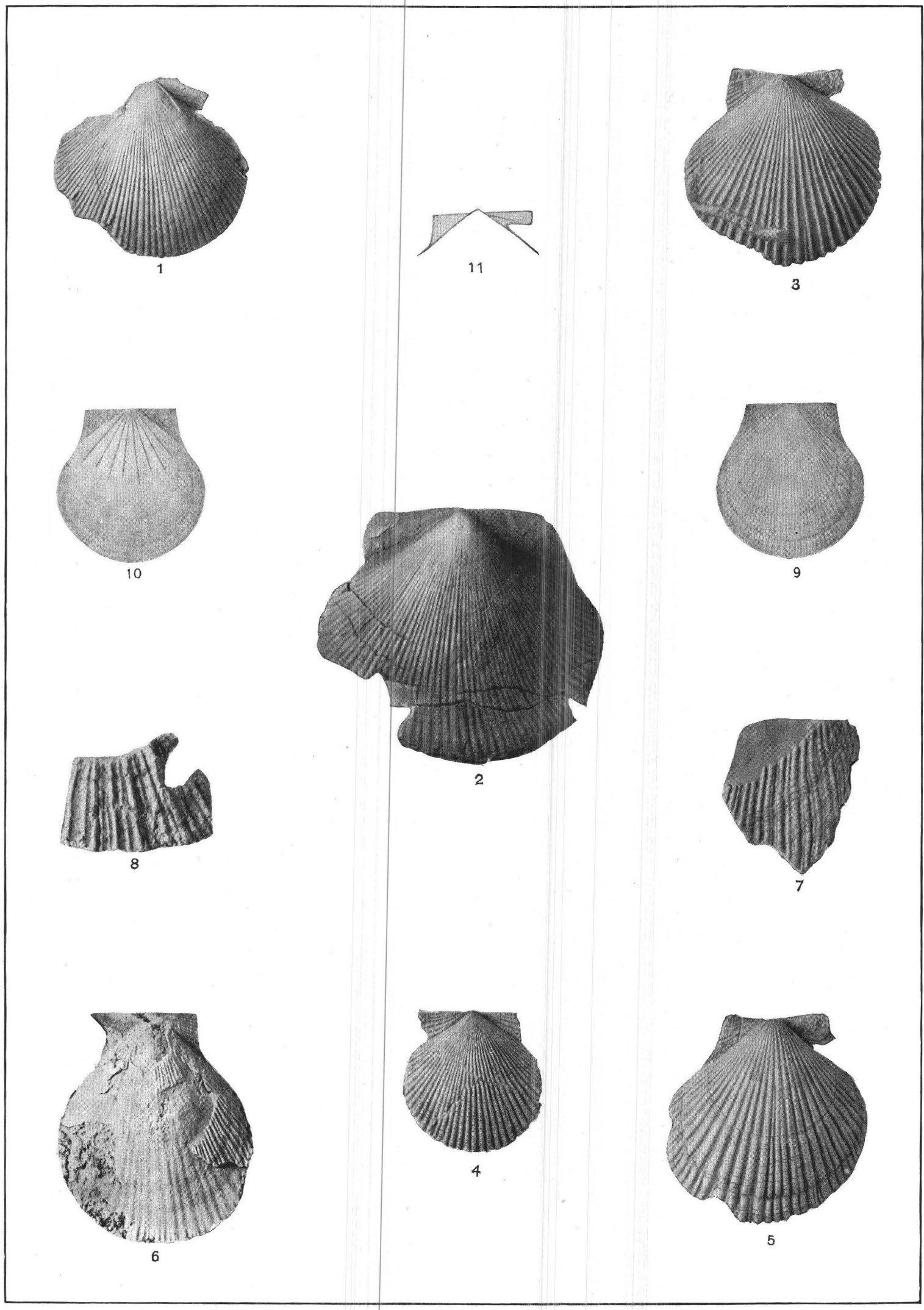

EOCENE PECTENS. 


\section{PLA TE III.}

\section{OLIGOCENE-MIOCENE PECTENS.}

[Unless otherwise stated all figures are approximately natural size.]

FIG. 1. Pecten (Propeamusium) clallamensis n. sp. U. S. N. M. 164923. Cotype................ Imperfect mold of exterior of right valve; hinge line $6.5 \mathrm{~mm} ., \times 3$. Oligocene-Miocene, Loc. 4070, Bean Point, King County, Wash. (M. P.)

FIg. 2. Pecten (Propeamusium) clallamensis n. sp. U. S. N. M. 164922. Cotype ............... Imperfect mold of interior of left valve; altitude $7 \mathrm{~mm} ., \times 3$. Oligocene-Miocene, Loc. 4100, $1 \frac{1}{2}$ miles east of Pillar Point, Clallam County, Wash. (M. B.)

F'Ig. 3. Pecten (Propeamusium) clallamensis n. sp. U. S. N. M. 164922. Type ................ Mold of exterior of left valve; altitude $10 \mathrm{~mm} ., \times 3$. Same locality as fig. 2. (M. P.)

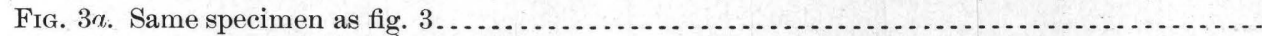
Portion of disk (not mold) enlarged 6 times.

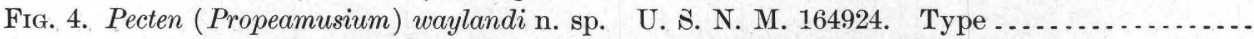
Imperfect mold of exterior of left valve; longitude $7 \mathrm{~mm} ., \times 3$. Same locality $(4100)$ as fig. 2. (M. B.)

Fig. 5. Pecten (Propeamusium) waylandi n. sp. U. S. N. M. 164924. Cotype.........................

Mold of interior of right valve; altitude $10 \mathrm{~mm} ., \times 3$. Oligocene-Miocene, Loc. 4115 , $2 \frac{1}{2}$ miles west of Gettysburg, Clallam County, Wash. (M. B.)

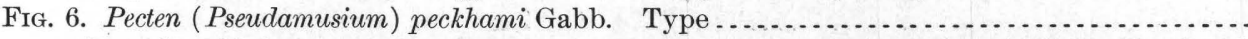

Exterior of left valve; altitude $21 \mathrm{~mm}$. Copied from Pal. Cal., vol. 2, pl. 16, fig. 19. Specimen from Ojai ranch, Ventura County, Cal.

Fig. 7. Pecten (Pseudamusium) peckhami Gabb. Cotype .

Outline of hinge line and ears of right valve. Copied from Pal. Cal., vol. 2, pl. 16, fig. 19a. Same locality as fig. 6.

Frg. 8. Pecten (Pseudamusium) peckhami Gabb. U. S. N. M. 164839

Casts of right and left valves in matrix. Monterey shale (Miocene), sor Contra Costa County, Cal. (M. P.)

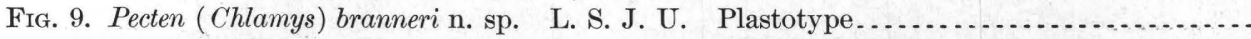
Cast from imperfect moild (type) of left valve; hinge line $33 \mathrm{~mm}$. Vaquero formation (lower Miocene), Tuff Hill, near Stanford University, Santa Clara County, Cal. (M. P.)

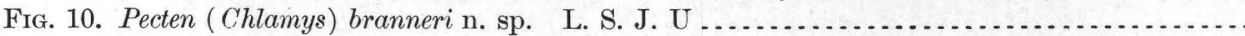

Cast from fragment of mold of disk, showing sculpture. Same locality as fig. 9. (M. P.)

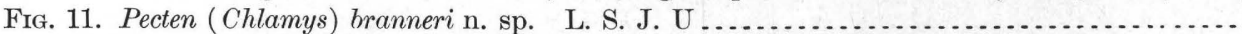

Cast from fragment of mold of disk, showing sculpture. Same locality as fig. 9. (M. P.)

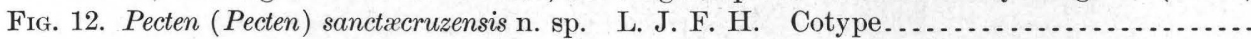

Exterior of portion of right valve; longitude $48 \mathrm{~mm}$. San Lorenzo formation (Oligocene), Bear Creek, Santa Cruz County, Cal. (M. B.)

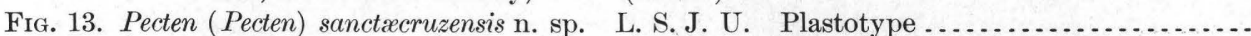

Exterior of cast from mold (type) of left valve; altitude $52 \mathrm{~mm}$. San Lorenzo formation (Oligocene), Twobar Creek, Santa Cruz County, Cal. (M. B.)

Page. 


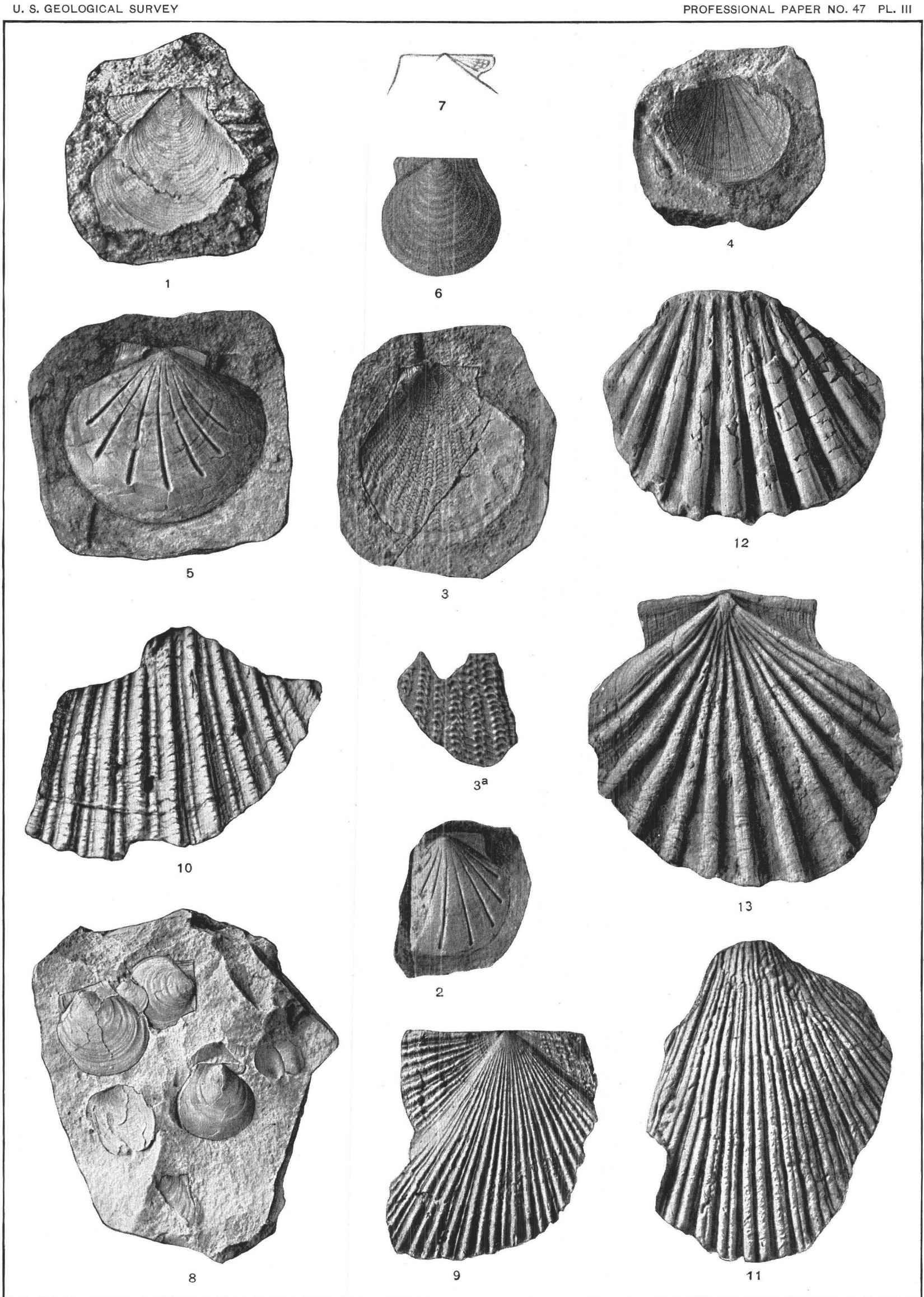

OLIGOCENE-MIOCENE PECTENS. 


\section{PLATE I V. \\ MIOCENE AND PLIOCENE PECTENS.}

[Uuless otherwise stated all figures are approximately natural size.]

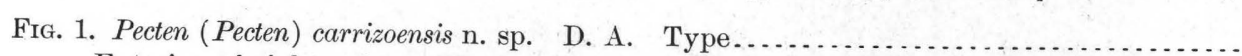

Exterior of right valve; altitude $36 \mathrm{~mm}$. Carrizo formation (Miocene), Alverson Canyon, San Diego County, Cal. (M. B.)

Frg. 1a. Same specimen as fig. 1 Exterior of left valve.

FIG. 1b. Same specimen as fig. 1

Profile of both valves viewed from rear. (M. P.)

FIG. 2. Pecten (Pecten) carrizoensis n. sp. U. S. N. M. 164847

Exterior of left valve; altitude $63 \mathrm{~mm}$. Miocene, Santa Rosalia, Lower California. (M. P.)

FIG. 3. Pecten (Pecten) carrizoensis n. sp. U. S. N. M. 164848

Exterior of imperfect right valve; longitude $44 \mathrm{~mm}$. Same locality as fig. 2. (M. B.)

FIG. $3 a$. Same specimen as fig. 3 .

Profile of right valve viewed from front. (M. P.)

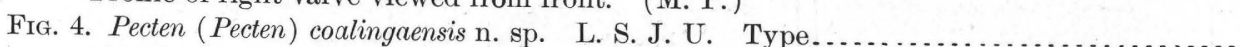

Exterior of slightly distorted right valve; altitude $47 \mathrm{~mm}$. Lower Pliocene, Coalinga, Fresno County, Cal. (M. B.)

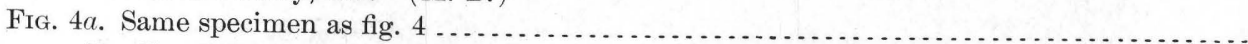
Profile of right valve viewed from rear. (M. P.)

FIG. 5. Pecten (Pecten) coalingaensis n. sp. C. A. S. Cotype -

Exterior of left valve; altitude 35 m. County, Cal. (S.) 


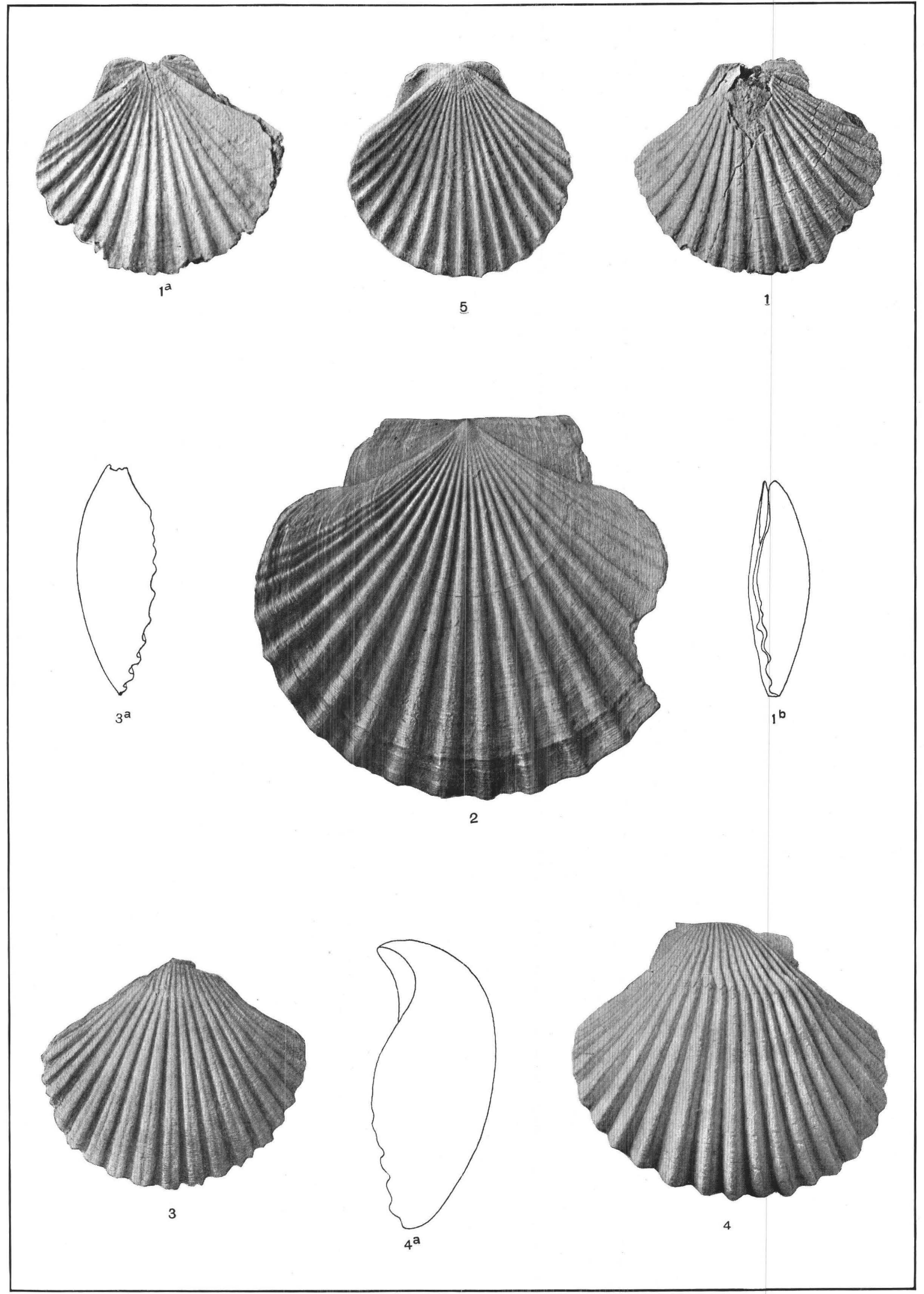

MIOCENE AND PLIOCENE PECTENS. 


\section{P L A T E V. \\ MIOCENE PECTENS.}

[Unless otherwise stated all figures are approximately natural size.]

Page.

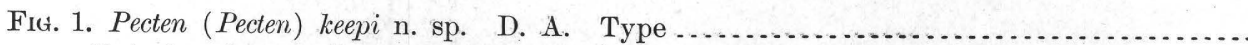
Exterior of somewhat imperfect and worn left valve; altitude $75 \mathrm{~mm}$. Miocene, Carrizo Creek district, San Diego County, Cal. (M. P.)

Fig. 2. Pecten (Patinopecten) dilleri Dall. U. S. N. M. 164846. Cotype ....................... Exterior of imperfect right valve; altitude (restored) $180 \mathrm{~mm}$. Upper Miocene or lower Pliocene, Eel River, Humboldt County, Cal. (M. B.)

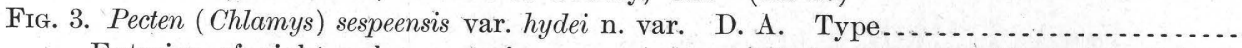

Exterior of right valve, anterior ear missing; altitude $46 \mathrm{~mm}$. Vaqueros sandstone (lower Miocene), Lynch's Mountain, Monterey County, Cal. (M. B.)

Fig. $3 a$. Same specimen as fig. 3

Exterior of left valve, anterior ear missing. (M. B.)

FIG. $3 b$. Same specimen as fig. 3

Profile of both valves as viewed from the rear. (M. P.) 

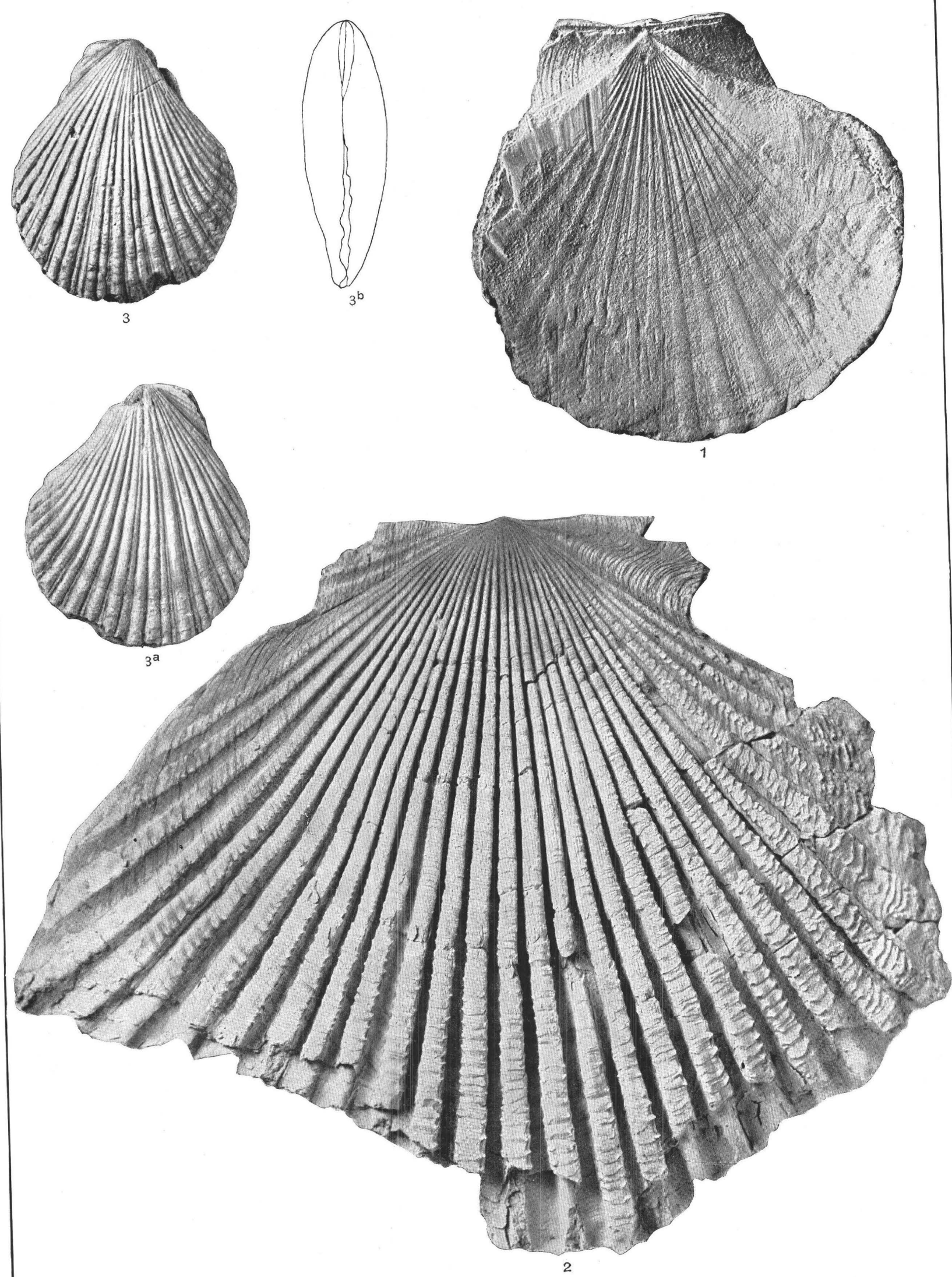

MIOCENE PECTENS. 


\section{P L A T E VI.}

\section{MIOCENE PECTENS.}

[Unless otherwise stated all figures are approximately natural size.]

Fig. 1. Pecten (Pecten) keepi n. sp. D. A Type '... Exterior of right valve; altitude $75 \mathrm{~mm}$. Carrizo formation (Miocene), Carrizo Creek district, San Diego County, Cal. (M. P.)

FIG. 1a. Same specimen a founty, Cal. (M. P.)

Profile of right valve viewed from rear.

FIG. 2. Pecten (Patinopecten) coosensis Shumard. U. S. N. M. 107791

Exterior of left valve; altitude $103 \mathrm{~mm}$. (M. P.)

Page. 


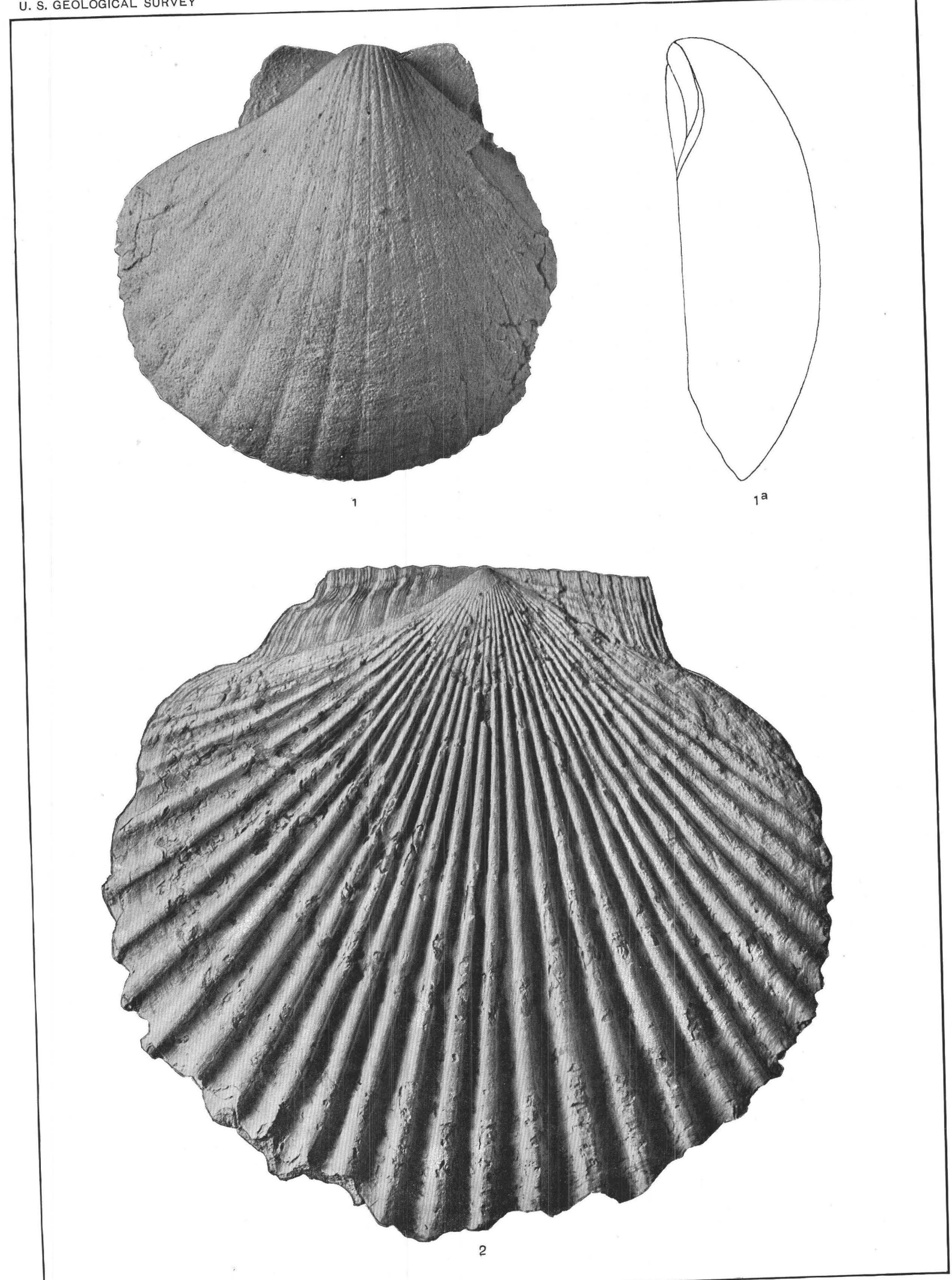

MIOCENE PECTENS. 


\section{PLATE VII.}

\section{MIOCENE PECTENS.}

[Unless otherwise stated all figures are approximately natural size.]

FIG. 1. Pecten (Patinopecten) propatulus Conrad. U. C.

Mold of interior of right valve, showing a portion of the umbonal area and ears; altitude Fig. 2. Pecten (Patinopecten) coosen (Miocene), Astoria, Oreg. (H.)

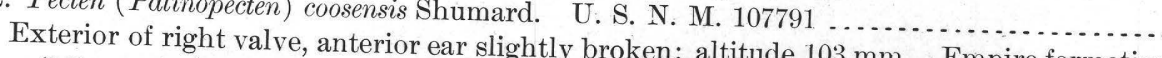
(Miocene), Coos Bay, Oreg FIG. 'a Same specimen as fig, Oreg. (M. P.)

Profile of both valves, viewed from rear. 


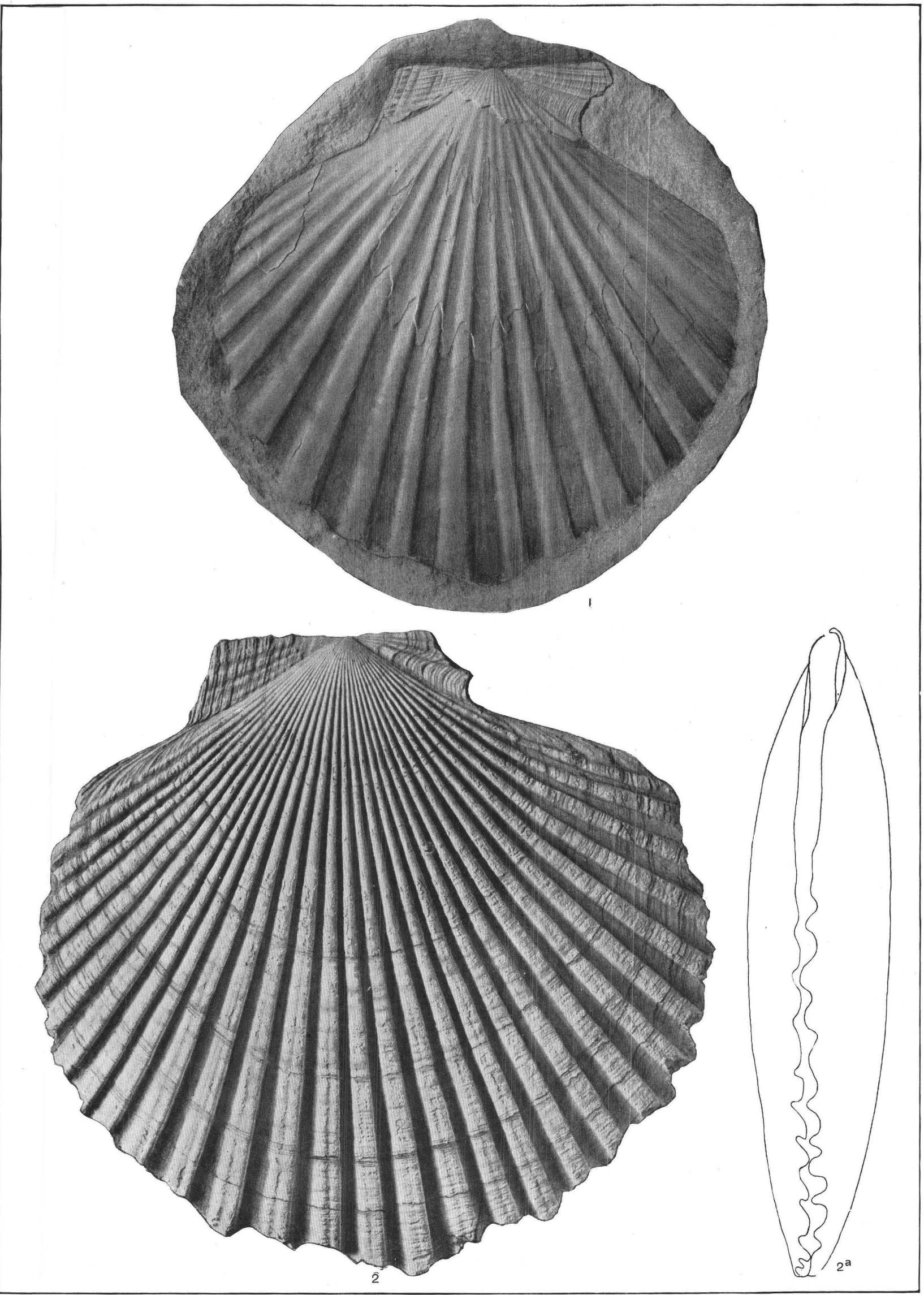

MIOCENE PECTENS. 
P L A T E. VIII.

\section{MIOCENE AND PLIOCENE PECTENS.}

[Unless otherwise stated all figures are approximately natural size.]

FIG. 1. Pecten (Patinopecten) oweni n. sp. U. C. Type Page. Exterior of right valve, anterior ear slightly broken; altitude $85 . \ldots 3$ cene?), Foxin's ranch, Santa Barbara County, Cal. (M. B.)

County, Cal. (M. B.) Exterior of left valve. (M. B.)

FIG. 1b. Same specimen as fig.

Profile of both valves viewed fom

Fig. 2. Pecten (Chlamys) sespeensis n.

Portion of mold of interior of right valye Miocene), Sespe Canyon, Ventura Co; altitude $50 \mathrm{~mm}$. Vaqueros formation (lower Fig. 2a. Same specimen as fig. 2 ( Ventura County, Cal. (M. B.)

Portion of mold of interior of left valve.

FIG. 3. Pecten (Chlamys) sespeersis n. sp. C. S. M. B. Plastotype...

Cast of exterior of slightly imperfect left valve (young); altitude 18 . as fig. 2. (M. B.) 


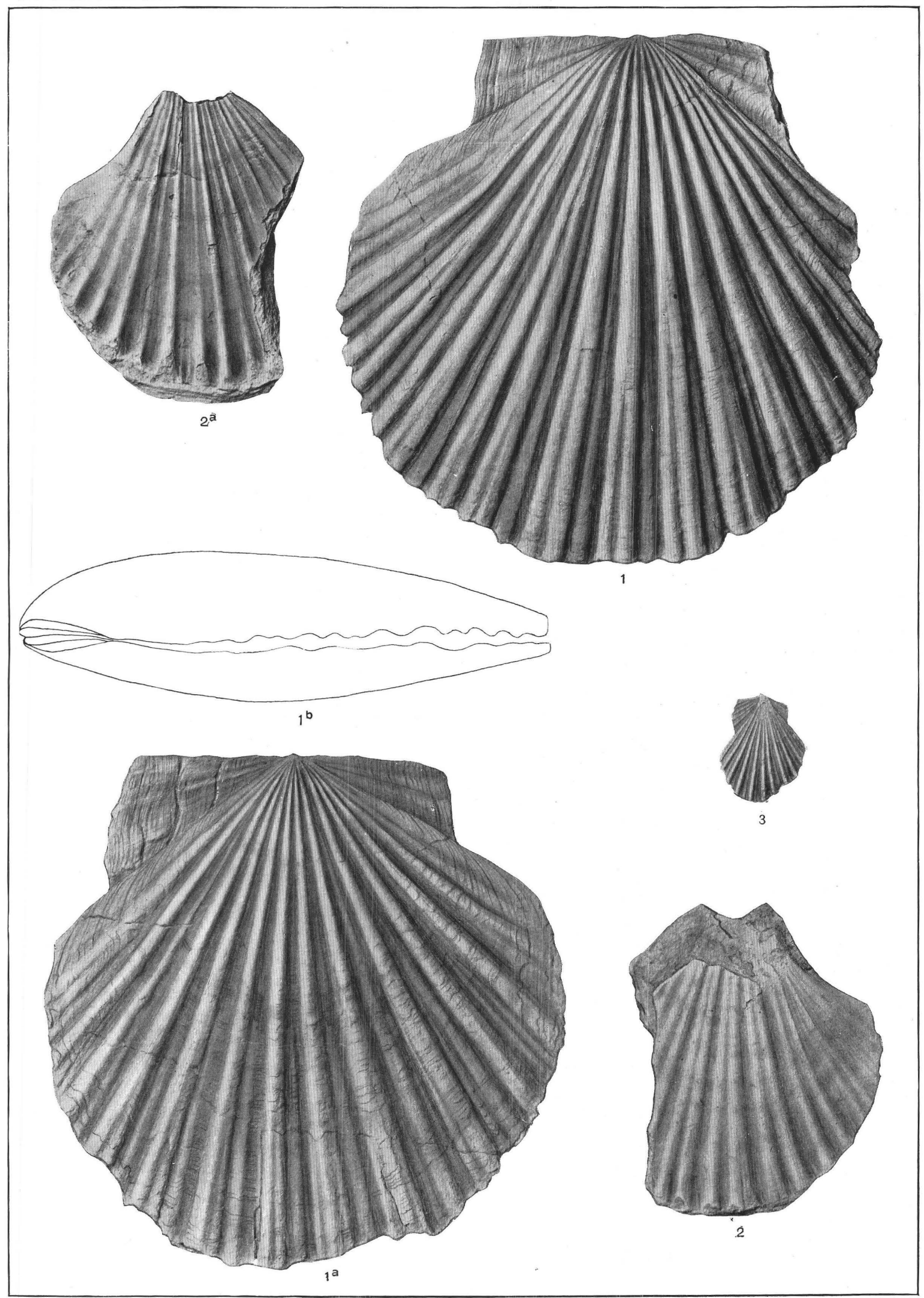

MIOCENE AND PLIOCENE PECTENS. 


\section{P L A T E IX.}

\section{MIOCENE PECTENS.}

[Unless otherwise stated all figures are approximately naturø,1 size.]

F1G. 1. Pecten (Patinopecten) propatulus Conrad, U. S. N. M. 3558. Cotype.

Exterior of portion of right valve; altitude $100 \mathrm{~mm}$ Astoria Astoria, Oreg. (M. B.)

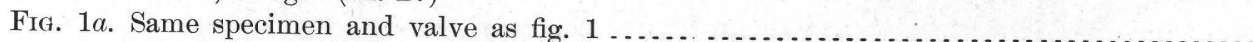

Portion of disk, showing part of two ribs and included interspace, $\times 3$. (M. B.)

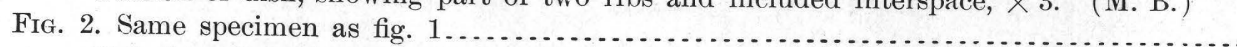

Exterior of portion of left valve.

a. Same specimen as fig. 1, left valve

Portion of disk, showing part of three ribs and included interspaces, $\times 3$. 


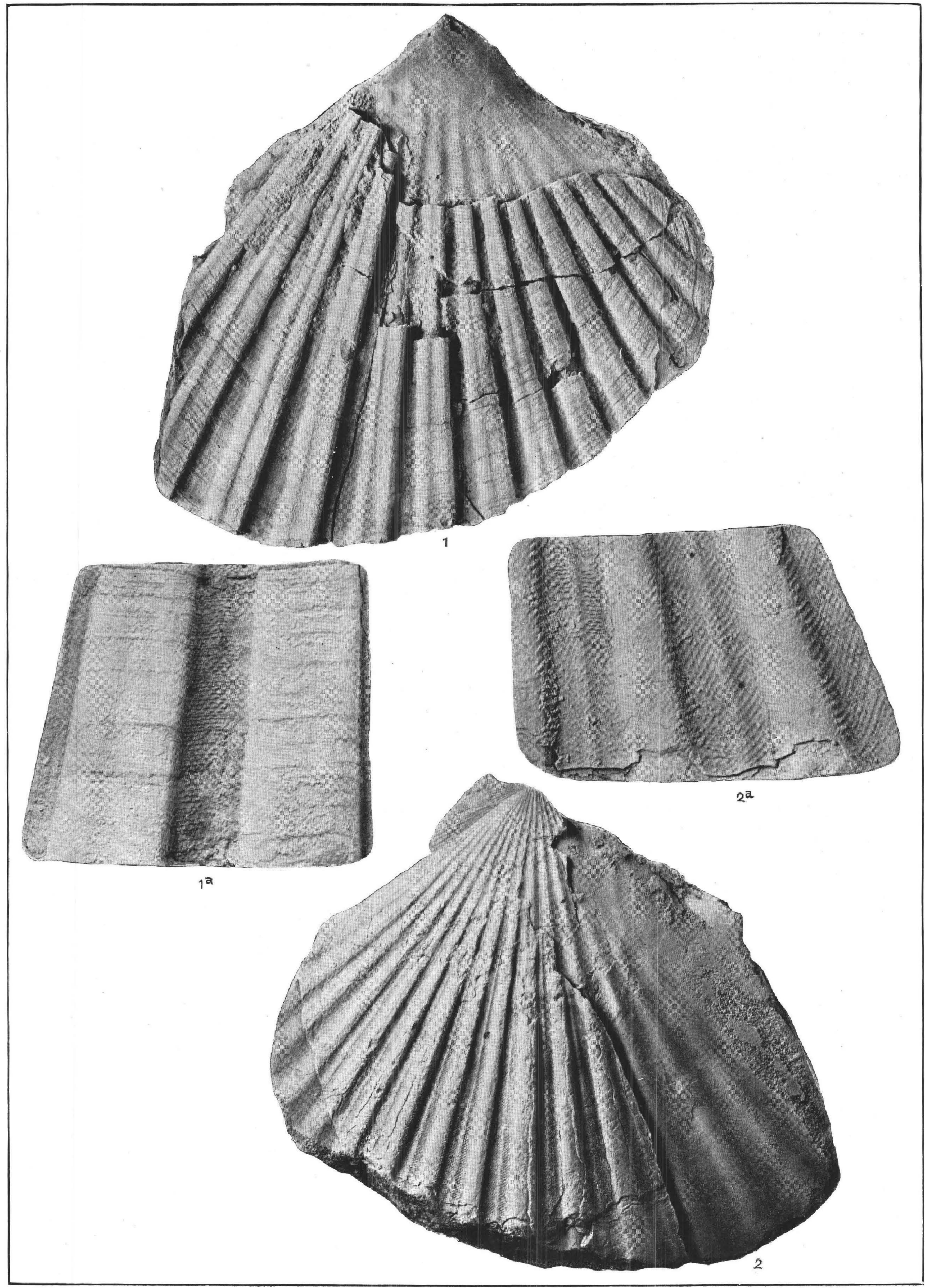

MIOCENE PECTENS. 


\section{P L A T E X. \\ MIOCENE AND PLIOCENE PECTENS.}

[Unless otherwise stated all figures are approximately natural size.]

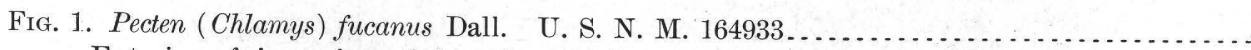

Page.

Exterior of imperfect right valve; altitude $83 \mathrm{~mm}$. Miocene, coast of Strait of Juan de Fuca, east of Clallam Bay, Clallam County, Wash. (M. B.)

FIG. 2, Pecten (Chlamys) fucanus Dall. U. S. N. M. 107790. Plastotype.

Cast of exterior of left valve; altitude $81 \mathrm{~mm}$. Same locality as fig. 1 .

FIg. 2a. Same specimen as fig. 2

Profile of left valve viewed from front. (M. P.)

Fig. 3. Pecten (Chlamys) wattsi var. morani n. var. U. S. N. M. 164929. Type..............

Exterior of imperfect right valve; altitude $63 \mathrm{~mm}$. Lower Pliocene, Moran's place, Priest Valley, Monterey County, Cal. (M. B.)

FIG. 4. Pecten (Chlamys) wattsi var. morani n. var. U. S. N. M. 164929. Cotype

Exterior of imperfect

. Pecten (Chlamys) wattsi var. morani n. var. U. S. N. M. 164929 ................... .

Exterior of imperfect left valve; longitude $41 \mathrm{~mm}$. Same locality as fig. 3 .

FIG. 6. Pecten (Chlamys) wattsi var. morani n. var.

Exterior of imperfect left valve (young); altitude $30 \mathrm{~mm}$. Same locality as fig. 3 . 164 


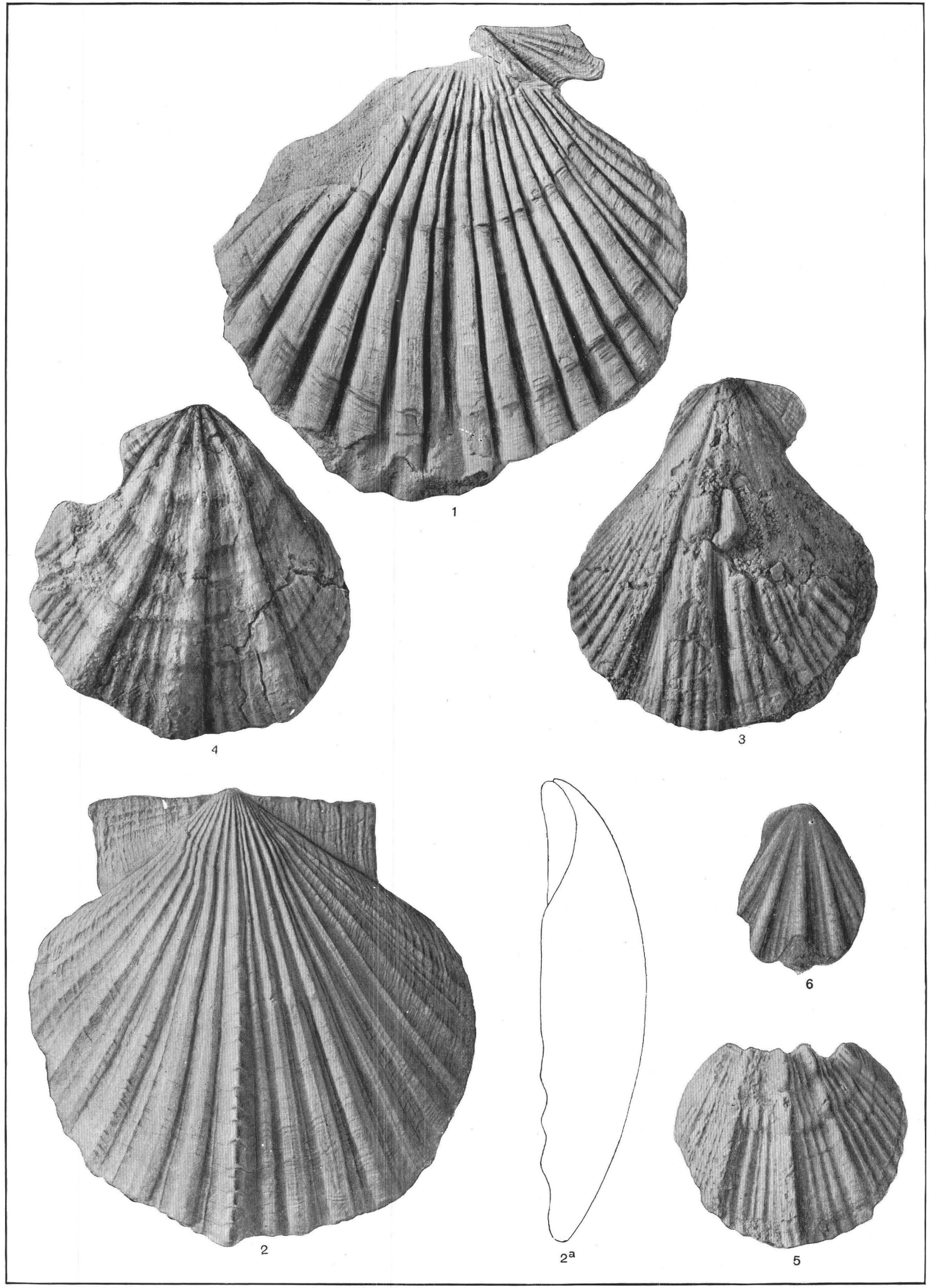

MIOCENE AND PLIOCENE PECTENS. 


\section{PLA TE XI. \\ MIOCENE AND PLIOCENE PECTENS.}

[Ưnless otherwise stated all figures are approximately natural size.]

Page.

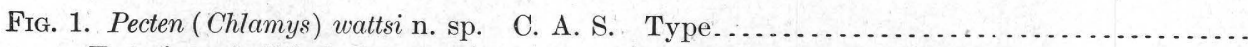

Exterior of slightly imperfect left valve; altitude $66 \mathrm{~mm}$. Lower Pliocene, Kreyenha-

gen's ranch, Fresno County, Cal. (S.)

Fig. 1a. Same specimen as fig. 1

Profile of left valve, viewed from rear. (M. P.)

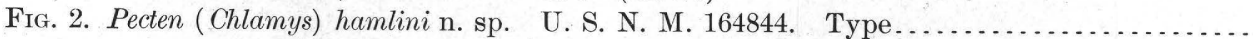

Exterior of contorted (lengthened) right valve; altitude $50 \mathrm{~mm}$. Miocene (lower?), head of Slacks Canyon, Monterey County, Cal. (M. B.)

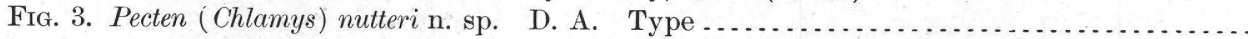
Exterior of slightly imperfect right valve; altitude $74 \mathrm{~mm}$. Purisima formation (lower Pliocene), south of mouth of San Gregorio Creek, San Mateo County, Cal. (M. B.)

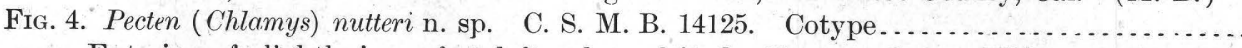
Exterior of slightly imperfect left valve; altitude $63 \mathrm{~mm}$. Lower Pliocene, Kreyenhagen's ranch, Fresno County, Cal. (M. B. )

FIg. 4a. Same specimen as fig. 4 .

Profile of left valve, viewed from rear.

Fig. 5. Pecten (Lyropecten) crassicardo Conrad var. hamiltoni n. var. U. S. N. M. $164845 . \quad$ Type.

Exterior of slightly contorted and imperfect right valve; altitude $40 \mathrm{~mm}$. Miocene, Alum Rock Canyon, Santa Clara County, Cal.

FIG. 6. Pecten (Lyropecten) crassicardo Conrad var. hamiltoni n. var. U. S. N. M. 164845.

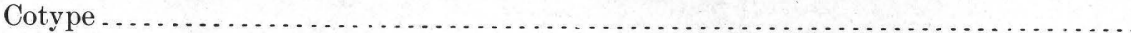

Exterior of imperfect (earless) right valve; altitude $63 \mathrm{~mm}$. Same locality as last.

166 


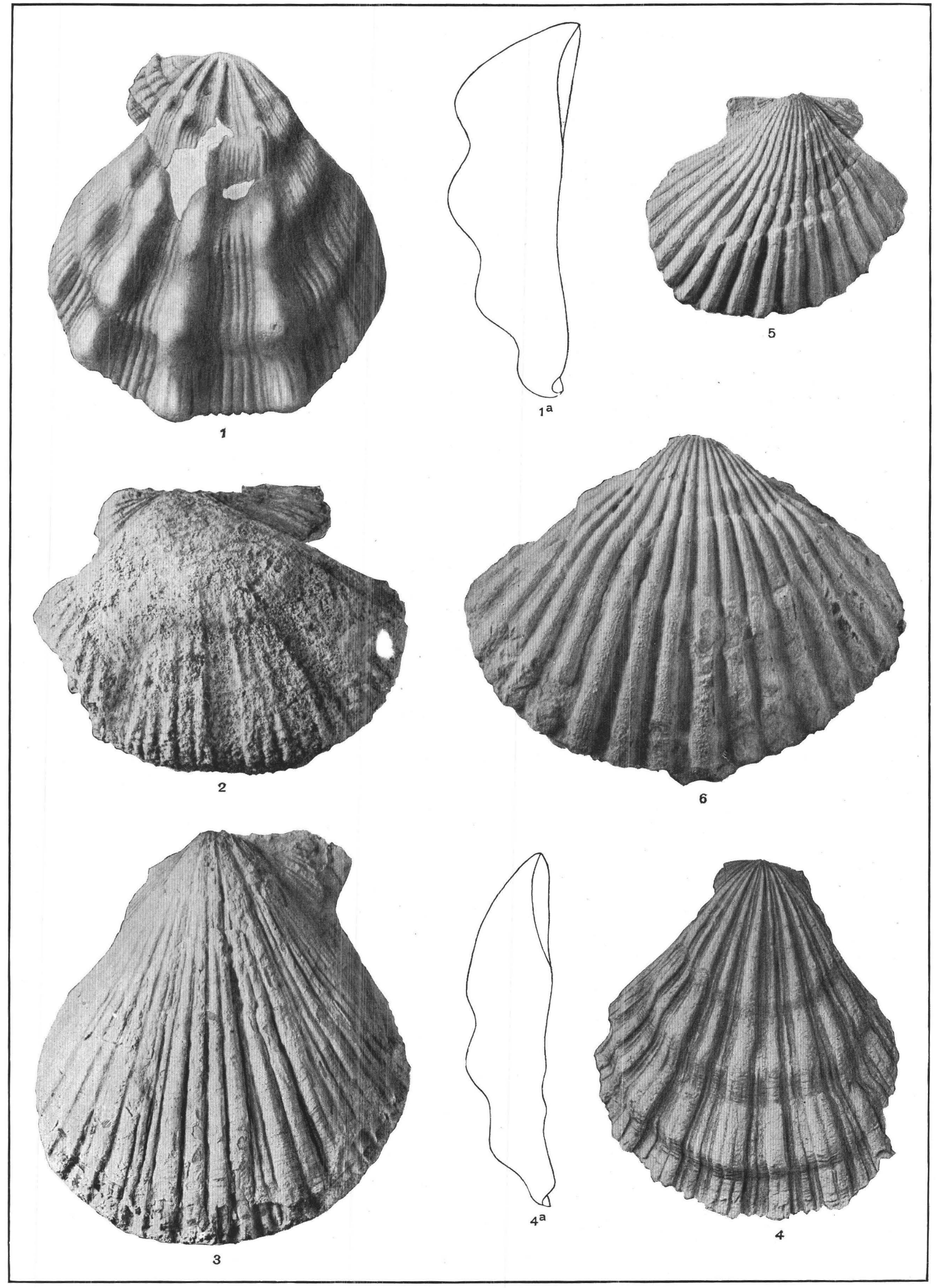

MIOCENE AND PLIOCENE PECTENS. 


\section{PLATE XII.}

MIOCENE PECTENS.

[Unless otherwise stated all figures are approximately natural size.]

FIG. 1. Pecten (Lyropecten) bowersi n. sp. U. C. Type

Exterior of slightly imperfect right valve; altitude $150 \mathrm{~mm}$. Miocene (lower) Santa Inez Canyon, Santa Barbara County, Cal. (M. B.)

FIG. 2. Pecten (Lyropecten) bowersi n. sp. D. A.................

Exterior of umbo and ears (the anterior somewhat imperfect) of restored $86 \mathrm{~mm}$. Miocene (lower), Santa Monica Mountains, Ventura County, Cal.
(M. P.)

168 


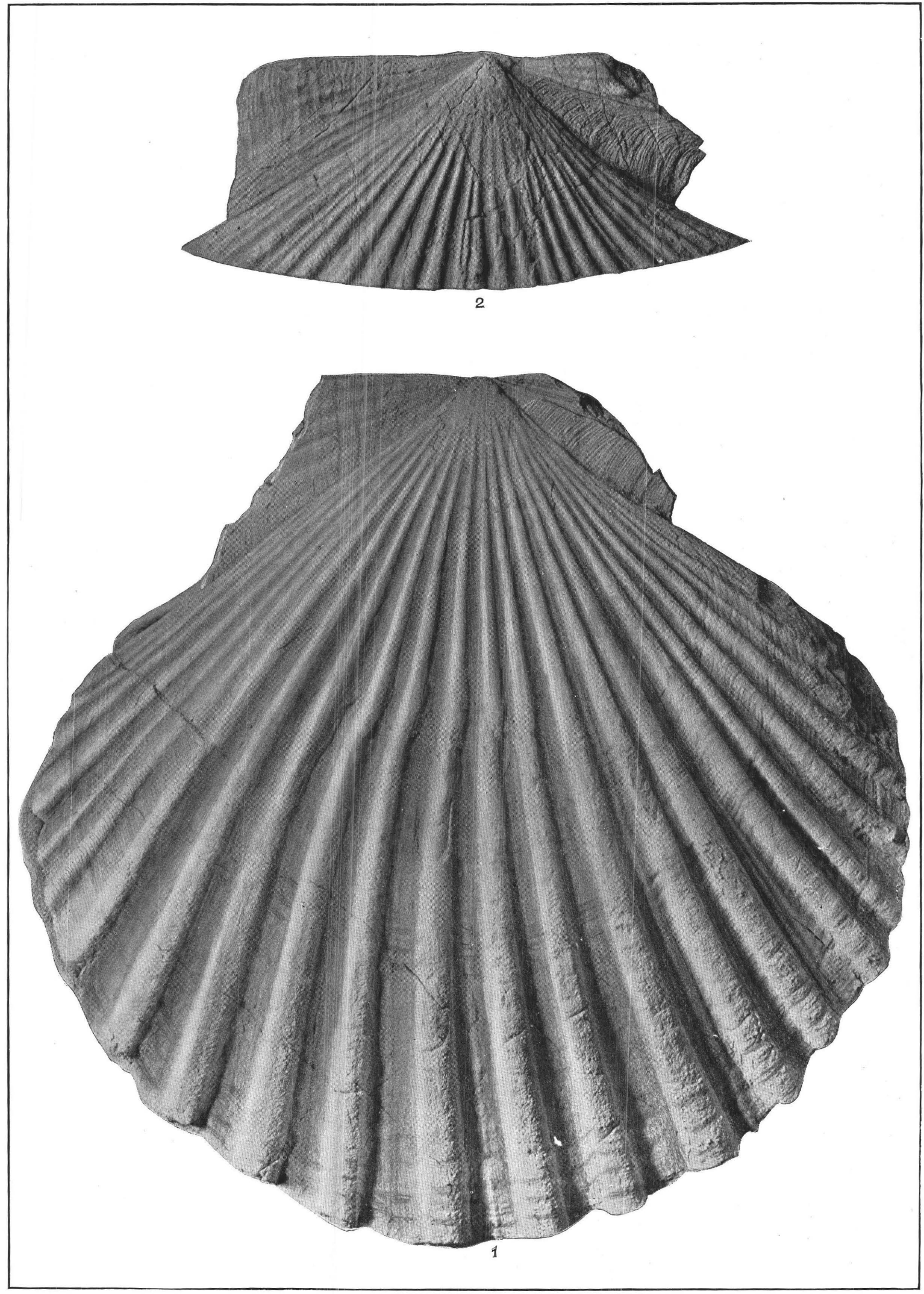

MIOCENE PECTENS. 


\section{PLATE XIII.}

MIOCENE PECTENS.

[Unless otherwise stated all figures are approximately natural size.]

Fig. 1. Pecten (Lyropecten) bowersi n. sp. U. C. Type ........................... Page

Exterior of left valve, èars imperfect; altitude $150 \mathrm{~mm}$. Miocene (lower), Santa Inez

Canyon, Santa Barbara County, Cal. (H.)

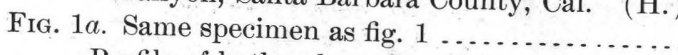

Profile of both valves viewed from rear. (M. P.)

170 

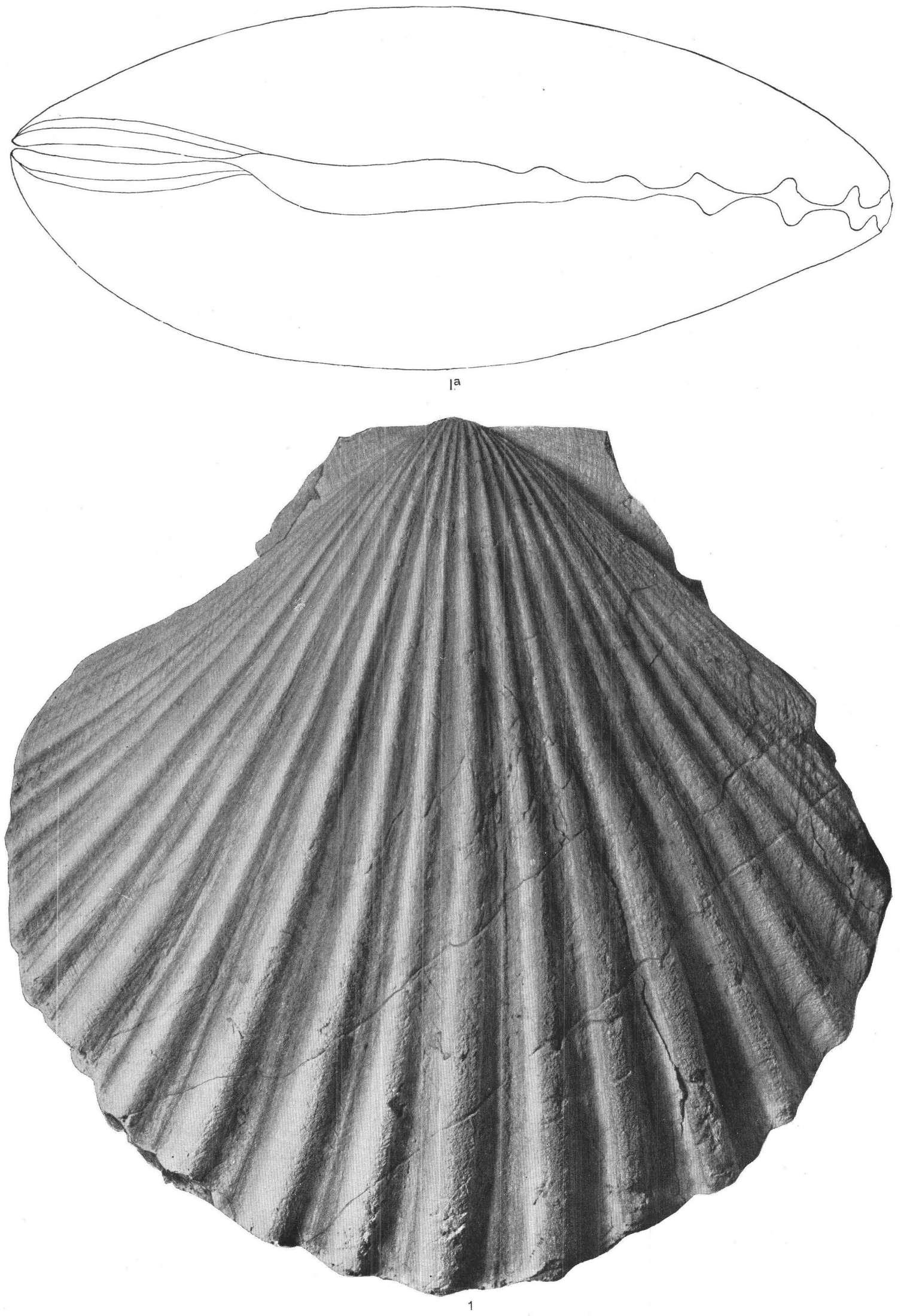

MIOCENE PECTENS. 


\section{PLATE XIV.}

MIOCENE PECTENS.

[Unless otherwise stated all figures are approximately natural size.]

Page

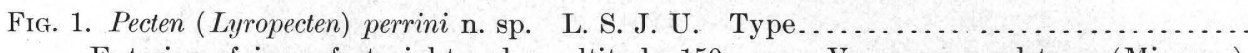
Exterior of imperfect right valve; altitude $150 \mathrm{~mm}$. Vaqueros sandstone (Miocene), between Morro and Toro creeks, San Luis Obispo County, Cal. (M. B.)

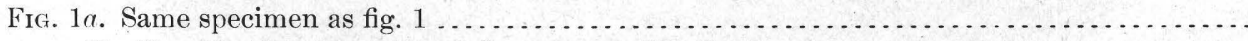
Profile of both valves viewed from rear. (M. P.) 


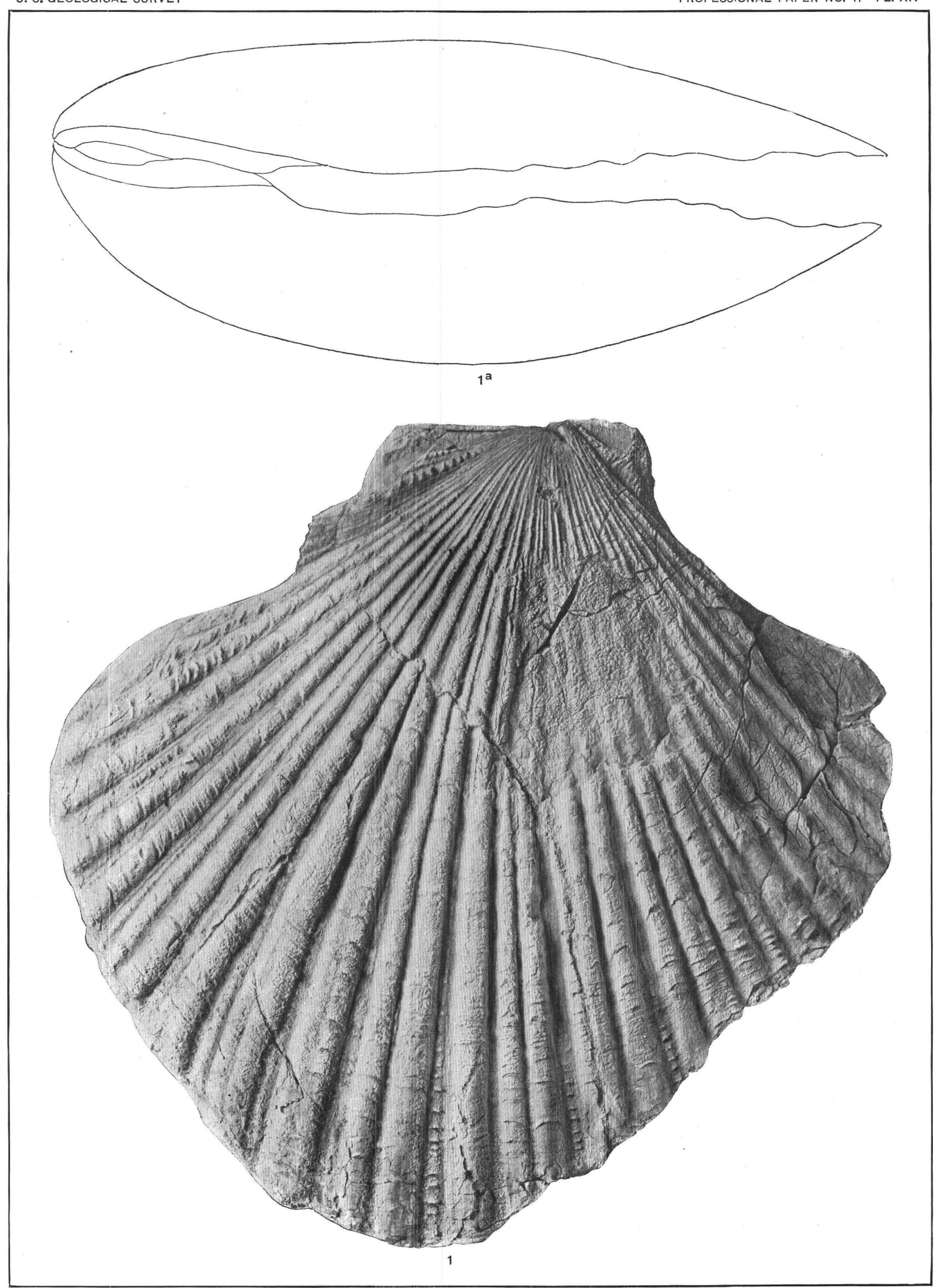

MIOCENE PECTENS. 


\section{PLA TE XV. \\ MIOCENE PECTENS.}

[Unless otherwise stated all figures are approximately natural size.]

Page.

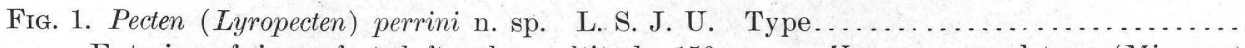
Exterior of imperfect left valve; altitude $150 \mathrm{~mm}$. Vaqueros sandstone (Miocene), between Morro and Toro ereeks, San Luis Obispo County, Cal. (M. B.)

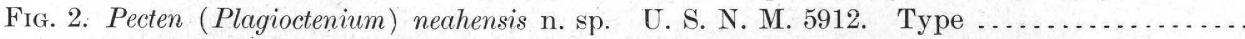

Exterior of imperfect right valve; longitude $49 \mathrm{~mm}$. Miocene, Strait of Fuca, east of Neah Bay, Clallam County, Wash. (M. B.)

FIG. $2 a$. Same specimen as fig. 2.

Exterior of imperfect left valve. (M. B.)

FIG. 2b. Same specimen as fig. 2

View of both valves from the rear. (M. B.)

174 


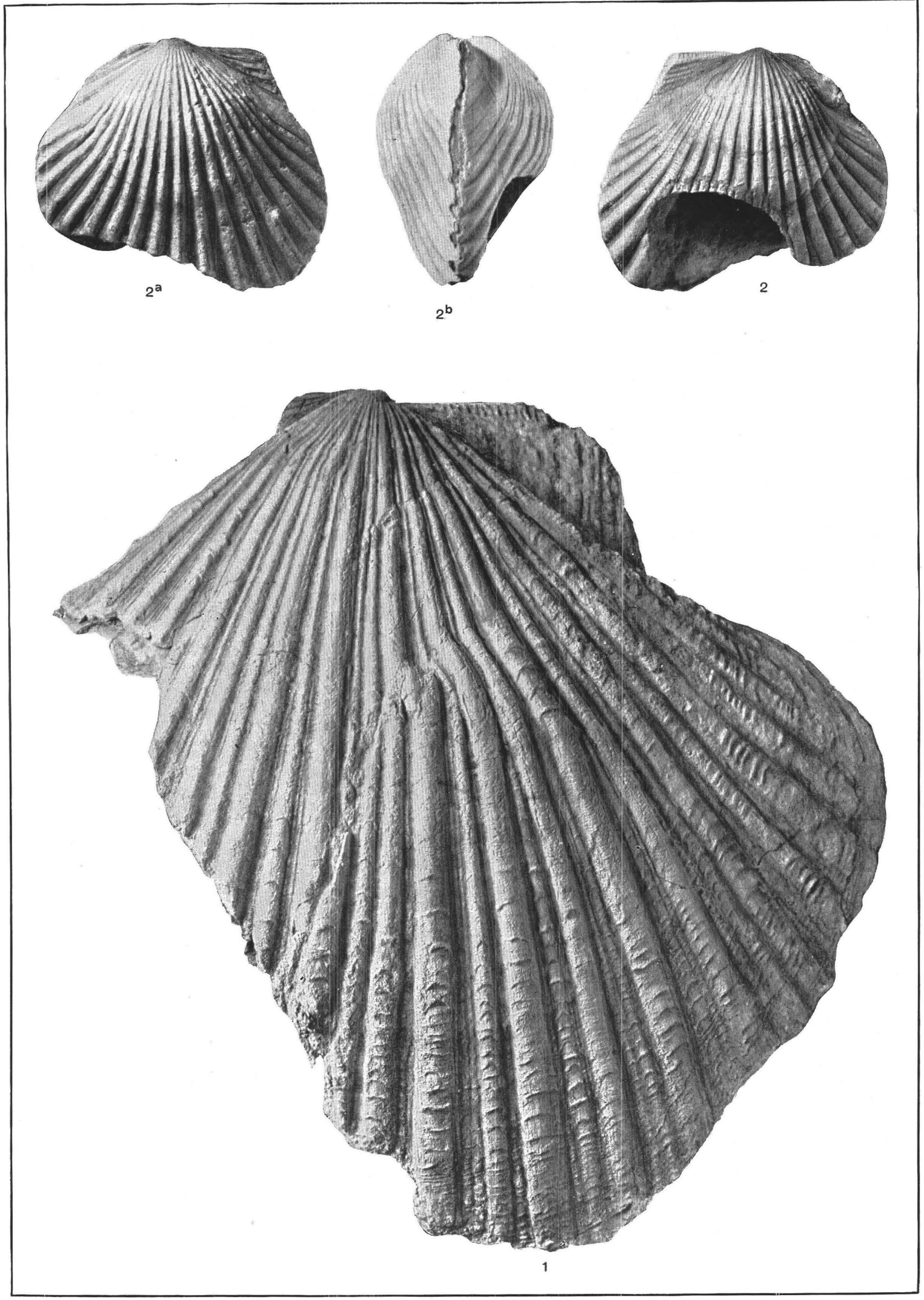

MIOCENE PECTENS. 


\section{PLATE XVI.}

\section{MIOCENE PECTENS.}

[Unless otherwise stated all figures are approximately natural size.]

FIg. 1. Pecten (Lyropecten) crassicardo Conrad. U. S. N. M. 154154 (Miocene), Kirker Pass, Contra Costa County, Cal. (M. B.)

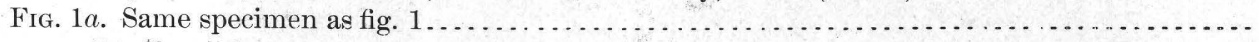

Profile of right valve viewed from rear. (M. P.)

176 


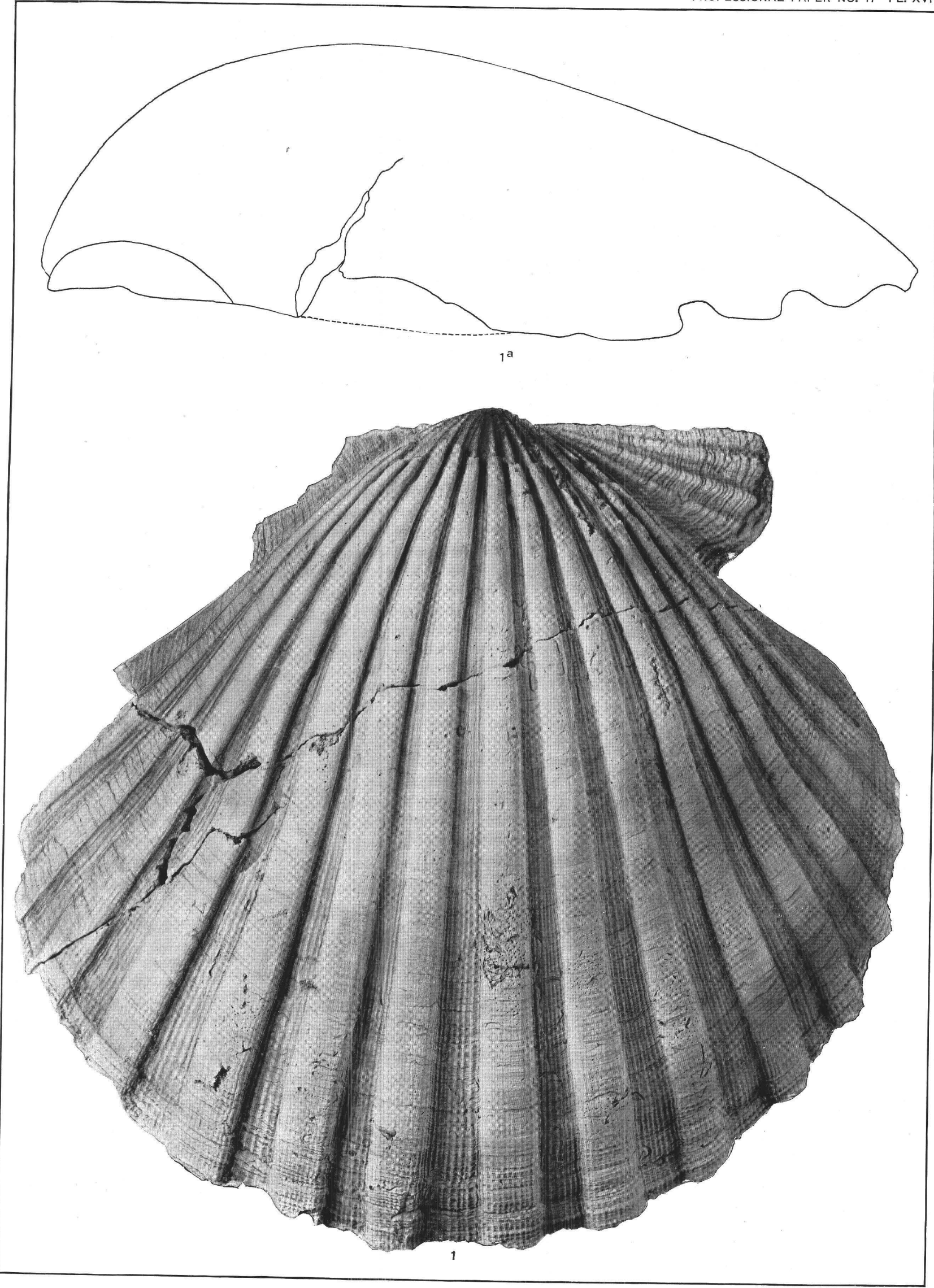

MIOCENE PECTENS. 


\section{PLATE XVII. MIOCENE PECTENS.}

Fig. 1. Pecten (Lyropecten) crassicardo Conrad. U. C ..................................................... San Pablo formation (upper
Exterior of slightly imperfect right valve; altitude $97 \mathrm{~mm}$. San

Miocene), Contra Costa County, Cal. (M. B.)

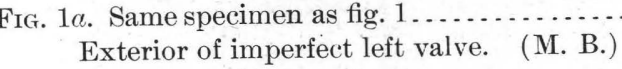

FIG. 1b. Same specimen as fig. 1

View of both valves from the rear, showing constriction of disk.

(S.)

178 


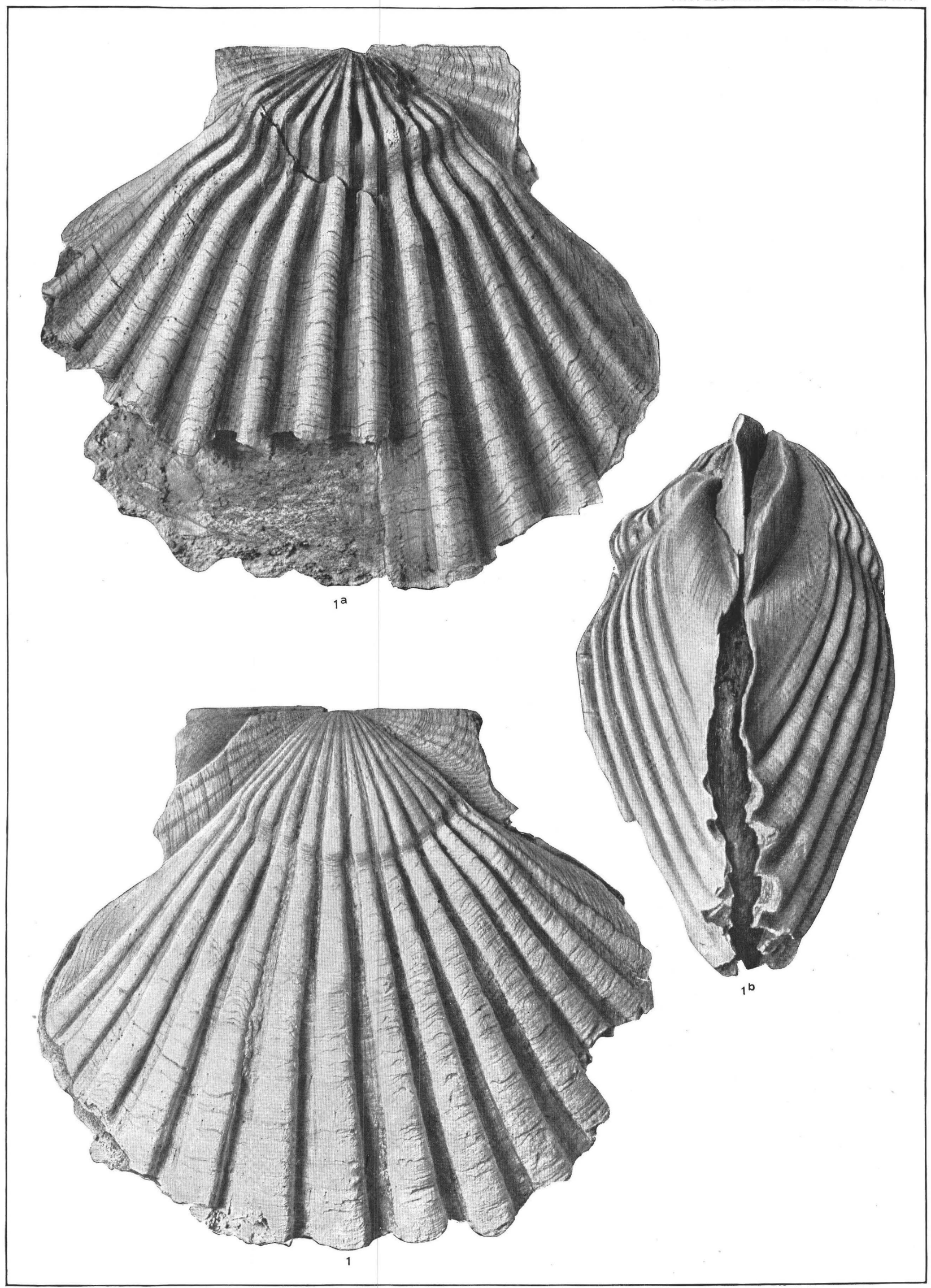

MIOCENE PECTENS. 


\section{P LA TE X VIII. MIOCENE PECTENS.}

[Unless otherwise stated all figures are approximately natural size.]

Fig. 1. Pecten (Lyropecten) crassicardo Conrad. A. N. S., Phila. Type

Exterior of left valve (ears gone); altitude 135 Pablo formation), "California," (Photograph by Ralph Arnold Shell not coated.

FIG. 2. Pecten (Lyropecten) crassicardo Conrad. C. S. M. B. 12772 . . . . . . . . . . . . . . . Exterior of left valve (ears gone); altitude $88 \mathrm{~mm}$. Miocene, Ventura County. (S.)

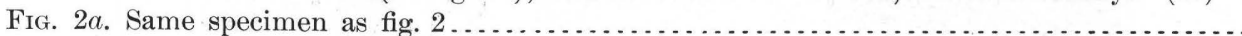

View of both valves from the rear, showing constriction of disk. (M. B.) 

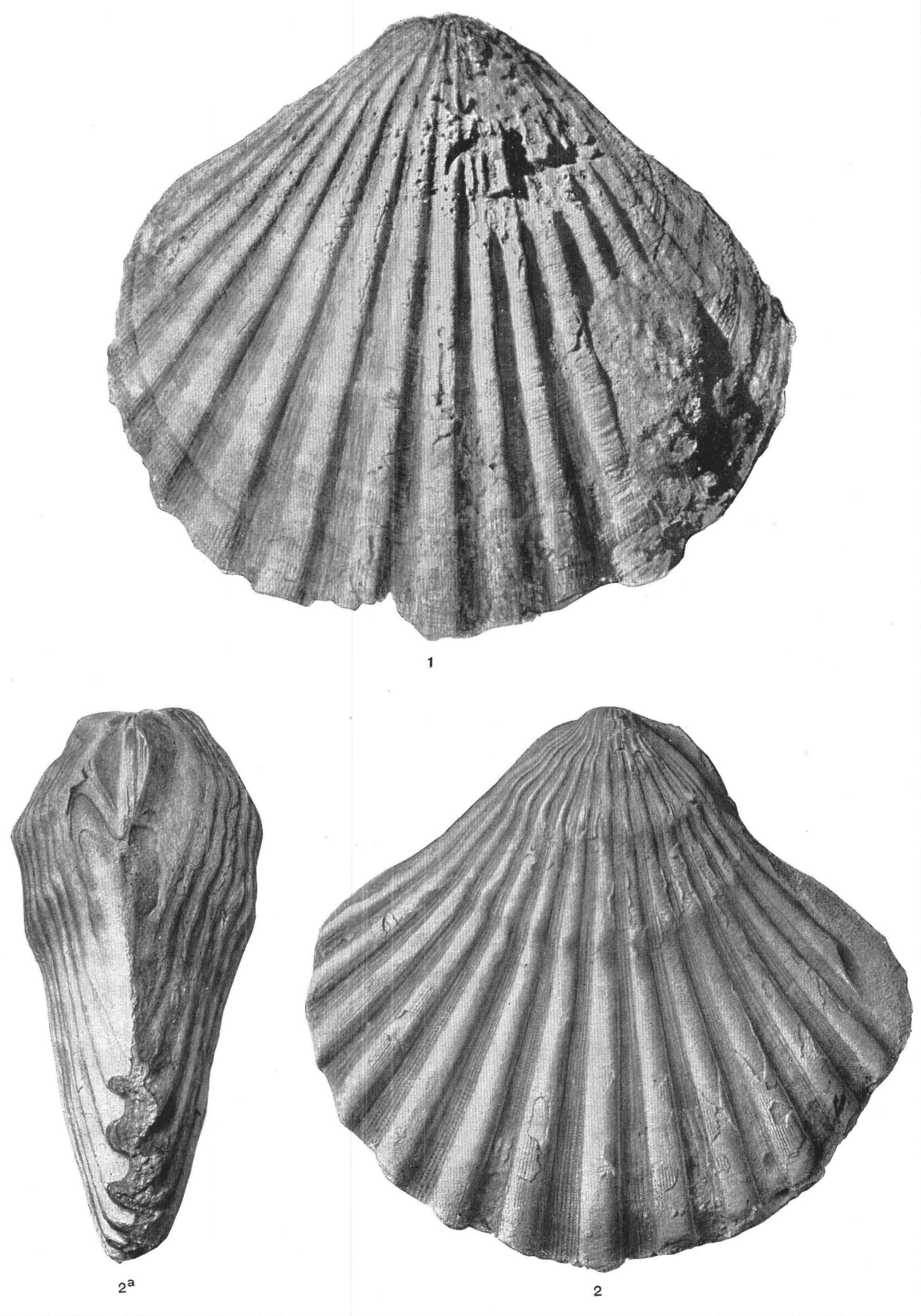

MIOCENE PECTENS. 


\section{PLATE XIX.}

MIOCENE PECTENS.

[Unless otherwise stated all figures are approximately natural size.]

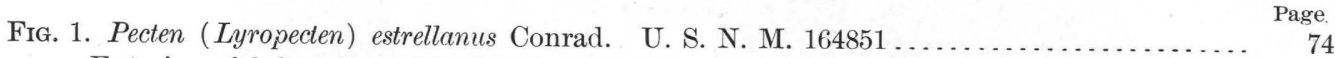
Exterior of left valve; altitude $97 \mathrm{~mm}$. Santa Margarita formation (upper Miocene), Wildhorse Canyon, Monterey County, Cal. (M. B.)

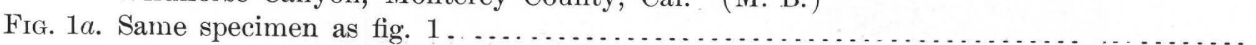
Interior of left valve. (M. B.) 

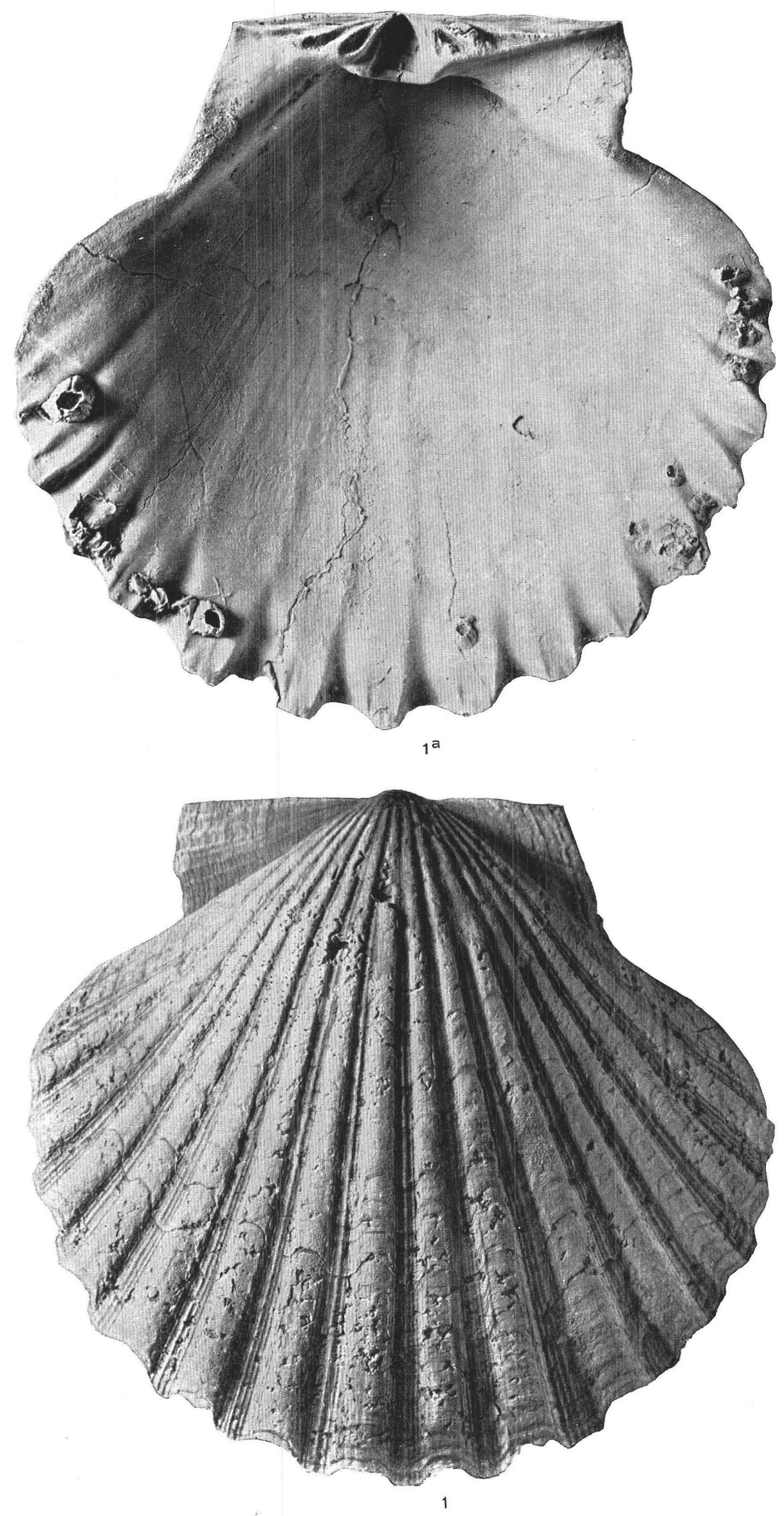

MIOCENE PECTENS. 



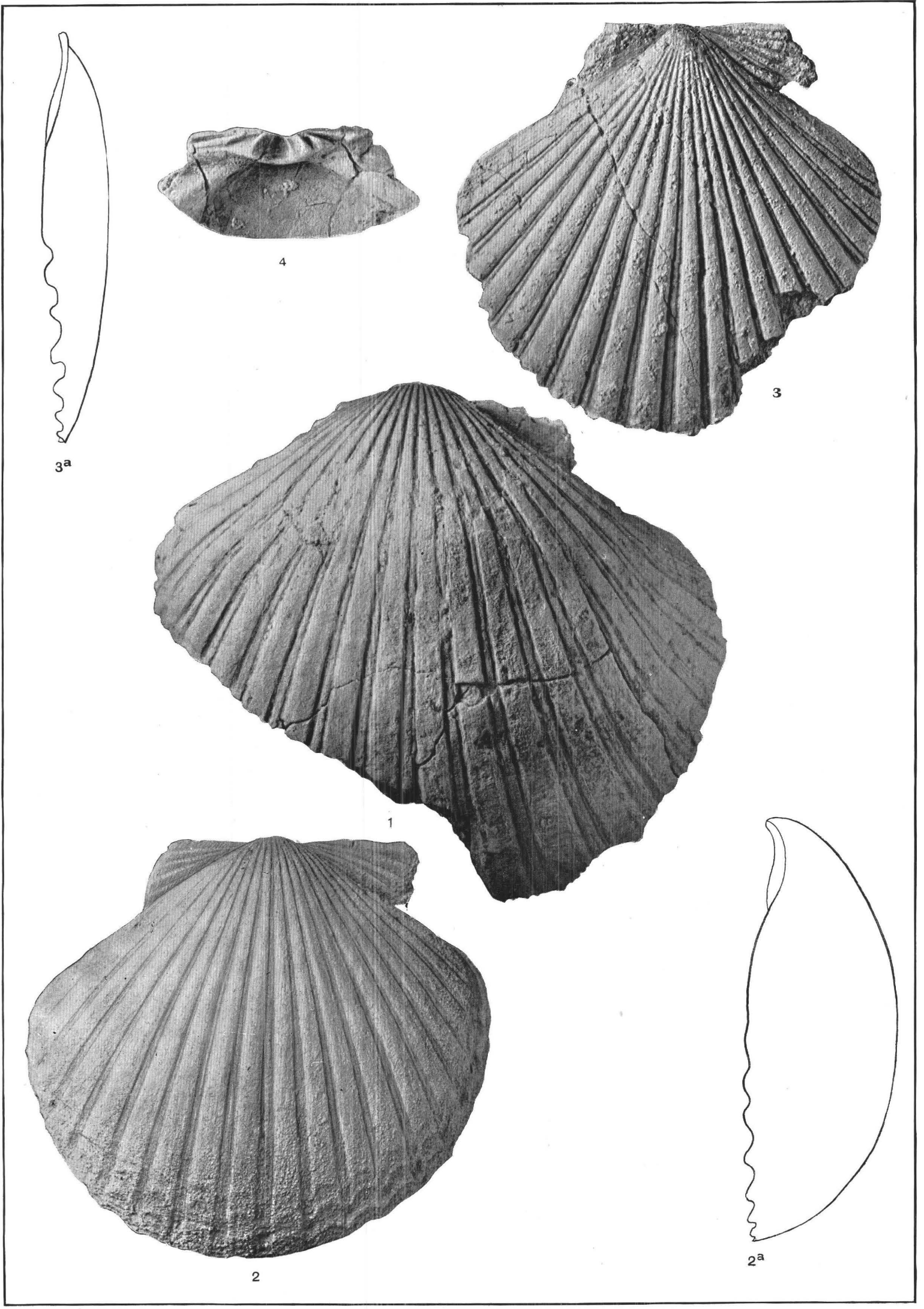

MIOCENE AND PLIOCENE PECTENS. 


\section{PLATE XXI.}

MIOCENE PECTENS.

[Unless otherwise stated all figures are approximately natural size.]

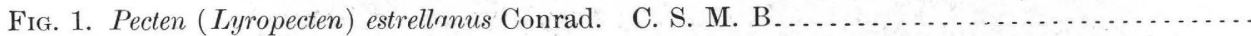

Exterior of right valve (ears imperfect); altitude $77 \mathrm{~mm}$. San Pablo formation (upper Miocene), Coalinga, Fresno County, Cal. (M. B.)

Fig. 1a. Same specimen as fig. 1 .

Exterior of left valve (ears imperfect). (M. B.)

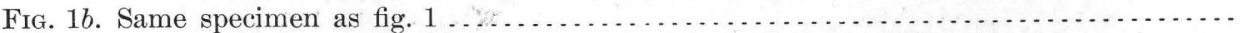

View of both valves from the rear, showing constriction. (M. B.)

Fig. 2. Pecten (Lyropecten) estrellanus Conrad. J. H. W . . . . . . . . . . . . . . . . . . .

Exterior of right valve (ears slightly broken); altitude $60 \mathrm{~mm}$. Miocene, Cholame Mountains, 40 miles east of Paso Robles, San Luis Obispo County, Cal. (M. B.)

Fig. 2a. Same specimen as fig. 2 .

Exterior of left valve (ears slightly broken).

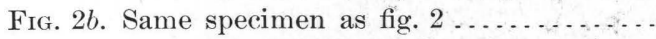

Profile of both valves viewed from rear. 

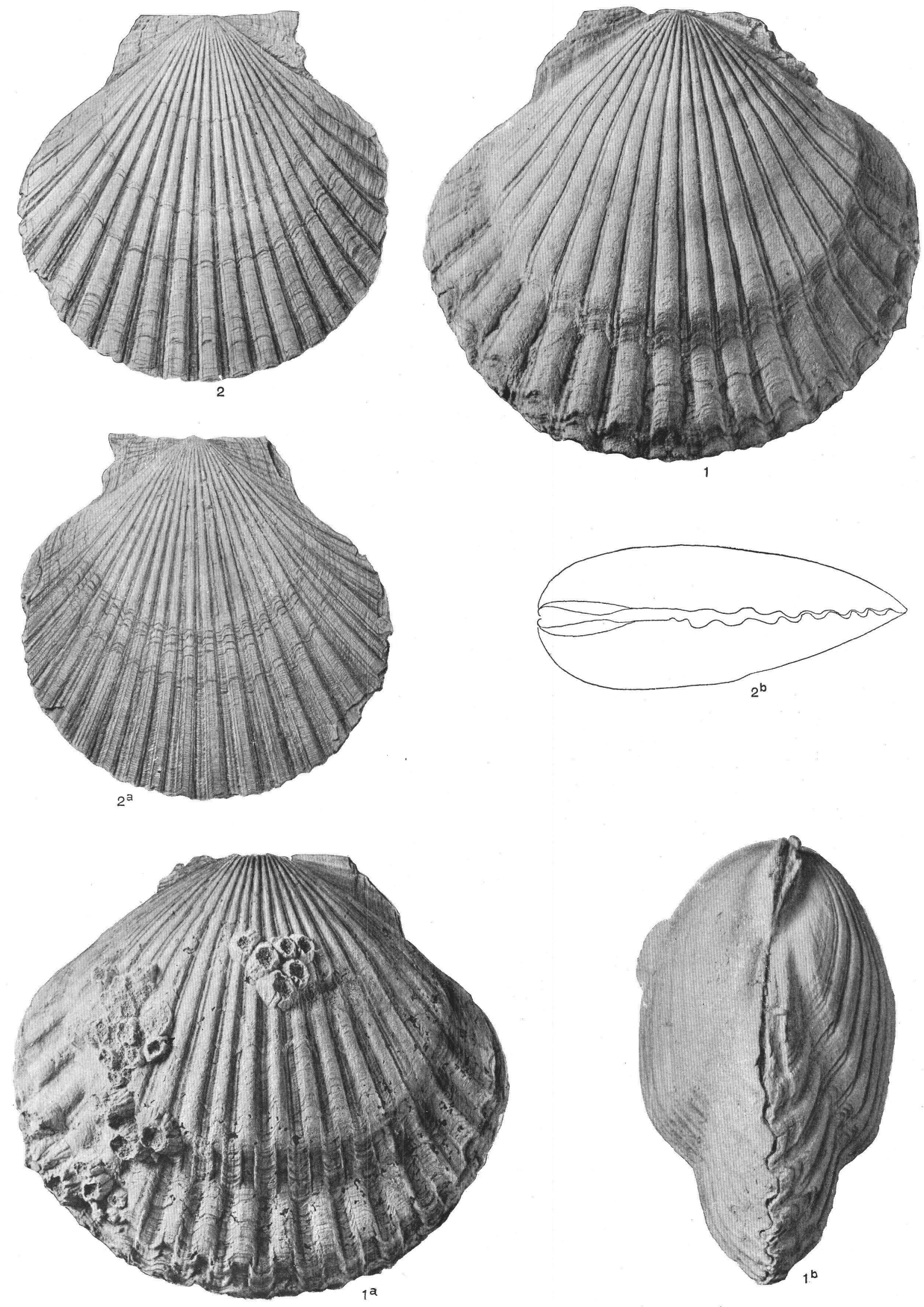

MIDCENE PECTENS. 


\section{PLATE XXII.}

MIOCENE PECTENS.

[Unless otherwise stated all figures are approximately natural size.]

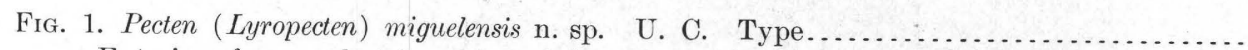

Exterior of somewhat imperfect right valve; altitude $110 \mathrm{~mm}$. Miocene (lower), San

Miguel Island, Santa Barbara County, Cal. (M. B.)

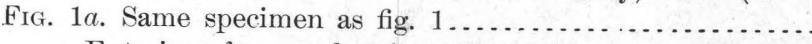

Exterior of somewhat imperfect left valve. (M. B.)

FIG. 1b. Same specimen as fig. 1 . 188 


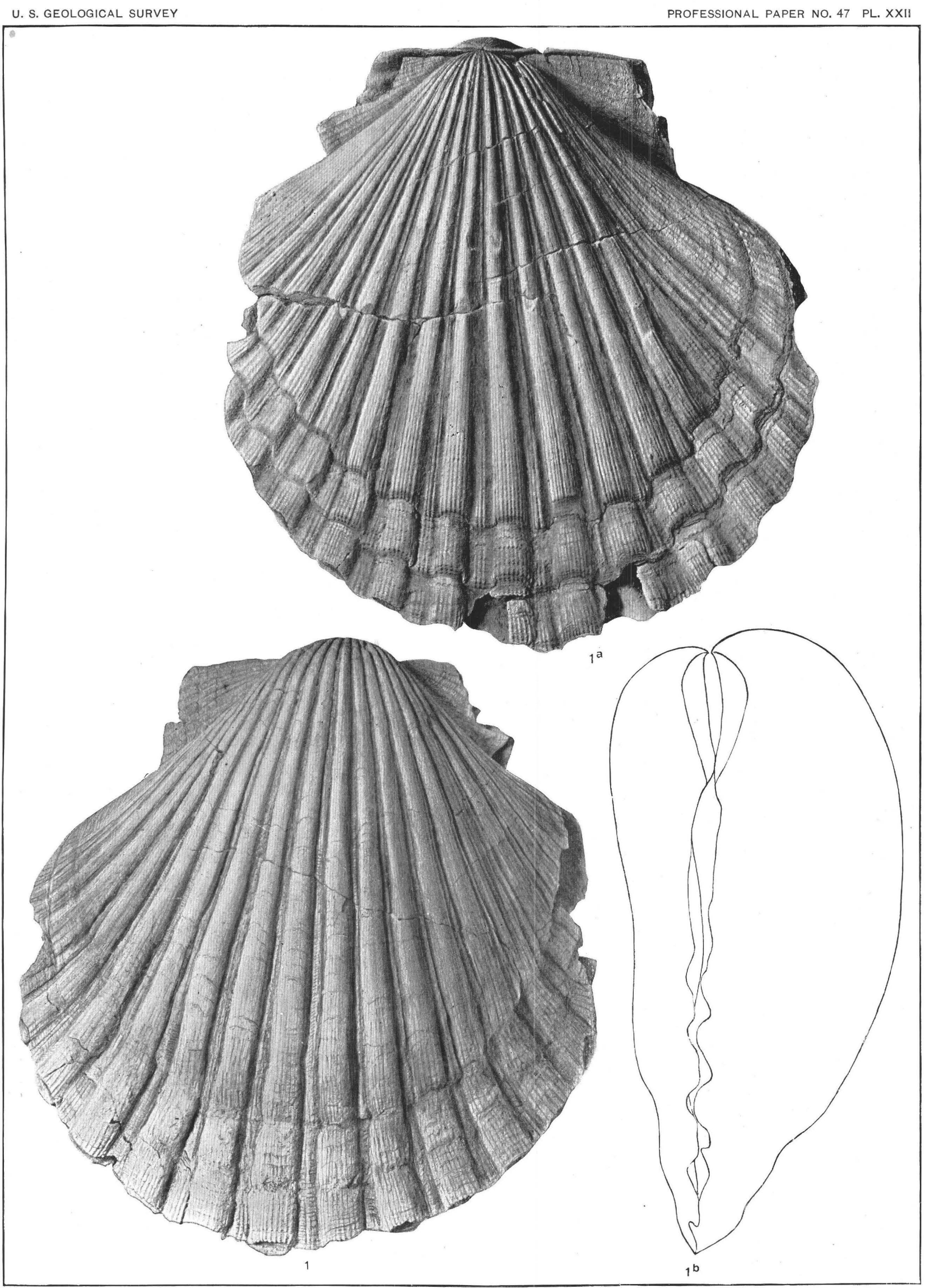

MIOCENE PECTENS. 


\section{P LA TE X X I I. MIOCENE PECTENS.}

[Unless otherwise stated all figures are approximately natural size.]

Page.

FIG. 1. Pecten (Lyropecten) miguelensis n. sp. U. S. N. M. 6397

Exterior of umbonal region and imperfect ears of left valve; altitude of fragment $76 \mathrm{~mm}$. Copied from drawing by Doctor McConnell. Miocene, Santa Inez Mountains, Santa Barbara County, Cal.

Fig. 2. Pecten (Lyropecten) estrellanus Conrad var. terminus n. var. U. C. Type.............

Exterior of right valve; altitucie $70 \mathrm{~mm}$. Santa Margarita formation (upper Miocene), Monterey County, Cal. (M. B.)

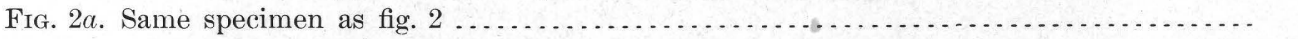

Profile of right valve, viewed from rear. (M. P.)

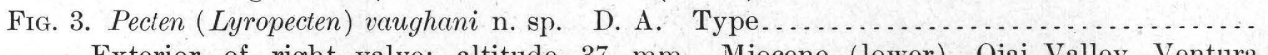

Exterior of right valve; altitude $37 \mathrm{~mm}$. Miocene (lower), Ojai Valley, Ventura County, Cal. (M. B.)

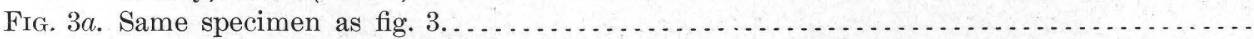

Exterior of left valve. (M. B.)

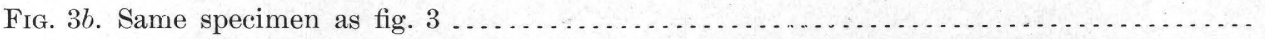

Profile of both valves, viewed from the rear, showing contraction of disk. (M. P.)

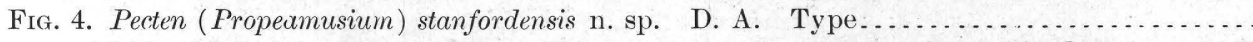

Mold of interior of right valve and cast of exterior of left valve; altitude $7 \mathrm{~mm}$., $\times 3$.

Miocene, Burke ranch, near Stanford University, Santa Clara County, Cal. (M. B.)

Fig. 5. Pecten (Pseudamusium) lompicoensis n. sp. U. S. N. M. 164931

Mold of exterior of contorted left valve; altitude $14 \mathrm{~mm}$., $\times 3$.

Miocene shale, head of Lompico Creek, Santa Cruz County, Cal. (M. P.) 190 

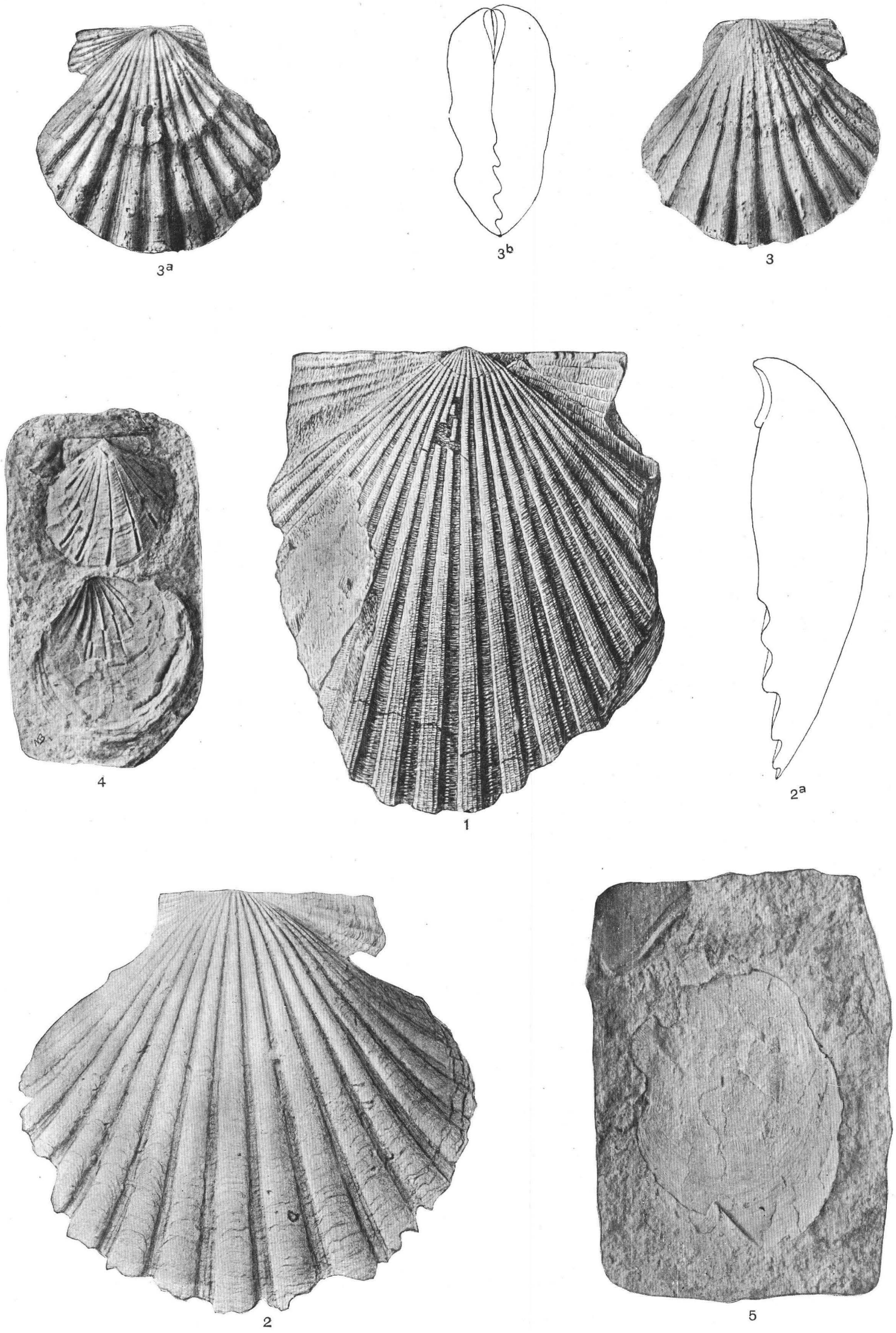

MIOCENE PECTENS. 


\section{PLATE XXIV. MIOCENE PECTENS.}

[Unless otherwise stated all figures are approximately natural size.]

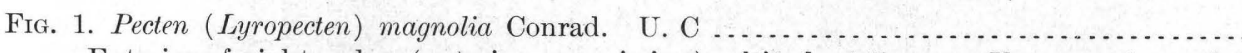

Exterior of right valve (anterior ear missing), altitude $145 \mathrm{~mm}$. Vaqueros formation (lower Miocene), Ojai ranch, Ventura County, Cal. (S.)

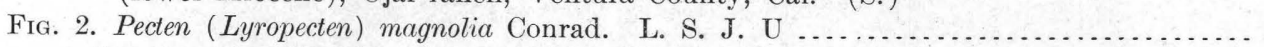

Exterior of umbonal region and ears; hinge line $95 \mathrm{~mm}$. Miocene (lower), between Morro and Toro creeks, San Luis Obispo County, Cal. 


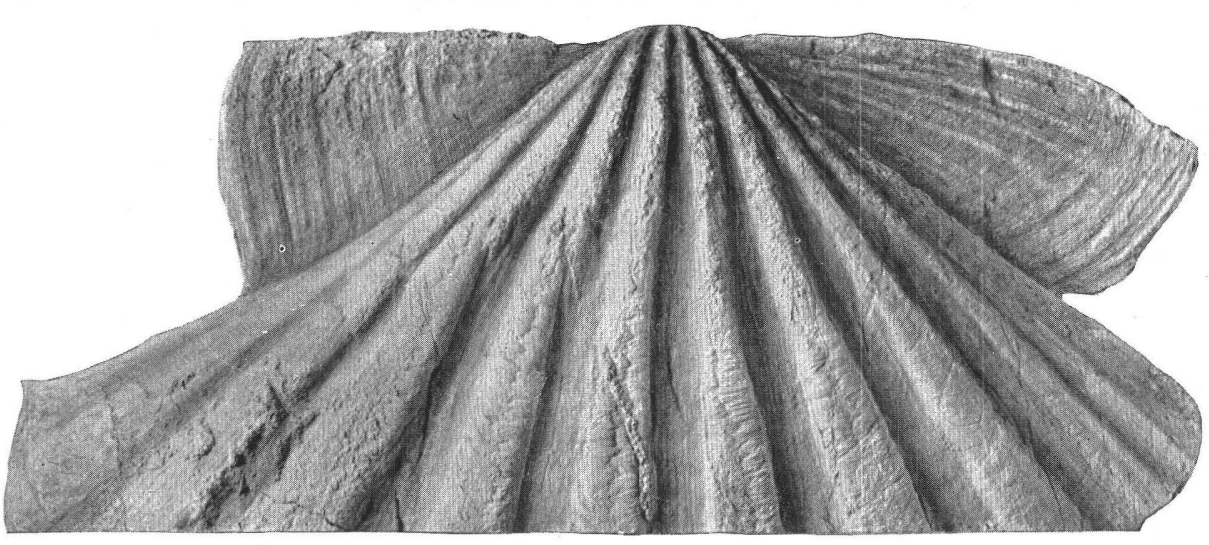

2

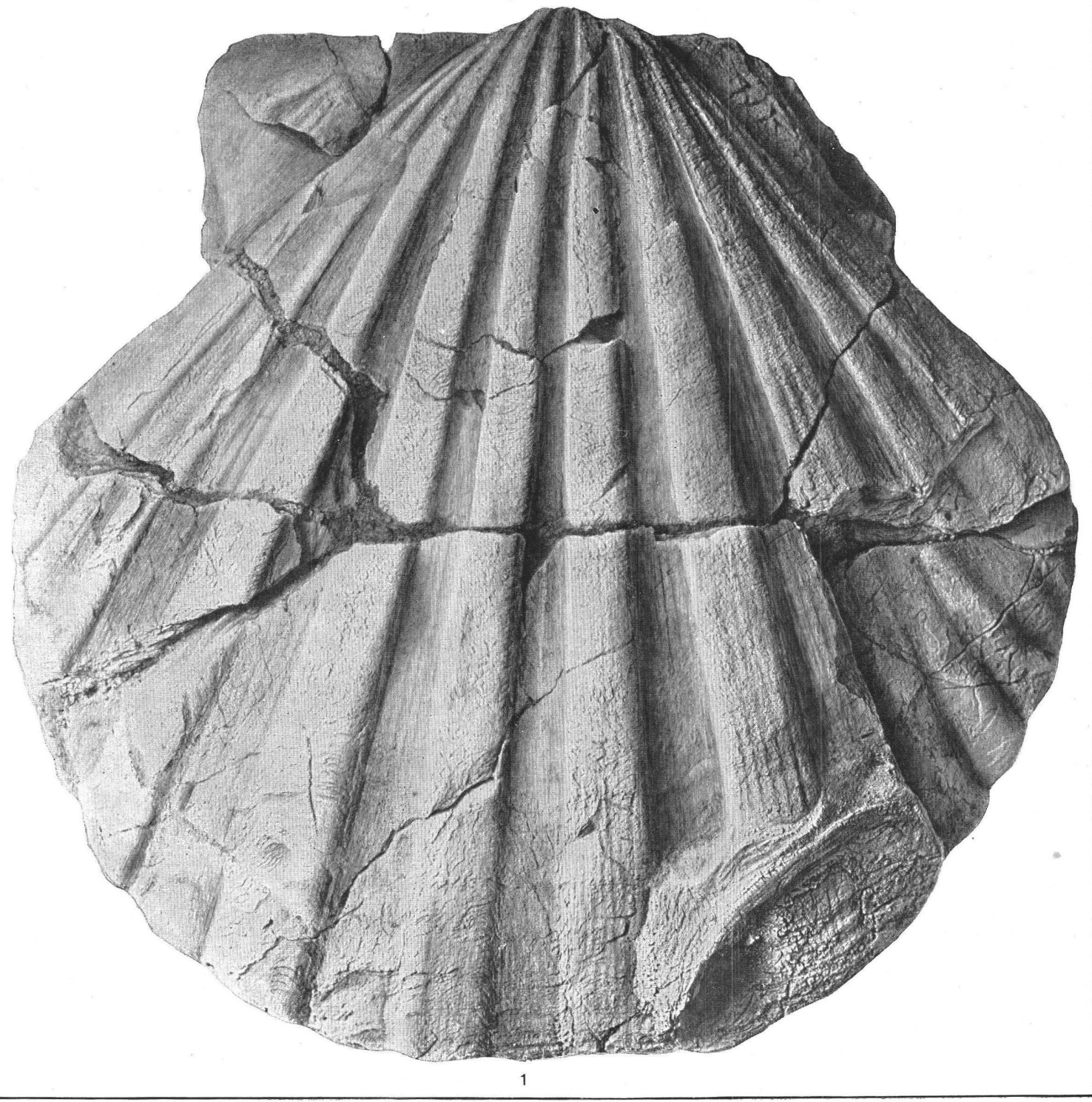

MIOCENE PECTENS. 


\section{PLATE XXV. MIOCENE PECTENS.}

[Unless otherwise stated all figures are approximately natural size.]

Page.

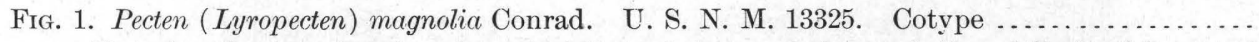
Exterior of valve, showing characteristic sculpture and shape of ribs; altitude of fragment $130 \mathrm{~mm}$. Vaqueros formation (lower Miocene), Santa Inez Mountains, Santa Barbara County, Cal. (M. B.)

Fig. 2. Pecten (Plagioctenium) cerrosensis Gabb var. mendenhalli n. var. U. S. N. M. 164849.

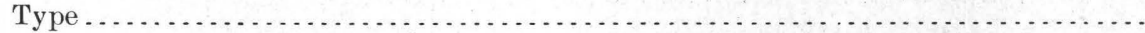
Exterior of right valve; altitude $43 \mathrm{~mm}$. Miocene, Santa Rosalia, Lower California. (M. B. )

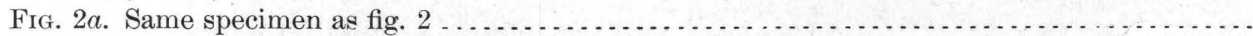
Exterior of left valve. (M. B.)

Fig. 2b. Same specimen as fig 2

Profile of both valves, viewed from the rear. (M. P.)

Fig. 3. Pecten (Plagioctenium) eldridgei n. sp. U. S. N. M. 164850. Type ...............................

Exterior of left valve; altitude $20 \mathrm{~mm}$. San Pablo formation (upper Miocene), McKittrick district, Kern County, Cal. (M. P.)

Fıg. 3a. Same specimen as fig. 3

View of interior of left valve. (M. P.)

Fig. $3 b$. Same specimen as fig. 3 .

Profile of left valve, viewed from rear, showing great convexity. (M. P.)

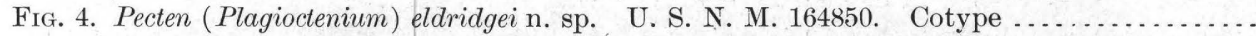

Exterior of right valve (anterior ear slightly broken); altitude $17 \mathrm{~mm}$. Same locality as fig. 3. (M. P.)

FIG. $4 a$. Same specimen as fig. 4

Profile of right valve as viewed from the rear. (M. P.)

Fig. 5. Pecten (Plagioctenium) eldridgei n. sp. U. S. N. M. 164850. Cotype

Exterior of right valve (anterior (M. P.)

Fig. 5a. Same specimen as fig. 5 .

Profile of right valve as viewed from the rear. (M. P.)

Fig. 6. Pecten (Plagioctenium) eldridgei n. sp. U. S. N. M. 164850.

Exterior of fragment of a large valve of this species. Same locality as fig. 3. (M. P.) 


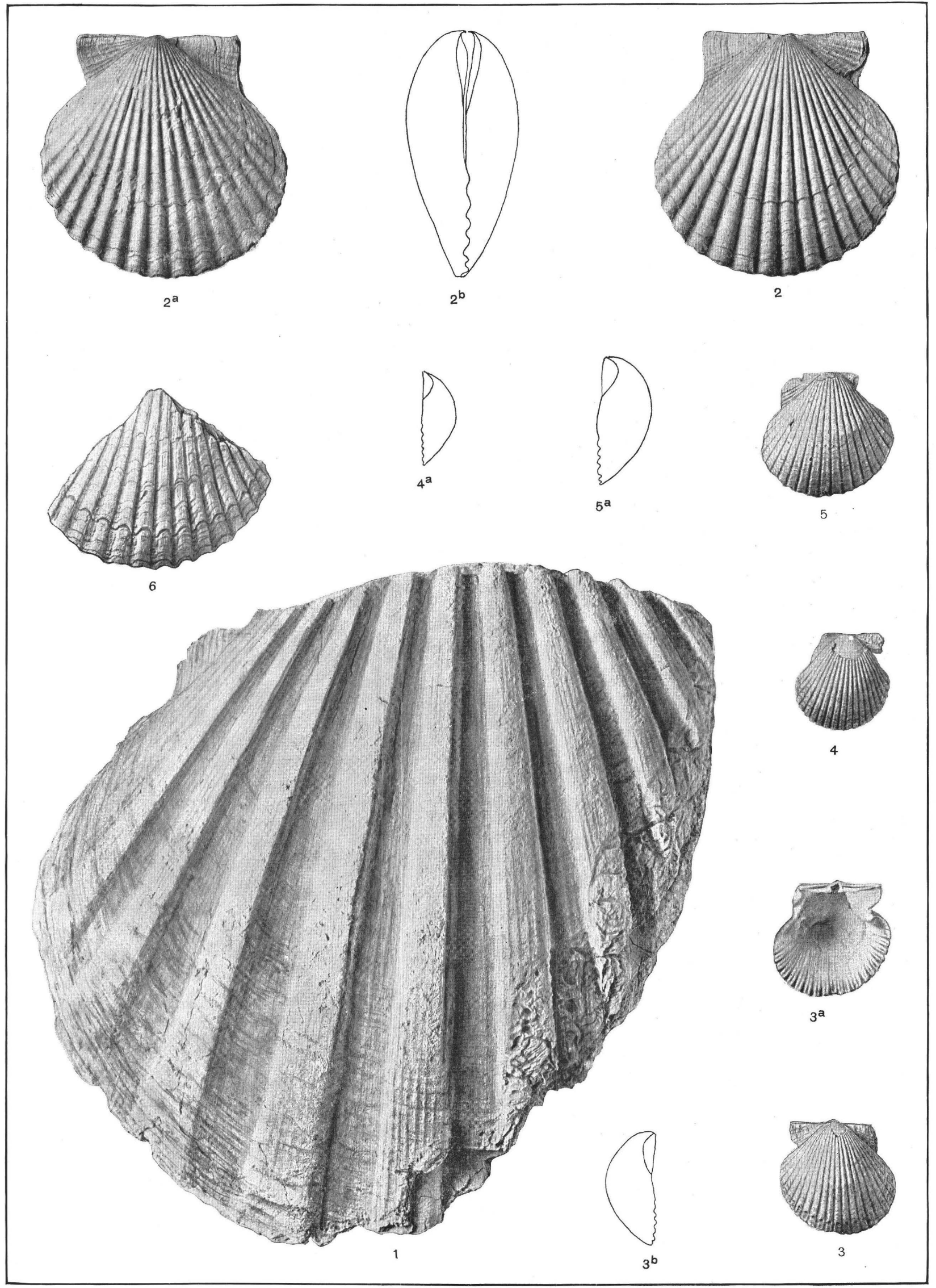

MIOCENE PECTENS. 


\section{P L A T E X X I. MIOCENE PECTENS.}

[Unless otherwise stated all figures are approximately natural size.]

Page.

Exterior of slightly worn right valve; altitude $35 \mathrm{~mm}$. Miocene, Carrizo Creek district, San Diego County, Cal. (M. B.)

Fig. 2. Pecten (Plagioctenium) deserti Conrad. D. A . . . . . . . . . . . . . . . . . . . . . . . .

Exterior of slightly imperfect right valve; altitude $40 \mathrm{~mm}$. Same locality as for fig. 1. (S.)

FIG. 2a. Same specimen as fig. 2

Profile of a somewhat unusually convex right valve as viewed from the rear. (M. P.)

Fic. 3. Pecten (Plagioctenium) deserti Conrad. D. A . . . . . . . . . . . . . . . . . . . . .

Exterior of a slightly imperfect left valve; altitude $34 \mathrm{~mm}$. Same locality as for fig. 1. (S.)

Fic. 4. Pecten (Plagioctenium) deserti Conrad. D. A . . . . . . . . . . . . . . . . . . . . .

Exterior of left valve; altitude $37 \mathrm{~mm}$. Same locality as for fig. 1. (M. B.)

Fig. $4 a$. Same specimen as fig. 4.

Profile of left valve as viewed from the rear. (M. P.)

Fig. 5. Pecten (Plagioctenium) andersoni n. sp. U. S. N. M. 164932. Type.

Mold of interior of left valve with portion of exterior showing sculpture; altitude $38 \mathrm{~mm}$. Miocene, Zayante Creek, Santa Cruz County, Cal. (M. P.)

Fig. 5a. Same specimen as fig.

Profile of left valve as viewed from the rear. (M. P.)

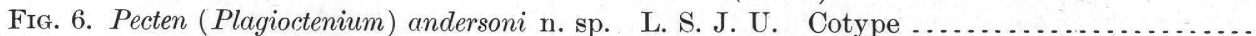

Exterior of left valve; altitude $14 \mathrm{~mm} ., \times 2$. Miocene, Frenchman's Tower, near Stanford University, Santa Clara County, Cal. (M. B.)

Fig. 7. Pecten (Plagioctenium) andersoni n. sp. U. S. N. M. 164932. Cotype ...............

Exterior of right valve (anterior ear broken); altitude $20 \mathrm{~mm}$. Same locality as fig. 5. (M. P.)

Fig. 8. Pecten (Plagioctenium) andersoni n. sp. L. S. J. U. Cotype

Mold of interior of in ear; altitude $30 \mathrm{~mm}$. Vaqueros formation (lower Miocene), Searsville road, near Stanford University, Santa Clara County, Cal. (M. B.)

Fig. $8 a$. Same specimen as fig. 8

Profile of right valve as viewed from the rear. (M. P.)

Fig. 9. Pecten (Plagioctenium) andersoni var. barkerianus n. sp. and var. C. A. S. Type..... Imperfect mold of interior of right valve showing portion of exterior, with sculpture; altitude 41 mm. Lower Miocene, Barker's ranch, Kern County, Cal. (S.) 


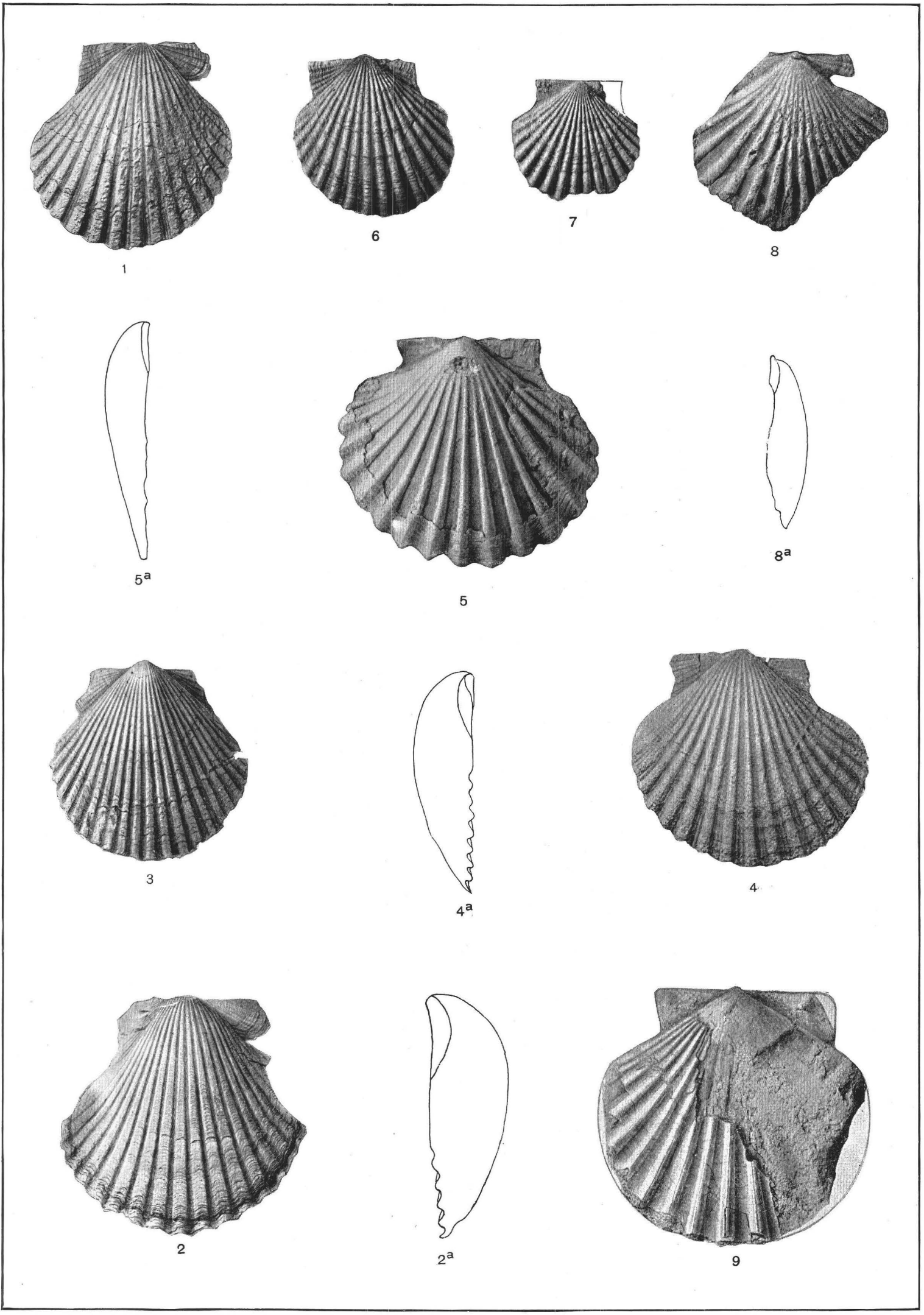

MIOCENE PECTENS. 


\section{P L A T E X X V I .}

\section{MIOCENE PECTENS.}

[Unless otherwise stated all figures are approximately natural size.]

Page.

86

FIG. 1. Pecten (Plagioctenium) discus Conrad. U. C.

Exterior of left valve (anterior ear slightly broken); altitude $46 \mathrm{~mm}$. Miocene (upper), Walnut Creek, Contra Costa County, Cal. (S.)

Fig. 1a. Same specimen as fig. 1..

Profile of left valve as viewed from the rear. (M. P.)

Fig. 2. Pecten (Plagioctenium) discus Comrad. U. S. N. M. 138.

Copied from a drawing by Doctor McConnell of a slightly contorted of a left valve; altitude $47 \mathrm{~mm}$. Miocene, Ventura County, Cal.

Fig. 3. Pecten (Plagioctenium) discus Conrad. L. S. J. U. Wax cast of exterior of right valve; altitude $30 \mathrm{~mm}$. Miocene, Santa Maria, Santa Barbara County, Cal. (M. P.)

Fig. 4. Pecten (Plagioctenium) discus Conrad. D. A.

Mold of exterior of imperfect right valve; linge and Little Morro creeks, San Luis Obispo County, Cal. (M. B.)

Fig. 5. Pecten (Plagioctenium) pabloensis Conrad. D. A.

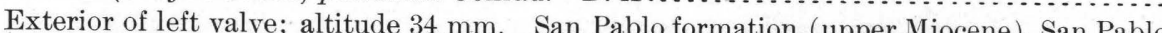
Bay, Contra Costa County, Cal. (M. P.)

Fig. $5 a$. Same specimen as fig. 5

Profile of left valve as viewed from the rear. (M. P.)

FIG. 6. Pecten (Plagioctenium) pabloensis Conrad. D. A.

Exterior of imperfect right valve; altitude $32 \mathrm{~mm}$. Same locality as fig. 5. (M. P.)

Fig. $6 a$. Same specimen as fig. 6

Profile of right valve as viewed from the rear. (M. P.)

Fig. 7. Pecten (Plaginctenium) publoensis Conrad.

Exíerior of right valve of a young specimen, showing prominence of ribs near umbo altitude $24 \mathrm{~mm}$. Same locality as fig. 5. (M. P.)

FIG. 8. Pecten (Pseudamusium) lompicoensis n. sp. U. S. N. M. 164931. Type Mold of exterior of right (type) and left valves and imperfect cast of exterior of right valve; altitude of mold of right valve, $11.5 \mathrm{~mm}$., $\times 3$. Miocene shale, head of Lompico Creek, Santa Cruz County, Cal. (M. B. )
86 

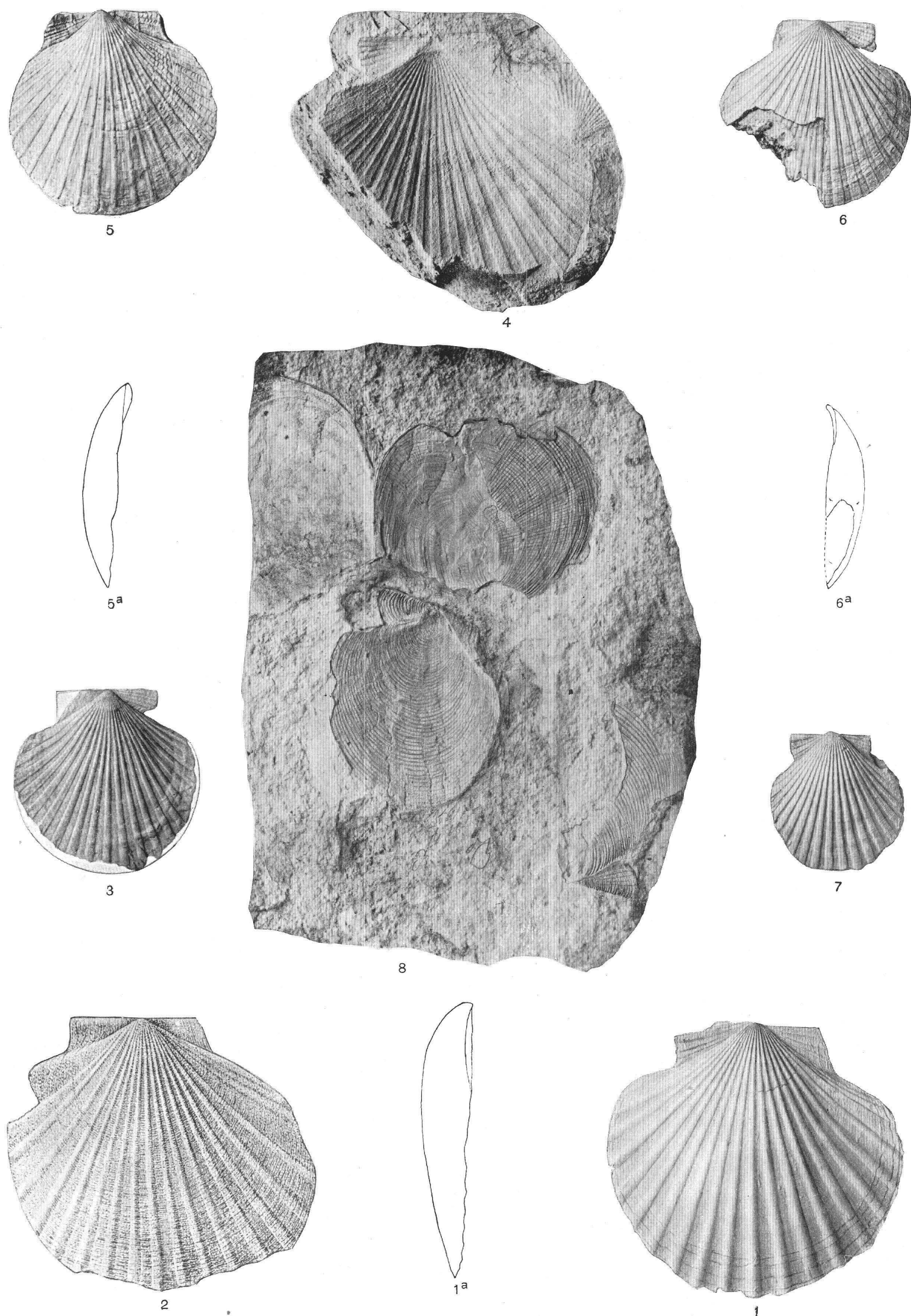

MIOCENE PECTENS. 


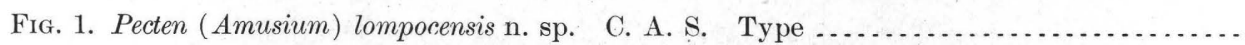

Mold of interior of left valve: altitude $105 \mathrm{~mm}$. Miocene, 4 miles south of Lompoc, Santa Barbara County, Cal. (M. B.)

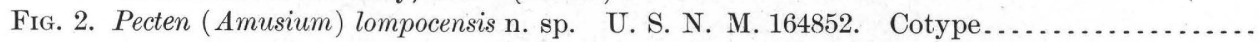
Interior of a portion of a left valve; altitude $90 \mathrm{~mm}$. Miocene (lower), Ojai Valley, Ventura County, Cal. (M. B.)

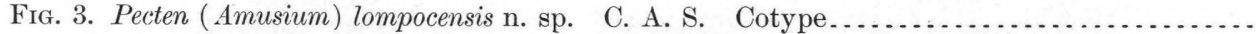

Imperfect mold of interior of right valve; hinge line $42 \mathrm{~mm}$. Same locality as fig. 1. (M. B. )

Fig. 4. Pecten (Pseudamusium) pedroanus Trask. U. S. N. M. 164840.

Exterior of imperfect left valve; altitude $30 \mathrm{~mm}$. Tower Plioc Los Angeles, Cal. (M. B.)

FIg. 5. Pecten (Pseudamusium) pedroanus Trask. U. S. N. M. 164840

Exterior of right valye and young left valve; altitude of former fig 4. (M. B.)

200 


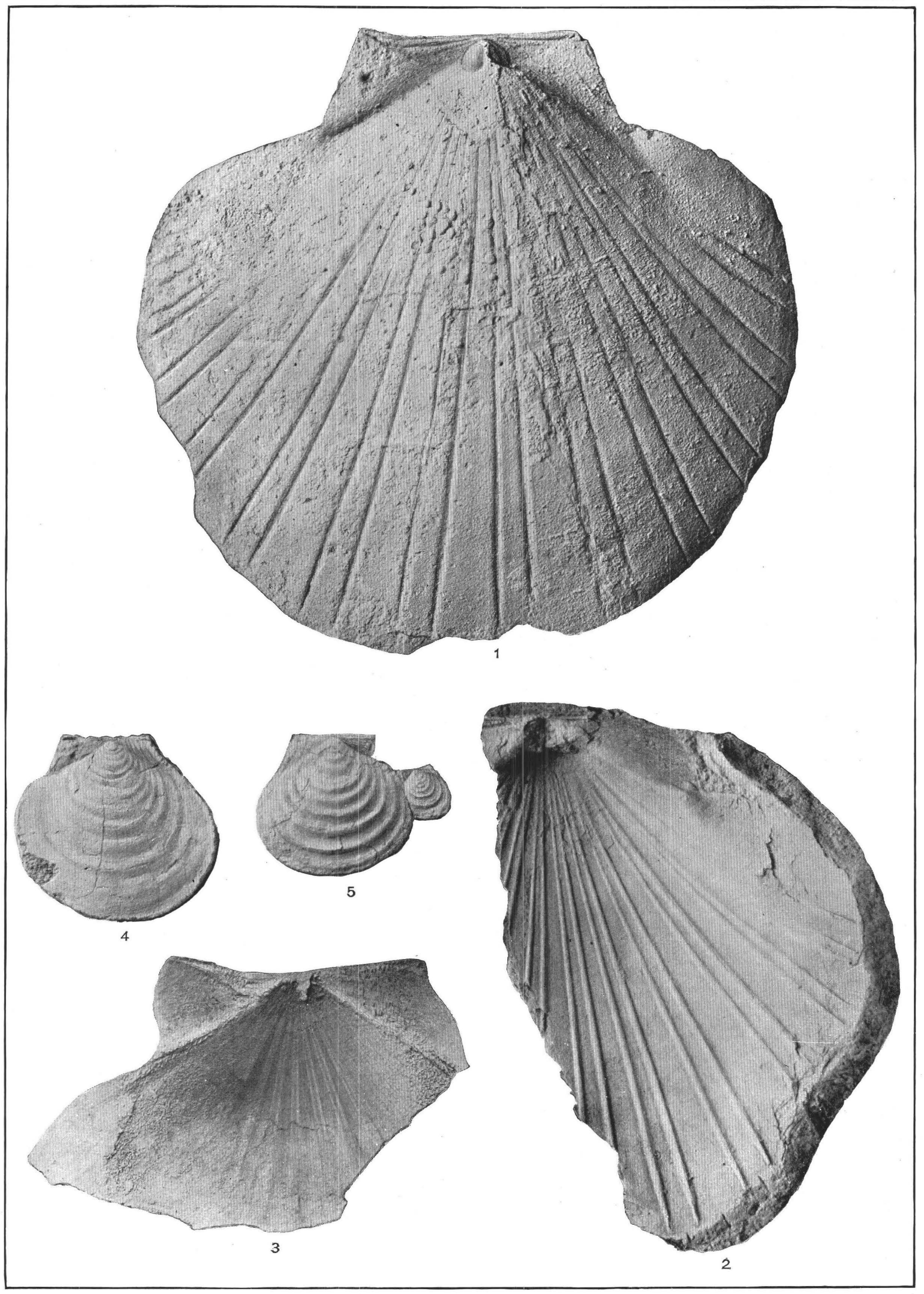

MIOCENE AND PLIOCENE PECTENS. 


\section{PLA TE XXIX.}

MIOCENE, PLIOCENE, AND、QUATERNARY PECTENS.

[Unless otherwise stated all figures are approximately natural size.]

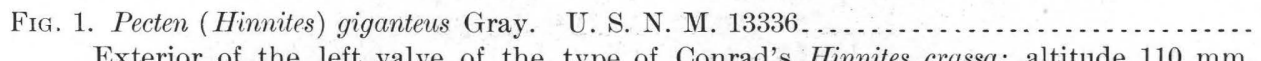

Exterior of the left valve of the type of Conrad's Hinnites crassa; altitude $110 \mathrm{~mm}$.

Santa Margarita formation (upper Miocene), Santa Margarita, San Luis Obispo County, Cal. (M. B. )

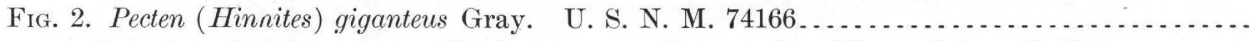
Exterior of right valve; altitude $70 \mathrm{~mm}$. Recent, San Diego, Cal. (M. B.)

Fig. $2 a$. Same specimen as fig. 2 .

Exterior of left valve. (M. B.) 

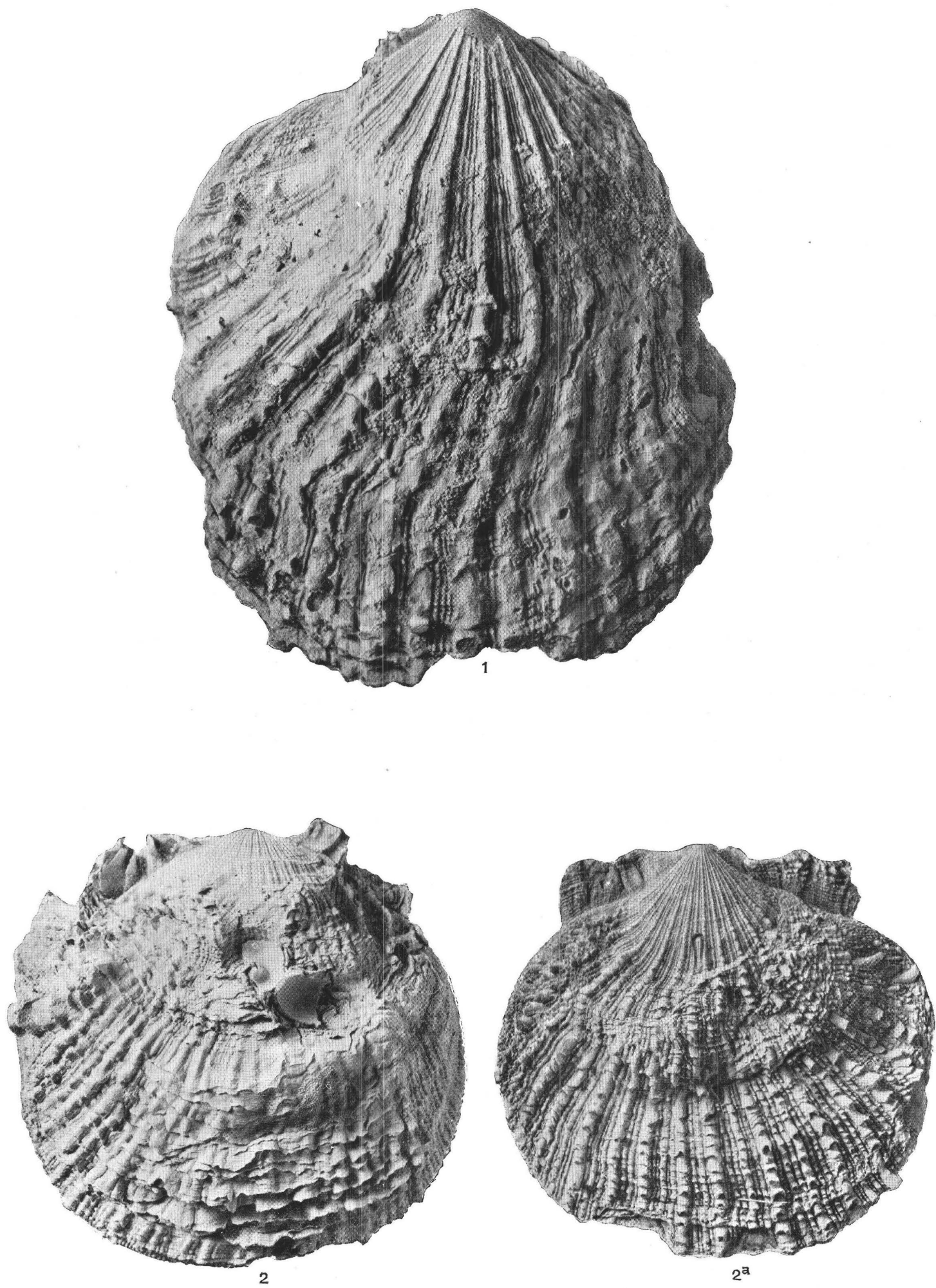

MIOCENE, PLIOCENE, AND QUATERNARY PECTENS. 


\section{P L A T E X X X. PLIOCENE PECTENS.}

[Unless otherwise stated all figures are approximately natural size.]

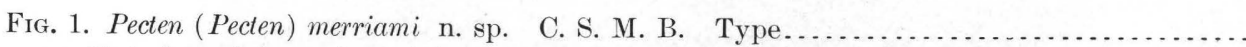

Exterior of imperfect right valve; altitude $120 \mathrm{~mm}$. Pliocene, Piru Creek, Ventura County, Cal. (M. B.)

FIG. 1a. Same specimen as fig. 1. Profile of both valves as viewed from the rear. (M. P.)....

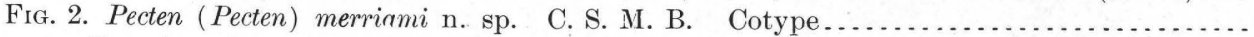

Exterior of imperfect left valve, altitude $110 \mathrm{~mm}$. Same locality as fig. 1. (M. B.)

204 


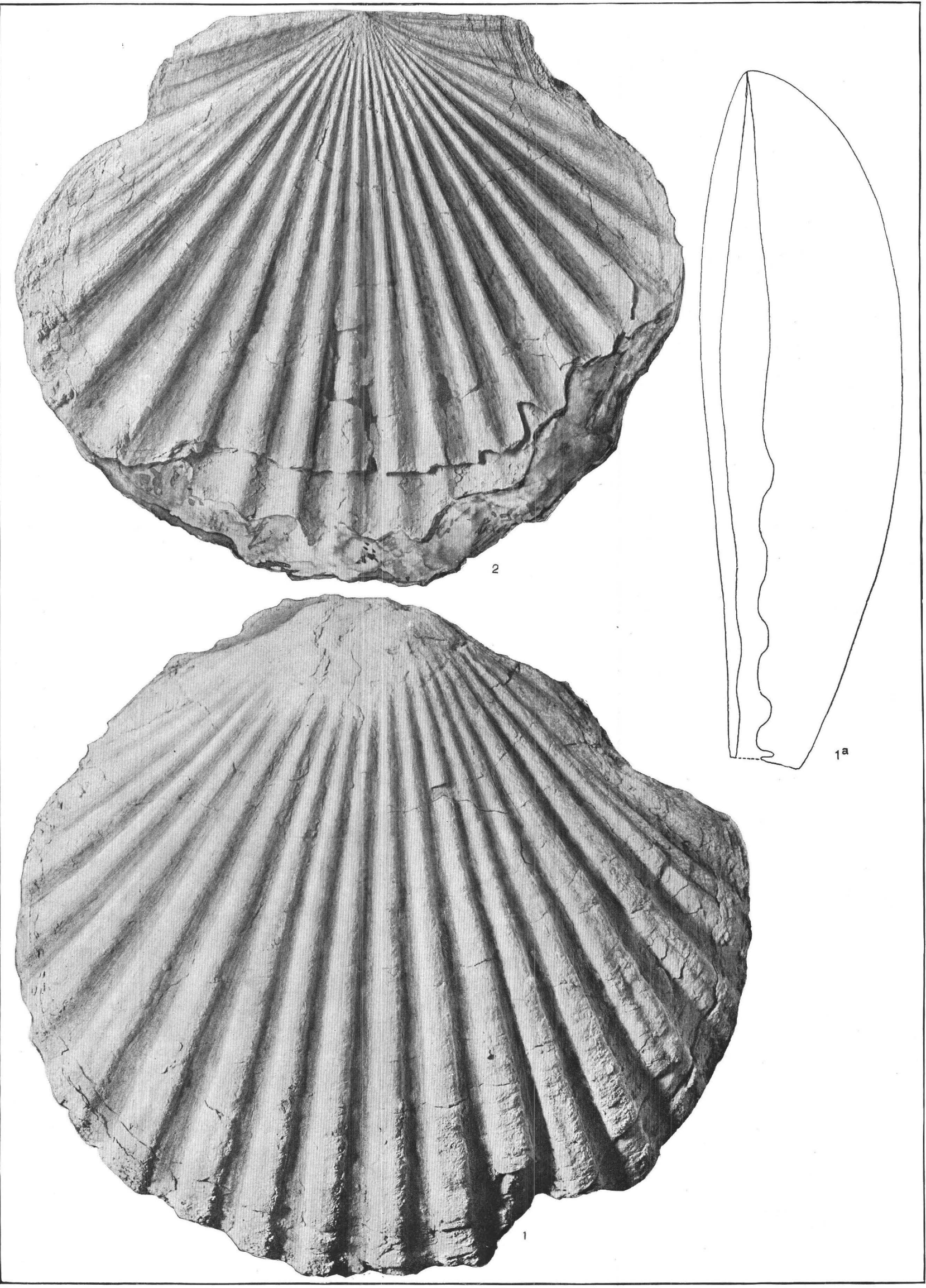

PLIOCENE PECTENS. 


\section{PLATE XXXI. PLIOCENE PECTENS.}

[Unless otherwise stated all figures are approximately natural size. The light in these two figures comes from the right-hand side. Photographs by Ralph Arnold.]

Page.

Fig. 1. Pecten (Pecten) bellus Conrad. A. N. S., Phila., 960.

Exterior of right valve of Gabb's Janira bella; altitude $80 \mathrm{~mm} ., \times 5 / 4$. Pliocene, Santa Barbara, Cal.

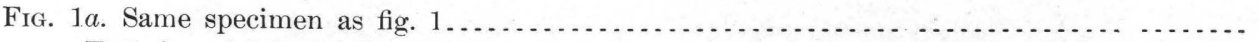

Exterior of left valve, $\times 5 / 4$. 

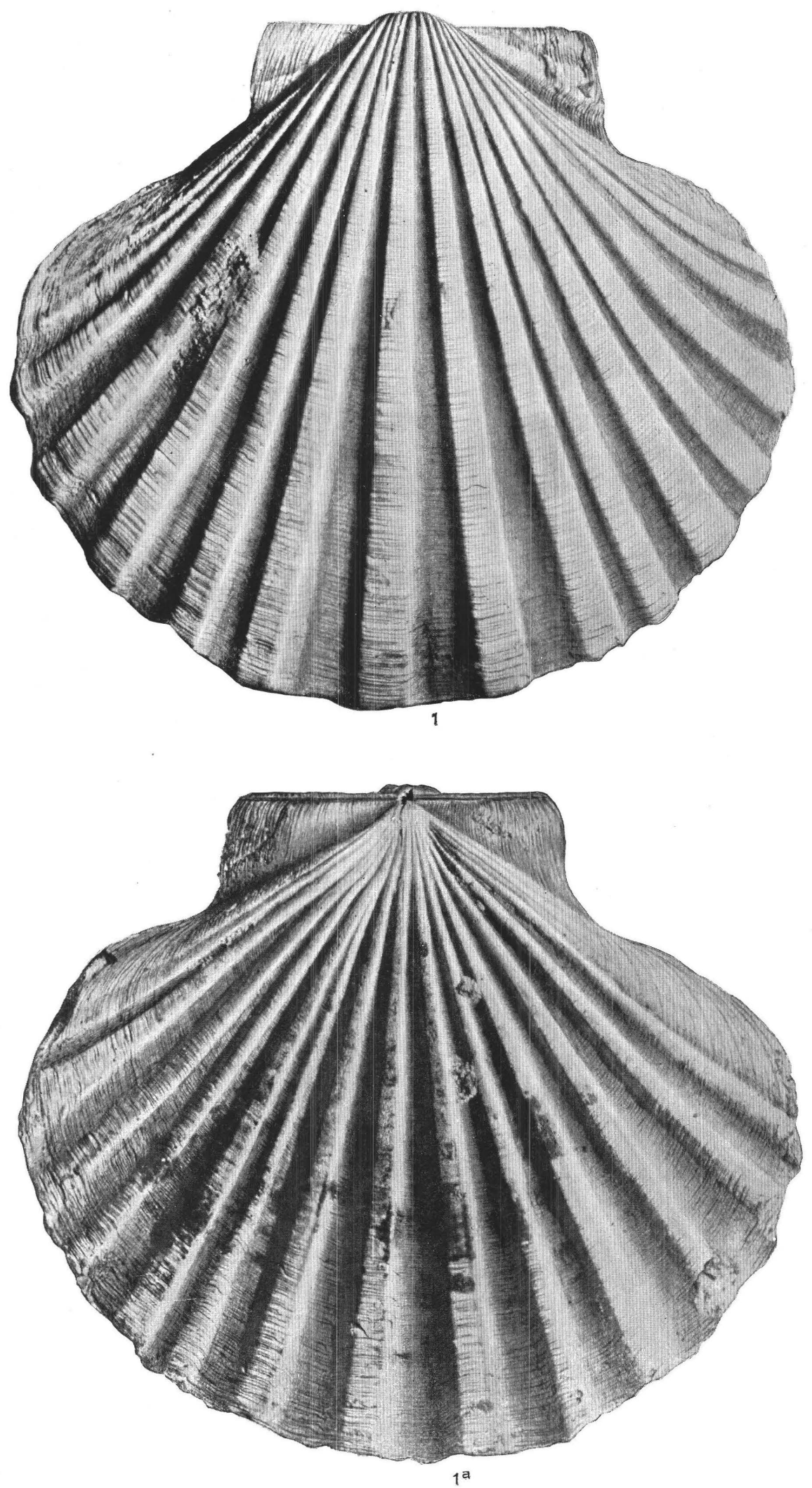

PLIOCENE PECTENS. 


\section{PLATE XXXII.}

\section{PLIOCENE PECTENS.}

[Unless otherwise stated all figures are approximately natural size.]

Fig. 1. Pecten (Pecten) stearnsii Dall. U. S. N. M. 148008 .

Exterior of right valve; altitude $87 \mathrm{~mm}$. San Diego formation (Pliocene), Pacific Beach, San Diego County, Cal. (M. B.)

FIG. 1a. Same specimen as fig. 1 . . . .

Exterior of left valve. (M. B.)

208 


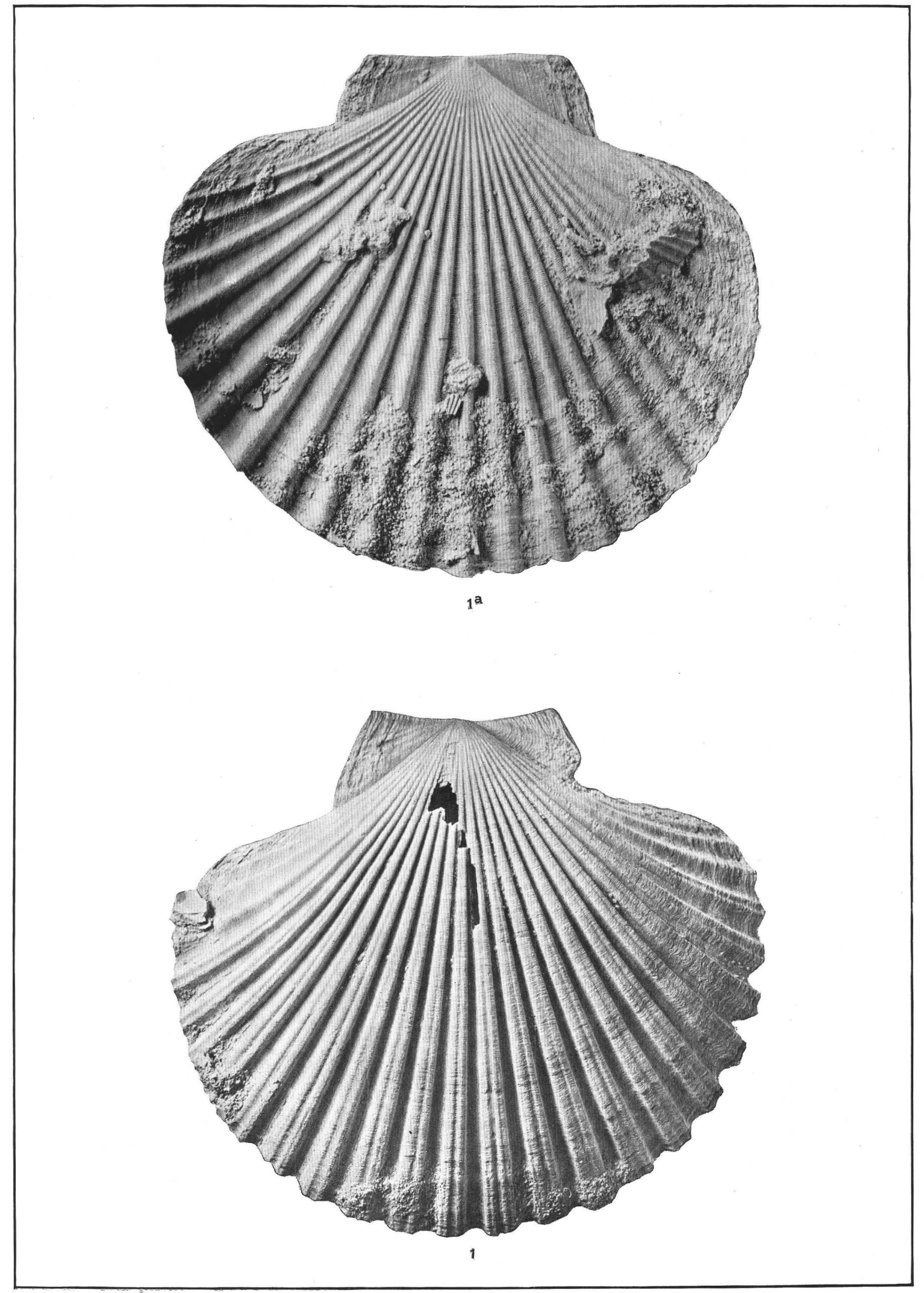

PLIOCENE PECTENS. 


\section{PLATE XXXIII.}

PLIOCENE AND PLEISTOCENE PECTENS.

[Unless otherwise stated all figures are approximately natural size.]

Fig. 1. Pecten (Pecten) vogdesi n. sp. D. A. Type

Exterior of imperfect right valve; altitude $68 \mathrm{~mm}$. San Pedro formation (Pleistocene), San Pedro, Los Angeles County, Cal. (M. P.)

Fig. 1a. Same specimen as fig. $1 .$.

Profile of right valve as viewed from the rear. (M. P.)

Fig. 2. Pecten (Pecten) auburyi n. sp. C. S. M. B. Type.

Exterior of imperfect right valve; altitude $46 \mathrm{mym}$ County, Cal. (S.)

FIG. $2 a$. Same specimen as fig. $2 \ldots$

Profile of right valve as viewed from the rear. (M. P.)

Fig. 3. Pecten (Pecten) hemphilli Dall. U. S. N. M. 7943. Type...

Exterior of right valve; altitude $57 \mathrm{~mm}$. San Diego formation (Pliocene), Pacific Beach San Diego County, Cal. (M. P.)

FIG. $3 a$. Same specimen as fig. $3 . . . .$.

Exterior of left valve. (M. P.)

Fig. $3 b$. Same specimen as fig. 3

Profile of both valves as viewed from the rear. (M. P.)

FIG. 4. Pecten (Pecten) lecontei n. sp. D. A. Type.

Exterior of right valve; altitude $59 \mathrm{~mm}$. Pliocene, Cerros Island; of (M. B. )

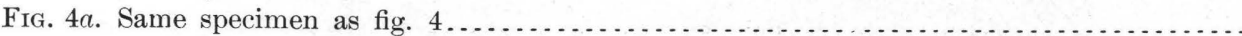

Exterior of left valve. (M. B.)

Fig. $4 b$. Same specimen as fig. 4 .

Profile of both valves as viewed from the rear. (M. P.) 


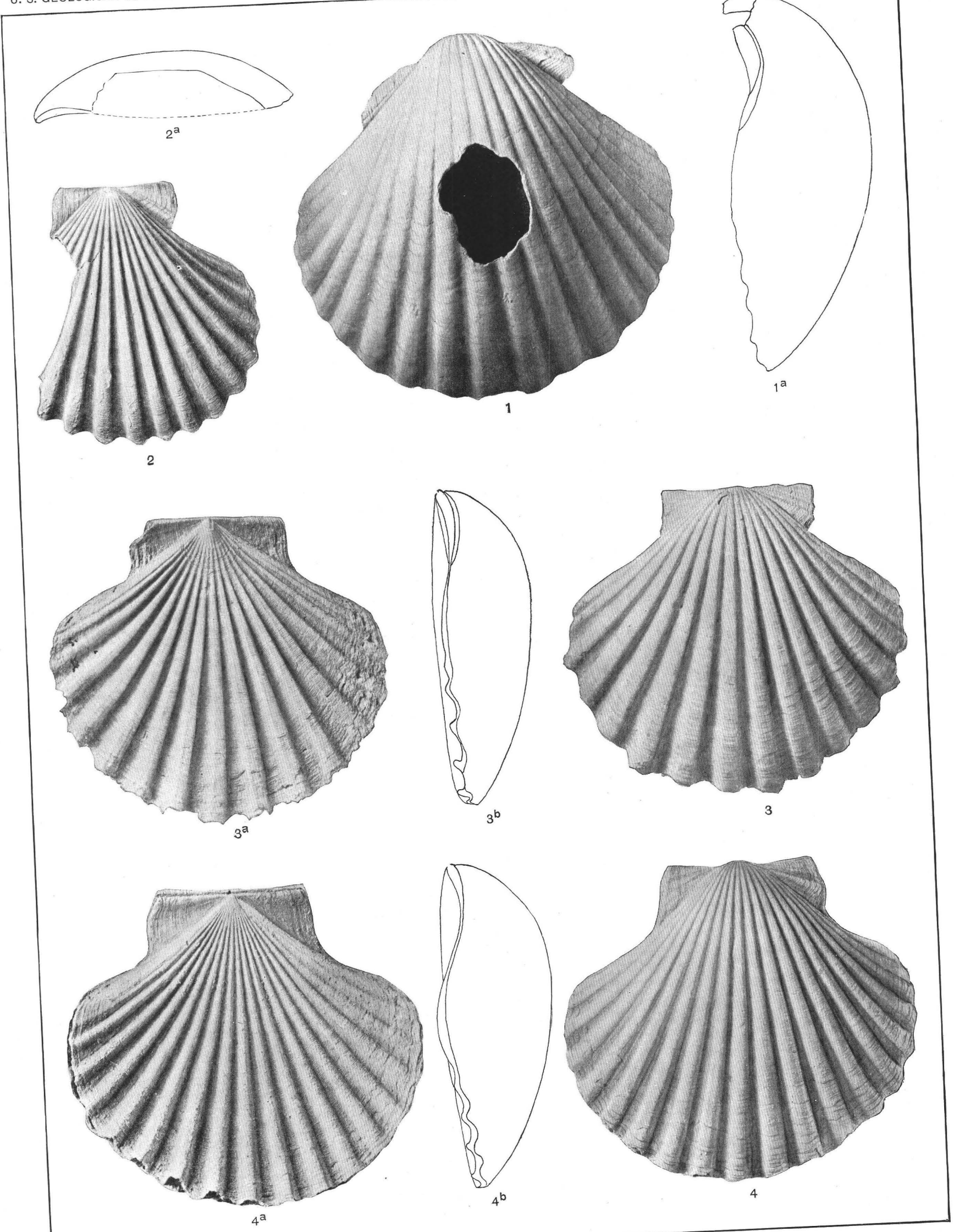

PLIOCENE AND PLEISTOCENE PECTENS. 


\section{PLA TE XXXIV. PLIOCENE AND PLEISTOCENE PECTENS.}

[Unless otherwise stated all figures are approximately natural size.]

FIG. 1. Pecten (Pecten) vogdesi n. sp. C. A. S. Cotype..

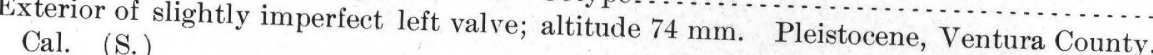

FIG. 2. Pecten (Pecten) auburyi n. sp. C. S. M. B. Cotype

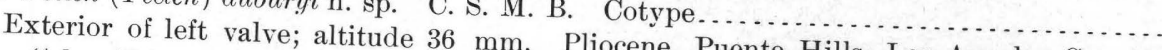

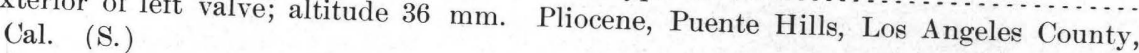

FIG. $2 a$. Same specimen as fig. 2

Profile of left valve as viewed from the rear. (M. P.)

Fig. 3. Pecten (Patinopecten) purisimaensis the rear. (M. P.)

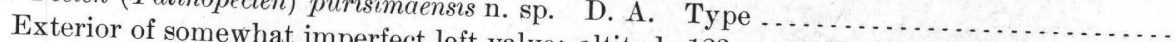
Pliocene), north of the mouth of valve; altitude $123 \mathrm{~mm}$. Purisima formation (lower FIG. 4. Pecten (Patinopecten) turrieri n. sp. L. S. J. U. Cotype Mateo County, Cal. (M. B.) Exterior of a portion of the disk of L. S. J. U. Cotype Cal.

Pliocene, Tomales Bay, Marin County 


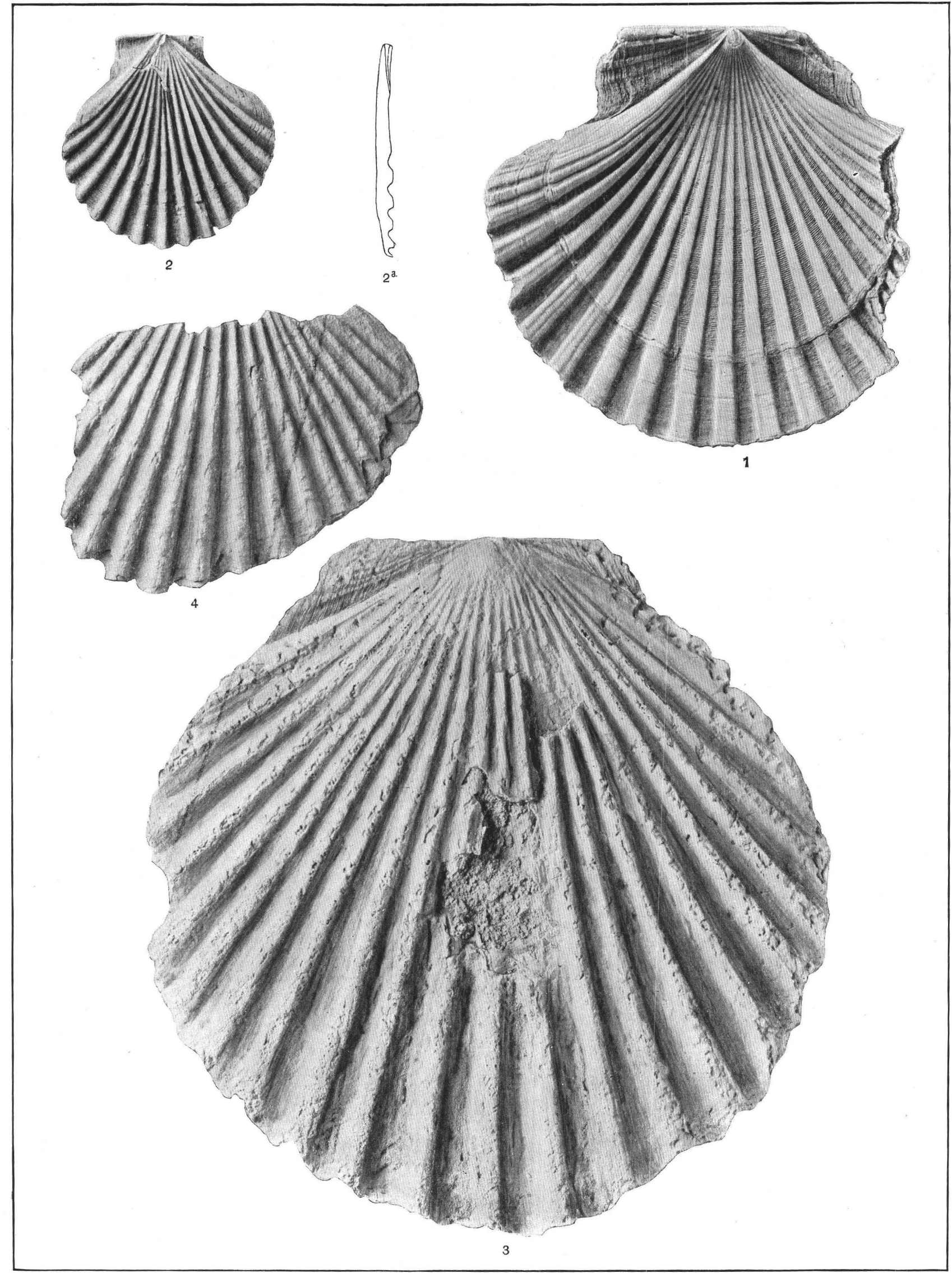

PLIOCENE AND PLEISTOCENE PECTENS. 


\section{PLA TE XXXV. PLIOCENE PECTENS.}

[Unless otherwise stated all figures are approximately natural size.]

FIG. 1. Pecten (Patinopecten) purisimaensis n. sp. D. A Type Page.

Exterior of a slightly imperfect right valve; altitude $123 \mathrm{~mm}$. Purisima formation (lower Pliocene), north of the mouth of Pescadero Creek, San Mateo County, Cal.
(M. B. ) FIG. 1a. Same specimen as fig. 1

Profile of both valves as viewed from the

Fig. 2. Perten (Patinopecten) as viewed from the rear. (M. P.)

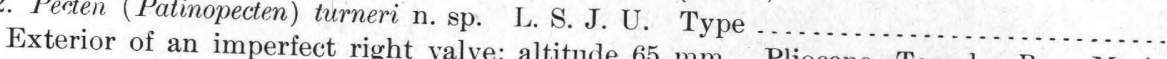
County, Cal. (M. B ) Pliocene, Tomales Bay, Marin

Pecter (M. B.)

Fig. 3. Pecten (Patinopecten) turneri n. sp. L. S. J. U. Cotype

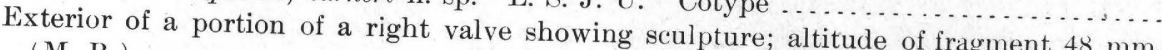
(M. B. ) 

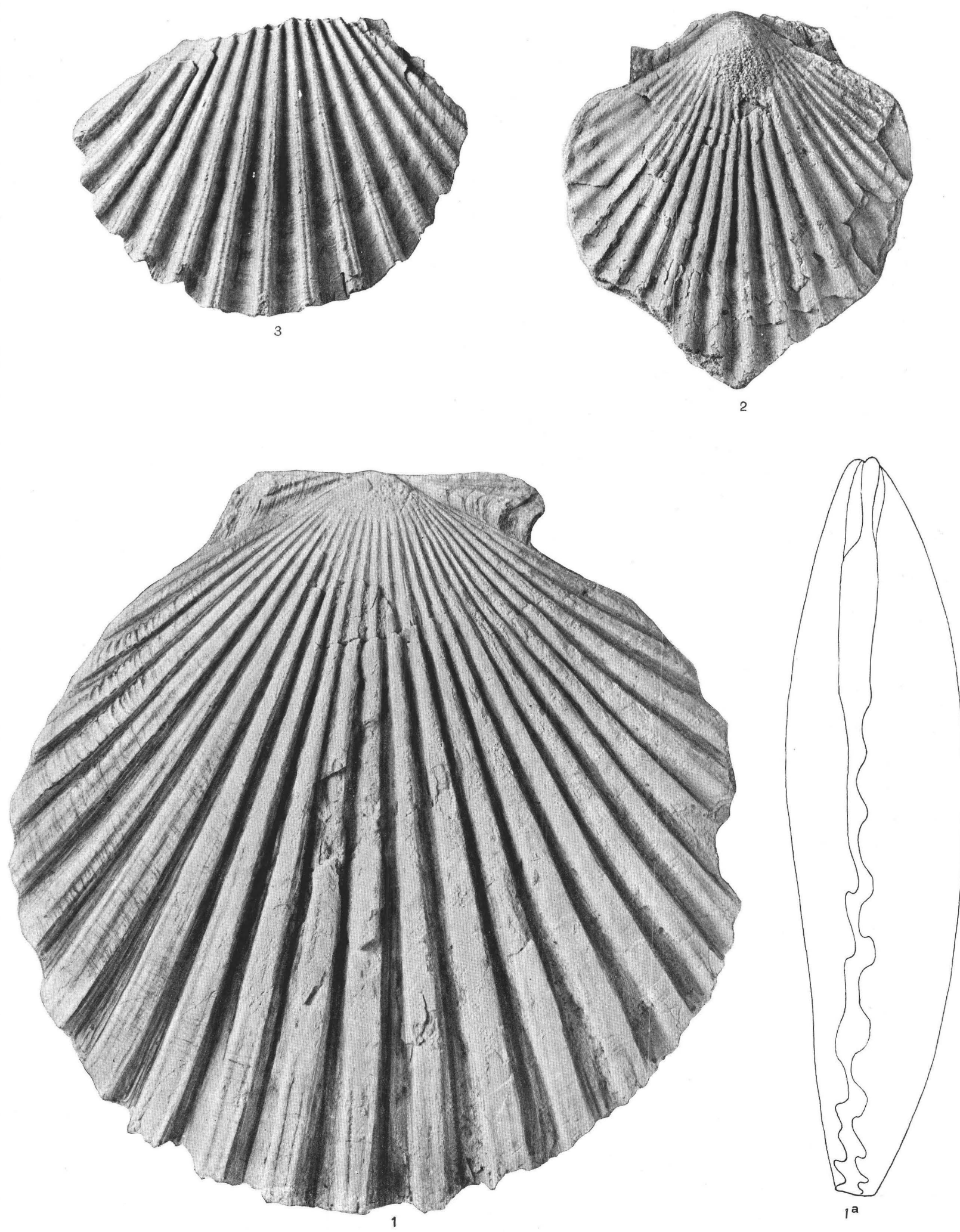

PLIOCENE PECTENS. 


\section{PLATE XXXVI.}

PLIOCENE PECTENS.

[Unless otherwise stated all figures are approximately natural size.]

FIG. 1. Pecten (Patinopecten) healeyi n. sp. U. S. N. M. 154162. Cotype

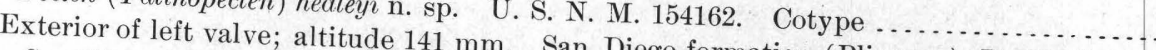

San Diego County, Cal. (M. B.) FIG. 1a. Same specimen

Profile of left valve, as viewed from the rear. (M. P.) 


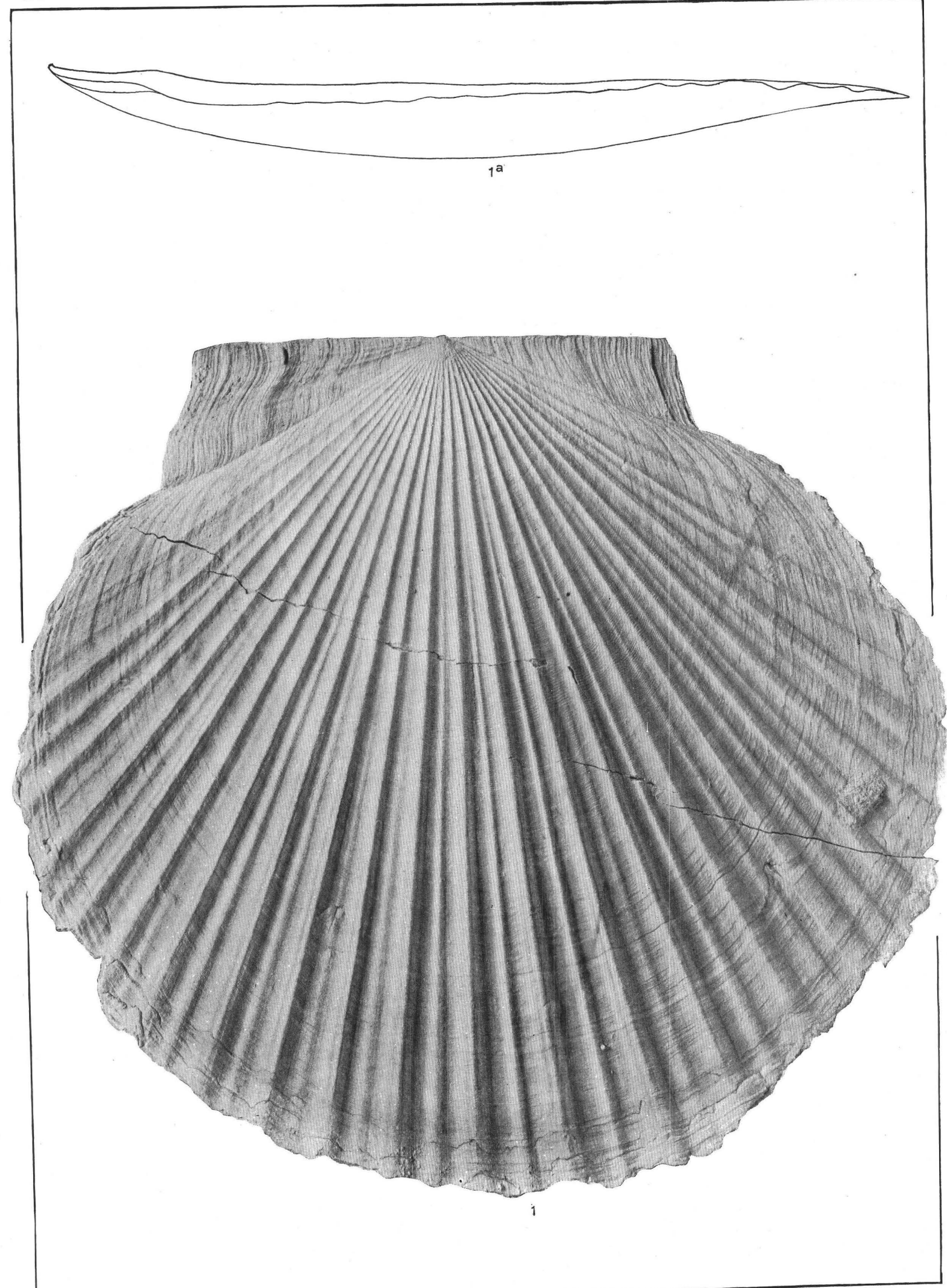

PLIOCENE PECTENS. 


\section{PLATE XXXVII.}

\section{PLIOCENE PECTENS.}

[Unless otherwise stated all figures are approximately natural size.]

FIG. 1. Pecten (Patinopecten) healeyi n. sp. U. S. N. M. 148012. Type.

Exterior of right valve; altitude $121 \mathrm{~mm}$. San Diego formation (Pliocene), San Diego County, Cal. (M. P.)

FIG. 1a. Same specimen as fig. 1

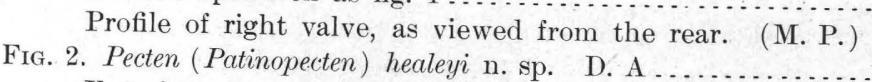

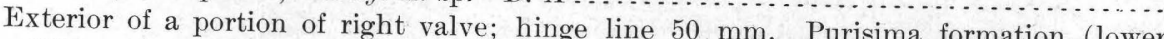
103 Pliocene), near San Gregorio, San Mateo County, Cal. (M. B.) 


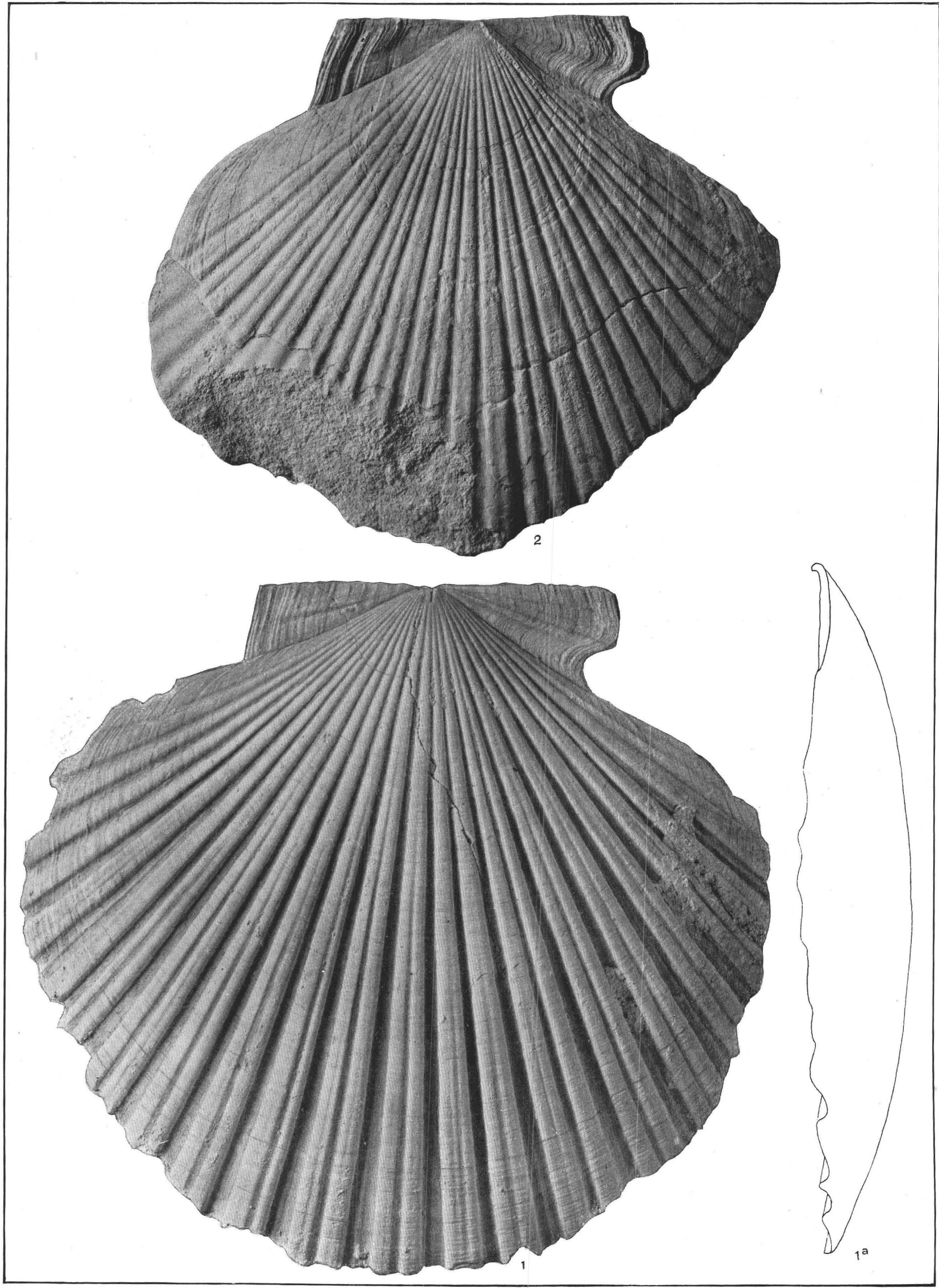

PLIOCENE PECTENS. 
PLA TE XXXVIII. PLIOCENE AND QUATERNARY PECTENS.

[Unless otherwise stated all figures are approximately natural size.]

FIg. 1. Pecten (Patinopecten) caurinus Gould.

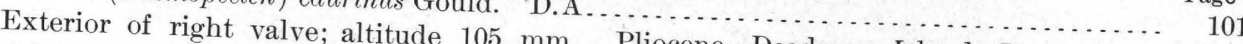
County, Cal. (M. B.) Fig. 1a. Same specimen as fig.

Exterior of left valve. (M. P.)

FIG. 1b. Same specimen as fig. 1 . 220 


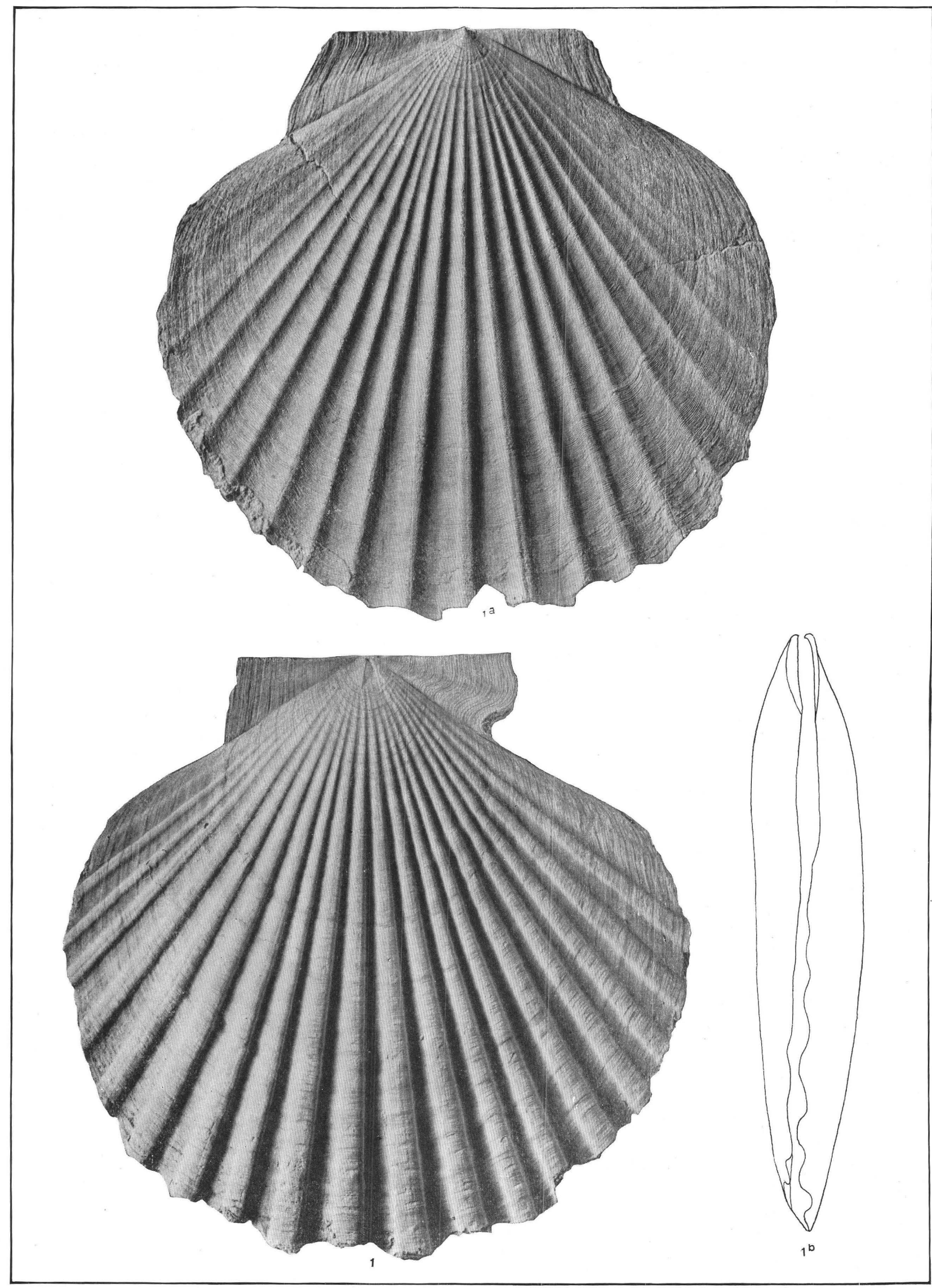

PLIOCENE AND QUATERNARY PECTENS. 


\section{P L A T E X X X I X. PLIOCENE AND QUATERNARY PECTENS.}

[Unless otherwise stated all figures are approximately natural size.]

FIG. 1. Pecten (Patinopecten) caurinus Gould. U. S. N. M. 13333 Fage.

Exterior of imperfect right valve of type of Conrad's Pecten meekii; aititude $154 \mathrm{~mm}$. Pliocene, San Raphael Hills; Santa Barbara County, Cal. (M. P.)

FIG. 2. Pecten (Patinopecten) caurinus Gould. A. N. S., Phila ................

Exterior of right valve of type of Conrad's Pecten Pliocene, Santa Barbara, Cal.

FIG. 3. Pecten (Plagioctenium) paucicostaturene, Panta Barbara, Cal. Py Ralph Arnold. (M. B.)

Exterior of right valve, anterior ear brenter. U. S. N. M. 15634b. Type .......... California rear broken off; altitude $32 \mathrm{~mm}$. Recent, Gulf of FIG. $3 a$. Same specimen as

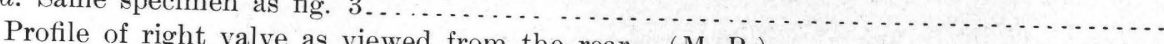

Pecten (Plagioctenium) pacicd

Exterior of left valve; altitude 35 Carpenter. U. S. N. M. 15634b. Cotype. terior of left valve; altitude $35 \mathrm{~mm}$. Same locality as fig. 3 . (M. P.) 

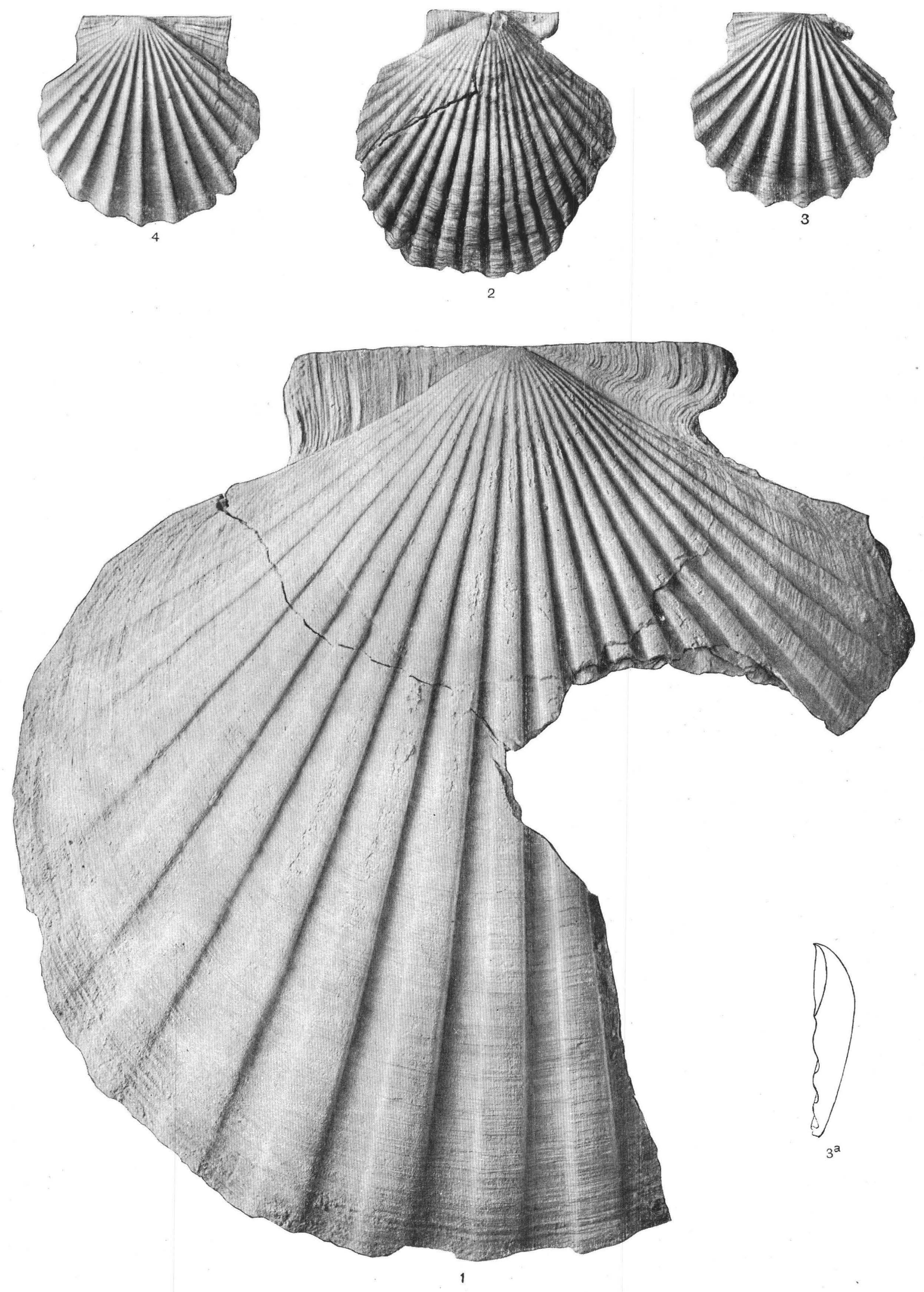

PLIOCENE AND QUATERNARY PECTENS. 


\section{P L A T E X L. \\ PLIOCENE PECTENS.}

[Unless otherwise stated all figures are approximately natural size. The light in these two figures comes from the right-hand side. Specimen not coated by Williams process. Photographs by Ralph Arnold.]

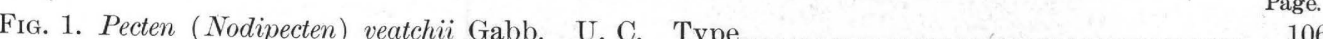

Exterior of right valve; altitude $130 \mathrm{~mm} ., \times \frac{11}{13}$. Pliocene, Cerros Island, off Lower California. (M. B.)

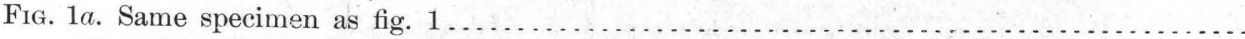

Exterior of left valve. (M. P.) 


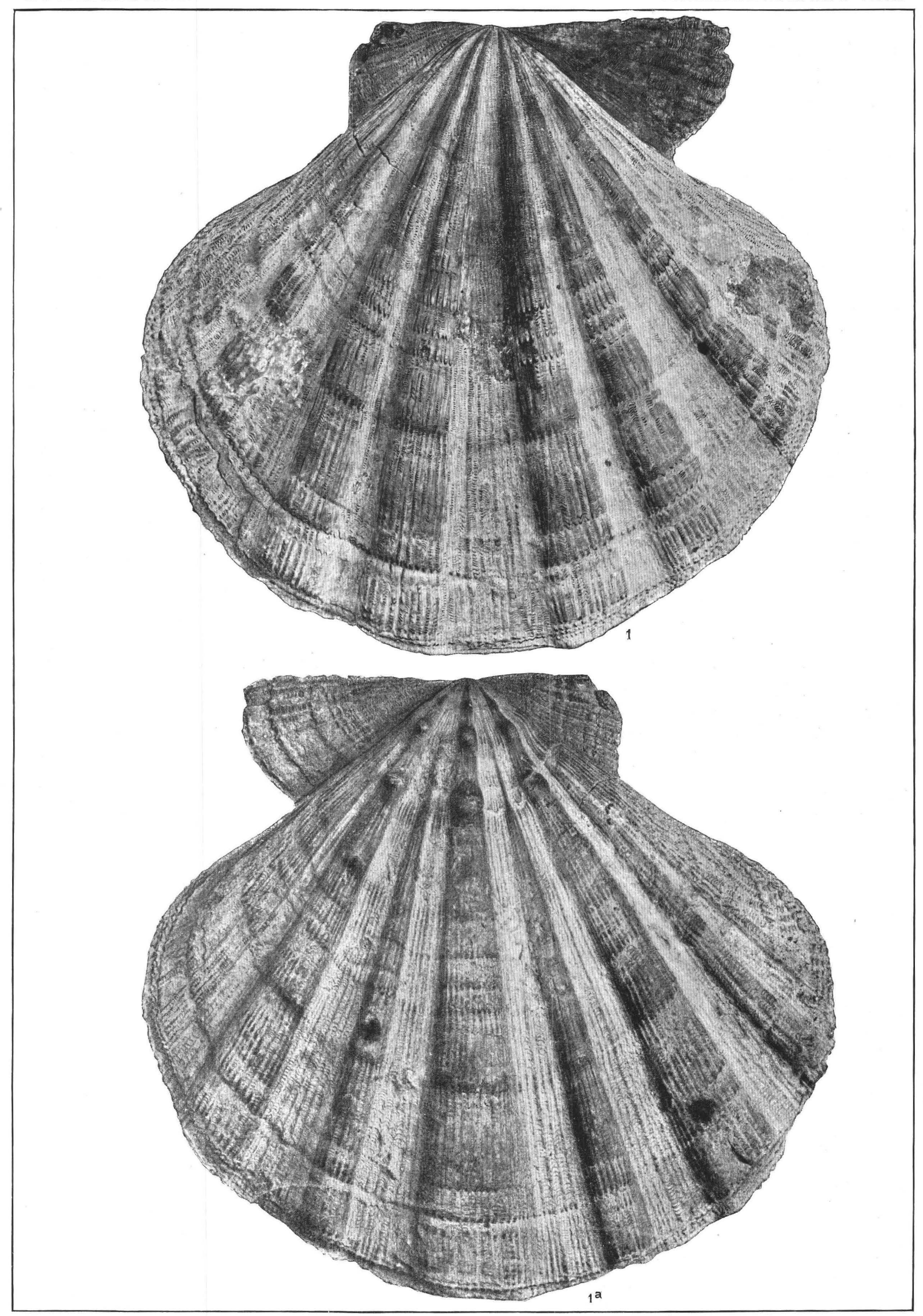

PLIOCENE PECTENS. 


\section{P L A T E X L T. PLIOCENE AND QUATERNARY PECTENS.}

Fig. 1. Pecten (Chlamys) parmeleei Dall. U. S. N. M. 154479. Type..................... . .

Copied from Doctor McConnell's drawing of left valve; altitude $45 \mathrm{~mm} ., \times 5 / 4$. (Trans. Wagner Free Inst. Sci., vol. 3, pt. 5, pl. 37, fig. 14.) San Diego formation (Pliocene), Pacific Beach, San Diego County, Cal.

Fig. 1a. Same specimen as fig. 1 . . . . . . . . . . . . . . . . . . . . . . . . . . . . . . .

Copied from Doctor McConnell's drawing showing detail of secondary sculpture highly magnified. (Idem., pl. 37, fig. 14a).

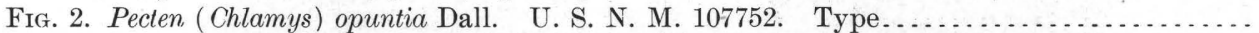

Copied from Doctor McConnell's drawing of right valve; altitude $33 \mathrm{~mm}$. (Trans. Wagner Free Inst. Sci., vol. 3, pt. 4, pl. 29, fig. 6.) San Diego formation (Pliocene), Pacific Beach, San Diego County, Cal.

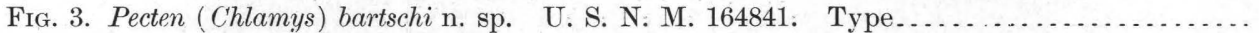

Exterior of portion of disk; altitude $55 \mathrm{~mm}$. Pliocene, Crescent City, Del Norte County, Cal. (M. P.)

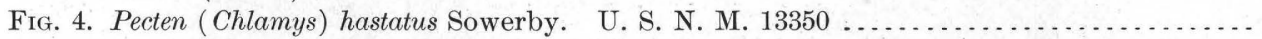

Exterior of left valve of Conrad's type of Pecten altiplicatus; longitude $55 \mathrm{~mm}$. Pliocene, San Raphael Hills, Santa Barbara County, Cal. (M. B.)

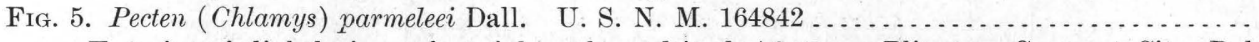

Exterior of slightly imperfect right valve; altitude $70 \mathrm{~mm}$. Pliocene, Crescent City, Del Norte County, Cal. (M. B.)

Fig. $5 a$. Same specimen as fig. 5 .

Profile of right valve, as viewed from the rear. (M. P.)

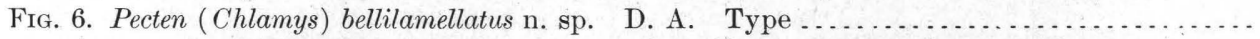

Exterior of right valve (anterior ear slightly broken); altitude $18 \mathrm{~mm} ., \times 3$. San Diego formation (Pliocene), Pacific Beach, San Diego County, Cal. (M. B.)

Fig. $6 a$. Same specimen and valve as fig. 6 , natural size. (M. P. ) . . . . . . . . . . . . . .

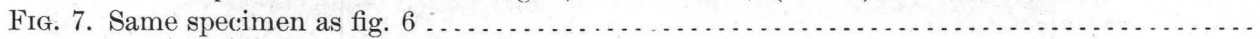
Exterior of left valve, $\times 3$. (M. B. )

FIG. $7 a$. Same specimen and valve as fig. 7 , natural size. (M. P.) . . . . . . . . . . . . . . . 

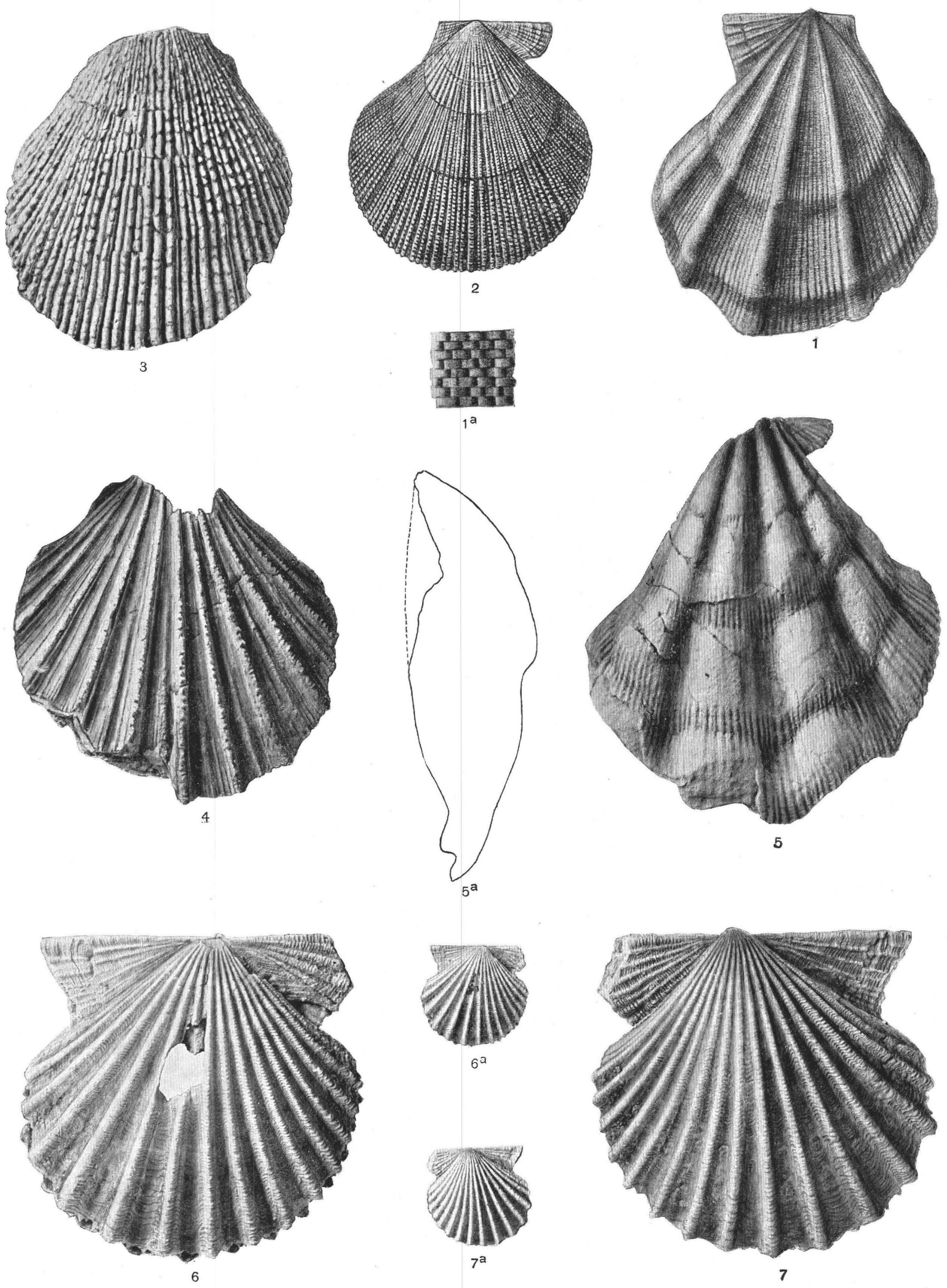

PLIOCENE AND QUATERNARY PECTENS. 


\section{PLA TE X L I I. PLIOCENE AND QUATERNARY PECTENS.}

[Unless otherwise stated all figures are approximately natural size. The light in these figures comes from the righthand side. Photographs by Ralph Arnold.]

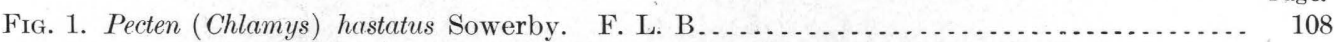

Exterior of right valve; altitude $59 \mathrm{~mm}$. Recent, Monterey Bay, Monterey County, Cal.

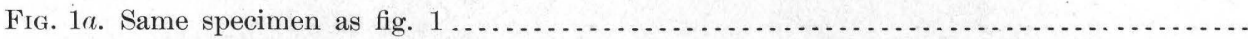

Exterior of left valve.

Fig. 2. Pecten (Chlamys) hastatus Sowerby. F. L. B

Exterior of right valve; altitude $49 \mathrm{~mm}$. Same locality as fig. 1

FIG. $2 a$. Same specimen as fig. 2 Exterior of left valve.

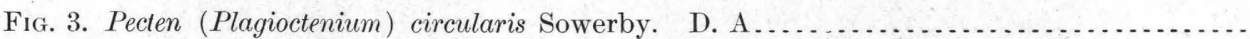

Exterior of right valve; altitude $54 \mathrm{~mm}$.; San Pedro formation (Pleistocene), San Pedro, Los Angeles County, Cal.

Fig. 4. Pecten (Plagioctenium) circularis Sowerby. D. A . . . . . . . . . . . . . . . . . . .

Fxterior of left valve; altitude $49 \mathrm{~mm}$. Same locality as fig. 3.

FIG. 5. Pecten (Plagioctenium) circularis Sowerby, equilateral variety. D. A...........

Exterior of right valve; altitude $53 \mathrm{~mm}$. Same locality as fig. 3.

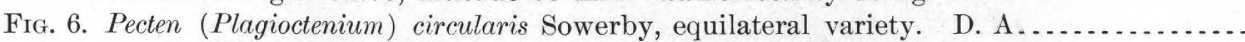
Exterior of left valve; altitude $56 \mathrm{~mm}$. Same locality as fig. 3 . 


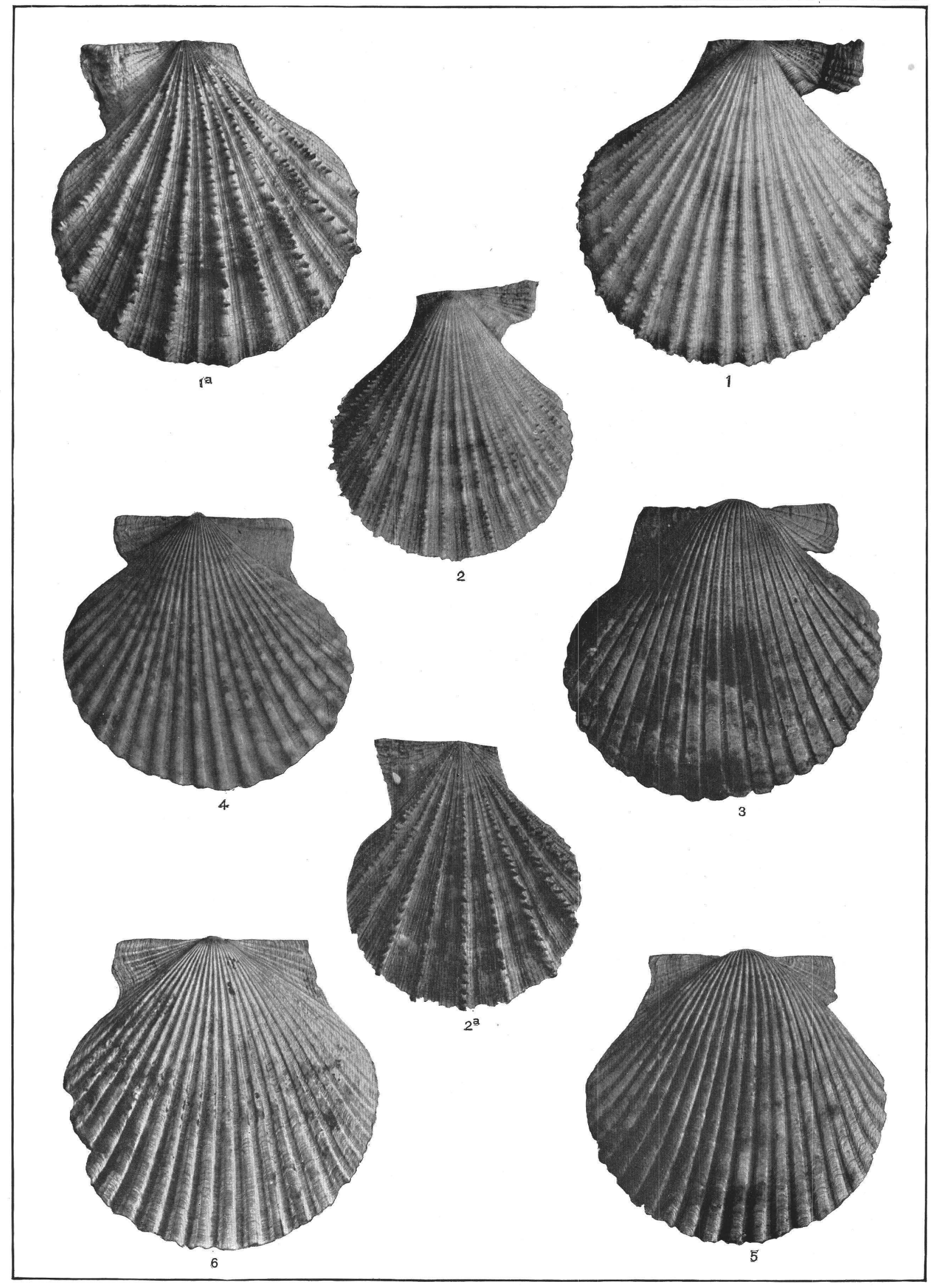

PLIOCENE AND QUATERNARY PECTENS. 


\section{PLATE X L II. \\ MIOCENE, PLIOCENE, AND QUATERNARY PECTENS. \\ [Unless otherwise stated all figures are approximately natural șize.]}

Fig. 1. Pecten (Chlamys) hastatus Sowerby var. navarchus Dall. L. S. J. U......... Page. Exterior of right valve; altitude $56 \mathrm{~mm}$. Recent, Puget Sound, Washington. (M. P.)

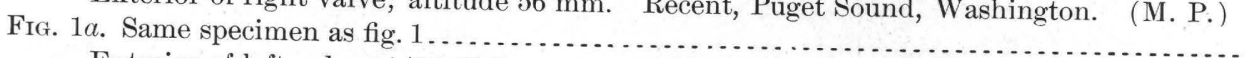
Exterior of left valve. (M. P.)

FIG. 1b. Same specimen as fig. 1...

Profile of both valves as viewed from the rear. (M. P.)
FIG. 2. Pecten (Chlamys) hastatus Sowerby var. hindsii Carpenter.

Exterior of right valve; altitude $56 \mathrm{~mm}$. Recent, southeast Alaska (U. S. Fish Com. stations 2850-2851). (S.)

FIg. $2 a$. Same specimen as fig. 2

Exterior of left valve. (S.)

FIG. 3. Pecten (Chlamys) hastatus Sowerby var. hericius Gould. U. S. N. M. 3881

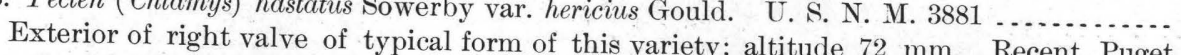
Sound, Washington. (M. P.)

FIg. $3 a$. Same specimen as fig. 3

Exterior of left valve. (M. P.) 

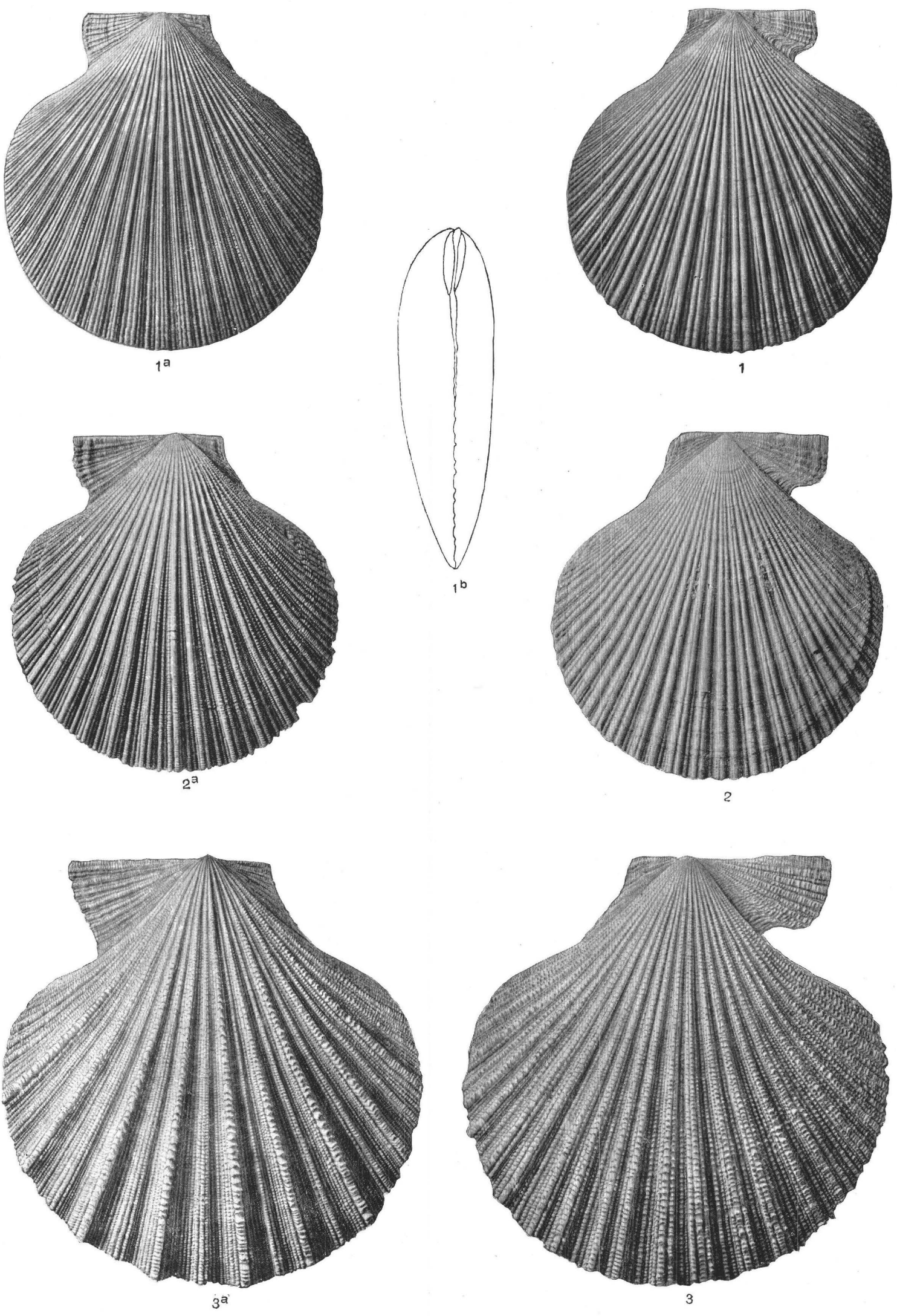

miocene, PLIOCEne, ANd QUATERnARy PECTENS. 


\section{P L A T E X L I V. PLIOCENE AND QUATERNARY PECTENS.}

[Unless otherwise stated all figures are approximately natural size.]

Fig. 1. Pecten (Chlamys) jordani Arnold. U. S. N. M. 162522. Type ...............................

Exterior of right valve; altitude $45 \mathrm{~mm}$. Pliocene, Deadman Island, near San Pedro, Los Angeles County, Cal. (Mem. Cal. Acad. Sci., vol. 3, pl. 12, fig. 6.) (M. P.)

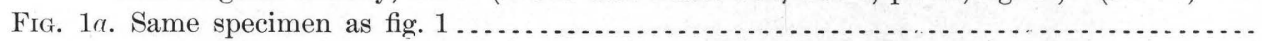
Exterior of left valve. (Idem., pl. 12, fig. 7.) (M. P.)

FIG. 1b. Same specimen as fig. 1

Profile of both valves as viewed from the rear. (M. P.)

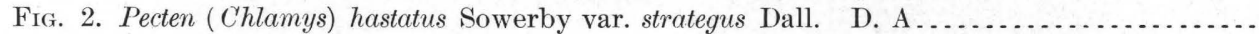
Exterior of left valve; altitude $36 \mathrm{~mm}$. Pleistocene, near bath house, Santa Barbara, Cal.

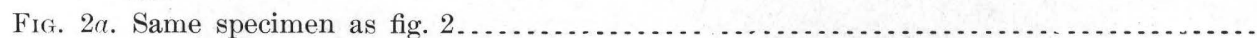
Profile of left valve as viewed from the rear. (M. P.)

Fig. 3. Pecten (Chlamys) hastatus Sowerby var. strategus Dall. D. A

Exterior of small left valve; altitude $21 \mathrm{~mm}$. Pleistocene, San Pedro formation, Deadman Island, near San Pedro, Los Angeles County, Cal. (M. B.)

FIG. 4. Pecten (Chlamys) hastatus Sowerby var. strategus Dall. D. A ....................

Exterior of right valve showing secondary sculpture; altitude $21 \mathrm{~mm} ., \times 3$. Same locality as fig. 3.

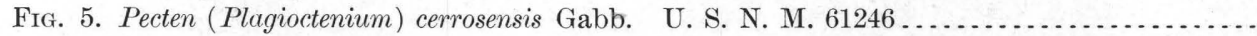

Copied from Doctor McConnell's drawing of the left valve of Dall's type of Pecten subventricosus; longitude $63 \mathrm{~mm}$. (Trans. Wagner Free Inst. Sci., vol. 3, pt. 4, pl. 29, fig. 8. ) Pliocene or Pleistocene, Ventura County, Cal.

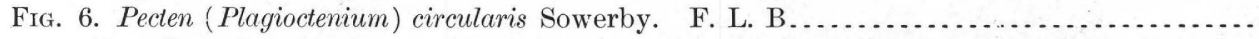
Exterior of right valve; altitude $45 \mathrm{~mm}$. Recent, Gulf of Calitornia. (M. B.) (Photographed without coating by the Williams process.)

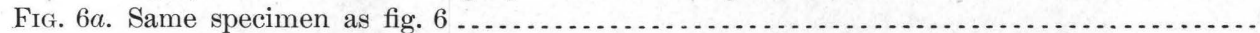

Exterior of left valve. (M. B.) (No coating.)

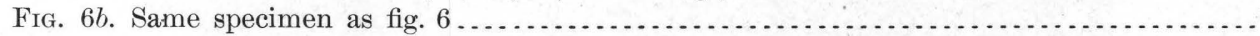

Profile of both valves as viewed from the rear, showing great convexity of the typical form of this species. (M. P.)

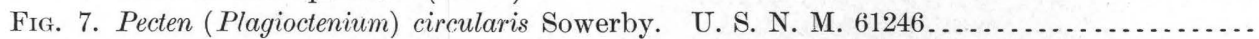

Copied from Doctor MeConnell's drawing of the type (right valve) of Dall's Pecten compactus; longitude $26 \mathrm{~mm} ., \times 7 / 5$. (Trans. Wagner Free Inst. Sci., vol. 3, pt. 4, pl. 34, fig. 5.) Pleistocene or Pliocene, Ventura County, Cal.

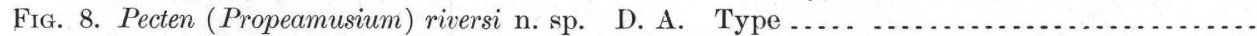

Interior of right valve, showing short internal liræ; altitude $17 \mathrm{~mm}$. Pliocene, Santa Monica Canyon, Los Angeles County, Cal. (S.)

Fig. 9. Pecten (Propeamusium) riversi n. sp. D. A. Cotype

Exterior of imperfect left valve; longitude $15 \mathrm{~mm}$. Same locality as fig. 8. (S.) 

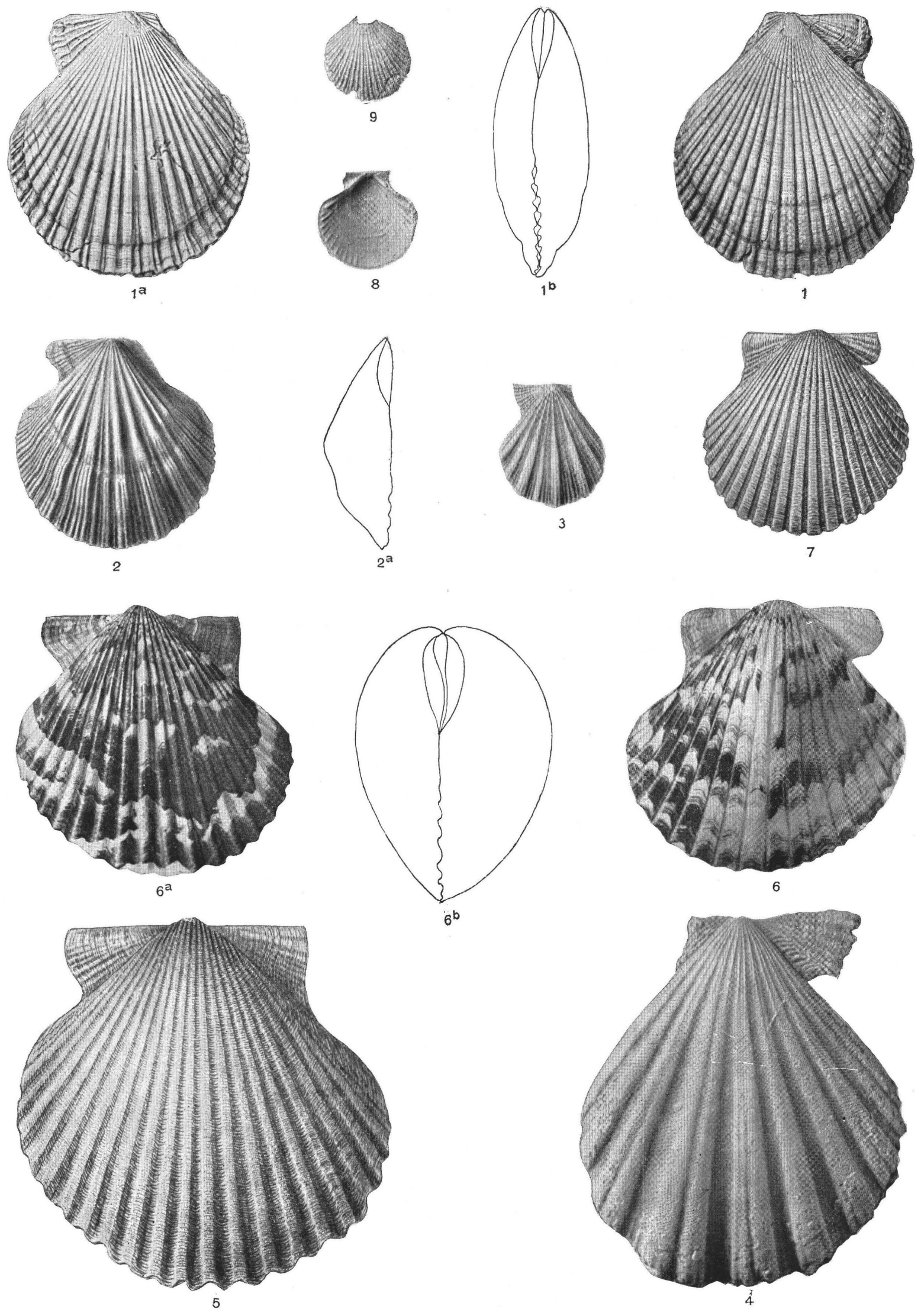

PLIOCENE AND QUATERNARY PECTENS. 
PLATE XLV.

PLIOCENE AND QUATERNARY PECTENS.

[Unless otherwise stated all figures are approximately natural size.]

FIG 1. Pecten (Chlamys) Page

Exterior of right valve; altitude $83 \mathrm{~mm}$. Recent, Banks of Newfoundland. (M. B.)

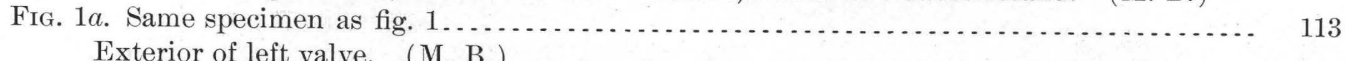

FIG. 2. Pecten (Chlamys) washburnei n. sp. U. S. N. M. 164843. Type................... 119

Exterior of imperfect left valve; altitude $108 \mathrm{~mm}$. Pliocene, mouth of Yachates River, Lincoln County, Oreg. (M. B.)

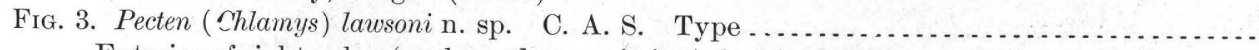

Exterior of right valve (umbo and ears missing); longitude $65 \mathrm{~mm}$. Pliocene, 4 miles south of Guadalupe, Santa Barbara County, Cal. (S.)

Fig. 4. Pecten (Chlamys) lawsoni n. sp. C. A. S. Cotype

Exterior of an imperfect left valve in which the umbonal region has been partially restored with plaster; longitude $34 \mathrm{~mm}$. Same locality as fig. 3 . (M. B.) 


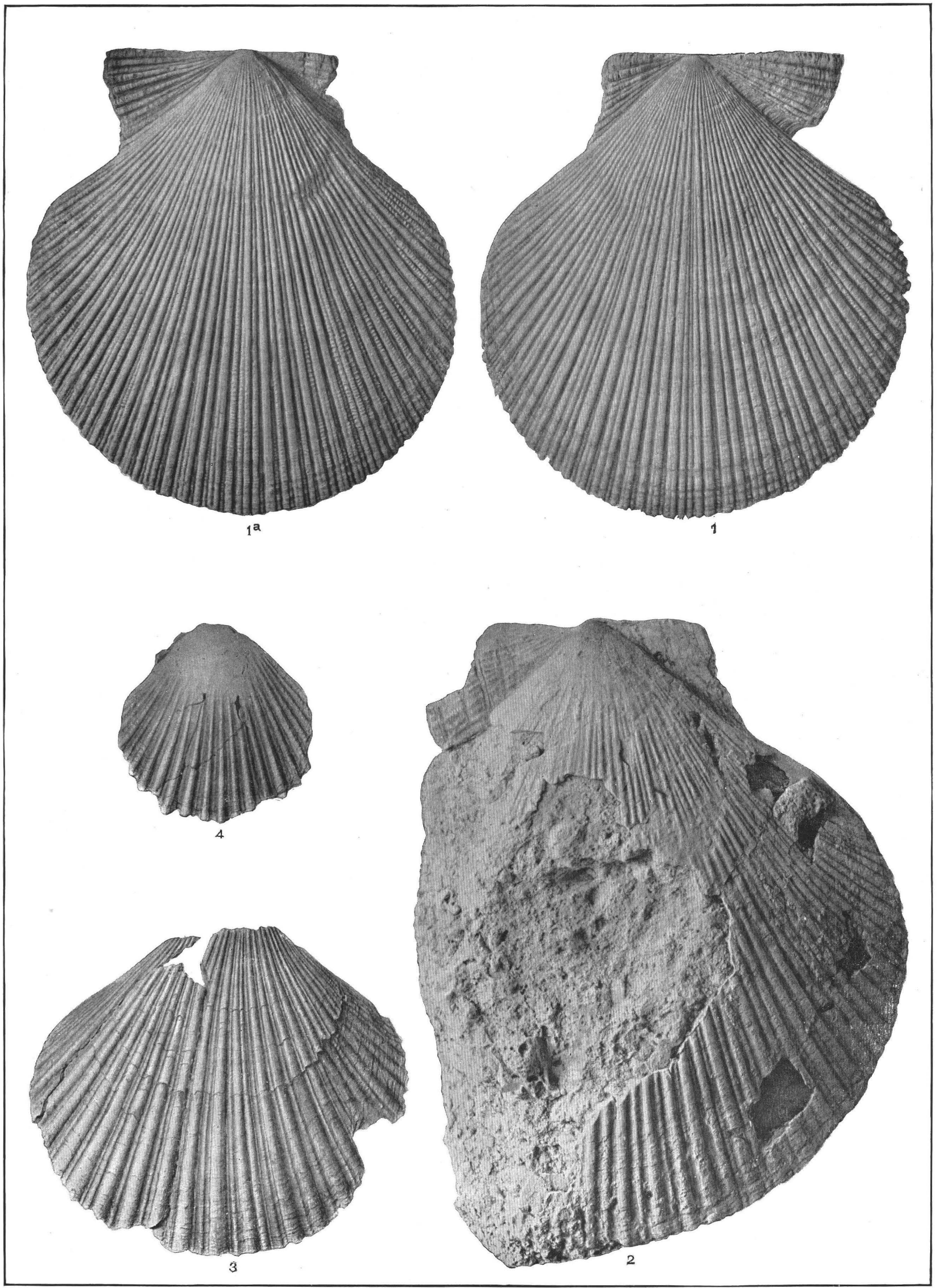

PLIOCENE AND QUATERNARY PECTENS. 


\section{PIATE XLVI. PLIOCENE AND QUATERNARY PECTENS.}

[Unless otherwise stated all figures are approximately natural size.]

Fig. 1. Pecten (Pecten) excavatus Anton. I. S. J. U-z-2.-.

Exterior of right valve; altitude $65 \mathrm{~mm}$. Recent, Gulf of California. (M. B.)

FIg. 1a. Same specimen as fig. 1

Exterior of left valve; altitude $57 \mathrm{~mm}$. (M. P.)

Fig. $1 b$. Same specimen as fig. 1

Profile of both valves as viewed from the rear. (M. P.)

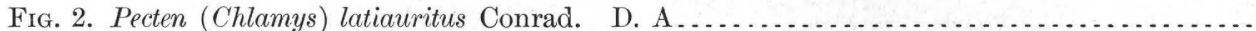

Exterior of right valve; altitude $25 \mathrm{~mm}$. San Pedro formation (Pleistocene), San Pedro, Los Angeles County, Cal. (M. P.)

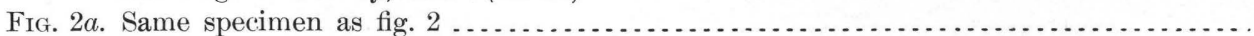

Profile of right valve as viewed from the rear, showing convexity of typical form.

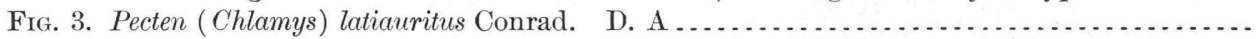

Exterior of left valve; altitude $27 \mathrm{~mm}$. Same locality as fig. 2. (M. B.)

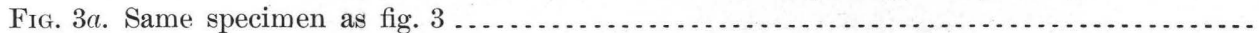

Profile of left valve as viewed from the rear. (M. P.)

FIg. 4. Pecten (Chlamys) latiauritus Conrad var. monotimeris Conrad. D. A ................

Exterior of right valve; altitude $20 \mathrm{~mm}$. San Pedro formation (Pleistocene), Los Cerritos, Los Angeles County, Cal. (M. P.)

Fig. 5. Pecten (Chlamys) latiauritus Conrad var. monotimeris Conrad. D. A .................

Exterior of left valve; altitude $22 \mathrm{~mm}$. Same locality as fig. $4 . \quad$ (M. P.)

FIg. $5 a$. Same specimens as figs. 4 and 5 .

Profile of both valves, as viewed from the rear. Note the greater convexity of the left valve as compared with the greater convexity of the right valve in Pecten s. s. (M. P.)

Fig. 6. Pecten (Chlamys) latiauritus Conrad var. cerritensis n. var. D. A. Type ............. Exterior of right valve; altitude $24 \mathrm{~mm}$. San Pedro formation (Pleistocene), San Pedro, Los Angeles County, Cal. (M. B.)

Fig. 7. Pecten (Chlamys) latiauritus Conrad var. cerritensis n. var. D. A. Cotype............. Exterior of left valve; altitude $21 \mathrm{~mm}$. Same locality as fig. 6 . (M. P.)

Fig. 8. Pecten (Chlamys) latiauritus Conrad var. fucicolus Dall. U. S. N. M. 96049 ...........

Exterior of right valve; altitude $30 \mathrm{~mm}$. Recent, on kelp, off Cerros Island, Lower California. (M. P.)

Fig. $8 a$. Same specimen as fig. 8

Exterior of left valve. (M. P.)

Fig. 9. Pecten (Chlamys) latiauritus Conrad var. delosi n. var. D. A. Type

Exterior of right valve; altitude $12 \mathrm{~mm}$., $\times 3$. San Pedro formation (lower portion), Pleistocene, Deadman Island, near San Pedro, Los Angeles County, Cal. (S.)

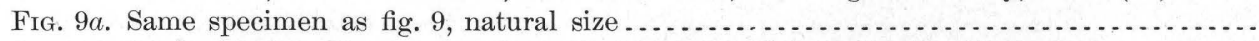

FIG. 10. Pecten (Chlamys) latiauritus Conrad var. delosi n. var. D. A. Cotype...............

Exterior of left valve; altitude $11 \mathrm{~mm} ., \times 3$. Same locality as fig. 9 . (S.)

Fig. 10a. Same specimen as fig. 10, natural size

age.

134

134

134 

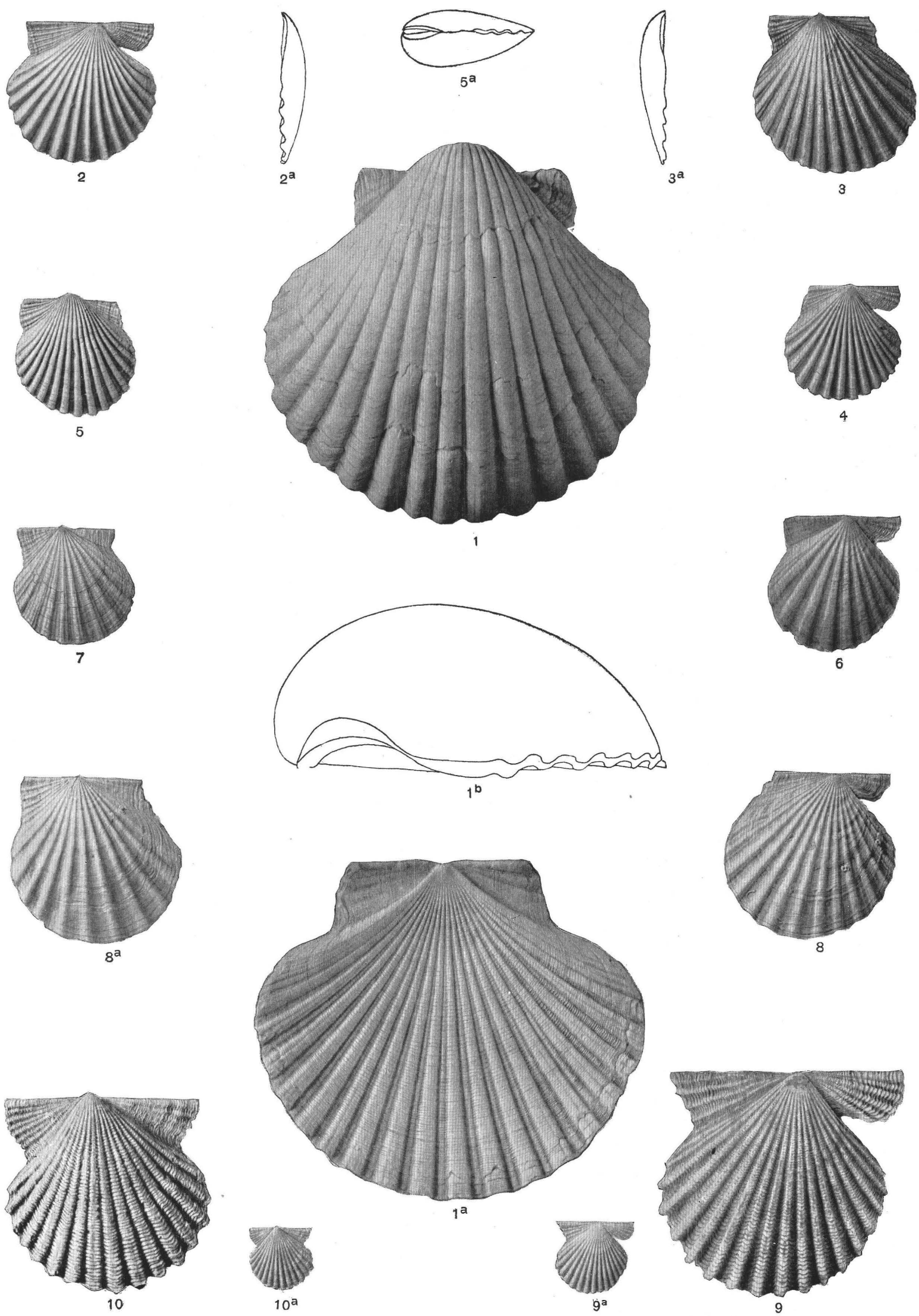

PLIOCENE AND QUATERNARY PECTENS. 


\section{P L A TE X L V I T.}

\section{PLIOCENE PECTENS.}

[Unless otherwise stated all figures are approximately natural size.]

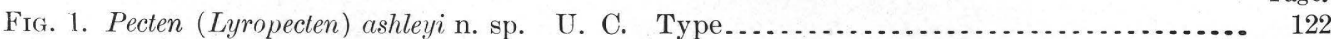
Exterior of right valve; altitude $155 \mathrm{~mm}$.

Pliocene, Cerros Island, off Lower California. (H.)

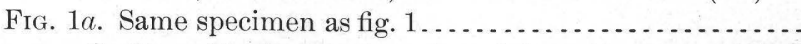

Outline of both valves as viewed from the rear. (M. P.) 


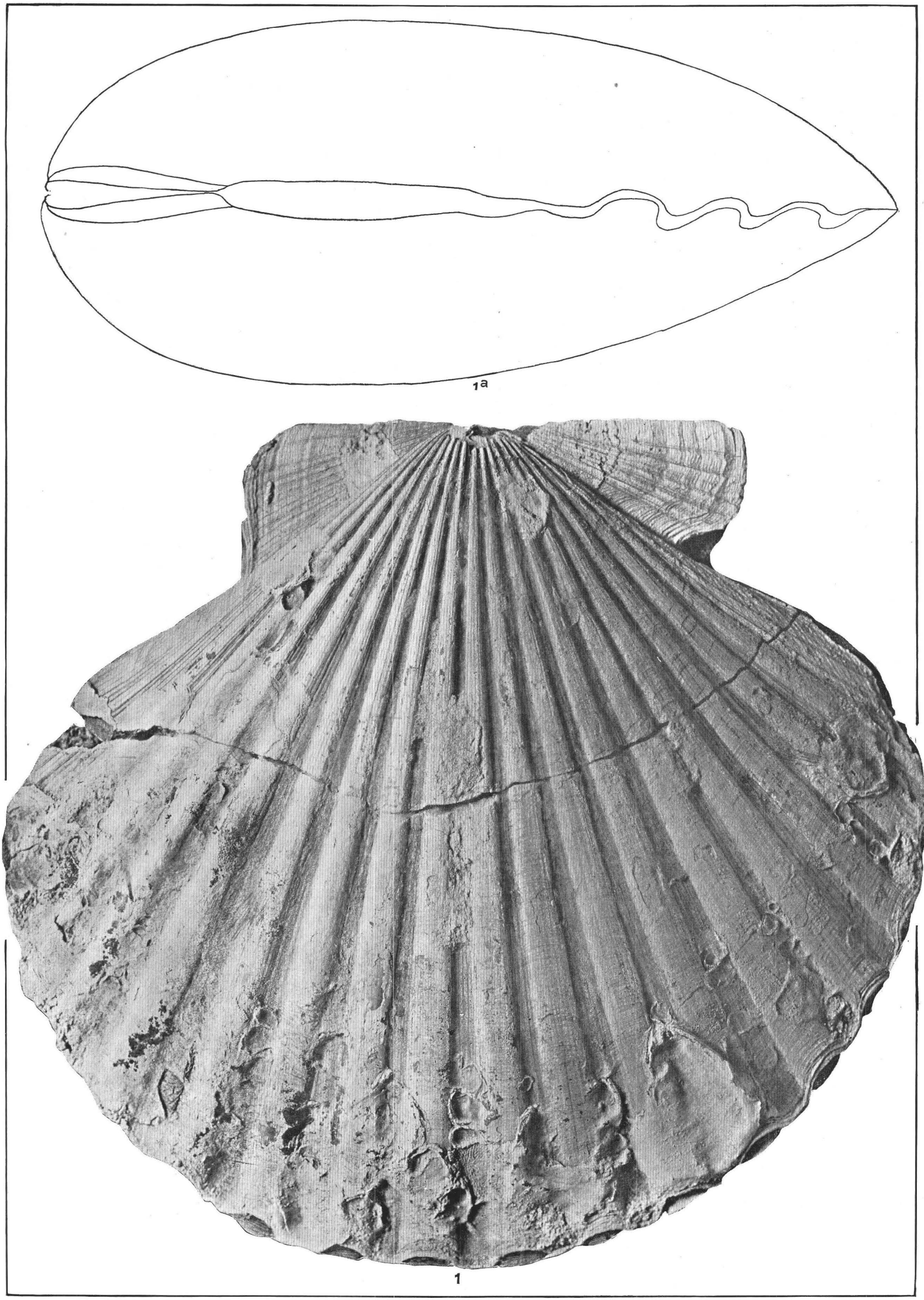

PLIOCENE PECTENS. 


\section{PLA T E X L V I I . PLIOCENE AND RECENT PECTENS.}

[Unless otherwise stated all figures are approximately natural size.]

Page.

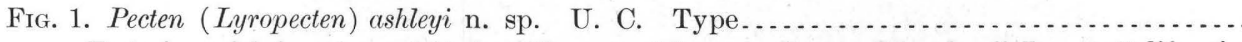

Exterior of left valve; altitude $155 \mathrm{~mm}$. Pliocene, Cerros Island, off Lower California. (H.)

Fig. 2. Pecten (Pseudamusium) randolphi Dall. U. S. N. M. 107749.

Exterior of right valve; altitude $29 \mathrm{~mm}$. Recent, off Destruction Island, Wash., 516 fathoms. (U. S. Fish Com. station 3343.) (M. P.)

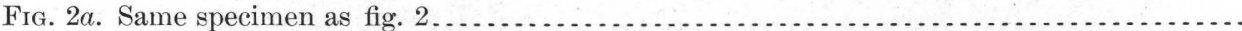

Exterior of left valve. (M. P.)

FIg. 3. Pecten (Pseudamusium) randolphi Dall var. tillamookensis n. var. U. S. N. M. 150233.

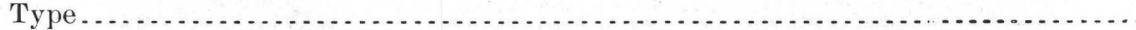

Exterior of right valve; altitude $30 \mathrm{~mm}$. Recent, off Tillamook, Oreg., 786 fathoms. (U. S. Fish Com. station 3346.) (M. P.)

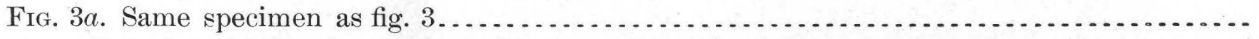

Exterior of left valve; altitude $31 \mathrm{~mm}$. (M. B.)

240 


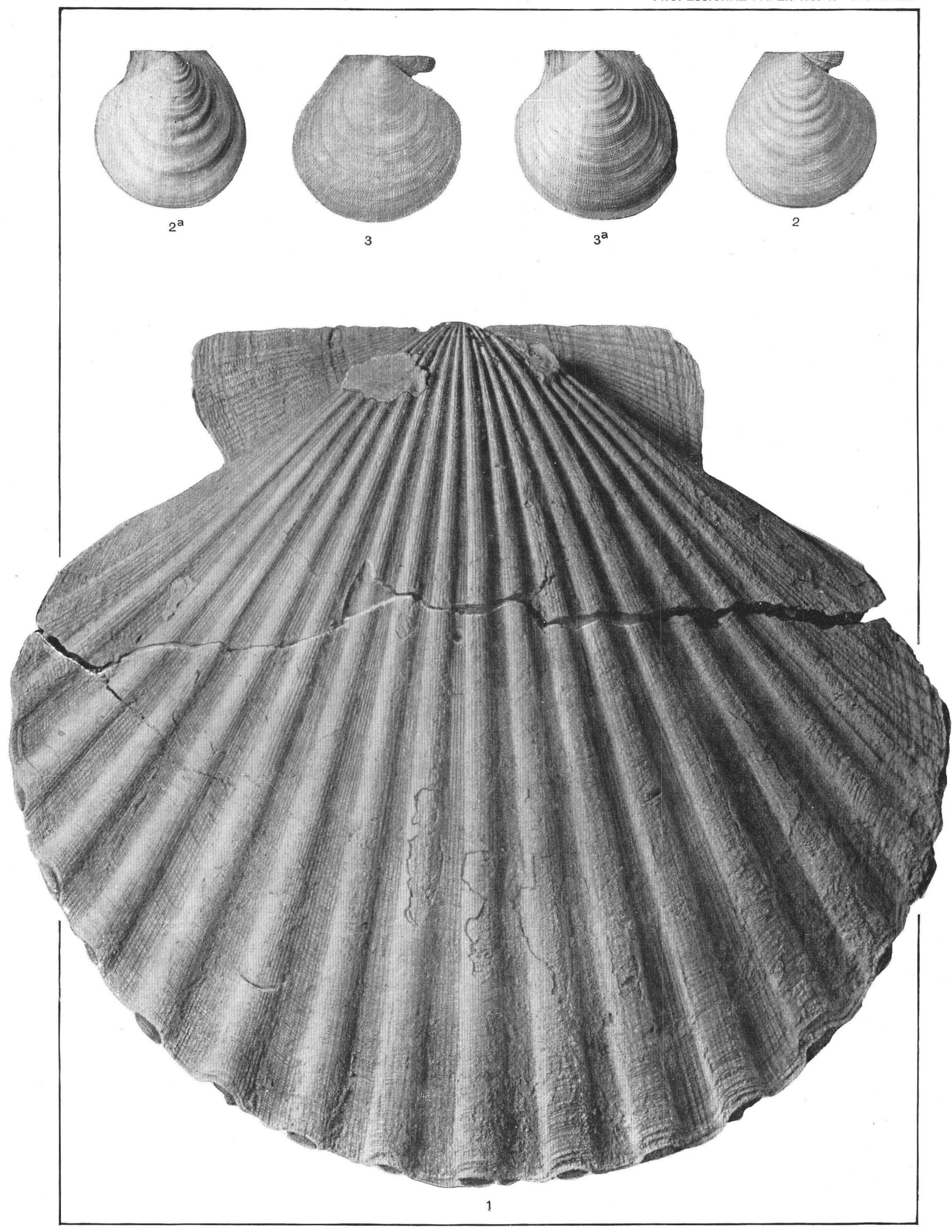

PLIOCENE AND RECENT PECTENS. 


\section{PLA TE XLIX. PLIOCENE PECTENS.}

[Unless otherwise stated all figures are approximately natural size.]

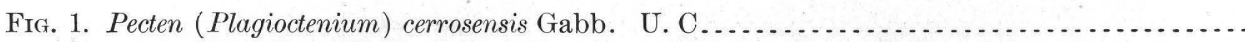
Exterior of right valve (anterior ear somewhat imperfect); altitude $106 \mathrm{~mm}$. Pliocene, Cerros Island, off Lower California. (S.)

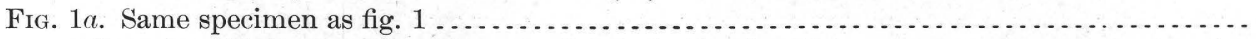
Exterior of left valve (anterior ear slightly broken). (S.)

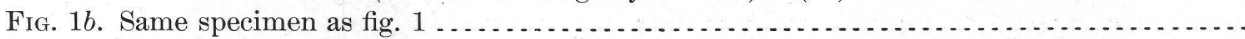
Profile of both valves as viewed from the rear.

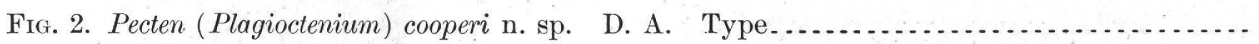
Exterior of right valve (anterior ear somewhat imperfect); altitude $35 \mathrm{~mm}$. San Diego formation (Pliocene), Pacific Beach, San Diego County, Cal. (M. B.)

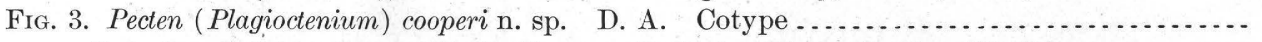
Exterior of right valve; altitude $30 \mathrm{~mm}$. Same locality as fig. 2. (M. B.)

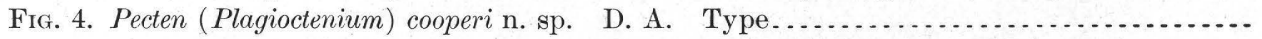
Exterior of left valve; altitude $27 \mathrm{~mm}$. Same locality as fig. 2. (M. B.) 


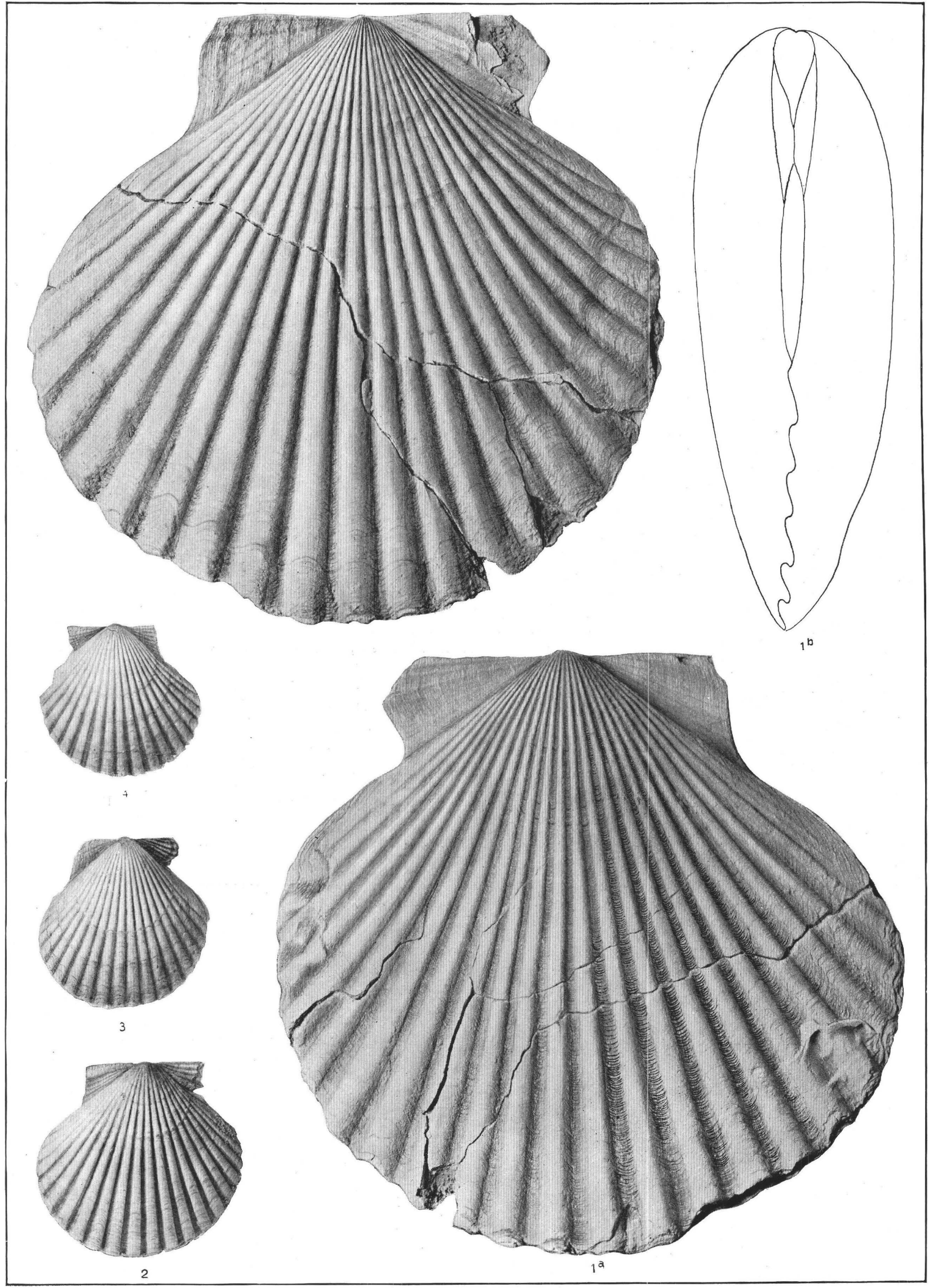

PLIOCENE PECTENS. 


\section{P L A T E L. QUATERNARY PECTENS.}

[Unless otherwise stated all figures are approximately natural size.]

FIG. 1. Pecten (Plagioctenium) circularis Sowerby var. æquisulcatus Carpenter. U. S. N. M.

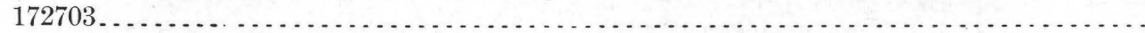

Exterior of right valve; altitude $82 \mathrm{~mm}$. Recent, San Pedro, Los Angeles County, Cal. (Photographed without coating to show coloration.) (M. B.)

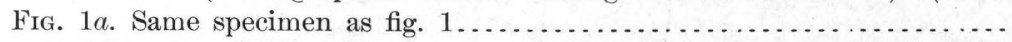

Exterior of left valve. (Photographed without coating.) (M. B.)

Fig. 1b. Same specimen as fig. 1.

Profile of both valves as viewed from the rear. (M. P.)

Fig. 2. Pecten (Equipecten) palmeri Dall. U. S. N. M. 150980. Cotype.................. .

Exterior of right valve (young); altitude $26 \mathrm{~mm}$. Recent, head of Gulf of California. (M. P.)

Fig. 2a. Same specimen as fig. 2 . .

Profile of right valve, as viewed from the rear. (M. P.)

FIG. 3. Pecten (Equipecten) palmeri Dall. U. S. N. M. 150980. Type

Exterior of left valve; altitude $48 \mathrm{~mm}$. Same locality as fig. 2. (M. P.)

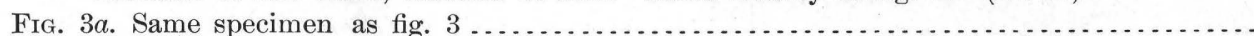

Profile of left valve as viewed from the rear. (M. P.)

Fig. 4. Pecten (Pseudamusium) davidsoni Dall. U. S. N. M. 107747. Type............... 138

Copied from Doctor McConnell's drawing of the right valve of the type; altitude 14.7 mm. (Proc. U. S. Nat. Mus., vol. 24, pl. 40, fig. 6.) Recent, Davidson Banks, north of Unalaska, 351 fathoms (U. S. Fish Com. Station 3330).

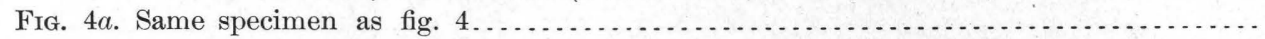

Page.

Copied from drawing of left valve. (Idem, pl. 40, fig. 5.) 

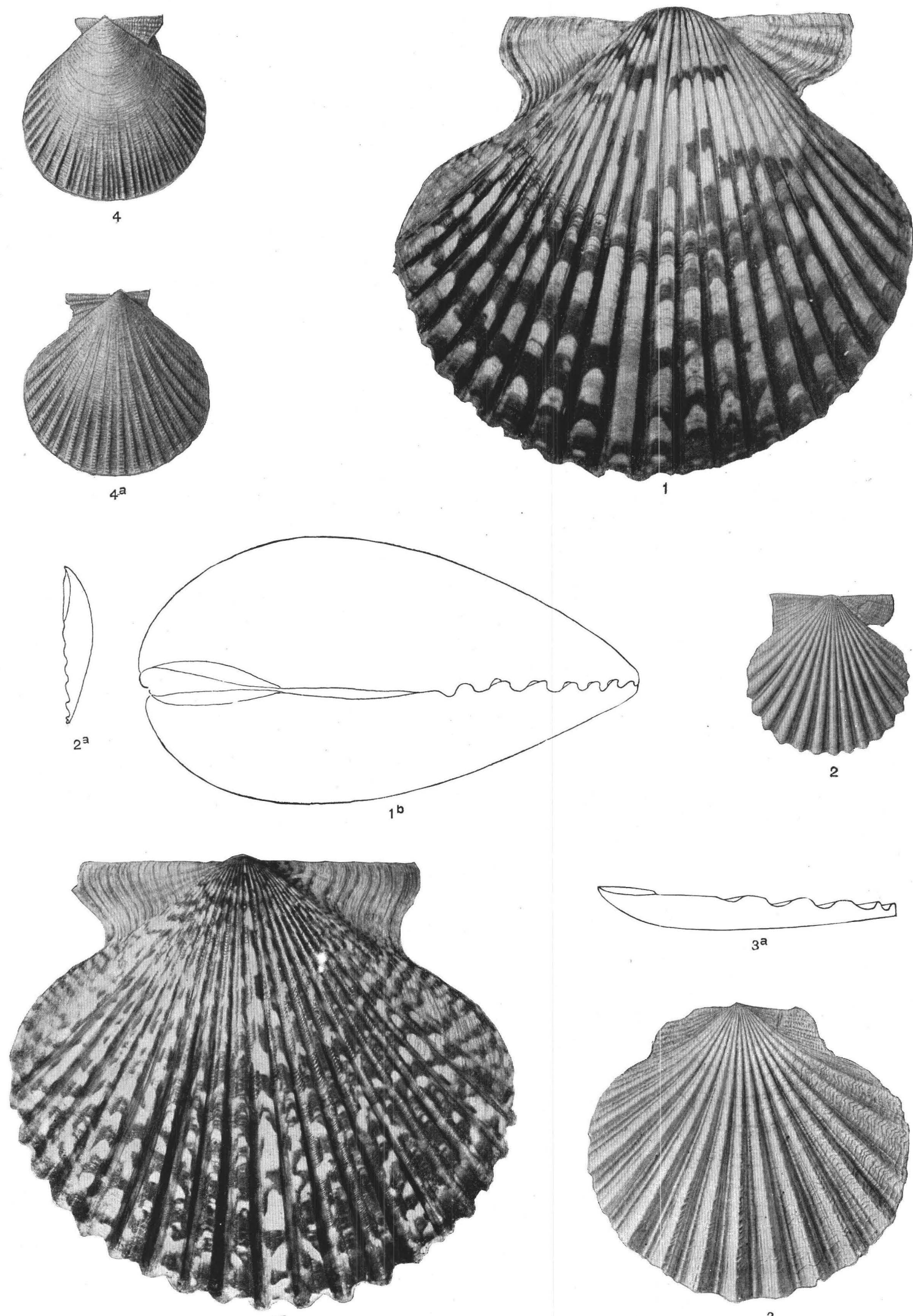


\section{P L A T E L T. \\ QUATERNARY PEC'TENS.}

[Unless otherwise stated all figures are approximately natural size.]

Fig. 1. Pecten (Pecten) diegensis Dall. U. S. N. M. 150980. Type.................. 127 Exterior of right valve; altitude $86 \mathrm{~mm}$. Recent, San Pedro, Los Angeles County, Cal., dredged. (M. P.)

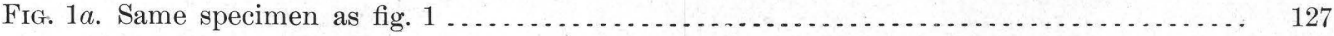

Exterior of left valve. (M. P.)

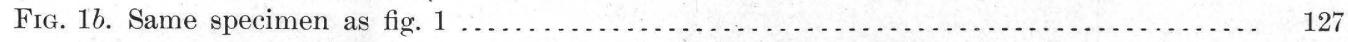

Profile of both valves as viewed from the rear. (M. P.) 


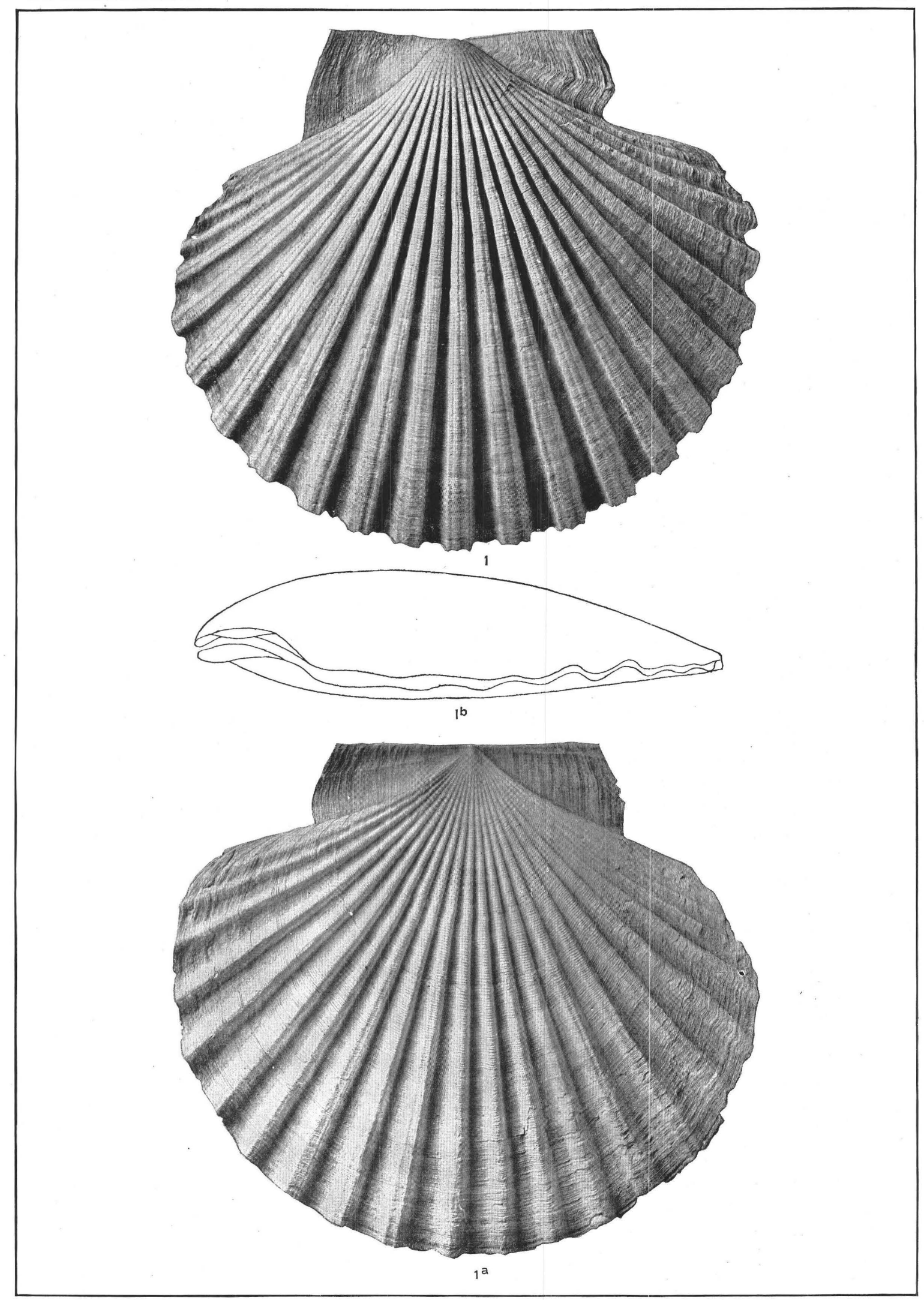

QUATERNARY PECTENS. 


\section{P L A.TE LII. QUATERNARY PECTENS.}

[Unless otherwise stated all figures are approximately natural size.]

Fig. 1. Pecten (Nodipecten) subnodosus Sowerby. L. S. J. U . . . . . . . . . . . . . . . . 128 Exterior of right valve; altitude $112 \mathrm{~mm}$. Recent, west coast of Mexico. (M. B.)

FIG. 2. Pecten (Chlamys) hastatus Sowerby var. albidus Dall, U. S. N. M. 150207. Type .... 136 Exterior of right valve, showing broad fasciculi; altitude $45 \mathrm{~mm}$. Recent, Iliukliuk Harbor, Unalaska, 68 fathoms (U. S. Fish Com. station 3313). (M. P.)

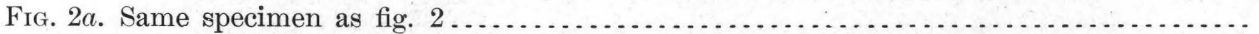
Exterior of left valve, showing narrow fasciculi. (M. P.)

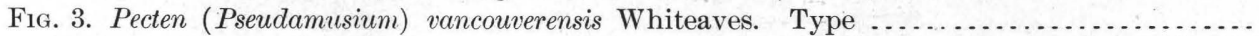
Copied from original drawing of right valve of type; altitude $8 \mathrm{~mm} ., \times 4$. (Ottawa Naturalist, vol. 7, pl. 1, figs. 1 and 1a.)

Recent, off Vancouver Island, British Columbia.

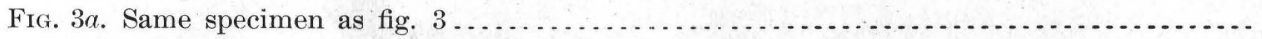

Copied from drawing of left valve of type. 

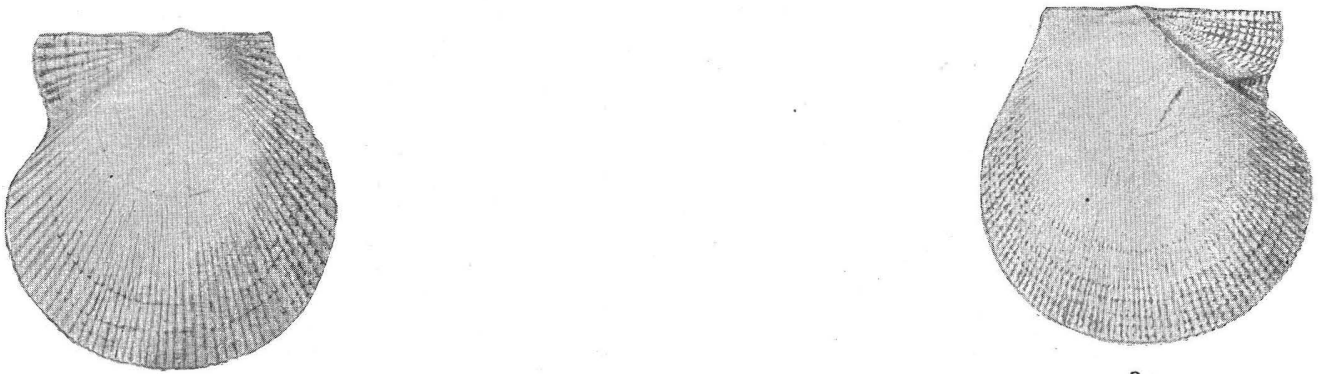

$3^{a}$

3

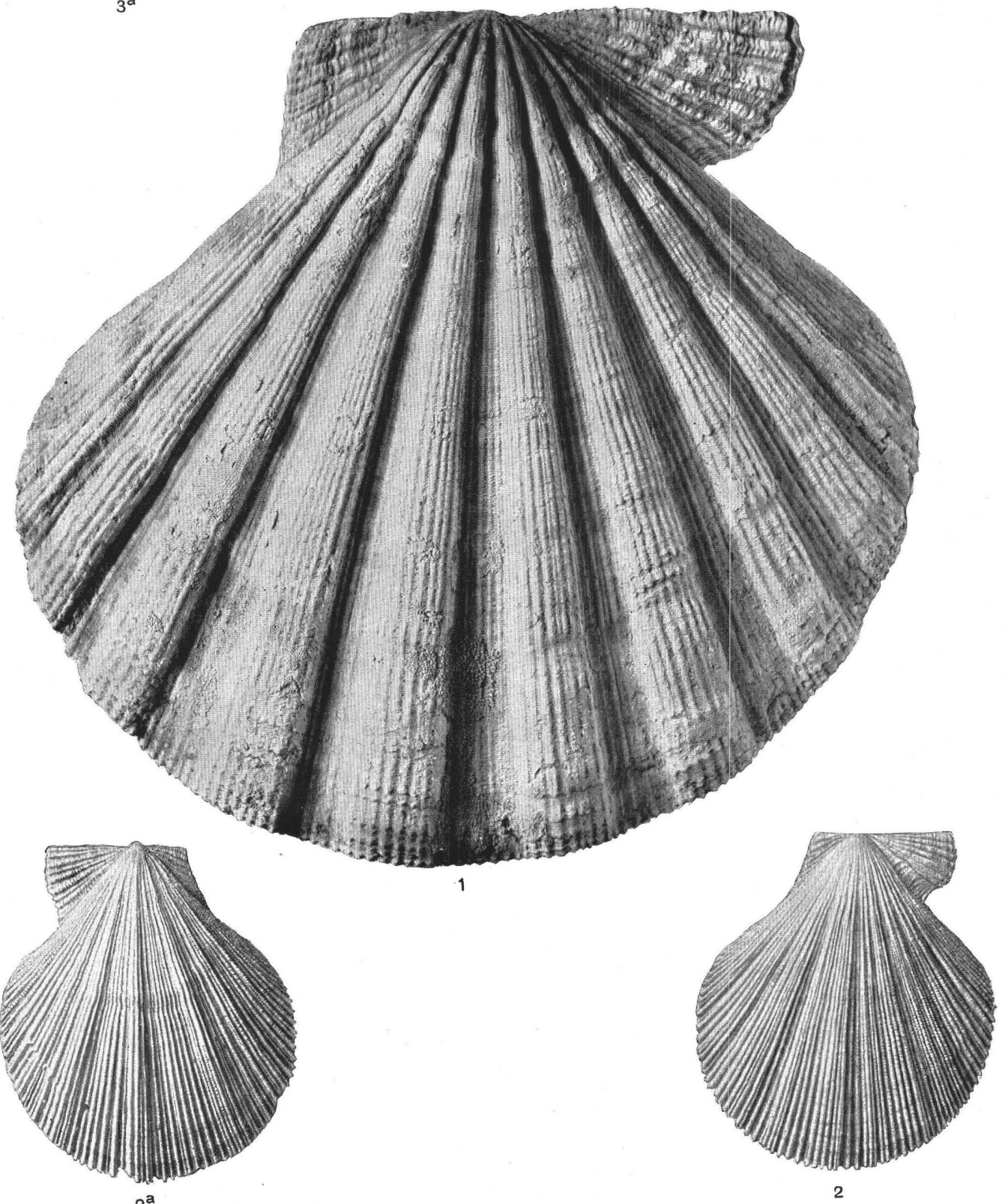

QUATERNARY PECTENS. 


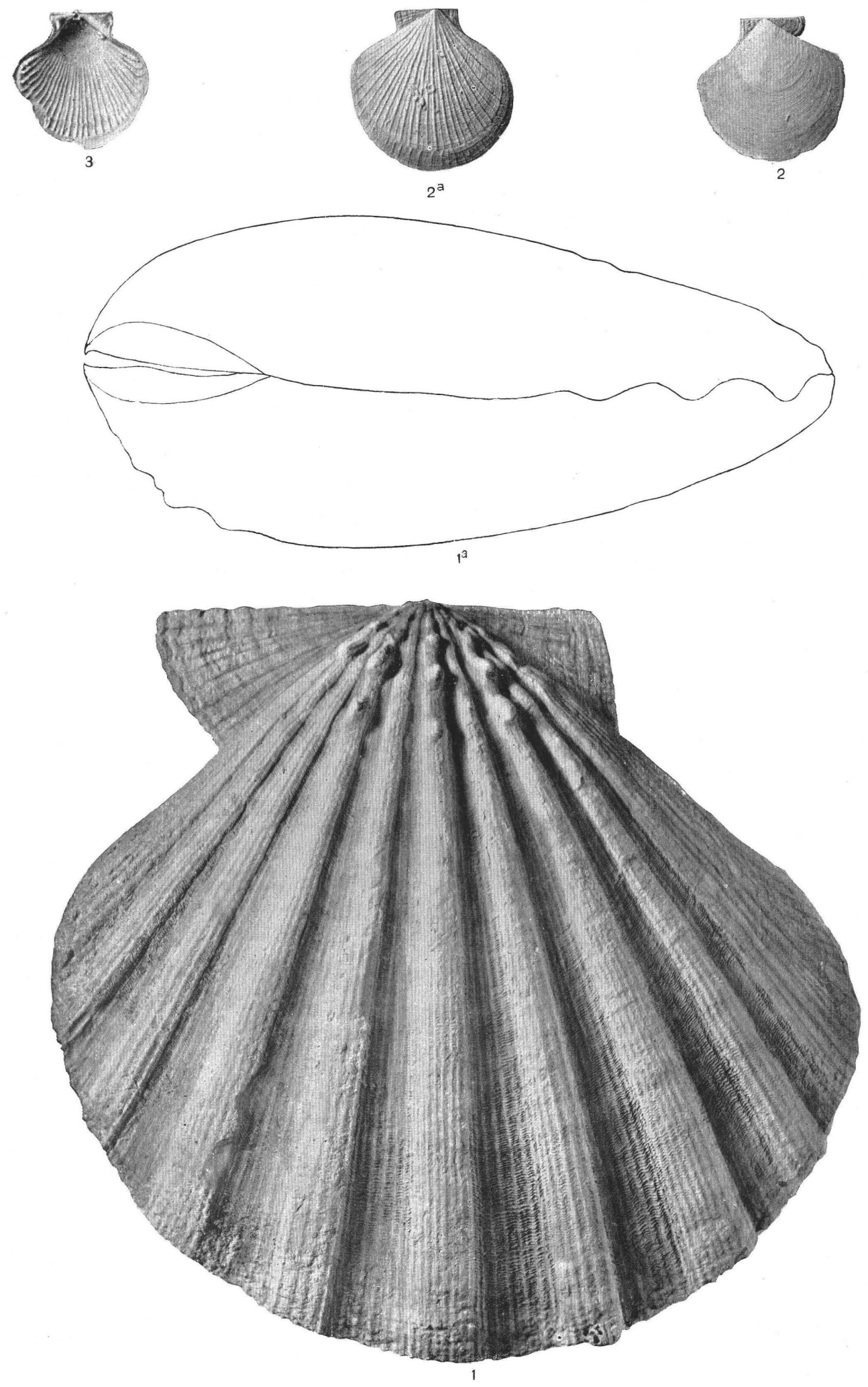

QUATERNARY PECTENS. 


\section{IN D E X .}

[Names in italic are synonyms; figures in black-face type are of pages giving descriptions; figures in italic show location of illustrations.]

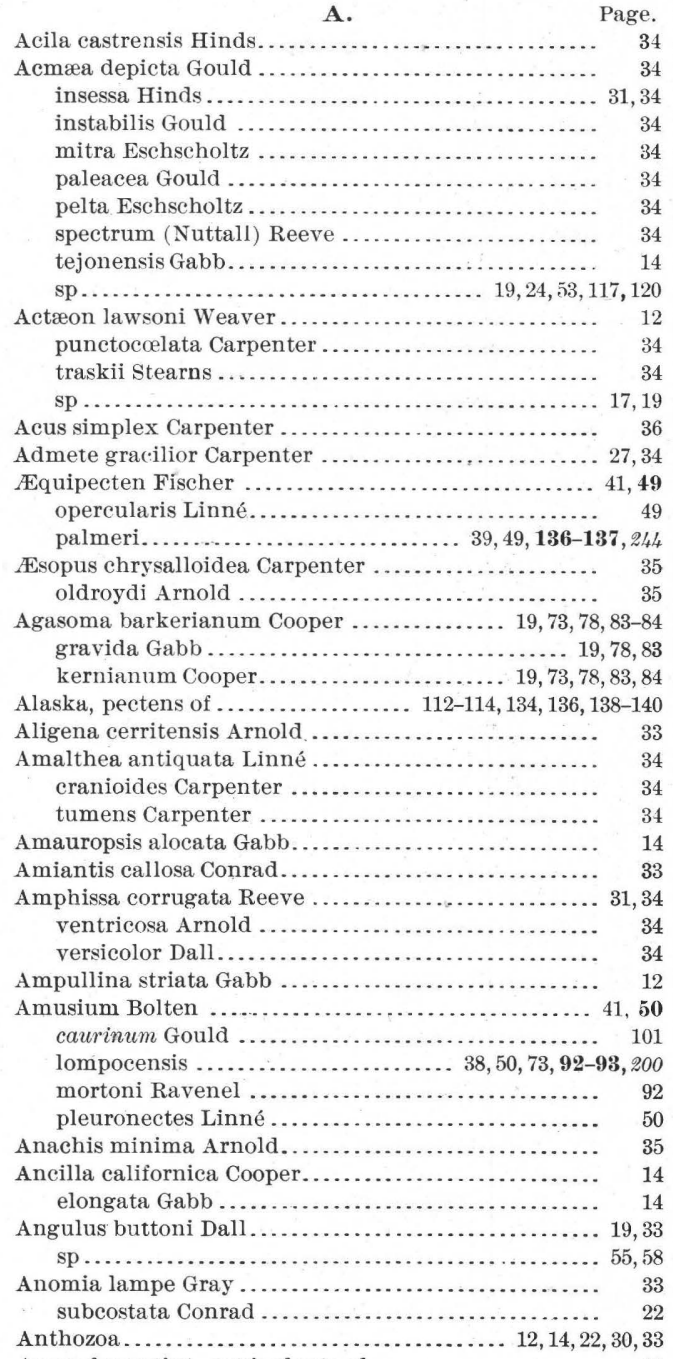

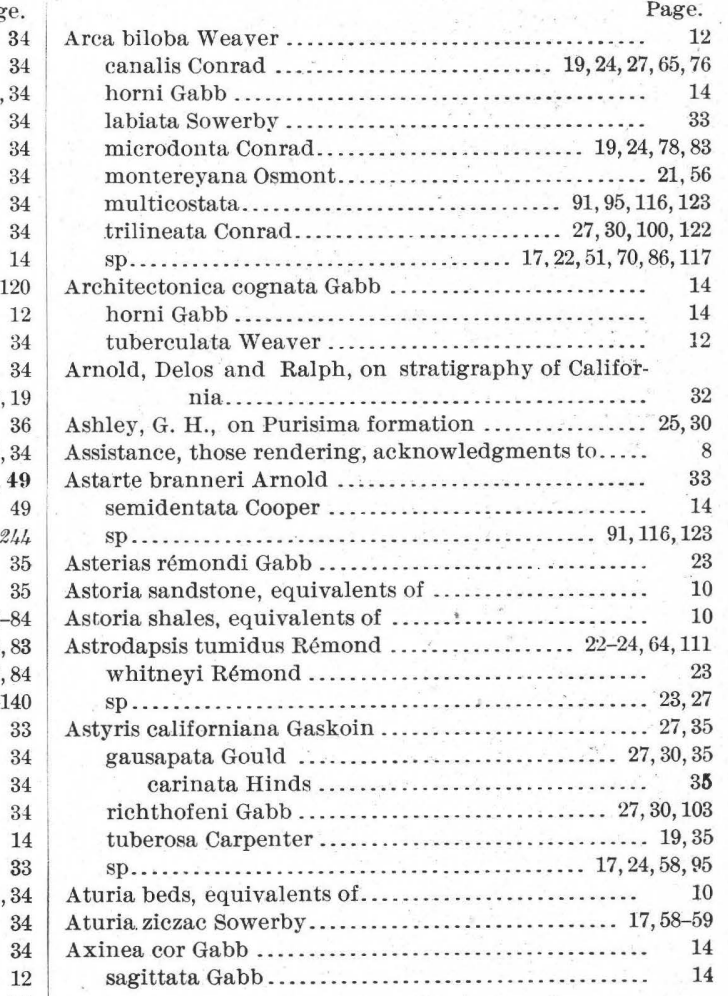

B.

Balanus estrellanus Conrad ............ 19, 24, 28, 64, 79, 83 sp................................. $70,73,93$ Barbatia morsei Gabb ............................. 14

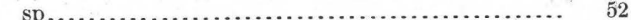
Bean Point, rocks near ......................... 15 Bela clathrata Gabb ........................... 14, 17 fidicula Gould ............................. 31,34 sanctæ-monicæ Arnold ......................... 34 Bibliography ................................. 142-146 Bittium asperum Gabb ................. 24, 27, 30, 31, 34,117 californicum Dall and Bartsch .................. 34 filosum Gould 
Page. quadriflic rugatum Carpenter. williamsoni Arnold

, on shale

Boreotrophon cerritensis Arnold ..................... gracilis Perry Eschseholtz ..................... 36, 103 Dail pedroanus Arnold ........................... $\quad 36$ triangulatus Carpenter ........................ Bornia retifera Dall

Borsonia bartschi Arnold dalli Arnold

- hooveri Arnold

Boulder Creek, Cal., rocks near ......................

Brachiopoda:

$12,17,19,27,28,30$

Brachysphingus liratus Gabb. sinuatus Gabb

British Columbia, pectens of

$12,17,19,27,28,30$ $27,91,116,120,123$ la horni Gabb. punctulata A. Adams quoyi Gray

Bullia striata Gabb

ullinula subglobosa Weaver

\section{C.}

Cadulus fusiformis Sharp and Pilsbry.

Cæcum californicum Dall crebricinctum Carpenter magnum Stearns

California, formations in ....... 10 fossil localities in ............ 11,13,16,18, 20-22, 26, 29,32 fossils from........... 51, 53-57,60-62, 64, 67-133, 139, 141 map of, showing fossil localities...

post-Cretaceous correlation table of . post-Cretaceous geologic column in............. 9 figure showing

Calliostoma annulatum Martyn .................... 35 canaliculatum Martyn ........................ 31,35 costatum Martyn ........................... 35, 95 gemmulatum Carpenter .................... 35, 117 tricolor Gabb ............................. 31,35 sp ................................ 19,24, 27, 118, 120

Callista angustifrons Conrad ................... 17,21,27 newcombiana Gabb.

33
$17,52,55,83$ sp................................... $17,52,55,83$ Callistata subdiaphana Carpenter ................. 33, 103 Calyptrophorus sp ............................ 52

Cancellaria cooperi Gabb.

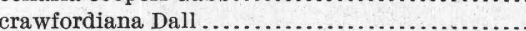

irelaniana Cooper...........................

tritonidea Gabb..............................

vetusta Gabb sp....

Cancer sp.

Cardita subquadrata Carpenter...................... sp....................................... 85

Carditamera subquadrata Carpenter.................. 33 sp ............................................ 85

Cardium breweri Gabb ....................... 14,17, cooperi Gabb .......................... 12,14, 55 corbis Martyn .......................... 30, 33, 95, 104 elatum Sowerby linteum Conrad ........... 14 meekianum Gabb.......................... 24, 27, 30 procerum Sowerby
Conrad...... '22, 23, 24, 30,33, 95, 121 sp ................................ 17, 19, 52, 79

Carrizo Creek beds, equivalents of................. 10 fauna of..................................... 21-22

Caryophyllia arnoldi Vaughan ...................... 33 californica Vaughan........................... $\quad 30$ pedroensis Vaug

Cassis sp. . .

Cephalopoda .................................. 17

Cerithidea californica Haldemann ................. 31, 35

Cerithiopsis alternata Gabb....................... 12,14

Cerostoma monoceros Sowerby .................... 36

Chama exogyra Conrad ............................ 33

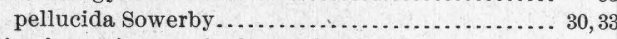

Chico formation, equivalents of................... 10

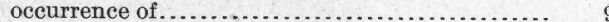

Chicoreus leeanus Dall .......................... $\quad 36$

Chione fluctifraga Sowerby....................... gnidia Broderip and Sowerby ............... 27, 34,84 mathewsonii Gabb.................. 19, 21, 55, 67, 79 neglecta Sowerby ........................... 34 simillima Sowerby.

succincta Valenciennes ................ 19,30,34, 104 sp......... 19, $24,27,55,64,66-67,70,73,76,79,83,85,93,95$

Chlamys Bolten ....................41, $46-47, \mathbf{4 9}, 55,66,81,94$ bartschi ...................... 26, 37, 49, 107-108, 226 bellilamellatus................ 26, 28, 29, 37,49, 108, 226 branneri ................. 16, 19, 37, 49, 55, 55-56, 83,150 calkinsi .......................... 14, 37, 49, 51, 52, 148 discus Conrad............................... 86 fucanus Dall ................. 19, 21, 23, 38, 49, 66-67, 164 hamlini ....................... 19, 38,49,67,122, 166 hastatus Sowerby ..........................26-29, $31,33-34,38,49,69,94,108-110,112,115,117,226,228$ var. albidus Dall .................. 38,49, 136, 248

var. hericius Gould ...................... 23-24 $26-29,31,33-34,38,49,70,109,110-111,112,115,230$ var. hindsii Carpenter................... 26, $29,31,33,38,49,111-112,115,230$

var. navarchus Dall ..................... 26 $28-29,33,38,49,112-113,115,118,230$ var. strategus Dall........ 26, 29, 33-34,38, $49,113,232$ hericeus Gould ............................. $\quad 110$

var. hindsii Carpenter ...................... 111

var. navarchus Dall ........................ 112

var. strategus Dall......................... 113

hericius var. albidus Dall....................... $\quad 136$

hydei Arnold...,.,............................ 69

islandicus Müller......................... 16 $26,29,33,38,49,52,55,107,112,113-114,115,120,234$ jordani Arnold.......... 26, 29,31,34,38, 49, 114-115, 232 landesi ........................ 14,38, 49, 51-52, 148 latiauritus Conrad .................. 26-27, 29-30, 33-34, $38,47,49,82,91,108,115-116,123,129,131,137,236$ var. cerritensis............ 33-34, 38, 49, 129-130, 236 var. delosi................... 33-34,38,49, 130, 296 var. fragilis Arnold ......................... 129 var. fucicolus Dall .............. 33, 38,49, 130, 131, 236 var. monotimeris Conrad .... 33-34,38, 49, 82, 131, 236 lawsoni........................ 27,39,49, 117-118, 294 nutteri................. 19, 21, 23, 27, 39, 49; $\mathbf{6 7 - 6 8}, 105,166$ opuntia Dall......... 27-29, 39, 49, 91, 107, 116, 118, 123, 226 parmeleei Dail ... 27, 29, 39, 49, 68, 100, 108, 119, 120-121, 226 proavus...................... 11-12,39,52, 52-53, 148 sespeensis ........................ 19,39,49, 69,160 var. hydei ................. 19, 39, 49, 69-70,79, 83,154 washburnei ................... 27, 39, 49, 119-120,234 
Page.

Chlamys wattsi...... 27, 39, 49, 67-68, 95, 119, 120-121, 122,166 var. morani............... $27,39,49, \mathbf{1 2 1 - 1 2 2 , 1 6 4}$

Chlorostoma aureotinctum Forbes ................. 35 brunneum Philippi........................... 31, 35 funebrale A. Adams.

var. subapertum Carpenter.

gallina Forbes.

montereyi kiener ............................ 31,35

pulligo Martyn

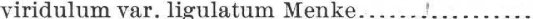

sp................................. 19,24

Cholame Valley beds, equivalents of ................ 10

Chorus belcheri Hinds ................ 23, 24, 35, 76,111

Chrysodomus liratus Martyn ................... 27,30

rectirostris Carpenter...................... 31,35

tabulatus Baird......................... 27,30,31,35

sp.................................. 27,31,103

Cidaris sp......................... 12, 24, 53, $55,92,120$

Clathurella conradiana Gabb.................... 31, 35

Clementia subdiaphana Carpenter ................ 31

Clidiophora punctata Conrad.................... 27, 33

Clypeaster bowersi Merriam..................... ${ }_{22}$

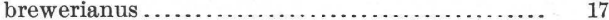

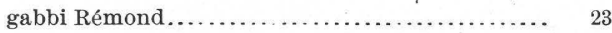

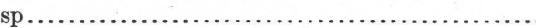

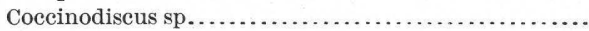

Codakia sp..

Columbella californiana Gaskoin.................... chrysalloidea Carpenter........................ gausapata Gould.

var carinata Hinds.

oldroydi Arnold

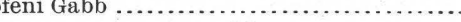

solidula var. præcursor Arnold

tuberosa Carpenter

Colombia, pectens of.

Contra Costa Miocene, equivalents of .............. 126

occurrence of .................... 17

Conus californicus Hinds ........................ 31, 35

horni Gabb ................................ 14

rémondi Gabb .............................. 15

sp................................. 19,52,84, 104

Cooper, J. G., on Eocene fossils.................. 14

Cooperella subdiaphana Carpenter...................

Coos conglomerate, equivalents of

Coralliophila nux Reeve.

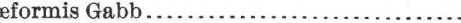

evansiana Shumard

horni Gabb

Carpenter............................. 30,33

parilis $\mathrm{Gat}$

primorsa Gabb ............................... sp............................ 17, 21,27,52,55,56

Cordiera gracillima Cooper. microptygma Gabb

rassatellites grandis Gabb.

unioides Stanton

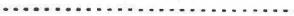

uvasana Conrad ...............................

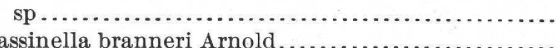

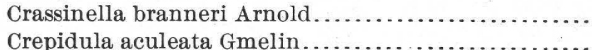

....... 24, 35

dorsa ta Broderip .......................... 35

navicelloides Nuttall....................... 27, 30

onyx Sowerby

prærupta Conrad
Crepidula princeps Conrad ..... 19, 24, 27, 28, 30, 35, 79, 105, 117 rugosa Nuttall........................... 27,35,95 sp

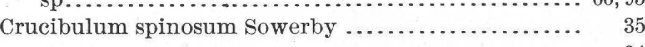
sp......................................... 8 Crustacea.............................. 12, 19,24, 28

Cryptochiton stelleri Middendorf .................. 31, 35 Cryptomya californica Conrad ........................ $27,30,33,65$ Cucullæa mathewsoni Gabb..................... 12

Cuma biplicata Gabb......................... 19,79

Cumingia californica Conrad ..................... 30,33

Cylichna alba Brown............................

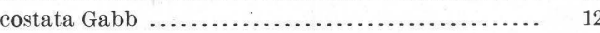
hørni Gabb.............................. 17 petrosa Conrad ............................ 17, 21

Cypræa bayerquei Gabb ........................ 15 mathewsoni Gabb .......................... 15

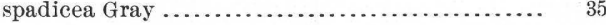
sp. Cyrena californica Gabb ........................ Cythara branneri Arnold ........................ 35

Cytherea vespertina Conrad..................... 17, 55 sp.................................. 17,21,56,57

D.

Dall, W. H., on classification of pectens............ 45-50 on San Pedro formation $\ldots$ on Tertiary horizons........................... 10

Deadman Island Pliocene, equivalents of ........... 10 fauna of ................................ $30-31$

Dentalium eooperi Gabb .................. 12, 15, 17,52 indianorum Carpenter ..................... $\quad 35$ neohexagonum Sharp and Pilsbry ............ 28,95 neohexagonum Sowerby ..................... 35 pseudohexagonum Dall ....................... $\quad 35$ semipolitum Broderip and Sowerby ............. $\quad 35$ stramineum Gabb.......................... 12,15 substriatum Conrad ..................... 17,57-58 sp........................ 17, 19,66, 73, 84, 93, 95, 117 Dentipecten circularis Sowerby.................. 125 Diastoma sp ................................ $\quad 35$ Diller, J. S., on Oligocene of Washington ............ 15

Diodus tenuis Gabb............................ 15

Diplodonta orbella Gould......................... serricata Reeve............................ 21, 33

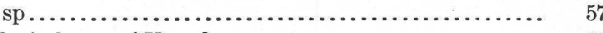

Diploria bowersi Vaughan.......................

Discohelix californicus Weaver................... 12

Dolichotoma carpenteriana Gabb.............. 27, 36, 117 cooperi Arnold............................ $\quad 36$ tryoniana Gabb............................. 36,117 sp......................................... 84

Dolium petrosum Conrad........................ $57-58$

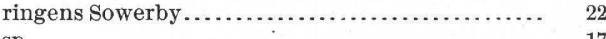
sp ........................................... 17

Donax californica Conrad.......................... lævigata Deshayes............................ latus Gabb................................. 14

Dosinia conradi Gabb............................ 19, 79 elevata Gabb................................ 14 gyrata Gabb .............................. 14 mathewsonii Gabb..................... 19, 79,83 montana Conrad........................... 19,79 ponderosa Gray................ 19, 23, 27, 73, $79,83,104$ sp............................... 22, 27,65,83-84 Drillia cancellata Carpenter....................... 35 hemphilli Stearns............................. incisa Carpenter.......................... 27, 30 


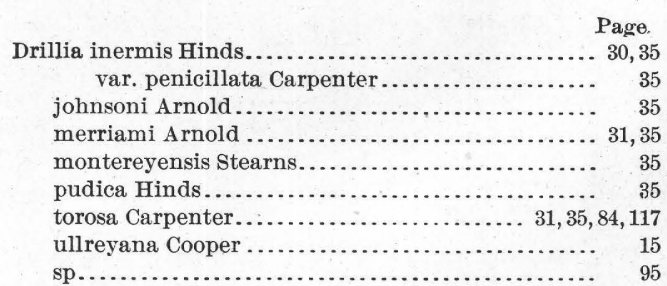

\section{E.}

Echinarachnius excentricus Eschscholtz... 28, 30,33, 99, 122 sp.................................... 103,117 Echinoidea.................. 12, 19,22, 23-24, 27, 28, 30, 33

Empire beds, equivalents of ...................... 10

Enspira alveata Conrad ........................... 15

Eocene rocks, formations of $\ldots \ldots \ldots \ldots \ldots \ldots \ldots \ldots \ldots .9 . \ldots \ldots \ldots$

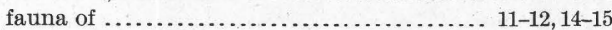

occurrence of ............................ 9,10 pectens of ..................... 11,14,37-41,51-54,148

Epiphragmorphora sp.

Epona mathewsoni Gabb.

Erato columbella Menke

Eulima falcata Carpenter.......................... 35 hastata Sowerby. micans Carpenter

Eupleura muriciformis Broderip muriciformis var. curta Arnold..................

\section{F.}

Fairbanks, H. W., on Vaqueros sandstone.

Fasciolaria io Gabb.

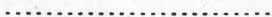

læviuscula Gabb...............................

sinuata Gabb.

Fauna, fossil, lists of....... 12,14-15, 17, 19, 21-24, 26-31, 33-37 localities where found, lists of ... 11, 13, 16, 20-22, 26, 29, 32

Favia merriami Vaughan

Ficopsis angulatus Weaver cooperi Gabb

horni Gabb...

rémondi Gabb

Fissurella volcano Reeve

Fissuridea aspera Eschscholtz

inæqualis Sowerby

murina (Carpenter) Dall

sp

Flabellum californicum Vaughan rémondianum Gabb

Foraminifera nummuloid....

$$
\text { sp. }
$$

Fort Tejon, Cal, rocks near map showing location of....................... 7

Fusus æquilateralis Weaver. arnoldi Cossmann

barbarensis Trask. .......... californicus Conrad ......................... 15 diaboli Gabb

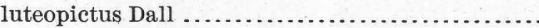

martinez Gabb.

mathewsonii Gabb

oregonensis Conrad

robustus Trask .................................. 24, 35

rugosus Trask ............................. 27, 35

supraplanus Cooper............................
Fusus thracius Conrad Page sp........................ 17, 19, 24, 52, 57-59, 73, 93 G.

Gadinia reticulata Sowerby ......................

Galeocerdo productus Agassiz ......................

Galerus excentricus Gabb................. 12, 15,17, 19,79

inornatus Gabb .............................. 27

mammillaris Broderip...................... 17, 19, 35 Gari alata Gabb.............................. 23 Gasteropoda...... 12,14-15, 17, 19, 21-22, 24, 27-28, 30, 31, 34-37 Gastrochæna sp............................. 22 Glottidia albida Hinds........................... $\quad 27$

Glycymeris barbarensis Conrad .................... 33 cor Gabb............................... 14 patulus Conrad........................... 24,64,118 sagittata Gabb . . septentrionalis Middendorf..................... veatchii Gabb var. major Stanton ............... 14 sp................... 19, $21,23,52,58,73,79,83,85,118$ Glyphis densiclathrata................... 91, 116, 123 Gyrodes dowelli white............................ 15 sp ............................................ 75

H.

Haliotis fulgens Philippi .......................

Haminea virescens Sowerby .......................

Hamlin, Homer, on Vaqueros sandstone............ 18

Helcion dichotoma Gabb........................ 12,53

Helix (Epiphragmophora) sp ....................

Heteroterma gabbi Stanton....................... 1

striata Stanton .............................. 12

trochoidea Gabb............................ 12

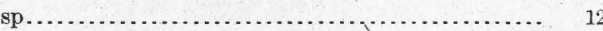

Hinnites Defrance ..................... 41, 48, 50,94 cortezi Defrance............................ $\quad 50$ crassa Conrad............................ 93,94,209 giganteus Gray .............................. 19 $21,22,23,26,29,33,38,50, \mathbf{9 3}-\mathbf{9 4}, 95,109,202$ poulsoni Conrad ..............................

Hipponyx antiquatus Linné...................... 31, 34 Hyatt, A., on law of evolution ..................... Hypogella diegoensis Gabb......................... 14

I.

Isapis fenestrata Carpenter........................ Ischnochiton regularis Carpenter ................... Ivara turricula (Carpenter) Dall and Bartsch......... 35

J.

Janira bella Conrad ............................ 95-96 dentata Cooper.............................. 100 dentata Gabb............................... 100 dentata Sowerby ........................... 135-136 florida Hinds.

K.

Kellia laperousii Deshayes $-\frac{30,33}{3}$ suborbicularis Montague .......................

Kennerlia bicarinata Carpenter ....................... 33, 103 filosa Carpenter.............................. 33 grandis Dall ............................... 103

L.

Lacuna compacta Carpenter porrecta Carpenter

(1)

$-2$

4

14
43

5

5
5
8
3
5
2
2
2
2
0
2
7
3
4
4

.

\begin{tabular}{l}
5 \\
0 \\
0 \\
\hline
\end{tabular}


Page.

Lacuna solidula (Loven) Carpenter

Lævicardium linteum Conrad. substriatum Conrad $\mathrm{sp} . .$.

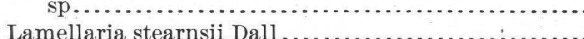

Tamna clat

Laqueus californicus jeffreysi Dall

Lawson, A. C., on Monterey shale .

Leda alæformis Gabb ............................ 12 fossa Baird ................................... $27,33,84$ gabbi Conrad ............................... 12, 14 hamata Carpenter ........................... 33 minuta var. præcursor Arnold . ................ 33 taphria Dall .............. 19, 27, 28, 30, 33, 83-84, 95, 117 sp.................... 17, 19, 21, 55, 57-59,66,73,98

Leptopecten monotimeris Conrad................... 131

Leptothyra bacula Carpenter...................... 35 carpenteri Pilsbry ........................ 35 paucicostata Dall......................... 27,35

Leucosyrinx pedroana Arnold .................. 36, 84

Lima dehiscens Conrad ......................... 33 hamlini Dall......................... 91,116, 123 multiradiata Gabb........................ 12,14

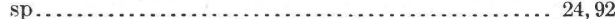

Liropecten crassecardo Conrad.................... 71 estrellanus Conrad ........................... 74-75 Heermanni Dall....................... 75, 79, 101 veatchii Cooper........................... 77, 106

Lithophaga plumula Hanley .................... $\quad 33$

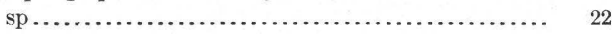

Litorina planaxis Phil..................... 24, 30, 31,35 rémondi Gabb ............................ 24, 73 scutulata Gould.............................. $\quad 35$

Little Falls, Wash., formations near.............. 10 Localities, fossil, lists of......... 11, 13, 16, 18, 20-22, 26, 29, 32

Loxotrema turrita Gabb.................. 15

Lucapina crenulata Sowerby .................... $\quad 35$

Lucapinella callomarginata Carpenter............. 35

Lucina acutilineata Conrad .................... 34, 117

californica Conrad........................... 34

cretacea Gabb ............................. 14

tenuisculpta Carpenter ......................... 34

Luponia bayerquei Gabb ........................ 15

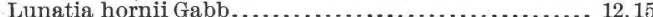
lewisii Gould ................... 24, 27, 30, 36,117-118 nuciformis Gabb........................... 15 shumardiana Gabb ....................... 15, 17 sp................................. 52,57-58,84 Lutraria traskii Conrad........................ 20,21 Lyonsia californica Conrad............................ 31, 33
Lyropecten Conrad..................... $41,46,49,71,81,141$

, ashleyi...

$28,29,37,49,72,91,95,116,118,121,122-128,238,240$ bowersi ............. 19, 21,37,47,49, 70-71, 141, 168,170 crassicardo Conrad. $19,21,23,24$ $38,49, \mathbf{7 1 - 7 3}, 78,81,83,89,92-93,122,141,176,178,180$ var. hamiltoni ........... 19, 23, $38,49, \mathbf{7 3 - 7 4}, 81,166$ diabloensis Arnold estrellanus Conrad.

19,21 , $23-24,38,49,64,67,70,72-74,74-76$ $77,79-80,102,111,141,182,184,186$ var. catalinæ ...........23, 26, 38,49, 63, 76-77, 184 var. terminus ......................23, 24, $38,49,77,190$ Heermanni Dall ....................... 75, 79, 101, 102 magnolia Conrad. 19,39, 49, 70-72, 77-79,80-81, 107,192-194 miguelensis............... 19, 39, 49, 79-80, 102, 188, 190 perrini. $19,21,39,49,80-81,172,17 / 4$
Pyge. (19.............. 19, 49, 81-82, 19 voloformis Conrad........................ $74,75,184$

M.

Macoma calcarea Gmelin............. 19, 27, 30, 31, 33, 103 indentata............................... 33 inquinata Deshayes................ 27, 30,31,33, 103 nasuta Conrad............... 17, 19, 23, 27, 28, 30, 33, 103 var. kelseyi Dall ........................ 33 sabulosa spngl............................ $\quad 30$ secta Conrad.............................. 33,99 yoldiformis Carpenter ......................... 33

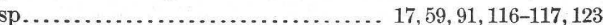
Macron kellettii A. Adams ...................... 35 lividus A. Adams ......................... 35 Mactra californica Conrad ........ 19, 23, 24, 27, 30, 33, 83, 103 catilliformis Conrad . . . . . . . . . . . . . . . . . . . 28, 67 exoleta Gray............................. 34 falcata Gould .................................. 23, 24 hemphilli Dall............................ 27,34 planulata................................... 84 sp............................................ 66

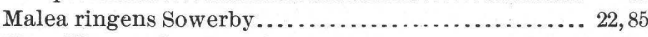
Mangilia angulata Carpenter..................... 35 hooveri Arnold ............................ interfossa var. pedroana Arnold ................. interlirata Stearns ......................... oldroydi Arnold .............................. 35 painei Arnold................................. $\quad 35$ saturalis Cooper ............................. 15 sculpturata Dall ........................... 31,35 striosa C. B. Adams.......................... 35

Map of California, showing fossil localities........... 7 Marcia subdiaphana Carpenter...................... 31 Margarita optabilis var. knechti Arnold............... optabilis var. nodosus A rnold ................... $\quad 36$ parcipicta var. pedroana Arnold ................. $\quad 36$ pupilla Gould.............................. Margaritella crenulata Gabb ........................ 15 Marginella jewettii Carpenter.................... $\quad 36$ sp...................................... 57-58 Martesia ovoides Gould .......................... 117 Martinez, Cal., rocks near........................ 11 Martinez formation, character of .................. 11 equivalents of $\ldots \ldots \ldots \ldots \ldots \ldots \ldots \ldots \ldots \ldots \ldots \ldots, 10$ fauna of $\ldots \ldots \ldots \ldots \ldots \ldots \ldots \ldots \ldots \ldots \ldots \ldots \ldots \ldots \ldots \ldots \ldots, 11-12$ occurrence of .............................. 9,11 pectens of ............................. 11,37-40

Megatebennus bimaculatus Dall ................. 19, 36 sp........................................ 12 Megistostoma striata Gabb ....................... 12,15 Merced, Lake, rocks near ........................ 28

Merced formation, character of................... $\quad 29$ equivalents of $\ldots \ldots \ldots \ldots \ldots \ldots \ldots \ldots \ldots \ldots \ldots . \quad 10$

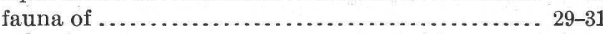
occurrence of .......................... 9, 28-29 pectens of................................ 29,37-40

Meretrix californica Conrad...................... 14 horni Gabb .................................... 14,51 ovalis Gabb.................................. 14 uvasana Conrad .............................. 14 sp........................................ 12,52

Merriam, J. C., on Contra Costa Miocene........... 17 on Martinez formation ........................ 11 on pecten in Cretaceous shale.................. 54 on San Pablo formation ....................... 22, 23 on Tejon formation ........................ 14 on Vaqueros formation........................ 18 
Merriam, J. C., on Ventura County fossils............ Page. Metis alta Conrad

Mexico, fossils from

Miocene rocks, formations of................. 9-10,17-2 fauna of $18-19,21-24$ occurrence of pectens of .... 18-19, 21, 23,37-42, 56, 59-94, 111, 150-202, 230

Mitra cretacea Gabb. maura Swainson. simplicissima Cooper

Mitramorpha filosa Carpente intermedia Arnold

Modiolus fornicatus Carpenter merriami Weaver

ornatus Gabb rectus Conrad ...................... 17, 27, 28,30,34, 95 $\mathrm{sp}$ $17,23,69$

Moerella salmonea Carpenter ................. 27, 34

Molopophorus striata Gabb.

Monia macroschisma Deshayes.

Monoceros engonatum Conrad lapilloides Conrad

Monterey, Cal., rocks near

Monterey shale, character of equivalents of .

fauna of .

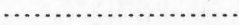

occurrence of pectens of

Mopalia ciliata Sowerby........................ 36

Morio tubereulatus Gabb ...................... 12,15

Mulinia densata Gabb

Murex festivus Hinds.

foliatus Martyn

monoceros Sowerby

nuttalli Conrad.

trialatus Sowerby:

sp.

Myrtea?.

Mysia polit

Mytilimeria nuttalli Conrad....................... 31, 3

Mytilus ascia Gabb .......................... 14

californianus Conrad ......................... 30

dichotomous Cooper......................... 14

edulis Linné.

30-34

humerus Conrad...

mathewsonii Gabb................ 19, 27, 70, 73, 79, 86

sp ................................. 23, 24,66,117

Mytilus beds, equivalents of...................... 10

\section{N.}

Nassa antiquata Gabb. californiana Conrad ..................... 27, 31,36

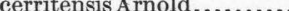
cretacea Gabb............................... 15 fossata Gould ........................ 30-31, 36, 95, 104 insculpta Carpenter........................... 36 mendica Gould ................... 19, 27, 30,31,36, 100 var. cooperi Forbes ..................... 31, 36 perpinguis Hinds ................... 27, 31, 36, 84, 95, 117 tegula Reeve.

versicolor var. hooveri Arnold.................. 36 sp ........................... 24, 73, 91, 93, 99, 116, 123

Natica clausa Broderip and Sowerby ......... 27, 30, 31, 36, 103 ocoyana Conrad.

lewisii Gould .

recluziana

uvasana Gabb. sp
Naticina obliqua Gabb ......................... 15

Nautilus sp ................................... ${ }_{52}$

Neæra pectinata Carpenter........................ 17,34

Neptunea cretacea Gabb.......................... 15

gracilis Gabb................................. 15

humerosa Gabb.............................. 27

mucronata Gabb

supraplicata Gabb ............................ 15

sp

Nerita triangulata Gabb ........................ 15

Neverita globosa Gabb........................... 15

recluziana Petit........................... 19,

$22,28,31,36,79,91,95,104,116,121,123$

saxea Conrad ................................. 17

secta Gabb .................................. 15

sp......................................... 24, 120

Nodipecten Dall........................... 41,49

nodosus Linné............................ 49, 129

subnodosus Sowerby ... 33-34, 39, 49, 107, 128-129, 248,250 veatchii Gabb ................ 27, 39, 49, 98, 106-107, 224 .

Norrisia norrisii Sowerby........................ 36

Nucula castrensis Hinds................... 27,31, 34, 65

decisa Conrad ............................ 57, 66

suprastriata Carpenter......................... 34

truncata Gabb ............................ 12,14

sp ................................... 17,55, 57,58

Nutter, E. H., work of.

o.

Ocinebra barbarensis Gabb $\ldots \ldots \ldots \ldots . .36$ cancellina Philippi............................ 24, 86

foveolata Hinds............................. 36

interfossa Carpenter......................... 31,36

keepi Arnold ................................ $\quad 36$ lurida Midd............................. 19, 24, 36 var. aspera Baird......................... $\quad 36$ var. cancellina Philippi .................... 36

var. cerritensis Arnold ...................... $\quad 36$ var. munda Carpenter ........................ $\quad 36$ micheli Ford.................................. perita Hinds................................ $\quad 36$ poulsoni Nuttall.............................. $\quad 36$ sp .......................................... 23, 52

Odostomia gouldii Carpenter..................... $\quad 36$ nuciformis var. avellana Carpenter............. 36 tenuis Carpenter.............................. $\quad 36$

Oligocene rocks, fauna of ....................... 16-17 formations of ........................ occurrence of $\ldots \ldots \ldots \ldots \ldots \ldots \ldots \ldots \ldots \ldots \ldots, 9,15$ pectens of ...................... 16,37-41,54-59, 150 Oligocene-Miocene rocks, pectens of............ $55,57,59$ Oliva sp................................... 22 Olivella biplicata Sowerby................... 30-31,36 intorta Carpenter....................... 28, 30,31,36 mathewsoni Gabb .......................... 15 pedroana Conrad ......................... 19, 24, 31, 36 Oliverato californica Cooper...................... 14 Omphalius viridulum var. ligulatum Menke......... 35 Opalia anomala Stearns. . borealis Gould................................. 36 condoni Dall................................ 120 crenitoides var. insculpta Carpenter.............. 36 mathewsoni Gabb...................... 15 varicostata Stearns ......................... 28, 100 ...... 17,24 Oregon, formations in $\ldots \ldots \ldots \ldots \ldots \ldots \ldots \ldots \ldots \ldots \ldots \ldots \ldots \ldots, 10$ fossil localities in ........................... 13 fossils from .................... $62,65,111-112,120,142$ Ostrea appressa Gabb............................ 14 


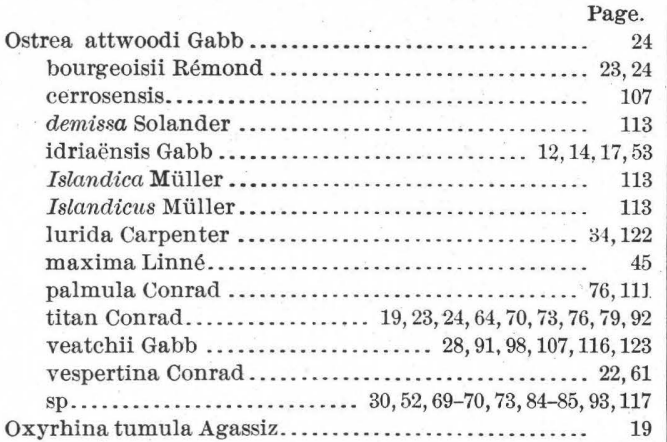

\section{P.}

Pachypoma inæquale Martyn ....................... $\mathrm{sp}$

Pallium crassicardo Conrad estrellanum Conrad... stokesi Arnold

Pandora seapha Gabb ......................... 117

Panomya ampla Dall..................... 27,31,34,103 Panopea generosa Gould .......... 17, 19, 27, 31, 34, 65, 79, 117 Paracyathus pedroensis Vaughan

perivalents of.................... 10

Paso Robles formation, equivalents of....................

Patella traski Gabb................................ 5

$$
\text { sp ............................................ } 53
$$

Patinopecten Dall ..................... 41, 48-49, 66 caurinus Gould .......................... 26, $29,31,33-34,37,48-49,65,99, \mathbf{1 0 1}-103,106,220$, 222 coosensis Shumard ..........23, 37, 49,61-62, 105, 156, 158 dilleri Dall..................... 23, $26,38,49, \mathbf{6 2}, 105,15$, healeyi....... 26-29, 38,49,63,65,100, 103-105, 108, 216,218 oweni.............. 23-24, $27,39,49, \mathbf{6 3 - 6 4}, 65,95,121,160$ propatulus Conrad......... 19, 21, 23, 39, 49, 64-65, 158,162 purisimaensis .................. 27, 39,49,62, 105, 212,214 turneri ........................... 27, 39, 49, 106, 212 Pecten Müller ................ 41-44, 45-50,51-146, 148-250 xquisulcatus Carpenter........................ 132 (Propeamusium) alaskensis Dall .................. 33 $37,50,127, \mathbf{1 3 3}-134,138,250$

(Pseudamusium) Alaskensis Dall................. 133 alaskensis Whiteaves........................ 133,140 altiplectus Conrad............................. 108 altiplicatus Conrad .......................... 108-109, 226 (Plagioctenium) andersoni................... 18, $21,23,37,47,50,79, \mathbf{8 2 - 8 3}, 89,196$ var. barkerianus............ 18-19, 37, 50, 83-84, 196 (Lyropecten) ashleyi ........................ 26, $28,29,37,49,72,91,95,116,118,121, \mathbf{1 2 2}-123,288,240$ auburyi ................... 26,37,48, 94-95, 121, 210, 219 (Chlamys) bartschi.............. 26, 37, 49, 107-108, 226 bellis McCoy .................................. 95 bellus Conrad...... 16, 26, 29, 37, 48, 54-55, 95-96, 98-99, 206 (Chlamys) bellilamellatus ....... 26, 28, 29, 37, 49, 108, 226 (Lyropecten) bowersi... 19, 21, 37, 47, 49, 70-71, 141, 168, 170 (Chlamys) branneri ..... 16, 19, 37, 49, 55, 55-56, 67, 83, 150 (Chlamys) calkinsi ............... 14, 37, 49, 51, 52, 148 carrizoensis.......... 19, 21, 22, 23, 37, 48, 59-60, 61, 85, 152 catilliformis Conrad ........................ 80, 141 caurinus Dall .................................. 99, 101, 140 (Patinopecten) caurinus Gould................ 26, $29,31,33-34,37,48,49,65,99,101-103,106,220,222$
Pecten (Plagioctenium) cerrosensis Gabb Page. $37,50,63,77,84,98-99,107, \mathbf{1 2 3}-124,125,133,282,242$ var. mendenhalli $21,22,23,37,50,60,63, \mathbf{8 4}-85,85,194$ cinnabarina Born ......................... 113 (Plagioctenium) circularis Sowerby ............. 33, $34,37,50,87-88,125-126,133,228,232$ var. æquisulcatus Carpenter ................. 33-34, $37,45,46,50,88,89,124,125, \mathbf{1 3 2 - 1 3 3}, 244$ (Propeamusium) clallamensis................. 14, $\mathbf{1 6}, 37,50,53, \mathbf{5 7 - 5 8}, 59,150$ coalingaensis...................... 26,37, 48,97, 152 compactus Dall ............................. 125, 232 (Plagioctenium) cooperi.... 26, 28-29, 37, 50, 124-125, 242 coosaensis Shumard.......................... 61 (Patinopecten) coosensis Shumard............. 23, $37,49, \mathbf{6 1 - 6 2}, 105,156,158$ (Hinnites) cortezi Defrance .................. 50 (Lyropecten) crassicardo Conrad ............ 18, 21, 38 , $49, \mathbf{7 1 - 7 3}, 78,81,83,89,92-93,122,141,176,178,180$ var. hamiltoni ............ 19, 23, 38, 49, 73-74, 81,166 (Pseudamusium) davidsoni Dall...... 38, 50,134, 138, 244 dentatus Arnold ............................. $\quad 100$ dentatus Sowerby ........................... 134-135 (Vola) dentatus Sowerby....................... 135 (Plagioctenium) deserti Conrad...... 19, 22, 38, 50, 85, 196 (Lyropecten) diabloensis Arnold ................ 72 diegensis Dall ........ 33, 38, 48, 60, 96, 98, 100, 127-128, 246 (Patinopecten) dilleri Dall ...... 23, 26, 38, 49, 62, 105, 154 dislocatus Say ............................... 133 (Plagioctenium) discus Conrad................ 21, $23,24,38,50,71,73,80,82, \mathbf{8 6}-\mathbf{8 7}, 198$ (Chlamys) discus Conrad....................... 86 discus Cooper ............................... 82, 86 eboreus Say............................... 102 (Plagioctenium) eldridgei .......... 23, 24, 38, 50, 87, 194 estrellanus Ashley........................... 122 (Lyropecten) estrellanus Conrad... 19, 21, 23, 24, 38, 49, 64, $67,70,72-74,74-76,77,79-80,102,111,141,182,184,186$ var. catalinæ..............23, 26, 38, 49, $63, \mathbf{7 6 - 7 7}, 184$ var. terminus ................. 23, 24,38,49, 77, 190 excavatus Anton.... 38, 47, 48, 61, 96, 100, 101, 134-136, 236 (Pseudamusium) exoticus Chemnitz............ 50 (Patinopecten) expansus Dall ................. 103-104 Fabricii Philippi............................. 114 (Propeamusium) fenestratus Forbes............. 50 (Vola) floridus Hinds ......................... 127 fragilis Jeffreys ............................ 129 (Chlamys) fucanus Dall...... 19, 21, 23, 38, 49, 66-67, 164 (Hinnites) giganteus Gray .................... 19, $21,22,23,26,29,33,38,50,93-94,95,109,202$ (Chlamys) hamlini .............. 19, 38, 49, 67, 122, 166 (Chlamys) hastatus Sowerby................. 26-29, $31,33-34,38,49,69,94,108-110,112,115,117,226,228$ var. albidus Dall.................... 38, 49, 136, 248 var. hericius Gould ................... 23, 24, 26 , $28,29,31,33-34,38,49,70,109,110-111,112,115,230$ var. hindsii Carpenter.................... 26 , $29,31,33,38,49,111-112,115,230$

var. navarchus Dall ....................... 26 $28-29,33,38,49,112-113,115,118,230$ var. strategus Dall........ 26, 29, 33-34, 38, 49, 113, 232 (Patinopecten) healeyi...................... 26-29, $38,49,63,65,100,103-105,108,216,218$ Heermanni Conrad ................. 75, 79, 101-102, 232 (Lyropecten) Heermanni Dall .............. 75, 79, 101-102 hemphilli Dall ...... 16,26, 28-29, 38, 48, 96, 97-98, 100, 210 hericeus Gould ............................. 10 
Pecten hericeus var. hindsii Carpenter............... Page. hericeus var. navarchus Dall. var. strategus Dall

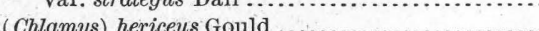
var. strategus Dall .

\section{hericius Gould}

var. albidus Dall

Humphreysii

(Chlamys)

inca Orbigny.

(Propeamusium) inequisculptus Tiberi ..............

intermedius Conrad

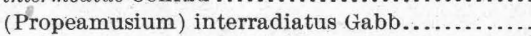
$38,50,53-54,59,91,1$

irradians .............. 133

Islandica Müller

Islandicus Chem

Islandicus Cooper.

(Chlamys) Islandicus Müller Jeffersonius Say

(Chlamys) jordani Arnold......................... 26 $29,31,34,38,49,114-115,232$

Pecten keepi ..... 19, 21, 22, 23, 38, 48, 60-61, 85, 135, 154, 156 (Chlamys) landesi n. sp............ 14, 38, 49, 51-52, 148 laqueatus Sowerby ........................ 135 (Chlamys) latiauritus Conrad ..... 26-27. 29-30, 33-34, 38, $47,49,82,91,108,115-116 ; 123,129,130,131,137,236$ var. cerritensis n. var... 33-34, 38, 49, 108, 129-130, 236 var. delosi n. sp. .............. 33-34, 38, 49, 130, 236 var:fragilis Arnold

var. fucicolus Dall............ 33, 38, 49, 130, 131, 236 var. monotimeris Conrad ..... 33-34,38,49,82, 131, 236 (Chlamys) lawsoni n. sp ........... 27, 38, 49, 117-118, 234 lecontei n. sp.....................27, 38, 48,94,98, 107, 210 (Pseudamusium) lompicoensis...... 21, 38, 50, 89, 190, 198 (Amusium) lompocensis........... 38, 50,73, 92-93, 200 madisonius Say..

(Lyropecten) magnolia Conrad $39,49,70-72,77-79,80-81,107,192,194$

magnolia Dall . 72 maximus Linné.............................. 48 Meekii Conrad............................ 101-102, 222 meekii Merriam .............................. 99 membranosus Morton ….......... 52 merriami.......................... 27, 39, 48,99, 204 mesotimeris Sowerby .. 115 (Lyropecten) miguelensis ... 19,39, 49, 79-80, 102, 188, 190

(Leptopecten) monotimeris Conrad................ 131 (Amusium) mortoni Ravenel................. 92 (Plagioctenium) neahensis.... 18, 21, 23, 39, 50, 87-88, 174 nevadanus Conrad

nevadanus Conrad , 70

(Plagioctenium) newsomi Arnold................ 132 nodosus................................... 49.129 (Chlamys) nutteri...... 19; 21, 23, 27, 39, 49, 67-68, 105, 166 (Æquipecten) opercularis Linné

(Chlamys) opuntia Dall $39,49,91,107,116,118,123,226$

(Patinopecten) owen 23 , $24,27,39,49,63-64,65,95,121,160$ (Plagioctenium) pabloensis Conrad $39,50,63,86,88-89,198$ (Æquipecten) palmeri Dall.......... 39,49, 136-137, 244 (Chlamys) parmeleei Dall

$29,39,49,68,100,108,119,120-121,226$ (Plagioctenium) paucicostatus Carpenter. 39, 50, 137, 222 reale $i$ Conrad
Pecten (Pseudamuium) Page. $17,19,21,39,47,50,55, \mathbf{5 6}-\mathbf{5 7}, 89,138-139,150$

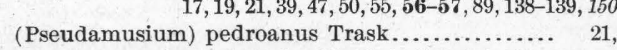
$23,27,39,50,90-91,92,116,123,138-139,200$ (Lyropecten) perrini ......... 19, 21, 39, 49, 80-81, 172, 174 (Amusium) pleuronectes Linné ................ 50 pomatia Valenciennes ......................... 125 (Chlamys) proavus n. sp ...... 11, 12, 39, 49, 52, 52-53, 148 (Patinopecten) propatulus Conrad............. 19,
$21,23,39,49,64-65,158,162$ propatulus Cooper........................... 101, 106 (Pseudamusium) Sowerby ...................... 50 (Patinopecten) purisimaensis... 27, 39, 49, 62, 105, 212, 214 pyxidatus Carpenter....................... 141,142 (Pseudamusium) randolphi Dall. 39, 50, 89,91,138-139,240 var. tillamookensis n. var............39, 50, 139, 240 - (Propeamusium) riversi.... 27, 29, 39, 50, 126-127, 134, 232 rubidus Hinds ............................. 112,113 sanctæcruzensis .............. 16, 17, 19, 39, 48, 54-55, 150 (Chlamys) sespeensis. . $19,39,49,69,70,160$ var. hydei n. var .......... 19, 39, 49, 69-70, 79, 83, 154 (Propeamusium) stanfordensis................ 14, $19,21,39,50,53,58-59,91-92,190$

Pecten stearnsii Dall ........................27-29, $31 ., 39,48,60,63,77,91,96,98,100,108,116,123,128,135,208$ subcrenatus Carpenter ..................... 142 (Nodipecten) subnodosus Sowerby ............... 33-34, $39,49,107,128-129,2 / 48,250$ (Plagioctenium) subventricosus Dall .......... 123, 125, 232 swiftii Bernhardi ......................... 46,119-121 thalassinum Dall ................................ 46 townsendi Gould $. . . \ldots \ldots \ldots \ldots \ldots \ldots \ldots \ldots \ldots . .142$ traski Gabb................................ 58 tumbezensis Orbigny ........................... 116 tumidus Sowerby ............................. 125 tunica Philippi.............................. 115 (Patinopecten) turneri $\ldots \ldots .27,39,49,106,212,214$ twobarensis Arnold............................ 54 (Pseudamusium) vancouverensis Whiteaves....... 39 , $50,101,133,139,140,2 L 8$ (Lyropecten) vaughani.............. 19,39, 49, 81-82, 190 (Nodipeeten) veatchii Gabb ... 27, 39, 49, 98, 106-107, 22/4 (Plagioctenium) ventricosus Arnold ............... 132 ventricosus Dall ........................... 132 ventricosus Gabb ........................... 132 ventricosus Sowerby ........................ 123, 125 vogdesi............... 33-34,39,48, 100-101, 135, 210,212 voloeformis Conrad ........................ 74, 75, 184 (Chlamys) washburnei........... 27, 39, 49, 119-120, 234 (Chlamys) wattsi ......................... 27 , $39,49,67-68,95,119,120-121,122,166$ var. morani ............... 27,39,49,121-122, 16 (Propeasmusium) waylandi ... 14, 16, 39, 50, 53, 58-59, 150 Yessoensis Carpenter......................... 101 yessoensis Jay ............................ 102 sp ..................................... 59,63, 94, 117 s. s. Müller......................... 41, 46, 48, 236 Pectens, collection of, examination of .............. 8

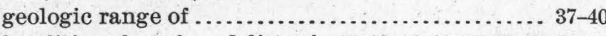
localities where found, lists of. $11,13,16,18,20-22,26,29,32$ plates showing .......................... 148-250 summary of................................... 44 unidentifiable specimens of ............... 44,141, 142 value of, in stratigraphy ...................... 7 Pectinacea.................................. 41-250 Pectinidæ .................................... 41-250 Pectunculus patulus Conrad..................... 118 Pelecypoda.... 12, 14, 17, 19, 21, 22, 23-24, 27, 28, 30, 33-34, 41-250 


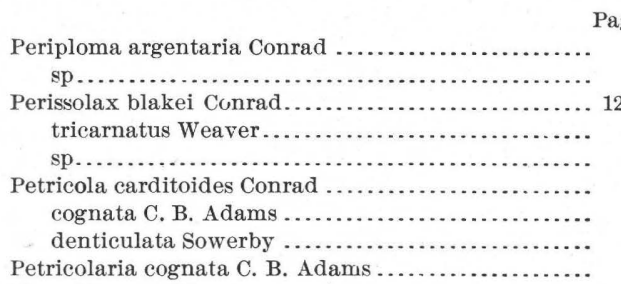

Petricolaria cognata C. B. Adams

$17,19,22,24,27$,

Phacoides acutilineatus Conrad................. $28,31,34,57,65,79,83,89,95,104-105,107-108,117$ californicus Conrad ..................... 31, 34, 95, 121 crenulata.

nuttalli Conrad........................... 27-28,84,95 richthofeni Gabb..................... 19, 79, 95, 104 tenuisculpta Carpenter.......................... 34 turneri Stanton

sp........................... 17, 55, 57, 73,84,93,117

Phasianella compta Gould ....................... $\quad 36$

Pholadidea penita Conrad ............................. 31,34

Pholadomya nasuta Gabb. .

Pholas erucigera Sowerby.

Phorcus pulligo Martyn

Physa heterostropha Say

Pinna alamedensis Yates. .

(n)

31,34

Pis fortis Carpenter ........................24,36,64

Pisces -

Pismo formation, equivalents of ................. 10

Plagioctenium ............................. $41, \mathbf{5 0}$ andersoni .......... 18, 21, 23, 37, 47, 50, 79, 82-83, 89, 196 var. barkerianus..... 18-19, 37, 50, 83-84, 196 cerrosensis Gabb...................... 26, 28-29, $37,50,63,77,84,98-99,107, \mathbf{1 2 3 - 1 2 4 , 1 2 5 , 1 3 3 , 2 3 2 , 2 4 2 ~}$ var. mendenhalli......................... 19, $21,22,23,37,50,60,63, \mathbf{8 4}-85,85,194$ $37,50,87-88,125-126,133,228,232$ var. æquisuleatus Carpenter............... 33-34, $37,45,46,50,88-89,124-125,132-133$, 244 cooperi................. 26, 28-29, 37, 50, 124-125, 242 deserti Conrad .................... 19, 22, 38, 50, 85, 196 discus Conrad ..... 21, 23-24, 38, 50, 71, 73, 80, 82, 86-87, 198 eldridgei ...... $23,24,38,50,87,194$ neahensis.................. 19, 21, 23, 39, 50, 87-88, 174 newsomi Arnold... pabloensis ................... 23, 39,50,63, 86, 88-89, 198 paucicostatus Carpenter ...... 39, 50, 137, 222 subventricosus Dall....................... 123, 125, 232 ventricosus Dall ............................ 132 ventricosus Sowerby ...................... 123, 125, 132

Plagiostoma annulatus Trask....................... 90 Pedroana Trask.................................. 99

truncata Trask.

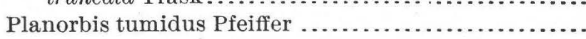
vermicularis Gould.

Platyodon eancellatus Conrad

Pleistocene rocks, formations of.............. 9-10, 31-37

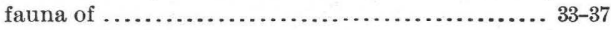
occurrence of

pectens of ............................ $94,101,103,109,111-114,116,126-136,210-212,224,250$

Plesiastrea californica Vaughan................... 22

Pleurotoma bartschi Arnold ......................... 31, 36 carpenteriana Gabb ....................... 36,117 cooperi Arnold ................................. 36

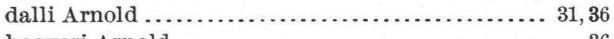

hooveri Arnold ..

pedroana Arnold

.

Pleurotoma perkinsiana Cooper .................. $\quad 15$ perversa Gabb........................ 28,31,36, 103 raricostata Gabb............................. $\quad 17$

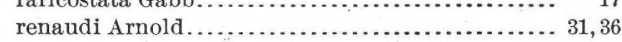

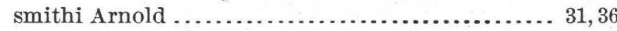
tryoniana Gabb........................... 36, 117 sp........................... 17, 28, 30, 84, 91, 116, 123 Plicatula ......................................... 46 ostreiformis Stanton........................... 12

Pliocene rocks, fauna of ...................... 26-31 formations of $\ldots \ldots \ldots \ldots \ldots \ldots \ldots \ldots \ldots \ldots .9,10,25-31$ occurrence of ........................... 9,25 pectens of .................... $26-27,29,37-40,42-43$, $62,64,77,91,94-127,152,164-166,200,204-228,232-242$ Pododesmus macroschisma Deshayes............ 28, 30, 34 Polynices recluziana Deshayes ...................... ${ }_{22}$ Pomaulax undosus Wood ............................. sp ........................................... 104

Porter, Wash., rocks near......................... 15 Potamides carbonicola Cooper..................... 15 davisiana Cooper ................................... 15

Priene oregonensis Redfield $\ldots \ldots \ldots \ldots \ldots \ldots \ldots \ldots \ldots .28$, $31,36,91,95,103,116-117,121,123$ sp....................................... 24 Prionodesmacea .............................. 41-250 Propeamusium Gregorio ....................... 41, 50 alaskensis Dall.......... 33, 37, 50, 127, 133-134, 138, 250 clallamensis ............... 14, 16, 37, 50, 53, 57-58,59, 150 fenestratus Forbes........................... 50 inequisculptus Tiberi....................... 50 interradiatus Gabb ............ 14, 38, 50, 53-54 $, 59,91,148$ riversi .................... 27, 29, 39, 50, 126-127, 134, 232 stanfordensis..........14,19, 21, 39, 50, 53, 58, 59, 91-92, 190 waylandi .................. 14, 16, 39, 50, 53, 58-89, 150

Protocardia centifilosa Carpenter................... 31, 34 Psammobia edentula Gabb .......................... 19, 34 Psephis lordi Baird .............................. 30 salmonea Carpenter .......................... 34

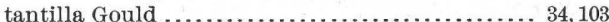
Pseudamusium H. and A. Adams ............... 41, 50 Alaskensis Dall............................. 133 davidsoni Dall..................... 38, 50, 134, 138, 244 exoticus Chemnitz...................... 50 lompicoensis ...................... 21, 38, 50, 89, 190, 198 peckhami Gabb........................... 16-17, $19,21,39,47,50,55, \mathbf{5 6 - 5 7}, 89,138,139,150$ pedroanus Trask ............................ 21 $23,27,39,50,90-91,92,116,123,138-139,200$ randolphi Dall .............. 39, 50,89, 91, 138-139, 240 var. tillamookensis ................ 39, 50, 139,240 vancouverensis Whiteaves.... 39, $50,101,133, \mathbf{1 3 9}, \mathbf{1 4 0}, 248$ Pseudocardium gabbi Rémond ................... 24 Pteria limula Conrad .............................. Pterohytis foliatus Martyn ....................... $\quad 36$ nuttalli Conrad............................... 36 Pteronotus festivus Hinds ....................... $\quad 36$ Puget group, equivalents of ..................... 10 Puncturella cucullata Gould ...................... 31, 36 galeata Gould ............................. 31,36 Purisima Creek, Cal., rocks near ................... 25 Purisima formation, eharacter of.................... 25-26 equivalents of ............................... 10 fossils of $\ldots \ldots \ldots \ldots \ldots \ldots \ldots \ldots \ldots \ldots \ldots \ldots \ldots, 26,28$ occurrence of ........................... 9,25-26 pectens of ............................... 26-27,37-40 Purpura canaliculata Duclos ......................24, 30 crispata Chemnitz ....................... 28, 36,117 saxicola Valenciennes.................... 24, 30,36 
Page. Pyrula sp $\ldots \ldots \ldots \ldots \ldots \ldots \ldots \ldots \ldots \ldots \ldots \ldots \ldots \ldots \ldots \ldots \ldots$
Pyrula $\quad 36$
19,117

R.

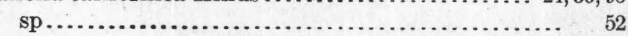
Range of California pectens.................... $37-40$ See also particular species.

Recent time, pectens of..... 37-40, 43-44, 94, 103, 111-114, 116, $126,128,130,202,220-222,226-236,240,244,246-250$. Rictaxis punctocœlata Carpenter

Rimella canalifera Gabb simplex Gabb.

Rissoa acutelirata Carpenter.

Rock Creek Eocene, equivalents of.

Rostellaria indurata Conrad.

Rupellaria lamellifera Conrad.

$$
\text { s. }
$$

Salinas Valley, Cal., formations in

San Diego formation, equivalents of .

faung of

San Joaquin Valley, formations in.

San Juan de Fuca Strait, rocks near

San Lorenzo formation, character of.

equivalents of occurrence of................................ 9,16 pectens of ............................... 16,37-40

San Pablo Bay, Cal., rocks near............ 22

San Pablo formation, character of ................. 22

equivalents of ................................. 10

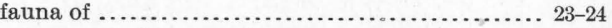

occurrence of .............................. 9, 92

pectens of............................... 23, 37-40

San Pedro, Cal., rocks from ......................... 32

San Pedro formation, character of .................. 32

equivalents of $\ldots \ldots \ldots \ldots \ldots \ldots \ldots \ldots \ldots \ldots \ldots \ldots . .10$

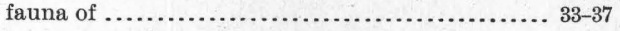

occurrence of ................................. 9, 92

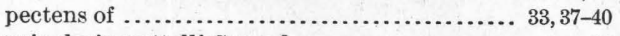

Sanguinolaria nuttalli Conrad..................... 34

Santa Cruz, quadrangle, rock in................... 16

Santa Margarita formation, equivalents of.......... 10 fauna of .

Santa Rosalia, Mex., fossils from................ 84-85

Saxidomas gibbosus Gabb ............... 19, 24, 27,30,64, 8 gracilis Gould............................ 24, $30,34,73$ $\mathrm{sp}$.

Scala bellastriata Carpenter

36

hemphilli Dall................................ 36

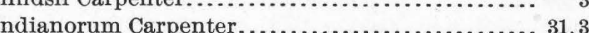

stearnsii Dall $\ldots \ldots .28,100$

tincta Carpenter........................... 28, 36

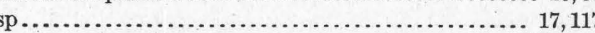

Scalaria mathewsoni Gabb ..................... 15

Schizaster lecontei Merriam...................... 12

Sconsia tuberculatus Gabb ....................... 15

Scutella fairbanksi Merriam ................. 19, 70,122

gabbi Rémond.............................. 23

interlineata Stimpson ..................... 27, 30

sp........................................ 92-93, 103

Seila assimilata C. B. Adams .....................

Semele decisa C'onrad ............................. 34

pulchra Sowerby .......................... 34, 85

var. montereyi Arnold..................... 34
Page.

ptifer bifureatus Conrad ........................ 34

dichotomus Gabb............................ 14

Serpula sp ..................................... 12

Serpulorbis squamigerus Carpenter................ 28, 36

Siderastrea californica Vaughan ...................

Sigaretus debilis Gould............................ 28, 36

scopulosus Conrad.......................... 17, 19

sp ............................................. $65-66$

Siliqua lucida Conrad.......................... 27,34 patula Dixon ........................... 27, 28, 30, 103 var. nuttalli Conrad...................... 34 sp...................... 21

Siphonalia kellettii Forbes....................... lineata Stanton $. \ldots \ldots \ldots \ldots \ldots \ldots \ldots \ldots \ldots \ldots \ldots \ldots \ldots, 12$

Siphonodentalium pusillum Gabb................. 15

Solariella cidaris A. Adams . ...................... 31 peramabilis Carpenter........................ 28, 31

Solarium amoenum Conrad ........................ 17 sp........................................ 17,

Solemya ventricosa Conrad yo .................... 17

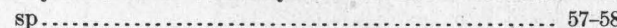

Solen curtus Conrad.............................

diegoensis Gabb ............................. 14

parallelus Gabb........................... 12 sicarius Goul 1 ....... 19, 24, 27, 30,31, 34,79, 84, 95, 99, 103 stantoni Weaver............................. sp .......................................... 24

Sooke beds, equivalents of ....................... 10

Spirocrypta pileum Gabb.......................... 15

Spiroglyphus lituella Morch.......................

Spirotropsis Smithi Arnold ........................ $\quad 36$

Spisula catilliformis Conrad................. 27-28, 34, 67 falcata Gould ............................. 27, 30,34

sp........................................ 66

Spondylus ....................................... 46 Estrallensis Conrad Estrellanus Conrad............................ 71

Stalagmium concentricum Gabb ................... 14 Stanton, T. W., on Tejon formation fossils........... 14

Stephanocoenia fairbanksi Vaughan................ 22 var. columnaris Vaughan .......................

Stratigraphy, value of Pecten genus in determining.. ? Strepsidura pachecoensis Stanton .................. 12

Strombus granulatus Sowerby.................... 22

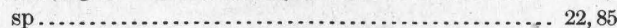
Strongylocentrotus franciscanus Agassiz ............ purpuratus Stimpson ..................... 28, 33, 120

Styliferina tenuisculpta Carpenter ................. $\quad 36$

Surcula claytonensis Gabb.......................... crenatospira Cooper ......................... 15 inconstans Cooper............................ 15 monilifera Cooper........................... 15 præattenuata Gabb......................... 15 raricostata Gabb............................ 15 sinuata Gabb .............................. 15

$\mathbf{T}$.

Tagelus californianus Conrad ............... 34 Tamiosoma gregaria Conrad ............... 23, 24, 64, 76, 111

Tapes conradiana Gabb ......................... 14 cretacea Gabb ............................. 14 lacineata Carpenter .......................... 34 quadrata Gabb .............................. 12,14 staleyi Gabb............................ 24, 27, 30,103 staminea Conrad ......................... 24, 28, 30 tenerrima Carpenter ....................... 27, 34 truncata Gabb............................... 19,83 sp......................................... 51 


\begin{tabular}{|c|c|}
\hline Taranis strongi Arnold........... & Trivia solandri Gray. \\
\hline 'ejon formation, character of...................... 13 & Trochita costellata Conrad.............. 17, 19, 79, 83, 117 \\
\hline equivalents of $\ldots \ldots \ldots \ldots \ldots \ldots \ldots \ldots \ldots \ldots \ldots \ldots \ldots \ldots \ldots \ldots$ & filosa Gabb ..................... 24, 30, 65, 84, 86, 104 \\
\hline 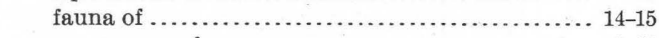 & inornata Gabb........................... 117-118 \\
\hline 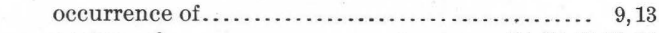 & 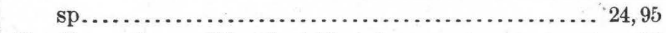 \\
\hline 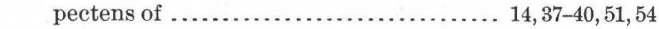 & Trochocyathus californicus Vaughan ................. 14 \\
\hline Tellina æqualis Gabb ............................... 12 & stantoni Vaughan ................................. \\
\hline aretata Conrad .................................. 17,66 & 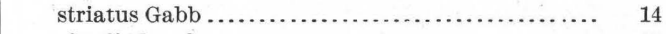 \\
\hline linds ................................... 19,34 & zitteli Vaughan ................. \\
\hline 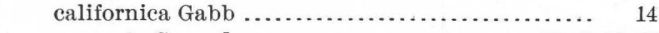 & Trophon cerritensis Arnold ......................... \\
\hline$\ldots \ldots \ldots \ldots \ldots \ldots \ldots \ldots \ldots \ldots \ldots \ldots \ldots, 21,27,57$ & gracilis Perry $\ldots \ldots \ldots \ldots \ldots \ldots \ldots \ldots \ldots \ldots \ldots \ldots \ldots \ldots \ldots$ \\
\hline Gabb $\ldots \ldots \ldots \ldots \ldots \ldots \ldots \ldots \ldots \ldots \ldots \ldots \ldots \ldots \ldots \ldots \ldots$ & tatus Eschscholtz........................ 36,103 \\
\hline 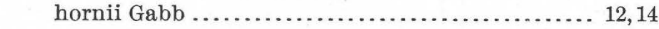 & us var. præcursor Arnold .................... 31, 36 \\
\hline$\ldots \ldots \ldots \ldots \ldots \ldots \ldots \ldots \ldots \ldots \ldots \ldots \ldots \ldots \ldots \ldots \ldots \ldots, 84,104$ & s Dall............................... 31,37 \\
\hline abb.................................. 14 & 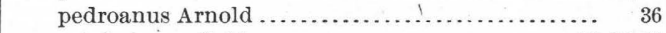 \\
\hline aver............................ & am Gabb......................... 19,24,84 \\
\hline 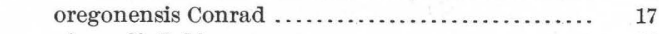 & 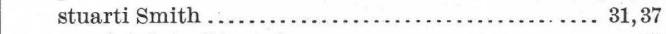 \\
\hline ( & Carpenter...................... 31 \\
\hline n.............................. & er.......................... \\
\hline abb.................................... & lents of..................... \\
\hline sp $\ldots \ldots \ldots \ldots \ldots \ldots \ldots \ldots \ldots \ldots \ldots \ldots \ldots, 27,55,58-59,66,73,83,117$ & Turbinella crassitesta Gabb ........................... \\
\hline Gabb ........................ 15 & 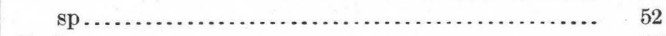 \\
\hline f & Turbo sp \\
\hline n............................ & Dall and Bartsch.................. \\
\hline 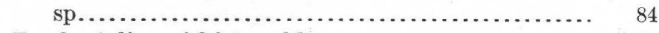 & rtsch ........................... \\
\hline ithi Arnold........................... & er................................ \\
\hline (n................................. & ter............................... \\
\hline erebratella transversa Sowerby ...................... & 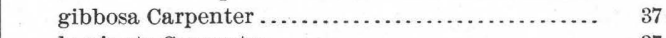 \\
\hline . & ter................................ \\
\hline rebratula nitens Conrad ............................. & latifundia Dall and Bartsch ..................... \\
\hline …..................... $12,53,5$ & 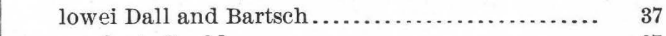 \\
\hline ensis Stanton ................... 12, 53 & 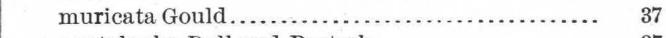 \\
\hline . & lopha Dall and Bartseh..................... \\
\hline 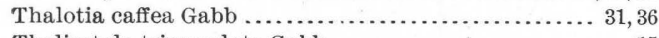 & dams .............................. \\
\hline ta Gabb......................... & asii Dall and Bartsch....... \\
\hline nesensis Weaver.................... & Carpenter .......... \\
\hline (n) 52 & ula Gould ................ \\
\hline d.......................... $17,31,34,103$ & Gould .................. \\
\hline hyasira bisecta Conrad........................... 31 & ata var. stylina Carpenter.................... \\
\hline . & 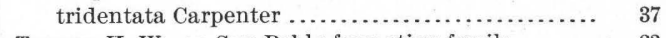 \\
\hline n.............................. & H. W., on San Pablo formation fossils ......... \\
\hline ides Conrad ......................... 34 & 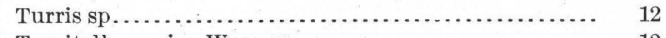 \\
\hline … & Turritella conica Weaver.......................... 12 \\
\hline Gould.......................... 36 & cooperi Carpenter .............. 28, 31,37,95, 100, 104, 117 \\
\hline 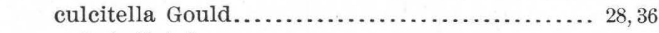 & abb........... 18, 19, 22,69-70,73,79,93-94 \\
\hline . & infragranulata Gabb............................ \\
\hline n................................. & er............................... 31,37 \\
\hline 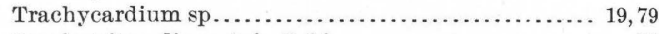 & ensis Gabb.............................. 12, 15 \\
\hline liegoensis Gabb...................... 15 & ina Conrad ............................. 18, 19,83,84 \\
\hline 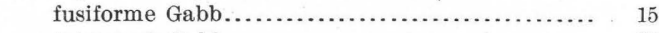 & tanton.............................. 12 \\
\hline n................................... & d ..................................... 51,52 \\
\hline 'resus nuttalli Conrad..................... 24, 27, 30,34, 73, 103 & 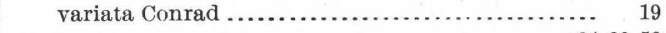 \\
\hline 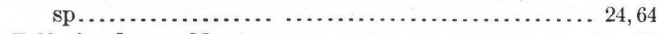 & 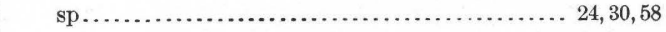 \\
\hline tague $\ldots \ldots \ldots \ldots \ldots \ldots \ldots \ldots \ldots \ldots \ldots \ldots \ldots \ldots \ldots \ldots$ & \\
\hline ritonium ealifornicum ( $\mathrm{abb} \ldots \ldots \ldots \ldots \ldots \ldots \ldots \ldots \ldots \ldots \ldots$ & U. \\
\hline . & 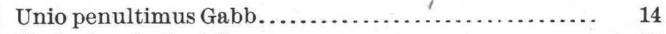 \\
\hline 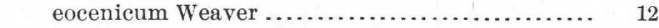 & 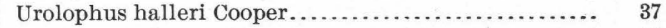 \\
\hline mereng. & adata Gabb................................. \\
\hline (2) & robusta Weaver................................... \\
\hline & \\
\hline ( & \\
\hline ( & character of..................... \\
\hline 然 & \\
\hline 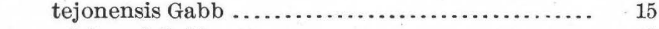 & a \\
\hline (n) & (n) \\
\hline$\ldots 19,24,28,52,55,73,83,93,1$ & ......... $18-19,37-40$ \\
\hline ea Gabb $\ldots \ldots \ldots \ldots \ldots \ldots \ldots \ldots$ & deros Valley, Cal., rocks in..... \\
\hline & \\
\hline
\end{tabular}




\begin{tabular}{|c|c|}
\hline $\begin{array}{ll}2 & \text { Page. }\end{array}$ & Page. \\
\hline Venericardia planicosta Lamarck ................. 14, 52 & Volvarina varia Sowerby ....... \\
\hline $\begin{array}{l}\text { planicosta var. hornii Gabb................... 12,14, } 51 \\
\text { ventricosa Gould } \ldots \ldots \ldots \ldots \ldots, 30-31,34,100,117-118\end{array}$ & Volvula cylindrica Carpenter ... \\
\hline sp.............................................. 57,66 & W. \\
\hline Venus æquilateralis Gabb .......................... 14 & Washington, formations in \\
\hline 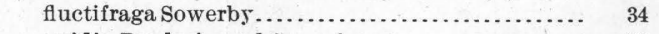 & $52,57-59,65-67,87-88$ \\
\hline ind Sowerby ..................... & Whitney, J. D., on Martinez formation................ 11 \\
\hline b..................................... & on Tejon formation........................... \\
\hline 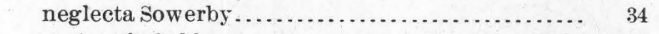 & Wildeat formation, equivalents of...................... \\
\hline pertenuis Gabb ..................... 19,24,27,73, 76,83 & \\
\hline 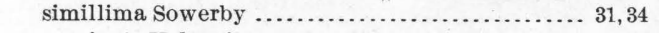 & \\
\hline ennes......................... 34 & \\
\hline tantilla Gould ................................ 34 & Xenophora zitteli Weaver... \\
\hline 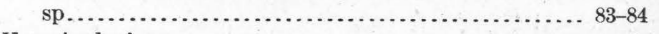 & \\
\hline . & \\
\hline ata Adams and Reeve.......... & Yoldia cooperi Gabb.... \\
\hline lliamsoni Dall........................... & impressa Conrad... \\
\hline Vola dentatus Sowerby ................................. & scissurata Dall....... \\
\hline floridus Hinds... & \\
\hline . & \\
\hline 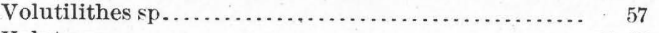 & Zirphæa gabbi Tryon.... \\
\hline 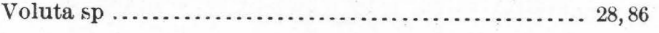 & sp..................... \\
\hline
\end{tabular}




\section{CLASSIFICATION OF THE PUBLICATIONS OF THE UNITED STATES GEOLOGICAL SURVEY.}

[Professional Paper No. 47.]

The serial publications of the United States Geological Survey consists of (1) Annual Reports, (2) Monographs, (3) Professional Papers, (4) Bulletins, (5) Mineral Resources, (6) Water-Supply and Irrigation Papers, (7) Topographic Atlas of the United States--folios and separate sheets thereof, (8) Geologic Atlas of the United States-folios thereof. The classes numbered 2, 7, and 8 are sold at cost of publication; the others are distributed free. A circular giving complete lists may be had on application.

Most of the above publications may be obtained or consulted in the following ways:

1. A limited number are delivered to the Director of the Survey, from whom they may be obtained, free of charge (except classes 2,7 , and 8 ), on application.

2. A certain number are delivered to Senators and Representatives in Congress, for distribution.

3. Other copies are deposited with the Superintendent of Documents, Washington, D. C., from whom they may be had at practically cost.

4. Copies of all Government publications are furnished to the principal public libraries in the large cities throughout the United States, where they may be consulted by those interested.

The Professional Papers, Bulletins, and Water-Supply Papers treat of a variety of subjects, and the total number issued is large. They have therefore been classified into the following series: A, Economic geology; B, Descriptive geology; C, Systematic geology and paleontology; D, Petrography and mineralogy; E, Chemistry and physics; F, Geography; G, Miscellaneous; H, Forestry; I, Irrigation; J, Water storage; K, Pumping water; L, Quality of water; M, General hydrographic investigations; $\mathrm{N}$, Water power; O, Underground waters; $\mathrm{P}$, Hydrographic progress reports. This paper is the seventy-sixth in Series $\mathrm{C}$, the complete list of which follows. ( $\mathrm{PP}=$ Professional Paper; $\mathrm{B}=\mathrm{Bulletin}$.)

SERIES C, SYSTEMATIC GEOLOGY AND PALEONTOLOGY.

B 3. Fossil faunas of Upper Devonian, along the meridian $76^{\circ} 30^{\prime}$, from Tompkins County, New York, to Bradford County Pennsylvania, by H. S. Williams, 1884, $36 \mathrm{pp}$, (Out of stock.)

B 4. Mesozoic fossils, by C. A. White. 1884.36 pp., 9 pls. (Out of stock.)

B 10. Cambrian faunas of North America; preliminary studies, by C. D. Walcott. 1884.74 pp., 10 pls. (Out of stock.)

B 11. Quaternary and recent Mollusea of the Great Basin, with deseriptions of new forms, by R. Ellsworth Call. Introduced by a sketch of the Quaternary lakes of the Great Basin, by G. K. Gilbert. $1884.66 \mathrm{pp} ., 6 \mathrm{pls}$.

B 15. Mesozoic and Cenozoic paleontology of California, by C. A. White. 1885. $33 \mathrm{pp}$. (Out of stock.)

B 16. Higher Devonian faunas of Ontario County, New York, by J. M. Clarke. 1885.86 pp., 3 pls.

B 18. Marine Eocene, fresh-water Miocene, and other fossil Mollusca of western North America, by C. A. White. 1885.26 pp., 3 pls.

B 19. Notes on the stratigraphy of California, by G. F. Becker, 1885, 28 pp. (Out of stock.)

B 22. New Cretaceous fossils from California, by C. A. White. 1885 . 25 pp., 5 pls. (Out of stock.)

B 24. List of marine Mollusca, comprising the Quaternary fossils and Recent forms from American localities between Cape Hatteras and Cape Roque, including the Bermudas, by w. H. Dall. 1885.336 pp.

B 29. Fresh-water invertebrates of the North American Jurassic, by C. A. White, 41 pp., 4 pls.

B 30. Second contribution to the studies on the Cambrian faunas of North America, by C. D. Walcott. $1886 . \quad 369$ pp., 33 pls. (Out of stock.)

B 31. Systematic review of our present knowledge of fossil insects, including myriapods and arachnids, by S. H. Scudder 1886. $128 \mathrm{pp}$.

B 34. Relation of the Laramie molluscan fauna to that of the succeeding fresh-water Eocene and other groups, by C. A. White. 1886.54 pp., 5 pls.

B 37. Types of the Laramie flora, by L. F. Ward. 1887.354 pp., $57 \mathrm{pls}$.

B 41. Fossil faunas of the Upper Devonian-the Genesee section, New York, by H. S. Williams. $188 \%$. 121 pp., 4 pls. (Out of stock.) 
B 13. Tertiary and Cretaceous strata of the Tuscaloosa, Tombigbee, and Alabama rivers, by E. A. Smith and L. C. Johnson. 1887. 189 pp., 21 pls.

B 51. Invertebrate fossils from the Pacific coast, by C. A. White. $1889.102 \mathrm{pp} ., 14 \mathrm{pls}$. (Out of stock.)

B 56. Fossil wood and lignite of the Potomac formation, by F. H. Knowlton. 1889.72 pp., 7 pls.

B 63. Bibliography of Paleozoic Crustacea from 1698 to 1889 , including a list of North American species, and a systematic arrangement of genera, by A. W. Vogdes. $1890.177 \mathrm{pp}$.

B 69. Classed and annotated bibliography of fossil insects, by S. H. Scudder. $1890.101 \mathrm{pp.}$

B 71. Index to known fossil insects of the world, including myriapods and arachnids, by S. H. Scudder. $1891.744 \mathrm{pp}$

B 77. The Texan Permian and its Mesozoic types of fossils, by C. A. White. 1891. 51 pp., 4 pls.

B 80. Correlation papers-Devonian and Carboniferous, by H. S. Williams. 1891. 279 pp. (Out of stock.)

B 81. Correlation papers-Cambrian, by C. D. Walcott. $1891.447 \mathrm{pp} ., 3 \mathrm{pls}$. (Out of stock.)

B 82. Correlation papers-Cretaceous, by C. A. White. 1891.273 pp., 3 pls. (Out of stock.)

B 83. Correlatior papers-Eocene, by W. B. Clark. 1891.173 pp., 2 pls.

B 84. Correlation papers-Neocene, by W. H. Dall and G. D. Harris. 1892. 349 pp., 3 pls. (Out of stock.)

B 85. Correlation papers-The Newark system, by I. C. Russell. 1892.344 pp., 13 pls. (Out of stock.)

B 86. Correlation papers-Archean and Algonkian, by C. R. Van Hise. 1892.549 pp., 12 pls. (Out of stock.)

B 87. Synopsis of American fossil Brachiopoda, including bibliography and synonymy, by Charles Schuchert. 1897. $464 \mathrm{pp}$.

B 88. Cretaceous foraminifera of New Jersey, by R. M. Bagg, jr. 1898.89 pp., 6 pls

B 93. Some insects of special interest from Florissant, Colo., and other points in the Tertiaries of Colorado and Utah, by S. H. Scudder. 1892. 35 pp., 3 pls. (Out of stock.)

B 97. Mesozoic Echinodermata of the United States, by W. B. Clark. $1893.207 \mathrm{pp} ., 50 \mathrm{pls}$.

B 98. Flora of the outlying Carboniferous basins of southwestern Missouri, by David White. $1893.139 \mathrm{pp} ., 5 \mathrm{pls}$.

B 101. Insect fauna of the Rhode Island coal field, by S. H. Scudder. $1893.27 \mathrm{pp} ., 2 \mathrm{pls}$.

B 102. Catalogue and bibliography of North American Mesozoic Invertebrata, by C. B. Boyle. $1893.315 \mathrm{pp}$.

B 105. The Laramie and the overlying Livingston formation in Montana, by W. H. Weed, with report on flora, by F. H. Knowlton. 1893. 68 pp., 6 pls.

B 106. Colorado formation and its invertebrate fauna, by T. W. Stanton. 1893.288 pp., 45 pls. (Out of stock.)

B 110. Paleozoic section in the vicinity of Three Forks, Mont., by A. C. Peale. 1893. 56 pp., 6 pls.

B 120. Devonian system of eastern Pennsylvania and New York, by C. S. Prosser. 1895. 81 pp., 2 pls. (Out of stock.)

B 121. Bibliography of North American paleontology, by C. R. Keyes. $1894.251 \mathrm{pp.}$

B 124. Revision of North American fossil cockroaches, by S. H. Scudder. 1895.176 pp., 12 pls.

B 128. Bear River formation and its characteristic fauna, by C. A. White. 1895.108 pp., 11 pls.

B 133. Contributions to the Cretaceous paleontology of the Pacific coast: The fauna of the Knoxville beds, by T. W. Stanton. 1895. $132 \mathrm{pp} ., 20 \mathrm{pls}$.

B 134. Cambrian rocks of Pennsylvania, by C. D. Walcott. 1896.43 pp., 15 pls.

B 141. Eocene deposits of the middle Atlantic slope in Delaware, Maryland, and Virginia, by W. B. Clark. 1896.167 pp., $40 \mathrm{pls}$.

B 142. Brief contribution to the geology and paleontology of northwestern Louisiana, by T. W. Vaughan. $1896.65 \mathrm{pp} .4 \mathrm{pls}$. B 145. Potomac formation in Virginia, by W. M. Fontaine. 1896. 149 pp., 2 pls.

B 151. Lower Cretaceous gryphæas of the Texas region, by R. T. Hill and T. W. Vaughan. $1898.139 \mathrm{pp} ., 35 \mathrm{pls}$.

B 152. Catalogue of Cretaceous and Tertiary plants of North America, by F. H. Knowlton. 1898. $247 \mathrm{pp.}$

B 153. Bibliographic index of North American Carboniferous invertebrates, by Stuart Weller. $1898.653 \mathrm{pp.}$

B 163. Flora of the Montana formation, by F. H. Knowlton. 1900.118 pp., 19 pls.

B 173. Synopsis of American fossil Bryozoa, including bibliography and synonymy, by J. M. Nickles and R. S. Bassler. 1900. $663 \mathrm{pp}$.

B 179. Bibliography and catalogue of fossil Vertebrata of North America, by O. P. Hay. 1902. 868 pp.

B 191. North American geologic formation names: Bibliography, synonymy, and distribution, by F. B. Weeks. 1902 . 448 pp.

B 195. Structural details in the Green Mountain region and in eastern New York (second paper), by T. Nelson Dale. 1902. 22 pp., 4 pls.

B 204. Fossil flora of the John Day basin, Oregon, by F. H. Knowlton. 1902.153 pp., 17 pls.

B 205. The Mollusca of the Buda limestone, by G. B. Shattuck, with an appendix on the corals of the Buda limestone, by T. W. Vaughan. 1903. 94 pp., 27 pls.

B 206. A study of the fauna-of the Hamilton formation of the Cayuga Lake section in central New York, by H. F. Cleland, 1903. 112 pp., 5 pls.

B 210. The correlation of geological faunas; a contribution to Devonian paleontology, by H. S. Williams. $1903.147 \mathrm{pp} ., 1 \mathrm{pl}$.

B 211. Stratigraphy and paleontology of the Upper Carboniferous rocks of the Kansas section, by G. I. Adams, G. H. Girty, and David White. 1903. 123 pp., 4 pls.

PP16. Carboniferous formations and faunas of Colorado, by G. H. Girty. 1903.546 pp., 10 pls.

PP19. Contributions to the geology of Washington, by G. O. Smith and Bailey Willis. 1903. 101 pp., 20 pls.

PP 21. The geology and ore deposits of the Bisbee quadrangle, Arizona, by F. L. Ransome. $1904 . \quad 168 \mathrm{pp} ., 29 \mathrm{pls}$.

PP 24. Zinc and lead deposits of northern Arkansas, by G. I. Adams, assisted by A. H. Purdue and E. F. Burchard, with a section on the determination and correlation of formations, by E. O. Ulrich. 1904.118 pp., 27 pls.

PP31. Preliminary report on the geology of the Arbuckle and Wichita mountains in Indian Territory and Oklahoma, by J. A. Taff, with an appendix on the reported ore deposits in the Wichita Mountains, by H. F. Bain. 1904.97 pp., 8 pls.

PP 32. Preliminary report on the geology and underground water resources of the central Great Plains, by N. H. Darton. 1905. 433 pp., 72 pls. 
B 244. Contributions to Devonian paleontology, 1903, by H. S. Williams and E. M. Kindle. 1905.137 pp., 4 pls.

PP 35. The geology of the Perry basin in southeastern Maine, by G. O. Smith and David White. 1905.107 pp., 6 pls.

PP 36. The lead, zine, and fluorspar deposits of western Kentucky, by E. O. Ulrich and W. S. T. Smith. 1905.218 pp., 15 pls.

B 257. Geology and paleontology of the Judith River beds, by T. W. Stanton and J. B. Hatcher, with a chapter on the fossil plants, by F. H. Knowlton. 1905. 174 pp., 19 pls.

B 266. Paleontology of the Malone Jurassic formation of Texas, by F. W. Cragin, with stratigraphic notes on Malone Mountain and the surrounding region near Sierra Blanca, Texas, by T. W. Stanton. $1905.172 \mathrm{pp} ., 29 \mathrm{pls}$

PP 40. The Triassic cephalopod genera of America, by Alpheus Hyatt and J. P. Smith. 1905.394 pp., 85 pls.

B 268. Miocene foraminifera from the Monterey shale of California, with a few species from the Tejon formation, by R. M. Bagg, jr. 1905, $78 \mathrm{pp}, 11 \mathrm{pls}$

Pि 47. The Tertiary and Quaternary Pectens of California, by Ralph Arnold. 1906.264 pp., 53 pls.

Correspondence should be addressed to

The Director

United States Geological Survey,

Washington, D. C.

MARCH, 1906. 